\title{
Archaeological Mitigation at 41BX300, Salado Creek Watershed, South-Central Texas
}

Paul R. Katz

Follow this and additional works at: https://scholarworks.sfasu.edu/ita

Part of the American Material Culture Commons, Archaeological Anthropology Commons, Environmental Studies Commons, Other American Studies Commons, Other Arts and Humanities Commons, Other History of Art, Architecture, and Archaeology Commons, and the United States History Commons

Tell us how this article helped you.

This Article is brought to you for free and open access by the Center for Regional Heritage Research at SFA ScholarWorks. It has been accepted for inclusion in Index of Texas Archaeology: Open Access Gray Literature from the Lone Star State by an authorized editor of SFA ScholarWorks. For more information, please contact cdsscholarworks@sfasu.edu. 


\section{Archaeological Mitigation at 41BX300, Salado Creek Watershed, South-Central}

Texas

\section{Creative Commons License}

\section{(c) (1) (9)}

This work is licensed under a Creative Commons Attribution-NonCommercial 4.0 International License 


\title{
ARCHAEOLOGICAL MITIGATION AT 41 BX300, SALADO CREEK WATERSHED, SOUTH-CENTRAL TEXAS
}

\author{
Paul R. Katz
}

With Contributions By

Glen L. Evans, Eric C. Gibson; Joel Gunn, Rebekah E. Halpern,

Paul D. Lukowski, Donald McLain. Harold Murray, and Harold Wooldridge

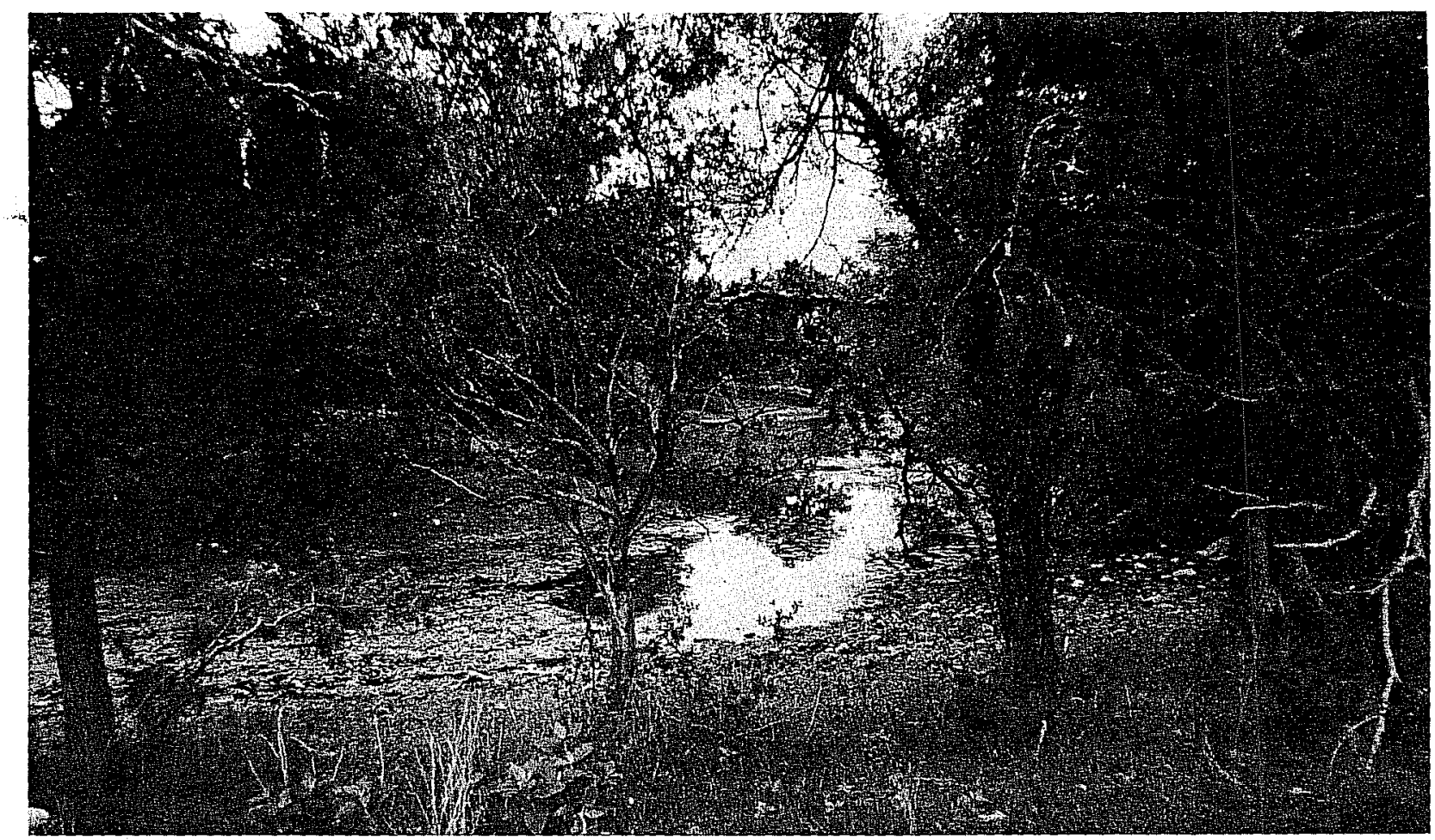

Center for Archaeological Research The University of Texas at San Antonio

Archaeological Survey Report, No. 130 

ARCHAEOLOGICAL MITIGATION AT 41 BX 300, SALADO CREEK WATERSHED, SOUTH-CENTRAL TEXAS

\title{
Paul R. Katz
}

\author{
with contributions by \\ Glen L. Evans, Eric C. Gibson, Joel Gunn, \\ Rebekah E. Halpern, Paul D. Lukowski, \\ Donald McLain, Harold Murray, and Harold Wooldridge
}

Prepared under the supervision of

Thomas R. Hester, Principal Investigator

National Park Service Contract C3561(78)

Center for Archaeological Research The University of Texas at San Antonio® Archaeological Survey Report, No. 130 



\section{FOREWORD}

The archaeological investigations reported in this volume represent the culmination of a series of cultural resource studies conducted in the area of site 41 BX 300 in south-central Texas. Plans by the Soil Conservation Service, United States Department of Agriculture, to construct a floodwater retarding structure on Elm Waterhole Creek, a tributary of Salado Creek, Ted to an initial survey at this Tocality by The University of Texas at Austin in the early 1970s. As plans for the construction moved forward, the Center for Archaeological Research at The University of Texas at San Antonio contracted with the Soi] Conservation Service to carry out more intensive surveys and site evaluations. We began to 1 earn more about site $41 \mathrm{BX} 300$, as well as other sites within the proposed construction area. For example, contact was made with an artifact collector who made available his materials from the site surface, and these were published by a graduate student associated with the Center. Fina17y, in 1978, as the construction got underway, a ful1-scale excavation, aimed at mitigating the inevitable loss of the site, was conducted by the Center under the aegis of the National Park Service.

These excavations, directed by Paul Katz, provided an opportunity to examine certain facets of Middle Archaic, Late Archaic, and Late Prehistoric occupations recognized at the site. A variety of excavation and analytical techniques was implemented that had not previously been applied at other south-central Texas sites. The well organized and executed excavations, followed by an equally comprehensive laboratory phase, has provided a wealth of new data and interpretations. Some of the special studies attempted during this project proved to be of 1 imited success or still remain preliminary. Even these, however, can serve as guides in terms of planning similar kinds of research in the future.

In summary, this project combined the requirements of systematic cultural resource studies with a distinctive research orientation. As a result, we not only have a body of "salvaged" data that would have otherwise been lost, but also a body of information and interpretation that can be utilized in continuing archaeological research in the south-central Texas region.

Thomas R. Hester January 1987 


\section{ABSTRACT}

Site 41 BX 300, a multicomponent 1 imited activity occupation site situated in the upper Salado Creek watershed of northern Bexar County, Texas, was first recorded in 1971 and initially tested in 1975 and 1976 . This report concerns three months of mitigation work conducted in 1978 by the Center for Archaeological Research, The University of Texas at San Antonio.

Geomorphological investigation has determined that the site locality only became stable enough to make habitation suitable in the middle of the postPleistocene period. At that time its peripheral resources included a permanent water source in the Elm Waterhole Creek, immediately adjacent to the site, and two nearby chipped stone resource areas.

Investigation by means of controlled surface collection in 10-m blocks, hand excavation of 121 one-meter squares, and 18 backhoe-cut trenches removed $335 \mathrm{~m}^{3}$ of soil, recovered over 110,000 specimens and samples, recorded 10 cultural features, and identified four periods of occupation.

Artifacts diagnostic of the Early Archaic period were recovered in random locations and redeposited situations, not associated with any features. No occupation of the site at this time is identifiable, supporting the geomorphological evidence of instability. The first well-represented occupation occurred early in the Middle Archaic period, ca. 2600-500 B.C. Three burned rock hearths and diagnostic artifacts, such as Bulverde, Nolan, and Travis projectile points, and associated tools indicate a faunal procurement and processing suite of activities.

Stratigraphically higher and Tater in time an occupation late in the Middle Archaic period (ca. 500-250 B.C.) was discerned, characterized by one burned rock midden and an adjacent burned rock scatter which may be an incipient midden. There was no evidence of primary activity associated with it, and the interpretation is that of a "community dump." The presence of Pedernales projectile points assist with the chronological placement within the Round Rock phase. Higher in the topsoil are two burned rock hearths and an associated 1 iving floor assigned to the Late Archaic period (ca. 250 B.C.A.D. 750) on the basis of diagnostic projectile point types such as Castroville, Ensor, Frio, and Marcos. While there is some artifactual evidence for vegetal processing, most of the artifacts indicate faunal procurement and processing activities.

The fourth and final occupation at the site occurred during the Late Prehistoric period (ca. A.D. 750-1800). Diagnostic artifacts of both the Austin and Toyah phases are present in a very restricted and intensively utilized $12-\mathrm{m}^{2}$ area close to ground surface. Faunal procurement and processing and chipped stone tool manufacture and maintenance, are the primary activity clusters represented. The Historic period is represented by a few scattered artifacts, hardly indicative of intentional occupation.

Site 41 BX 300 functioned as a hunting camp for over four millenia, from early in the Middle Archaic through the Late Prehistoric cultural periods. The attraction of this site over other potential hunting loci was most likely the combination of a constant water source in the Elm Waterhole and abundant 
Tithic raw materials. Use of space at the site and in particular the treatment of burned rock features varies with each cultural period, providing comparative behavioral data for future investigation of south-central Texas prehistory.

KEYWORDS: prehistoric archaeology, south-central Texas, Archaic, Late Prehistoric, burned rock, midden, hearth, waterhole, hunter-gatherer. 


\section{TABLE OF CONTENTS}

FOREWORD (Thomas R. Hester) . . . . . . . . . . . . . i i

ABSTRACT. . . . . . . . . . . . . . . † †

LIST OF FIGURES ............................. vi

LIST OF TABLES. . . . . . . . . . . . . . . . . . . . . . viii

ACKNOWLEDGMENTS ..................... . . . $\mathrm{ix}$

INTRODUCTION. . . . . . . . . . . . . . . . . . . . . 1

ENVIRONMENTAL CHARACTERISTICS . . . . . . . . . . . . . . 4

Physical Setting (Paul D. Lukowski) . . . . . . . . . . . 4

Geology. . . . . . . . . . . . . . . . 4

Soils......................... 4

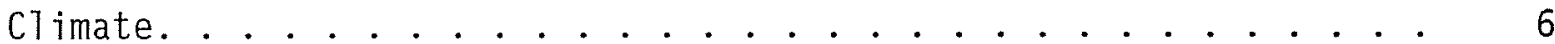

Flora. . . . . . . . . . . . . . . . 6

Fauna. . . . . . . . . . . . . . . . . . 7

Paleoclimate ..................... . . . . 7

Observations of the Geology and Geomorphology of Site 41 BX 300

(Glen L. Evans) . . . . . . . . . . . . . . . . 9

Bedrock. . . . . . . . . . . . . . . . . . 9

Faulting . . . . . . . . . . . . . . . . 10

Drainage and Stream Deposits............... 11

Elm Waterhole. ................. . . 13

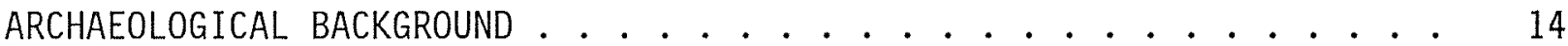

Chronology of South-Central Texas (Eric C. Gibson and Paul Katz). . . . 14

Paleo-Indian Period. . . . . . . . . . . . . . . . 14

Archaic Period ................... . . . . 15

Ear7y Archaic Period. . . . . . . . . . . . . . . . . . 15

Middle-Late Archaic Periods . . . . . . . . . . . . . . . . 17

Late Prehistoric Period. . . . . . . . . . . . . . . . . . . . 19

Historic Period. . . . . . . . . . . . . . . . . . 19

Review of Archaeological Investigations in Bexar County

(Eric C. Gibson). . . . . . . . . . . . . . . . . . 20

The Panther Springs Creek Site (41 BX 228). . . . . . . . . . . 21

Vicinity of 41 BX 300 (Paul D. Lukowski). . . . . . . . . . . . . . 22

The Menger Collection. . . . . . . . . . . . . . . . 23

Phase I Activities at 41 BX $300 . \ldots 23$

Phase II Activities at $41 \mathrm{BX} 300 \ldots . . . . . . . . .23$

The Sites. . . . . . . . . . . . . . . . . . 27

Site 41 BX 484...................... . . . 27

Site 41 BX 485....................... . . . 27

Site 41 BX 486..................... . . 29

Site 41 BX 299..................... . . . 29

Site 41 BX 301...................... . . . 29

Site 41 BX 300.................... . . . . 30

Summary. . . . . . . . . . . . . . . . . . 31

RESEARCH DESIGN ...................... . . . . . 32

Research Objectives..................... 32

Research Hypotheses . . . . . . . . . . . . . . . . . 33

Research Areas. . . . . . . . . . . . . . . . . . . 36

EXCAVATION PROCEDURES (Paul Lukowski and Paul Katz) . . . . . . . . 37

Excavation Contro1. . . . . . . . . . . . . . . 37

Horizontal . . . . . . . . . . . . . . . . . . 37

Vertical...................... 43 
Excavation Methods and Techniques .............. 46

Methods. . . . . . . . . . . . . . . . . . . 46

Techniques .................. . . . 53

Data Recovery . . . . . . . . . . . . . . . . . 54

Clearing ................... . . . 54

Surface Collection . . . . . . . . . . . . . . . 54

Excavation .................. . . . 56

Screening. . . . . . . . . . . . . . . . . . 56

Special Samples. . . . . . . . . . . . . . . . 56

Excavation Statistics. . . . . . . . . . . . . 58

Data Recording. . . . . . . . . . . . . . . . . . . 58

Forms. . . . . . . . . . . . . . . . . 58

Classification Type Codes. . . . . . . . . . . . . . 60

Special Samples.................. 61

Total Inventory Recovery Experiment. . . . . . . . . . . . . . 61

Pictorial Recording. . . . . . . . . . . . . . . . 62

STRATIGRAPHY. . . . . . . . . . . . . . . . . . . . . . . . . . . 62

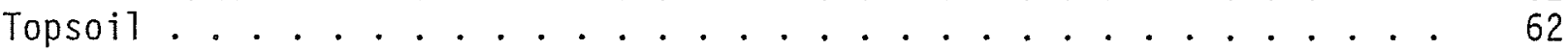

Del Rio Clay. ............................ 68

Edwards Limestone. . . . . . . . . . . . . . . . . . . . . . . . . . 69

Stratum Comparisons and Distribution. . . . . . . . . . . . 69

DESCRIPTION AND ANALYSIS OF ECOFACTS AND SPECIAL SAMPLES. . . . . . 72

Soil Samples. . . . . . . . . . . . . . . . . . 72

Collection and Processing of Constant Volume Samples (Rebekah E.

Halpern and Paul Katz) ................ . 73

Particle Size and Constituent Anaiyses . . . . . . . . . . 76

Ecofactua7 Material . . . . . . . . . . . . . . . 76

Botanical Identification and Analysis (Dr. Donald McLain). . . . . 82

Phytolith Analysis................. . . 82

Faunal Analysis (Harold Wooldridge). . . . . . . . . . . . 89

Molluscan Analysis (Dr. Harold Murray) . . . . . . . . . . . . . . . 92

Chronological Samples . . . . . . . . . . . . . . . 97

Radiocarbon Dating Samples. . . . . . . . . . . 97

Archaeomagnetic Dating Samples............. . . 98

Thermoluminescence Dating Samples . . . . . . . . . . . 98 98

DESCRIPTION AND ANALYSIS OF ARTIFACTS ............. 103

Introduction. . . . . . . . . . . . . . . . . . . . 103

Chipped Stone . . . . . . . . . . . . . . . . . . 105

Varieties of Raw Material. . . . . . . . . . . . . . . 105

Manufactured Tools . . . . . . . . . . . . . . . . . 106

Manufactured Tool By-Products. . . . . . . . . . . . . . . . 135

Rough Stone....................... . . . 138

She11 . . . . . . . . . . . . . . . . . . . . 138

Bone. . . . . . . . . . . . . . . . . . . . . 138

Prehistoric Pottery . . . . . . . . . . . . . . . . . . . . 139

Historic Artifacts. . . . . . . . . . . . . . . . . . . . 139

Summary Analysis. . . . . . . . . . . . . . . . . . . . . . 139

DESCRIPTION AND ANALYSIS OF FEATURES. . . . . . . . . . . . . . . . . 140

Burned Rock Midden. . . . . . . . . . . . . . . . . . . . . . . . . . . 140

Feature 2. . . . . . . . . . . . . . . . 140

Burned Rock Hearths . . . . . . . . . . . . . . . . . . . . . . . . . 150

Feature 3. . . . . . . . . . . . . . . . . 150

Feature 6.................. 153 
Feature 9. . . . . . . . . . . . . 158

Feature 10 . . . . . . . . . . . . . . . 161

Feature 11 .................. . . 161

Burned Rock Scatter . . . . . . . . . . . . . . . 165

Feature 8................. . . 165

0ccupation Floors ........................ 167

Feature 4. . . . . . . . . . . . . . . 167

Feature 5.................. 168

Feature 7. . . . . . . . . . . . . 168

SUMMARY AND EVALUATION. . . . . . . . . . . . . . . . . . . . 169

Background and Implementation of Phase III Mitigation Project . . . . . 169

Results of the Phase III Mitigation Project . . . . . . . . . . . 170

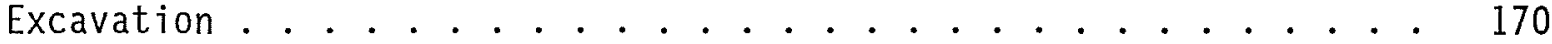

Stratigraphy .................. . . 171

Features................... 171

Material Recovered .................. 172

Environment and Seasonatity. . . . . . . . . . . . 174

Occupational Summary. . . . . . . . . . . . . . . . . 175

Evidence for Pre-Middle Archaic Occupation . . . . . . . . . . . 175

Early Middle Archaic Period. . . . . . . . . . . . . . . . . . . 177

Late Middle Archaic Period . . . . . . . . . . . . . . . . . . . . . 178

Late Archaic Period. . . . . . . . . . . . . . . . . . . . . . . 180

Late Prehistoric Period. . . . . . . . . . . . . . . . 181

Historic Period. . . . . . . . . . . . . . . . . . . . 182

Behavioral Trends Through Time............... 182

Evaluation of the Research Design . . . . . . . . . . . . . 183

Research Areas . . . . . . . . . . . . . . . . . . 183

Research Objectives. . . . . . . . . . . . . . . . 184

Research Hypotheses. . . . . . . . . . . . . . . . . . . . 185

REFERENCES CITED. . . . . . . . . . . . . . . . 189

APPENDIX I: MATERIALS RECOVERED AT 41 BX $300 \ldots . . . . . . . . . .201$

APPENDIXII: VEGETATIONAL ANALYSIS OF 41 BX 300 (John E. Cook and

Michae 1 Laquey). ............ 251 


\section{LIST OF FIGURES}

1. Location of $41 \mathrm{BX} 300$ and Vicinity Sites . . . . . . . . . . 2

2. Views of 41 BX 300 ................... . . . 5

3. Paleophysiography of Elm Waterhole . . . . . . . . . . . 12

4. Upper Salado Creek Watershed . . . . . . . . . . . . . . . . . . 16

5. Phase II Testing. . . . . . . . . . . . . . . 26

6. Excavation at Site $41 \mathrm{BX} 300$.............. 38

7. Southern and Northern Views of 41 BX 300 ............. 39

8. Site Contours and Phase III Excavation Areas . . . . . . . . . . . 40

9. System of Designating 10-m Blocks, and Blocks Surface Collected. . 42

10. Contour Map of Site, Showing A11 Trenches and Units Excavated During A17 Phases.

11. Trenches and Units Excavated During Al7 Phases, With Phase III Features Indicated . . . . . . . . . . . . . . . . . 47

12. Excavation Units, Trenches, and Features in Area Red ...... . 48

13. Alfa-E Trench. . . . . . . . . . . . . . . . 49

14. Views of Feature 2 and Feature 7 .............. 50

15. Views of Area Blue and Area White. . . . . . . . . . . . . . . 51

16. Views of Hotel and November Trenches . . . . . . . . . . . . . . 59

17. Profile Drawings of A7fa and Bravo Trenches, Area Yellow..... 63

18. Profile Drawings of Delta and Golf Trenches, Area Green. . . . . . 64

19. Profile Drawings of Echo Trench, Area Green, Indicating Feature 9. 65

20. Profile Drawings of Foxtrot Trench, Area Green . . . . . . . . . 66

21. Profile Drawings of Kilo and November Trenches, Areas White and Blue, Respectively........... . 67

22. Profile Drawings of Hotel Trench, Area Red, Indicating Feature 2 . 70

23. Profile Drawings of Omega-W and India-E Trenches, Area Red, Indicating Feature 2............... . 71

24. Projectile Points. . . . . . . . . . . . . . . 108

25. Projectile Points. . . . . . . . . . . . . . . . . 113

26. Projectile Points, Specialized Tools, and Miscellaneous Artifacts. 119

27. Bifaces. . . . . . . . . . . . . . 125

28. Bifaces. . . . . . . . . . . . . . . . 126

29. Bifaces. . . . . . . . . . . . . . . . 128

30. Unifaces ..................... . . . . 130

31. Typed Tools. . . . . . . . . . . . . . . . . 132

32. Views of Feature 2 ..................... 144

33. Views of Features 2 and 5.................. 146

34. Plan Drawing of Feature 3, Area Red. . . . . . . . . . . . . 151

35. Views of Feature 3 . . . . . . . . . . . . . . 152

36. Plan Drawing of Feature 6, Area Red. . . . . . . . . . . 155

37. Views of Features 4 and 6................. 156

38. Grinding S7ab, Reused as a Hearthstone in Feature 6, Area Red. . . 157

39. Views of Features 8 and 9. . . . . . . . . . . . . 159

40. Profile Drawing of Feature 9, Area Green . . . . . . . . . . . . 160

41. Views of Features 10 and 11................ 162

42. Plan and Profile Drawings of Feature 10, Area White. . . . . . . 163

43. Plan Drawing of Feature 11, Area Yellow. . . . . . . . . . . . 164

44. Plan Drawing of Feature 8, Area Red. . . . . . . . . . . 166 


\section{LIST OF TABLES}

1. Summary of Selected Environmental, Chronological, and Cultural Data for South and Central Texas . . . . . . . . . . . . . 8

2. Frequency of Projectile Point Types Within the Menger Collection Donated to The University of Texas at San Antonio for Archaeological Research. . . . . . . . . . . . . . . 24

3. 41 BX 300 Excavation Statistics: Phase I and II........ 25

4. Summary of Recovered Specimens at Sites in the Vicinity of Flood Water Retarding Structure 13A, 1975-1976........... 28

5. Research Design Matrix: Objectives and Hypotheses ........ 33

6. Elevational Relationships Between Site Datum and Area Datum Points................. . . 45

7. Phase III Trench Data................... 52

8. Statistics for Controlled Surface Collection by 10-Meter Blocks. . 55

9. Excavation Statistics: Phase III (Mitigation)......... 57

10. Excavation Statistics: Summary of A11 Projects. . . . . . . . 58

11. Stratum Characteristics............... 68

12. Distribution of Constant Volume Samples. . . . . . . . . . . . 74

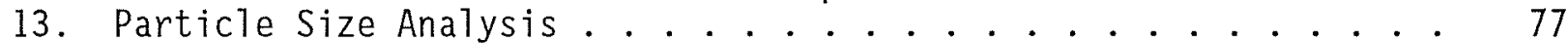

14. Chemical Constituent Analysis. . . . . . . . . . . . . . 79

15. Identification of Charcoal Samples ............. 83

16. Identification of Ecofactual Material Associated With Feature Soil Samples................... . . 84

17. Distribution of Phytolith Samples. . . . . . . . . . . 87

18. Faunal Inventory ................. . 90

19. Distribution of Identified Faunal Elements ............ . 91

20. Distribution of Unidentified Faunal Fragments. . . . . . . . . 93

21. Distribution of Radiocarbon Dating Samples ............. . 97

22. Distribution of Archaeomagnetic Dating Samples . . . . . . . . . 99

23. Distribution of Thermoluminescence Dating Samples. . . . . . . . . 100

24. Summary of Artifacts Collected During Phase III Investigations . . 104

25. Feature Data . . . . . . . . . . . . . . . . 141

26. Feature Associations ........... . . . 142

27. Chronologically Diagnostic Artifacts Associated With Features. . 148

28. Chronological Associations of Projectile Points. . . . . . . . . . 149

29. Summary of A11 Material Recovered During Phase III Mitigation Activities at 41 BX 300 . . . . . . . . . . . . . . . . 173

30. Site 41 BX 300 , Occupational Summary ............... 176

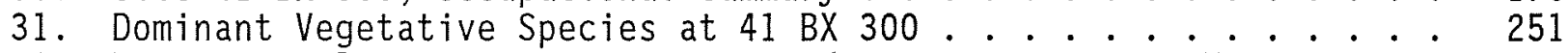

32. Vegetational Density, Frequency, and Dominance at 41 BX 300. . . . 252 


\section{ACKNOWLEDGMENTS}

To the $41 \mathrm{BX} 300$ field crew, the writer extends his appreciation for a professional effort accomplished successfully and according to schedule. The site was pleasant, the archaeology challenging, and the comradeship at a very high level. The regulars included Darrel Creel, Augustine Frkuska, Carolyn Furman, Rebekah Halpern, Thomas Kelly, Paul Lukowski, Thomas Miller, and Robert Scott IV. To these must be added a series of volunteers associated with the Southern Texas Archaeological Association, The University of Texas at San Antonio, and Incarnate Word College. Specific thanks go to Daniel Fox, Kathleen Gonzales, Amy Johnston, and Susanna Katz. Unskilled labor was provided by many individuals from Manpower, Inc., but Frank must be singled out for special mention. Bill Cline and Mike Wright are to be complimented on their excellent backhoe control and operation.

Providing the critical bridge between field and 1aboratory was Elizabeth Frkuska, the project's laboratory supervisor and data analyst. She supervised all the steps from data capture in the field, through initial material processing and cataloging, to the production of computerized inventories and analyses. Assisting her in the Taboratory procedures were Augustine Frkuska, Rebekah Halpern, Roberta McGregor, and Lang Scruggs. Again there were volunteers, primarily from The University of Texas at San Antonio; Virginia Nones and Harold Prestridge deserve special mention. Deepest gratitude goes to Karin Check, for 7 iterally months of volunteered time measuring and classifying artifacts to produce Appendix I.

A number of consultants and analysts provided valuable assistance to the project, and they are acknowledged here: Glen Evans, Austin; Tim Hunkapillar, University of Oklahoma; University of Georgia Radiocarbon Laboratory; Dr. Donald McLain, Incarnate Word College; Dr. Harold Murray, Trinity University; soils laboratories at Oklahoma State and Texas A\&M Universities; and Harold G. Wooldridge, Austin.

Technical assistance in analyses and report production is gratefully acknowledged, and the following individuals are thanked for their participation: Dr. Joel Gunn and ETizabeth Frkuska, CAR-UTSA, for the computer programming assistance; Augustine Frkuska, CAR-UTSA, for his drafting of al1 plans, profiles, and other illustrative material; John Poindexter, Office of Media Resources, UTSA, for photographing all artifacts; Bruce Ellis, CARUTSA, for assistance in photography layout and drafting; Fay Johnson, Incarnate Word College, and Mary Lou Ellis and Ann Young, CAR-UTSA, for manuscript typing; and Sharon Quirk for her editorial assistance.

Interpretive assistance from Drs. Joel Gunn and Thomas Hester of UTSA and Elton Prewitt of Austin was generously provided and is here acknowledged with gratitude.

A variety of administrative assistance was provided throughout the project period and beyond, by many individuals and agencies. The writer wishes to thank the Tandowner, Elgin Steubing, for his consideration during the field work portion. James Thompson provided Tiaison during the same period at the San Antonio River Authority. Mention must be made of several individuals at the Denver office of the Interagency Archeological Services who were 
variously associated with the project: Robert Alexander, William Butler, Donald Fiero, Jake Hoffman, and Jack Rudy. Finally, to Jack Eaton, associate director, and Dr. Thomas R. Hester, director of the Center for Archaeological Research, The University of Texas at San Antonio, and to Susanna Katz, my deepest appreciation for the years of patience and pushing towards this final product. 


\section{INTRODUCTION}

The following report of investigations details the intensive testing, subsequent analysis, and resultant interpretations of site $41 \mathrm{BX} 300$, a multicomponent, limited activity occupation area in northern Bexar County, south-central Texas.

Site 41 BX 300, and two adjacent 1ithic resource areas designated 41 BX 299 and $41 \mathrm{BX} 301$, were recorded in 1975 by a survey team from the Center for Archaeological Research (CAR), The University of Texas at San Antonio (UTSA), under a contract with the Soil Conservation Service. This represents Phase I of the total project. The locality in question was to be impacted by Floodwater Retarding Structure (FRS) 13A, one of a series of such facilities being constructed in the upper Salado Creek drainage basin of northern Bexar County (see Fig. 1).

Based on the results of the initial 1975 reconnaissance, a CAR-UTSA crew conducted 1imited testing of 41 BX 300 during the winter of 1976. Also funded by the Soil Conservation Service, this activity is designated as Phase II of the 41 BX 300 project. The multicomponent nature of the site, suspected during reconnaissance by a range of chronologically diagnostic projectile points, was documented by the identification of a Late Archaic occupation area horizontally distinct from a Middle Archaic burned rock midden. The site was at this time nominated to the National Register of Historic Places. The result of both actions was the preservation of about three acres of the most intensive occupational remains, around which deep pit borrowing was carried out as part of the construction of FRS 13A.

Subsequent monitoring of the site by CAR-UTSA staff members ascertained several facts. The resultant pedestal of preserved site area provided a unique opportunity to observe its subsurface aspects, and vertical stratigraphic components were added to the horizontal stratigraphy identified by initial testing. Multiple burned rock features and chipped stone artifacts were observed in the profiles provided on the site's vertical periphery.

Unfortunately, natural erosion, exacerbated by cattle grazing, was having an adverse impact on the preserved portion of the site, accelerating the eventual loss of this high data potential locality. Apprised of the situation, and after several visits to the site, the Denver office of the National Park Service Interagency Archeological Services decided to fund a final mitigation program at $41 \mathrm{BX} 300$. The CAR-UTSA received the contract, and intensive testing of the site took place in the spring of 1978. This was the third, and final, phase of investigations.

In its response to the Scope of Work, the CAR-UTSA identified the following major problems facing south-central Texas archaeology. It was intended that investigations at $41 \mathrm{BX} 300$ would shed some 7 ight on a 17 of them, and indeed the research was designed to accomplish just this.

1. The two previous phases of investigation, and subsequent site monitoring, identified both horizontal and vertical cultural stratigraphy. By means of an excavation $\mathrm{plan}$ in which different areas of the site were investigated in depth, a chronological framework for the site's occupation 


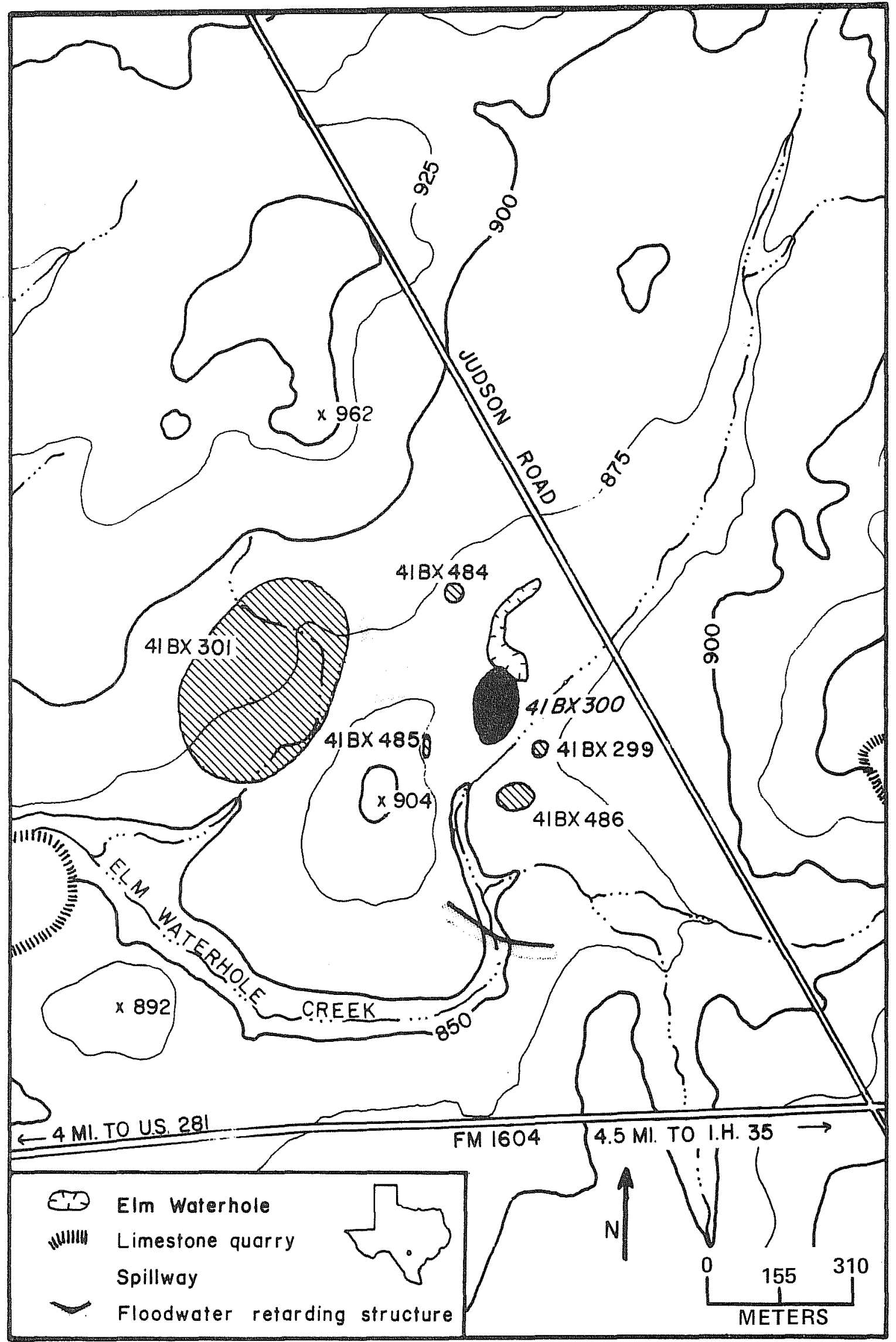

Figure 1. Location of 41 BX 300 and Vicinity Sites. 
would be constructed. Integrating the site sequence into an extant regional chronology would provide data to expand interpretations about, and assist in the refinement of, the latter.

2. The steep-sided nature of the extant site, resulting from pedestaling the preserved portion, would provide the basis for a thorough study of the locality's geomorphology. A series of special samples, recovered from all portions and depths of the site, would form the basis for interpretations of both paleoclimatic episodes and seasonality of occupation phases. These samples would include soil for standard mechanical and organic content analyses, additional soil for micro-specimen recovery of artifacts and ecofacts, soil for phytolithic analysis, burned rock samples for thermoluminescence dating, wood charcoal for species identification, and samples for radiocarbon dating.

3. By employing the method of block excavation in at least one portion of the site, a functionally oriented analysis of the cultural remains would be greatly facilitated. The identification of contemporaneous features and their associated tool kits would provide significant data on site utilization, both from the point of view of specific activities and to observe overall site patterning. Comparison and contrast of stratigraphically distinct patterns would provide data on variations in site utilization and idiosyncratic behavior through time.

4. Patterns identified by the stratigraphic block excavation technique can be related to settlement and demographic interpretations as well as to subsistence activities. The size and number of features, inter-feature spatial considerations, total site area utilization, resource proximity, and artifact density all provide useful data for hypothesizing population density and distribution.

5. Artifactual and ecofactual type and density provide data for interpretations of subsistence activities, and their distribution across the site provides for studies of organization, scheduling, seasonality, and subsistence behavior. Consideration of the nature and usage of nearby sites would help to build a picture of resource exploitation and seasonal rounds for each phase documented in the occupational sequence of the site.

6. Full investigation of the features at the site would provide data on site function at each occupational phase associated with the features. In particular, the burned rock midden, while a common feature in central Texas Archaic prehistory, was accompanied by a variety of functional and architectural interpretations. Careful excavation of the mound at 41 BX 300 would add valuable data to the current state of this feature's interpretations.

The report of investigations is organized into nine sections. The first two provide background about the site locality, from both environmental and cultural perspectives. These are followed by the research design for the mitigation project. Excavation methods and techniques, followed by a summary of the site's natural stratigraphy, precede three descriptive sections. These latter discuss the ecofacts and special samples, artifacts, and features recorded or recovered during the mitigation activities. The final section includes a summary of the project, providing conclusions drawn from 
the field work and analyses. 0ccupational chronology and site function throughout time are discussed in detail; and the research design is evaluated at the conclusion of this section.

\section{ENVIRONMENTAL CHARACTERISTICS}

\section{PHYSICAL SETTING (PauT D. Lukowski)}

Bexar County is situated in south-central Texas and has within its boundaries portions of three physiographic divisions: the West Gulf Coastal Plain, the Balcones Fault Zone, and the Edwards Plateau (Taylor, Hailey, and Richmond 1962).

The almost level to gently undulating plains of the Balcones Fault Zone and West Gulf Coastal Plain occupy the southern two-thirds of Bexar County. Elevations in this portion of the county range from about 500 to 1000 feet. The Edwards Plateau, characterized by a more rugged topography and dissected by southeasterly trending streams, takes up the remaining northern area of the county, with elevations there ranging from about 1000 to 1900 feet (Taylor, Hailey, and Richmond 1962).

Site 41 BX 300 lies within the Balcones Fault Zone in the northeastern part of Bexar County, approximately 4.5 miles due east of the intersection of US Highway 281 and FM 1604 (Fig. 1).

\section{GEOLOGY}

Geological activity some 12 million years ago lifted lower cretaceous deposits in the area relative to the coastal plain, creating the present-day drainage and topographic patterns characteristic of the southern edge of the Edwards Plateau (Gerstle, Kel1y, and Assad 1978:25-26). While most of the drainage systems within the Balcones Fault Zone lose much of their water to the underground Edwards Aquifer, springs of various sizes may be formed along these faults. The large pond adjacent to 41 BX 300 may be one of these springs (Fig. 2,a).

Site 41 BX 300 , situated on the southern edge of an exposure of the Edwards limestone formation, is near a series of fault lines (Barnes 1974). The Edwards limestone formation, a chert-bearing source (Gerstle, Kel1y, and Assad 1978:25-26), is a lower cretaceous formation contained within the Balcones Fault Zone, generally between the upper Cretaceous deposits of the Edwards Plateau and the Eocene deposits characteristic of the West Gulf Coastal Plain. A detailed geological summary is presented by Evans in the next section of this report.

\section{SOILS}

Soils, for a large area around 41 BX 300 (and including sites 41 BX 301 , $41 \mathrm{BX} 484$, and $41 \mathrm{BX} 485$ ), are of the Crawford-Bexar association. A different soil association, the Tarrent, begins just on the east side of the 


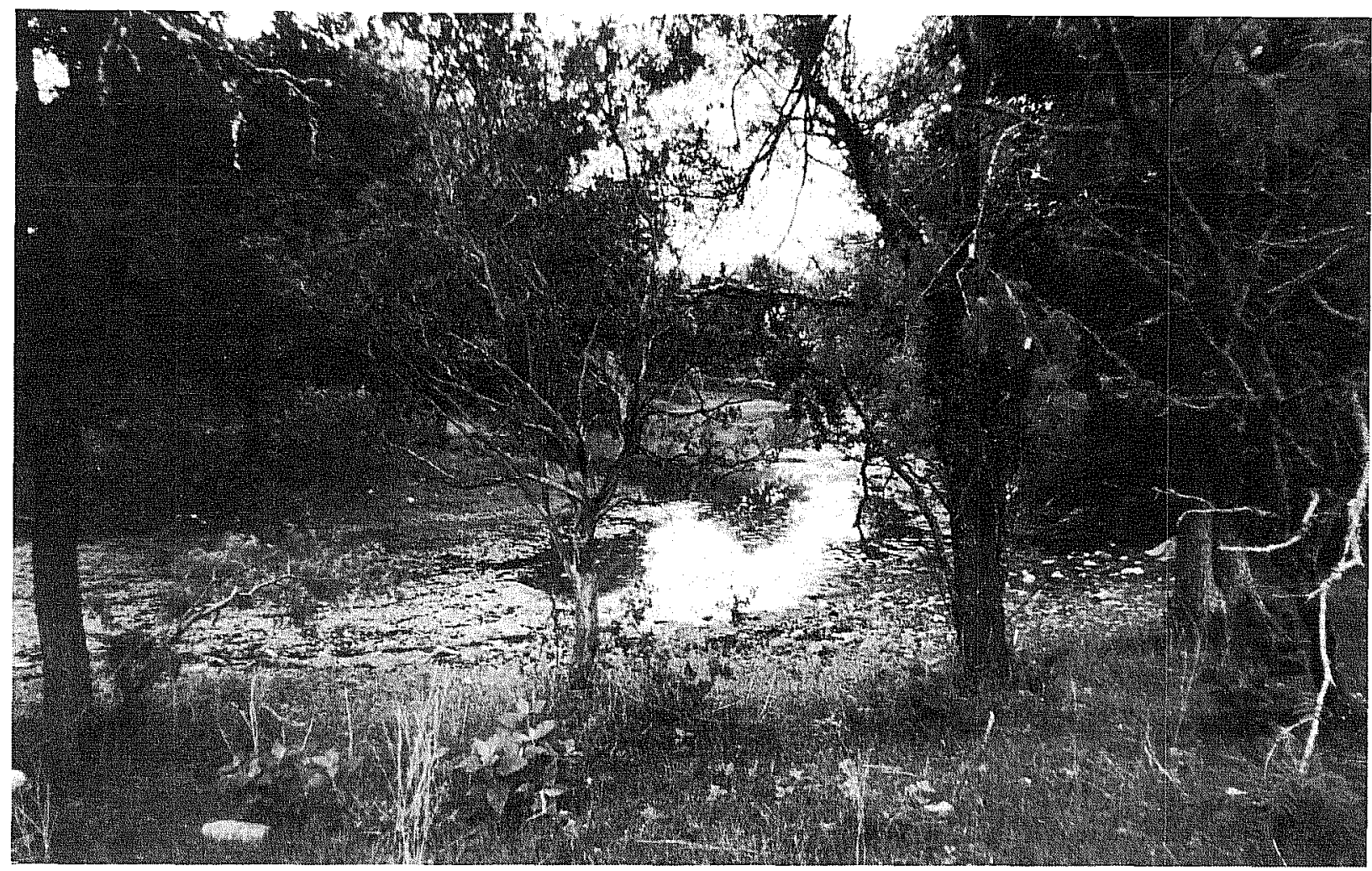

a

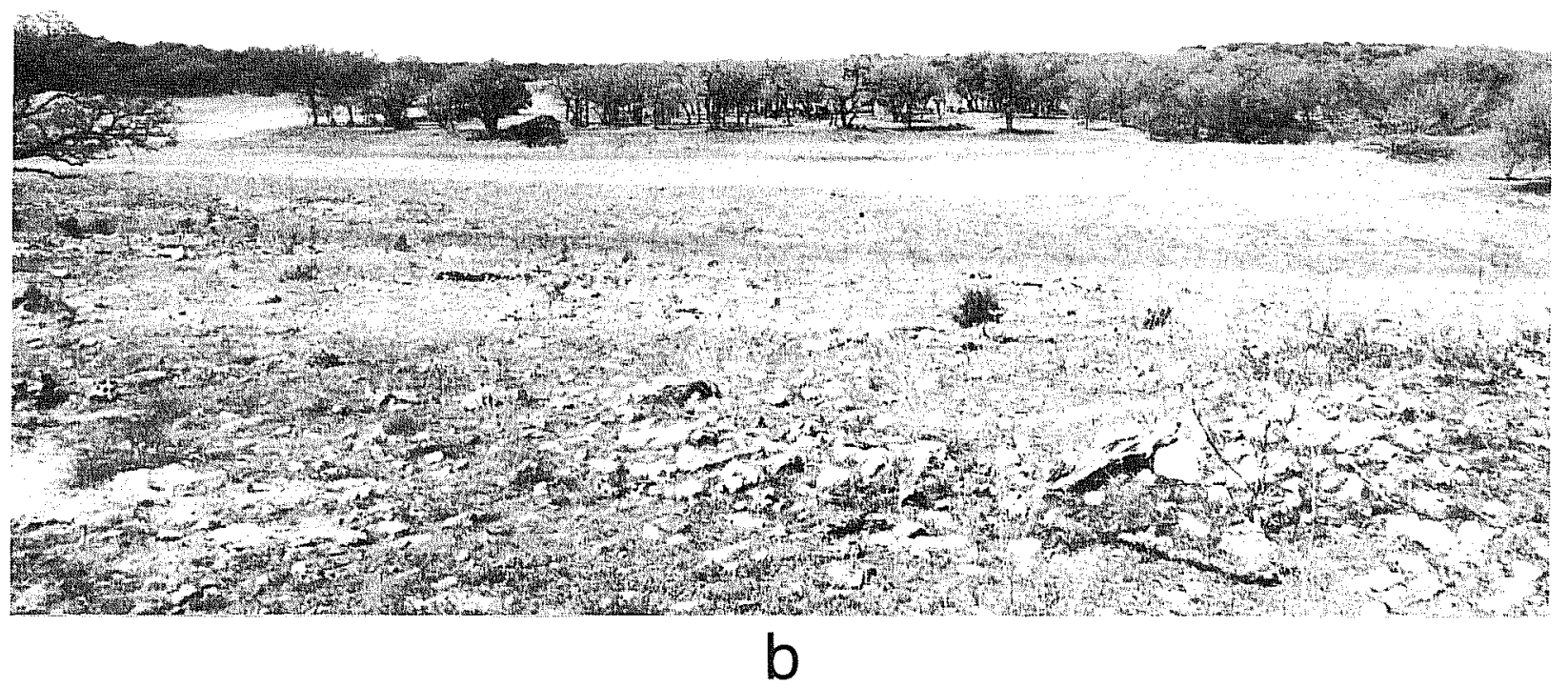

Figure 2. Views of 41 BX 300. a, E1m Waterhole, looking north; b, general view of 41 BX 300 during Phase III mitigation activities, looking south. 
creek across from 41 BX 300 and characterizes sites 41 BX 299 and 41 BX 286. The Tarrent soils differ from the Crawford-Bexar soils mainly in that the former are much shallower.

Crawford and Bexar Stoney soils have 10w slopes (0-5\% slopes) and can be characterized as occupying large, broad areas supporting post oak and blackjack oak savannas (Taylor, Hailey, and Richmond 1962). Depth to bedrock ranges from 17 to 35 inches, and these profiles can contain $10-40 \%$ chert and limestone pieces ranging in size from 1/4-inch to 24 inches. Reaction may be from slightly acid to mildly alkaline. When dry, the clay is very hard and develops many cracks (Taylor, Hailey, and Richmond 1962).

The upper layer of Crawford and Bexar Stoney soils is very dark grayish brown to reddish brown clay, six to 10 inches thick. The layer has a structure described as fine, subangular blocky, and granular (Taylor, Hailey, and Richmond 1962). The subsurface layer, about 26 inches thick, is a dense, angular blocky clay and is browner or more reddish than the surface 1 ayer. This zone either overlies a thin layer of yellowish red to pale brown clay; or, if the thin soil zone is missing, it rests directly on fractured limestone that may be many feet thick (Taylor, Hailey, and Richmond 1962).

\section{CLIMATE}

Bexar County has a modified subtropical climate with mild winters and hot summers. Average daily temperatures (as recorded during the years 1931-1960) range from $53.7^{\circ} \mathrm{F}$ for the months of December, January, and February, and $83.2^{\circ} \mathrm{F}$ during June, July, and August. Yearly average rainfall for the previously mentioned years was 27.89 inches, with the largest amounts of precipitation occurring in the form of short thundershowers between April and September and the lowest monthly averages occurring generally as light rain or drizzle during November through March.

\section{FLORA}

Although 41 BX 300 is located within the southern boundary of the Texan Biotic Province, its proximity to two other biotic provinces (the Balconian and the Tamaulipan) places it in an ecotonal setting. The Balconian Biotic Province generally occupies the Edwards Plateau area and can be characterized as an oak-juniper vegetational region (Gould 1969). The Tamaulipan Biotic Province generally begins west of the San Antonio River and south of the Edwards Plateau. Vegetation in the region is characterized by species of the South Texas brushlands such as mesquite, acacia, mimosa, and whitebrush (BTair 1950).

Species from the Balconian and Tamaulipan Biotic Provinces recorded at 41 BX 300 include such invaders as prickly pear, yucca, whitebrush, condalia, agarita, juniper, Texas persimmon, and stunted 1 ive oak (Cook and Laquey, Appendix II). Cedar elm, Texas persimmon, and mesquite are the dominant woody species at the site, and, together with the brush species (mainly agarita and whitebrush), comprise the most common vegetation at the site. Because of the disturbed nature of the site, no climax grasses are evident. 
Overa $11,57 \%$ of the cover at the site is woody vegetation; the remaining $43 \%$ is comprised of grasses, forbs, and bare ground (Cook and Laquey, Appendix II).

It can be inferred from the literature that relatively recent vegetational changes, mainly in the form of increased brush cover, have occurred since the 18th century (Ingl is 1964:94-101). One of the first recorded visits to Bexar County was an expedition 1ed by Teran de Tos Rios in 1691. Manzanet, a diarist on the journey, noted that on a day's travel, estimated to have begun near the present-day San Antonio International Airport and having proceeded in an east-northeasterly direction (placing the end of the day's journey in the general vicinity, but slightly south, of 41 BX 300), they traveled,

... over lands without woods. To the north are some low ranges, but with little timber. A still higher hill could be seen in the distance. This had tall timber on it. As we progressed on our journey it was left to north. Near this hill there is a heavy mesquite woods which rapidly descend to a dry arroyo [E]m Creek?]. There are very 1 arge mulberry trees, pecans, vines, oaks, and hackberries (Ingl is 1964:21).

Later, travelers Ferdinand Roemer and W. A. McClintock, crossing the same general area in northern Bexar County in the middle 19th century, noted open prairies of gently rolling hills and groves of timber with numerous deer between the Cibolo and Salado Creeks (Inglis 1964).

\section{FAUNA}

BTair (1950) notes 49 species of mammals, 39 species of snakes, 15 species of lizards, and other species of reptiles and birds within the Texan Biotic Province. It can be expected that some species from the Balconian and Tamaulipan Biotic Provinces also occur in the area. The more common species within Bexar County are white-tailed deer, opossum, squirrels, cottontail rabbit, jackrabbit, quail, armadi110, and various species of reptiles. A more complete listing of fauna is presented by Gerstle, Kelly, and Assad (1978:29).

Species once present in the area, but now very rare or missing are bison, antelope, bear, turkey, and prairie dog (Ingl is 1964; Campbe17 1975). Wild turkeys, however, were observed on several occasions during the archaeological investigations at $41 \mathrm{BX} 300$.

\section{PALEOCLIMATE}

In a recent discussion of the Archaic cultures of the West Gulf Coastal P1ain, Story (1980:5-9) summarizes information currently available on the environment of the Holocene. Although the paleoenvironment is poorly known and sometimes conflicting, Story has organized the data into a tentative model containing three provisional periods (Table 1). 
TABLE 1. SUMMARY OF SELECTED ENVIRONMENTAL, CHRONOLOGICAL, AND CULTURAL DATA FOR SOUTH AND CENTRAL TEXAS

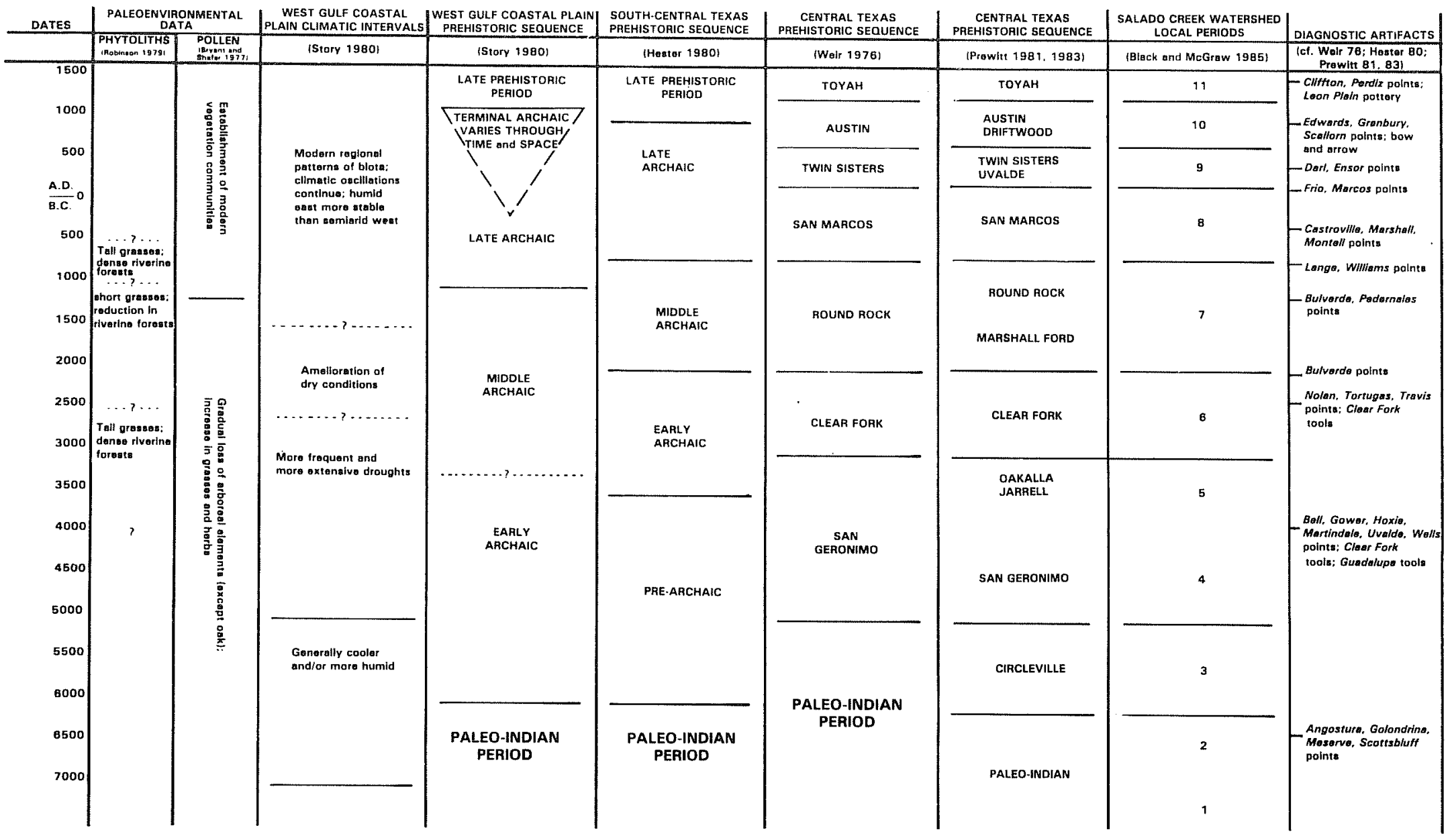


A moister, cooler, and seasonally less differentiated climate characterizes the earliest period (ca.7000-5000 B.C.) of the Holocene in this model. In the second period, sometime between 5000-2500 B.C., dryer conditions were more prevalent and droughts become more frequent, probably allowing for the expansion of xerophytic species in the region. The basic biotic patterns of the present were then established around 3000-2500 B.C., al though there are indications of short-term climatic variations subsequent to 1500 B.C. (Story 1980:8).

\section{OBSERVATIONS ON THE GEOLOGY AND GEOMORPHOLOGY OF SITE 41 BX 300}

(GTen L. Evans)

My investigations of this site and its environs were largely restricted to such geologic and geomorphic features and resources as seemed likely to have influenced, in one way or another, the human prehistory of the area. I hoped to determine the origin of the alluvial land feature on which the site was located, and to form some useful estimate of when it became suitable for sustained human occupation. Another focus of study was, of course, the spring fed pool known as Elm Waterhole, for it may have been the single most important resource influencing the selection of the adjacent occupation site. It seemed desirable to learn, if possible, how and when it formed--could it have served as an inducement for Paleo-Indian campers. My objectives were by no means fulty reatized, but possibly useful opinions were formed.

\section{BEDROCK}

The outcropping bedrock in the immediate vicinity of the site includes the Edwards limestone and the overlying Del Rio clay, both formations of early Cretaceous age. The Edwards is composed mainly of hard but often highly porous limestone and some dolomite, which form conspicuous and widespread outcrops in the general area. Some members of the formation contain abundant flint nodules, many of which are of a grade suitable for the manufacture of piercing and cutting implements. Rich sources of such flint in the near vicinity of 41 BX 300 were doubtlessly one of the major attractions for aboriginal occupants of the area. Flint, or chert, deposits were generally omitted from my investigations, as they were an integral part of the archaeological survey crews' investigations.

However, one feature observed at the large surface flint quarry designated as 41 BX 301 , southwest of site 41 BX 300 (Fig. 1), deserves special mention because of the significant information it provides bearing on the rate of soil erosion that has taken place in the area during the post-Archaic centuries. The site encompasses several acres on a gentle slope of a flint nodule-bearing member of the Edwards Timestone. The upper surface of the 7 imestone bed has been eroded to a considerable extent and is covered in most places by a thin, stony, residual soil. Many of the slopes contain erosionresistant flint nodules, whose lower parts are still firmly encased in the parent 7 imestone, and which now project well above the soil level, thus giving the slopes the appearance of a strewn boulder field. 
Virtually al1 of the projecting nodules show unmistakable evidence of aboriginal knapping or quarrying activity, and many have flakes struck off down to the level of the present soil surface. This shows convincingly that the cobbles were exposed as fully to the Indians as they are to us, and clearly indicates that there has been little or no net loss of soil by erosion on this segment of the Edwards Plateau since the Archaic period. Doubtlessly there have been some solution effects, and at least minimal sheet wash during torrential rains, but residual soil accumulations appear to have approximately kept pace with such losses to erosion.

The Edwards formation provided aborigines not only with flint for tool making and 7 imestone slabs for hearths, but al so met their need in other indirect ways as we11. Where suitable recharge conditions exist, certain porous members of the formation serve as aquifers, and discharge as springs wherever the aquifer is intersected down from the recharge area by erosion or open fractures. There are a number of Edwards limestone springs of different types in the faulted and dissected parts of the plateau region. Some of these, 1 ike Elm Waterhole at $41 \mathrm{BX} 300$, are remote from other sources of permanent water, and must have been of major importance to aboriginal hunting and gathering peoples, especially during severe drought intervals.

The Del Rio clay in this vicinity is a yellowish gray, marly clay with some thin 7 imestone members. The formation is easily eroded, and typically forms low-relief, inconspicuous outcrops. It contains a great abundance of the marine pelecepod, Exogyra artietina, which is a useful aid in identifying the formation. It also contains appreciable amounts of pyrite, which, where well oxidized, may have served the Indians as a pigment.

\section{FAULTING}

The Edwards and Del Rio formations, as well as other Cretaceous strata outcropping in the site vicinity, have been extensively displaced by a cluster of predominantly northeast trending and southeast trending faults, which are in the central part of the broad Balcones Fault system. This fault cluster includes a narrow, down-faulted block, or graben, that lies immediately beneath 41 BX 300 . In this structure, the impervious Del Rio clay appears to have been down-faulted against the porous, water-bearing Edwards $1 \mathrm{imestone,} \mathrm{thus} \mathrm{forming} \mathrm{a} \mathrm{kind} \mathrm{of} \mathrm{subsurface} \mathrm{dam} \mathrm{that} \mathrm{blocked} \mathrm{the}$ down-dip lateral movement of water in the Edwards aquifer, and set the stage for the development--much later--of the sinkhole spring now known as Elm Waterhole. 


\section{DRAINAGE AND STREAM DEPOSITS}

The site area is drained by Long Creek, 1 an intermittent, headward branch of the San Antonio River system. Long Creek now flows only when fed by runoff from occasional heavy rains in its watershed, and no indication was seen that it was ever a perennial flowing stream, although it may have formerly carried considerably more water than at present.

Where the creek crosses the outcropping Edwards formation, upstream from the site, the channel is entrenched in limestone, not in floodplain alluvium. The channel appears disproportionately broad and shallow, and its bed is strewn with an undetermined thickness of 1 imestone and flint pebbles and cobbles, and numerous subrounded boulders up to 30 inches or more in diameter. The boulders, especially, must have required the transporting energy of infrequent exceptionally heavy floods. A fairly thick stand of trees, mainly cedar elm and juniper, some of which appear to be 30 or 40 years old, grows on the rock-strewn channel floor. Driftwood caught in the lower branches of the trees reveals a recent flow of water to a depth of three or four feet, but the generally healthy appearance of the trees indicates that the channel has carried no major floods during their lifetime.

The only fine-grained alluvium observed along the stream's course through the Edwards limestone terrain was very minor, thin patches of floodplain alluvial soil on the 1 ower parts of the divide between Long Creek and El $\mathrm{m}$ Waterhole Creek, where the stream crosses the outcrop of the easily eroded De1 Rio clay at and near 41 BX 300; however, the greatly broadened valley floor was covered with an extensive alluvial deposit, from two to four meters in thickness. Most of this alluvium, and part of the underlying Del Rio clay, was removed prior to our investigation by large-scale excavations for earthen dam-making material. Even so, the following interpretation of stream activity in the vicinity could be deduced from the distribution of channel, floodplain, and terrace alluvium observed in the excellent backhoe trench exposures at $41 \mathrm{BX} 300$, and in a few preserved a1luvial remnants around the large excavations.

Before Elm Waterhole sink came into existence, Long Creek, at flood stage, flowed through both its own channel and the channel of its minor tributary, the upper part of which is now known as Elm Waterhole Creek. The two channels then flowed on opposite sides of the area where 41 BX 300 is now located, and formed their confluence downstream from the site (Fig. 3). Both channels meandered freely, causing at times of high water severe lateral erosion; and the interchannel divide, including most of $41 \mathrm{BX} 300$, was subject to periodic flooding. Alluvium, ranging in texture from coarse cobbles and boulders to silty clay, was deposited on the site from at least late Pleistocene times.

1Editor's note: The stream referred to by Evans as "Long Creek" (Fig. 3) is designated as "Elm Waterhole Creek" elsewhere in this report (e.g., Fig. 1). The discrepancy stems from a change in the stream designation on successive editions of USGS topographic maps. The reader should consider Long Creek and Elm Waterhole Creek references to be synonymous except in this section by Evans. 


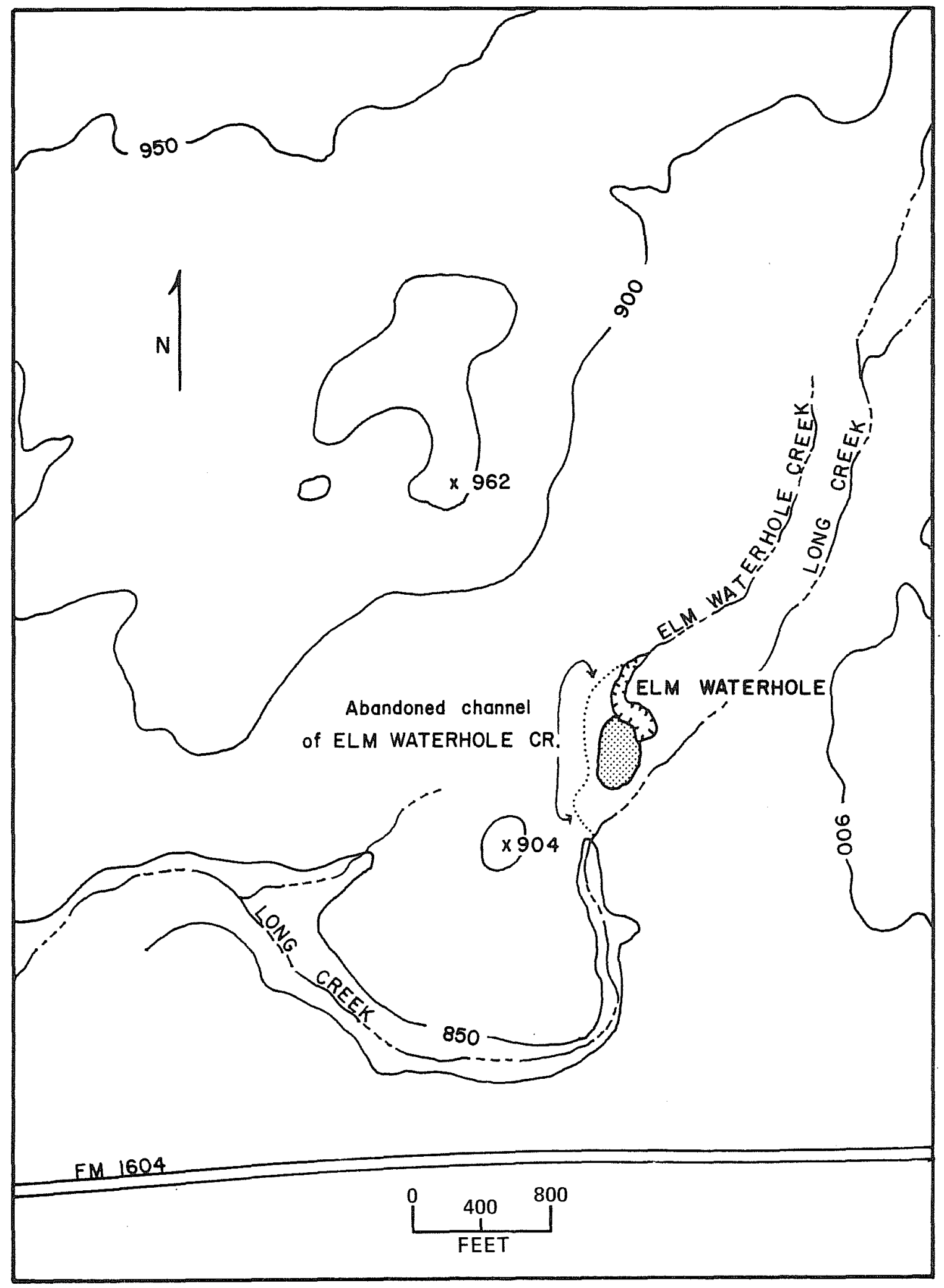

Figure 3. Paleophysiography of Elm Waterhole. After Glen L. Evans. 
Formation of the elongated $\mathrm{E} 7 \mathrm{~m}$ Waterhole sink transected the inter-stream divide just above 41 BX 300 and pirated the tributary by deflecting its flow through the sink to a new confluence with Long Creek. Thereafter Long Creek seems to have shifted its course eastward away from the site and deepened its channel to some extent. The site area was then a flat to gently sloping terrace segment, no longer subject to stream erosion, and much less subject to flooding. It was then--probably for the first time--a desirable occupation site for aboriginal people. There is no means of accurately dating this event, but the position and appearance of the alluvium in the abandoned portion of the tributary channel suggest that the sink and related phenomena may have occurred around the middle of the post-Pleistocene. If so, the site probably would not have been suitable for occupation by PaleoIndians, perhaps not even for Indians of the Early Archaic period.

\section{ELM WATERHOLE (Fig. 2,a)}

Elm Waterhole, a spring-fed pool, is an elongated subsidence feature, or sink, which apparently formed by collapse of overlying, fracture-weakened strata into solution caverns in the Edwards limestone. The collapse may have resulted from post-Pleistocene lowering of the water table, which partially drained previously water-filled caverns, and thus eliminated their aqueous roof support. The subsidence of bedrock could have been progressive rather than a single event. There is evidently still a degree of downward adjustment of sediments that are washed into the hole during occasional local floods; otherwise the sink would have long since been filled and obliterated.

In the alluvium downstream from the spring, no trace was seen of aquatic mo17usks, travertine, clean, we1l-sorted deposits, or other evidence of a former spring-fed flowing stream. It seems likely, therefore, that the spring has never supported even a moderate flow down the Long Creek channel, probably because the hydrostatic head in the feeding aquifer has always been insufficient to raise the water in the sinkhole spring to stream bed level. From this it can be assumed that any downstream campsites, however suitable in other respects, would not have been habitable in drought intervals unless some other water source was available. On the other hand, the spring, from the time of its origin, has probably been a permanent, if localized, source of water. The Tandowner, Mr. Elgin Steubing, has stated that the spring has never failed during his long tenure in the area, not even in the great drought of the 1950s.

As previously stated, Elm Waterhole may have originated around the middle of post-Pleistocene times, perhaps somewhat later. The formation of the sinkhole spring provided a permanent source of water for people and wildlife in an area where none previously existed. It also deflected a stream's course and converted an adjacent land area into a desirable occupation site. 


\section{ARCHAEOLOGICAL BACKGROUND}

\section{CHRONOLOGY OF SOUTH-CENTRAL TEXAS (Eric C. Gibson and PauT Katz)}

The following summary presents current concepts of the succession of cultures in south-central Texas. A more detailed summary of archaeological research in the general area is available in Hester (1980). In this discussion all dates for cultural-historical periods are considered approximate. The term "cultural-historical period" as used in this report indicates a range of behavioral and cultural activities and their observed traits documented within a broad but identifiable geographic and temporal parameter.

The cultural-historical periods related to south-central Texas prehistory are not fully understood, because only in the 1 ast 20 years have extensive excavations been conducted and radiocarbon dates obtained (Hester 1980:131). Diagnostic artifacts dated by radiocarbon have generally been reported from outside of Bexar County (e.g., the lower Pecos region to the west and the Edwards Plateau region to the north), and cross dating has usually been necessary. In the absence of published materials some of these data came from the site files of the Texas Archeological Research Laboratory (TARL), The University of Texas at Austin and the Center for Archaeological Research (CAR), The University of Texas at San Antonio.

\section{PALEO-INDIAN PERIOD (9200 to 6500 B.C.)}

Most archaeologists use the term Paleo-Indian when referring to the earliest human inhabitants of North America. Other terms such as "Early Man" or "Paleo-American" have an equivalent meaning but are used less frequently (Jennings 1974). Some archaeological data suggest that humans entered North America from eastern Asia as early as 30,000 years ago (Evans 1961; Krieger 1964; Gagliano 1967), al though these data still remain controversial. The professional consensus places the entry of Homo sapiens into North America during the terminal stages of the Wisconsin glaciation, ca. 13,000 to 11,000 B.C. (Jennings 1974; Adovasio et a 1. 1978, 1980). The range of welldocumented dates for Paleo-Indian occupation of North America falls between 9200 B.C. and 6500 B.C. (Hester 1980).

Freisenhahn Cave, located on the border of Comal and Bexar Counties, contained chipped stone objects from buried strata that also yielded the remains of Pleistocene mammals (Evans 1961). These chipped stone objects and some bone fragments are believed by some archaeologists to be artifacts. However, others contend that these specimens were modified by nature and not by humans. Thus, Freisenhahn Cave remains the south-central Texas representative to that group of controversial and problematic pre-Paleo-Indian sites in North America.

In south-central Texas, a major cultural tradition appears to be present in the area at ca. 9200 to 8500 B.C. This tradition is characterized by fluted points and includes all of the known Clovis and Folsom sites in the region (Hester 1976:5). Around 8200 B.C., the Plainview complex is recognized. During this early period, in Texas and on the western plains, megafauna such as giant bison, mammoth, came1, and horse was hunted. The "Big Game Hunters" 
have received much emphas is among students of North American prehistory; however, many sites (e.g., Lindenmeir, Blackwater Draw, Levi Rockshelter) show evidence that small game and wild plants were also important food resources (Jennings 1974).

Paleo-Indian occupation is indicated at several sites in Bexar County, and many of these sites are located within the Salado Creek watershed (i.e., the Salado Creek and its many tributaries; Fig. 4). The Panther Springs Creek site (41 BX 228) is a stratified site with occupational evidence from Late Paleo-Indian to Late Prehistoric times (B7ack and McGraw 1985). The stratified St. Mary's Hall site (41 BX 229) on a hillside overlooking the Salado Creek valley also yielded Paleo-Indian projectile points (Folsom, Plainview, Golondrina), a Plainview occupational component, as well as Archaic and Late Prehistoric artifacts (Hester 1979).

Most recently, investigations at the Peacock Bluff site (41 BX 52), in a 1 luvial/colluvial deposits adjacent to Leon Creek, yielded lithic assemblages indicating a Folsom occupation and possible early Clovis habitation in excellent archaeological context. This excavation was conducted by archaeologists of the State Department of Highways and Public Transportation (Hester 1980).

Sites in the Amistad Reservoir region, a transitional zone between southern and Trans-Pecos Texas, have produced subsurface evidence of Paleo-Indian occupations. Bone Bed II at Bonfire Shelter contained Folsom and Plainview points in direct association with extinct bison (Dibble and Lorrain 1968). The lowest level of the Devil's Mouth site contained Lerma, Angostura, Plainview, and Golondrina projectile points (Johnson 1964). Golondrina points dated to 7000 B.C. also occurred in the lowest cultural stratum at Baker Cave (Hester 1979). The Golondrina complex, found across much of south-central and southern Texas, existed within a post-Pleistocene environment.

Additionally many surface Paleo-Indian artifact finds have been reported from south-central Texas (e.g., Orchard and Campbe11 1954; Hester 1968; Howard 1971; Fawcett 1972; Howard 1974; Fox 1975; Kelly and Hester 1976; Cox 1977). Taken together, these data suggest that south-central Texas was extensively occupied by Paleo-Indian groups, especially in Late Paleo-Indian times (ca. $8000-6500$ B.C.).

ARCHAIC PERIOD (6500 B.C. to A.D. 750)

Early Archaic Period (6500-2600 B.C.)

Sollberger and Hester (1972) first described a Pre-Archaic culturalhistorical period. Alternatively, other researchers have objected to the use of the term "Pre-Archaic" and prefer to divide the Archaic into only three subperiods: Early, Middle, and Late (Story 1980:10).

Weir (1976), after a reexamination of the Archaic in central Texas, offered another chronological framework for that region, one based on cultural phases rather than chronological periods or subperiods. Weir's original seven 


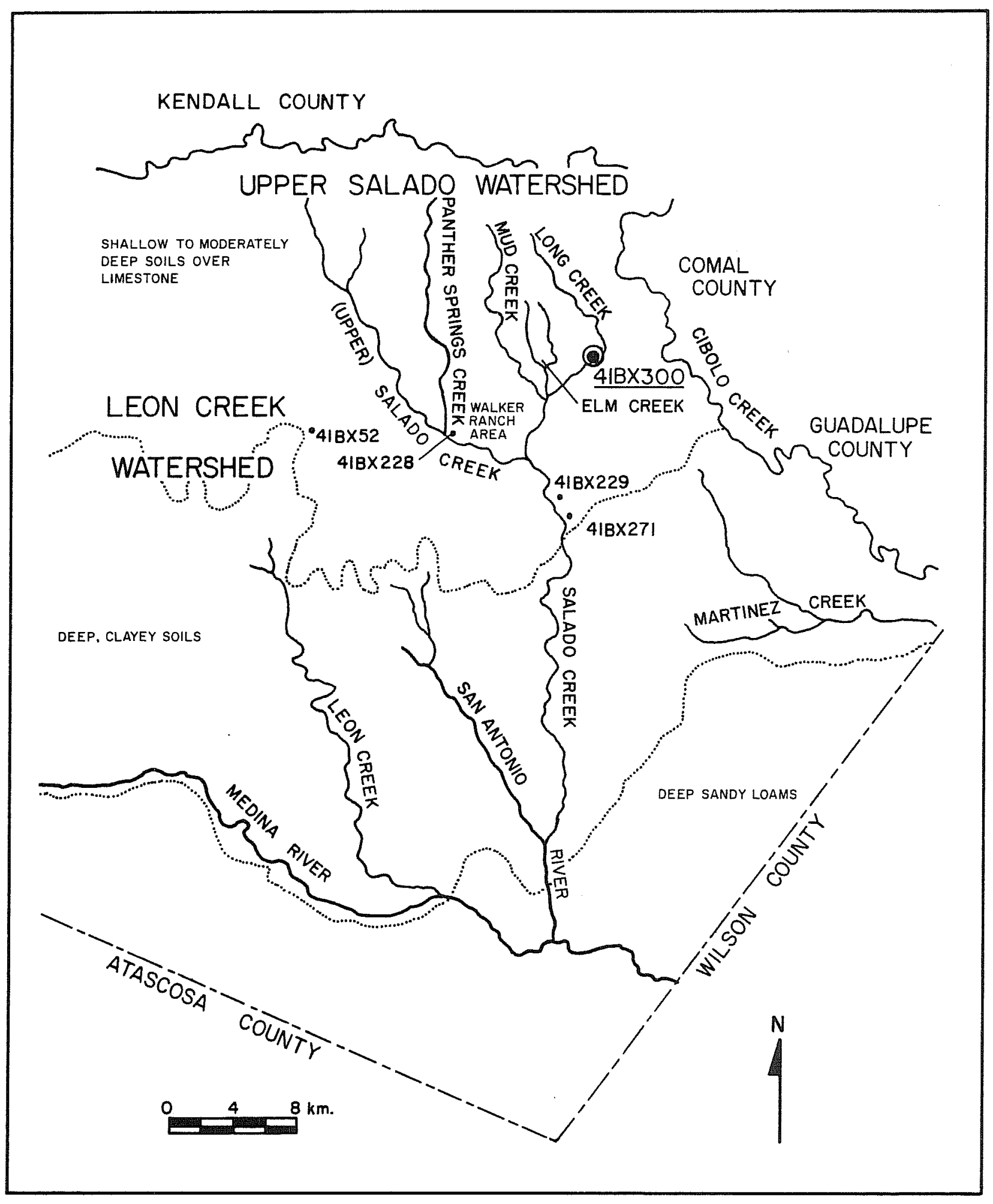

Figure 4. Upper Salado Creek Watershed. 
phases were later expanded to 11 by Prewitt (1981, 1983), while still maintaining the tripartite subdivision of the Archaic period. Table 1 provides a comparison of these various schemes.

The use of any of the Archaic period chronologies presented here is conditioned by how various archaeologists view the interval that follows the Paleo-Indian period. If it appears to be a transitional period, then a PreArchaic is usual7y recognized. If it appears distinctively Archaic, then the chronology favored by Story is frequently used. If one is working in central Texas, the phase model of Weir and Prewitt is often followed.

Paleoenvironmental data (Table 1) indicate the pinon pine parkland of Texas was gradual1y replaced by a grassland savanna early in the Early Archaic period (Bryant 1969; Bryant and Shafer 1977). In particular, the time span between ca. 5000 and 3000 B.C. may have been a period of prolonged aridity (Story 1980:12). This increasingly semiarid climate (cf. the "Altithermal" of the western United States) probabiy diminished the amount of available ground water.

The archaeological record shows that throughout Texas, as Pleistocene megafauna became extinct, more animals, such as bison, deer, rabbit, squirrel, and other small game, were hunted. Due to the aridity of the Early Archaic period, large game may have been scarce in the region (Dillehay 1974). During this interval, techniques and tools for hunting and plant processing gradually became more specialized. This technological specialization continued and became more pronounced in the subsequent Archaic period.

Early Archaic sites are interpreted as small hunting camps, and it is estimated that population densities were probably low throughout Texas (Sollberger and Hester 1972; Weir 1976; Story 1980). The Early Archaic settlement pattern has been summarized as follows (Story 1980:13):

The sites are characteristically sma11, widely distributed, and non-specialized. They are often surface or slightly buried scatters of lithic tools and debitage on knolls and fossil floodplains, many times mixed with later materials. Less common are components deeply buried in alluvial terrace deposits. When deeply buried components are found, they usually underlie larger Middle and Late Archaic occupations.

Typical Early Archaic projectile points are triangular, basally notched, corner-notched, and stemmed varieties (Table 1). Significant Early Archaic sites in central, southern, and western Texas are Landslide (Sorrow, Shafer, and Ross 1967), Jetta Court (Wesolowsky, Hester, and Brown 1976), 41 KE 49 (Kelly and Hester 1976), La Jita (Hester 1971), Baker Cave (Word and Douglas 1970), Devi1's Mouth (Johnson 1964), Devil's Rockshelter (Prewitt 1966), and Granberg II (Hester and Kohnitz 1975).

Middle-Late Archaic Periods (2600 B.C. to A.D. 750)

Paleoenvironmental data from south and central Texas indicate that drying conditions that began in the Early Archaic continued into the Middle Archaic 
period (Table 1). These data show that climatic fluctuation may have been more frequent in some regions and less so in others. Research conducted in central Texas has suggested that the driest interval in that area was from ca. 3000 to 2000 B.C. (Gunn and Weir 1976:32). These climatic fluctuations probably influenced, but did not determine, prehistoric human patterns of adaptation in these regions (Story 1980).

In terms of a general overview, Middle and Late Archaic sites are more numerous and varied than those of the preceding Early Archaic period. This phenomenon may indicate an increase in prehistoric populations (Story 1980). Many archaeologists have viewed this increase in population as a rather sudden occurrence (Sollberger and Hester 1972:338; Gunn and Weir 1976:32; Weir 1976:124). Recent calculations by Prewitt (1983) have demonstrated considerable fluctuations throughout the Archaic period.

Sollberger and Hester (1972) have also suggested that the arid conditions were ameliorated in Texas at this time and, therefore, the habitat became more productive. Additional1y, Hester (1981) has proposed that in south Texas, when food resources were (and are) irregularly spaced, short-term climatic fluctuations would have a greater adverse impact on the prehistoric inhabitants. It is suggested here that during times when adverse ecological impacts occurred in south Texas, the Salado Creek drainage system may have been more intensively occupied.

In south-central Texas, Middle and Late Archaic occupation sites vary in size, and it has been suggested that the size of the local groups changed with seasonal and spatial variations in food resources (story 1980:26). Southern Texas was predominantly characterized by a savanna (or prairie) vegetational pattern later in the Archaic period. But the region may have been as ecologically diverse then as it is now. At present, the most diverse food resources cluster along the major river systems (Rio Grande, Nueces, Frio, and San Antonio) and the coast (Hester 1981).

During the Archaic period, seed-bearing plants, succulents (such as prickly pear), and acorns became increasingly important food resources to the local inhabitants of south Texas. Methods of processing these foods also became more specialized, as is indicated by many grinding function artifacts (e.g., manos, metates). Characteristic of a majority of later Archaic period sites is the burned rock midden feature. As in the Early Archaic period, hunting continued to be focused on deer and smaller game. Evidence also suggests that bison were again present in the region. A study by Dillehay (1974) proposes that bison were present during two different periods, from approximately 10,000-6000/5000 B.C. (the Paleo-Indian period) and from 2500 B.C.A.D. 500 (the Middle-Late Archaic period). Dillehay further suggests that warmer climatic fluctuations may have caused these herd movements and subsequent regional abandonments.

The Middle-Late Archaic period (Table 1) in south Texas is characterized by such 1ithic artifacts as percussion-flaked triangular, leaf-shaped, and stemmed projectile points (e.g., Abasolo, Catan, Desmuke, Tortugas). In central Texas, Travis, Nolan, Pedernales, Bulverde, and Marshall are common Middle Archaic dart points; Marcos, Monte11, Castroville, Ensor, Frio, Fairland, and Darl are characteristic of the Late Archaic period. In both 
central and south Texas, other Archaic period artifacts are manos and metates, other rough stone artifacts, unifacial and bifacial choppers, Clear Fork gouges, various kinds of large scrapers, drills, and utilized flakes. "Perishable" artifacts such as baskets, nets, mats, fur, leather, cloth, sandals, cordage, wooden darts, atlat $1 \mathrm{~s}$, and clubs have been reported from Archaic components in southwest Texas rockshelters (Kelley 1959:281).

\section{LATE PREHISTORIC PERIOD (A.D. 750-1800)}

The Late Prehistoric lifeway bears many similarities in its settlement and subsistence patterns to the Archaic; and indeed Late Prehistoric components often overlie Archaic campsites. The Late Prehistoric period is distinguished from the preceding Archaic by a set of technological innovations, most notably the introduction of the bow and arrow. Sma11, very 1ight, and thin pressure-flaked projectile points of various types (Perdiz, Scallorn, Cliffton, Granbury) are diagnostic artifacts of the Late Prehistoric period (Table 1). The bow and arrow diffused into some regions of Texas earlier than in others, and thus the beginning of the Late Prehistoric period varies across the state (Table 1). Other indicators of this period are new kinds of lithic tools (blade technology, end scrapers, beveled knives) and the making of bone-tempered (Leon Plain) pottery.

\section{HISTORIC PERIOD (A.D. 1800 -present)}

The account of Cabeza de Vaca's travels through southern and western Texas during the $1520 \mathrm{~s}$ and $1530 \mathrm{~s}$ is the first documented contact between Spanish explorers and the aboriginal inhabitants. However, the Europeans had minimal cultural impact on the natives of south-central Texas until the arrival of the Spanish missionaries during the late 1600s (Hester 1980:160).

Southern and south-central Texas, throughout the Historic period, were the domain of numerous small bands of Indians who spoke coahuilteco ("Coahuiltecan") and other poorly known languages. Hester (1980:40) has summarized the lifeways of these bands as:

The Coahuilteco and other hunting and gathering Indians in southern Texas lived in small groups, each with a distinctive name and territory utilized for the hunting, plant food gathering and fishing necessary to obtain subsistence. They moved throughout their territories, sometimes overlapping into the territories of other groups, in a seminomadic fashion. More detailed population estimates are difficult, as many groups were often found in widely separated areas during the seventeenth and eighteenth centuries. Villages were established at favored locations near rivers or creeks, occupied for a short time, and then the group would move on.

As the missions were built and more Spaniards settled in south Texas, the cultural impact on the region's aboriginal populations resulted in their being missionized, displaced to remote areas, assimilated into SpanishMexican groups, or killed by European-introduced diseases. 


\section{REVIEW OF ARCHAEOLOGICAL INVESTIGATIONS IN BEXAR COUNTY (EriC C. Gibson)}

In recent years, Bexar County has been the focus of some of the most intensive archaeological research in Texas. A brief review of the county is provided here, and the reader is referred to Hester (1980) for a more detailed summary.

Prior to 1974, few archaeological projects had been conducted in Bexar County. The first documented investigation of Bexar County was in 1935 by S. W. Woolford (1935). Woolford discerned certain archaeological zones with specific kinds of sites. C. D. Orchard (1938) revised Woolford's assessment after his study of 01 mos Basin.

A long hiatus in published research followed, and it was not until 1954 that further archaeological work was reported from Bexar County. Orchard and Campbe11 (1954) published a description of Paleo-Indian materials collected by Orchard from the 01 mos Basin in the 1920s during the construction of 01 mos Dam. Orchard observed over 100 hearths, and Plainview and Angostura points were listed among the collection.

The next published investigations from Bexar County appeared in 1960. Schuetz (1960) identified a number of flintworking locations on Pleistocene gravels along the Martinez Creek drainage. In the vicinities of the $01 \mathrm{mos}$ Basin and San Pedro Park, Orchard and Campbell (1960) described a series of sites containing such southwestern ceramics as Reserve Black-on-White, Tularosa Black-on-White, and Las Lunas Smudged. These may be indicators of an extensive exchange network and are dated between A.D. 950-1250.

In 1964, Wise (1964) excavated the Robard site in northeastern Bexar County. This site was interpreted as a flintworking location situated on a hilltop. Several large bifaces were recovered from this site, and it was stylistically dated to the Archaic period.

During 1966, three archaeological investigations were reported from Bexar County. The Rogers site (41 BX 22), located on a tributary of the Salado Creek, contained Archaic and Late Prehistoric components (Fawcett 1970). The Cutaway site (41 BX 37) was a Paleo-Indian site reported by Uecker (1966). A Plainview projectile point and other artifacts associated with an ash lense were recovered from this site. The Granberg site was reported in detail by Schuetz (1966), who was associated with the Witte Memorial Museum in San Antonio. The Granberg site was also located in the Salado Creek drainage and was probably a large camp occupied from Early Archaic to Late Prehistoric times (Schuetz 1966:67-68).

An archaeological survey was conducted by Hsu and Ralph in 1968 along the Cibolo Creek drainage in adjacent Wilson County. Late Prehistoric and Archaic sites were recorded along large alluvial terraces (Hsu and Ralph 1968). Also in 1968, Givens (1968) reported on excavations conducted by Trinity University at the Hitzfelder Cave site in 1967. Givens made the controversial interpretation that the human remains recovered from Hitzfelder Cave (41 BX 26) were morphologically distinct from American Indian Homo sapiens populations. Givens also suggested the Hitzfelder Cave specimens were biologically a heterogeneous population that exhibited evidence of pre- 
sapiens ancestry or were pre-sapiens themselves. The implication meant that the site would date from the extreme Lower Paleolithic, or more than 250,000 years ago. Collins (1970) demonstrated that this was unlikely, and that the morphological crania attributes discussed by Givens fell well within the range of Archaic period Homo sapiens populations from Texas. Furthermore, Middle and Late Archaic points were found with these skeletal materials (Co11 ins 1970:301).

In 1970, W. B. Fawcett, Jr., became actively involved in the archaeology of Bexar County (e.g., Fawcett 1970; Fawcett and McGuff 1970). This interest culminated in a published overview of the prehistory of Bexar County (Fawcett 1972).

In 1971 , C. D. Howard reported on surface finds of Paleo-Indian points in southern Bexar County, south of the Medina River (Howard 1971). Also in 1971, the Texas Archeological. Survey conducted the initial reconnaissance of the Salado Creek watershed (Dibble 1979). One of their field recorded sites was subsequently designated 41 BX 300. During 1973, Scurlock and Hudson (1973) published their initial findings from the Walker Ranch, which is also situated in the upper Salado Creek drainage.

In 1974, the Center for Archaeological Research (CAR-UTSA) was created and immediately became actively involved in archaeological investigations in south-central Texas (Hester 1974). Additionally, 1974 was the year that the Southern Texas Archaeological Association (STAA) began publishing its journal, La Tierra, which furthered the documentation of archaeological research in Bexar County.

Since their inception in 1974, the CAR and the STAA have been extremely active in Bexar County and elsewhere in south, south-central, and southwestern Texas. By 1986, in Bexar County alone there are close to 600 recorded archaeological sites, where there were fewer than 50 in 1974 . This is an average of 45 sites per year, and the CAR and STAA are almost total1y responsible for this impressive archaeological achievement. In addition to site recording, both organizations have participated in the assessment, testing, and mitigation of numerous sites, one of which was 41 BX 300 .

\section{THE PANTHER SPRINGS CREEK SITE (41 BX 228)}

Site $41 \mathrm{BX} 228$ is located approximately $10 \mathrm{~km}$ southwest of $41 \mathrm{BX} 300$, near the confluence of Panther Springs Creek and the upper Salado Creek (Fig. 4). Survey and testing activities between 1973 and 1978 had determined that the site was multicomponent, multifunctional, and quite rich in artifactual material and cultural features. Ongoing and uncontrolled looting activity was causing partial destruction of the site, and additional impact was anticipated directly from a Soil Conservation Service flood control project and indirectly from surrounding urban development. As a site within the Walker Ranch National Register Historic District, funds were provided in 1978 by the National Park Service, Rocky Mountain Region to conduct archaeological mitigation under the same contract (C3561[78]) as 41 BX 300. 
Investigations at the site were conducted during the six months from JulyDecember 1979. A wide range of methods was employed, including shovel tests, test squares, block excavation units, and backhoe trenches. Techniques for data recovery consisted of surface collection, hand and mechanical investigation, screening, extensive profile drawing, and the collection of samples of nonartifactual materials in variety and quantity. Among the most important aspects of the research design were the investigation of multiple burned rock features, the elucidation of the Early Archaic occupation period identified in the backhoe trenches, and the integration of this extensive and complex site into the larger patterns of prehistoric life in the upper Salado creek watershed.

As a result of the archaeological mitigation of 41 BX 228 , it is now well documented that "the Panther Springs Creek site, 1 ike many central Texas sites, was intermittently occupied over a relatively long time span (at least 5000 years)" (Black and McGraw 1985:272). From this investigation, a series of components was identified, described, and ordered into a sequence of local periods representing a substantial portion of the prehistory of the upper Salado Creek watershed. The earliest major occupation (Local Period 5), with a radiocarbon date of 3380 B.C., falls within the Early Archaic regional cultural period (Table 1). "The Local Period 5 component, although distinct from succeeding components, begins a long occupational sequence exhibiting considerable cultural continuity through time. Deer hunting and chipped stone tool making remain important activities throughout the succeeding components" (B1ack and McGraw 1985:275). These occupational components continue throughout the Archaic and Late Prehistoric regional cultural periods, concluding with Local Periods 10/11 radiocarbon dated at A.D. 980 (Table 1).

\section{VICINITY OF 41 BX 300 (PauT D. Lukowski)}

Archaeological activity in the vicinity of Elm Waterhole has been reported over a period of 40 years (Kelly 1976). Professional archaeological investigations, however, on $7 y$ began a decade ago, in 1971. During August through November 1971, the Texas Archeological Survey Project, The University of Texas at Austin conducted a survey of the upper Salado Creek watershed (Fig. 4) prior to the construction of a series of floodwater retarding structures by the Soil Conservation Service (SCS). Fifteen potential dam sites were investigated, surface collections were made, and limited shovel testing was conducted (Dibble 1979).

At the proposed location of Floodwater Retarding Structure 13-A, six archaeological sites were recorded and numbered 1-6 (Dibble 1979:22). It is these six sites that were later re-recorded in 1975, when the Soil Conservation Service contracted with the CAR-UTSA to inventory the prehistoric resources in the Floodwater Retarding Structure 13-A project area. In 1976, an intensive survey and testing program were conducted by the CAR (Hester, Katz, and Kelly 1977). Monitoring of the sites between 1976 and 1978 led to the final phase of investigations, the activities reported herein. 
Figure 1 indicates the relationship of the six prehistoric sites to Floodwater Retarding Structure 13-A. The 1971 arabic designations have been superseded by official trinomial site numbers: 41 BX 299, 41 BX 300 , $41 \mathrm{BX} 301,41 \mathrm{BX} 484,41 \mathrm{BX} 485$, and $41 \mathrm{BX} 486$.

\section{THE MENGER COLLECTION}

The number and variety of prehistoric artifacts collected by various people in the Elm Waterhole vicinity are best documented by an extensive collection from the Menger brothers. A quantity of projectile points (Table 2), bifaces, and gouges, representative of different Archaic periods, were donated to the CAR-UTSA for analysis. These artifacts are reportedly from the Elm Waterhole Creek drainage, near 41 BX 300 . The Mengers also carried out small, uncontrolled excavations within the northern portions of the burned rock midden at $41 \mathrm{BX} 300$ and have reported the location of other burned rock middens along Elm Waterhole Creek and other streams in the area.

\section{PHASE I ACTIVITIES AT $41 \mathrm{BX} 300$}

A surface reconnaissance was conducted by a two-man survey team, directed by Thomas C. Kelly, in the vicinity of 41 BX 300 in October 1975, under contract with the Soil Conservation Service, in order to inventory the prehistoric resources prior to construction of a floodwater retarding structure. This survey was part of a continuing series of surface surveys being conducted at that time by the CAR within the Salado Creek watershed. A total of 294 acres was surveyed in the area to be impacted by Floodwater Retarding Structure 13$A$ (Ke11y 1975). During this time, three sites were recorded (41 BX 299, $41 \mathrm{BX} 300$, and 41 BX 301). Sites 41 BX 299 and 41 BX 301 were identified as extensive quarry workshops, and 41 BX 300 was described as a large open campsite (Fig. 1). A 7ight lithic scatter, Tater designated 41 BX 486, was noted at this time, although indications during the Phase I survey were not sufficient to warrant site designation at that time (Kelly 1975). Sma11, general surface collections were made at 41 BX 300 and 41 BX 301; additionally, several test units and small shovel tests were excavated at 41 BX 300 (Table 3). The subsequent recommendations for sites 41 BX 300 and 41 BX 301 resulted in Phase II activities.

\section{PHASE II ACTIVITIES AT 41 BX 300}

As a result of the recommendations presented at the conclusion of Phase $I$, 41 BX 300 and 41 BX 301 were contracted for additional work during JanuaryMarch 1976. An intensive survey of 41 BX 301 was conducted by Katz (1978); the work was directed at sampling this extensive quarry workshop and mapping the cultural and material resource areas. Field work at 41 BX 300 involved power augering to help delineate site boundaries and the excavation of additional test pits located in various areas of the site (Fig. 5,a,b; Table 3). Thomas C. Kelly directed the efforts at 41 BX 300 with volunteers from the STAA and The University of Texas at San Antonio anthropology classes (Hester, Katz, and Kelly 1977). The test units and auger holes located a large burned rock midden and at least two occupation areas. The occupation 
TABLE 2. FREQUENCY OF PROJECTILE POINT TYPES WITHIN THE MENGER COLLECTION DONATED TO THE UNIVERSITY OF TEXAS AT SAN ANTONIO FOR ARCHAEOLOGICAL RESEARCH

a. FREQUENCY BY QUANTITY

\begin{tabular}{lcc}
\hline Type Designation & $\begin{array}{r}\text { Number of Specimens } \\
\text { per Type }\end{array}$ & $\begin{array}{r}\text { Percentage of Total } \\
\text { per Type }\end{array}$ \\
\hline Pedernales & 66 & 25 \\
Monte11 & 27 & 10 \\
Marshal1 & 21 & 8 \\
Frio & 18 & 5 \\
Uvalde & 14 & 5 \\
Martindale & 12 & 4 \\
Ensor, Edgewood, Castrovil1e & 11 & 3 \\
Marcos & 9 & 3 \\
Tortugas, Lange & 8 & 3 \\
Nolan, Marcos-1ike & 7 & 2 \\
Angostura, Early Barbed, & & $<1$ \\
Travis, Triangular & 5 & $<1$ \\
Ensor-Frio, Langtry, Williams & 2 & \\
Bel1, Early Corner Notched, & & \\
Fairland, Gower, La Jita & 1 & \\
\hline
\end{tabular}

b. FREQUENCY BY CULTURAL PERIOD

\begin{tabular}{|c|c|c|c|c|c|}
\hline \multicolumn{2}{|l|}{ Early Archaic } & \multicolumn{2}{|c|}{ Middle Archaic } & \multicolumn{2}{|c|}{ Late Archaic } \\
\hline $\begin{array}{c}\text { Type } \\
\text { Designation }\end{array}$ & $\begin{array}{l}\text { umber of } \\
\text { pecimens } \\
\%\end{array}$ & $\begin{array}{c}\text { Type } \\
\text { Designation }\end{array}$ & $\begin{array}{c}\text { Number of } \\
\text { Specimens } \\
\%\end{array}$ & $\begin{array}{c}\text { Type } \\
\text { Designation }\end{array}$ & $\begin{array}{c}\text { Number of } \\
\text { Specimens } \\
\%\end{array}$ \\
\hline $\begin{array}{l}\text { Uvalde } \\
\text { Martindale } \\
\text { Tortugas } \\
\text { Angostura } \\
\text { Early Barbed } \\
\text { Triangular } \\
\text { Bell } \\
\text { Early Corner Notched } \\
\text { Gower }\end{array}$ & $\begin{array}{r}14 \\
12 \\
8 \\
5 \\
5 \\
5 \\
1 \\
1 \\
1 \\
1\end{array}$ & $\begin{array}{l}\text { Pedernales } \\
\text { Marshal } \\
\text { Lange } \\
\text { Nolan } \\
\text { Travis } \\
\text { Langtry } \\
\text { Williams } \\
\text { La Jita }\end{array}$ & $\begin{array}{r}66 \\
21 \\
8 \\
7 \\
5 \\
2 \\
2 \\
1\end{array}$ & $\begin{array}{l}\text { Montel1 } \\
\text { Frio } \\
\text { Ensor } \\
\text { Edgewood } \\
\text { Castrovil1e } \\
\text { Marcos } \\
\text { Marcos-1 ike } \\
\text { Ensor-Frio } \\
\text { Fairland }\end{array}$ & $\begin{array}{r}27 \\
18 \\
11 \\
11 \\
11 \\
9 \\
7 \\
2 \\
1\end{array}$ \\
\hline Total & $\begin{array}{c}52 \\
(20 \%)\end{array}$ & & $\begin{array}{c}112 \\
(43 \%)\end{array}$ & & $\begin{array}{c}97 \\
(37 \%)\end{array}$ \\
\hline
\end{tabular}


TABLE 3. 41 BX 300 EXCAVATION STATISTICS: PHASES I AND II

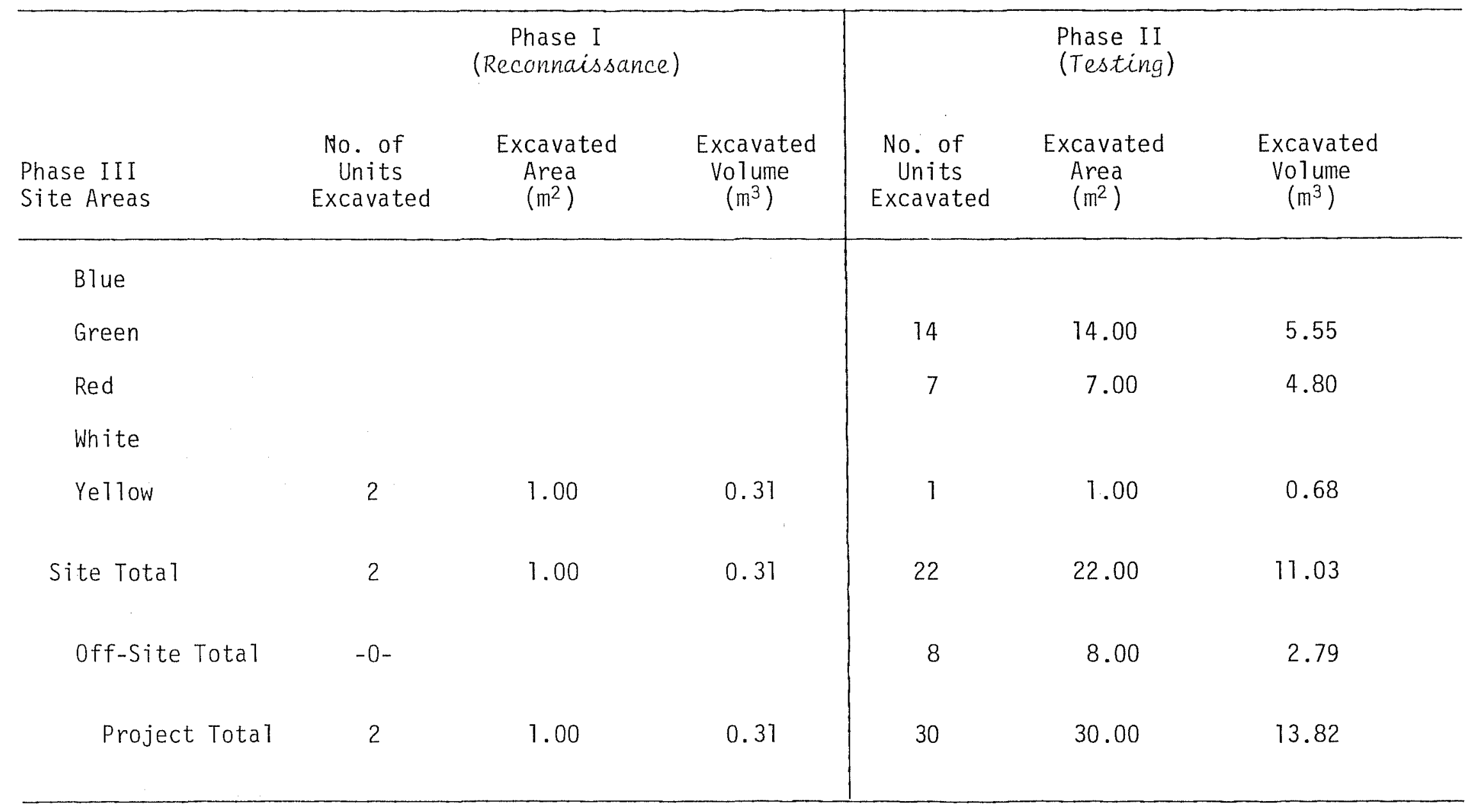


Site 41 BX 300/Archaeological Background

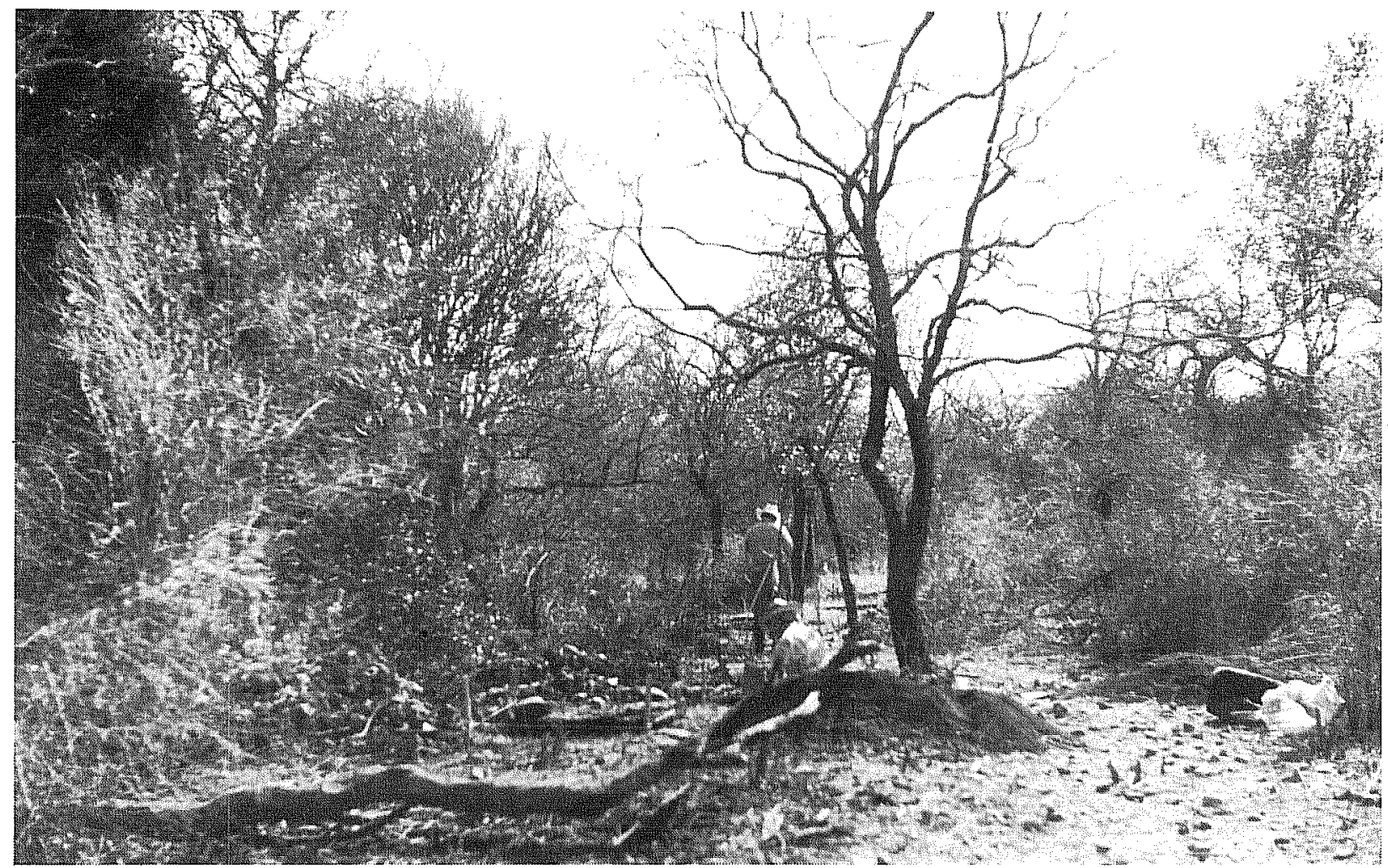

a

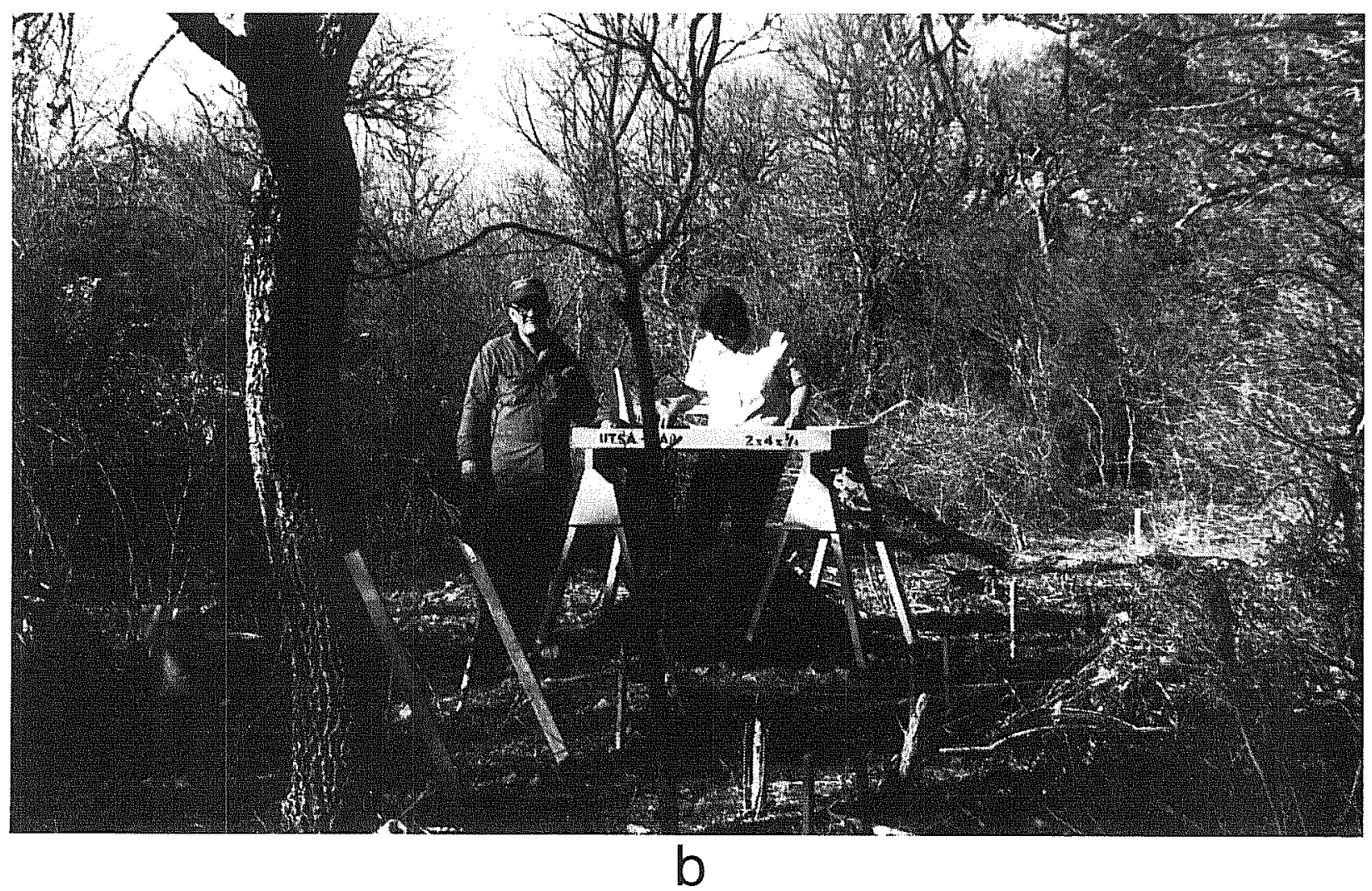

Figure 5. Phase II Testing. a, cleared survey lane shown; b, screening of excavated matrix, Thomas C. Kelly at 1eft, Shirley Van Der Veer at screen. 
areas seemed to indicate the presence of multiple components, both vertically and horizontally distinct.

It was during the Phase II work that the potential for providing valuable scientific data was reinforced at 41 BX 300 . Negotiations were carried out by $\mathrm{Dr}$. Thomas R. Hester and the SCS to provide for the protection of 41 BX 300 during construction activities. The result was to pedestal the site, as the surrounding soil was removed for dam fill. Observations of the sides of the site exposed by pedestaling indicated the possibility of further vertical differentiation of cultural groups.

After construction operations were completed, three new sites were identified in the disturbed soil: 41 BX 484, 41 BX 485, and 41 BX 486. Previous to their partial destruction, these sites had been noted as areas with light flake scatters, and they had been subjected to a controlled surface collection (Table 4).

\section{THE SITES}

\section{Site 41 BX 484}

Site $41 \mathrm{BX} 484$ is 10 ated $180 \mathrm{~m}$ north-northeast of the $41 \mathrm{BX} 300$ central datum (Fig. 1). Most of the site was removed during borrow activities in 1976. However, two test pits (1- x 1-m units) were excavated on what is now believed to be the northern limits of the site. Additional work at the site consisted of a controlled surface collection of $300 \mathrm{~m}^{2}$, organized by laying out 12 continuous pairs of $5-\times 5-m$ units, and including the two excavated test units. Surface collections produced one Castroville projectile point, one Marshall projectile point, 11 biface fragments, 22 scrapers, 59 retouched flakes, and 261 unmodified flakes. Surface indications were of a moderately light (under 20 flakes per square meter) lithic scatter, although two adjacent collection units produced 70 and 117 flakes, respectively.

The two excavated units yielded moderately dense subsurface concentrations. One unit produced the following inventory from Level $1(0-15 \mathrm{~cm})$ : a Castroville point, a Marshall point, the distal end of a biface, three scrapers, a blank, four retouched flakes, 51 primary flakes, 88 secondary flakes, and 595 interior flakes. Level $2(15-30 \mathrm{~cm})$ produced only unmodified flakes (two primary flakes, 23 secondary flakes, and 108 interior flakes). Only one level $(0-15 \mathrm{~cm})$ was excavated in the second unit; this produced one unidentified projectile point, five biface fragments, three cores, 22 scrapers, 15 retouched flakes, 12 primary flakes, 193 secondary flakes, and 519 interior flakes. A general surface collection after construction activities were completed yielded projectile points of the Bulverde (one), Darl (six), Monte11 (one), and Pedernales types. Table 4 provides a summary of the site collection.

\section{Site 41 BX 485}

Site $41 \mathrm{BX} 485$ is $10 \times 50 \mathrm{~m}$ in size, situated $180 \mathrm{~m}$ south-southwest of the 41 BX 300 central datum (Fig. 1). It is identified as a buried burned rock 
TABLE 4. SUMMARY OF RECOVERED SPECIMENS AT SITES IN THE VICINITY OF FLOODWATER RETARDING STRUCTURE 13-A， 1975-1976

\begin{tabular}{|c|c|c|c|c|c|c|c|}
\hline Specimens & $41 \mathrm{~B} \times 484$ & $41 \mathrm{BX} 485$ & 41 BX 486 & 41 BX 299 & $41 \mathrm{~B} \times 301$ & $\begin{array}{l}41 \text { BX } 300 \\
\text { Phase I }\end{array}$ & $\begin{array}{l}41 \text { BX } 300 \\
\text { Phase II }\end{array}$ \\
\hline \multicolumn{8}{|l|}{$\begin{array}{l}\text { CHIPPED STONE MANUFACTURING } \\
\text { AND MAINTENANCE }\end{array}$} \\
\hline Cores & & & & 28 & 26 & & 4 \\
\hline Chunks & 4 & 24 & & & & & 1273 \\
\hline $\begin{array}{l}\text { Interior flakes } \\
\text { Platform cortex flakes }\end{array}$ & 1433 & 625 & + & 38 & 9 & 847 & $\begin{array}{r}17,838 \\
525\end{array}$ \\
\hline Secondary flakes & 348 & 168 & + & 186 & 10 & 216 & 2406 \\
\hline Primary flakes & 78 & 30 & + & 728 & 72 & 68 & 639 \\
\hline Blanks & 1 & & & + & 3 & 5 & 16 \\
\hline Tested nodules & & & & & 44 & & 4 \\
\hline \multicolumn{8}{|l|}{ OTHER CHIPPED STONE TOOLS } \\
\hline $\begin{array}{l}\text { Perforators, gravers, } \\
\text { and notches }\end{array}$ & & & & & & & 75 \\
\hline Retouched flakes & 69 & 26 & & & 3 & 2 & 161 \\
\hline Guadal upe tools & & & 2 & & & & 2 \\
\hline Unifaces and fragments & 58 & 12 & & + & & 4 & 3 \\
\hline Bifaces and fragments & 23 & & & + & & & 144 \\
\hline \multicolumn{8}{|l|}{ PROJECTILE POINTS } \\
\hline Unidentifiable dart points & 10 & & + & & & & 37 \\
\hline $\begin{array}{l}\text { Paleo-Indian dart points } \\
\text { Early Archaic dart points }\end{array}$ & & & & & 1 & & \\
\hline Early Archaic dart points & 1 & & & & & & 1 \\
\hline Middle Archaic dart points & 6 & & & & 1 & 4 & 14 \\
\hline $\begin{array}{l}\text { Late Archaic dart points } \\
\text { Arrow points }\end{array}$ & 9 & & & 1 & 1 & 4 & $\begin{array}{r}19 \\
4\end{array}$ \\
\hline & & & & & & & \\
\hline MINERALS & & 63 & & & & & 86 \\
\hline \multicolumn{8}{|l|}{ ORGANIC MATERIALS } \\
\hline Other land snails & & 59 & & & & & 1156 \\
\hline Rabdotus & & 120 & & & & & 8831 \\
\hline Vegetal material & & & & & & & 1 \\
\hline Seeds & & & & & & & 8 \\
\hline Bones & & & & & & & 76 \\
\hline \multicolumn{8}{|l|}{ HISTORIC PERIOD } \\
\hline Ammunition & & & & & & & 1 \\
\hline Metal & & 13 & & & & & \\
\hline GTass & & & & & & & 5 \\
\hline Rough stone & & & & & & & 2 \\
\hline
\end{tabular}


midden. The midden was located immediately west and upslope from two test pits excavated in 1976. Material recovered in 1976 from Level 1 of a test pit included red ochre, yellow ochre, hematite, 25 primary flakes, 59 secondary flakes, and 354 interior flakes. Level $2(15-30 \mathrm{~cm})$ contained a distal biface fragment, five scrapers, 13 retouched flakes, five primary flakes, 105 secondary flakes, and 265 interior flakes. Data on material from the other test pit is not available. Table 4 summarizes the site collection.

\section{Site 41 BX 486}

Site 41 BX 486 was initially noted as a very light lithic scatter during $41 \mathrm{BX} 300$ Phase I investigations. The site is $70 \mathrm{cated}$ on the east bank of E1m Waterhole Creek, $200 \mathrm{~m}$ south of the 197841 BX 300 central datum (Fig. 1). Site size was estimated at $50 \times 75 \mathrm{~m}$, but only after it was disturbed by construction activity. The site is in a flat area slightly elevated above the stream. A scatter of flakes, two Guadalupe tools, and a small collection of Late and Early Archaic projectile point types were collected at this site (Table 4).

\section{Site 41 BX 299}

Site 41 BX 299 is located approximately 100 m southeast of the 41 BX 300 central datum, across what was once a small intermittent stream (Fig. 1) which has since been enlarged by borrow activities. Cultural material covered a surface area $30 \times 45 \mathrm{~m}$ adjacent to the bank, with the major axis running east to west. The soil is a thin, brown clay loam with limestone and chert exposed throughout the site.

A strip of six contiguous $5-\times 5-m$ units, or an area of $150 \mathrm{~m}^{2}$, was laid out through the long axis of the site and then surface collected. Given the original site size estimates, this surface collection represents a $9 \%$ sample of the site area. A17 humanly altered chert was collected, and subsequent analys is indicated that every available piece of chert had been altered in one manner or another (Kelly 1975).

The artifact inventory included a Fairland projectile point, quarry blanks, unifaces, preforms, and large chunks of chert, probably representing exhausted cores and core fragments. Additionally, 952 flakes were collected (Table 4).

Analysis indicated that flake type frequency decreased from primary flakes to secondary flakes to interior flakes (Table 4). Combined with the high incidence of roughly chipped stone tool forms, such as preforms and quarry blanks, and the relative scarcity of finished tools (only one dart point was recovered), the site was designated a quarry workshop.

\section{Site 41 BX 301}

During the 41 BX 300 Phase I survey, 41 BX 301 was recognized as a very large chert quarry on the southern slope of a hi17 $700 \mathrm{~m}$ west of the $41 \mathrm{BX} 300$ 
central datum and across a shallow drainage (Fig. 1). Site size is $400 \mathrm{x}$ $300 \mathrm{~m}$. During Phase II activities (Katz 1978), a grid of 100- x 100-m units was established for the site, and all lithic use and source localities were mapped by unit. During this activity, a parallel-flaked bifacial blade, a Pedernales point base, and an Edgewood-7ike projectile point were recovered. Additionally, a grid was laid out for a $25-\mathrm{m}^{2}$ dense use and source locality for detailed field analysis of 1ithic materials. Eleven of the 25 units were investigated (a $44 \%$ random sample). A virtual absence of quarry blanks and tools was recorded; the most common artifacts present were "tested cobbles" and primary flakes (Table 4).

Katz (1978:7) suggested a "test and retrieve" behavioral pattern for this site. Whether or not the artifacts were removed to another work (use) area within the site or the tested cobbles were completely removed to another Tocality (perhaps $41 \mathrm{BX} 300$ ) is unknown.

\section{Site 41 BX 300}

When 41 BX 300 was first recorded in 1975, it was immediately recognized as a major open campsite with extensive boundaries (Fig. 1). Two small units $(0.50 \times 1 \mathrm{~m})$ were excavated in the side of a SCS geological test pit (Fig. 11) to obtain profiles and to gain some perspective on the extent and nature of cultural depositions. In addition, a small surface collection was made, and small shovel tests were located around the site to assist in estimating the boundaries. The soil profiles indicated dark clayey soils, minimally $50 \mathrm{~cm}$ deep, overlying sterile bedded yellow gravels. Two Frio, two Monte11, and four Pedernales projectile points were recovered from the test pits. Also, one biface, two retouched flakes, and 1107 unretouched flakes were recovered.

Phase II activities carried out in 1976 resulted in 29 additional $1-\mathrm{m}^{2}$ units, widely spaced around the site (Fig. 5,a,b). In addition, a program of extensive power augering was conducted across the site in an attempt to establish its periphery. The excavations located one burned rock midden (designated Area Red) and a Late Archaic and Late Prehistoric activity area (designated Area Green). Diagnostic artifacts in identifiably distinct horizontal and vertical contexts were projectile points relatively dated from the Early Archaic to the Late Prehistoric periods. Table 4 provides a summary of a 11 material recovered during the Phase I (reconnaissance) and Phase II (testing) activities at $41 \mathrm{BX} 300$.

Immediately after completion of the testing program, borrow activities at the site began. Through negotiations between the SCS and the CAR-UTSA it was agreed to modify the proposed borrow area which would have resulted in the destruction of the site. Circumferential borrowing continued around the remaining three areas of the site area, resulting in a pedestal 12 feet above the surrounding floodpool areas.

Profiles exposed around the periphery of the remaining site showed an even more complex and deeper site than the Phase II testing had indicated. Deep sections were revealed in the northwest portion (later designated Area Blue), and more evidence of horizontally separate components was suggested by 
artifacts eroding from all sides of the site. It soon became apparent that erosion of the pedestaled sides of the site would lead to its rapid destruction. Due to its National Register status (41 BX 300 was nominated to the National Register of Historic Places in 1976), funds for archaeological mitigation were provided by the National Park Service, Rocky Mountain Region under the provisions of Public Law 93-291.

\section{SUMMARY}

Although only 1 imited work was conducted at the six sites, evidence of a prehistorically popular area was indicated. Of the six sites, two (41 BX 299 and $41 \mathrm{BX} 301$ ) are chert quarry areas, apparently serving $41 \mathrm{BX} 300$ and the other sites in different capacities. Sites 41 BX 300, 41 BX 484, and 41 BX 486 show ample evidence of being open campsites; and it is likely that $41 \mathrm{BX} 485$, with its high concentration of tool forms, also represents a campsite. However, the amount and diversity of the cultural deposits at, and the physical extent of, 41 BX 300 indicated that it was the primary locus of activity in the area.

The most significant aspects of prehistoric human behavior brought to light by the previous research in the area are: (1) the clustering of occupational sites around Elm Waterhole (Fig. 1); and (2) the differences reflected within the inventories of the chert quarries in the area.

The sites occurring along the stream channel in the immediate vicinity of 41 BX 300 indicate a preferred habitation area extant during the Archaic and Late Prehistoric cultural periods. A series of burned rock middens reported by the Menger family just outside of the study area of 41 BX 300 tends to support this view. This pattern is further reflected in other areas along the Edwards Plateau boundary in Bexar County (Gerstle, Kelly, and Assad 1978:195-213; Fig. 4).

The quarry sites reflect different resource utilization patterns, possibly relating to their proximity to adjacent sites and/or the quality of the material available. The distance between 41 BX 301 and 41 BX 300 is $700 \mathrm{~m}$. This distance may be a factor in the differential utilization patterns expressed between $41 \mathrm{BX} 301$ and 41 BX 299, the 7atter 1ocated less than $100 \mathrm{~m}$ from 41 BX 300.

Katz (1978) demonstrates that the proportionally high occurrence of primary flakes and tested cobbles, and an unusual absence of quarry blanks, rough tools, and cores, probably reflect what he terms "a test and retrieve" resource procurement strategy at 41 BX 301 . This contrasts with the increase in secondary flakes and the more common occurrence of rough tool forms and cores noted at 41 BX 299 (Table 4), which indicates some tool processing prior to transporting the chert resources to other locations. It may be that there was a tendency for specific trips to 41 BX 301 to gather cobbles and return them, essentially unaltered, to a campsite, while the closer (and smaller) quarry (41 BX 299) may have been utilized more often, resulting in heavier concentrations of 1 ithic reduction debris. In other words, the minimum amount of effort needed to quickly retrieve material from 41 BX 299 and the ability to do so without losing contact with a nearby camp area may 
have made the site a more desirable location for small, quickly needed supplies of chert. To obtain larger amounts of raw materials for major tool production, however, it is suggested that planned procurement trips to 41 BX 301 may have been necessary.

\section{RESEARCH DESIGN}

Mitigation activities at 41 BX 300 represented the 1 ast opportunity to retrieve valuable cultural and behavioral data before the dual effects of flooding and erosion took their toll. Earlier phases of investigation had indicated that the site was as potentially complicated as it was rich. There was depth to the site, with definite evidence for multiple episodes of human occupation. In addition, different areas of the site yielded chronologically different material, which suggested horizontally distinct components as well. As a final complication, different types of burned rock features, such as a midden, hearths, and a scatter, were identified in distinct areas of the site.

A detailed research design was developed to guide the field investigations, structure the subsequent analyses, and provide a framework for the interpretations. There are three components, or dimensions, to the design. First, there are a series of 10 objectives which the project intended to achieve through field work and subsequent analysis of recovered artifacts, ecofacts, and special samples. One or more of these objectives was al so subsumed within at least one of four hypotheses, which the project proposed to test. These two dimensions of the design are graphically presented as a matrix in Table 5. The third dimension is space, in that the different areas of the site which were suspected of representing chronologically distinct occupation episodes were identified and individually investigated.

\section{RESEARCH OBJECTIVES}

Of the following 10 objectives, the first nine were provided in the scope of work prepared by the National Park Service for this mitigation project. Some are considered problems important for south-central Texas archaeology, and others are presented as more general anthropological issues. It is clearly stated in the scope of work that these problems, both local and general, represent only a minimal set of problems that could be addressed by this research project. However, we considered this 1 ist to be fairly comprehensive, and only one additional objective was added. Our primary expansion of the scope of work was to reformulate these objectives into four testable hypotheses. Each of the 10 objectives was considered achievable in its own right, and they retained their identity during the field work, analysis, and interpretive phases of the project. The 10 research objectives are briefly stated; the degree of their achievement will be considered in the Summary and Evaluation section of this report.

1. To define the function(s) of burned rock features, including middens, concentrations, and scatters, identified at the site.

2. To reconstruct the accumulation processes of these features. 
3. To define the functions of specific artifacts and tool kits recorded during the investigation.

4. To identify and chronologically order artifact assemblages identified at the site.

5. To conduct functionally oriented lifeway analyses employing material recovered during the investigation.

6. To identify specific activities by means of activity area analyses.

7. To determine the relative sizes of population aggregates occupying the site through time.

8. To identify subsistence organization and 1 and and resource utilization at different periods of site occupation.

9. To conduct diachronic studies of sociocultural stability and change in hunting-gathering groups frequenting the site and its vicinity.

10. To reconstruct climate and the natural environment of the site vicinity through time.

TABLE 5. RESEARCH DESIGN MATRIX: OBJECTIVES AND HYPOTHESES

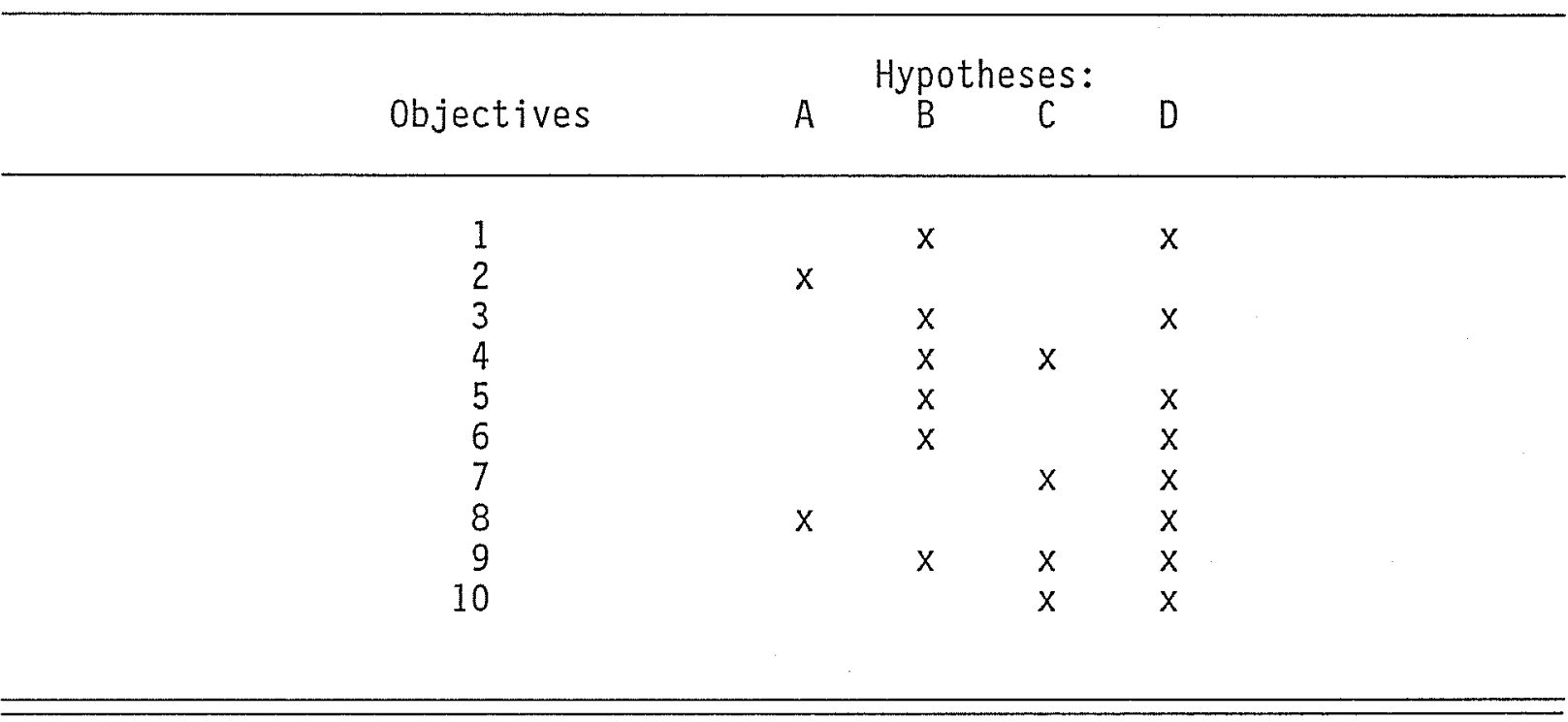

\section{Research Hypotheses}

The following hypotheses were developed by Dr. Joel Gunn, of The University of Texas at San Antonio, one of the co-principal investigators of this 
project, as part of the ongoing research being conducted by the UTSA Center for Archaeological Research which is concerned with central and south-central Texas. The hypotheses are presented in the light of testable objectives to be achieved by the subsurface investigations at 41 BX 300 . The research hypotheses are again examined in the Summary and Evaluation section of this report in order to assess the data obtained through mitigation activities at $41 \mathrm{BX} 300$.

\section{A. Positive Sedimentation Hypothesis}

This hypothesis investigates the relationships between physiography and the amount of deposition, both cultural and natural, at archaeological sites. An inverse relationship has been demonstrated between the presence of physiographic restraints and the concentration of human activity. Where the terrain is relatively flat and open, sites tend to be extensive but shallow. By contrast, where there are slopes, bluffs, and terraces, the sites tend to be smaller in area and more extensive in depth. These relationships have been empirically demonstrated by several extensive surveys conducted by the UTSA Center for Archaeological Research, such as that for the 201 Wastewater Treatment project (Fox 1977; Gunn, Ivey, and Hester 1977) and the Fort Sam Houston project (Gerstle, Kelly, and Assad 1978).

The buildup of sediment at sites characterized by physical restraints is thought to occur as follows. The limited physical space results in repeated occupation in a small area, perhaps even the same spot. This intensity of human activity results in more intensive and luxuriant plant growth, due to reasons such as the disturbed soil, chemical additives, and the introduction of additional plant material through human agents. More vegetation in this restricted space, coupled with the presence of burned rock debris deposited at certain cultural phases, act as a sediment trap, and soil accumulates at a faster rate than would normally be the case.

Site 41 BX 300 represents a good test of this hypothesis. It is a deeply stratified site situated in a very restricted physical space. Burned rock is known to be present. What will be tested is not so much the basic relationship, which seems to be well in evidence, but rather the corollary that more intensive human occupation will result in a faster buildup of soil. This quantitative relationship can be tested by studying the relationship between different phases of cultural occupation and the dimensions of their associated soil zones.

\section{B. Occupation Floor Trajectory Hypothes is}

Previous research in the region has demonstrated the ability of researchers to recognize aggradation floors within nonstratified burned rock features associated with habitation activities (Gunn and Mahula 1977). This requires employment of what has been called the "rock bottom" microstrata excavation technique, involving the careful peeling of individual layers of rock and the recording of cultural material, ecofacts, and burned rock morphology associated with each microstratum.

Some of the results of this technique have indicated that a single burned rock midden is able to demonstrate a change in tool orientation from core 
tool/biface to flake to0 $/$ blade-and-core from the bottom (earlier) to the top (7ater) portions of the feature. As these tool orientations are associated with a climatic change from mesic to xeric conditions, the data potential of the longevity of the feature's use as a habitation platform becomes even more valuable.

Preliminary investigation at $41 \mathrm{BX} 300$ has recognized several types of burned rock features. One is a "domed" midden similar to that which yielded the preceding interpretation when subjected to microstrata excavation. This technique will be applied to a portion of the burned rock midden at $41 \mathrm{BX} 300$. In addition, intrasite comparison of burned rock features wi17 be conducted, with the objective of identifying habitation and nonhabitation types or examples within types. Complementing this refined excavation technique will be a battery of analyses conducted on recovered cultural and natural material to obtain functional, chronological, and environmental data.

\section{Population Variation on a Broad Ecotone Hypothesis}

South-central Texas is part of the broad plains/forest ecotone which transects Texas from north to south and which is affected by changes in both temperature and moisture which move in east-west shifts. Human populations exploiting the resources of this ecotone are expected to exhibit characteristics of either the desert west or the humid east at different phases of occupation, depending on which climatic regime is dominant in the region at the time of the occupation.

Reconstruction of historic Indian demographic structure in south Texas (Campbel1 1975, 1977) has enabled archaeologists to correlate population estimates and rainfall amounts and then extrapolate this index into prehistoric times (Gunn and Hester n.d.). If a reasonable reconstruction of climate during a specific prehistoric period can be made, then it is possible to suggest comparable demographic characteristics as we17 (Gunn 1979).

Several avenues of investigation for the reconstruction of climate and environment are being pursued at 41 BX 300, including the collection of a variety of organic samples and the analysis of phytoliths. Changes in climate and environment are expected to be documented by integrating the climatic data with the culture historic sequence to be developed at the site. Following from this, relative demographic changes through time can be postulated by reference to changes in climate.

\section{General Occupation Density Hypothesis}

In order to gather base 1 ine data and to provide a control for both field and analytical investigations, a 1 inear physiographic/ecological transect has been estab7ished by the UTSA Center for Archaeological Research through the region in which most of its archaeological work is conducted. The transect spans

microhabitats--from terraces adjacent to water courses, through valley slopes, upland margins, uplands, upland slopes and hilltops. The transect trends linearly from low and wet to high and dry, and reflects, in general outline, the relative usefulness of each 
microhabitat to hunter and gatherer exploitation (Hester, Gunn, and Katz 1977:29).

The definition and isolation of microhabitats are crucial for an analysis of hunter-gatherer exploitation. We are operating under the hypothes is that, given a specific climatic regime, subsistence procurement time is apportioned between microhabitats according to a seasonal schedule of resource availability within each microhabitat.

Site 41 BX 300 is situated at the lower and wetter end of the physiographic transect. It can be hypothesized that the site would have been occupied by relatively dense hunter-gatherer populations during wetter climatic regimes, when subsistence was relatively easy due to abundant resources in the aquatic and riparian zones and on the nearby slopes and terraces of the small valley. By contrast, during drier regimes, the site would have been less attractive and consequently less utilized; reduced subsistence resources are presumed to have resulted in more nomadism by smaller groups of people, exploiting a more extensive area for a broader spectrum of subsistence items.

\section{$\underline{\text { Research Areas }}$}

While the exact extent and depth of the site could not be determined until the mitigation phase of investigation, a great deal of data about artifact distribution and tentative chronological periods were available from a number of sources. These include the Phase I and Phase II activities; a large collection of projectile points and other chipped stone artifacts donated to UTSA by the Menger brothers of San Antonio, and occasional visits to the site during and after SCS construction activities by UTSA and NPS staff members.

The conclusions drawn from all these data sources permit the subdivision of the site remnant into four preliminary sectors. Each has its own stratigraphic and culture content character, suggesting that each should be independently investigated with methods and techniques appropriate to the specific area. The following descriptions are taken from the proposal submitted by the UTSA Center for Archaeological Research to the National Park Service (Hester, Gunn, and Katz 1977):

\section{Southern Sector}

The bulldozer cuts have exposed burned rock lenses (perhaps living floors) and isolated hearths. Soil changes from a brown, culturebearing alluvium, to a tannish-clay, containing patinated flakes (such patina has been found, based on other excavation in the region, to indicate relative antiquity--to Pre-Archaic times and earlier).

\section{Central Sector}

In this area there is a "classic" central Texas domed burned rock midden, essentially buried. Portions were tested in 1976; it 
appears to date from the Middle Archaic, and to be underlain by an Early to Pre-Archaic occupation. Testing was not sufficiently refined to determine whether or not the entire midden dated to the Middle Archaic, or if, in fact, deeper portions had accumulated prior to that time.

Northeastern Sector

To the northeast of the burned rock midden is a high area adjacent to the west bank of $E 1 \mathrm{~m}$ Waterhole. Test excavations in 1976 revealed abundant cultural debris from Late Archaic and Late Prehistoric occupations. In addition to 1 ithics and burned rock debris, an in situ hearth was uncovered. Deposits in this area are shallow $( \pm 30-40 \mathrm{~cm})$, overlying a cobble-gravel formation. The Late Archaic and Late Prehistoric occupations at the site appear to be mainly restricted to this midden area.

Northwestern Sector

This area is thought to be 3-4 $\mathrm{m}$ in depth, and is exposed by a borrow pit cut. Stratigraphy is variable, and has not yet been systematically studied. This area, and its potential for deep, chronologically-significant, deposits was not recognized until after the borrow pit had been dug. In one area, about a meter of gray-brown alluvium (with flakes and other debris) overlies a clay formation. Weathering from that formation, 2-3 $\mathrm{m}$ below the surface, was a Guadalupe tool (Pre-Archaic) and a fragment of bison bone.

\section{EXCAVATION PROCEDURES}

(Paul Lukowski and Paul Katz)

\section{EXCAVATION CONTROL}

\section{HORIZONTAL}

As previously mentioned, the construction of the eastern dam and emergency spil1way berms for Floodwater Retarding Structure 13-A necessitated the borrowing of soil from the periphery of site 41 BX 300 (Figs. 1; 6,a). When the project was finished, the site had been completely pedestaled. With Elm Waterhole on the north end, cattle ponds along the west side, and the channel of Elm Waterhole Creek running along the east and south peripheries, the remnant of 41 BX 300 took on the aspect of an island, especially after a heavy or prolonged rain (Figs. $2, b ; 7, a, b ; 8$ ).

The subsequent water erosion at the base of the pedestal was actually a mixed blessing. In time, of course, irreparable damage will be done to the site; and this fact accounts in large measure for the funding provided for mitigation by the National Park Serivce. At the same time, however, stratigraphic 


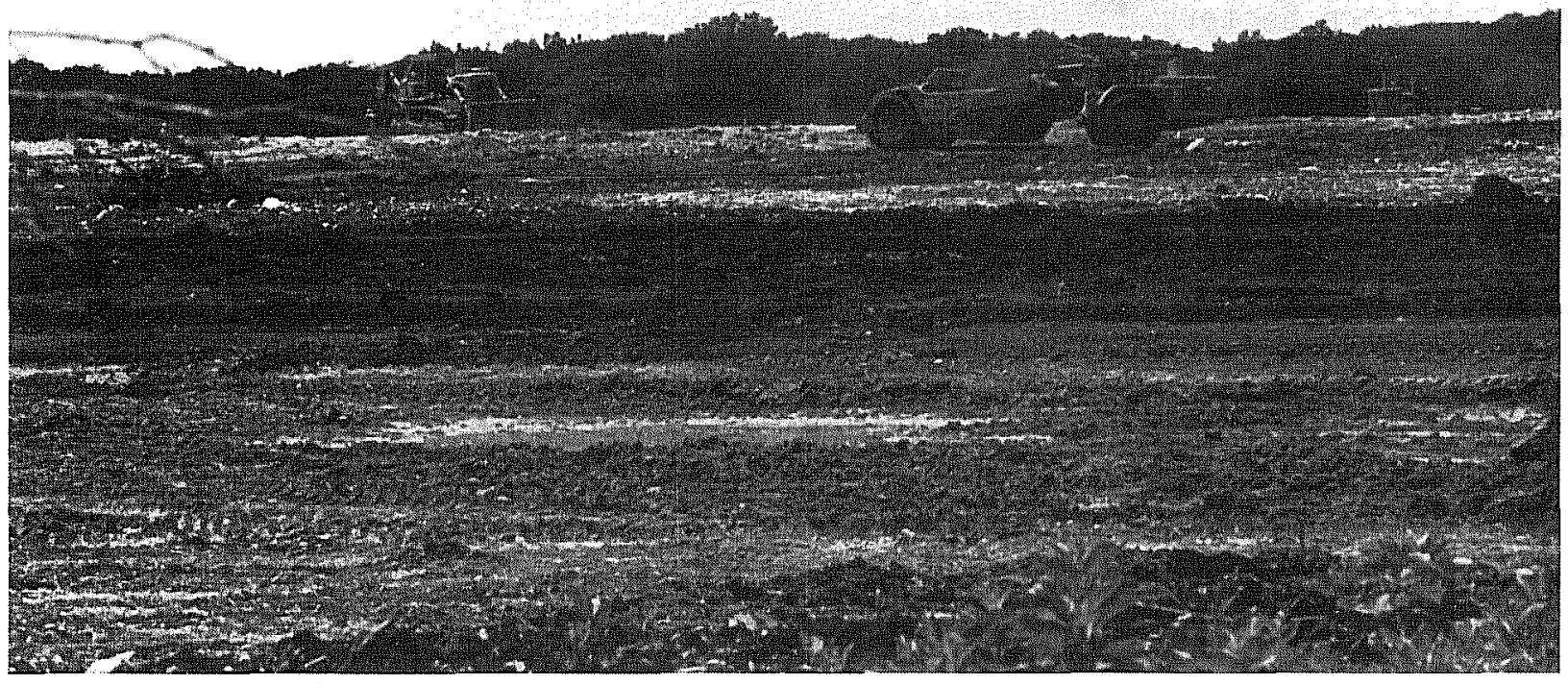

a

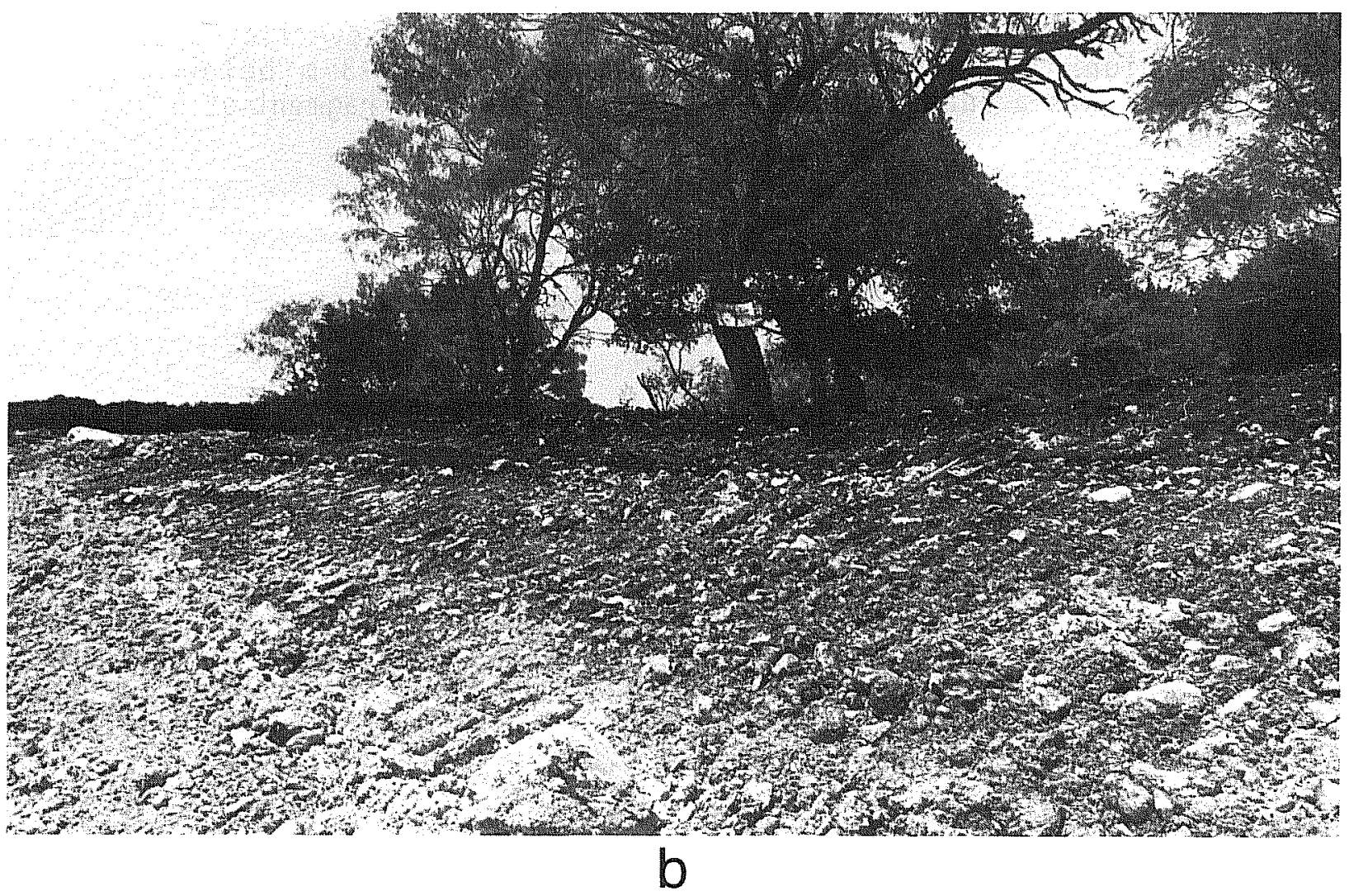

Figure 6. Excavation at Site $41 \mathrm{BX} 300$. a, construction activity between Phases II and III; b, steep embankment at northwest corner (Area BI ue). 


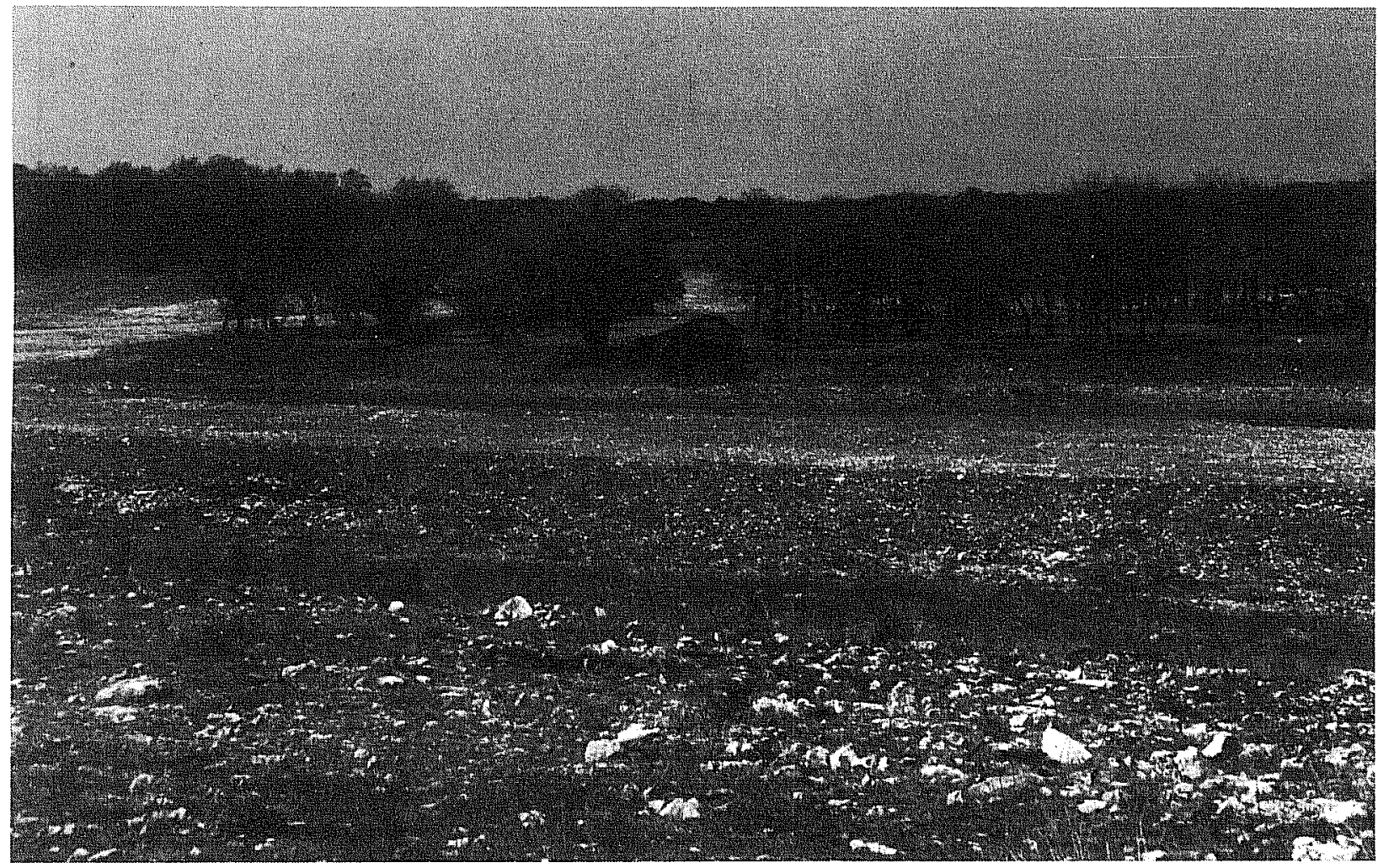

a

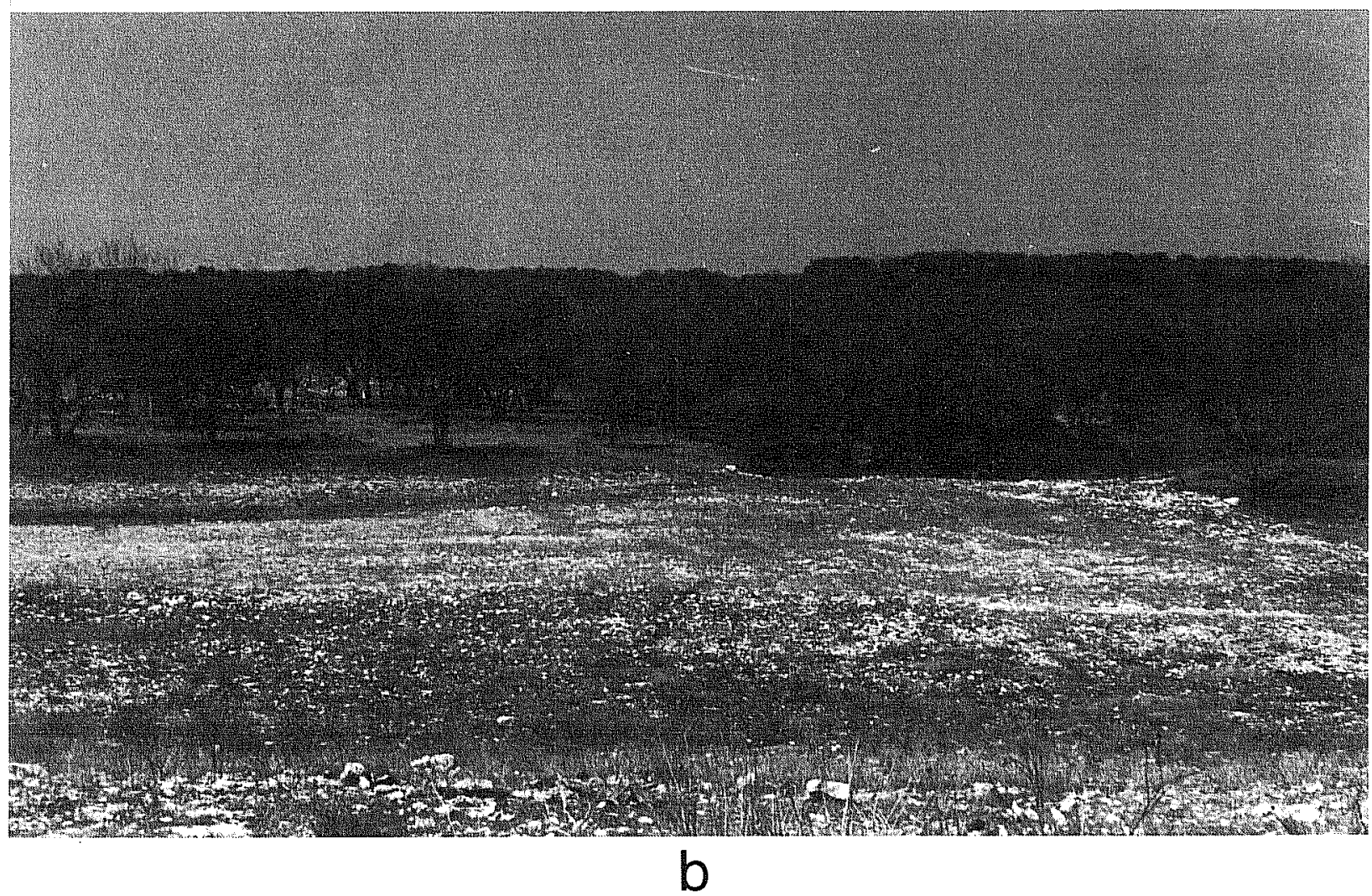

Figure 7. Southern and Northern Views of 41 BX 300. a, south portion of site during Phase III; b, north portion of site; note waterhole at right. 


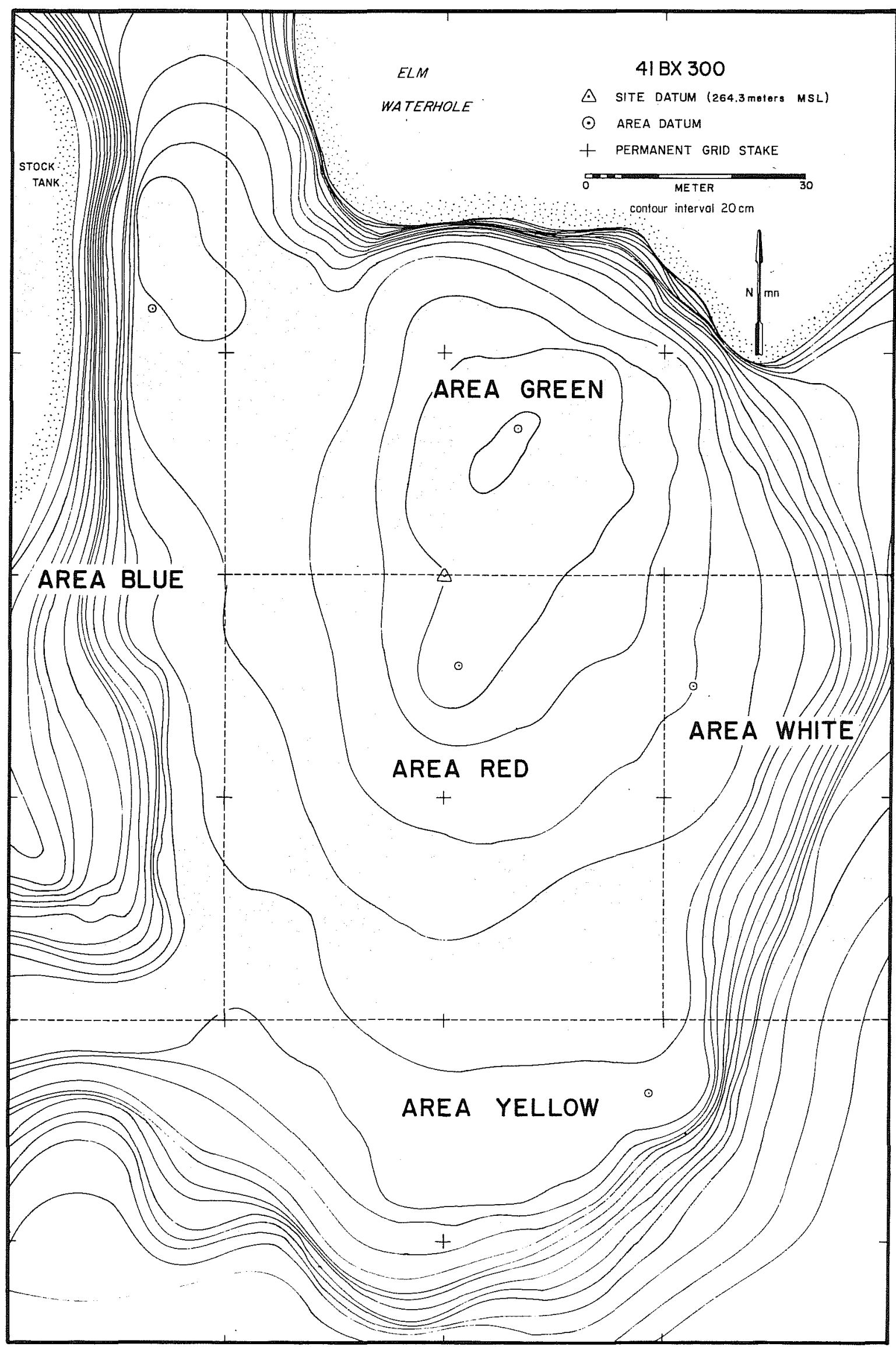


exposures and uncovered artifactual material, especially on the northwestern margin (Figs. 6,b; 8), strengthened the case for mitigation activity and provided valuable data for excavation strategy and documentation.

Pedestaling of the remaining portion of the original site area produced one additional advantage: the exact boundaries of the excavation were sharply delineated. It was thus possible to calculate the remnant site area to be $13,800 \mathrm{~m}^{2}$ (1.38 hectares), or 3.41 acres.

Horizontal control of the excavation was maintained by means of two completeTy independent systems. First a Point Designation System was established by selecting a single point to be the Site Datum (denoted ST) and assigning coordinates to this unique point. As the anticipated computerization of the data base necessitated avoiding negative coordinates or letters representing compass directions, the Site Datum was consequently assigned the coordinates of $1000 \mathrm{~m}$ east and $1000 \mathrm{~m}$ north (Fig. 9) of an arbitrary and inconsequential point. Any point on the site could then be assigned corresponding coordinates by ostensibly measuring from the Zero point, but in actuality measurements were taken from the Site Datum. Coordinates were always recorded as east and north of the Zero point, and in this specific order, again for computerization consistency. Site points with coordinates smaller than $1000 \mathrm{~m}$ were located either west and/or south of the Site Datum, those greater than $1000 \mathrm{~m}$ were east and/or north of the Site Datum.

A more elaborate Unit Designation System was also established. First a grid of $10 \times 10 \mathrm{~m}$ blocks was laid down over the entire site, keyed into the Point Designation System and the Site Datum (Fig. 9). Each block was assigned a three-digit identification, beginning in the northwest corner of the site with "001." Numbers were assigned consecutively in rows from west to east, moving progressively from north to south. One hundred and fifty block designations were assigned, although some blocks did not actually exist (Fig. 9). Subsequently, identified blocks around the periphery of the initial 150 were numbered in a clockwise manner, beginning with "151" in the northwest corner (Fig. 9).

Each block could then be subdivided into $1001 \times 1$ m squares, or Units: These were also individually numbered in the same manner, row by row, beginning with "001" in the northwest corner of each block and terminating with "100" in the southwest corner. A unique six-digit designation was thus available for any $1-m^{2}$ unit anywhere on the site, the first three digits representing a $10-\mathrm{m}^{2}$ b] ock, and the second three digits identifying the specific interior $1-\mathrm{m}^{2}$ unit. Units could also be identified by the coordinates of their southwest corner, using the Point Designation system. Because the entire site was gridded down to the square meter, it was possible to incorporate Phase II excavation units into the Phase III system of control, excavation, and analysis.

The Unit Designation System was found to be more convenient in daily excavation activities than was the Point Designation System. It was easier to refer to, and record data about, a unit designated by a six-digit number than it would have been using two alpha-numeric coordinates. Furthermore, an 


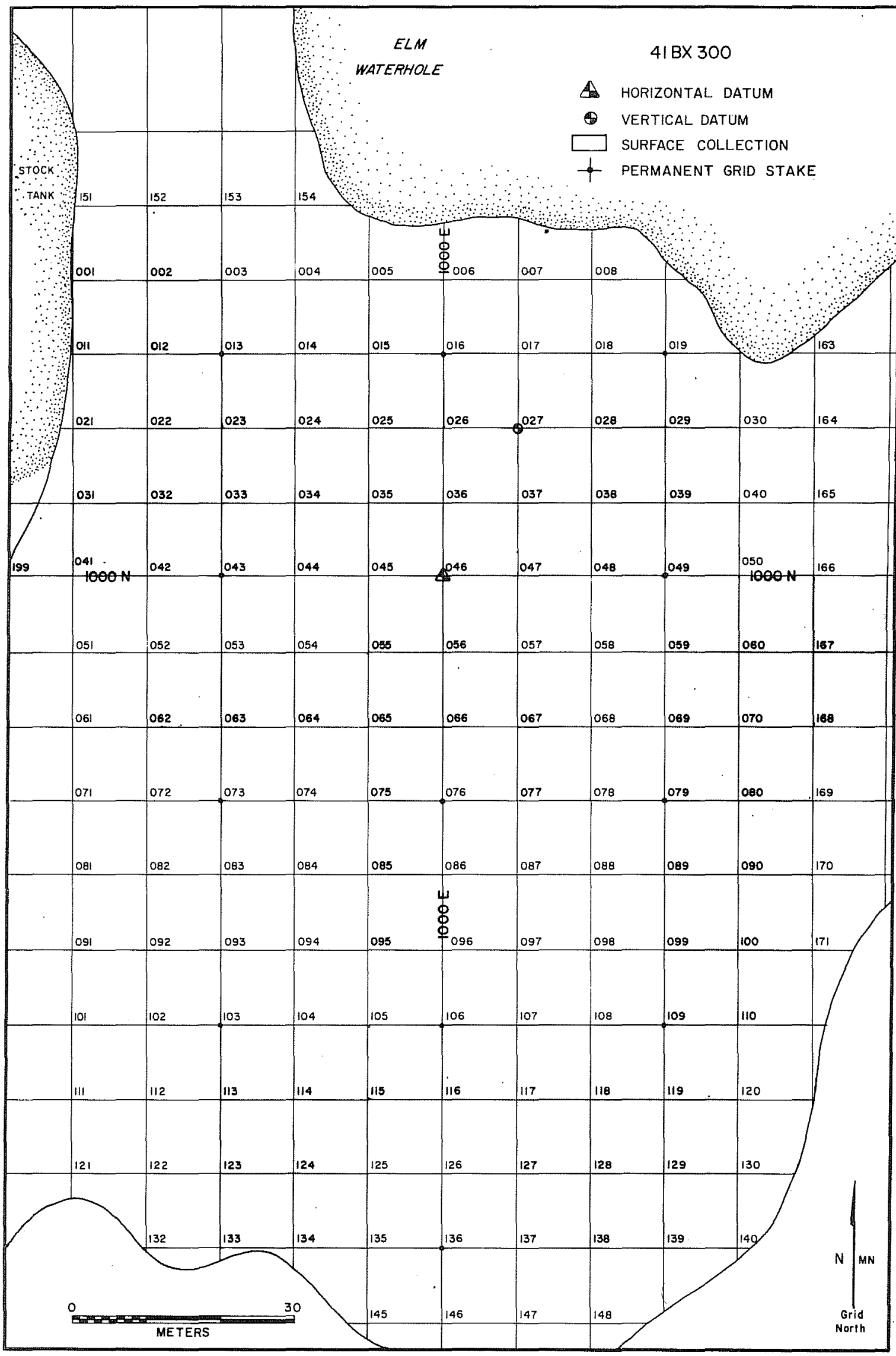

Figure 9. System of Designating 10-m Blocks, and Blocks Surface Collected. 
inevitable confusion would have developed in trying to refer to a block and its southwesternmost interior unit (Unit 091) by the same coordinates.

The Site Datum, and every coordinate point at $30 \mathrm{~m}$ intervals from it in every cardinal direction, were permanently marked on the ground by metal rods (Fig. 8). These permitted the rapid location of any block or unit.

A third system of subdividing the horizontal area of the site was employed, although it functioned more for convenience and quick reference than it did for strict control. Based on the Phase II investigations and subsequent monitoring of site periphery erosion and artifact occurrences, a tentative pattern of horizontally distinct, diachronic occupations was recognized (see preceding section). The site was consequently apportioned into five different areas, and each was designated by a different color (Fig. 8). Area Blue represents the western edge of the site, in particular the northwestern corner where artifacts of Early Archaic, and possibly Late Paleo-Indian affiliation, were recovered by monitoring the eroding slope (Fig. 6,b). The northern and northeastern portion, abutting Elm Waterhole, was designated Area Green (Fig. 7,b); Phase II testing recovered evidence of Late Archaic and Late Prehistoric activity in this area. Area White, along the eastern side of the site (Fig. 7,a,b), exhibited small 1 imestone hearths eroding from the subsoil. The southern end of the site (Fig. 7,a), Area Yellow, consistently yielded Early and Middle Archaic artifacts when surveyed. Finally, the center of the site, characterized by the single observable burned rock midden, was designated as Area Red.

\section{VERTICAL}

While ultimate vertical control of the excavation was maintained from the Site Datum (coordinates $1000 \mathrm{E}, 1000 \mathrm{~N}$ ), measurements of excavation depth could be taken from any of three different types of control points. The Site Datum itself was one such point; and whether or not it was employed directly in the field, al1 depth measurements were eventually related to the Site Datum for intra-site comparisons and overall excavation consistency. In practice, however, the size of the site and the extensive distribution of excavation units made direct depth measurement from the Site Datum impractical, even with a telescopic 7 evel and stadia rod. Furthermore, the Site Datum was not the point of highest site elevation (Figs. 8, 10), as it was selected with the primary consideration of establishing the horizontal grid system. It was located in a central east to west position, close to the midden which was the focus of the research design, and it was situated in a cleared portion of the site to facilitate the taping of the initial $10-\mathrm{m}$ blocks (Figs. 8, 9).

A series of intermediate-level depth control points was established to assist in the daily recording of excavation data and to facilitate the establishment of new excavation units. The highest point of elevation in each of the fivecolored designated areas became a secondary, or Area Datum, point (Fig. 8). A11 excavation depths not determined directly by instrument from the Site Datum were measured with respect to the ground surface level of the appropriate Area Datum. All depths so measured were subsequently recalculated in the laboratory to reflect depth below the Site Datum for 


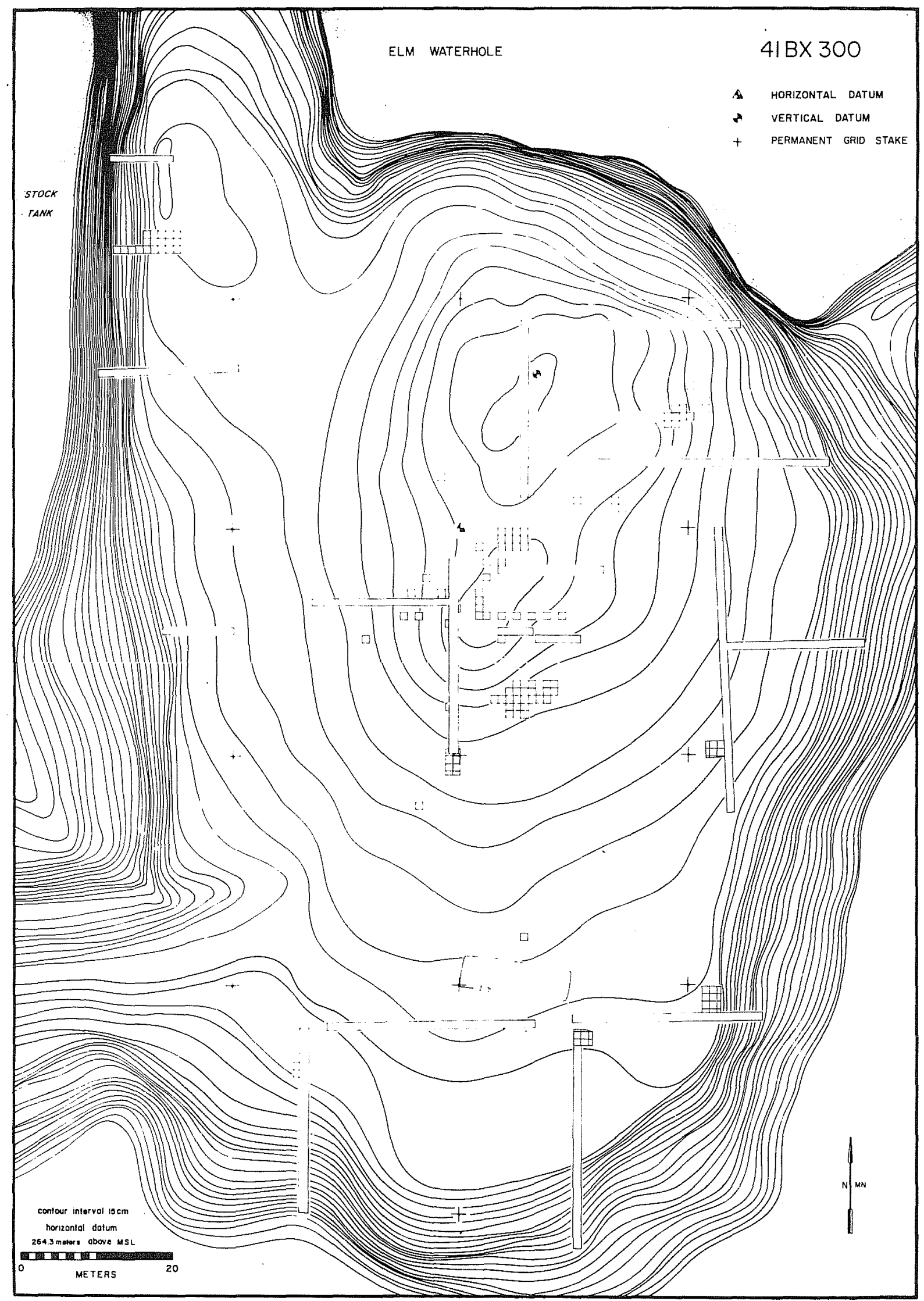

Figure 10. Contour Map of Site, Showing A11 Trenches and Units Excavated During A11 Phases. 
mutual comparability between areas. The Area Green Datum is the point of highest elevation on the site (Figs. 8, 10). Table 6 provides the relationships between the Site Datum elevation and the five surrounding Area Datum points, as well as the relative elevational differences between the five Area Datum points.

During the course of excavations, depth measurements were usually recorded manually with string, line level, and folding rule. The southwest corner was consistently employed, this being the corner with unit designation coordinates. Depth below ground surface at the southwest corner was initially recorded as depth below ground surface at the appropriate Area Datum, later to be further converted to depth below ground surface at the Site Datum.

TABLE 6. ELEVATIONAL RELATIONSHIPS BETWEEN SITE DATUM AND AREA DATUM POINTS

Centimeters Above (-)

Area Datum or Below $(+)$ Site Datum
Centimeters Below Green Datum
Green

Red

White

B7ue

Yellow
$-22.0$

$-13.5$

$+40.0$

$+44.0$

$+86.5$
0.0

8.5

62.0

66.0

108.5

As the field work progressed, natural and cultural stratigraphic levels were identified and integrated into the excavation design. Whenever possible thereafter, the stratigraphic level being excavated was recorded along with the metric depth below datum as a further means of vertical control. After a11 Area Datum measurements were converted to depths below Site Datum, the stratigraphic level designations recorded everywhere in the excavations significantly aided the comparisons and interpretations of stratigraphic profiles drawn in selected, but less numerous, locations around the site.

A final aspect of vertical control was the special consideration accorded features whenever one was so designated. As feature excavation proceeded holistically and typically overrode local arbitrary levels, depth controls were established which pertained specifically to the feature under investigation. Usually a special tertiary datum point was established for the duration of the feature's excavation. The ground surface of this point was visually related directly to the ground surface of the Site Datum, if possible; if not, then the nearest Area Datum point was employed as an intermediate point of reference, with depth measurements converted to Site Datum ground surface as usual. 
Site 41 BX 300/Excavation Procedures

\section{EXCAVATION METHODS AND TECHNIQUES}

METHODS

Six distinct methods of excavation were employed during the course of Phase III investigations at 41 BX 300 . These included the backhoe trench, trench section, block, isolated unit, and two varieties of feature excavation.

Eighteen backhoe trenches were cut, all one meter wide (Fig. 15,b), and their combined lengths totaled $381 \mathrm{~m}$ (Tables 7 and 9 ). Average trench depths varied from $55 \mathrm{~cm}$ in Omega-E (Fig. 23) to $217 \mathrm{~cm}$ in November (Fig. 21). A11 trenches were cut into the subsoil to a depth definitely below any cultural manifestations identified in the respective trench. Area Red contained the largest number with six trenches (Fig. 12), followed by Areas Green and Yellow with four each, then Areas Blue and White with two each (Figs. 10 and 11). Trenches were cut along lines of the grid system (Fig. 11) to facilitate their mapping and the recording of their associated artifacts by exact coordinates (Fig. 13,a). Trenches were assigned names in the order they were cut, employing the words associated with the phonetic alphabet of the armed services and aeronautics. Components of a broken or offset trench Tine were designated by the same name, but distinguished by compass letters (Fig. 11). Table 7 provides the names of the various trenches, their respective areas, maximum lengths, average depths, and orientation.

A trench section was a small area cut away from the side of a trench for the purpose of investigating an anomaly identified in the trench wall (Fig. 13,b). The size and extent of extra-trench penetration was determined entirely by the anomaly and whatever measures were needed for its exploration. For easier mapping and data recording, trench sections were incorporated into the grid system and, upon completion, took on the appearance of block excavations. Four trench sections were cut during Phase III investigations, all designed to pursue lenses of burned rock in their associated trench walls (Fig. 11). Three trench sections uncovered concentrations of rock that were later accorded feature status: Feature 8, at the south end of Hotel trench (Figs. 12; 34,a; 41); Feature 10, on the west side of Kilo trench (Figs. 36,a; 37); and Feature 11 , at the north end of Charlie trench (Figs. 36,b; 39). The fourth trench section, on the north side of Alfa-E trench, revealed burned rock in too dispersed a configuration to be considered a feature (Fig. 13,b).

The various block excavations conducted during the 41 BX 300 mitigation activities should not be confused with the $10-\mathrm{m}$ "blocks" comprising the framework of the site grid system. The excavated block grew by accretion, representing a series of contiguous one-meter units (Fig. 14,b). A block of excavated units usually resulted either from the search for something specific or from the expansion from something previously located. "Search" blocks characterize the excavations in Areas Blue and Green (Figs. 8, 10, 11), where surface collection and limited testing in previous phases produced artifacts of several distinct chronological periods. While technically a block excavation, one series of contiguous units in Area Blue took on the appearance of a trench when completed (Figs. $10 ; 11 ; 15, a)$. The objective of precise artifact recording necessitated digging by hand; but difficulties 


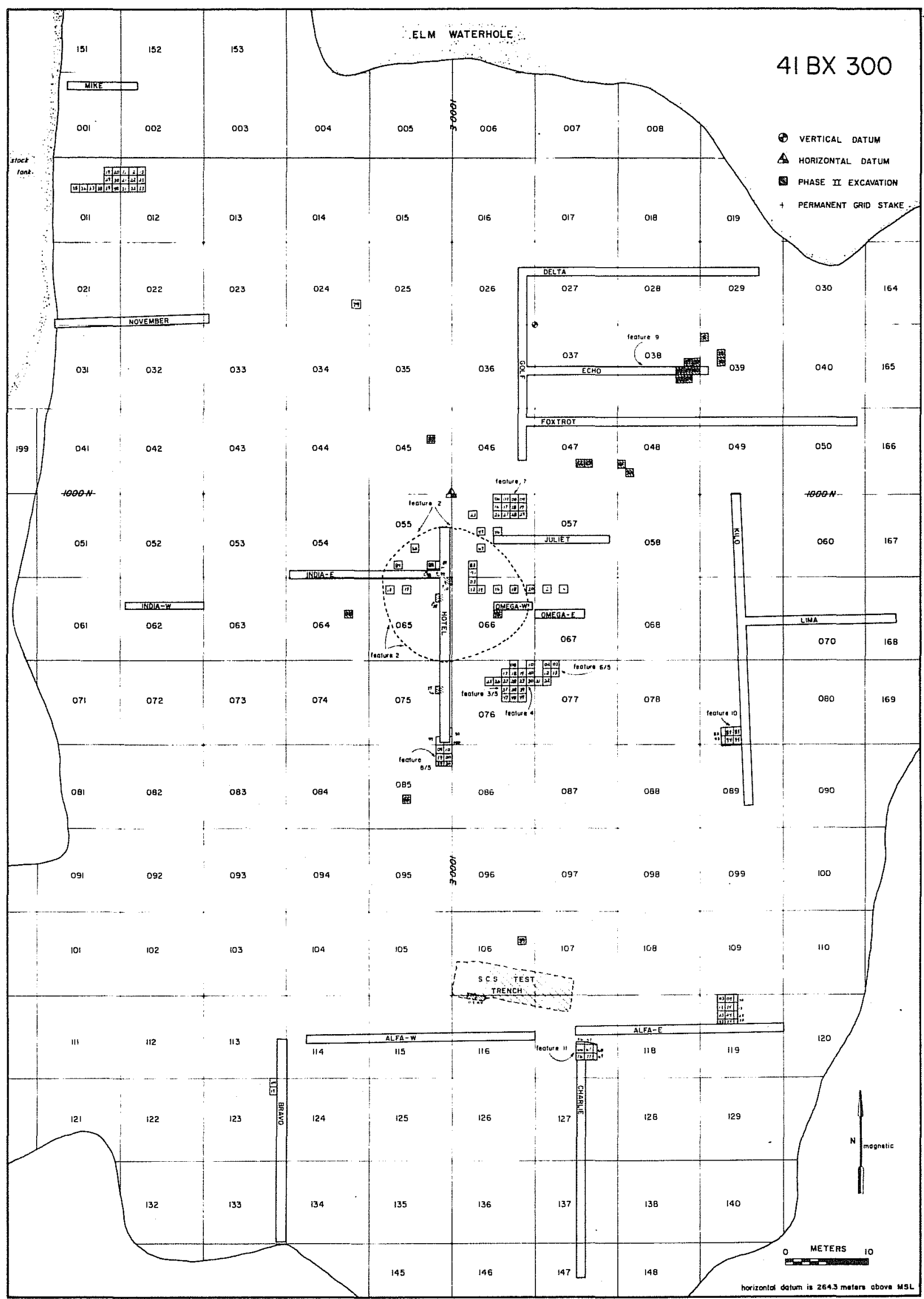

Figure 11. Trenches and Units Excavated During A1 1 Phases, With Phase III Features Indicated. 


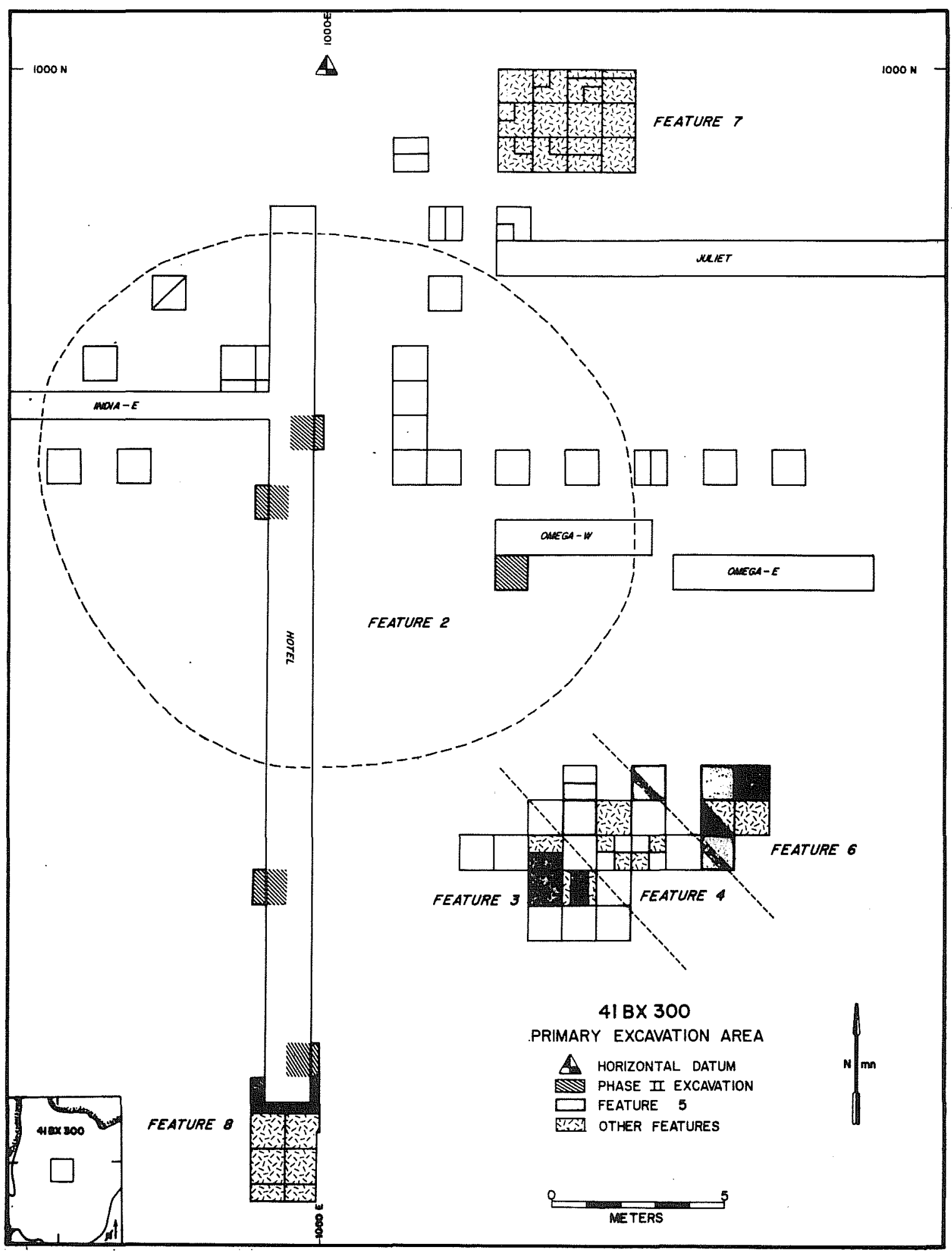

Figure 12. Excavation Units, Trenches, and Features in Area Red. 


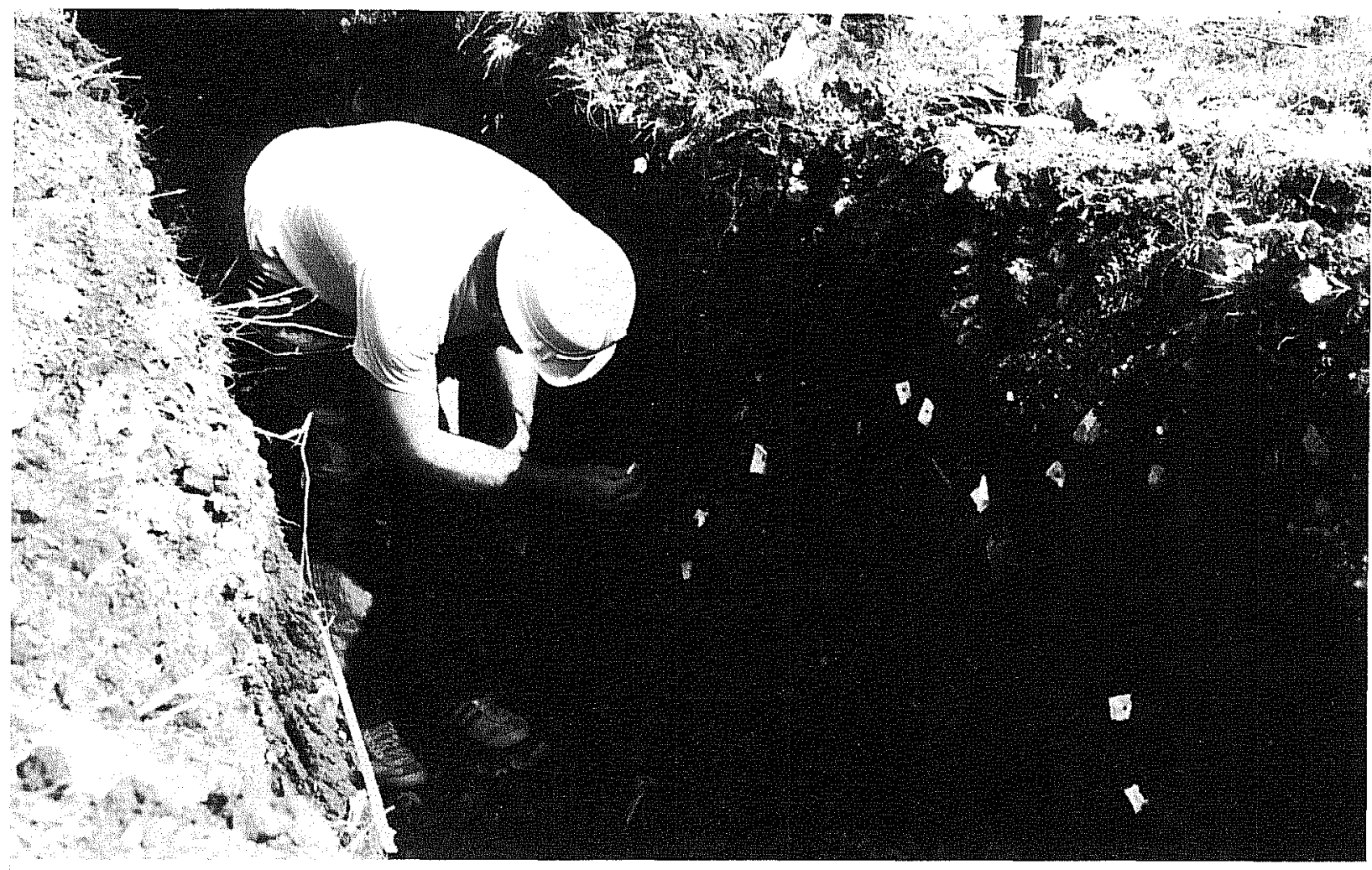

a

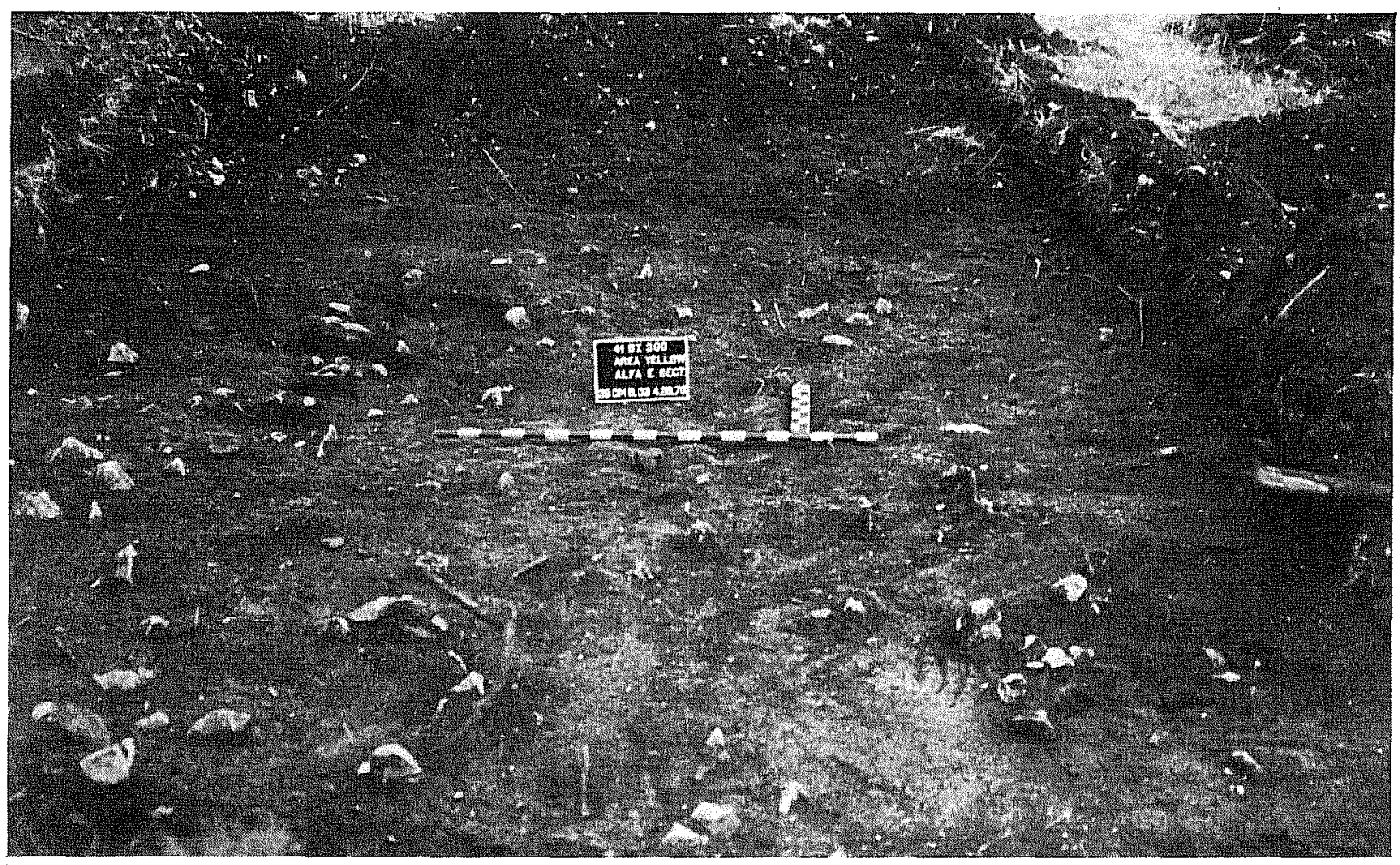

b

Figure 13. Alfa-E Trench. a, artifact recording along trench wä1 (A1fa-E); b, exploratory backhoe section beside trench (Alfa-E). 
Site 41 BX 300/Excavation Procedures

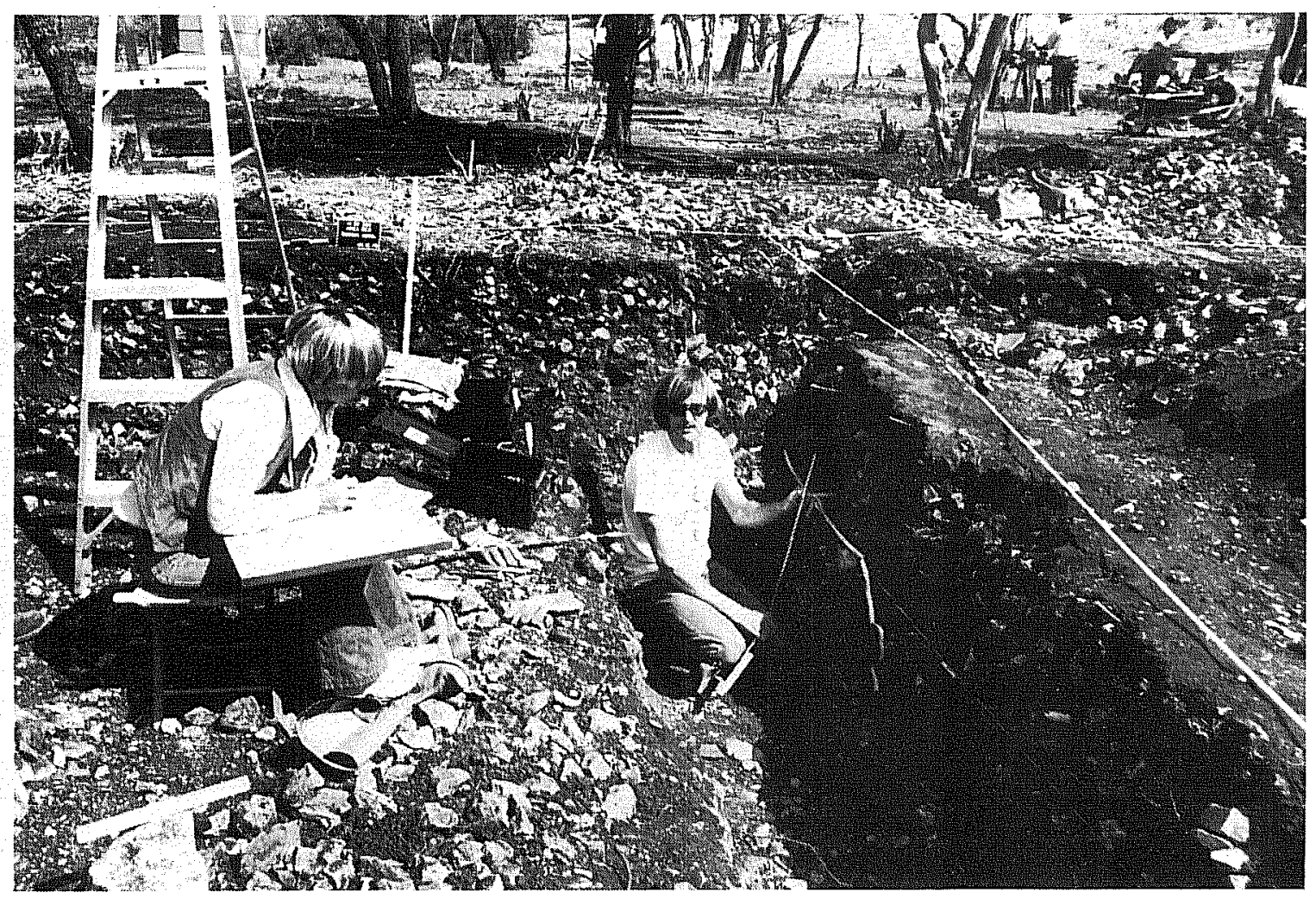

a

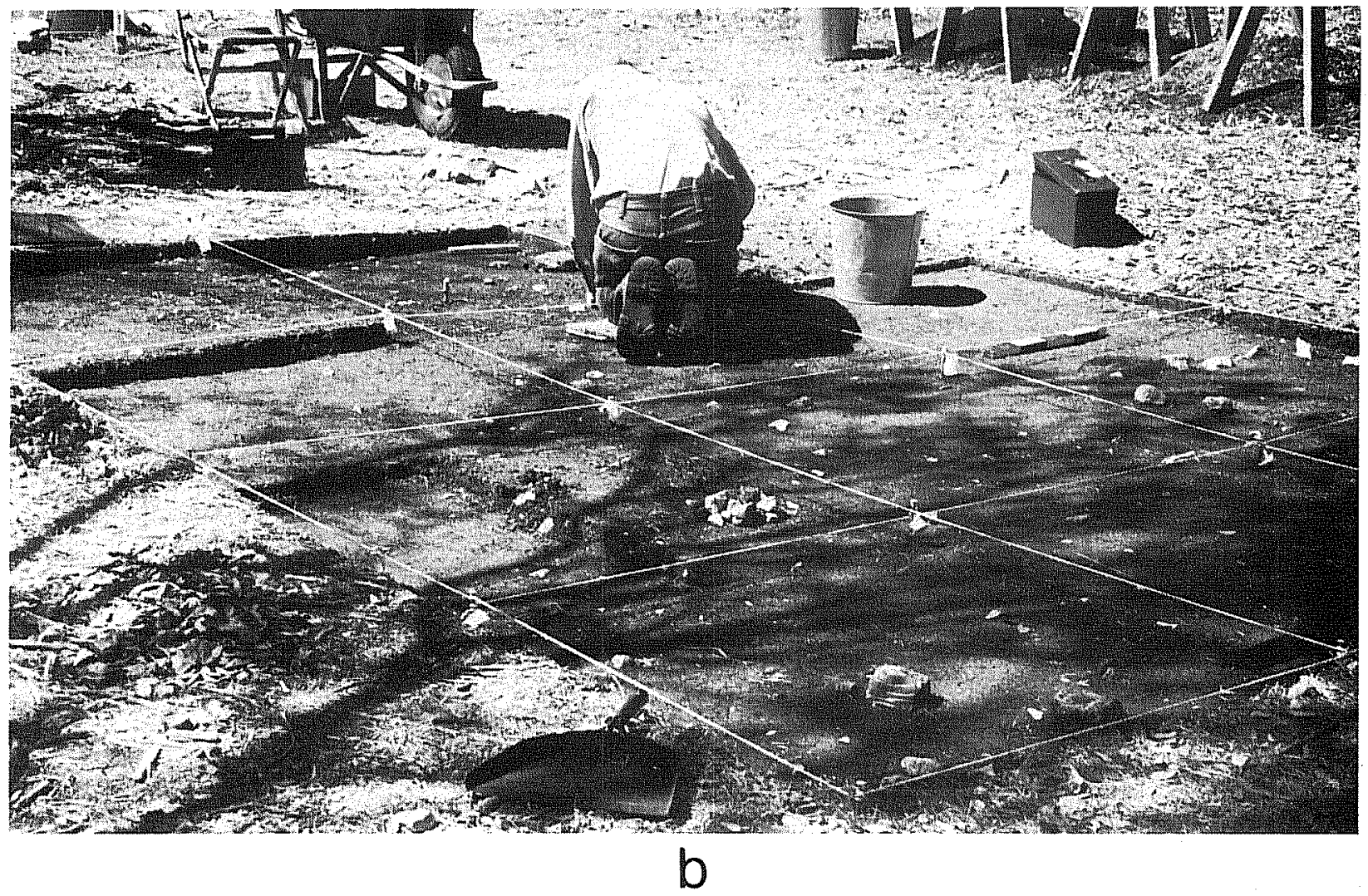

Figure 14. Views of Feature 2 and Feature 7. a, trench wall profile (recording Feature 2 in India-E); b, Feature 7, during excavation (Area Red). 


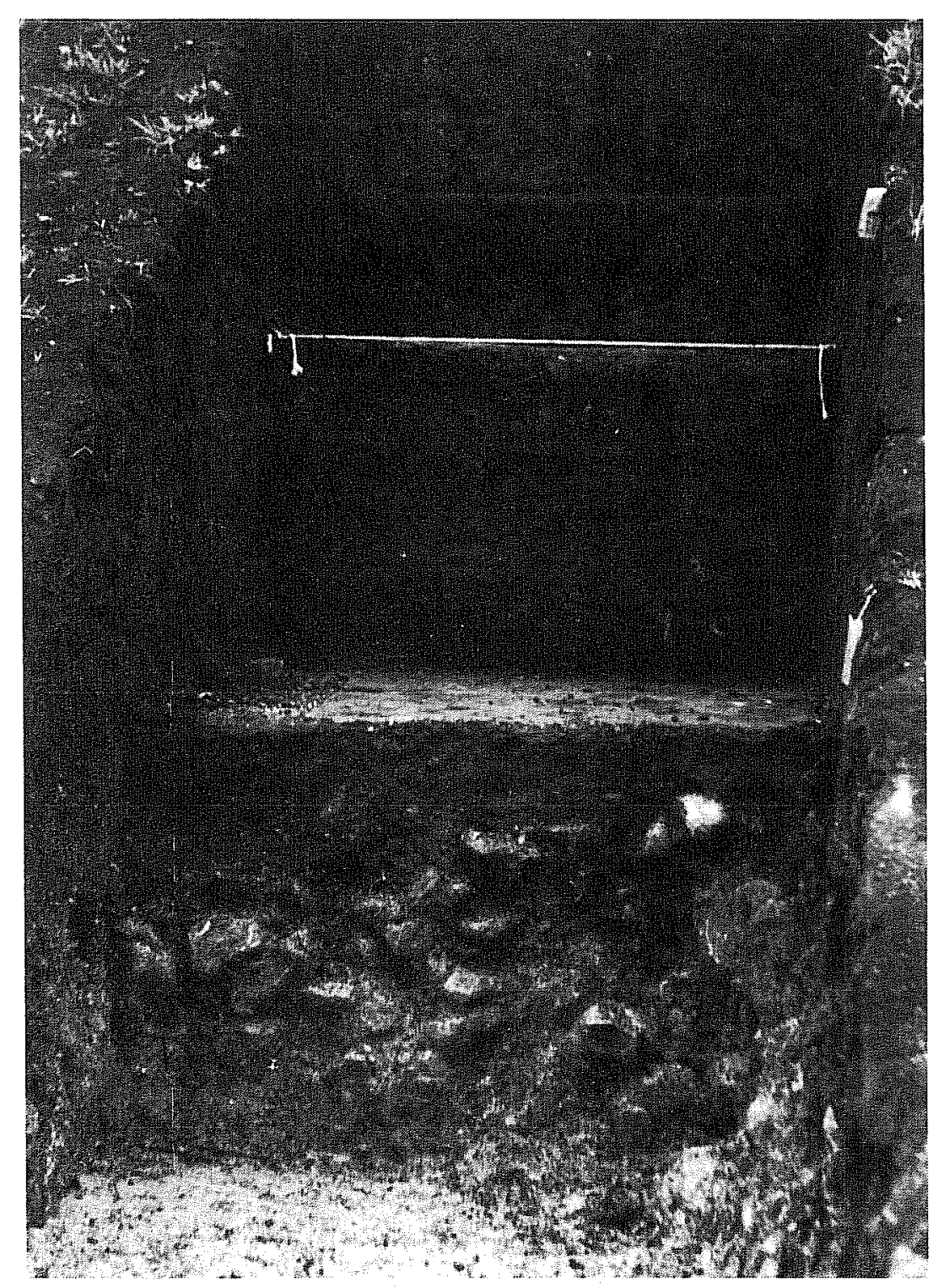

a

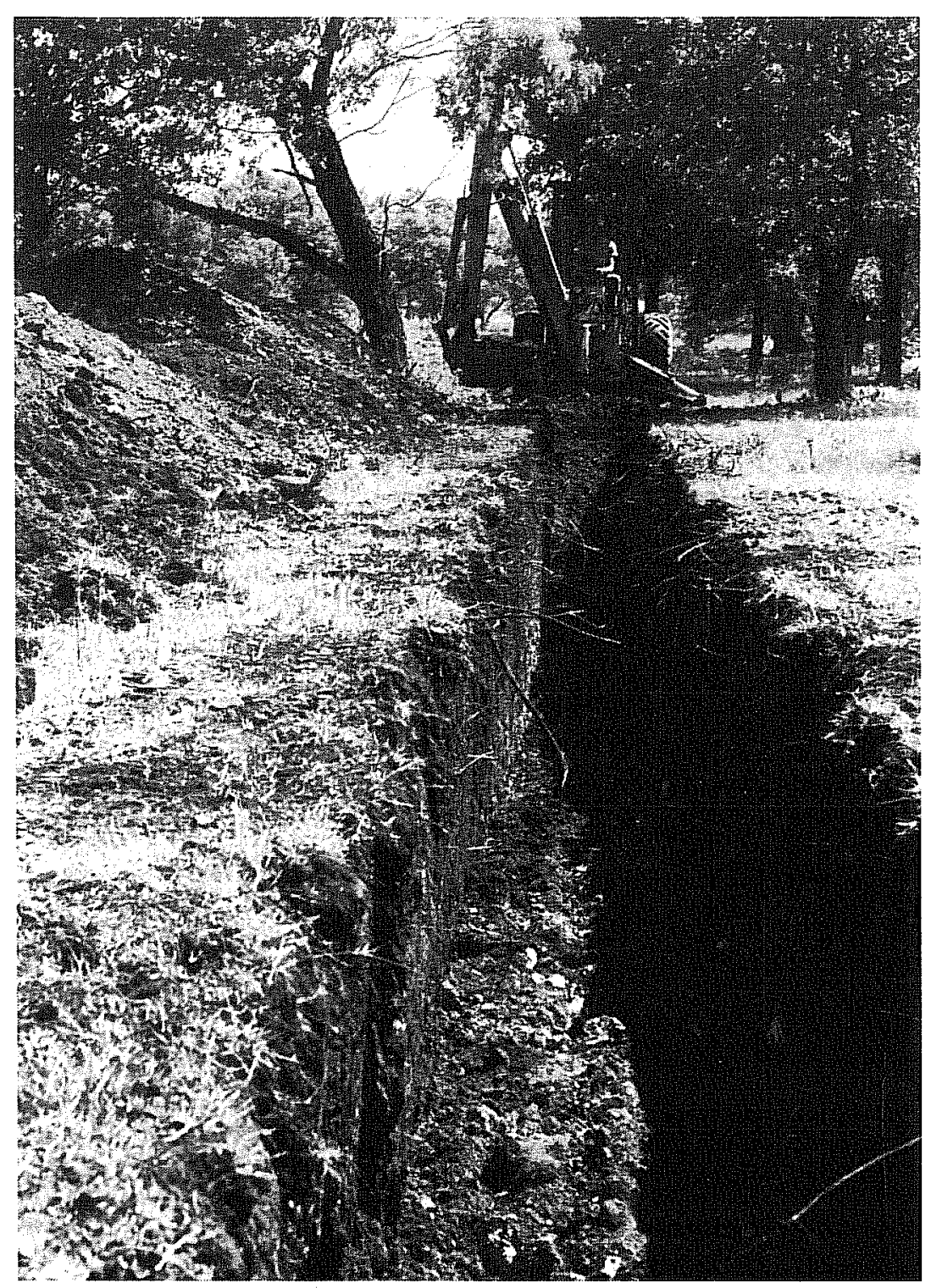

b

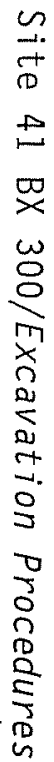

Figure 15. Views of Area Blue and Area White. a, hand-excavated trench in Area Blue; b, machineexcavated trench in Area White (Kilo). 
TABLE 7. PHASE III TRENCH DATA

\begin{tabular}{llrll}
\hline & & Maximum Length & Average Depth \\
Name & Site Area & $(\mathrm{m})$ & & Orientation \\
& & & & \\
Alfa-E & Yellow & 25.1 & 133 & east-west \\
Alfa-W & Yellow & 27.7 & 119 & east-west \\
Bravo & Yellow & 24.5 & 63 & north-south \\
Charlie & Yellow & 28.6 & 126 & north-south \\
Delta & Green & 28.0 & 58 & east-west \\
Echo & Green & 21.9 & 65 & east-west \\
Foxtrot & Green & 39.9 & 61 & east-west \\
Golf & Green & 23.2 & 56 & north-south \\
Hotel & Red & 25.7 & 87 & north-south \\
India-E & Red & 18.2 & 113 & east-west \\
India-W & Red & 9.6 & 73 & east-west \\
Juliet & Red & 14.1 & 93 & east-west \\
Kilo & White & 38.1 & 202 & north-south \\
Lima & White & 18.3 & 182 & east-west \\
Mike & Blue & 8.5 & 195 & east-west \\
November & Blue & 18.7 & 217 & east-west \\
Omega-E & Red & 6.2 & 55 & east-west \\
Omega-W & Red & 4.7 & 70 & east-west \\
\hline
\end{tabular}

Total number: 18; total 1ength: 381.0 meters.

presented by both the steep slope and the compacted soil resulted in a minimum of excavation over a maximum of ground, i.e., a "trench." "Expansion" blocks resulted from the enlargement of trench sections, such as those associated with Alfa-E, Charlie, Hotel, and Kilo trenches (Figs. Il; 13,b), or features, such as Features 3 and 7 in Area Red (Figs. 11; 12; $14, b)$. In both situations, a smal1 area was enlarged in an orderly manner, and integrated into the site grid system, by the excavation of adjacent units in whatever number and direction was necessary to fully investigate the particular cultural manifestation.

The isolated unit was the basic search instrument. A point on the ground deemed necessary to investigate was subsumed within a $1-\mathrm{m}$ unit, determined by the inclusive site grid system. In some instances, an isolated unit became the initial unit of a subsequent block excavation (Fig. 24,a), but most remained as discontinuous squares (Fig. 24,b). The primary function of the isolated unit during the Phase III excavations at 41 BX 300 was to locate the periphery of the burned rock midden, designated Feature 2 (Figs. 11, 12, 24). The Phase II testing program also employed the isolated unit as the primary investigative device. 
The method of feature investigation necessarily depended upon the nature of the feature itself. The extensive size of the burned rock midden (Feature 2) required a combination of isolated units, to identify points on its circumference and trenches and to investigate its internal character (Figs. 11, 12). Other features, however, could be divided into either a hearth or occupation floor category. Hearth features were excavated as a complete excavation unit whenever identified, regardless of the eventual depth and extent. Associated units and excavation levels were recorded, but these artificial constructs were only a secondary means of control. Due to the fact that this type of feature exceeded the size of a single unit, the final configuration took on the appearance of a block excavation; Features 3 (Figs. 12; 28,a,b; 27) and 6 (Figs. 12; 30; 31,b) are in this category. Occupation floors provided a difficult excavation problem, in that a single centimeter below ground surface was designated the feature, and investigation in a series of adjacent or isolated units attempted to locate this plane. The final configuration of Feature 7 was a block excavation (Figs. 12; 14,b); but Feature 4 resulted in several small blocks (Figs. 12; 31 ,a) and Feature 5 , a series of isolated units (Figs. $12 ; 25, \mathrm{~b}$ ).

\section{TECHNIQUES}

A11 18 of the trenches were excavated by means of a backhoe. The initial machine was a Ford 4500 with a two-foot wide bucket, but the trench was too narrow to work in, and the machine was not powerful enough to cut straight trenches through the rocky subsoil. This machine's single advantage was its maneuverability in among the trees. A replacement was quickly obtained, a Case 580, with a three-foot bucket (Fig. 15,b). Not only was the extra foot of trench width more convenient for profiling and artifact recording (Fig. 13,a), but the essentially meter-wide trenches were positioned so that they corresponded to the grid system imposed on the site (Fig. 11). Once cut, however, all subsequent work associated with the trenches was conducted by hand, employing hand tools. Both machines were able to excavate sufficiently deep to pass below all cultural material and into the subsoil; average trench depths varied from $55 \mathrm{~cm}$ (Omega-E) to $217 \mathrm{~cm}$ (November).

Trench sections were initially excavated by backhoe, in that their function was purely exploratory. Overburden above a possible feature observed in the wall of a trench was mechanically removed, to facilitate investigation of the nature and extent of the anomaly. In all four instances where trench sections were opened, continued excavation was conducted by using hand tools. In the case of the Alfa-E trench section (Fig. 13,b), this simply entailed cleanup for photography and artifact recording; in the case of Features 8 (Figs. 12; 34,a; 41), 10 (Figs. 36,a; 37), and 11 (Figs. 36,b; 39), the hand work was more extensive.

Al1 other types of investigations were conducted by using hand tools. These included the excavation of isolated units (Fig. 24,b), units subsumed into block excavations (Fig. 14,b), the line of contiguous units in Area Blue having the appearance of a trench (Fig. 15,a), and both the hearth (e.g., Fig. 28,a) and occupation floor (e.g., Fig. 25,b) types of feature. 
The three most commonly employed hand tools were the long-handled shovel, folding entrenching tool, and trowel. Special conditions of rocky soil or sensitive recovery problems necessitated the use of other tools ranging from a pick-mattock to dental probes.

After the completion of the field work portion of the project, all excavated units and trenches were backfilled using the front-end loader of the Case 580 which cut the trenches.

\section{DATA RECOVERY}

\section{CLEARING}

Extensive clearing of the brush cover was undertaken prior to the initiation of data collection. Brush cover at 41 BX 300 was heavy (Fig. 5), consisting primarily of agarita and whitebrush (see Appendix II). To do the minimum amount of damage to the ground surface, and yet proceed with the clearing as quickly as possible, gasoline-powered weed trimmers with circular cutting blades were employed. The preliminary phases had indicated that all portions of the site would be under investigation, so the entire site area, 3.41 acres, was cleared of brush; this task took three days to accomplish. A completely cleared site allowed for good lines of sight when establishing the grid system and for maintaining both horizontal and vertical controls by telescopic instrument; also surface collection would be facilitated, as would general administration of the project activities. Much of the site was heavily wooded (Fig. 7), predominantly with cedar elm, Texas persimmon, and mesquite (see Appendix II). Trees were left undisturbed as much as possible, however, so as to provide shade, subdued lighting for photography and soi1 color resolution, and to retard the drying of exposed subsoils. Only when a tree blocked a line of sight, or was physically located in a unit to be excavated, was it removed; and cedar elm branches overhanging work areas were pruned to eliminate ticks dropping onto personnel below.

\section{SURFACE COLLECTION}

Every unit selected for investigation was intensively collected prior to excavation. As the material recovered was associated with a specific unit, it was recorded as if it represented the first level of excavation and analyzed accordingly.

A more general, and extensive, program of surface collection utilized the skeletal grid system composed of $10-\mathrm{m}$ blocks. At irregular intervals throughout the period of field work, one or more of these blocks would be intensively collected by the crew; this activity usually took place during or immediately after inclement weather, when excavation was not possible. Material recovered from one block was kept separate from other blocks, although blocks within the same color area were analyzed together. Figure 9 indicates the location of all blocks intensively surface collected, and Table 8 provides collection statistics. While not much more than one-half of the entire site was collected (about two acres), at least one-third and usually at least one-half of every area was thoroughly investigated in this 
TABLE 8. STATISTICS FOR CONTROLLED SURFACE COLLECTION BY 10-METER BLOCKS

\begin{tabular}{|c|c|c|c|c|c|}
\hline $\begin{array}{l}\text { Site } \\
\text { Area }\end{array}$ & $\begin{array}{l}\text { Total Number } \\
\text { of 10-Meter } \\
\text { Blocks per Area }\end{array}$ & $\begin{array}{c}\text { Percentage } \\
\text { of } \\
\text { Site }\end{array}$ & $\begin{array}{l}\text { Total Number } \\
\text { of Blocks } \\
\text { Collected }\end{array}$ & $\begin{array}{l}\text { Percentage } \\
\text { of Area } \\
\text { Collected }\end{array}$ & $\begin{array}{l}\text { Percentage } \\
\text { of Site } \\
\text { Collected }\end{array}$ \\
\hline $\begin{array}{l}\text { Blue } \\
\text { Green } \\
\text { Red } \\
\text { White } \\
\text { Yellow }\end{array}$ & $\begin{array}{l}25 \\
39 \\
36 \\
14 \\
24\end{array}$ & $\begin{array}{l}18 \\
28 \\
26 \\
10 \\
18\end{array}$ & $\begin{array}{l}12 \\
24 \\
12 \\
14 \\
17\end{array}$ & $\begin{array}{r}48 \\
62 \\
33 \\
100 \\
71\end{array}$ & $\begin{array}{r}9 \\
17 \\
9 \\
10 \\
12\end{array}$ \\
\hline Site Total & 138 & 100 & 79 & $N / A$ & 57 \\
\hline
\end{tabular}


manner. The material collected substantially augmented the excavated material, thus benefitting both analyses and interpretations.

\section{EXCAVATION}

Data, in the form of artifactual and ecofactual material, were recovered during the course of both hand and machine excavations. Trenches were closely monitored as they were being cut; freshly turned trench backdirt was collected for horizontally provenienced items; trench walls were carefully scrutinized for in situ, vertically provenienced items (Fig. 14,a); and finally, backfilled trench lines were walked in a last collection effort.

The hand excavation of all units permitted the recovery of most material items with their exact provenience known. Items recovered from each level within a unit, or from a distinct and designated feature, were packaged separately, and different types of material (e.g., flakes, burned rock, gastropods) were separated in the field during the collection process. This not only facilitated laboratory processing, but damage in transit was minimized.

\section{SCREENING}

A11 excavated soil was passed through 1/4-inch mesh screening, assisted by water pumped from the nearby stock tank (Fig. 8). After hand recovery of all visible material was completed, soil from the excavated unit-level was bucketed, barrowed, and bathed in a processing area well away from a 11 excavation activity. The same packaging distinctions were maintained between material types, so that both screened and provenienced materials could be more easily cataloged, and processed together for more efficient analysis.

\section{SPECIAL SAMPLES}

A very focused and specific source of data was the collection of a series of special samples, each type of sample characterized by its own collection technique.

Samples of burned earth and associated burned rock were collected from several hearth features (Fig. 28,a) for archaeomagnetic dating. Charcoal from hearth features and from several 10ci within the midden (Feature 2) was collected for radiocarbon dating. Burned rock from hearth features and from the midden were collected for thermoluminescence dating. A series of soil samples in a columnar array ( $F$ ig. 21) was taken from the walls of November trench in Area Blue (Fig. 16,b) and Kilo trench in Area White for analysis to identify phytoliths. A constant volume of soil (CVS), the size of sample being $2500 \mathrm{cc}$, was collected from a variety of unit-levels and features throughout the site. The quantity of soil was sufficient to allow each lot to be processed in a number of different ways to maximize the information retrieved. The specific recovery methods and subsequent analyses for each of the above-mentioned special samples will be discussed in detail in following sections. 
TABLE 9. EXCAVATION STATISTICS: PHASE III (MITIGATION)

\begin{tabular}{|c|c|c|c|c|c|c|c|c|c|c|c|c|}
\hline $\begin{array}{l}\text { Phase III } \\
\text { Site } \\
\text { Areas }\end{array}$ & $\begin{array}{l}\text { Size of } \\
\text { Area } \\
\left(\mathrm{m}^{2}\right)\end{array}$ & $\begin{array}{l}\text { Number } \\
\text { of Units } \\
\text { Excavated }\end{array}$ & $\begin{array}{l}\text { Square } \\
\text { Meters } \\
\text { Excavated }\end{array}$ & $\begin{array}{l}\% \text { of Area } \\
\text { Excavated }\end{array}$ & $\begin{array}{l}\text { Number of } \\
\text { Trenches } \\
\text { Excavated }\end{array}$ & $\begin{array}{l}\text { Square } \\
\text { Meters } \\
\text { Excavated }\end{array}$ & $\begin{array}{l}\% \text { of Area } \\
\text { Excavated }\end{array}$ & $\begin{array}{l}\text { Total Square } \\
\text { Meters } \\
\text { Excavated }\end{array}$ & $\begin{array}{l}\text { Total \% } \\
\text { of Area } \\
\text { Excavated }\end{array}$ & $\begin{array}{l}\text { Cu. Meters } \\
\text { Excavated } \\
\text { Units }\end{array}$ & $\begin{array}{l}\text { Cu. Meters } \\
\text { Excavated } \\
\text { Trenches }\end{array}$ & $\begin{array}{l}\text { Total } \\
\text { Excavated } \\
\text { Volume }\end{array}$ \\
\hline $\begin{array}{l}\text { Blue } \\
\text { Green } \\
\text { Red } \\
\text { White } \\
\text { Yellow }\end{array}$ & $\begin{array}{l}2500 \\
3900 \\
3600 \\
1400 \\
2400\end{array}$ & $\begin{array}{r}19 \\
4 \\
67 \\
9 \\
22\end{array}$ & $\begin{array}{r}17.00 \\
0.28 \\
62.38 \\
5.13 \\
14.63\end{array}$ & $\begin{array}{l}0.7 \\
0.0 \\
1.7 \\
0.4 \\
0.6\end{array}$ & $\begin{array}{l}2 \\
4 \\
6 \\
2 \\
4\end{array}$ & $\begin{array}{r}27.20 \\
112.96 \\
78.43 \\
56.40 \\
105.77\end{array}$ & $\begin{array}{l}1.1 \\
2.9 \\
2.2 \\
4.0 \\
4.4\end{array}$ & $\begin{array}{r}44.20 \\
113.24 \\
140.81 \\
61.53 \\
120.40\end{array}$ & $\begin{array}{l}1.8 \\
2.9 \\
3.9 \\
4.4 \\
5.0\end{array}$ & $\begin{array}{r}4.95 \\
0.06 \\
15.13 \\
1.59 \\
9.83\end{array}$ & $\begin{array}{l}28.56 \\
59.31 \\
66.11 \\
55.27 \\
94.12\end{array}$ & $\begin{array}{r}33.51 \\
59.37 \\
81.24 \\
56.86 \\
103.95\end{array}$ \\
\hline $\begin{array}{l}\text { Project } \\
\text { Total }\end{array}$ & $13,800 *$ & 121 & 99.42 & 0.7 & 18 & 380.76 & 2.8 & 480.18 & 3.5 & 31.56 & 303.37 & 334.93 \\
\hline
\end{tabular}




\section{EXCAVATION STATISTICS}

Table 9 provides data on the number of units and trenches excavated, the area disturbed, and the volume of soil removed for each colored area and for this phase of investigation in total. Summarizing, of the $13,800 \mathrm{~m}^{2}$ estimated for the size of the site, $480 \mathrm{~m}$, or $3.5 \%$ of the site, was excavated by units and trenches combined. Three hundred and thirty-five cubic meters of soil were removed. In that the project was scheduled for 60 days, the statistics indicate an average of $8 \mathrm{~m}^{2}$ excavated and $5.6 \mathrm{~m}^{3}$ of soil removed each day. Crew size was so variable that rates per person-day cannot be calculated.

Table 10 combines the data from Phases I and II (Table 3) with that from Phase III (Table 9) to provide a summary of all archaeological activity at $41 \mathrm{BX} 300$.

TABLE 10. EXCAVATION STATISTICS: SUMMARY OF ALL PROJECTS

\begin{tabular}{lccccc}
\hline $\begin{array}{c}\text { On/Off } \\
\text { Site }\end{array}$ & $\begin{array}{c}\text { Number of } \\
\text { Excavated } \\
\text { Units }\end{array}$ & $\begin{array}{c}\text { Number of } \\
\text { Excavated } \\
\text { Trenches }\end{array}$ & $\begin{array}{c}\text { Excavated } \\
\text { Area } \\
\left(\mathrm{m}^{2}\right)\end{array}$ & $\begin{array}{c}\text { Percentage } \\
\text { of } \\
\text { Site }\end{array}$ & $\begin{array}{c}\text { Excavated } \\
\text { Volume } \\
\left(\mathrm{m}^{3}\right)\end{array}$ \\
\hline $\begin{array}{l}\text { On-Site } \\
\text { Off-Site }\end{array}$ & $\begin{array}{r}145 \\
8\end{array}$ & 18 & $\begin{array}{r}503.18 \\
8.00\end{array}$ & $\begin{array}{r}3.6 \\
\text { N/A }\end{array}$ & $\begin{array}{r}346.27 \\
2.79\end{array}$ \\
\hline Total & 153 & 18 & 511.18 & N/A & 349.06 \\
\hline \hline
\end{tabular}

\section{DATA RECORDING}

\section{FORMS}

Data recording during the field work portion of the project fell into three general categories: summary data on the various excavation activities, provenience data on al7 material recovered and samples collected, and pictorial data.

The basis of the field proveniencing system was a prenumbered form, or ticket. Using an automatic numbering machine to avoid duplicated numbers, 


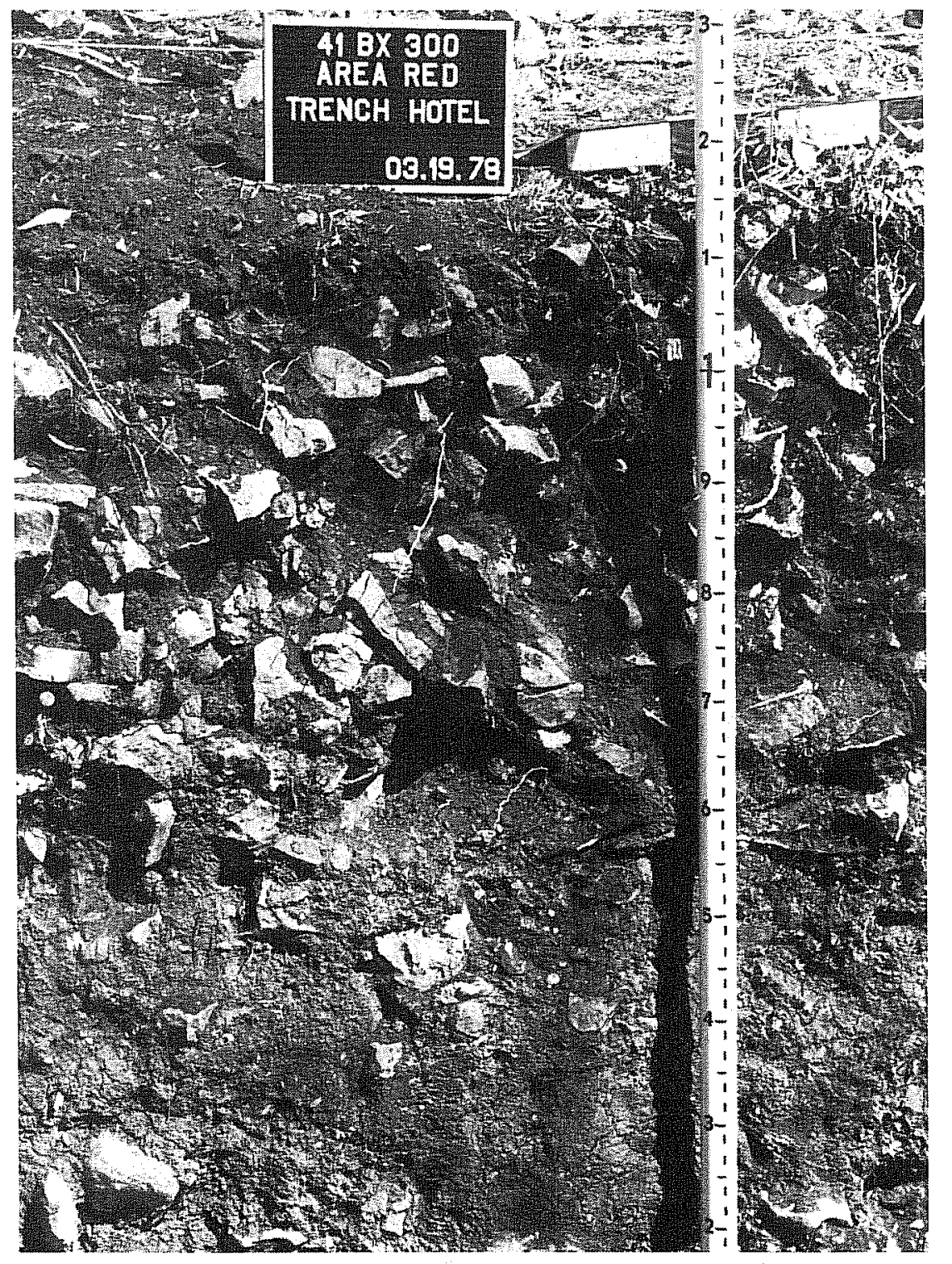

a

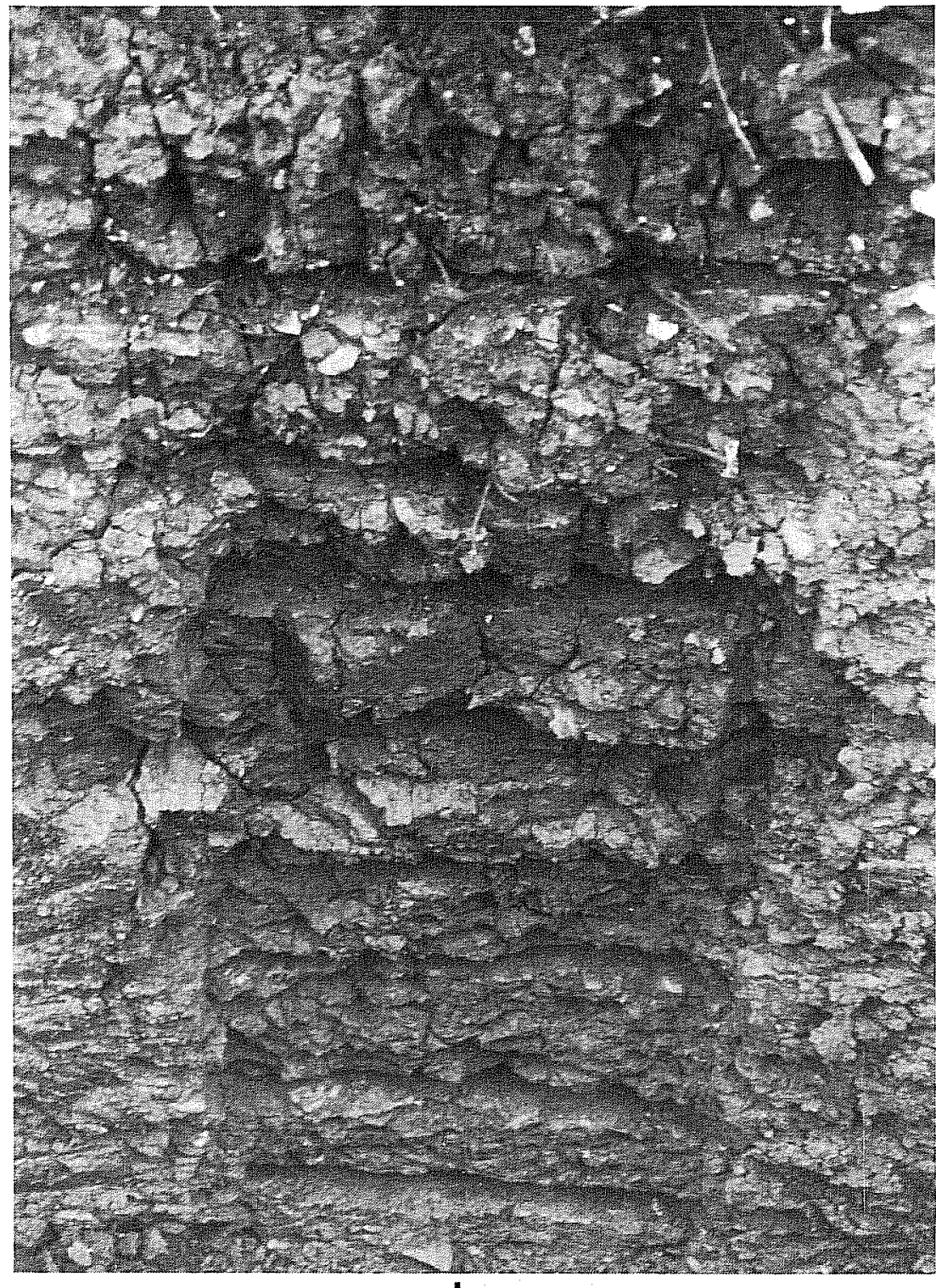

b

Figure 16. Views of Hotel and November Trenches. a, Feature 2 profile in wall of trench (Hote1); b. phytolith samples remioved from trench wall (November). 
batches of provenience slips were numbered and distributed in the field. To further assist with processing and analysis, the slips were colored according to the areas in which the material was recovered, i.e., a blue slip was only used to record items in Area Blue. The item, whether artifact, ecofact, or special sample, was packaged individually with its slip enclosed; and the number assigned to the item by virtue of its slip was recorded on the appropriate unit-level or feature summary form. The field number became the item's catalog number and could be permanently affixed early in the Taboratory processing operation.

This system of assigning catalog numbers in the field and recording them directly on both the package and the summary form proved to be so successful for individually provenienced items that it was expanded to screened material. Screened material recovered from an entire $10 \mathrm{~cm}$ level of a $10-\mathrm{m}$ unit would be recorded as having recovery dimensions and thickness rather than coordinates and a depth below datum or ground surface. The quantity of material would naturally be more than a single item, and this was determined by a count in the laboratory.

Surface collections from $10-\mathrm{m}$ blocks or trench backdirt generally included only items which, if excavated, would be individually provenienced, i.e., chronologically, morphologically, or functionally diagnostic artifacts. As such, assignment of a field number and individual packaging was usually carried out if the item had been excavated. A surface recovery slip, prenumbered and color-coded similar to the excavation recovery slips, was employed in like manner.

\section{CLASSIFICATION TYPE CODES}

The determination as to whether an item was assigned a permanent field number rested in large part on an object inventory developed by the CAR-UTSA. Designated "Classification Type Codes" (see Appendix I.A, this 1ist assigned unique numbers to historic, prehistoric, and ecofactual types of objects that previous archaeological work in the region had identified. While the final determination of an item's classification type code was made in the laboratory only after processing (similar to "quantity" for screened items), anything on the list even tentatively identified in the field could be assigned a field number in anticipation of subsequent cataloging. A cataloged item could have only one classification type code. Individually provenienced items were automatically given a field number, and usually a tentative classification type code was also noted. Screened material was separated into general classification types (e.g., flakes, shells, burned rock) and provisional field numbers assigned to each group. The same system was employed for surface collections, which included both individual items and less often groups of similar items. For analytical purposes, the classification type code equaled provenience in importance and was a primary sorting criterion for computer manipulation of the project data. 


\section{SPECIAL SAMPLES}

The samples of soil collected from various parts and levels of the site departed from the standardized recording procedures described above. As no attempt was made to deal with material included within the soil samples at the time of collection, multiple classification type codes were always associated with a single sample. For this reason, while distinctive field numbers were assigned to each soil sample, the numbers represented a different system from that which generated permanent catalog numbers for each material type code. The form, which recorded the sample provenience and assigned it its number, was similar to the item recovery form, but the "CVS" number pre-assigned to the slip was prefixed by a triple "9" to differentiate it from the consecutive integer field numbers ("FN"). During or after laboratory analyses, items retrieved from the soil sample matrix were assigned catalog number and classification type codes, processed like excavated material, and analyzed accordingly.

Other samples, being unique entities devoid of material inclusions and having a classification type code of their own, were assigned a field number just like any other item. Individualized inventory sheets were designed, however, to record those data elements unique to the particular sample. Archaeomagnetic samples required a compass direction; radiocarbon samples required the recording of sample weight; and phytolith soil samples needed a known and constant volume of soil recorded, while thermoluminescence samples were associated with a volume of burned rock.

Feature numbers were assigned consecutively as they were identified, and an inventory sheet listed the features in numerical order to avoid duplicating feature numbers. The type of feature being investigated was given the appropriate code number from the classification type code list, similar to any artifact or ecofact type.

\section{TOTAL INVENTORY RECOVERY EXPERIMENT}

The recording of an artifact's exact provenience included determination of the east and north coordinates of the grid system and a measurement of the depth relative to unit ground surface or one of the various datum points. Exact provenience was normally determined only for artifacts identified in the field as having some analytical importance, i.e., diagnostic of something. As a general rule, all manufactured stone tools (defined as retouched flakes and a11 items intentionally shaped) were provenienced, as well as al1 ground stone and ceramic items. Al1 unretouched flakes were bagged together. The utilization of an artifact was considered too technical and time-consuming for field determination. All ecofactual material was sorted in the field into similar classification types, and each type was bagged together by excavation unit-level.

The one exception to the above procedure was an experiment in total recovery. In two units at the site, a17 material was individually provenienced, thus allowing the computer generation of distribution maps at depths varying by only a single centimeter. This total inventory recovery experiment (TIRE) was carried out in conjunction with two features: (1) the $14 \mathrm{~cm}$ immediately 
below the burned rock of the midden (Feature 2); and (2) eight centimeters associated with the Feature 4 occupation floor. In both operations, each flake, shell, rock, and fleck was recorded, assigned a field number, and individually packaged.

\section{PICTORIAL RECORDING}

Plan drawings were made of those features characterized by burned rock, with the exception of the midden (Feature 2). These include Features 3 (Fig. 27), 6 (Fig. 30), 8 (Fig. 41), 10 (Fig. 37), and 11 (Fig. 39). The occupation floor Features 4 (Fig. 31,a), 5 (Fig. 25, b), and 7 (Fig. 14, b) were documented by photographs only, as was the midden because of its large size.

All trenches were drawn in profile at a point considered typical of their stratigraphy and for an extent sufficient to include any subsurface horizontal variability (see Figs. 17-23).

Plane table maps were drawn of the contours of the entire site and of all excavated units and trenches (Figs. 8, 10, 11, 12).

In addition to report-oriented photographs of all features and trenches, both color slides and black-and-white prints were taken in quantity to document all activities and progress during the course of the 41 BX 300 mitigation project. Field notes, photographs, and original maps and drawings are on file at the UTSA Center for Archaeological Research.

\section{STRATIGRAPHY}

The nature and extent of the various natural strata exposed during mitigation activity at 41 BX 300 are discussed. Stratigraphy at the site can be summarized as having three general strata (Fig. 21). These include the topsoil and the two bedrock formations previously discussed by Evans: the Edwards limestone and the overlying Del Rio clay. Both the Edwards and Del Rio strata have one, or even two, substrata in localized areas of the site, but their general characteristics remain the same throughout the stratum. Table 11 provides comparative data for these three strata obtained from soil samples collected from November trench. Actual values, rather than site means, are presented, thus giving considerable weight to the stratigraphic relationships demonstrated.

\section{TOPSOIL}

Topsoil at the site is represented by alluvial soil from Elm Waterhole (or Long) Creek, an intermittent stream flowing immediately to the east (Figs. 1 , 3). Topsoil depth is variable across the site, but it is shallowest in the southwest and northeast portions and deepest in the northwest and southeast portions (Fig. 11). Profiles from Bravo trench in the southwest (Fig. 17) and the Area Green trenches in the northeast (Figs. 18-20) reflect the bottom of the topsoil at depths between 20-35 cm below the ground surface. By contrast, Alfa and Kilo trenches in the southeast (Figs. 17, 21) exhibit a 


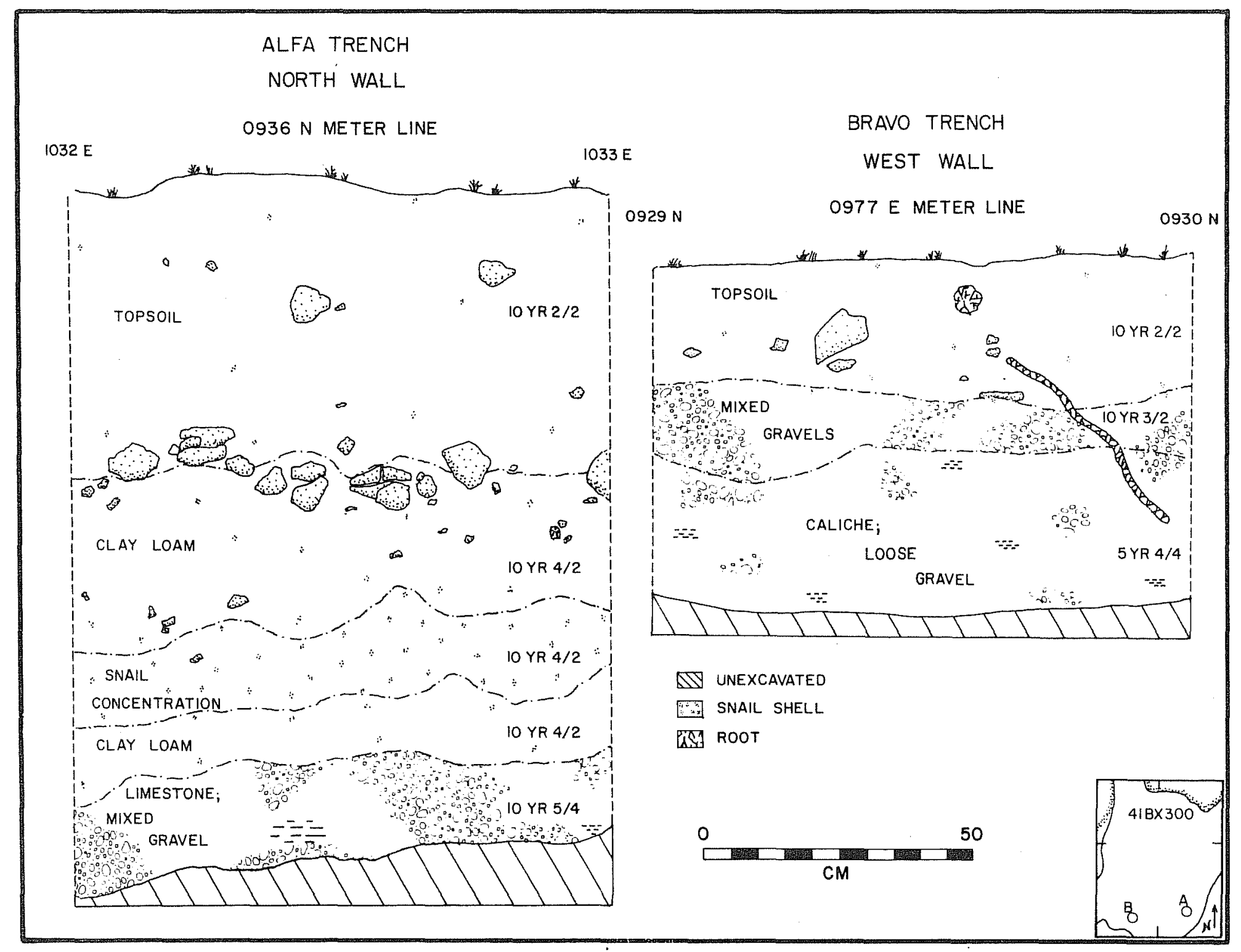




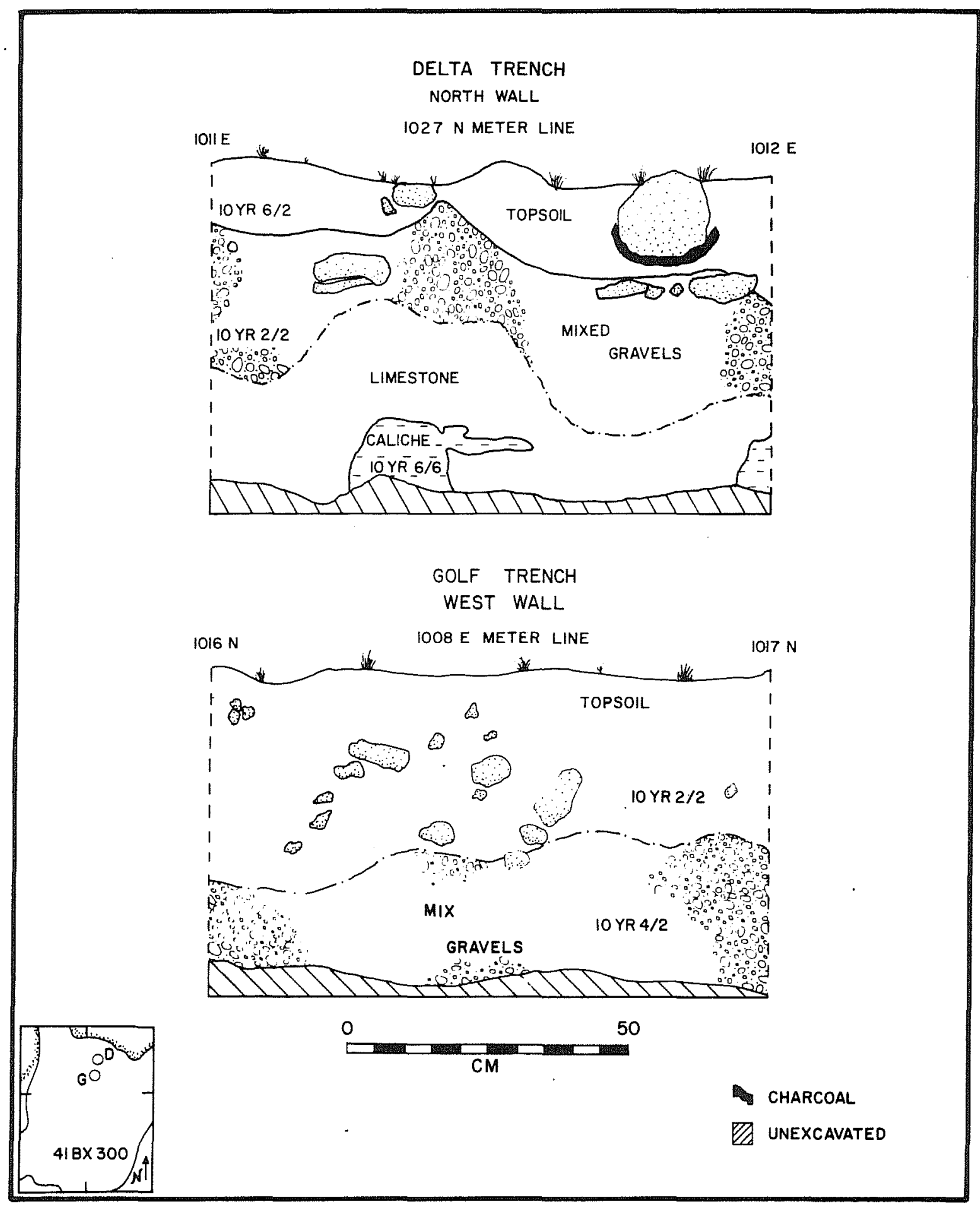

Figure 18. Profile Drawings of Delta and Golf Trenches, Area Green. 


\section{ECHO TRENCH \\ SOUTH WALL}

1014 N METER LINE
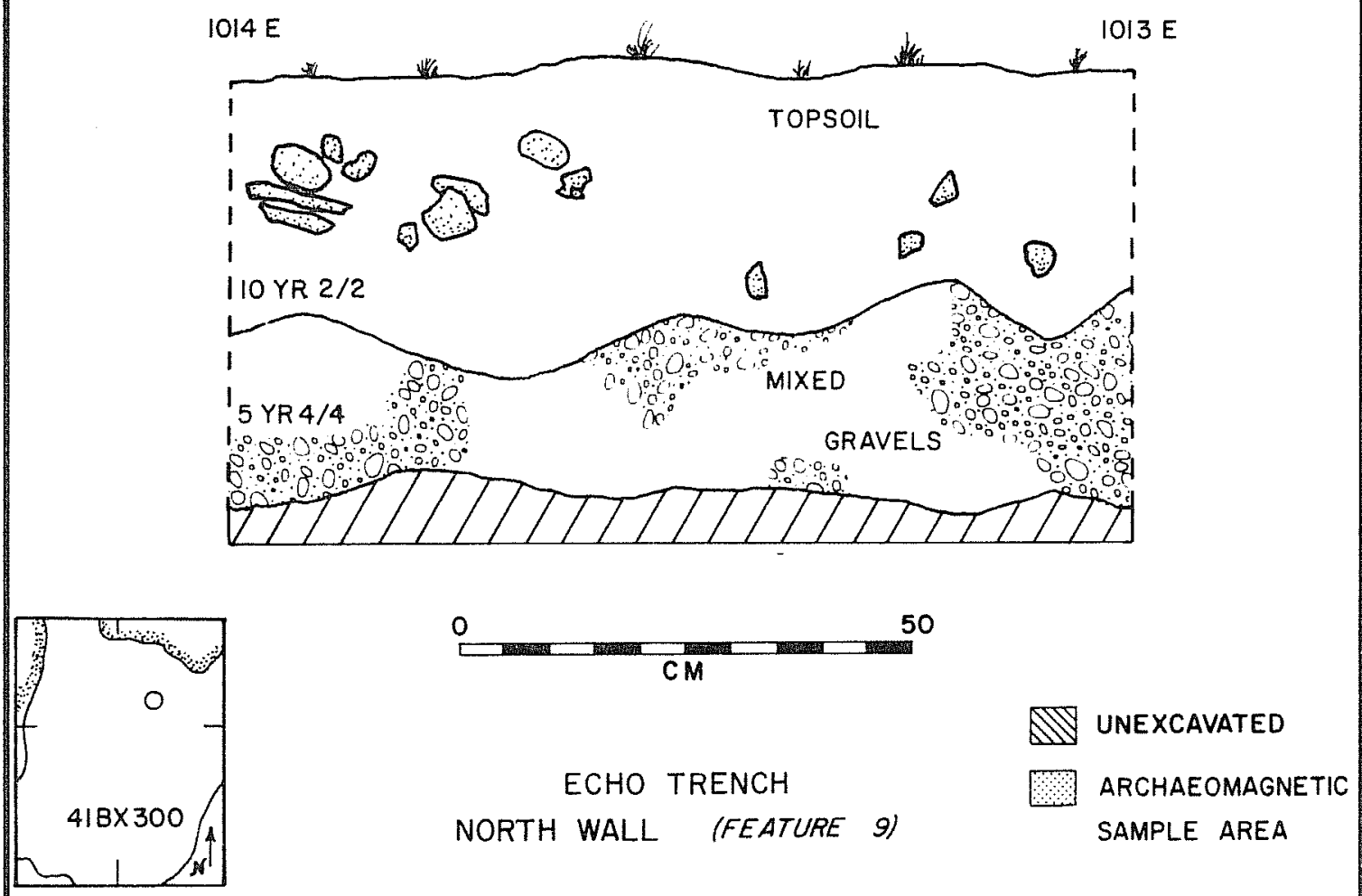

1015 N METER LINE

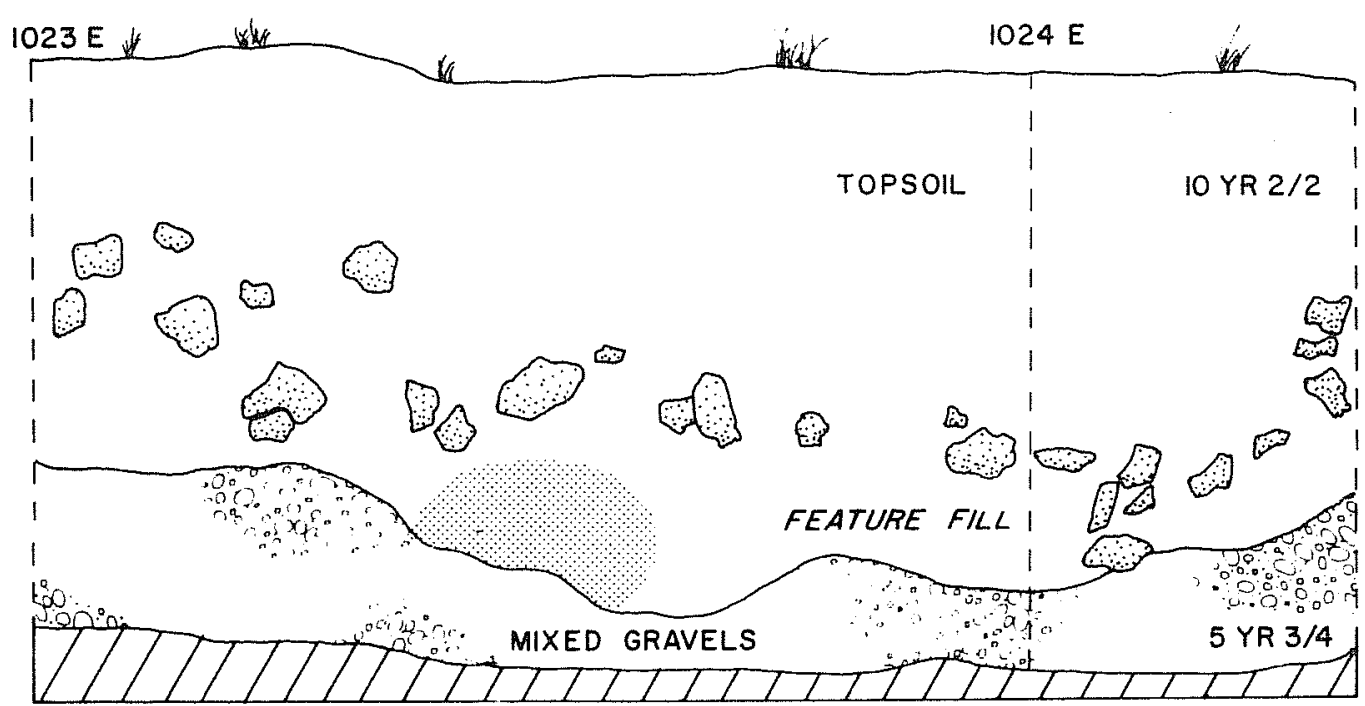

Figure 19. Profile Drawings of Echo Trench, Area Green, Indicating Feature 9. 


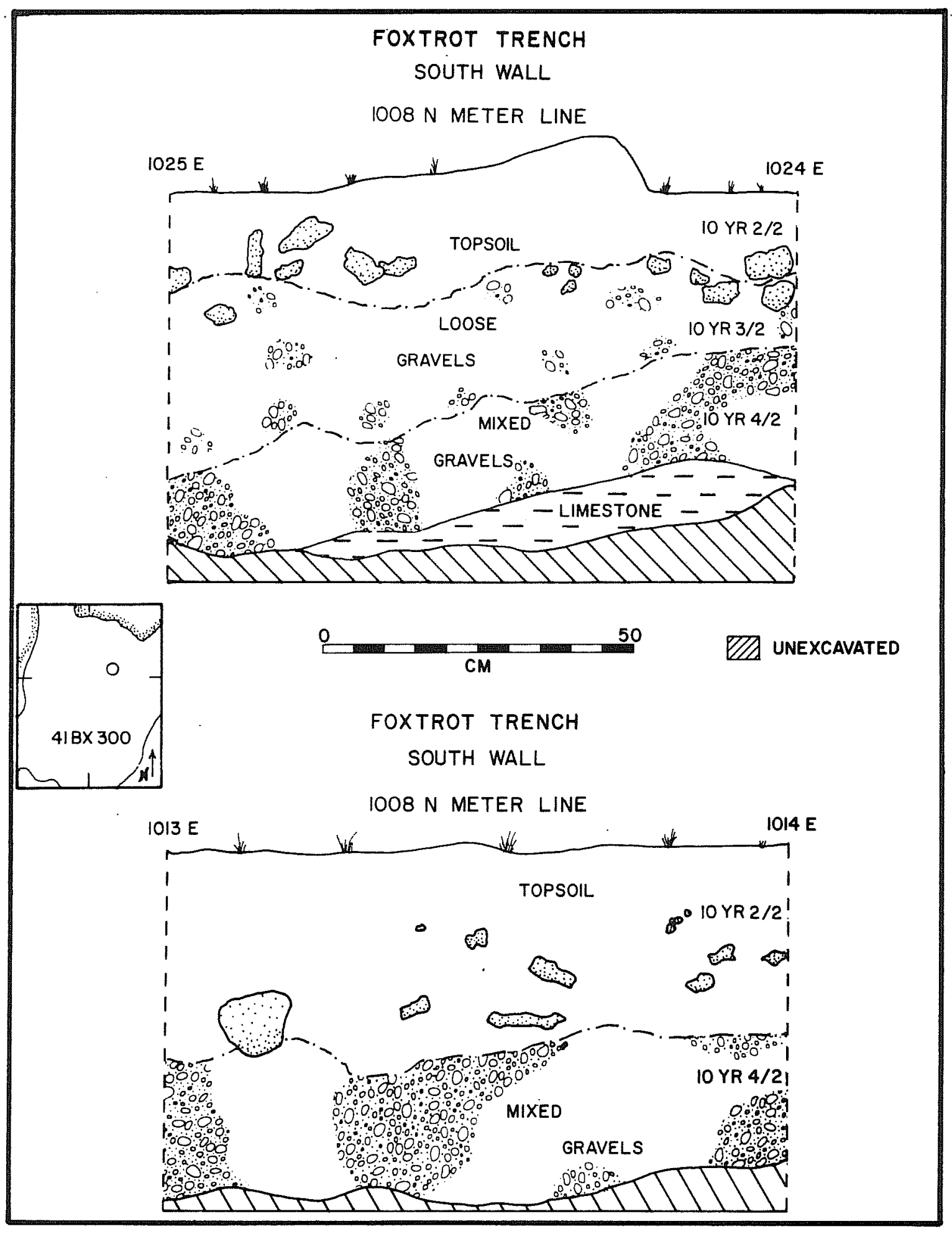

Figure 20. Profile Drawings of Foxtrot Trench, Area Green. 


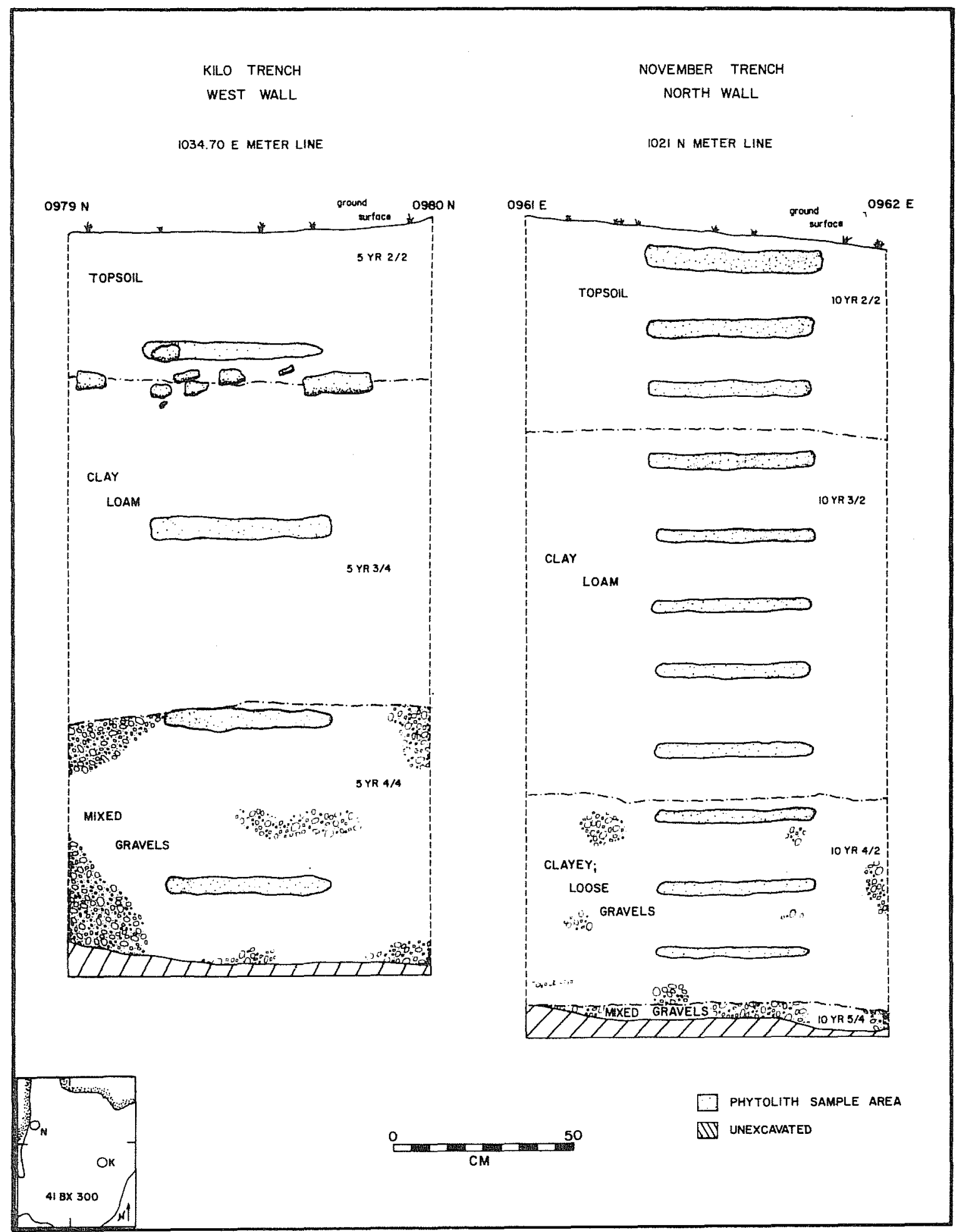

Figure 21. Profile Drawings of Kilo and November Trenches, Areas White and Blue, Respectively. The location of phytolith samples taken from the walls is indicated. 
topsoil thickness of $55 \mathrm{~cm}$ and $40 \mathrm{~cm}$, respectively, and November trench in the northwest (Fig. 21) had $50 \mathrm{~cm}$ of topsoil.

Topsoil color trends to be dusky yellowish brown, 10 YR 2/2 (Rock Color Chart Committee 1948), with about a $3 \%$ organic content. It is mildly alkaline, having an average $\mathrm{pH}$ of 7.7 . The overall texture of the topsoil is clay, as it is characterized by a $60 \%$ clay content. As a consequence, the topsoil becomes blocky when dry, developing fissures into which artifacts or ecofacts may fall. Excavation is equally difficult whenever this soil is too wet or too dry; only when freshly damp is digging reasonable and colors true.

TABLE 11. STRATUM CHARACTERISTICS

\begin{tabular}{lccc}
\hline Soil Characteristics* & Topsoil & Del Rio Clay & Edwards Limestone \\
\hline Texture & clay & clay & clay \\
& & & \\
Percentage of sand & 30.0 & 20.0 & 16.0 \\
Percentage of silt & 10.0 & 19.0 & 19.0 \\
Percentage of clay & 60.0 & 61.0 & 65.0 \\
& & & \\
pH level & 7.7 & 8.3 & 8.7 \\
Calcium level & very high & very high & very high \\
Magnesium leve1 & high & high & high \\
Phosphorus leve1 & very high & medium & high \\
Potassium leve1 & very high & very high & very high \\
Zinc (ppm) & $>20.0$ & 8.6 & $>20.0$ \\
Iron (ppm) & 11.2 & 13.0 & 11.0 \\
Manganese (ppm) & $>10.0$ & 9.4 & 4.0 \\
Organic content (\%) & 3.1 & 1.0 & 0.5 \\
Average color & 10 YR 2/2 & 10 YR 4/2 & 5 YR 4/4 \\
& (dusky & (dark & (moderate \\
& yellowish & yellowish & brown) \\
& brown) & brown) &
\end{tabular}

* Soil characteristics obtained from November trench (Fig. 21) in centimeters below ground surface: topsoil, 26; Del Rio clay, 103; Edwards 1 imestone, 182.

\section{DEL RIO CLAY}

Trench profiles indicate the presence of the Del Rio clay in quantity only in the northwest and southeast portions of the site; thicknesses range from one meter in Alfa trench (Fig. 17) and $120 \mathrm{~cm}$ in Kilo trench (Fig. 21) in the 
southeast to $150 \mathrm{~cm}$ in November trench (Fig. 21) in the northwest. The entire stratum is absent in the southwest, as indicated by Bravo trench (Fig. 17) and in the northeast, as shown by all Area Green trench profiles (Figs. 18-20). In Area Red, the site center, the stratum designated "submidden" or "subsoil" immediately beneath the midden in the profiles of Hotel (Fig. 22), India, and Omega (Fig. 23) trenches represents a remnant of the Del Rio clay. It is relatively thin here by comparison with the northwest and southeast representations, averaging $7 e s s$ than $20 \mathrm{~cm}$ thick.

The Del Rio clay stratum is lighter in color than the topsoil, averaging dark yellowish brown, 10 YR 4/2 (Rock Color Chart Committee 1948). It has a clay texture, with $61 \% \mathrm{cl}$ ay content and a $1.0 \%$ organic content. The $\mathrm{pH}$ is moderately alkaline, averaging 8.3 ; and it is characterized by a high iron (13 ppm) and low zinc (8.6 ppm) content.

\section{EDWARDS LIMESTONE}

The Edwards limestone formation is considered to be the typical bedrock in the locality of the site, and excavation terminated after modest penetration. The Edwards 7 imestone is the lightest of the three strata in color, appearing yellow or reddish in places but averaging moderate brown, 5 YR 4/4 (Rock Color Chart Committee 1948). It has the highest clay content, $65 \%$, the highest $\mathrm{pH}, 8.7$ (strongly alkaline), and the lowest organic content, $0.5 \%$. In the profiles from around the site (Figs. 17-23), this formation is variously referred to as "7imestone," "mixed gravel," "caliche," or "loose grave1." In some profiles there will be indicated substrata of more than one of these terms, but this is considered a combination of microvariation and archaeological enthusiasm rather than completely different geological formations; the analytical characteristics are identical.

\section{STRATUM COMPARISONS AND DISTRIBUTION}

The three strata at the site, well represented in November trench in the northwest (BTue) area, exhibit a series of trends which reflect the stratigraphic relationship between them (Table 11). While all have an overall clay texture, the proportion of clay and silt increase below the surface at the expense of sand. Inclusive rock size and amount increase with depth. The color becomes lighter as one progresses deeper; the $\mathrm{pH}$ increases, and the organic content decreases with depth as we1l. Individual variations in mineral content, such as the higher iron and lower phosphorus and zinc content of the Del Rio clay, help to identify this formation and give it some distinctiveness; but the overall similarity in composition reflects close geological relationships between the three strata.

The geomorphological history of $41 \mathrm{BX} 300$, and the fact that the Del Rio clay is easily eroded, account for the fact that it is not present in all portions of the site. Evans' postulation of two streams until middle post-Pleistocene times would result in constant erosional activity on both sides of the site simultaneously (Fig. 3). The interfluvial, or interchannel, divide between the two streams would be the area most likely to retain evidence of the De1 Rio clay, and this area should reflect a linear orientation. The presence of 


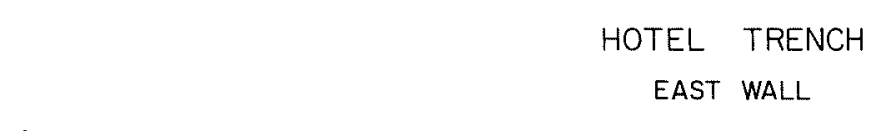

METERS

999.75 E METER LINE

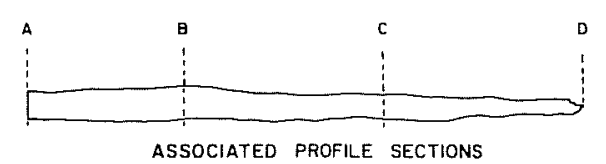

ASSOCIATED PROFLE SECTIONS
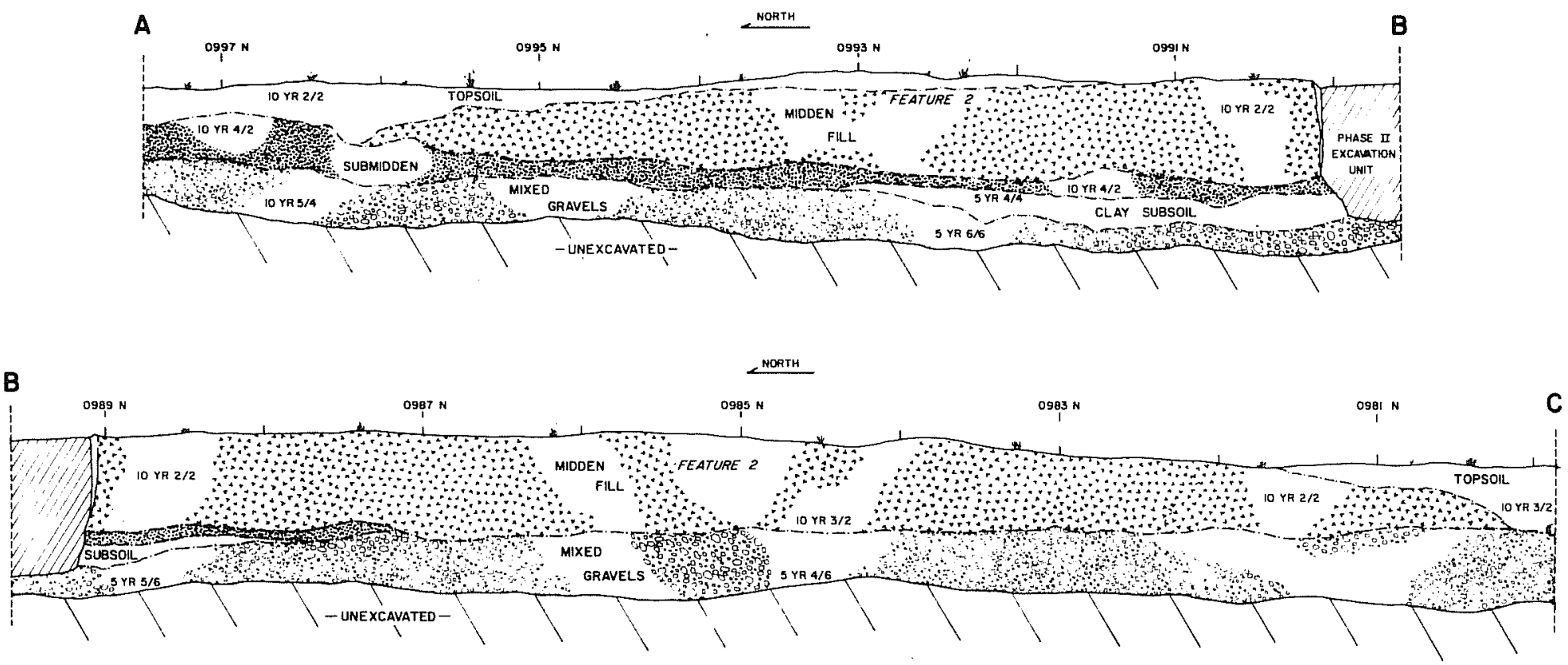

C

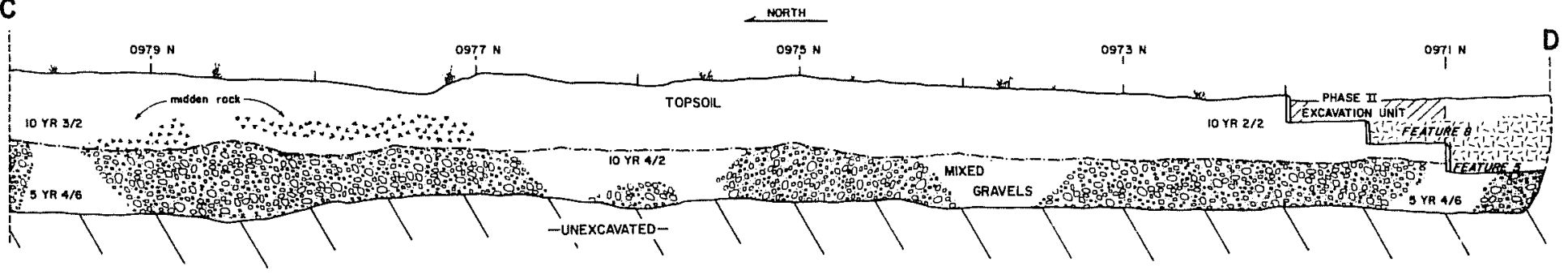

Figure 22. Profile Drawings of Hotel Trench, Area Red, Indicating Feature 2. 


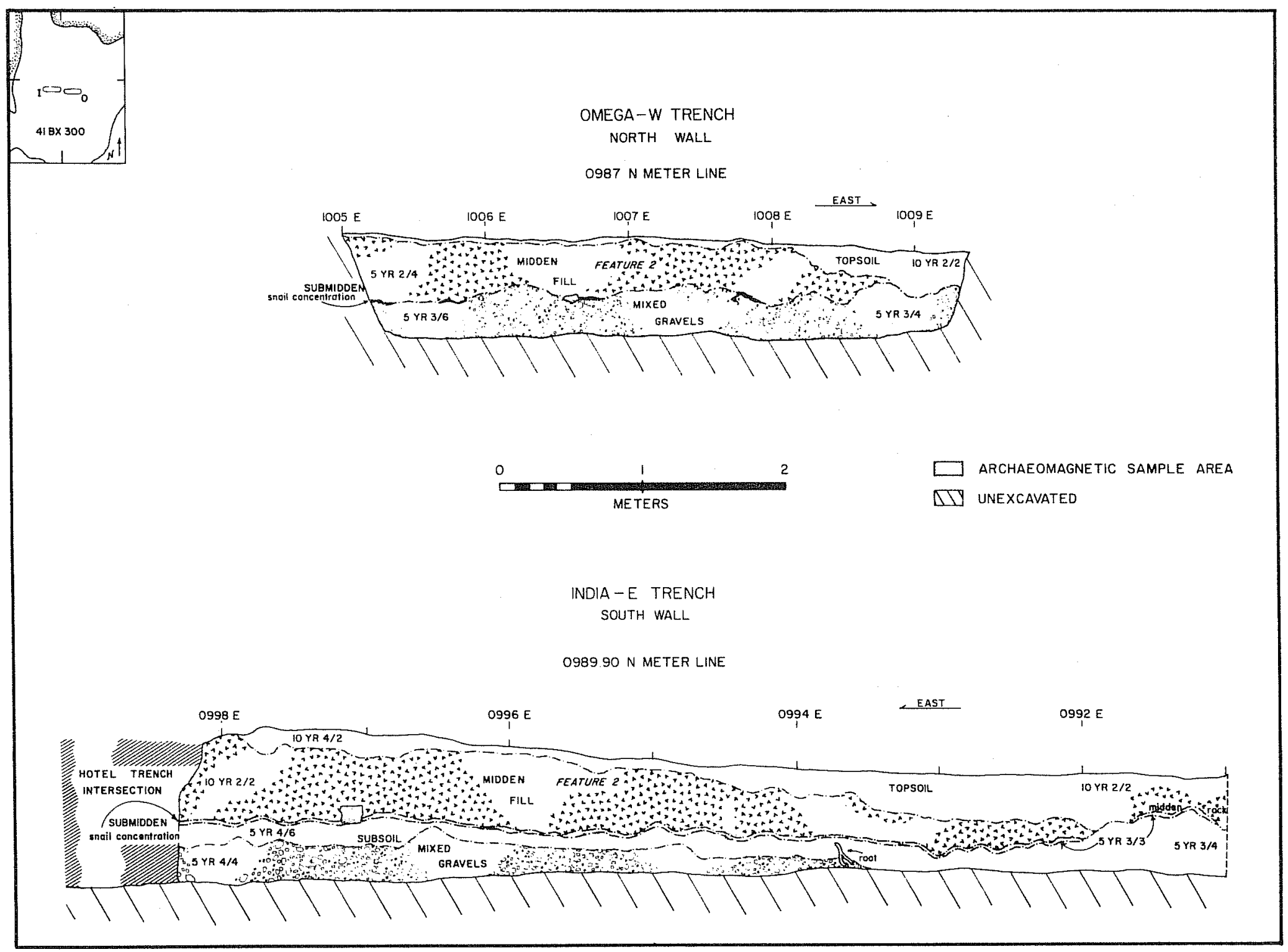

Figure 23. Profile Drawings of Omega-W and India-E Trenches, Area Red, Indicating Feature 2. 
this stratum only in profiles extending across the site from southeast to northwest supports this reconstruction. This 1 ine also marks the highest elevations of the site (Figs. 8, 10), likewise suggesting a remnant "spine" from bilateral erosion. Subsequent alluvial buildup from the remaining intermittent stream to the east would crest on the remnant Del Rio clay; the thinnest alluvial topsoil is in the southwestern portion of the site (see Bravo trench profile, Fig. 17), sheltered behind the central "ridge" of Del Rio clay.

According to Evans (this report), the site became habitable about the middle of the post-Pleistocene. At that time, the ground surface would have been characterized by a thick stratum of clayey soil in the northwest and southeast and a thin layer of clay over $1 \mathrm{imestone}$ bedrock in the center of the site. Limestone rock would have been the surface of the ground in the northeast and southwest portions of the site.

The differential buildup of topsoil, for geomorphological reasons previously discussed, makes relative dating by comparative depth below present ground surface inadvisable. The best chronometric base line is the postulated surface of the ground in middle post-Pleistocene times, when the stream channels were rearranged and the site became habitable; this is the point in time preceding the buildup of topsoil. Artifacts and features identified in contextual association within the top of the limestone or clay formations are both roughly contemporaneous among themselves and earlier in time than other material and features recovered from within the topsoil stratum. Stratigraphic dating of all cultural material within the topsoil must be corroborated by other means, although the topsoil stratum is sufficiently thick as to suggest material closer to the surface is younger than material closer to the topsoil/clay or limestone transition zone.

\section{DESCRIPTION AND ANALYSIS OF ECOFACTS AND SPECIAL SAMPLES}

\section{SOIL SAMPLES}

The collection of samples of soil during the mitigation activities at 41 BX 300 served four distinct purposes.

1. The recovery of micro-ecofactual and artifactual material from the samples helped to provide a more complete representation of the cultural activities within the site. These were specimens which would otherwise have been lost, as the laboratory processing procedures for soil samples were much more rigorous and of a higher resolution than was the water screening procedure employed in the field.

2. A portion of each soil sample was submitted for analyses to determine the chemical content and the mechanical composition of the sample, and thus the matrix from which it was obtained.

3. The samples, because of their similar and constant volumes, provided statistically comparable proportions of both soil charactertistics and associated material throughout the site. 
4. The samples provided an unbiased and adequate amount of soil on which to experiment with methods for the cleaning and sorting procedures used for obtaining materials for analysis.

\section{COLLECTION AND PROCESSING OF CONSTANT VOLUME SAMPLES}

(Rebekah E. Halpern and Paul Katz)

Seventy-nine samples were collected during the mitigation phase, each composed of a constant volume of $2500 \mathrm{~cm}^{3}$ of soil. Experiments early in the field work phase determined that this size sample was large enough to provide a series of smaller subsamples for various analyses, yet small enough to pose no problems in collection, packaging, and transport.

Sixty-four (81\%) of the samples were associated with cultural features. At least two samples were collected either directly from or in close proximity to every one of the ten features investigated during the mitigation phase. As the features were located in all areas of the site and associated with all three of the soil zones, the samples are considered representative of site variability with respect to soil characteristics. Moreover, it was assumed that the features were the focus of site activity at the time the feature was in use; samples taken from them were expected to provide additional data for feature, and thus site activity, interpretation.

In addition, a stratigraphic series of samples was collected from two trenches, one series from November trench in the northwest area (B1ue) and the other from Kilo trench on the east (White) side of the site (Figs. 11, 12). These 15 (19\%) additional samples were not directly associated with cultural activity, and they provided an accurate picture of the natural soil characteristics and stratigraphic relationships. Table 12 provides data on the distribution of these 79 constant volume samples (CVS).

Laboratory processing of the CVS samples initially consisted of dry screening, first through 1/8-inch and then through 1/16-inch mesh. This procedure removed the larger specimens of artifacts and ecofacts, not recovered in the field because of the direct bagging of the sample. Dryscreened items were subsequently processed as if they were field-recovered specimens, however. Soil passing through both screens was mechanically seaparated using a geological sample splitter, so as to produce a series of unbiased and comparably -sized subsamples. Subsample size was $480 \mathrm{~cm}^{3}$, determined by the volume of a Texas A\&M Soil Testing Laboratory sample bag. Four subsamples were produced: one for particle size analysis; one for constituent analyses, and one each for further separation by water and chemical flotation techniques.

Experimentation concluded that hydrogen peroxide performed better than water flotation for the recovery of carbonized materials from the 41 BX 300 soil matrix. This is due to the high clay content of the soil, which was more effectively broken down by hydrogen peroxide, releasing 1 arger amounts of whole pieces of charcoal and seeds. Sorting time of the resultant fractions was shortened as well, as the material from the chemical flotation was cleaner than similar material resulting from water flotation. The details of this experiment are on file at the CAR-UTSA (Halpern 1978). 
TABLE 12. DISTRIBUTION OF CONSTANT VOLUME SAMPLES

\begin{tabular}{|c|c|c|c|c|c|}
\hline $\begin{array}{l}\text { Catalog } \\
\text { Number }\end{array}$ & Area & $\begin{array}{l}\text { Unit or } \\
\text { Trench }\end{array}$ & $\begin{array}{l}\text { Depth Below } \\
\text { Ground } \\
\text { Surface }(\mathrm{cm})\end{array}$ & $\begin{array}{l}\text { Associated } \\
\text { Feature }\end{array}$ & Stratum \\
\hline 999500 & Red & 076037 & 22 & 3 & Feature zone \\
\hline 999501 & Red & 076037 & 23 & 3 & Feature zone \\
\hline 999502 & Red & 076037 & 24 & 3 & Feature zone \\
\hline 999503 & Red & 076037 & 25 & 3 & Feature zone \\
\hline 999504 & Red & 076037 & 26 & 3 & Feature zone \\
\hline 999505 & Red & 076037 & 28 & 3 & Feature zone \\
\hline 999506 & Red & 076030 & 10 & 4 & Occupation zone \\
\hline 999507 & Red & 076037 & 33 & 3 & Feature zone \\
\hline 999508 & Red & 076030 & 11 & 4 & Occupation zone \\
\hline 999509 & Red & 076037 & 36 & 3 & Feature zone \\
\hline 999510 & Red & 076038 & 26 & 3 & Feature zone \\
\hline 999511 & Red & 076038 & 33 & 3 & Feature zone \\
\hline 999512 & Red & 076029 & 10 & 4 & Occupation zone \\
\hline 999513 & Red & 076038 & 40 & 3 & Feature zone \\
\hline 999514 & Red & 077012 & 35 & 6 & Feature zone \\
\hline 999515 & Red & 076029 & 11 & 4 & Occupation zone \\
\hline 999516 & $\operatorname{Red}$ & 076037 & 45 & 3 & Feature zone \\
\hline 999517 & Red & 065005 & 75 & $(2)$ & Submidden zone \\
\hline 999518 & Red & 085009 & 30 & 8 & Feature zone \\
\hline 999519 & Red & 076010 & 39 & 5 & Occupation zone \\
\hline 999520 & Green & 037044 & 45 & 9 & Feature zone \\
\hline 999521 & Green & 037044 & 71 & (9) & Mixed gravel \\
\hline 999522 & $\operatorname{Red}$ & 077012 & 53 & 5 & Occupation zone \\
\hline 999523 & Red & 077012 & 47 & 5 & Occupation zone \\
\hline 999524 & Red & 077002 & 34 & 5 & Occupation zone \\
\hline 999525 & Red & 077003 & 32 & 6 & Feature zone \\
\hline 999526 & Red & 077003 & 38 & 5 & Occupation zone \\
\hline 999527 & Red & 056008 & 5 & 7 & Occupation zone \\
\hline 999528 & Red & 085009 & 49 & 8 & Feature zone \\
\hline 999529 & Red & 056016 & 9 & 7 & Occupation zone \\
\hline 999530 & Red & 056008 & 8 & 7 & Occupation zone \\
\hline 999531 & Red & 056016 & 11 & 7 & Occupation zone \\
\hline 999532 & Red & 056007 & 5 & 7 & Occupation zone \\
\hline 999533 & Red & 056027 & 8 & 7 & Occupation zone \\
\hline 999534 & Red & 056008 & 10 & 7 & Occupation zone \\
\hline 999535 & Red & 056007 & 8 & 7 & Occupation zone \\
\hline 999536 & Red & 077012 & 35 & 6 & Feature zone \\
\hline 999537 & Red & 077012 & 40 & 6 & Feature zone \\
\hline 999538 & Red & 055066 & 8 & 2 & Midden fill \\
\hline 999539 & Red & 055066 & 20 & $(2)$ & Submidden zone \\
\hline 999540 & Red & 055084 & 23 & 2 & Midden fill \\
\hline 999541 & Red & 056084 & 33 & 2 & Midden fill \\
\hline 999542 & $\operatorname{Red}$ & 056008 & 14 & 7 & Occupation zone \\
\hline
\end{tabular}


Site 41 BX 300/Ecofacts and Special Samples

TABLE 12. (continued)

\begin{tabular}{|c|c|c|c|c|c|}
\hline $\begin{array}{l}\text { Catalog } \\
\text { Number }\end{array}$ & Area & $\begin{array}{l}\text { Unit or } \\
\text { Trench }\end{array}$ & $\begin{array}{l}\text { Depth Below } \\
\text { Ground } \\
\text { Surface }(\mathrm{cm})\end{array}$ & $\begin{array}{l}\text { Associated } \\
\text { Feature }\end{array}$ & Stratum \\
\hline 999543 & Red & 056016 & 14 & 7 & Occupation zone \\
\hline 999544 & Red & 056016 & 17 & 7 & Occupation zone \\
\hline 999545 & Red & 056007 & 11 & 7 & Occupation zone \\
\hline 999546 & Red & 056027 & 11 & 7 & Occupation zone \\
\hline 999547 & Red & 056027 & 13 & 7 & Occupation zone \\
\hline 999548 & Red & 055084 & 43 & 2 & Midden fil \\
\hline 999549 & Red & 055084 & 50 & $(2)$ & Submidden zone \\
\hline 999550 & Red & 055084 & 60 & (2) & Submidden zone \\
\hline 999551 & Red & 085010 & 30 & 8 & Feature zone \\
\hline 999552 & Red & 075100 & 30 & 8 & Feature zone \\
\hline 999553 & Red & 075099 & 28 & 8 & Feature zone \\
\hline 999554 & Red & 075100 & 35 & 8 & Feature zone \\
\hline 999555 & Red & 085010 & 35 & 8 & Feature zone \\
\hline 999556 & Red & 075009 & 30 & 8 & Feature zone \\
\hline 999557 & Red & 075009 & 32 & 8 & Feature zone \\
\hline 999558 & Red & 075009 & 34 & 8 & Feature zone \\
\hline 999559 & Red & 075009 & 36 & 8 & Feature zone \\
\hline 999560 & Red & 075009 & 38 & 8 & Feature zone \\
\hline 999561 & Red & 075099 & 43 & 8 & Mixed gravel \\
\hline 999562 & Yellow & 117062 & 35 & 11 & Feature zone \\
\hline 999563 & White & 079095 & 35 & 10 & Feature zone \\
\hline 999582 & ETue & November & 8 & 1 & Topsoi1 \\
\hline 999583 & Blue & November & 26 & 1 & Topsoil \\
\hline 999584 & Blue & November & 43 & 1 & Topsoi1 \\
\hline 999585 & B1ue & November & 63 & 1 & Subsoit \\
\hline 999586 & Blue & Novemiber & 84 & 1 & Subsoil \\
\hline 999587 & Bive & November & 103 & $i$ & Subsoit \\
\hline 999588 & B7ue & November & 121 & 1 & Subsoil \\
\hline 999589 & Blue & Novemiber & 143 & 1 & Subsoil \\
\hline 999590 & Blue & November & 162 & 1 & Mixed Gravel \\
\hline 999591 & Blue & November & 182. & 1 & Mixed gravel \\
\hline 999592 & Blue & November & 199 & 1 & Mixed gravel \\
\hline 999593 & White & $\mathrm{KilO}$ & 134 & 1 & Mixed gravel \\
\hline 999594 & White & $\mathrm{Kilo}$ & 180 & 1 & Mixed gravel \\
\hline 999595 & White & $\mathrm{Kilo}$ & 33 & $\overrightarrow{1}$ & Topsoit \\
\hline 999596 & White & $\mathrm{Kilo}$ & 81 & 1 & Subsoi1 \\
\hline
\end{tabular}

Note: Parentheses indicate indirect feature association. 
Organic material recovered from the flotation procedure was assigned the same catalog number as its CVS sample matrix, i.e., consecutively assigned in the field and prefixed by a triple "9." Light and heavy fractions of each sample, i.e., that material which floated and that which did not, were kept separated and designated by either an "L" or "H" suffix to the catalog number, as appropriate. This material was given to a botanist for identification, and the analysis is provided later in this section.

\section{PARTICLE SIZE AND CONSTITUENT ANALYSES}

Subsamples of $480 \mathrm{~cm}^{3}$ of soil from each of the 79 CVS samples collected during mitigation were submitted to the Oklahoma State University (OSU) and the Texas A\&M (TAMU) Soil Testing Laboratories. At OSU, the samples were mechanically analyzed for particle size; and at TAMU analyses were conducted to determine the $\mathrm{pH}$, organic content, and chemical constituents. Tables 13 and 14 present the results of these analyses, keyed to the provenience of the samples provided in Table 12 by catalog number.

A discussion of the general site soil characteristics and the stratigraphic relationships between them has been provided in the previous section. Table 11 presents data from three samples taken from each of the primary soil strata at the site, well represented in the profile of November trench in the northwest area (BIue) of the site (Fig. 21). The major characteristics of each stratum, and such stratigraphic relationships as the increase in clay content and the decrease in organic content with depth, are clearly evidenced.

As most of the soil samples were collected from individual cultural features, these data will be presented and analyzed in conjunction with the discussion of these features. Of general interest is the nature of the soil with respect to the potential for the preservation of organic material. The outlook is gloomy, as evidenced by the data for organic content presented in Table 14. Of the 79 samples, most from cultural features, only three exceed $3.0 \%$ in organic content. Despite the mild to moderate alkalinity of the soil (6.8-8.8 $\mathrm{pH}$, Table 14), the high clay content and the unusual hydrologic features of the site are factors which are attributed to poor organic preservation.

\section{ECOFACTUAL MATERIAL}

Only molluscan remains were recovered in any quantity during the mitigation activities. Faunal material was poorly preserved, and botanical remains were extremely limited in quantity. The rigor with which we collected and processed soil samples and then sorted the floated and cleaned organic residue left no doubt that this type of material was not missed; rather, it was never present in any appreciable quantity or, what is most $7 i k e 1 y$, did not survive in the soil matrix at 41 BX 300 . Factors of soil composition and continually high moisture content are suggested as most likely to account for this situation. The following reports from the respective consultants responsible for the various identifications and analyses of ecofactual 
Site 41 BX 300/Ecofacts and Special Samples

TAELE 13. PARTICLE SIZE ANALYSIS

\begin{tabular}{|c|c|c|c|c|}
\hline Number & Sand & sitt & CTay & Texture \\
\hline 999500 & 30.00 & 18.00 & 52.00 & Clay \\
\hline 999501 & 29.80 & 17.50 & 52.80 & Clay \\
\hline 999502 & 28.00 & 20.50 & 51.50 & CTay \\
\hline 999503 & 29.00 & 18.25 & 52.75 & Clay \\
\hline 999504 & 27.50 & 20.75 & 51.75 & Clay \\
\hline 999505 & 29.50 & 17.50 & 53.00 & Clay \\
\hline 999506 & 28.25 & 17.25 & 54.50 & Clay \\
\hline 999507 & 29.00 & 16.50 & 54.50 & Clay \\
\hline 999508 & 30.00 & 17.00 & 53.00 & Clay \\
\hline 999509 & 29.50 & 17.50 & 53.00 & Clay \\
\hline 999510 & 29.75 & 18.00 & 52.25 & Clay \\
\hline 999511 & 27.75 & 18.25 & 54.00 & Clay \\
\hline 999512 & 28.00 & 19.50 & 52.50 & Clay \\
\hline 999513 & 25.50 & 20.75 & 53.75 & C.1 ay \\
\hline 999514 & 28.50 & 18.75 & 52.75 & Clay \\
\hline 999515 & 28.50 & 18.50 & 53.00 & Clay \\
\hline 999516 & 28.75 & 17.25 & 54.00 & CTay \\
\hline 999517 & 22.50 & 17.50 & 60.00 & Clay \\
\hline 999518 & 27.50 & 17.00 & 55.50 & Clay \\
\hline 999519 & 26.50 & 20.00 & 53.50 & Clay \\
\hline 999520 & 28.50 & 17.00 & 54.50 & Clay \\
\hline 999521. & 22.25 & 19.25 & 58.51 & Clay \\
\hline 999522 & 24.25 & 21.25 & 54.50 & CTay \\
\hline 999523 & 26.50 & 18.00 & 55.50 & Clay \\
\hline 999524 & 26.50 & 19.00 & 54.50 & Clay \\
\hline 999525 & 26.50 & 19.00 & 54.50 & Clay \\
\hline 999526 & 23.50 & 23.00 & 53.50 & $\mathrm{Cl} \div \mathrm{y}^{\prime}$ \\
\hline 999527 & 28.50 & 17.00 & 54.50 & Clay \\
\hline 999528 & 27.50 & 16.50 & 56.00 & Clay \\
\hline 999529 & 29.50 & 14.75 & 55.75 & Clay \\
\hline 999530 & 27.25 & 16.75 & 56.00 & Clay \\
\hline 999531 & 26.00 & 18.00 & 56.00 & C.7ay \\
\hline 999532. & 28.50 & 18.00 & 53.50 & Clay \\
\hline 999533 & 28.50 & 18.00 & 53.50 & C.7 ay \\
\hline 999534 & 30.00 & 16.25 & 53.75 & Clay \\
\hline 999535 & 27.00 & 18.50 & 54.50 & Clay \\
\hline 999536 & 30.00 & 17.50 & 52.50 & Clay \\
\hline 999537 & 30.50 & 18.00 & 51.50 & Clay \\
\hline 999538 & 28.00 & 17.25 & 54.75 & Clay \\
\hline 999539 & 25.50 & 18.75 & 55.75 & Clay \\
\hline 999540 & 30.25 & 18.00 & 51.75 & Clay \\
\hline
\end{tabular}


Site 41 BX 300/Ecofacts and Special Samples

TABLE 13. (continued)

\begin{tabular}{|c|c|c|c|c|}
\hline $\begin{array}{l}\text { Catalog } \\
\text { Number }\end{array}$ & Sand & Silt & Clay & Texture \\
\hline $\begin{array}{l}999541 \\
999542 \\
999543 \\
999544 \\
999545 \\
999546 \\
999547 \\
999548 \\
999549 \\
999550 \\
999551 \\
999552 \\
999553 \\
999554 \\
999555 \\
999556 \\
999557 \\
999558 \\
999559 \\
999560 \\
999561 \\
999562 \\
999563 \\
999582 \\
999583 \\
999584 \\
999585 \\
999586 \\
999587 \\
999588 \\
999599 \\
999590 \\
999591 \\
999592 \\
999593 \\
999594 \\
999595 \\
999596\end{array}$ & $\begin{array}{l}26.50 \\
25.50 \\
27.75 \\
27.00 \\
29.00 \\
28.00 \\
28.00 \\
26.00 \\
23.25 \\
24.75 \\
25.50 \\
27.50 \\
27.50 \\
29.75 \\
29.50 \\
28.00 \\
27.00 \\
29.50 \\
27.50 \\
30.00 \\
30.00 \\
25.50 \\
29.50 \\
00.00 \\
30.50 \\
25.00 \\
31.50 \\
28.50 \\
20.00 \\
20.00 \\
19.50 \\
17.00 \\
16.50 \\
16.00 \\
29.00 \\
24.50 \\
50.00 \\
40.00\end{array}$ & $\begin{array}{r}18.75 \\
19.75 \\
17.75 \\
18.50 \\
16.50 \\
19.50 \\
19.50 \\
19.50 \\
18.50 \\
17.45 \\
20.00 \\
19.50 \\
19.75 \\
17.25 \\
16.50 \\
18.75 \\
20.00 \\
19.00 \\
21.00 \\
18.75 \\
26.50 \\
19.00 \\
19.00 \\
00.00 \\
10.00 \\
9.50 \\
9.00 \\
12.00 \\
19.00 \\
17.00 \\
15.00 \\
43.50 \\
19.00 \\
17.00 \\
16.00 \\
18.50 \\
14.50 \\
22.50\end{array}$ & $\begin{array}{l}54.75 \\
54.75 \\
54.50 \\
54.50 \\
54.50 \\
52.50 \\
52.50 \\
54.50 \\
58.50 \\
57.50 \\
54.50 \\
53.00 \\
52.75 \\
53.00 \\
54.00 \\
53.25 \\
53.00 \\
51.50 \\
51.50 \\
51.25 \\
43.50 \\
55.50 \\
51.50 \\
00.00 \\
59.50 \\
65.50 \\
59.50 \\
59.50 \\
61.00 \\
63.00 \\
65.50 \\
39.50 \\
64.50 \\
67.00 \\
55.00 \\
57.00 \\
35.50 \\
37.50\end{array}$ & $\begin{array}{l}\text { Clay } \\
\text { Clay } \\
\text { Clay } \\
\text { Clay } \\
\text { Clay } \\
\text { Clay } \\
\text { Clay } \\
\text { Clay } \\
\text { Clay } \\
\text { Clay } \\
\text { Clay } \\
\text { Clay } \\
\text { Clay } \\
\text { Clay } \\
\text { Clay } \\
\text { Clay } \\
\text { Clay } \\
\text { Clay } \\
\text { Clay } \\
\text { Clay } \\
\text { Clay } \\
\text { Clay } \\
\text { Clay } \\
\text { Not enough sample } \\
\text { Clay } \\
\text { Clay } \\
\text { Clay } \\
\text { Clay } \\
\text { Clay } \\
\text { Clay } \\
\text { Clay } \\
\text { Silt clay loam } \\
\text { Clay } \\
\text { Clay } \\
\text { Clay } \\
\text { Clay } \\
\text { Sandy clay } \\
\text { Loam } \\
\text { Clat }\end{array}$ \\
\hline
\end{tabular}


TABLE 14. CHEMICAL CONSTITUENT ANALYSIS

\begin{tabular}{|c|c|c|c|c|c|c|c|c|c|c|c|c|c|c|c|}
\hline $\begin{array}{l}\text { Catalog } \\
\text { Number }\end{array}$ & $\mathrm{PH}$ & $C A / A$ & $\mathrm{C} / \mathrm{L}$ & $M G / A$ & $M / L$ & NIT & $\mathrm{PO} / \mathrm{A}$ & $P / L$ & $\mathrm{KO} / \mathrm{O}$ & $K / L$ & SALIN & ZINC & IRON & MANG & ORG \\
\hline 999500 & 6.8 & $>6000$ & $\mathrm{VH}$ & $=425$ & $\mathrm{H}$ & $=14$ & $=395$ & VH & $=570$ & $\mathrm{HH}$ & NONE & $>20.0$ & $=4.0$ & $=8.0$ & 2.7 \\
\hline 999501 & 7.8 & $>6000$ & VH & $=400$ & $H$ & $=8$ & $=395$ & $\mathrm{VH}$ & $=520$ & $\mathrm{HH}$ & NONE & $>20.0$ & $=3.6$ & $=6.1$ & 2.9 \\
\hline 999502 & 7.9 & $>6000$ & VH & $=365$ & $H$ & $<8$ & $=310$ & $\mathrm{VH}$ & $=480$ & $\mathrm{HH}$ & NONE & $>20.0$ & $=4.0$ & $=6.0$ & 2.7 \\
\hline 999503 & 7.9 & $>6000$ & $\mathrm{VH}$ & $=375$ & $\mathrm{H}$ & $=11$ & $=328$ & $\mathrm{VH}$ & $=480$ & $\mathrm{HH}$ & NONE & $=19.0$ & $=3.6$ & $=4.9$ & 2.9 \\
\hline 999504 & 8.1 & $>6000$ & $\mathrm{VH}$ & $=385$ & $\mathrm{H}$ & $<8$ & $=259$ & $\mathrm{VH}$ & $=470$ & $\mathrm{HH}$ & NONE & $>20.0$ & $=4.2$ & $=5.3$ & 2.9 \\
\hline 999505 & 8.0 & $>6000$ & $\mathrm{VH}$ & $=405$ & $\mathrm{H}$ & $=10$ & $=279$ & $\mathrm{VH}$ & $=610$ & $\mathrm{HH}$ & NONE & $=10.0$ & $=4.4$ & $>10.0$ & 2.7 \\
\hline 999506 & 8.1 & $>6000$ & VH & $=345$ & $H$ & $<8$ & $=310$ & VH & $=680$ & VH & NONE & $=14.6$ & $=3.2$ & $=6.1$ & 2.7 \\
\hline 999507 & 7.8 & $>6000$ & VH & $=400$ & $H$ & $<8$ & $=172$ & $\mathrm{HH}$ & $=510$ & $\mathrm{HH}$ & NONE & $>20.0$ & $=4.6$ & $=6.3$ & 3.1 \\
\hline 999508 & 8.2 & $>6000$ & $\mathrm{VH}$ & $=375$ & $\mathrm{H}$ & $<8$ & $=348$ & $\mathrm{VH}$ & $=* * *$ & VH & NONE & $>20.0$ & $=3.2$ & $=6.8$ & 2.6 \\
\hline 999509 & 7.8 & $>6000$ & VH & $=365$ & $H$ & $<8$ & $=194$ & $\mathrm{HH}$ & $=480$ & $\mathrm{HH}$ & NONE & $=19.4$ & $=4.2$ & $=6.4$ & 3.4 \\
\hline 999510 & 7.8 & $>6000$ & $\mathrm{VH}$ & $=365$ & $H$ & $<8$ & $=373$ & $\mathrm{VH}$ & $=420$ & $\mathrm{HH}$ & NONE & $=18.8$ & $=3.4$ & $=7.7$ & 2.7 \\
\hline 999511 & 8.1 & $>6000$ & $\mathrm{VH}$ & $=375$ & $H$ & $<8$ & $=83$ & $\mathrm{HH}$ & $=380$ & $\mathrm{HH}$ & NONE & $=19.6$ & $=3.0$ & $=5.5$ & 2.0 \\
\hline 999512 & 8.1 & $>6000$ & $\mathrm{VH}$ & $=385$ & $\mathrm{H}$ & $<8$ & $=297$ & $\mathrm{VH}$ & $=450$ & $\mathrm{HH}$ & NONE & $=9.0$ & $=2.8$ & $=6.2$ & 2.2 \\
\hline 999513 & 8.1 & $>6000$ & VH & $=380$ & $H$ & $<8$ & $=38$ & LL & $=390$ & $\mathrm{HH}$ & NONE & $>20.0$ & $=3.4$ & $=5.7$ & 2.0 \\
\hline 999514 & 8.2 & $>6000$ & VH & $=435$ & $H$ & $<8$ & $=107$ & $\mathrm{HH}$ & $=420$ & $\mathrm{HH}$ & NONE & $=15.6$ & $=3.0$ & $=7.0$ & 2.4 \\
\hline 999515 & 8.2 & $>6000$ & $\mathrm{VH}$ & $=420$ & $H$ & $<8$ & $=194$ & $H H$ & $=410$ & $\mathrm{HH}$ & NONE & $=18.0$ & $=3.0$ & $=5.0$ & 2.7 \\
\hline 999516 & 8.2 & $>6000$ & VH & $=420$ & $H$ & $<8$ & $=194$ & $\mathrm{HH}$ & $=410$ & $\mathrm{HH}$ & NONE & $=18.0$ & $=3.0$ & $=5.5$ & 2.7 \\
\hline 999517 & 8.1 & $>6000$ & VH & $=430$ & $H$ & $=8$ & $=51$ & $M M$ & $=440$ & $\mathrm{HH}$ & NONE & $=18.4$ & $=3.6$ & $=5.5$ & 2.6 \\
\hline 999518 & 8.1 & $>6000$ & VH & $=305$ & $H$ & $<8$ & $=5$ & VL & $=350$ & $\mathrm{HH}$ & NONE & $=5.0$ & $=3.0$ & $=4.3$ & 1.1 \\
\hline 999519 & 8.0 & $>6000$ & VH & $=425$ & $H$ & $<8$ & $=56$ & $M M$ & $=510$ & $\mathrm{HH}$ & NONE & $>20.0$ & $=4.2$ & $=9.8$ & 2.3 \\
\hline 999520 & 8.2 & $>6000$ & VH & $=420$ & $H$ & $<8$ & $=42$ & $M M$ & $=560$ & $\mathrm{HH}$ & NONE & $=12.4$ & $=4.0$ & $=8.5$ & 2.6 \\
\hline 999521 & 8.2 & $>6000$ & $V H$ & $=485$ & $H$ & $<8$ & $=288$ & $\mathrm{VH}$ & $=650$ & VH & NONE & $=13.2$ & $=2.0$ & $=5.4$ & 2.7 \\
\hline 999522 & 8.6 & $>6000$ & VH & $=440$ & $H$ & $<8$ & $=181$ & $\mathrm{HH}$ & $=630$ & VH & NONE & $=14.0$ & $=2.0$ & $=5.5$ & 2.2 \\
\hline 999523 & 8.2 & $>6000$ & VH & $=375$ & $H$ & $<8$ & $=34$ & LL & $=490$ & $\mathrm{HH}$ & NONE & $=19.4$ & $=3.4$ & $=7.0$ & 2.0 \\
\hline 999524 & 8.1 & $>6000$ & VH & $=440$ & $H$ & $<8$ & $=34$ & LL & $=450$ & $\mathrm{HH}$ & NONE & $=11.0$ & $=3.0$ & $=6.6$ & 2.3 \\
\hline 999525 & 8.0 & $>6000$ & VH & $=380$ & $H$ & $<8$ & $=38$ & LL & $=530$ & $\mathrm{HH}$ & NONE & $>20.0$ & $=3.2$ & $=8.9$ & 2.3 \\
\hline 999526 & 8.0 & $>6000$ & VH & $=300$ & $H$ & $<8$ & $=56$ & $M M$ & $=420$ & $\mathrm{HH}$ & NONE & $>20.0$ & $=2.2$ & $=5.5$ & 2.0 \\
\hline 999527 & 8.3 & $>6000$ & VH & $=325$ & $H$ & $<8$ & $=38$ & $L L$ & $=440$ & $\mathrm{HH}$ & NONE & $>20.0$ & $=2.4$ & $=4.7$ & 1.9 \\
\hline 999528 & 7.8 & $>6000$ & $\mathrm{VH}$ & $=440$ & $\mathrm{H}$ & $=16$ & $=529$ & VH & $=900$ & VH & NONE & $>20.0$ & $=3.6$ & $=6.7$ & 1.2 \\
\hline 999529 & 7.7 & $>6000$ & $\mathrm{VH}$ & $=440$ & $\mathrm{H}$ & $<8$ & $=38$ & LL & $=530$ & $\mathrm{HH}$ & NONE & $=12.6$ & $=3.8$ & $=6.0$ & 2.2 \\
\hline 999530 & 7.8 & $>6000$ & $\mathrm{VH}$ & $=440$ & $\mathrm{H}$ & $=12$ & $>640$ & VH & $=* * *$ & VH & NONE & $=14.4$ & $=4.0$ & $>10.0$ & 1.3 \\
\hline 999531 & 6.9 & $>6000$ & VH & $=455$ & $H$ & $<8$ & $>640$ & $\mathrm{VH}$ & $=850$ & VH & NONE & $=18.6$ & $=5.0$ & $=7.2$ & 0.8 \\
\hline
\end{tabular}




\begin{tabular}{|c|c|c|c|c|c|c|c|c|c|c|c|c|c|c|c|}
\hline $\begin{array}{l}\text { Catalog } \\
\text { Number }\end{array}$ & $\mathrm{PH}$ & $C A / A$ & $\mathrm{C} / \mathrm{L}$ & $M G / A$ & $M / L$ & NIT & $\mathrm{PO} / \mathrm{A}$ & $P / L$ & $\mathrm{KO} / \mathrm{O}$ & $\mathrm{K} / \mathrm{L}$ & SALIN & ZINC & IRON & MANG & ORG \\
\hline 999532 & 7.6 & $>6000$ & VH & $=420$ & $H$ & $<8$ & $>640$ & VH & $=900$ & VH & NONE & $=12.4$ & $=5.0$ & $=8.5$ & 1.3 \\
\hline 999533 & 7.2 & $>6000$ & $\mathrm{VH}$ & $=395$ & $\mathrm{H}$ & $<8$ & $>640$ & $\mathrm{VH}$ & $=900$ & $\mathrm{VH}$ & NONE & $>20.0$ & $=3.8$ & $=7.6$ & 1.7 \\
\hline 999534 & 8.0 & 26000 & $\mathrm{VH}$ & $=345$ & $\mathrm{H}$ & $<8$ & $>640$ & $\mathrm{VH}$ & $=550$ & $\mathrm{HH}$ & NONE & $>20.0$ & $=3.8$ & $=7.5$ & 2.0 \\
\hline 999535 & 7.6 & $>6000$ & $\mathrm{VH}$ & $=390$ & $H$ & $<8$ & $=580$ & $\mathrm{VH}$ & $=680$ & VH & NONE & $>20.0$ & $=4.4$ & $=7.5$ & 2.2 \\
\hline 999536 & 8.0 & $>6000$ & VH & $=350$ & $H$ & $<8$ & $>640$ & $\mathrm{VH}$ & $=600$ & $\mathrm{HH}$ & NONE & $>20.0$ & $=4.2$ & $=5.9$ & 1.8 \\
\hline 999537 & 7.7 & $>6000$ & $\mathrm{VH}$ & $=435$ & $H$ & $<8$ & $=94$ & $\mathrm{HH}$ & $=450$ & $\mathrm{HH}$ & NONE & $=17.0$ & $=3.2$ & $=5.6$ & 2.2 \\
\hline 999538 & 8.0 & $>6000$ & $\mathrm{VH}$ & $=475$ & $H$ & $<8$ & $=201$ & $\mathrm{VH}$ & $=510$ & $\mathrm{HH}$ & NONE & $>20.0$ & $=3.8$ & $=9.0$ & 2.8 \\
\hline 999539 & 7.8 & $>6000$ & VH & $=360$ & $\mathrm{H}$ & $<8$ & $=13$ & $V L$ & $=450$ & $\mathrm{HH}$ & NONE & $=12.0$ & $=3.4$ & $=5.3$ & 2.5 \\
\hline 999540 & 8.2 & $>6000$ & VH & $=360$ & $H$ & $<8$ & $=13$ & $V_{L}$ & $=420$ & $\mathrm{HH}$ & NONE & $=11.4$ & $=3.4$ & $=6.4$ & 1.7 \\
\hline 999541 & 7.8 & $>6000$ & VH & $=340$ & $\mathrm{H}$ & $=8$ & $=297$ & VH & $=550$ & $\mathrm{HH}$ & NONE & $=15.6$ & $=5.0$ & $=6.3$ & 2.3 \\
\hline 999542 & 8.2 & $>6000$ & VH & $=345$ & $H$ & $<8$ & $=56$ & $M M$ & $=500$ & $\mathrm{HH}$ & NONE & $=13.0$ & $=4.0$ & $=5.2$ & 2.0 \\
\hline 999543 & 7.9 & $>6000$ & VH & $=380$ & $H$ & $<8$ & $=268$ & $\mathrm{VH}$ & -700 & $\mathrm{VH}$ & NONE & $>20.0$ & $=5.0$ & $=5.6$ & 2.7 \\
\hline 999544 & 7.7 & $>6000$ & VH & $=395$ & $H$ & $<8$ & $>640$ & $\mathrm{VH}$ & $=810$ & VH & NONE & $=9.0$ & $=5.2$ & $=7.8$ & 2.1 \\
\hline 999545 & 7.9 & $>6000$ & $\mathrm{VH}$ & $=370$ & $H$ & $<8$ & $>640$ & VH & $=650$ & $\mathrm{VH}$ & NONE & $=11.4$ & $=3.8$ & $=7.9$ & 2.1 \\
\hline 999546 & 8.0 & $>6000$ & VH & $=330$ & $\mathrm{H}$ & $<8$ & $=529$ & VH & $=510$ & $\mathrm{HH}$ & NONE & $=14.6$ & $=3.6$ & $=5.8$ & 1.9 \\
\hline 999547 & 7.9 & $>6000$ & VH & $=335$ & $H$ & $<8$ & $=540$ & $\mathrm{VH}$ & $=490$ & $\mathrm{HH}$ & NONE & $=6.8$ & $=3.4$ & $=6.2$ & 2.0 \\
\hline 999548 & 8.0 & $>6000$ & VH & $=375$ & $H$ & $=8$ & $=453$ & VH & $=470$ & $\mathrm{HH}$ & NONE & $=5.4$ & $=3.4$ & $=7.6$ & 1.9 \\
\hline 999549 & 8.0 & $>6000$ & $\mathrm{VH}$ & $=390$ & $\mathrm{H}$ & $=8$ & $=60$ & $M M$ & $=500$ & $\mathrm{HH}$ & NONE & $=11.8$ & $=3.8$ & $=5.7$ & 2.2 \\
\hline 999550 & 8.2 & $>6000$ & $\mathrm{VH}$ & $=385$ & $\mathrm{H}$ & $=8$ & $=18$ & $V L$ & $=480$ & $\mathrm{HH}$ & NONE & $>20.0$ & $=3.6$ & $=7.0$ & 1.4 \\
\hline 999551 & $7.9^{\circ}$ & $>6000$ & $\mathrm{VH}$ & $=41.5$ & $H$ & $=8$ & $=16$ & VL & $=440$ & $\mathrm{HH}$ & NONE & $=16.6$ & $=3.8$ & $=5.7$ & 1.1 \\
\hline 999552 & 8.1 & $>6000$ & VH & $=415$ & $\mathrm{H}$ & $<8$ & $=83$ & $\mathrm{HH}$ & $=550$ & $\mathrm{HH}$ & NONE & $>20.0$ & $=4.2$ & $=6.2$ & 2.1 \\
\hline 999553 & 8.0 & $>6000$ & VH & $=405$ & $H$ & $<8$ & $=78$ & $M M$ & $=610$ & $\mathrm{HH}$ & NONE & $>20.0$ & $=8.0$ & $=10.0$ & 2.7 \\
\hline 999554 & 8.0 & $>6000$ & VH & $=410$ & $H$ & $<8$ & $=94$ & $M M$ & $=550$ & $\mathrm{HH}$ & NONE & $=20.0$ & $=5.8$ & $=8.0$ & 2.0 \\
\hline 999555 & 8.0 & $>6000$ & VH & $=395$ & $\mathrm{H}$ & $<8$ & $=42$ & $M M$ & $=560$ & $\mathrm{HH}$ & NONE & $=13.0$ & $=6.0$ & $=7.0$ & 1.9 \\
\hline 999556 & 8.0 & $>6000$ & VH & $=500$ & $\mathrm{H}$ & $<8$ & $=60$ & $M M$ & $=580$ & $\mathrm{HH}$ & NONE & $=19.6$ & $=6.8$ & $=7.5$ & 2.1 \\
\hline 999557 & 8.0 & 26000 & VH & $=460$ & $\mathrm{H}$ & $<8$ & $=69$ & $M M$ & $=590$ & $\mathrm{HH}$ & NONE & $=16.0$ & $=7.2$ & $=9.4$ & 2.5 \\
\hline 999558 & 8.2 & $>6000$ & VH & $=410$ & $\mathrm{H}$ & $<8$ & $=42$ & $M M$ & $=560$ & $H H$ & NONE & $>20.0$ & $=11.6$ & $=5.4$ & 2.5 \\
\hline 999559 & 7.6 & $>6000$ & $\mathrm{VH}$ & $=380$ & $\mathrm{H}$ & $<8$ & $=51$ & $M M$ & $=510$ & $\mathrm{HH}$ & NONE & $=12.0$ & $=20.0$ & $>10.0$ & 1.9 \\
\hline 999560 & 7.8 & $>6000$ & $\mathrm{VH}$ & $=420$ & $\mathrm{H}$ & $<8$ & $=31$ & LL & $=570$ & $\mathrm{HH}$ & NONE & $=10.0$ & $=10.0$ & $=8.0$ & 1.9 \\
\hline 999561 & 8.0 & $>6000$ & VH & $=390$ & $H$ & $<8$ & $=27$ & LL & $=510$ & $\mathrm{HH}$ & NONE & $=5.6$ & $=6.8$ & $=5.2$ & 2.1 \\
\hline 999562 & 8.0 & $>6000$ & $\mathrm{VH}$ & $=385$ & $H$ & $<8$ & $=18$ & $\overline{V L}$ & $=530$ & $\mathrm{HH}$ & NONE & $=4.0$ & $=11.6$ & $=7.3$ & 1.9 \\
\hline 999563 & 8.2 & $>6000$ & $\mathrm{VH}$ & $=460$ & $H$ & $<8$ & $=150$ & $\mathrm{HH}$ & $=730$ & $\mathrm{VH}$ & NONE & $=6.0$ & $=18.6$ & $=5.9$ & 1.5 \\
\hline
\end{tabular}


TABLE 14. (continued)

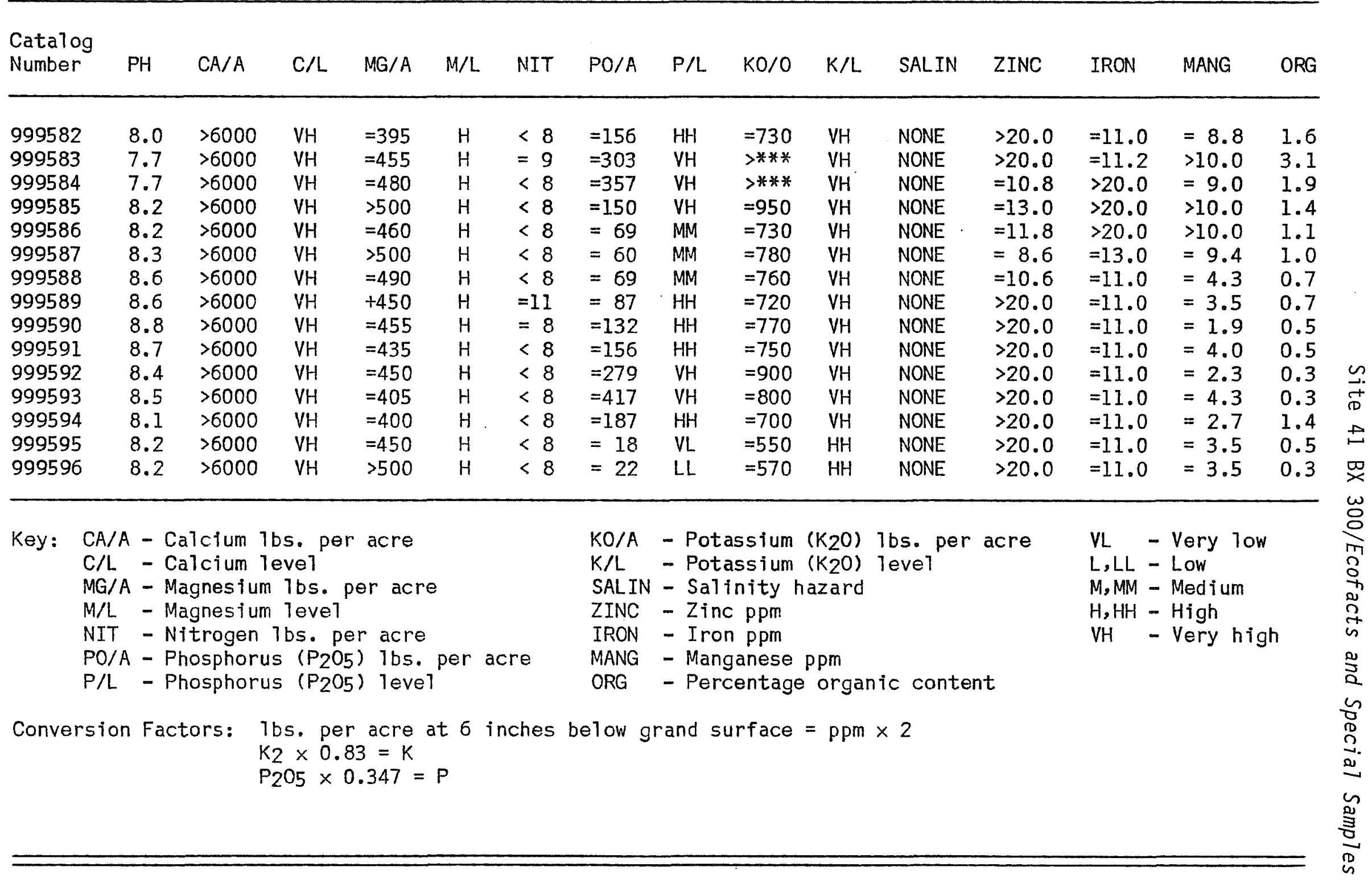


material are thus correspondingly brief; they are presented here in their entirety, with only minor editorial changes.

BOTANICAL IDENTIFICATION AND ANALYSIS* (Dr. Donald McLain, Department of Biology, Incarnate Word Col7ege, San Antonio, Texas)

Botanical materials recovered by excavation were, as would be expected, mostly fragments of charcoals. These were only partially burned; they were usually heavily permeated with calcium carbonate; and on occasion they were saturated with unsaponified lipids (e.g., Charcoal Sample No. 999613; see Table 15). To me, this would indicate almost immediate covering of a low temperature fire with soil, rather than long exposure to the weather. Such exposure would permit saponification by the action of rain and wood ashes on the fatty materials.

Charcoal Sample No. 1089 consists of fragments of angiosperm wood which are dusted with pollen grains of Juniperus sp. Assuming a similar climate to that of today, this charcoal was exposed during the first quarter of the year when clouds of juniper pollen are shed.

Several other collections of seeds and other uncharred plant materials (e.g., Soil Sample Nos. 999505-L, 999514-L, 999519-L, 999520-L, see Table 16) indicate deposition during the last or first quarter of the year. These collections contain nearly intact winter buds of UImus sp., Juniperus sp. pollen, short shoots, immature inflorescences of grasses, and Capsella and other crucifer seeds, all of which are produced only in cold weather.

\section{PHYTOLITH ANALYSIS}

In 1971, Rovner published a position paper detailing the potential of opal phytolith analysis in paleoecological reconstruction. Nine years later, Rovner was able to organize the first symposium specifically on the subject of plant opal phytolith analysis in archaeology at the 1980 Annual Meeting of the Society for American Archaeology. In the keynote paper for this symposium, Rovner (1980:1) states the following:

Opal phytoliths are biogenous plant particles comprised predominantly of opaline silica precipitated by the living parent plant in, around and/or between plant cells, variously throughout some plants, more localized in others. Study of the mineralogical nature of these particles indicates that the opal is "surprisingly pure" and of "gemstone quality." Significantly, hydrocarbons--

\footnotetext{
*Author's note: Two collections of material were submitted to Dr. McLain for identification. One consisted of charcoal samples not used for radiocarbon dating; their provenience and identification are provided in Table 16 . The other collection consisted of the light and heavy fractions of floated feature soil; the identifiable specimens are listed in Table 17, with provenience keyed to Table 12 by means of the catalog number.
} 
TABLE 15. IDENTIFICATION OF CHARCOAL SAMPLES

\begin{tabular}{|c|c|c|c|c|c|}
\hline $\begin{array}{l}\text { Catalog } \\
\text { Number }\end{array}$ & Area & $\begin{array}{l}\text { Unit: or } \\
\text { Trench }\end{array}$ & $\begin{array}{l}\text { Depth Below } \\
\quad \text { Ground } \\
\text { Surface }(\mathrm{cm})\end{array}$ & $\begin{array}{l}\text { Associated } \\
\text { Feature }\end{array}$ & $\begin{array}{l}\text { Identifiable Material } \\
\quad \text { or Item(s) }\end{array}$ \\
\hline 118 & Red & 066020 & $21-31$ & & Elm (U1mus sp.); charcoal and uncharred wood \\
\hline 1089 & Yellow & 123009 & $0-15$ & & $\begin{array}{l}\text { Unidentifiable charcoal fragments with } \\
\text { quantities of Juniper (Juniperus sp.) pollen }\end{array}$ \\
\hline 1694 & Red & 085009 & $0-20$ & & Not identifiable \\
\hline 1696 & Red & 085009 & $0-20$ & & Not identifiable \\
\hline 1697 & Red & 085009 & $0-20$ & & Not identifiable \\
\hline 4031 & Red & 076037 & $0-10$ & & Charred $x y l$ em of angiosperm plant \\
\hline 4137 & Red & 085009 & $30-43$ & 8 & $\begin{array}{l}\text { We1 1-preserved fragments of hackberry (Celtis } \\
\text { sp.) seed and fruit; charcoal fragments of } \\
\text { live oak (Quercus virginianus) }\end{array}$ \\
\hline 4627 & Red & 055088 & $38-51$ & 2 & Baked earth; unidentifiable vegetal fragments \\
\hline 6347 & Red & Hotel & Backdirt & & $\begin{array}{l}\text { Burned soil with some highly calcified charred } \\
\text { xylem in minute fragments }\end{array}$ \\
\hline 6431 & Yellow & Bravo & Backdirt & & $\begin{array}{l}\text { Uncharred pecan (Carya pecan) hu 11; wel1- } \\
\text { preserved hackberry (Ce1tis sp.) charcoal }\end{array}$ \\
\hline 7251 & Red & 076038 & $20-40$ & 3 & Baked earth; unidentifiable vegetal fragments \\
\hline 7334 & Red & 076037 & $20-40$ & 3 & $\begin{array}{l}\text { Baked earth; slightly charred pecan (Carya } \\
\text { pecan) hulls }\end{array}$ \\
\hline 999713 & Red & 056026 & $9-12$ & 7 & Fat-saturated, powdered charcoal \\
\hline
\end{tabular}


TABLE 16. IDENTIFICATION OF ECOFACTUAL MATERIAL ASSOCIATED WITH FEATURE SOIL SAMPLES

\begin{tabular}{|c|c|c|}
\hline $\begin{array}{l}\text { Catalog } \\
\text { Number }\end{array}$ & $\begin{array}{l}\text { Associated } \\
\text { Feature }\end{array}$ & $\begin{array}{l}\text { Identifiable Material } \\
\text { or Item(s) }\end{array}$ \\
\hline $999505-L$ & 3 & $\begin{array}{l}\text { Unknown item; e } 1 \mathrm{~m} \text { (U1 mus sp.) bud scales; } \\
\text { mustard (Crucifereae fan;ily); snail }\end{array}$ \\
\hline $999505-H$ & 3 & E1m (U1mus sp.) winter bud scales; snails \\
\hline $999508-L$ & 4 & $\begin{array}{l}\text { Snai1; unknown seed, sedge (Carex sp.) seed; } \\
\text { e } 7 \text { m (U1mus sp.) winter bud scale }\end{array}$ \\
\hline $999508-H$ & 4 & Snai1; pigweed (Chenopodium sp.) seeds \\
\hline 999514-L & 6 & $\begin{array}{l}\text { Snail; elm (U1mus sp.) winter bud scale; } \\
\text { grass (Poaceae family) inflorescence fragment }\end{array}$ \\
\hline $999514-\mathrm{H}$ & 6 & Snai1; juniper (Juniperus sp.) shoots \\
\hline $999516-L$ & 3 & Snail \\
\hline $999516-H$ & 3 & Snail; unknown item, not plant material \\
\hline $999517-L$ & $(b \in l o w 2)$ & $\begin{array}{l}\text { Snail; oak (Quercus sp.) acorn; hackberry } \\
\text { (Celtis sp.); shepherds purse (Capsel1a sp.) }\end{array}$ \\
\hline $999517-\mathrm{H}$ & $(b \in\rceil$ ow 2$)$ & Prick7y poppy (Argemone sp.) seed \\
\hline 999519-L & 5 & $\begin{array}{l}\text { Snail; mustard (Crucifereae family); elm } \\
\text { (U1mus sp.) winter bud scales; orchard grass } \\
\text { (Dactyl is sp.) inflorescence; unknown seeds }\end{array}$ \\
\hline $999519-H$ & 5 & $\begin{array}{l}\text { Juniper (Juniperus sp.) shoots: dock or } \\
\text { sorrel (Rumex sp.) }\end{array}$ \\
\hline $999520-L$ & 9 & $\begin{array}{l}\text { Snail; grass (Poaceae family) inflorescence; } \\
\text { shepherds purse (Capse11a sp.); dock or } \\
\text { sorre11 (Rumex sp.); unknown iten }\end{array}$ \\
\hline $999520-\mathrm{H}$ & 9 & Snail \\
\hline 999527-L & 7 & $\begin{array}{l}\text { Amaranth (Amaranthaceae family); juniper } \\
\text { (Juniperus sp.) buds; unknown fragments }\end{array}$ \\
\hline 999527 & 7 & $\begin{array}{l}\text { Beard, broom or sand grass (Andropogon sp.); } \\
\text { eroded seed fragnent }\end{array}$ \\
\hline 999538-H & 2 & $\begin{array}{l}\text { Hackberry (Celtis sp.); gourd (Curcurbita } \\
\text { sp.) seed }\end{array}$ \\
\hline
\end{tabular}


TABLE 16. (continued)

\begin{tabular}{|c|c|c|}
\hline $\begin{array}{l}\text { Catalog } \\
\text { Number }\end{array}$ & $\begin{array}{l}\text { Associated } \\
\text { Feature }\end{array}$ & $\begin{array}{c}\text { Identifiable Material } \\
\text { or Item(s) }\end{array}$ \\
\hline $999540-L$ & 2 & $\begin{array}{l}\text { Amaranth (Amarantheceae family); mustard } \\
\text { (Crucifereae family) }\end{array}$ \\
\hline $999541-L$ & 2 & Plant fragment, but not a seed \\
\hline $999541-H$ & 2 & Sedge (Carex sp.) seed \\
\hline 999546-L & 7 & $\begin{array}{l}\text { Unknown item; beard, broom or sand grass } \\
\text { (Andropogon sp.) seed; grass (Poaceae family) } \\
\text { bar seed }\end{array}$ \\
\hline $999546-\mathrm{H}$ & 7 & $\begin{array}{l}\text { Unknown iteri; juniper (Juniperus sp.) needles } \\
\text { and buds; gourd (Curcurbita sp.) seed }\end{array}$ \\
\hline $999551-L$ & 8 & Senna (Cassia sp.) seed \\
\hline $999551-H$ & 8 & $\begin{array}{l}\text { Dock or sorrel (Rumex sp.); clcver (Trifolium } \\
\text { sp.) seed }\end{array}$ \\
\hline 999562 & 11 & $\begin{array}{l}\text { Beard, broom cr sand grass (Andropogon sp.); } \\
\text { fruit wa } 11 \text { (daes not appear to be "ancient" } \\
\text { species) }\end{array}$ \\
\hline 999563 & 10 & Rush (Juncus sp.); unkriown seed \\
\hline
\end{tabular}

$L=1$ ight fraction (see Collection and Processing of Constant Volunie Samples Section)

$H=$ heavy fraction (see Collecticn and Processing of Constant Volume Samples Section) 
organic molecules--are virtually absent in the composition of opal phytoliths making them totally invulnerable to organic decay. Soil phytolith assemblages contributing to this study vary in age from 2000 years to more than 9000 years ago, and come from tropical forest, semiarid prairie and mixed hardwood forest environments. R. L. Hay (personal communication) reported opal phytoliths as the only ubiquitous plant fossil found at 01duvai Gorge. George Baker (1959) reports phytoliths in Pleistocene and Pliocene deposits. Opal phytoliths still retaining their morphological integrity have even been extracted from Cenozoic sedimentary rock. Phytoliths, then, are preserved over the total range of archaeological history - . [and] are categorical1y the most durable biogenous plant fossil known, bar none. Pollen is no exception.

The interest and excitement in opal phytolith analysis which culminated in the 1980 symposium was quite strong in 1977 when the proposal to mitigate $41 \mathrm{BX} 300$ was written. Years of continued attempts with consistently disappointing results had forced the conclusion that the identification and analys is of pollen from archaeological sites in south-central Texas was inconsistent and generally inconclusive. "Additional7y, UTSA testing has shown faunal remains to be few and poorly preserved at the site [i.e., $41 \mathrm{BX} 300]$. However, we place our greatest expectations on the rapidly developing potential of phytolith studies in central Texas" (Hester, Gunn, and Katz 1977:32).

We wish to thank the National Park Service for their foresight and generosity in providing funding as part of the 41 BX 300 mitigation project for opal phytolith analysis. We hope that it is understood and appreciated that this method of analysis was, and still is, in the research and development stage. Like the thermoluminescence dating of burned rock to be discussed later, our enthusiasm for the potential of the analytical method was always greater than our expectations of interpretable data.

Twenty-nine soil samples were collected specifically for phytolith identification and analysis. Fourteen were associated with features, intended to provide additional data on feature use or associated activities and to benefit from whatever chronological information was forthcoming from the feature analyses. The remaining 15 were taken from the walls of two trenches on different sides of the site to provide stratigraphic as well as comparative data on the paleoenvironment of the site (Figs. 16,b; 21). Table 1.7 provides provenience data for these samples. The phytolith samples were collected from the same features and trenches as were CVS samples intended for the various soil analyses and botanical identification previously discussed. This redundance was intentional, to provide a crosscheck on the respective results and to provide a backup for the still experimental phytolith analysis.

The laboratory analysis was conducted by Ralph Robinson, a research associate of the UTSA Center for Archaeological Research. Robinson employed a modified version of Rovner's (1971) method for separating the opal phytoliths from their soil matrix. This methodology is detailed in two reports by Robinson (1979, n.d.), in which the paleoenvironment at several archaeological sites in Goliad County, Texas, is reconstructed and compared by means of opal 
Site 41 BX 300/Ecofacts and Special Samples

TABLE 17. DISTRIBUTION OF PHYTOLITH SAMPLES

\begin{tabular}{|c|c|c|c|c|c|}
\hline $\begin{array}{l}\text { Catalog } \\
\text { Number }\end{array}$ & Area & $\begin{array}{l}\text { Unit or } \\
\text { Trench }\end{array}$ & $\begin{array}{l}\text { Depth Below } \\
\text { Ground } \\
\text { Surface }(\mathrm{cm})\end{array}$ & $\begin{array}{l}\text { Associated } \\
\text { Feature }\end{array}$ & Stratum \\
\hline 999700 & Red & 076038 & 13 & 3 & Feature zone \\
\hline 999701 & Red & 076038 & 23 & 3 & Feature zone \\
\hline $999702 *$ & Red & 076038 & 26 & 3 & Feature zone \\
\hline 999703 & Red & 076038 & 33 & 3 & Feature zone \\
\hline 999704 & Red & 076038 & 40 & 3 & Feature zone \\
\hline 999705 & Red & 077012 & 36 & 6 & Feature zone \\
\hline 999706 & Red & India-E & 85 & $(2)$ & Submidden zone \\
\hline 999707 & Green & 038054 & 110 & (9) & Mixed gravel \\
\hline 999708 & Green & 038054 & 85 & 9 & Feature zone \\
\hline 999709 & Red & 085009 & 44 & 8 & Feature zone \\
\hline $999710 *$ & Red & 077003 & 30 & 6 & Feature zone \\
\hline $999711^{*}$ & Red & 077003 & 40 & 5 & Occupation zone \\
\hline $999712^{*}$ & Red & 085009 & 49 & 8 & Feature zone \\
\hline 999713 & Red & 056026 & 12 & 7 & Occupation zone \\
\hline 999714 & Blue & November & 10 & & Topsoil \\
\hline 999715 & Blue & November & 25 & & Topsoi 1 \\
\hline 999716 & Blue & November & 42 & & Topsoi1 \\
\hline 999717 & Blue & November & 62 & & Subsoil \\
\hline 999718 & Blue & November & 82 & & Subsoil \\
\hline 999719 & Blue & November & 102 & & Subsoil \\
\hline 999720 & Blue & November & 121 & & Subsoil \\
\hline 999721 & Blue & November & 142 & & Subsoil \\
\hline 999722 & Bive & November & 161 & & Nixed gravel \\
\hline 999723 & Blue & November & 179 & & Mixed sravel \\
\hline 999724 & Blue & November & 197 & & Mixed gravel \\
\hline $999725 *$ & White & $\mathrm{Ki} 10$ & 48 & & Topsoit \\
\hline $999726 *$ & White & $\mathrm{KiTo}$ & 100 & & Subsoil \\
\hline $999727 *$ & White & Ki1o & 150 & & Mixed gravel \\
\hline $999728 *$ & White & Kilo & 200 & & Mixed gravel \\
\hline
\end{tabular}

Note: Parentheses indicate indirect feature association

*Analyzed 
phytolith analysis. The techniques which enabled Robinson to reach this stage were worked out in part during the 41 BX 300 project.

Among the primary difficulties which Robinson faced when attempting to extract the phytoliths from 41 BX 300 soil samples was the high clay content of the soil matrices, regardless of provenience. Reference has already been made to this fact, relative to the necessity of extracting and cleaning organic material from the CVS samples with hydrogen peroxide rather than with water. Several laboratory accidents occurred during the course of the phytolith extraction process, one of which caused physical injury to Robinson and each of which resulted in some damage and loss to the samples.

Once extracted, moreover, Robinson was 1 iterally overwhelmed by the sheer number of phytoliths in need of identification and classification. Their preservation is truly remarkable. Robinson, however, is the pioneer in this type of research in south-central Texas; there is no comparative collection available, either locally or regionally. It was necessary to build a "type collection" of phytolith specimens, not just for genus and species but for each part of each genus and species (e.g., leaf, stem, root). Robinson worked at this task long after the available funds were exhausted.

In order to reduce the quantity of material needed to be looked at, and to compensate for the loss of some matrix material, a selection of the remaining samples was made. The four samples from Kilo trench were considered, in order to provide a relative stratigraphic sequence of data. In addition, five samples from different features were selected, features which by this time had been assigned to chronologically distinct phases. The nine samples are indicated on Table 17.

The absence of comparative phytolith collections at the time Robinson conducted his identification necessitated a fairly gross classification level. He was able to make a general distinction between grasses and trees. Further, within grasses, tall could be distinguished from short; and within trees, the riverine species could be distinguished from upland or prairie. To these qualitatively identifiable phytoliths, he added data on quantity and chronology, resulting in the broad sequence of paleoclimatic change shown in the first column of Table 1 .

The phytolith sequence indicates that the environment at the site was either wooded with tall grass on the uplands or exhibited a savanna-like setting with grassy areas between groves of trees. This time corresponds to the Central Texas Oakalla phase/Local Period 5 (see Table 1), which, representing the several hundred years prior to the beginning of the Central Texas Clear Fork phase/Local Period 6, marks the transition from the Early to the Middle Archaic period. Fifteen hundred years later, about 1500 B.C., the conditions seem to have deteriorated, with fewer trees and a shorter species of grass in evidence. This is the time of the beginning of the Central Texas Round Rock phase/Local Period 7, the cultural peak of the Middle Archaic period in terms of population and number of sites. Fairly soon afterward, by about 800 B.C., the climate changes to one similar to that of 3000 B.C., with a return of tall grass and riverine forest trees. This particular time corresponds approximately to the Central Texas San Marcos phase/Local Period 8, which initiates the transition from Middle to Late Archaic. No phytolith data are 
available from the 41 BX 300 samples for the period prior to 3000 B.C. or after 500 B.C.

FAUNAL ANALYSIS (Harold Wooldridge, Austin, Texas)

Analysis of the faunal material recovered from site 41 BX 300 was undertaken in order to assess the importance of the vertebrate fauna in the subsistence strategies employed by the aboriginal occupants. The small amount of bone recovered, however, prevented detailed cultural inferences. Poor bone preservation negated such analysis goals as determining aboriginal exploitation patterns and habitat selection, seasonality, and explanation of cultural practices forced upon the fauna as evidenced by burning, cutting, shaping and the breakage of bone. The possible reasons for the apparent rapid deterioration of bone at $41 \mathrm{BX} 300$ are explored. It is indeed unfortunate that the small sample of faunal materials recovered restricts our analytical methods and limits our understanding of the role played by the vertebrate fauna in the aboriginal subsistence system.

\section{Methodology}

Identification of the specimens was accomplished by using the vertebrate collections of the Texas Archeological Research Laboratory and The University of Texas Vertebrate Paleontology Laboratory at Balcones Research Center, Austin, Texas, as comparative material. For each cultural unit identified, the species represented, age at death, sex, burning, and butchering marks were noted where possible. The minimum number of individuals within each unit was calculated according to the techniques recommended by Chaplin (1971:70-75), which involve the counting of specific skeletal elements with consideration given to symmetry (1eft versus right), size, age at death, and sex, where discernible. The criteria used to estimate the age at death of the animal represented by the elements recovered included the extent of epiphyseal fusion, presence of deciduous teeth, level of dental attrition, and the presence of horns and antlers in the deer and antelope. Correlation of these data provided the statistical base from which the spatial distribution of the fauna was determined and cultural inferences were developed.

\section{Statistical Base}

Three classes of fauna (reptiles, birds, mammals) were identified from 41 BX 300. Table 18 1ists the faunal inventory, the number of specimens recognized, and the minimum number of individuals represented by this count. As can be seen, the inventory is sparse and may reflect the poor organic preservation within the site. Those species recovered from the surface and not contextually related to cultural causation are herein assumed to have occurred because of noncultural phenomena. This premise is strengthened by the occurrence of javelina and armadi17o, two species that have expanded their range northward to include the area encompassing 41 BX 300 only within the last few hundred years. Those species recovered from the subsurface and those detected in situ within cultural features are more likely either the 
TABLE 18. FAUNAL INVENTORY

\begin{tabular}{lcc}
\hline \multicolumn{1}{c}{ Species } & $\begin{array}{c}\text { Number of } \\
\text { Fragments }\end{array}$ & $\begin{array}{c}\text { Minimum Number } \\
\text { of Individuals }\end{array}$ \\
\hline $\begin{array}{l}\text { REPTILES } \\
\text { Common snapping turtle (Chelydra serpentina) }\end{array}$ & 2 & \\
BIRDS & 1 & 1 \\
$\quad$ Caracara (Caracara cheirway) & & \\
MAMMALS & 1 & 1 \\
Pronghorn antelope (Antelocapra americana) & 9 & 1 \\
White-tailed deer (Odocoileus virginianus) & 1 & 3 \\
Cottontail rabbit (Sylvilagus floridanus) & 6 & 1 \\
Armadilo (Dasypus novemcinctus) & 2 & 1 \\
Raccoon (Procyon lotor) & 2 & \\
Javelina (Tayassu tajacu) & 1 & \\
Cotton rat (Sigmodon hispidus) & & \\
& & \\
\hline
\end{tabular}

result of human enterprise or at least co-inhabitants of $41 \mathrm{BX} 300$ and, given a larger sample, might have been conducive to environmental reconstruction.

of the ten distinct cultural features detected, only Features 2 and 7 from Area Red produced diagnostic elements for species identification (Table 19). An adult white-tailed deer was recognized from Feature 2, and an adult antelope was detected within Feature 7 . Feature 2 was determined during excavation to be a burned rock midden, and Feature 7 was classified as an occupational living floor. In addition to these individuals, a juvenile white-tailed deer, an adult raccoon, and an adult cotton rat were recovered from various units also within Area Red. These species are all within their present-day natural ranges, and it is assumed that they, with the possible exception of the cotton rat, provided a portion of the meat protein for the site occupants. Area Green produced an additional white-tailed deer and a snapping turtle. From the surface was recovered a cottontail rabbit and a scavenging bird (Caracara), as well as the armadillos and the javelina remains. Disregarding for now the doubtful cultural association of the surface finds, we might infer that the major exploitation emphasis was on deer and antelope.

Two biotic zones are represented by these recovered species: a mixed scrub forest is favored by white-tailed deer and raccoons, while antelope are found in grassland prairies. Until better temporal placement of the various cultural features is ascertained, the site, taken as a whole, reflects exploitation of both habitats. Again, the sample size is too small to justify inferences but may be indicative of a pattern, although supported by the data in only a limited way. 
TABLE 19. DISTRIBUTION OF IDENTIFIED FAUNAL ELEMENTS

\begin{tabular}{|c|c|c|c|c|c|c|c|}
\hline Area & $\begin{array}{l}\text { Unit or } \\
\text { Trench }\end{array}$ & Level & Species & Element & Symmetry & Age & Part \\
\hline Blue & 001000 & Surface & Deer/Antelope & Metatarsal & Left: & Adult & Proximal \\
\hline Green & 036000 & Surface & Deer/Antelope & Fenur & Right & Adult & Distal \\
\hline Green & 045037 & 1 & Snapping Turtte & Carapace & ? & $?$ & Fragment \\
\hline Green & Foxtrot & Backdirt & Javel ina & Molar, premolar & $?$ & AduTt & Fragment \\
\hline Green & Foxtrot & Backdirt & Javel ina & Canine & $?$ & Adult & Fragment \\
\hline Green & Golf & Backdirt & White-tailed Deer & Calcaneus & Left & Adult & Medial \\
\hline Green & 038069 & 2 & Deer/Antelope & U1na, metacarpal & Right & Adult & Fragment \\
\hline Red & 095000 & Surface & Cottontail Rabbit & Ferrur & Right & Adult & Proximal \\
\hline Red & 056064 & Feature 2 & Arriadi110 & Metatarsal & Left & Adult. & Complete \\
\hline Red & 056064 & Feature 2 & Armadi110 & Phalanx & $?$ & Aduit & Complete \\
\hline Red & 056064 & Feature 2 & Armadi110 & Carapace & $?$ & $?$ & Fragment \\
\hline Red & 055084 & Feature 2 & White-tailed Deer & Astragulus & Right & Adult & Fragment \\
\hline Red & 056016 & Feature 7 & Deer/Antelope & Metapodial & $?$ & Adult & Distal \\
\hline Red & 056016 & Feature 7 & Antelope & Metacarpai & Right & Adult & Medial \\
\hline Red & 085066 & 1 & Raccoon & Isolated molar & Right & Young adult & Comp lete \\
\hline Red & 085066 & 1 & Raccoon & Isolated molar & Right & Young adult & Comp lete \\
\hline Red & 085066 & 1 & Armad 1710 & Phalanx & Left & Juvenile & Complete \\
\hline Red & 085066 & 1 & Deer/Antelope & Second phatanx & $?$ & Juvenile & Comp lete \\
\hline Red & 076030 & 2 & Cotton Rat & Isolated molar & $?$ & Adu7t & Complete \\
\hline White & 069000 & Surface & White-tailed Deer, & & & & \\
\hline & & & female & Sku11 fragments & - & Adult & Fragment \\
\hline White & 069000 & Surface & White-tailed Deer & Third phalanx & $?$ & Adult & Comp lete \\
\hline White & 069000 & Surface & White-tailed Deer & Metapodial & $?$ & Adult & Distal \\
\hline White & 069000 & Surface & White-tailed Deer & Mandible, $M 1-M 3$ & Right & Adult & Medial \\
\hline White & 068000 & Surface & Caracara & Humerus & Left & Adu1t & Distal \\
\hline Yellow & Bravo & Backdirt & Armadil1o & Carapace & $?$ & $?$ & Fragment \\
\hline
\end{tabular}


The lack of rabbits and other smaller mammals within the assemblage may be attributed to poor preservation, screen-size bias, or to their absence from the area during the span of the 41 BX 300 occupation. This last possibility is unlikely, as a well-rounded faunal assemblage which includes these smaller animals was reported from nearby 41 BX 36 (Jerry Henderson, personal communication).

Fine screening was accomplished on those samples primarily intended for soil analysis, and recovery included only one identifiable element, a cotton rat molar. Altogether, the sample size is too small to justify many cultural inferences. The absence of migratory birds, hibernating or estivating species, and antlers or diagnostic skull parts precludes seasonality studies. Those elements that were species diagnostic did not exhibit any form of cultural modification, hence no data on butchering practices or bone tool manufacturing are available. Those data compiled concerning the weight of the unidentifiable fragments are 1 isted in Table 20 and concentrate, naturally, within the cultural features detected.

The poor preservation of bone at 41 BX 300 cannot easily be explained. The soil analysis conducted at Texas A\&M University indicates soil pH was basic, usually conducive to good organic preservation. The length of time that the bone remains exposed to the elements before being covered also affects the preservation and should be investigated as a possible explanation for the condition of the recovered material. Even granting the poor preservation, the limited number of species recovered is surprising if $41 \mathrm{BX} 300$ represents a major long-term occupation. Other artifactual data need to be consulted to see if the above reflects reality or if 41 BX 300 actually represents (a succession of) sporadic, short-duration occupation(s).

\section{Summary}

Faunal data from site 41 BX 300 were analyzed in order to determine the basic subsistence strategies utilized by the site occupants. A pattern of exploitation of both the mixed scrub forest and grassland prairie is indicated, but conclusive inferences are precluded by the limited sample. The range of elements recovered indicates the entire carcass was returned to the site, but again the limited sample size and absence of butchering evidence makes this interpretation only speculation. The lack of recovered species amenable to seasonality studies negated inference of the time of occupation of $41 \mathrm{BX} 300$. All species represented within the assemblage are found in the area today; from the data at hand, it would appear that conditions were much the same as today.

MOLLUSCAN ANALYSIS (Dr. Harold Murray, Department of Biology, Trinity University, San Antonio, Texas)

The mollusks obtained from the collections of 41 BX 300 are primarily gastropods (snails), with the exception of 31 specimens of Crassostrea virginica and 704 specimens of Exogyra. 
TABLE 20. DISTRIBUTION OF UNIDENTIFIED FAUNAL FRAGMENTS

\begin{tabular}{|c|c|c|c|c|c|c|c|c|c|c|}
\hline Area & $\begin{array}{l}\text { Unit or } \\
\text { Trench }\end{array}$ & Level & $\begin{array}{l}\text { Unburned } \\
(\mathrm{g})\end{array}$ & $\begin{array}{c}\text { Burned } \\
(g)\end{array}$ & 1 & Area & $\begin{array}{l}\text { Unit or } \\
\text { Trench }\end{array}$ & Level & $\begin{array}{l}\text { Unburned } \\
\text { (g) }\end{array}$ & $\begin{array}{c}\text { Burned } \\
(\mathrm{g})\end{array}$ \\
\hline & & III Excav & tions & & 1 & & Phase III & cavations & (continued) & \\
\hline B7ue & 011029 & 1 & 2.4 & 0.0 & $\begin{array}{l}1 \\
1\end{array}$ & Red & 077022 & 2 & 0.4 & 0.0 \\
\hline Blue & 011026 & 2 & 2.8 & 0.0 & 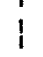 & Red & 056023 & 3 & 1.0 & 0.5 \\
\hline Green & Foxtrot & Backdirt & 1.7 & 0.0 & 1 & Red & 056044 & 3 & 0.0 & 0.2 \\
\hline Green & Echo & Backdirt & 1.2 & 1.8 & i & Red & 056046 & 3 & 1.1 & 0.0 \\
\hline Green & 024079 & 1 & 0.3 & 0.0 & 1 & Red & 066020 & 3 & 0.2 & 0.4 \\
\hline Green & 049016 & 1 & 0.8 & 0.0 & $i$ & Red & 077002 & 3 & 0.2 & 2.5 \\
\hline Red & JuTiet & Backdirt & 0.5 & 0.0 & i & Red & 056019 & 4 & 0.3 & 0.6 \\
\hline Red & 056008 & 1 & 0.1 & 0.0 & $i$ & Red & 056044 & 4 & 1.5 & 0.3 \\
\hline Red & 056009 & 1 & 0.0 & 0.5 & 1 & Red & 056046 & 4 & 0.1 & 0.4 \\
\hline Red & 056064 & 1 & 0.9 & 0.0 & $i$ & White & 100000 & Surface & 0.1 & 2.0 \\
\hline Red & 056083 & 1 & 0.0 & 0.2 & $i$ & White & 168000 & Surface & 0.5 & 0.0 \\
\hline Red & 065002 & 1 & 0.0 & 0.4 & $i$ & White & 059054 & 1 & 0.3 & 0.0 \\
\hline Red & 065013 & 1 & 0.0 & 0.5 & 1 & Yel low & Bravo & Backdirt & 0.0 & 0.5 \\
\hline Red & 066003 & 1 & 0.3 & 0.0 & 1 & Yellow & 138000 & Surface & 4.4 & 0.0 \\
\hline Red & 066014 & 1 & 0.4 & 0.0 & 1 & Yellow & 118050 & 2 & 0.0 & 0.4 \\
\hline Red & 066018 & 1 & 0.4 & 0.5 & 1 & Yel 1ow & 119045 & 2 & 0.0 & 0.4 \\
\hline Red & 067012 & 1 & 0.3 & 0.3 & 1 & Yellow & 123009 & 2 & 0.3 & 0.0 \\
\hline Red & 067014 & 1 & 0.2 & 0.3 & 1 & Yellow & 117039 & 3 & 0.1 & 0.0 \\
\hline Red & 076010 & 1 & 0.0 & 0.3 & 1 & Yellow & 118042 & 3 & 0.2 & 0.0 \\
\hline Red & 076038 & 1 & 0.0 & 0.5 & i & Yel low & 118045 & 3 & 0.0 & 0.5 \\
\hline Red & 055088 & 2 & 6.6 & 2.7 & 1 & Yellow & 118047 & 3 & 1.0 & 0.0 \\
\hline Red & 055089 & 2 & 0.3 & 0.0 & L & & & & & \\
\hline Red & 067012 & 2 & 0.7 & 0.8 & 1 & & \multirow{3}{*}{\multicolumn{4}{|c|}{ Phase II Excavations }} \\
\hline Red & 067014 & 2 & 0.2 & 0.4 & 1 & & & & & \\
\hline Red & 075099 & 2 & 1.3 & 0.0 & i & & & & & \\
\hline Red & 075100 & 2 & 0.0 & 0.4 & 1 & & & & & \\
\hline Red & 076047 & 2 & 0.0 & 0.4 & 1 & Green & 038068 & 1 & 2.4 & 0.3 \\
\hline Red & 076048 & 2 & 0.1 & 0.0 & 1 & Green & 038069 & 1 & 3.6 & 0.0 \\
\hline Red & 077003 & 2 & 2.4 & 0.6 & 1 & Green & 038049 & 1 & 2.9 & 0.0 \\
\hline
\end{tabular}


TABLE 20. (continued)

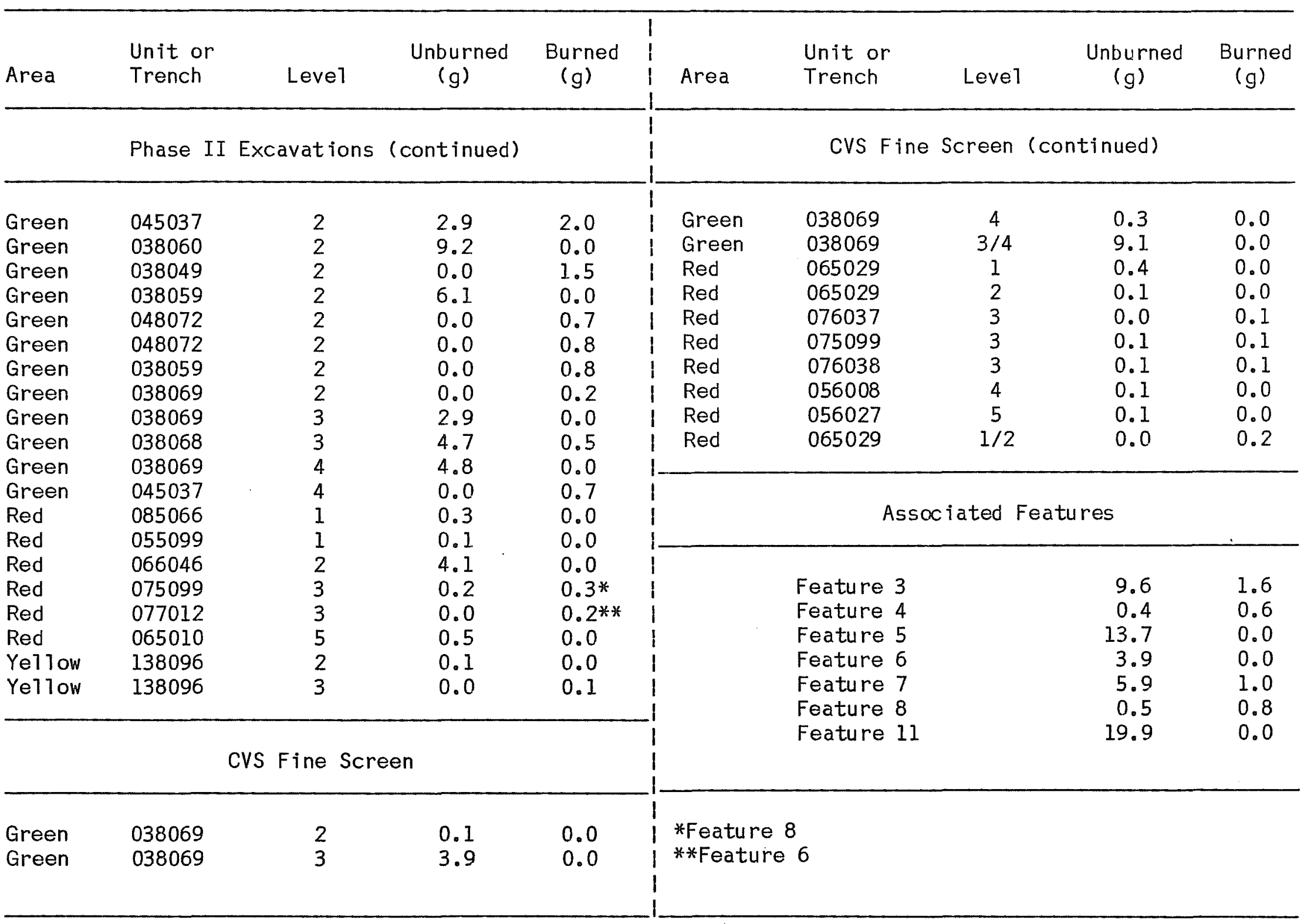


C. virginica, the eastern oyster, is a marine pelecypod. None of the $\mathbf{C}$. virginica is a fossil specimen. Twenty-nine of the specimens were obtained from the surface up to $22.99 \mathrm{~cm}$ in depth, one specimen was obtained from 23 to $42.99 \mathrm{~cm}$ below the surface, and one specimen from 53 to $53.99 \mathrm{~cm}$ below the surface. Because specimens occurred from the surface up to $53.99 \mathrm{~cm}$, and because none is a fossil, I judge that all were transported from the Texas coast either live or dead and deposited in the site.*

Exogyra sp. is a fossil pelecypod common to the area. The presence of Exogyra sp. in this collection is probably the result of either normal excavating procedures uncovering the fossil from its original stratum or the result of cultural interest on the part of the original inhabitants who discarded the specimens in the site when they were finished with them.

The on $1 y$ freshwater mollusks recovered from the site were 22 specimens of Helisoma sp., a pulmonate snail. Because of the small number recovered, and because 19 of the 22 specimens were in the upper $23 \mathrm{~cm}$ of the site, it is possible that Helisoma is an accidental contaminate to the site as a result of freshwater material (plants, etc.,) being carried into the site from a nearby stream or body of water.

A11 of the remaining mollusks from 41 BX 300 are 1 and gastropods which occur at present in the local fauna. Ten genera of 1 and gastropods were removed from the site and are as follows: Rabdotus, Polygyra, Helicina, Succinea, Praticolella, Vertigo, Carychium, Euglandina, Pupoides, and the shell of one slug.

From the above list of 1 and gastropods, the following are eliminated because of smal1 numbers recovered, lack of ecological information on the group, inability to determine the species, or any combinations of the above reasons: Pupoides sp., Carychium sp., Vertigo sp., Succinea sp., and the she 11 of one slug. Euglandina singleyana is a gastropod which feeds on other snails. Its presence in the site is to be expected, and at present it occurs in the area in small numbers.

The remaining species of 1 and gastropods--Rabdotus dealbatus, Polygyra texsiana, Helicina orbiculata, and Praticolella berlandieriana--occur in sufficient numbers and at sufficient depths to arrive at suggestions concerning the ecology of the area at time of deposition.

Rabdotus dealbatus is a species common to the area today. The 3114 specimens recovered from the site at depths of up to $165.5 \mathrm{~cm}$ from the surface indicate the broad length of time the species has occurred in the area. The large

*Author's note: A11 these specimens of C. virginica are considered to belong to a single cache of shells deposited quite recently at the site. Of the 31 specimens, 29 were recovered in a tight cluster on the surface in Block 123 in the southwest corner of the site (Fig. 11). The two subsurface specimens were excavated (one each) from the two units placed in this same block to investigate a possible feature appearing in the side of Bravo trench (Fig. 11). The feature was determined to be a recent7y dug pit associated with the shells. The pit and associated molluscan material are interpreted as a modern clambake. 
number recovered indicates it was a common snail in the past. Pilsbry (1946:13, 15) states that R. dealbatus is ". . in mesquite chaparra1, hibernating in the earth, estivating upon bushes, adhering to bark...." and ". . in estivation may be sealed to 7arge cactus, mesquite, coarse grass and shrubs. . . R. dealbatus is clearly adapted to a semiarid, wooded grassland area which indicates an early habitat similar to the present.

Polygyra texsiana is also a species common to the geographic area today. This species comprises over 13\% of the gastropods collected; therefore, it is a significant part of the past and present fauna. Unfortunately, there is little critical information on the habitat of P. texsiana; however, since it is a species common to the area today and is obviously well adapted to the semiarid, wooded grassland habitat, it is judged the previous habitat of the area was of this condition.

Pilsbry (1948:1084) stated that Helicina orbiculata ". . . is a snail that is especially hardy and has a great resistance to drought, individuals appear to be abundant in exposed areas as in protected woodlands." H. orbiculata is common to the area today and comprises over $32 \%$ of the 1 and gastropods collected at the site. Also, H. orbiculata was obtained (one specimen) from $165.5 \mathrm{~cm}$ below the surface, indicating its early occurrence in the area. other specimens occurred at shallower depths of excavations and in numbers sufficient to suggest that the semiarid, wooded grassland habitat of today existed in the past.

Praticolella berlandieriana occurs in the semiarid division of the Lower Sonoran Zone of Texas. During the rainy season, it is common on bushes such as mesquite and some grasses, and during dry spells it burrows in the soil and under wood or rubbish (Pilsbry 1940). Although small numbers of P. berlandieriana were recorded (84 specimens, or $1.1 \%$ of the total), this species confirms the ecological conditions of the area in conjunction with the three preceding species. The fact that this species also occurred to depths of at least $80 \mathrm{~cm}$ from the surface strengthens the case that this area was ecologically similar in the past as it is today.

There appears to be a concentration of the four above species from units in Area Red. I am unable to determine if this is the result of more thorough excavation in these units, the result of human transport to these areas during site activity, or the result of snail movement to the area of human debris and habitation. Of the four species, only Rabdotus dealbatus could be considered a possible food source, as it is the 1 argest species present in significant numbers.

In summary, the molluscan fauna from $41 \mathrm{BX} 300$ suggests that the ecology of the site at the time of habitation was similar to the area today. These data indicate that the area was a semiarid, wooded grassland habitat.*

*Author's note: Over 5500 mulluscan specimens were recovered during the mitigation activities. While most are cataloged by lots according to the unit-level of their recovery, many, especially in conjunction with the T.I.R.E. procedure, are individually cataloged. It was not considered feasible to include provenience data for this class of specimens in the actual report of investigations. A computer printout with complete provenience data is on file at the UTSA Center for Archaeological Research. 


\section{CHRONOLOGICAL SAMPLES}

\section{RADIOCARBON DATING SAMPLES}

Wood charcoal recovered during the mitigation of 41 BX 300 was generally very sparse; and where it was present, it was characterized by small pieces scattered throughout a unit-7evel. Most charcoal specimens were relegated to species identification (see "Botanical Identification and Analysis"), but four samples were considered 1 arge enough to attempt radiocarbon dating. Table 21 provides provenience data. Samples were submitted to the Center for Applied Isotope Studies at the University of Georgia, Athens, Georgia.

TABLE 21. DISTRIBUTION OF RADIOCARBON DATING SAMPLES

\begin{tabular}{llccl}
\hline $\begin{array}{l}\text { Catalog } \\
\text { Number }\end{array}$ & Area & $\begin{array}{l}\text { Unit or } \\
\text { Trench }\end{array}$ & $\begin{array}{c}\text { Associated } \\
\text { Feature }\end{array}$ & Stratum \\
\hline 118 & Red & 066020 & $(2)$ & Topsoil \\
4137 & Red & 085009 & 8 & Feature zone \\
4627 & Red & 055088 & 2 & Midden fi i 1 \\
4676 & Red & 055088 & 2 & Submidden zone
\end{tabular}

Note: parentheses indicate indirect feature association

Unfortunately, all four samples proved to be too small for dating purposes. Three were returned immediately without even having been cleaned. The fourth, Catalog No. 4676, was processed. Dr. Betty Lee Brandau, Associate Director of the facility, stated the results as follows (letter of September 20, 1978):

We burned your sample $41 \mathrm{BX} 300$ and as I feared it was really too sma11, yielding 1ess than 0.1 gram of benzene.

The calculations yield

$$
\begin{array}{rl}
\text { UGa }-2284 & 2020 \pm 845 \text { B.P. } \\
70 \text { B.C. }
\end{array}
$$

... theoretically the date should be $0 . K$. but so much can affect sma11 samples. 
The chronology of occupation and activity at 41 BX 300 will be presented and discussed in the Summary and Evaluation section of this report. Suffice it to say at this point that this radiocarbon date is not "0.K." The "submidden" zone (Figs. 22, 23) from which the charcoal was recovered is part of the Del Rio clay stratum, and occupation associated with this soil is assigned to the early part of the Middle Archaic period, dating between 2600 and 2000 B.C.

\section{ARCHAEOMAGNETIC DATING SAMPLES}

Thirty-seven samples of burned rock were collected from features at 41 BX 300 for the purposes of archaeomagnetic dating (Fig. 35,a). The samples were personally collected by Tim Hunkapillar, a graduate student of Dr. Robert DuBois, Director of the University of Oklahoma's Archaeomagnetic Laboratory of the Earth Sciences Observatory, Norman, Oklahoma, where the samples were processed. Table 22 provides provenience data for these samples.

\section{Analysis}

The following statements were dictated to the author by Dr. DuBois via telephone:

1. Measurements of paleomagnetic direction indicated drastic movements within features from which rock samples were recovered. Therefore, directional component of analysis is not fruitful. Measurements were taken for inter-rock comparisons.

2. Measurement of intensity of remnant paleomagnetism also not fruitful, as rocks heated to temperatures insufficiently high to align magnetic field for measurement purposes. Measurements taken for intra-rock investigation.

\section{Conclusion}

Internal feature movement and low firing temperature precluded any possibility of dating limestone rocks, either relatively or absolutely.

\section{THERMOLUMINESCENCE DATING SAMPLES}

Thirty-nine samples of burned rock were collected from features and several nonfeature locations at 41 BX 300 for the purpose of thermoluminescence dating. This technique is still highly experimental for burned limestone, and at best only a relative date could have been expected. The project had available the expert services of Dr. Donald Lewis, who developed the thermoluminescence analysis equipment while associated with the Shell 0il Company research laboratory in Houston, Texas. Table 23 provides data on the locations of these samples. 
Site 41 BX 300/Ecofacts and Special Samples

TABLE 22. DISTRIBUTION OF ARCHAEOMAGNETIC DATING SAMPLES

\begin{tabular}{|c|c|c|c|c|}
\hline $\begin{array}{l}\text { Catalog } \\
\text { Number }\end{array}$ & Area & Unit & $\begin{array}{l}\text { Associated } \\
\text { Feature }\end{array}$ & Stratum \\
\hline 999597 & Red & 085009 & 8 & Feature zone \\
\hline 999598 & Red & 085009 & 8 & Feature zone \\
\hline 999599 & Red & 085009 & 8 & Feature zone \\
\hline 999600 & Red & 085009 & 8 & Feature zone \\
\hline 999601 & Red & 085009 & 8 & Feature zone \\
\hline 999602 & Red & 085009 & 8 & Feature zone \\
\hline 999603 & Red & 085009 & 8 & Feature zone \\
\hline 999604 & Red & 085009 & 8 & Feature zone \\
\hline 999605 & Green & 037044 & 9 & Feature zone \\
\hline 999606 & Green & 037044 & 9 & Feature zone \\
\hline 999607 & Green & 037044 & 9 & Feature zone \\
\hline 999608 & Green & 037044 & 9 & Feature zone \\
\hline 999609 & Red & 065005 & 2 & Midden fill \\
\hline 999610 & Red & 065005 & 2 & Midden fill \\
\hline 999611 & Red & 065005 & 2 & Midden fil \\
\hline 999612 & Red & 065005 & (2) & Mixed gravel \\
\hline 999613 & Red & 077003 & 6 & Feature zone \\
\hline 999614 & Red & 077003 & 6 & Feature zone \\
\hline 999615 & Red & 077003 & 6 & Feature zone \\
\hline 999616 & Red & 077003 & 6 & Feature zone \\
\hline 999617 & Red & 077003 & 6 & Feature zone \\
\hline 999618 & Red & 077003 & 6 & Feature zone \\
\hline 999619 & Red & 077003 & 6 & Feature zone \\
\hline 999620 & Red & 077012 & 6 & Feature zone \\
\hline 999621 & Red & 077012 & 6 & Feature zone \\
\hline 999622 & Red & 077012 & 6 & Feature zone \\
\hline 999623 & Red & 077012 & 6 & Feature zone \\
\hline 999624 & Red & 077012 & 6 & Feature zone \\
\hline 999625 & Red & 077012 & 6 & Feature zone \\
\hline 999626 & Red & 076038 & 3 & Feature zone \\
\hline 999627 & Red & 076038 & 3 & Feature zone \\
\hline 999628 & Red & 076038 & 3 & Feature zone \\
\hline 999629 & Red & 076038 & 3 & Feature zone \\
\hline 999630 & Red & 076038 & 3 & Feature zone \\
\hline 999631 & Red & 076038 & 3 & Feature zone \\
\hline 999632 & Red & 076038 & 3 & Feature zone \\
\hline 999633 & Red & 076038 & 3 & Feature zone \\
\hline
\end{tabular}

Note: Parentheses indicate indirect feature association 
TABLE 23. DISTRIBUTION OF THERMOLUMINESCENCE DATING SAMPLES

\begin{tabular}{|c|c|c|c|c|}
\hline $\begin{array}{l}\text { Catalog } \\
\text { Number }\end{array}$ & Area & Unit & $\begin{array}{l}\text { Associated } \\
\text { Feature }\end{array}$ & Stratum \\
\hline 1102 & Green & 038054 & 9 & Feature zone \\
\hline 1103 & Green & 038054 & 9 & Feature zone \\
\hline 1105 & Green & 038054 & (9) & Mixed gravel \\
\hline 1104 & Green & 038054 & (9) & Mixed gravel \\
\hline 5085 & Red & 055066 & 2 & Midden fill \\
\hline 5084 & Red & 055084 & 2 & Midden fill \\
\hline 5091 & Red & 055084 & 2 & Midden fill \\
\hline 5092 & Red & 055084 & 2 & Midden fill \\
\hline 2558 & Red & 075099 & 8 & Feature zone \\
\hline 2559 & Red & 075100 & 8 & Feature zone \\
\hline 3295 & Red & 076037 & 3 & Feature zone \\
\hline 3297 & Red & 076037 & 3 & Feature zone \\
\hline 3827 & Red & 076037 & 3 & Feature zone \\
\hline 4539 & Red & 076037 & 3 & Feature zone \\
\hline 3294 & Red & 076037 & 3 & Feature zone \\
\hline 4573 & Red & 076037 & 3 & Feature zone \\
\hline 3299 & Red & 076038 & 3 & Feature zone \\
\hline 3298 & Red & 076038 & 3 & Feature zone \\
\hline 4572 & Red & 076038 & 3 & Feature zone \\
\hline 3303 & Red & 076038 & 3 & Feature zone \\
\hline 5164 & Red & 077003 & 6 & Feature zone \\
\hline 5163 & Red & 077003 & 6 & Feature zone \\
\hline 5167 & Red & 077003 & 5 & Occupation zone \\
\hline
\end{tabular}


TABLE 23. (continued)

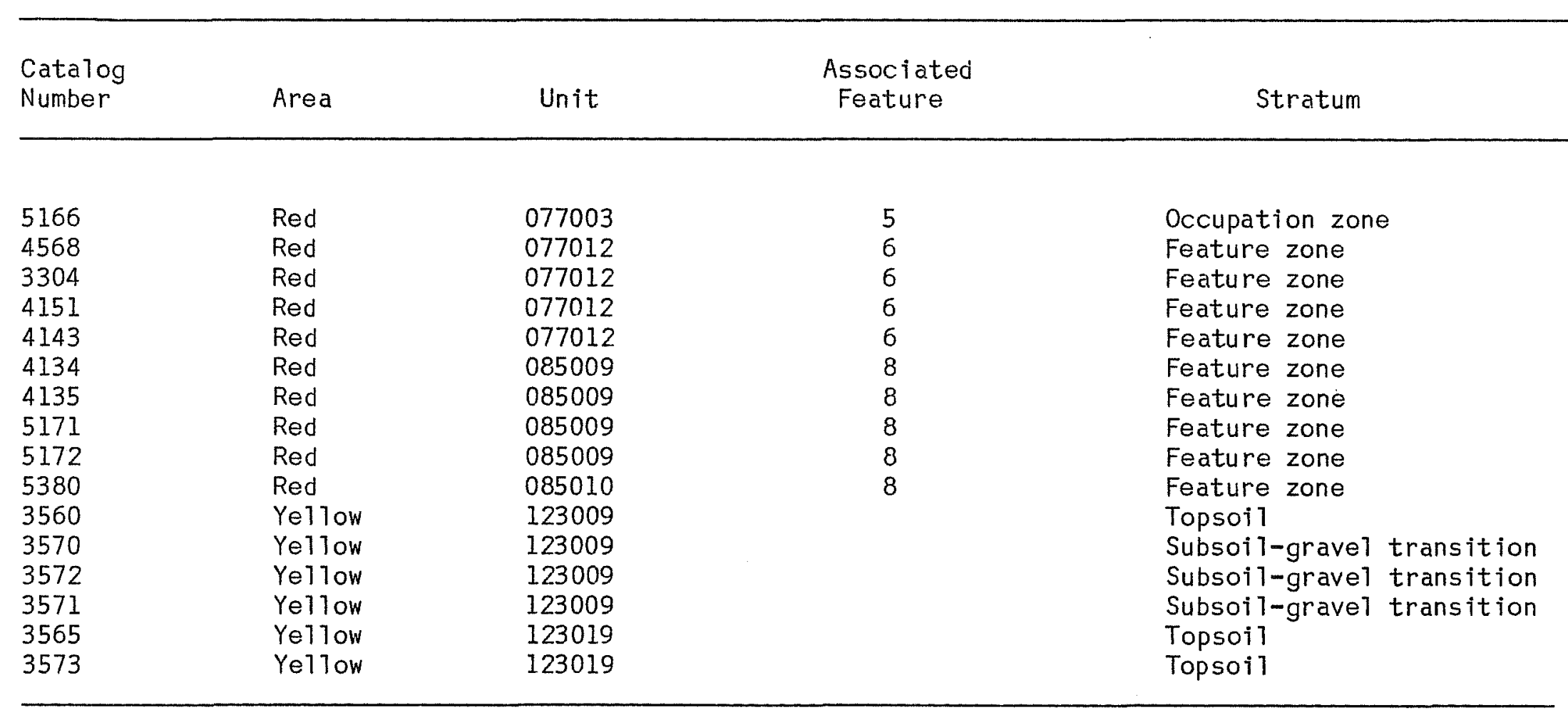

Note: Parentheses indicate indirect feature association 
The dating technique required the pulverization of the burned 1 imestone under carefully controlled conditions of light and heat. This was accomplished by Dr. John E. Funnell of the Department of Materials Sciences at the Southwest Research Institute, San Antonio, Texas, as follows:

The procedure employed in obtaining powders made for thermoluminescence examination from portions of the rock specimens that you left with us is outlined below. The bulk of the work was done in a dark room where the only source of 7 ight was a horizontal ventilation shaft that led to a vertical roof outlet; no direct light reached the materials.

Step 1: In turn, each specimen was unwrapped and fragments not extending deeper than about 1/4-inch below the surface were carefully chipped from the rock with a hammer and chisel. These were saved for further processing. If excessive soil was detected on the specimens, it was removed as completely as possible with a stiff-bristle brush prior to chipping.

Step 2: The chips were reduced by crushing to about $1 / 16$-inch size in a steel mold.

Step 3: The reduced material was placed in a clean, small porcelain jar with clean alumina pebbles which was then placed in a vibrating shaker for 10 to 15 minutes. This powdered the material.

Step 4. The powdered material was screened on a 200-mesh screen and retained on a 325 -mesh screen. Two fractions of at least 5 grams each were thus obtained, one being -200 and the other being -325 mesh.

Step 5: The powder fractions were placed in small amber glass containers. After identifying labels were placed on the inside and outside, the containers were tightly capped and placed in a cardboard box.

Step 6: Al1 surplus powdered materials were placed in 1 arger amber glass bottles and, with the remaining wrapped rock specimens, were placed in boxes.

Throughout the materials preparation procedure, none of the materials were exposed to temperatures more than a few degrees above ambient.

Once the specimens were pulverized, Dr. Lewis undertook to date the material. Mechanical difficulties with his equipment necessitated the transfer of the specimens to Dr. James McAttee of the Department of Chemistry at Baylor University in Waco, Texas.

As was the case with the archaeomagnetic samples, dating of burned limestone by thermoluminescence was not successful, and for exactly the same reason: the firing temperature of the rock was too low for this dating method to work. 


\section{DESCRIPTION AND ANALYSIS OF ARTIFACTS}

\section{INTRODUCTION}

The number of artifacts recovered in the field and processed in the laboratory totaled 101,598 specimens. Of these, 101,563 (99.97\%) were prehistoric specimens, and 38 specimens $(0.03 \%)$ were of contemporary manufacture (Table 24).

The system employed in this report for classifying the collection consists of a series of mutually exclusive and equally weighted major categories: chronological period, raw material, technology of manufacture, and morphology and function. A hierarchial element is introduced among the categories by virtue of the order in which they are considered for organization. As other arrangements are possible, it is not the intention to attribute undue weight or importance to any particular category with respect to the others.

The chronological component of the classification system is essentially binary, distinguishing between historic items of contemporary, Euro-American manufacture and prehistoric artifacts manufactured by aboriginal inhabitants of the site prior to ca. A.D. 1750.

A17 prehistoric material can be subdivided into a few, more manageable groups on the basis of the raw material from which it was manufactured. The vast majority of prehistoric artifacts $(101,533$, or $99.93 \%)$ are stone. On1 y 30 specimens (0.04\%) are manufactured of other materials: five are of she11, 25 of clay, and no bone tools were recovered. Comparably, historic items are first subdivided by material of manufacture; glass predominates with 29 items, followed by metal (five) and ceramic pieces (four).

A collection of over 100,000 prehistoric stone pieces necessitated several additional classificatory subdivisions before a group of manageable analytical size resulted. A technological distinction was made between chipped stone and stone tools manufactured by grinding or utilized in a rough state; the Tatter usually are denoted as hammerstones, handstones, and grinding slabs. Prehistoric chipped stone objects, totaling 101,519 specimens ( $99.2 \%$ of the total artifact inventory), were distinguished by an admittedly mixed array of categories representing technological, morphological, and functional criteria. Quarry blank and core, uniface and biface, projectile point and perforator, for example, do not make for a consistent classificatory system; but as the categories are both descriptive and commonly employed, the advantages of communicability and comparability far outweigh any analytical irregularities.

The number in the parentheses immediately following the descriptive name for each group of artifacts refers to the classification type code for that particular group. A complete listing of these codes is provided as Appendix I.A. 
Site 41 BX 300/Artifacts

TABLE 24. SUMMARY OF ARTIFACTS COLLECTED DURING PHASE III INVESTIGATIONS

\begin{tabular}{|c|c|c|}
\hline Classification & Quantity & Percentage \\
\hline CHIPPED STONE & $101,519 *$ & 99.92 \\
\hline Manufactured tools & 1,311 & \\
\hline $\begin{array}{l}\text { Projectile points } \\
\text { Bifaces } \\
\text { Unifaces } \\
\text { Typed tools } \\
\text { Specialized tools } \\
\text { Retouched flakes }\end{array}$ & $\begin{array}{r}154 \\
675 \\
35 \\
9 \\
94 \\
344\end{array}$ & \\
\hline Tool by-products & 100,208 & \\
\hline $\begin{array}{l}\text { Tested nodules } \\
\text { Production blanks } \\
\text { Unretouched flakes } \\
\quad \text { With cortex } \\
\text { Without cortex } \\
\text { Cores } \\
\text { Chunks }\end{array}$ & $\begin{array}{r}20 \\
167 \\
95,935 \\
14,213 \\
81,722 \\
76 \\
4,010\end{array}$ & \\
\hline ROUGH STONE & 14 & 0.01 \\
\hline $\begin{array}{l}\text { Hammerstone } \\
\text { Handstones } \\
\text { Grinding slabs } \\
\text { Unidentifiable fragments }\end{array}$ & $\begin{array}{l}1 \\
2 \\
9 \\
2\end{array}$ & \\
\hline SHELL & 5 & 0.01 \\
\hline PREHISTORIC POTTERY & 25 & 0.03 \\
\hline $\begin{array}{l}\text { HISTORIC SPECIMENS } \\
\text { Ceramic } \\
\text { G1ass } \\
\text { Meta1 }\end{array}$ & 38 & 0.03 \\
\hline TOTAL SPECIMENS & 101,601 & 100.00 \\
\hline
\end{tabular}

*Includes complete and fragmentary specimens 
CHIPPED STONE

VARIETIES OF RAW MATERIAL

Chert

Over $99 \%$ of the chipped stone specimens in all classes of artifacts, both tools and tool by-products, have been identified as chert. The almost exclusive use of this material is not surprising, given its occurrence and accessibility within close proximity to 41 BX 300 . Nodules of chert, eroded out of the Edwards limestone formation by the cutting action of the creeks immediately adjacent to the site, would have provided a constant, albeit fortuitous and often damaged, source of chert. The intentional exploitation of surficial outcroppings at nearby 41 BX 299 and 41 BX 301 (Fig. 1) provided a more substantial quantity of this material, however, with the additional benefits of a knapper being able to select for grade, control the recovery procedures, and minimize internal fracturing.

Data gathered from the two adjacent chert procurement sites (41 BX 299 and 41 BX 301) during field work and analyses of materials collected (Hester, Katz, and Kelly 1977; Katz 1978) were compared with chipped stone specimens recovered from $41 \mathrm{BX} 300$. Consistencies were noted between the range of colors, textures, cortex characteristics, nodule size, and nature of impurities. Despite the lack of trace element analysis data, the overwhelming similarity in the raw material outcropping at sites 41 BX 299 and $41 \mathrm{BX} 301$ and the artifactual material at 41 BX 300 , plus the fact of close proximity, leads to the conclusion that the chert at the latter site was local1y procurred. The presence of this resource was undoubtedly one of the primary attractions of the 41 BX 300 locality.

\section{Other Crystalline Materials}

Less than one percent of the chipped stone specimens collected during Phase III activities at 41 BX 300 was not identified as chert. These include chalcedony, quartzite, and quartz. Their minimal occurrence in the collection seems to be in direct proportion to the 7 imited extent of their natural occurrence in the locality, a fact observed by other researchers at nearby comparable sites (e.g., Black and McGraw 1985:59).

\section{$\underline{\text { Obsidian }}$}

One flake of obsidian was recovered during these investigations, a material so rare and so obviously exotic as to merit special consideration. The flake has a small amount of steep retouch flaking along one edge of the dorsal face; and it was recovered from the topsoil zone in the central portion (Area Red) of the site. Trace element analysis conducted at the Lawrence Berkeley Laboratory has determined that the probable derivation of the obsidian from which the flake was manufactured was the Malad source in southeastern Idaho (Hester 1986). Other obsidian specimens recovered in Texas and OkTahoma and linked to this source are dated to the Late Prehistoric period. They are thought to represent a long-distance trade network documented on the southern 
Plains during this period (Spielmann 1983). The provenience of the 41 BX 300 specimen would not be inconsistent with a Late Prehistoric dating.

\section{Limestone and Dolomite}

The few nonchipped stone artifacts, as we11 as all the burned rock comprising the cultural features, are either limestone or dolomite. These minerals are the prime components of the Edwards limestone bedrock formation, which is exposed in the stream bed and erodes out of its banks immediately adjacent to the site. The ready availability of this resource, highly suitable for hearth rocks and boiling stones, was another of the prehistoric attractions of the 41 BX 300 locality.

\section{MANUFACTURED TOOLS}

The artifacts classified as chipped stone tools are characterized by the presence of intentional retouching on one or more edges or faces. The purpose of this chipping is to create a functionally efficient overall shape and working edge(s). Separately considered are those chipped stone artifacts which are not tools themselves, but rather represent stages of manufacturing or the debris from manufacturing and maintenance activities.

\section{Projectile Points}

\section{Typological Identification}

Although projectile points are basically only one of many mutually exclusive artifact categories, in point of fact they assume an importance far exceeding even their functional interpretation of piercing tools employed for faunal procurement. Distinctive stylistic variations in morphological configuration are associated with fairly well-documented parameters of time, and to some extent, of space, so as to produce a powerful diagnostic element for culture historical interpretations.

Three separate methods of projectile point typological identification were employed with the collection of 154 Phase II specimens from 41 BX 300. First, published summaries of projectile point descriptions were consulted. Criteria for selection of these references included degree of descriptive detail, inclusion of many types, reputability of the author(s), number and quality of illustrations, and an appropriate relationship to the geographical region in which the site is situated. Primary sources consulted include Suhm and Jelks (1962), Gerstle, Kelly, and Assad (1978), Hester (1980), Woerner and Highley (1983), Black and McGraw (1985), and Turner and Hester (1985).

Another method of typological identification was the expert opinion, in particular Dr. Thomas R. Hester, director of the CAR-UTSA. His extensive experience with this category of artifact in this specific region allowed him to quickly refine initial groupings based solely on literature descriptions and photographic comparisons. 
The third option available for point typing was a computer program which compared attributes from untyped points against a data base of attributes of known types. The unknown specimens were assigned the type of the previously recorded type with which they most tightly clustered through multivariate statistical analyses. Developed by Gunn and Prewitt (1975), both individuals have continued to refine the clustering programs and the attributes in the data base, and the number of typological comparisons in the data base have been increased. The primary difficulty with employing the collection from 41 BX 300 with Gunn and Prewitt's analys is was due to a lack of interface between Prewitt's data base and Gunn's UTSA computer programs. A small number of previousiy untyped dart points were successfully clustered with known point type attributes; but in general, comparison with published typological descriptions and expert assistance proved far more successful with this particular collection at the time that analyses were being conducted.

\section{Angostura (203)}

Number of specimens: 1

Provenience: This point was recovered from the topsoil zone in the northwest portion (Area B7ue) of the site. It was removed from the north wall of November trench (Fig. 11).

Metrics: See Appendix I.B, Part 1.

Description (Fig. 24,a): This single specimen has a thin, lanceolate outline, with weak shoulders and a slightly contracting stem. The lateral edges are convex and the stem edges straight. The tip and the basal edge are broken off. The sides of the stem are ground. Flake scars are oblique, transverse ribbons.

Date range: Late Paleo-Indian/early part of the Early Archaic period; Central Texas Circleville phase; Salado Creek Watershed Local Period 3; 65004800 B.C.

References: Suhm and Jelks (1962:167-168), Black and McGraw (1985:124-125), Turner and Hester (1985:66-67).

Butverde (205)

Number of specimens: 13

Provenience: These specimens were recovered predominantly in the centrat (Area Red) and southern (Area Yellow) portions of the site. Depth of recovery ranges from the surface to $45 \mathrm{~cm}$ below ground surface, including four feature associations (Features 3, 6, 7, 11). Appendix I.B, Part 1 provides individual provenience data.

Metrics: See Appendix I.B, Part 1. 


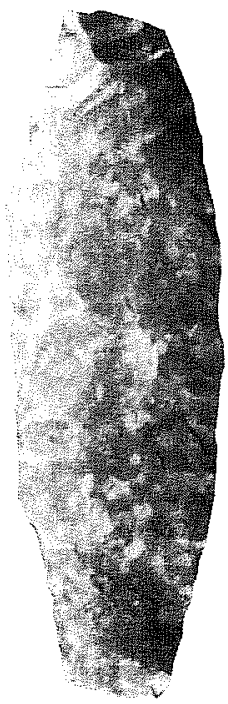

a

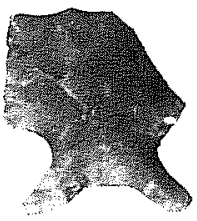

f

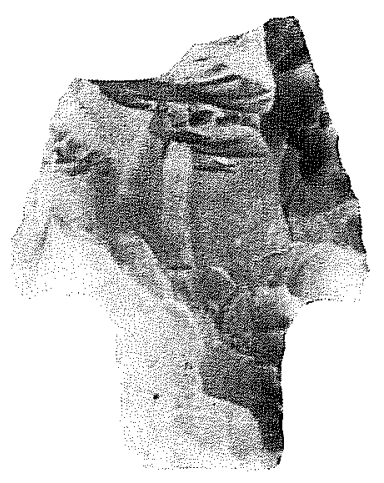

$\mathrm{b}$

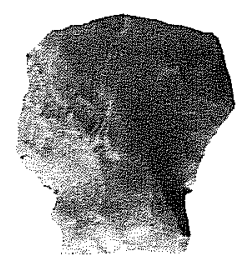

g

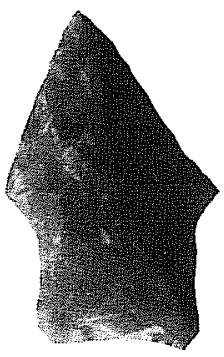

C

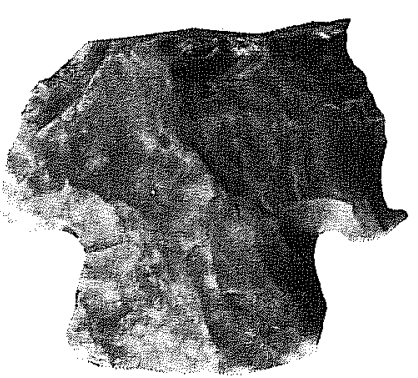

d

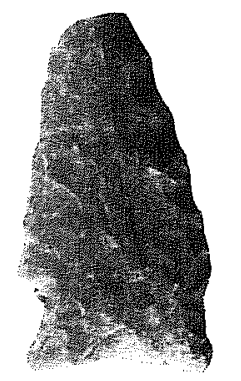

h

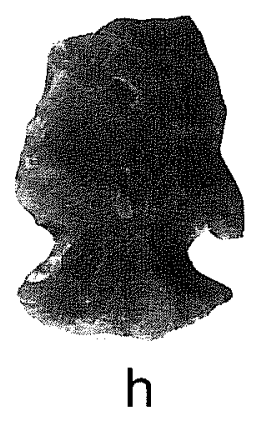

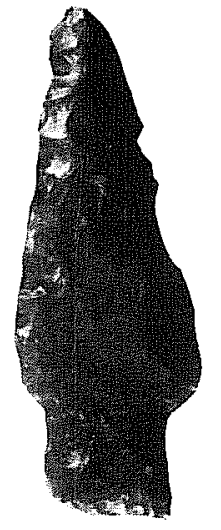

e

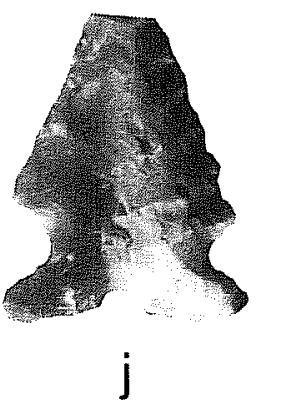

Figure 24. Projectile Points.. a, Angostura; b,c, Bulverde; d, Castroville; e, Dar1; f, Edwards; g. Ellis; h. Ensor; i, Fairland; j, Frio. 
Description (Fig. 24,b,c): These specimens are characterized by triangular blades with generally straight lateral edges. Most distinctive is the rectangular stem, with straight sides and either straight or slightly concave basal edges. Prominent shoulders or small barbs mark the transition from blade to stem. Overall size is quite variable. Since the stem remains consistent in size in time, the smaller specimens (Fig. 24,c) are likely reworked from larger originals.

Date Range: Middle portion of the Middle Archaic period; Central Texas Marsha71 Ford phase; Salado Creek Watershed Local Period 7 (ear7y); 2100 1500 B.C.

References: Suhm and Je1ks (1962:169-170), B7ack and McGraw (1985:115-116), Turner and Hester (1985:73).

\section{Castroville (207)}

Number of specimens: 11

Provenience: These specimens were recovered predominantly from the central (Area Red) and northeast (Area Green) portions of the site. Depth of recovery varied from the surface to $40 \mathrm{~cm}$ below ground surface, but all came from the topsoil zone. One was associated with Feature 3. Appendix I.B, Part 1 provides individual provenience data.

Metrics: See Appendix I.B, Part 1.

Description (Fig. 24,d): These are broad-bladed points, subovate in overall form. Most characteristic is the stem, which is trapezoidal in shape; the stem sides are straight, and the basal edge is straight to slightly convex. The neck width is very broad. Deep corner notches, cut at an angle between 450 and 900 from the 1 ine of the base, create prominent barbs.

Date range: Early in the Late Archaic period; Central Texas Uvalde phase; Salado Creek Watershed Local Period 9 (early); 250 B.C.-A.D. 200.

References: Suhm and Jelks (1962:173-174), Black and McGraw (1985:109, 111), Turner and Hester (1985:76-77).

\section{Dar1 (212)}

Number of specimens: 3

Provenience: These three specimens were found widely scattered at the site, one each was recovered from the northeast (Area Green), central (Area Red), and southern (Area Yellow) portions. The single subsurface recovery was from the topsoil zone, between $20-40 \mathrm{~cm}$ below the ground surface, and associated with Feature 3. Individual proveniences are provided in Appendix I.B, Part 1.

Metrics: See Appendix I.B, Part 1. 
Description (Fig. 24,e): The blades are long, narrow triangles with slightly convex lateral edges. Stems are rectangular, with straight sides and slightly convex basal edges. Shoulders are small and turned up toward the tip. No beveling or grinding of blade or stem edges are present on these three specimens. Based on the size, shape, and lack of grinding, these specimens are considered representative of Prewitt's (1981) Mahomet variety.

Date range: Late in the Late Archaic period; Central Texas Driftwood phase; Salado Creek Watershed Local Period 10 (early); A.D. 600-750.

References: Suhm and Jelks (1962:179-180), B1ack and McGraw (1985:108), Turner and Hester (1985:84).

\section{Edwards (216)}

Number of specimens: 2

Provenience: Both specimens were recovered on the surface, one from the centra 1 (Area Red) and the other from the northeast (Area Green) portion of the site. Exact provenience is provided in Appendix I.B, Part 1.

Metrics: See Appendix I.B, Part 1.

Description (Fig. 24,f): Small subovate forms with straight 1 ateral blade edges. Most distinctive are the deep side notches and broad concavity in the base, which combine to create a boomerang-shaped stem.

Date range: Early in the Late Prehistoric period; Central Texas Austin phase; Salado Creek Watershed Local Period 10 (1ate); A.D. 750-1350.

References: BTack and McGraw (1985:101), Turner and Hester (1985:173).

\section{Ellis (218)}

Number of specimens: 1

Provenience: This specimen was recovered from the surface in the central (Area Red) portion of the site.

Metrics: See Appendix I.B, Part 1.

Description (Fig. 24,g): A small triangular form characterized by corner notching and a straight basal edge, creating an expanding, triangular-shaped stem. The primary distinction between this type and the Ensor is the side notching of the latter; otherwise they are considered varieties of the same general form of sma11, triangular dart point.

Date range: Middle in the Late Archaic period; Central Texas Twin Sisters phase; Salado Creek Watershed Local Period 9 (late); A.D. 200-600.

References: Suhm and Jelks (1962:187-188), Turner and Hester (1985:93). 
Ensor (219)

Number of specimens: 20

Provenience: The Ensor is the most numerous projectile point type recorded during mitigation activities, and specimens were recovered in all parts of the site. The northern half of the site produced the most, however, especially the northeast (Area Green) and central (Area Red) portions. Individual proveniences are provided in Appendix I.B, Part 1.

Metrics: See Appendix I.B, Part 1.

Description (Fig. 24,h): These are small triangular forms, with substantial variation in overall out7ine; some specimens are long and narrow while others are short and squat. All are characterized by shallow to prominent side notches, which produce an expanding stem. Basal edges are straight to slightly convex. The method of stem production and the resultant stem morphology distinguish this type from the corner-notched Ellis, the basalnotched Frio, and the shallow side-notched and concave-based Fairland. In overall size and shape, these four types can be considered varieties of the same general form, however.

Date range: Middle in the Late Archaic period; Central Texas Twin Sisters phase; Salado Creek Watershed Local Period 9 (7ate); A.D. 200-600.

References: Suhm and Jelks (1962:189-190), Black and McGraw (1985:105-106), Turner and Hester (1985:94).

Fair1and (221)

Number of specimens: 7

Provenience: Five of these seven specimens were recovered from the northeast (Area Green) portion of the site. None of the seven were excavated; three were surface finds, and four were from trench backdirt, although al1 these trenches were located in Area Green. Individual proveniences are provided in Appendix I.B, Part 1.

Metrics: See Appendix I.B, Part 1.

Description (Fig. 24,i): Small triangular forms with straight lateral edges. The short expanding stem is created by shallow side notching, and the long concave basal edge results in very prominent stem corners. The flaking is well controlled and rather delicate.

Date range: Middle of the Late Archaic period; Central Texas Twin Sisters phase; Salado Creek Watershed Local Period 9 (late); A.D. 200-600.

References: Suhm and Jelks (1962:191-192), B1ack and McGraw (1985:106), Turner and Hester (1985:96). 


\section{Frio (224)}

Number of specimens: 12

Provenience: These specimens were recovered from all areas of the site, a7though the northeast (Area Green) and central (Area Red) portions produced two-thirds of the total number. Half were excavated under controlled conditions, and none of these were excavated deeper than $20 \mathrm{~cm}$ below the ground surface. One is associated with Feature 4. Individual proveniences are provided in Appendix I.B, Part 1.

Metrics: See Appendix I.B, Part 1.

Description (Fig. 24,j): Small triangular forms with slightly convex blade edges. The stem is the most distinctive feature, characterized by small side and basal notches to produce an eared or bifurcated appearance to the stem.

Date range: Middle of the Late Archaic period; Central Texas Twin Sisters phase; Salado Creek Watershed Local Period 9 (late); A.D. 200-600.

References: Suhm and Jelks (1962:195-196), BTack and McGraw (1985:103, 105), Turner and Hester (1985:100).

Gower (226)

Number of specimens: 1

Provenience: This specimen was recovered from the surface in the southwest (Area Yellow) portion of the site.

Metrics: See Appendix I.B, Part 1.

Description (Fig. 25,a): A small 1 anceolate form with slightly convex Tateral b7ade edges. Although both missing, this specimen had small barbs above a rectangular stem form with straight sides. Most characteristic is the carefully retouched deep concavity in the base, forming a perfect semicircle.

Date range: Middle of the Early Archaic period; Central Texas San Geronimo phase; SaTado Creek Watershed Local Period 4; 4800-4100 B.C.

References: Turner and Hester (1985:105).

La Jita (229)

Number of specimens: 1

Provenience: This specimen was recovered from the backdirt of Echo trench, located in the northeast (Area Green) portion of the site.

Metrics: See Appendix I.B, Part 1. 


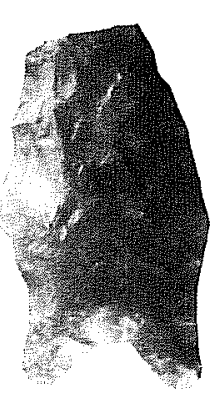

a

$$
0
$$
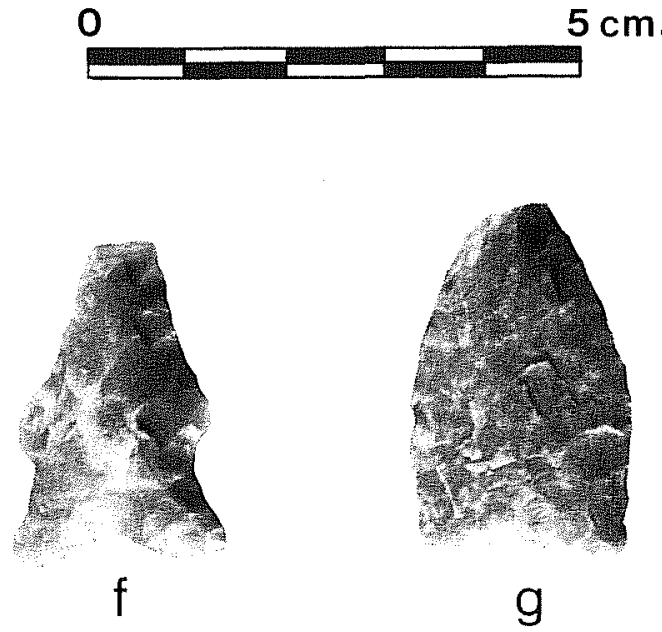
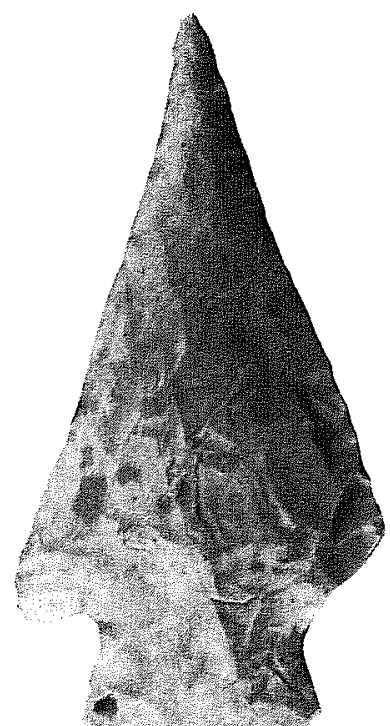

C

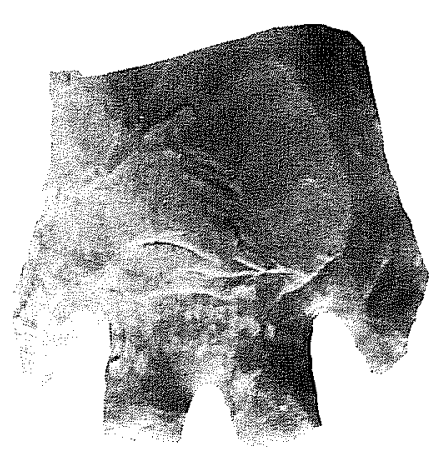

h
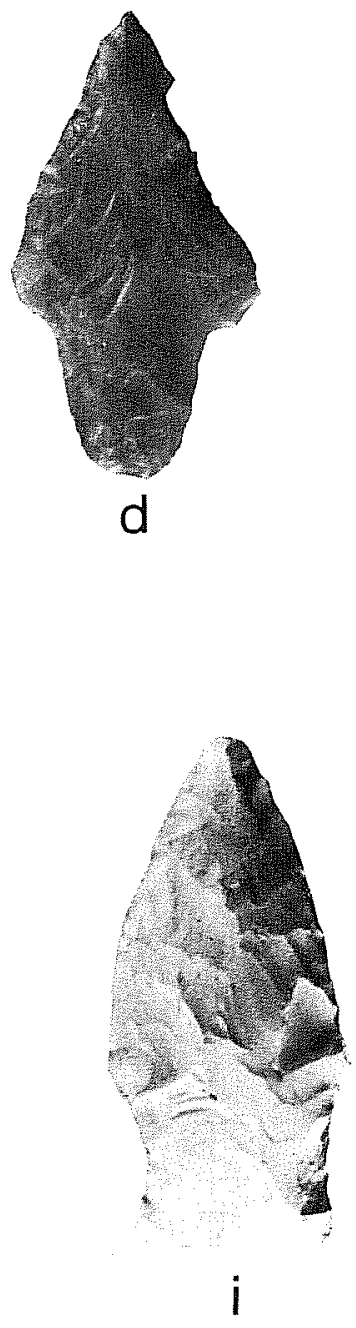

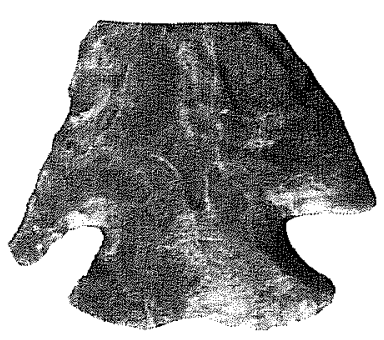

e

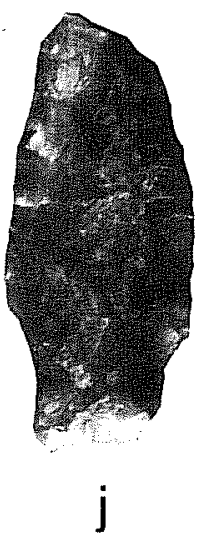

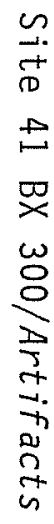
g. Matamoros; h, Monte11; i, Nolan; j, Palmillas. 
Site 41 BX 300/Artifacts

Description (Fig. 25,b): A large subtriangular form, with s1ightly convex sides and base. The stem is slightly expanding, with weak shoulders and rounded basal corners. The stem is thinned by the removal of a single large longitudinal flake from both faces of the stem.

Date range: Early in the Middle Archaic period; Central Texas Clear Fork phase; SaTado Creek Watershed Local Period 6; 2600-2100 B.C.

References: Black and McGraw (1985:117-119), Turner and Hester (1985:112).

Lange (230)

Number of specimens: 1

Provenience: The single specimen was excavated in association with Feature 5, between $20-40 \mathrm{~cm}$ below ground surface in the central (Area Red) portion of the site.

Metrics: See Appendix I.B, Part 1.

Description (Fig. 25,C): A large and broad triangular form with straight bTade edges. The barbs are small but sharp. The expanding stem has straight sides and a convex base.

Date range: Late in the Middle Archaic period; Central Texas San Marcos phase; Salado Creek Watershed Local Period 8; 600-250 B.C.

References: Suhm and Jelks (1962:203-204), Black and McGraw (1985:111-112), Turner and Hester (1985:113).

Langtry (231)

Number of specimens: 4

Provenience: Three of these specimens were recovered from the central (Area Red) portion of the site, and the fourth in the northwest (Area Blue). Three were excavated, all from the topsoil zone between $0-20 \mathrm{~cm}$ below ground surface. Individual proveniences are provided in Appendix I.B, Part 1.

Metrics: See Appendix I.B, Part 1.

Description (Fig. 25,d): A diamond-shaped form, with straight 7 ateral blade edges. The distinctive contracting stem begins below upturned, prominent shoulders on three specimens; on the fourth, the shoulders are large and pointed, almost barblike. The contracting stem truncates in a straight basal edge.

Date range: Middle part of the Middle Archaic period; Central Texas Round Rock phase; Salado Creek Watershed Local Period 7 (1ate); 1500-600 B.C. 
References: Suhm and Jelks (1962:205-206), Black and McGraw (1985:113, 115), Turner and Hester (1985:114-115).

$\operatorname{Marcos}(233)$

Number of specimens: 5

Provenience: Three specimens were recovered in the central (Area Red) portion of the site, all excavated between $0-20 \mathrm{~cm}$ below ground surface. One is associated with Feature 7 . The remaining two are from the northern half of the site, one in the northwest (Area Blue) and one in the northeast (Area Green). Specific proveniences are provided in Appendix I.B, Part 1.

Metrics: See Appendix I.B, Part 1.

Description (Fig. 25,e): A broad triangular form with straight lateral blade edges. The corner notching is finely done and consistently at a 450 angle, creating a short expanding stem. Basal edges tend to be straight, although several are slightly concave.

Date range: Early in the Late Archaic period; Central Texas Uvalde phase; SaTado Creek Watershed Local Period 9 (early); 250 B.C.-A.D. 200.

References: Suhm and Jelks (1962:209-210), Black and McGraw (1985:112), Turner and Hester (1985:117-118).

Martindale (235)

Number of specimens: 2

Provenience: Both specimens were recovered on the surface in the central (Area Red) portion of the site.

Metrics: See Appendix I.B, Part 1.

Description (Fig. 25,f): A sma77 triangular form with straight to slightly convex blade edges. The stem is formed by means of broad side notches or large corner notches, resulting in concave stem edges. Additional retouching from each basal corner inward toward the center of the base creates a concavity through the intersection of two convex curves. The resultant bifurcated stem is a characteristic of this point type.

Date range: Late in the Early Archaic period; Central Texas Jarrell phase; Salado Creek Watershed Local Period 5 (earty); 4100-3100 B.C.

References: Suhm and Jelks (1962:213-124), Black and McGraw (1985:123), Turner and Hester (1985:120-121). 
Site 41 BX 300/Artifacts

Matamoros (236)

Number of specimens: 1

Provenience: This specimen was recovered from the surface in the central (Area Red) portion of the site.

Metrics: See Appendix I.B, Part 1.

Description (Fig. 25,g): A small subtriangular form with moderately convex Tateral edges extending from tip to base. There is no stem modification. The base is broadly concave from corner to corner. Parallel flakes have been removed longitudinally on one face beginning at the basal edge, presumably to thin the proximal end to facilitate hafting.

Date range: Late part of the Late Archaic period; Central Texas Driftwood phase; Salado Creek Watershed Local Period 10 (early); A.D. 600-750.

References: Suhm and Jelks (1962:215-216), Turner and Hester (1985:122).

\section{Monte11 (238)}

Number of specimens: 10

Provenience: All but one of these specimens were recovered in the central (Area Red), northeast (Area Green), or eastern (Area White) portions of the site. Three were excavated, although the depths of recovery show great variation, from $0-39 \mathrm{~cm}$ below ground surface. Two of these excavated specimens are associated with Features 5 and 7 . Exact proveniences are provided in Appendix I.B, Part 1.

Metrics: See Appendix I.B, Part 1.

Description (Fig. 25,h): A large, broad-bladed point manufactured from a subtriangular preform. The lateral edges of the blade are straight or slightly convex. The stem modification begins like the Castroville, with nearly vertical notches removed from each end of the base to create large barbs and a long, almost rectangular stem. Distinctive of the Montell is the addition of a deep, narrow notch in the center of the base, which transforms the stem into a pair of small, rectangular appendages.

Date range: Early in the Late Archaic period; Central Texas Uvalde phase; Salado Creek Watershed Local Period 9 (early); 250 B.C.-A.D. 200.

References: Suhm and Jelks (1962:219-220), B1ack and McGraw (1985:109), Turner and Hester (1985:126).

Nolan (241)

Number of specimens: 10 
Provenience: Half of these specimens were recovered in the central (Area Red) portion of the site; the others were scattered about the other four areas. Of the four excavated specimens, three were recovered within the topsoil zone, although the depths ranged from $10-29 \mathrm{~cm}$ below ground surface. The fourth excavated specimen was recovered between $51-65 \mathrm{~cm}$ below the burned rock midden (Feature 2). Specific proveniences are provided in Appendix I.B, Part 1.

Metrics: See Appendix I.B, Part 1.

Description (Fig. 25,i): Manufactured from a subtriangular preform, the blade is long in relation to the stem. Blade lateral edges are distinctly convex. The stem is created by long, shallow retouching, resulting in weak shoulders and a slightly expanding stem. Basal edges are straight or slightly convex. Characteristic of this type is the steep alternate beveling of the stem edges.

Date range: Early part of the Middle Archaic period; Central Texas Clear Fork phase; Salado Creek Watershed Local Period 6; 2600-2100 B.C.

References: Suhm and Jelks (1962:225-226), Black and McGraw (1985:117), Turner and Hester (1985:132).

Pandale (224)

Number of specimens: 1

Provenience: This specimen was recovered in the backdirt of Golf trench in the northeast (Area Green) portion of the site.

Metrics: See Appendix I.B, Part 1.

Description (Fig. 25,j): A small lanceolate form, with slightly convex Tateral edges. The short expanding stem is achieved by shallow side notching, which also produces weak shoulders. The base is concave. Most characteristic is the longitudinally twisted blade, which produces a parallelogram cross section.

Date range: Early in the Middle Archaic period; Central Texas Clear Fork phase; Salado Creek Watershed Local Period 6; 2600-2100 B.C.

References: Suhm and Je1ks (1962:231-232), Black and McGraw (1985:120), Turner and Hester (1985:135-136).

Pedernales (246)

Number of specimens: 13

Provenience: These points are well distributed at the site: two from the northwest (Area Blue), three from the northeast (Area Green), and four each from the central (Area Red) and the southern (Area Yellow) portions of the 
site. Of the four excavated specimens, three are within the first $10 \mathrm{~cm}$ of the topsoil; the fourth, associated with Feature 5, was recovered between 20$30 \mathrm{~cm}$ below ground surface. Specific proveniences are provided in Appendix I.B, Part 1.

Metrics: See Appendix I.B, Part 1.

Description (Fig. 26,a): A large leaf-shaped blade, with slight to strongly convex lateral edges. The rectangular stem is formed by retouching longitudinally from the basal corners, resulting in sharp barbs of varying lengths. Most characteristic is the deeply concave base, which varies from a U-shape to a V-shape. Both small and large blade forms have a similarly sized stem, suggesting that the small forms are reworked from larger ones in the same manner as Bulverde points (cf. Fig. 24,b,c).

Date range: Middle part of the Middle Archaic period; Central Texas Round Rock phase; Salado Creek Watershed Local Period 7 (late); 1500-600 B.C.

References: Suhm and Jelks (1962:235-237), Black and McGraw (1985:113), Turner and Hester (1985:139-140).

Perdiz (247)

Number of specimens: 2

Provenience: One specimen was excavated from the first $10 \mathrm{~cm}$ of topsoil in the central (Area Red) portion of the site, and the other was recovered from the backdirt of a northeast (Area Green) trench.

Metrics: See Appendix I.B, Part 1.

Description (Fig. 26,b): Sma11 triangular arrow points characterized by sharp, prominent barbs and a pointed contracting stem.

Date range: Late in the Late Prehistoric period; Central Texas Toyah phase; Salado Creek Watershed Local Period 11; A.D. 1350-1800.

References: Suhm and Jelks (1962:283-284), Black and McGraw (1985:99, 101), Turner and Hester (1985:187).

\section{Scal1orn (250)}

Number of specimens: 1

Provenience: This specimen was recovered from the backdirt of a trench in the northeast (Area Green) portion of the site.

Metrics: See Appendix I.B, Part 1.

Description (Fig. 26,C): A subtriangular, almost lanceolate form. The blade edges are convex, with fine serrations on both sides. The flaking is good 


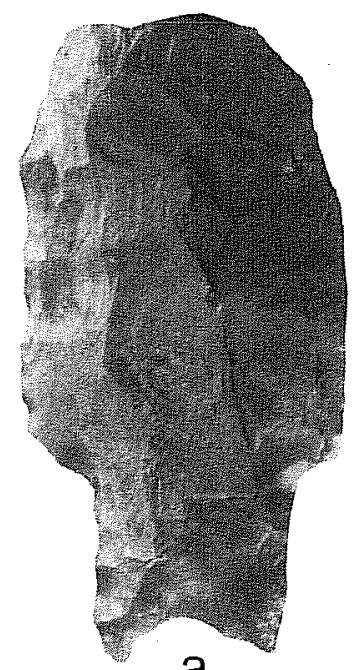

a

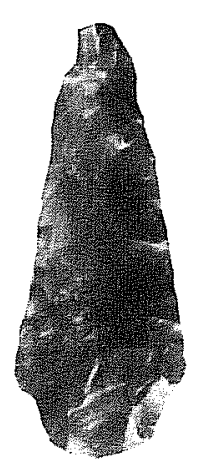

g

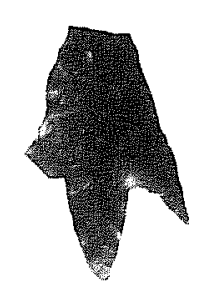

b

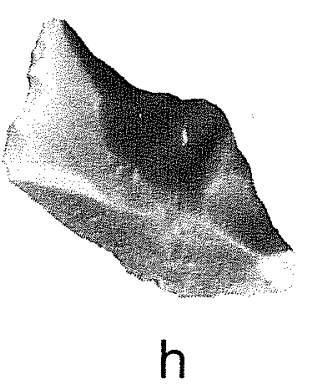

0

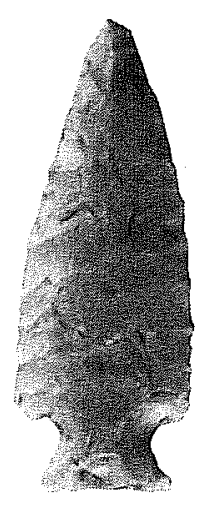

C

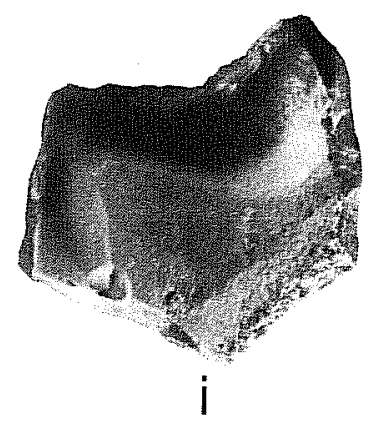

$5 \mathrm{~cm}$.

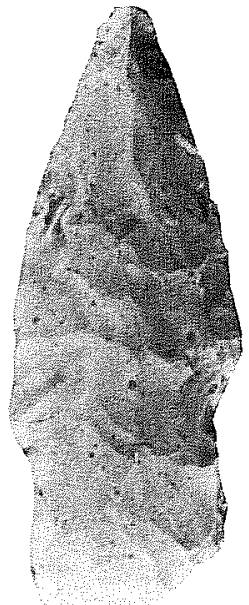

d

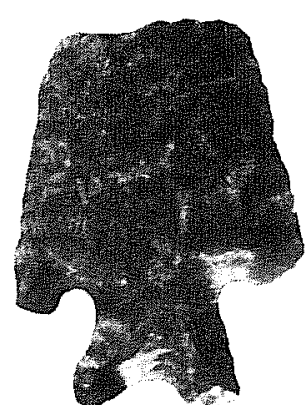

e

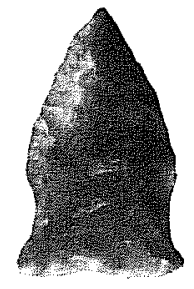

f

Figure 26. Projectile Points, Specialized Tools, and Miscellaneous Artifacts. a, Pedernales; b, Perdiz;

c, Scallorn; d, Travis; e, Uvalde; f, Zavala/Figueroa; g, perforator; h, graver, i, notch; $j$, shel 1 bead; $k$ s ceramic rim sherd.
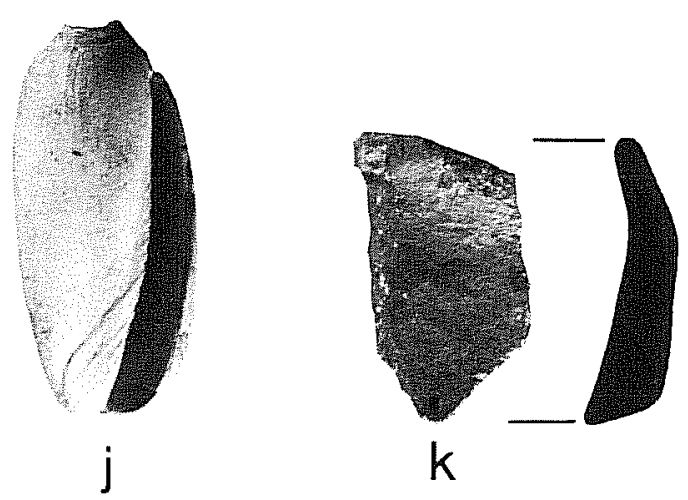
quality, characterized by diagonal ribbon scars. We11-formed corner notches have created a short expanding stem. The basal edge is straight.

Date range: Early in the Late Prehistoric period; Central Texas Austin phase; SaTado Creek Watershed Local Period 10 (1ate); A.D. 750-1350.

References: Suhm and Jelks (1962:285-286), Black and McGraw (1985:101-102), Turner and Hester (1985:189).

Toyah (256)

Number of specimens: 1

Provenience: This specimen was recovered between $0-9 \mathrm{~cm}$ below ground surface in the central (Area Red) portion of the site, associated with Feature 7.

Metrics: See Appendix I.B, Part 1.

Description (not 117 ustrated): All that remains of this specimen is the base of the stem, but it is the most characteristic part of this type of triangular arrow point. The base has a deep concavity which results in the bifurcated stem distinctive of the Toyah type.

Date range: Late in the Late Prehistoric period; Central Texas Toyah phase; Salado Creek Watershed Local Period 11; A.D. 1350-1800.

References: Suhm and Jelks (1962:291-292), Black and McGraw (1985:102), Turner and Hester (1985:193).

Travis (257)

Number of specimens: 10

Provenience: Five of the specimens were recovered in the central (Area Red) portion of the site, all from excavated contexts varying from $5-60 \mathrm{~cm}$ below ground surface. Four of these were associated with features: one each from Features 2 and 7 and two from Feature 5 . Four of the remaining five specimens were recovered in trench backdirt, two in the northeast (Area Green) and two in the southern (Area Yellow) portions of the site; the fifth was a surface find in Area Yellow. Specific provenience for each specimen is provided in Appendix I.B, Part 1.

Metrics: See Appendix I.B, Part 1.

Description (Fig. 26,d): A 1ong, slender subtriangular form, with convex Tateral edges and a convex base. The shoulders are weak, and the straightsided rectangular stem is almost as broad as the blade.

Date range: Early in the Middle Archaic period; Central Texas Clear Fork phase; Salado Creek Watershed Local Period 6; 2600-2100 B.C. 
References: Suhm and Jelks (1962:251-252), Black and McGraw (1985:117), Turner and Hester (1985:153).

Uvalde (259)

Number of specimens: 3

Provenience: These three specimens were recovered in widely scattered areas of the site. Two were in trench backdirt, one in the northeast (Area Green) and one in the northwest (Area Blue); and the third was a surface find at the southern end (Area Yellow) of the site. Appendix I.B, Part 1 provides the exact provenience for each specimen.

Metrics: See Appendix I.B, Part 1.

Description (Fig. 26,e): A subtriangular form with slightly convex lateral edges, the expanding stem is formed by deep corner notching, which results in prominent barbs. A deep concavity in the base produces the characteristic fish-tailed appearance of the stem.

Date range: Late in the Early Archaic period; Central Texas Jarrell phase; Salado Creek Watershed Local Period 5 (early); 4100-3100 B.C.

References: Suhm and Jelks (1962:255-256), Turner and Hester (1985:155).

Zavala/Figueroa (263)

Number of specimens: 3

Provenience: Two of these specimens were recovered in the northeast (Area Green) portion of the site, one from the backdirt of a trench and the other on the surface. The third specimen was from trench backdirt in the southern (Area Yellow) portion of the site. Exact provenience is provided in Appendix I.B, Part 1.

Metrics: See Appendix I.B, Part 1.

Description (Fig. 26,f): A smal1 triangular form with convex lateral edges and a straight base. Long, shallow side notches create an expanding stem and weak shoulders, with the corners of the base as wide as the width across the shoulders. There is great similarity in the overall morphology of the Zavala and Figueroa types. The generally smaller size and later dating of the Zavala usually results in its being classified as an arrow point, whereas the slightly larger and earlier Figueroa is classified as a dart point. The specimens under consideration fall within the size range of the Zavala but are within the geographical distribution of the Figueroa.

Date range: Late part of the Late Archaic or Late Prehistoric periods; Central Texas Driftwood, Austin, or Toyah phases; Salado Creek Watershed Local Periods 10 or 11; A.D. 600-1800. 
References: Turner and Hester (1985:97, 197).

Unidentifiable Arrow Points (264)

Number of specimens: 5

Provenience: Four of these specimens were recovered in the central (Area Red) portion of the site and the fifth from the northeast (Area Green). Four were excavated: two were associated with Feature 7, and the other two were recovered between $0-20 \mathrm{~cm}$ below ground surface. Exact provenience is provided in Appendix I.B, Part 1.

Metrics: See Appendix I.B, Part 1.

Description (not illustrated): Enough remains of these broken specimens to designate them as arrow points on the basis of overall size, morphology, and workmanship. Two blades are intact, but enough of the stems are missing to prevent typological assignment; however, the general impression is that of Perdiz. There are also two midsections and one distal portion.

Date range: Late Prehistoric period; Central Texas Austin and Toyah phases; Salado Creek Watershed Local Periods 10 (7ate) and 11; A.D. 750-1800.

Unidentifiable Dart Points (265)

Number of specimens: 11

Provenience: See Appendix Part I.B, Part 1.

Metrics: See Appendix I.B, Part 1.

Description (not illustrated): These specimens have enough stem modification remaining to identify them as projectile points, but there is not sufficient data to assign them to a specific type. Their size indicates that they functioned as dart points, however. Nine of them belong to the family of broad-bladed points which include Castroville, Marcos, Marshal1, Montel1, Lange, and Williams. The other two are smaller and probably belong to the family of types which include Edgewood, Ellis, Ensor, Fairland, and Frio. Three of the broad-bladed specimens were reworked after breaking to function as scraping tools; two (Cat. Nos. 5934, 6144) have steep unifacial retouch along one blade edge, and the third (Cat. No. 1107) has the same type of retouch at its distal end.

Date range: Late in the Middle Archaic to the middle part of the Late Ächaic periods; Central Texas San Marcos, Uvalde, and Twin Sisters phases; Salado Creek Watershed Local Periods 8 and 9; 600 B.C.-A.D. 600. 


\section{Bifaces}

A biface is a chipped stone artifact characterized by overall primary retouching on both faces. This extensive modification is intended to provide a geometric shape and to thin the cross section of the blank. Secondary retouch along both lateral margins and both ends is also typical, resulting in straight, sharp edges, thinned bases, and usually pointed distal ends.

The characteristic long, thin sharp edges of bifaces account for their usual functional interpretation as cutting tools. A projectile point is a variety of biface which has had its proximal end further modified for hafting, resulting in a reorientation of the primary function to a piercing tool.

The manufacturing process is particularly straightforward with bifaces. A bifacial blank is created from the nodule by percussion flaking to remove the cortex and roughly thin and shape it. Successive operations of shaping, thinning, and sharpening are subsumed within the preform stage. Because biface manufacture is a process, however, the distinctions between stages are never as sharp as the analyst would 1ike, especially between preform and completed tool.

Subcategorization of bifaces is accomplished by reference to their geometric shape, which is generally consistent despite variations in overall size. Circular, ovate and subovate, triangular and subtriangular, and lanceolate shapes have been identified in the 41 BX 300 mitigation collection. The same range of sizes characterizes each shape group: smal7 has a maximum length less than $50 \mathrm{~mm}$; medium has a maximum length between $50-80 \mathrm{~mm}$; and large has a maximum length exceeding $80 \mathrm{~mm}$.

The similarity in size regardless of geometric form suggests that technology is an important factor in the interpretation of the range of biface variability. Later stages of manufacture, i.e., preforms, are probably mixed in with completed tools; it is 7ikely that larger sizes represent preforms of more diminutive but geometrically similar forms. However, because the Targer forms exhibit the same attention to detail in shaping, edge straightening, and sharpening, they are more easily classified with the manufactured tools than with groups representing the stages of manufacture (e.g., nodules and blanks).

\section{Complete, Circular (283)}

Number of specimens: 7

Provenience: These specimens were widely distributed around the site, but recovery was 1 imited to the peripheral areas. No circular bifaces were recorded in the central (Area Red) portion. All but one item was recovered from the surface; the exception was from the backdirt of a trench in the northeast (Area Green). Exact provenience is provided in Appendix I.B, Part 2.

Metrics: See Appendix I.B, Part 2. 
Description (Fig. 27,a,b): The geometry of these specimens is circular. Primary fTake scars originate around the entire margin and terminate at a point approximately in the center of each face. Maximum length and maximum width are very similar. They may represent an extreme variety of ovate biface; they do not appear to be functional tools in and of themselves, and there are no other tool forms which might have used these circular bifaces as a preform.

Complete, Ovate and Subovate (283)

Number of specimens: 17

Provenience: Most of these specimens were recovered in the central (Area Red) and northeast (Area Green) portions of the site. Only one or two were located in each of the other areas. Of the two excavated specimens, one came from the subsoil zone and the other from the topsoil; the latter was associated with Feature 3 . Trench backdirt was a more common provenience than surface recovery, however, indicating some depth of deposit. The provenience of individual specimens is provided in Appendix I.B, Part 2.

Metrics: See Appendix I.B, Part 2.

Description (Fig. 27,C-e): The basic ovate form has a distinct convexity to both lateral edges, the distal end, and the proximal end. The proximal end is wider than the distal, with the maximum width in the proximal third of the specimen. The maximum length runs longitudinally from distal to proximal end. The subovate form is more pear-shaped, with a narrowing or even pointing of the distal end. Ovate and subovate forms most likely served as preforms for the broad-bladed Middle Archaic and Late Archaic projectile points.

Complete, Triangular and Subtriangular (283)

Number of specimens: 23

Provenience: As with the ovate and subovate forms, these specimens were recovered from all areas of the site but were also concentrated in the central (Area Red) and northeastern (Area Green) portions. Of the few that were excavated, most were recovered from the topsoil zone. One was associated with Feature 11 . Individual proveniences are provided in Appendix I.B, Part 2.

Metrics: See Appendix I.B, Part 2.

Description (Fig. 28): The basic form has straight sides, a straight base, a pointed distal end, and distinct corners between the lateral edges and the proximal end. The maximum width is along the proximal edge. The more common subtriangular form may have slightly convex lateral edges and a rounded base; however, the corners are usually always distinct. Smaller triangular forms probably functioned as preforms for the smaller triangular Archaic projectile points, characterizing both the Early and Terminal Archaic periods. 

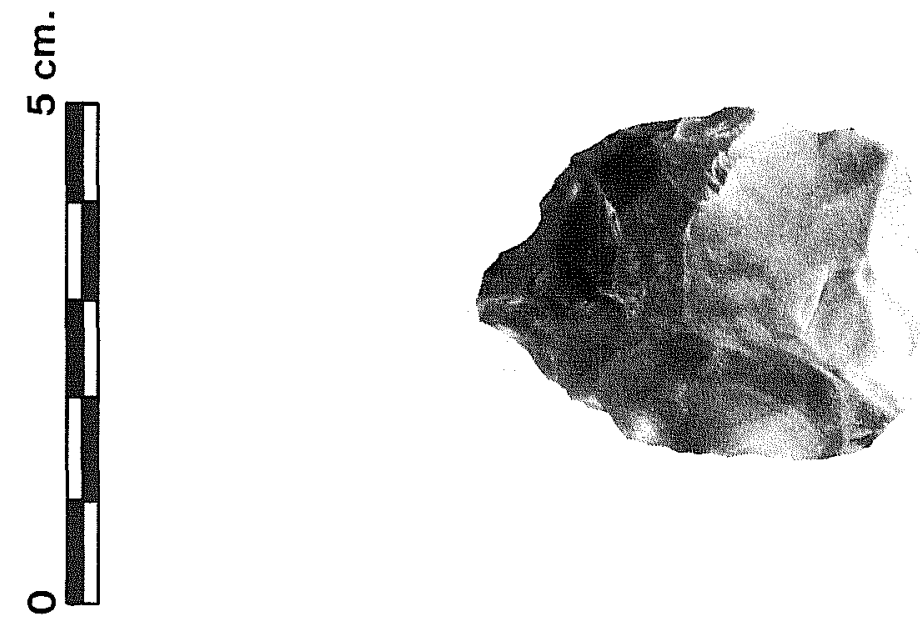

(1)
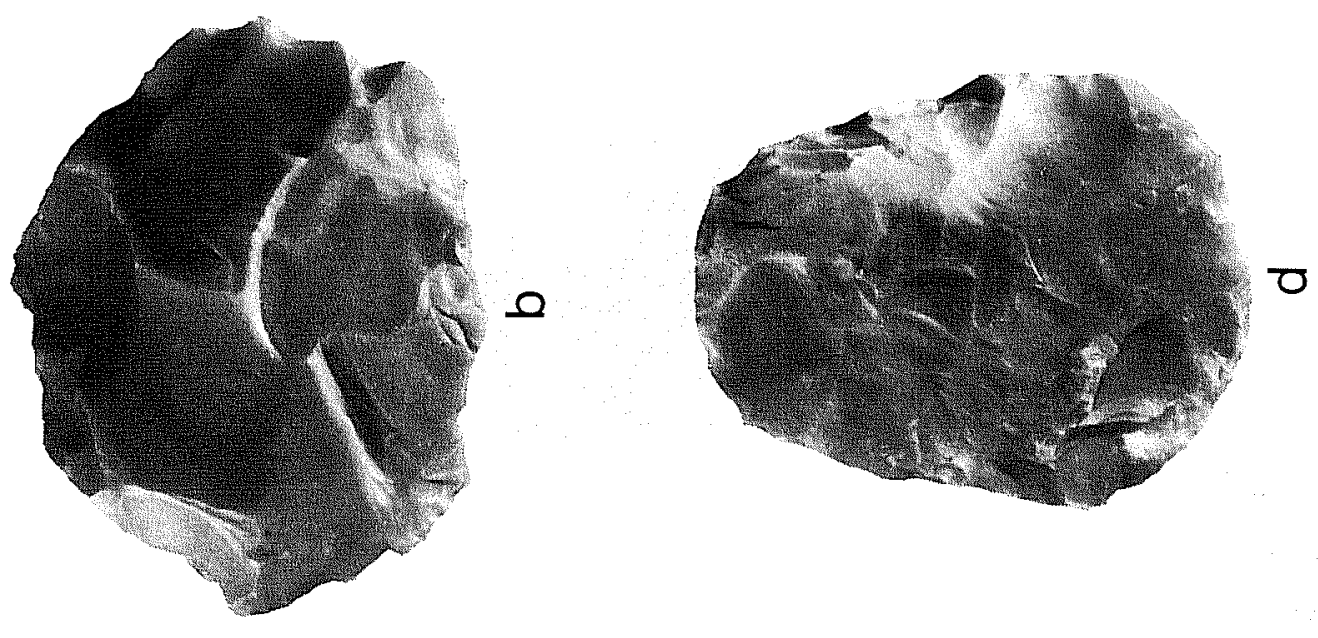

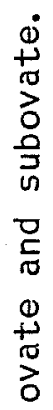

í

$\frac{\pi}{\frac{\pi}{3}}$

过
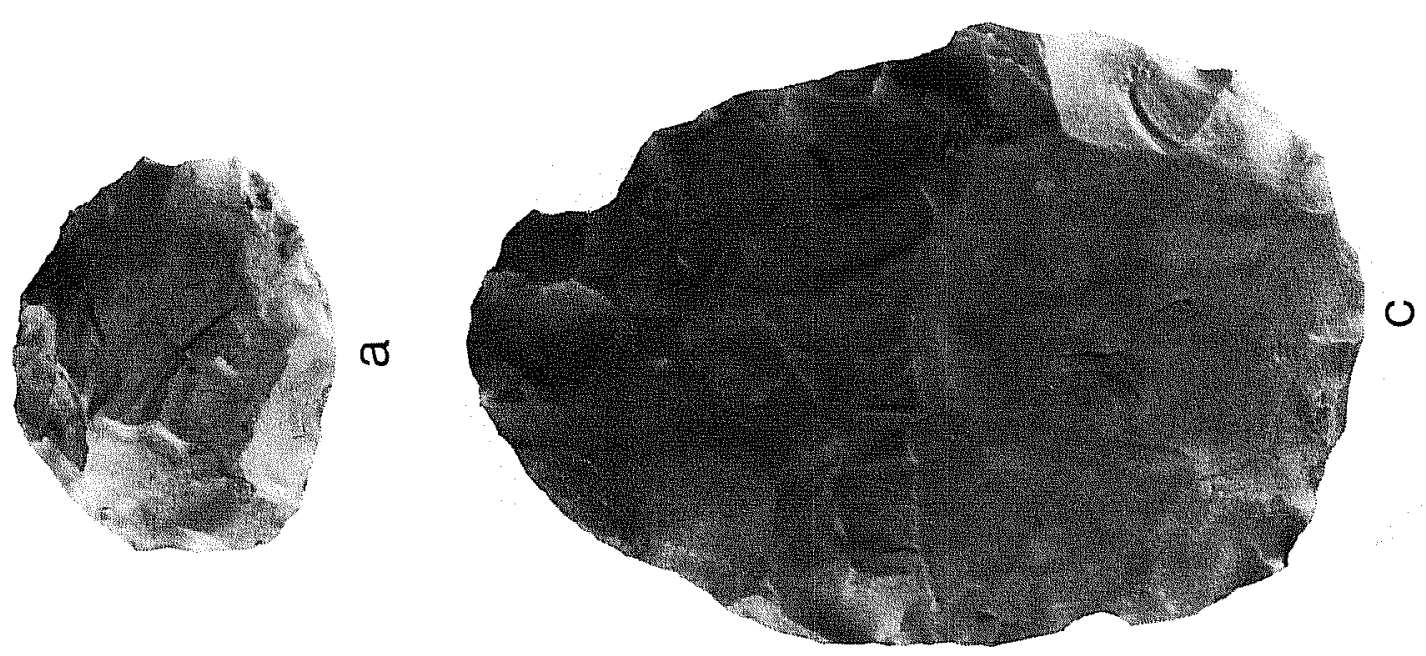

iv
$\frac{0}{3}$
$\frac{1}{4}$ 
Site 41 BX 300/Artifacts

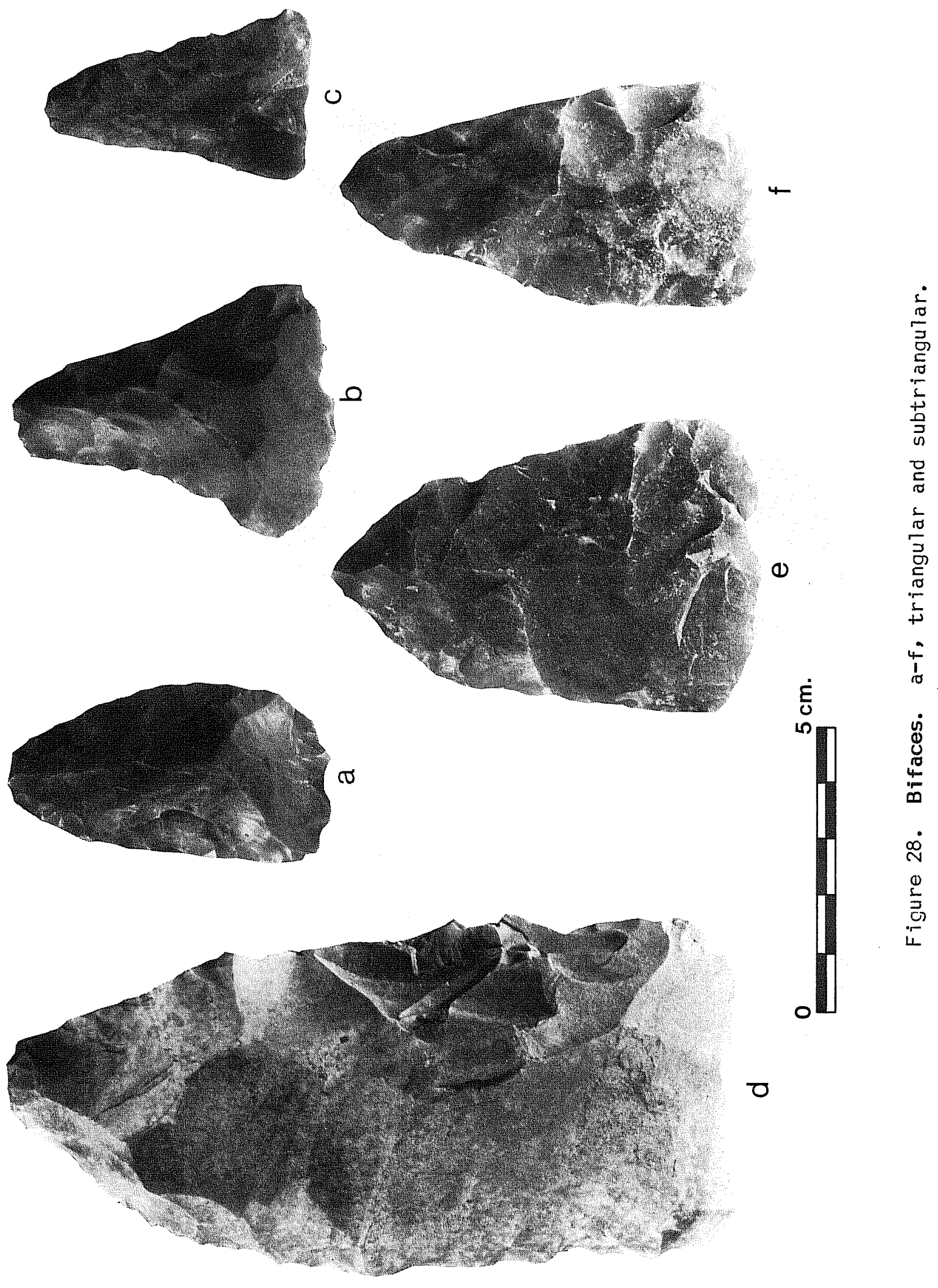


Complete, Lanceolate (283)

Number of specimens: 12

Provenience: These specimens follow the same distribution pattern as the circular bifaces. None were recovered from the central (Area Red) portion of the site, but were evenly distributed across the rest of the site. None were excavated; they were eventy divided between trench backdirt and surface recovery. Appendix I.B, Part 2 provides the exact provenience for each specimen.

Metrics: See Appendix I.B, Part 2.

Description (Fig. 29): The lanceolate form has two major varieties. One is parallel sided with rounded distal and proximal ends (Fig. 29,a,C); and the other is bipointed, with convex lateral edges (Fig. 29,b,d). The common characteristics are a maximum length at least twice as large as the maximum width, with the latter situated at the midpoint of the longitudinal axis. The usual functional interpretation is that of a cutting tool, and indeed some specimens 10ok very much 1ike contemporary knives (Fig. 29,e). One unique artifact from this investigation has steep unifacial retouch on the dorsal face of the distal end and probably functioned as a scraping tool. This is distinct from the bifacial Guadalupe tools, which have a beveled distal end.

Bifacial Fragments (284-288)

Number of specimens: 616

Provenience: These specimens reflect the distribution of the complete bifaces previously discussed. The majority were recovered from the central (Area Red) and northeast (Area Green) portions of the site. The fact that most of the specimens from Area Red were excavated and those from Area Green were recovered from trench backdirt is a function of the nature of investigations in these two areas. The other portions of the site are represented in the collection, but the quantities are significantly smaller. This is, in part, due to the relative amount of archaeological activity; but it is also interpreted as a measure of the relative amount of prehistoric activity as we11. Where general forms are identifiable, the fragments also reflect the distribution of the complete specimens: circular and lanceolate tended to occur in the more peripheral areas, while ovate/subovate and triangular/subtriangular forms were most commonly recovered in the central (Area Red) and northeast (Area Green) portions. Appendix I.B, Part 2 provides the exact provenience of each specimen.

Metrics: See Appendix I.B, Part 2.

Description: Fragments of bifacially retouched artifacts are grouped according to the portion of the complete artifact they represent. These include the following: 
Site 41 BX 300/Artifacts

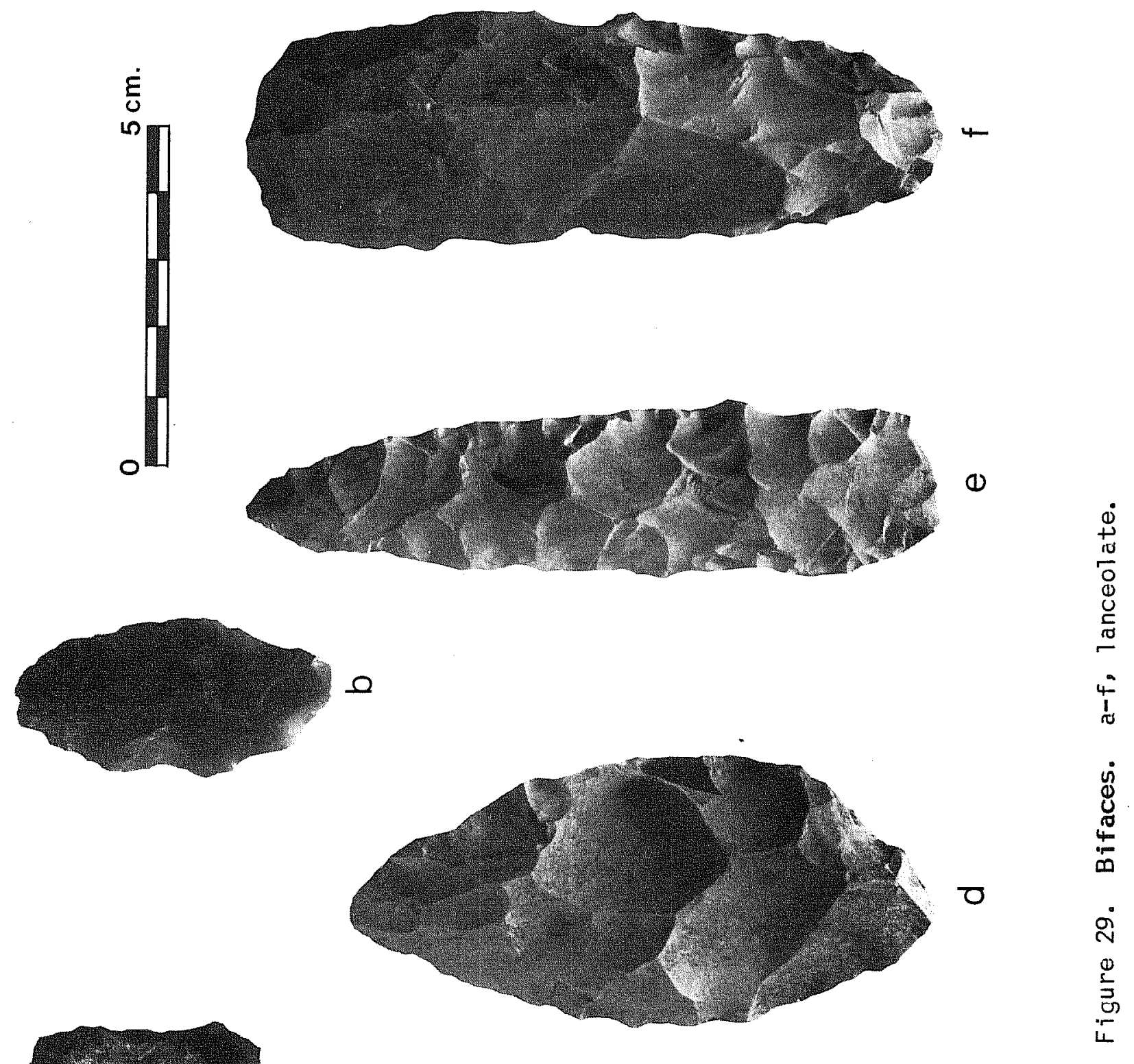


Portion

Distal (284)

Medial (285)

Proximal (286)

Lateral (287)

Unidentifiable (288)
Quantity

182

68

152

24

190

In addition to making the collection more manageable during analysis, this method of subdivision has the advantage of facilitating the identification of the complete form in many instances. Comparison of especially the proximal portions provides data which indicates that each general form occurs in approximately the same proportion among the fragments as they do among the sample of complete specimens. Ovate/subovate and triangular/subtriangular forms account for approximately two-thirds of the total; the remaining third is divided among lanceolate and circular, with the former twice as prevalent as the latter.

Unifaces (300-313)

Number of specimens: 35

Provenience: Eighty percent of these specimens were recovered from the central (Area Red) portion of the site. The remaining seven artifacts were evenly distributed among the other areas. Excavated specimens were associated with both the topsoil and subsoil zones and with a range of features dating to the Archaic and Late Prehistoric periods. Exact provenience data is provided in Appendix I.B, Part 3.

Metrics: See Appendix I.B, Part 3.

Description (Fig. 30): Unifacial tools are a small but distinctive group of artifacts characterized by overal1 primary retouch on one face on $1 y$, over which is applied steep secondary marginal retouch. The function of unifacial tools is usually presumed to be scraping and planing. As the morphology is almost always characterized by one flat face, a flake blank, as opposed to a core blank, is usually employed. Modification to the ventral surface of this flake is usually limited to bulb removal to further flatten this surface.

A system of subdividing unifaces was established prior to the initiation of field work. While it may seem overly detailed in light of the small collection, it was employed in anticipation of recovering larger numbers of this type of artifact. The system is based on the placement of the steep secondary retouch. The collection can be subdivided as follows:

\section{Placement}

Single end (312)

Unilateral and single end (302)

Bilateral (301)

Bilateral and single end (303)

Semicircular (313)

$\begin{array}{rll}\text { Quantity } & & \text { Figure } \\ & & 30, \mathrm{a} \\ 2 & & 30, \mathrm{~b} \\ 5 & & 30, \mathrm{e} \\ 12 & 30, \mathrm{c} \\ 2 & & \end{array}$


$\ddot{\omega}$

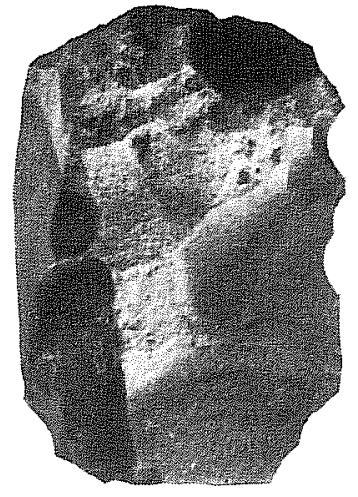

a

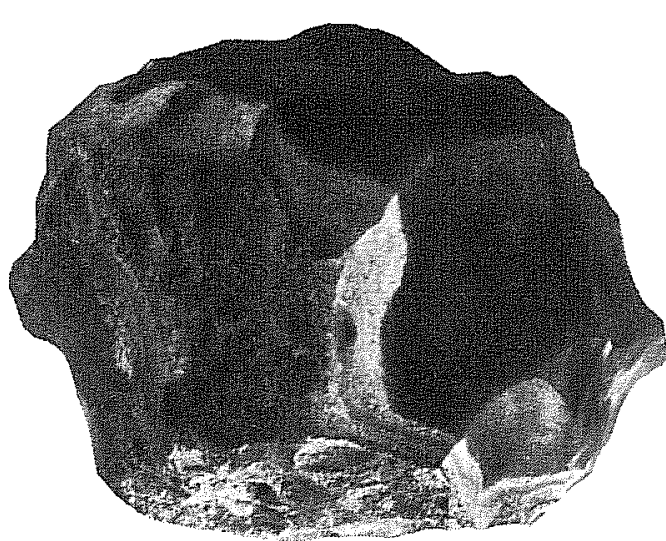

b

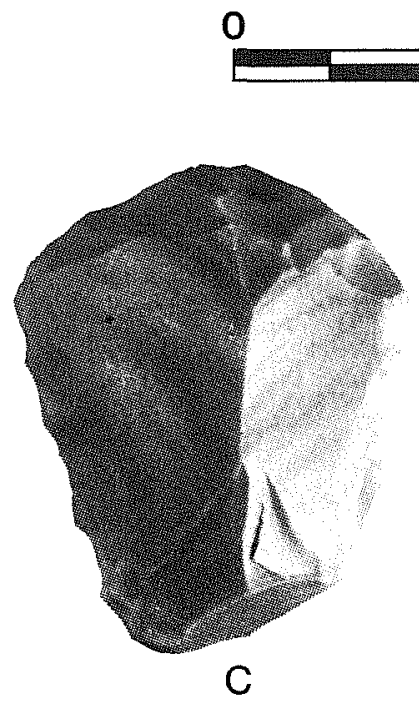

$5 \mathrm{~cm}$.

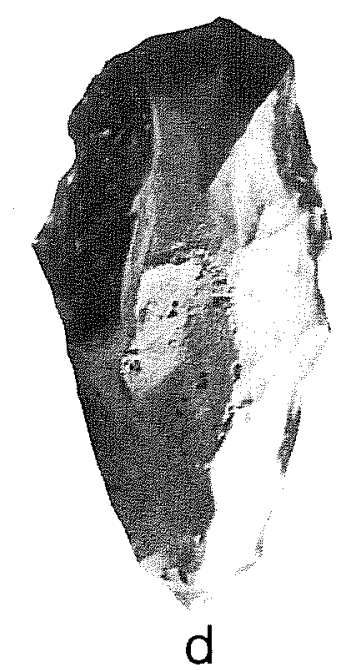

Figure 30. Unifaces. a, single end retouch; b, unilateral and single end retouch; c, bilateral and single end retouch; d, circumferential retouch; e, bilateral retouch. 
$\begin{array}{lll}\text { Circumferential (306) } & 2 & 30, \mathrm{~d} \\ \text { Irregular (308) } & 3 & \\ \text { Unidentifiable fragments (311) } & 4 & \end{array}$

Despite the small size of the collection, it is obvious that the bilateral and single end variety is the most popular, representing fully one-third of the sample. Unifaces with retouch on one or both lateral edges of the flake, moreover, account for almost two-thirds of the entire collection.

Typed Tools

Clear Fork (346)

Number of specimens: 1

Provenience: This specimen was excavated from the mixed gravel zone beneath the burned rock midden in the central (Area Red) portion of the site.

Metrics: See Appendix I.B, Part 4.

Description (Fig. 31,a): The specimen exhibits all the characteristics of the "classic" unifacial Clear Fork tool. The outline is triangular, with overall primary retouching on the dorsal face. Secondary retouch has been applied to the distal end at an approximately 450 angle, creating a chisellike working edge; the edge shape is convex. The ventral face is flat, representing the unmodified ventral surface of the flake blank.

Date range: Late in the Early Archaic to early in the Middle Archaic periods; Central Texas Jarre11, Oaka17a, and Clear Fork phases; Salado Creek Watershed Local Periods 5 and 6; 4100-2100 B.C.

References: B Back and McGraw (1985:138-142), Turner and Hester (1985:205208).

Guadalupe (349-350)

Number of specimens: 8

Provenience: Half the specimens were recovered in the southern (Area Yellow) portion of the site, and three of the remaining four came from the central (Area Red) area. Four were excavated, two from mixed gravels and the other two from the topsoil. Appendix I.B, Part 4 provides exact provenience data.

Metrics: See Appendix I.B, Part 4.

Description (Fig. 31,b-d): Six of these specimens are completed tools (349), and two are considered preforms for this type (350). The morphology is so distinctive that the latter can be identified with some confidence. The primary characteristics are bifacial primary retouching of a long, thick blank and a truncated distal end. Despite the small size of the sample, however, there is considerable variation in attributes. Figure $31, b$ 
Site 41 BX 300/Artifacts

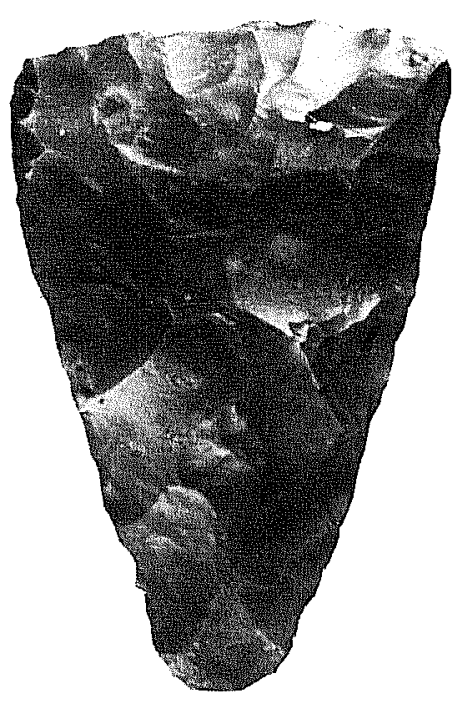

a

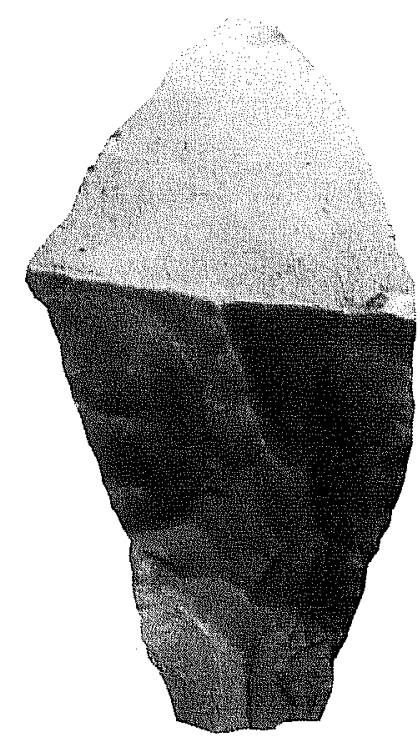

b

0 $5 \mathrm{~cm}$.

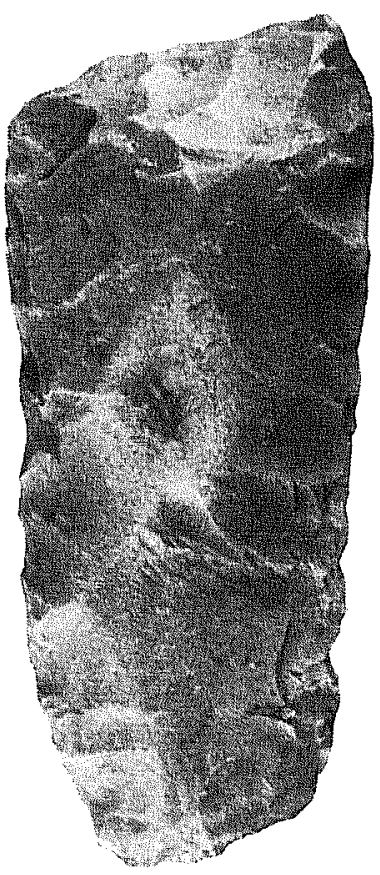

$\mathrm{C}$

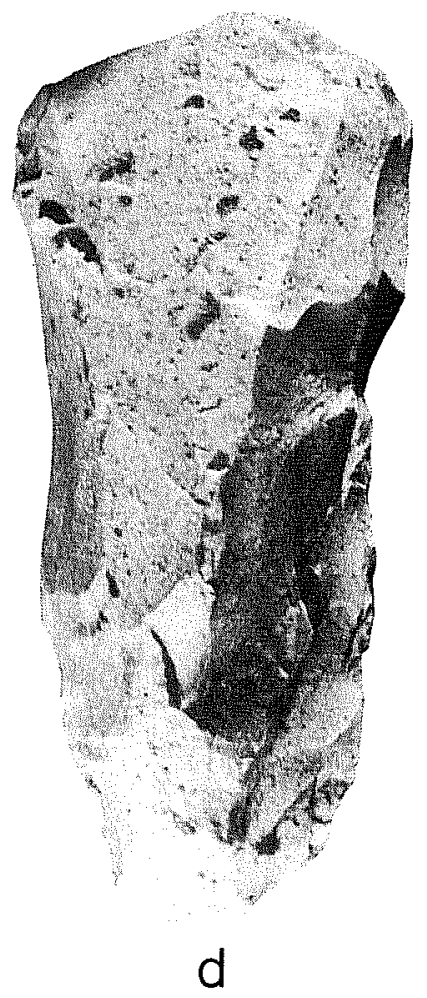

Figure 31. Typed Tools. a, Clear Fork; b-d, Guadalupe. 
illustrates the expanding bit form. The truncated distal end angles toward the ventral face and was created by a single flake removal; the cross section is triangular. Figure $31, \mathrm{c}$ is a narrow bit form, with multiple flakes removed to make the bit. This specimen is somewhat unusual in that the truncation angles toward the dorsal face rather than the ventral; the cross section is plano-convex. The third specimen illustrated (Fig. 31, d) has the ventrally oriented bit created by multiple flake scars and a triangular cross section.

Date range: Late in the Early Archaic period; Central Texas Jarrel1 and Oaka17a phases; Salado Creek Watershed Local Period 5; 4100-2600 B.C.

References: Black and McGraw (1985:142-156), Turner and Hester (1985:216$\overline{2} \overline{1} \overline{8})$.

\section{Specialized Tools}

Perforators (357)

Number of specimens: 14

Provenience: Nine of these specimens were recovered from the central (Area Red) portion of the site; of the remaining five, three came from the southern (Area Yellow) and one each from the northwest (Area Blue) and the northeast (Area Green). Ten were excavated, eight from the topsoil and two from the subsoil zone; three of these from feature associations. Specific proveniences are provided in Appendix I.B, Part 5.

Metrics: See Appendix I.B, Part 5.

Description (Fig. 26,g): The distinctive element of these tools is a conical or cylindrical projection retouched out of a side or end portion of either a flake or biface. The presumed function is one of drilling or perforating, using the projection with a rotary motion. Eight of the specimens are bifaces, at least one is a reworked projectile point. The other six are irregular flakes, probably selected for having a fortuitous projection which facilitated modification.

Date range: Hester (1980:110) states the concensus that the bifacial drills are more characteristic of the Archaic period, and the flake perforators are more often associated with the Late Prehistoric period. Although the sample is small, the two specimens recovered below the topsoil (i.e., presumably Archaic in age) are both bifacial forms.

\section{Gravers (358)}

Number of specimens: 20

Provenience: The largest number of specimens (seven) were recovered in the southern (Area Yellow) portion of the site. The remaining specimens are equally divided among the other four areas. Only three were excavated, all 
Site 41 BX 300/Artifacts

from the topsoil zone. Appendix I.B, Part 5 provides the exact provenience data.

Metrics: See Appendix I.B, Part 5.

Description: The distinctive characteristic of these artifacts is a small, sharp, beaked projection. The presumed function is graving or incision of softer materials such as bone and wood. The blank from which the projection is chipped is a flake in all but one instance; this latter is an irregular biface. The flake blanks are quite variable in size, shape, and material, evidently selected because of an incipient projection on some edge which facilitated the production of the graver tip.

Notches (359)

Number of specimens: 60

Provenience: These specimens are eventy distributed across the site, with approximately similar quantities recovered in each of the five areas. A11 eight of the excavated specimens were associated with the topsoil zone. of the remaining 52 specimens, 12 were recovered from trench backdirt and 40 (67\%) from the surface. Proveniences are is provided in Appendix I.B, Part 5 .

Metrics: See Appendix I.B, Part 5.

Description: The distinctive characteristic of this group of artifacts is a concavity chipped into the edge of a flake by means of steep unifacial retouching. The geometry of the notch tends to be semicircular. The flake blanks are extremely variable in size, shape, presence or absence of cortex, and material quality; the selection of a flake seems to have been quite expedient. The presumed function is one of scraping or shaving to shape and smooth a shaft or other curved surface of a softer material such as wood or bone.

Retouched Flakes (374-375)

Number of specimens: 344

Provenience: The distribution of retouched flakes reflects the nature of prehistoric human activity at the site as determined by other artifact categories and the presence or absence of features. The greatest number of specimens were recovered in the central (Area Red) and northeast (Area Green) portions of the site. Smaller quantities came from the eastern (Area White) and southern (Area Yellow) portions; and relatively few specimens were recovered in the northwest (Area Blue). Excavated specimens were recovered from a17 soil zones and in association with each of the 10 recorded features. Appendix I.B, Part 6 provides the specific provenience for each specimen.

Metrics: See Appendix I.B, Part 6. 
Description: Retouched flakes are expedient tools. The range of sizes, shapes, material varieties, and stages of manufacture present in this collection suggest that the source of blanks was equally varied. Core decortication flakes were a primary source, as evidenced by the fact that the number of retouched flakes with cortex $(175 ; 51 \%)$ slightly exceeds the number of retouched flakes without cortex $(169 ; 49 \%)$. Flakes produced by the biface thinning process provide another source of flake blank, represented in this case primarily by those without cortex. It is doubtful whether blanks were intentionally produced so that they could be marginally retouched into unshaped tools.

Retouch was applied to any or all margins of the flake blank, but most commonly only along one lateral edge. Bifacial retouching occurs, but steep unifacial flaking is most frequent. As this is typically interpreted to represent a scraping function, the small number of unifaces may have been functionally augmented by the large number of steeply retouched flakes.

\section{MANUFACTURED TOOL BY-PRODUCTS}

Table 24 summarizes those chipped stone specimens which are not considered manufactured tools or tool fragments. It is not simply a matter of whether or not retouching has been applied, as every specimen in this particular assemblage bears some retouching scars. The distinction is rather one based on technological considerations, that is, whether a chipped stone specimen represents a completed functional form or not. If not, then it can be considered as either an intermediate stage in the manufacture of a completed tool or a waste product of the manufacturing process. Both aspects of chipped stone nontools are grouped together in this assemblage of manufacturing and maintenance debris.

The analysis of this group takes into account that the failure to achieve the status of completed tool does not preclude its use as a functional implement. Many of the unretouched flakes exhibit edge modifications which can be interpreted as use-wear, for instance. The behavioral differences between functional expediency and intentional manufacture are what distinguish a utilized flake from a chipped stone tool, even if it could be documented that both were employed for the same task.

Table 24 is organized in approximately the order in which the chipped stone manufacturing process is reconstructed; the first categories were accomplished earliest in the process, proceeding finally to waste products and manufacturing debris. Concerning provenience data, the quantities of these groups of artifacts are such that individual consideration in this report of the sort provided for tools, even as an appendix, is not practical. Provenience and other data for these components of the mitigation collection are available to interested researchers in a series of computer printouts maintained with the project records at the Center for Archaeological Research and on magnetic tape by the Computer Resources Center, both located on the main campus of The University of Texas at San Antonio. The printouts and computer files are cross-indexed by (1) catalog number; (2) provenience (unit/level/depth); (3) feature/non-feature association; and (4) classification type, to facilitate use of the collection. 


\section{Tested Nodules (377)}

Twenty specimens $(0.02 \%$ of the chipped stone nontool assemblage) are characterized by a few flakes removed in an unpatterned manner from a nodule of local chert. The specimens are interpreted as efforts to ascertain the quality and workability of the raw material without any significant expenditure of chipping time or effort. The very small number of specimens in this category is assumed to be due to the fact that this initial assessment step would normally take place at the raw material source. Tested nodules would thus be expected to occur in much greater frequency at 7 ithic resource procurement sites such as 41 BX 299 and 41 BX 301 (see Fig. 1) than at a subsistence activity site such as 41 BX 300 . Seventy percent of the specimens (14 specimens) were recovered from Area White (see Fig. 8), that portion of the site closest to the nearby site of 41 BX 299 and thus representing the shortest "carry" for the nodules prior to testing them.

\section{Production Blanks $(281,289)$}

Production blank specimens represent $0.16 \%$ of the chipped stone nontool assemblage. "Production blank" is a generic term for that stage in the manufacturing process of chipped stone bifacial tools between the nodule and the preform. Production blanks have been subjected to overall primary bifacial retouch; complete decortication is common but not necessary for inclusion in the category. Outlines are vaguely geometrical; cross sections are thick and roughly lenticular; margins are characterized by alternating retouch; and mass tends to be large. Mean weight for this assemblage of 167 specimens is $112.9 \mathrm{~g}$; mean dimensions are $64.7 \mathrm{~mm}$ in length, $54.7 \mathrm{~mm}$ in width, and $22.5 \mathrm{~mm}$ thick.

A production blank, being an intermediate stage of manufacture, does not usually exhibit evidence of functional utilization; if it did, it would most likely be interpreted as a chopping tool. Provenience data shows a very high proportion (35.53\%) of quarry blanks recovered from Area Green (see Fig. 8), a portion of the site which has been associated with the later periods of occupation on the basis of diagnostic projectile points (see Appendix I.B, Part 1). A substantial number of completed bifaces and biface fragments were also recovered from Area Green, the tool for which the production blank was directed.

\section{Unretouched Flakes (370-373)}

The largest category by far in the 41 BX 300 Phase III mitigation collection consists of chipped stone flakes with no evidence of intentional retouch once removed from their respective blanks. Unretouched flakes represent $95.74 \%$ of the nontool chipped stone assemblage, $94.50 \%$ of the total chipped stone assemblage, and $94.43 \%$ of the entire site collection. Unretouched flakes are produced as by-products during every stage of chipped stone tool manufacture: nodule testing, blank production, biface thinning, secondary shaping retouch, sharpening, and edge rejuvenation. Unretouched flakes with a remnant cortex, which includes primary and secondary decortication flakes and platform cortex, account for $14.82 \%$ of the category; interior flakes with no cortex 
remaining represent $85.18 \%$. The proximity of 1 ithic resource sites 41 BX 299 and 41 BX 301 (Fig. 1) and the predominance of cortex-bearing flakes in their respective collections (see Table 4) undoubtedly account for the proportions at $41 \mathrm{BX} 300$. The close spatial relationship between the sites makes it reasonable to assume that the early stages of manufacture were generally accomplished at the source localities, with tools completed and maintained at 41 BX 300 .

\section{Cores $(330-338)$}

Cores are generally considered to represent the end product of the chipped stone manufacturing sequence, the exhausted remnant of a nodule after a 11 usable flakes have been removed. Cores also carry with them several important implications about a group's chipped stone technology. The preparation of a striking platform and the attempt at regularity of flake removal in both direction and pattern argue for a planned, controlled approach to technology and consequently behavior. In addition, the core is associated with a flake industry, generating flake blanks for subsequent tool manufacture. Unfortunately, the 76 specimens $10.08 \%$ of the nontool assemblage) were recovered from most areas at the site in relative quantity, as well as from varying depths below ground surface. The small number of items, especially when compared to the next category, seems to suggest most strongly that the cores were not a technological end-product but rather were only the penultimate stage in the nontool production sequence. An analogy would be the bifacial preform, which still had one more stage to pass through before completion.

\section{Chunks (376)}

Chunks represent the largest category of nontool chipped stone apart from unretouched flakes (4.00\%) and is considerably larger than the other categories. A chunk is what its name implies: a lump of chert, generally small (1ess than five centimeters in diameter), with flake scars over its entire surface. The scars are randomly distributed, exhibiting none of the patterned removal of a core; nor is there a prepared striking platform. The chunk is definitely an exhausted form, there being insufficient material to produce any more usable flakes and no purchase from which to detach them. The large number of chunks suggests that chipped stone raw material was at a premium, in that nodules and flake blanks were used down to a nubbin. The fact that two large resource areas (41 BX 299 and 41 BX 301) were situated adjacent to $41 \mathrm{BX} 300$ (Fig. 1) makes the quantity of chunks recovered difficult to interpret. The provenience distribution reflects the relative proportions of excavation, both horizontally by area and vertically by stratum, and thus no cultural or chronological pattern can be ascertained. What is apparent is that a great deal of chipped stone production took place at the site, and it was primarily of an expedient nature. 
ROUGH STONE (380-388)

Only 14 specimens of nonchipped stone tools were recovered, representing $0.01 \%$ of the total collection from 41 BX 300 (see Appendix I.B, Part 7). One hammerstone was collected on the surface, a fist-sized quartzite specimen bearing evidence of battering on the ends and margins. A single hammerstone in association with chipped stone tool production yielding over 100,000 items might seem ridiculous if it was not so typical in this region. The soft limestone interspersed with chert outcrops are the only 7 ithic materials; harder rocks suitable for percussion chipping are not locally available. Either aboriginal inhabitants used chert against chert, or they obtained an exotic material and treasured it, but traditional hammerstones do not occur in any appreciable quantity at sites along the margins of the Edwards Plateau.

Handstones, grinding slabs, and fragments are al1 pieces of fine-grained Timestone which bear evidence of smoothing on one or both faces. The common interpretation is that these tools were used to process vegetal material, the moveable handstone crushing and pulverizing nuts and seeds against a stationary grinding slab.

Because these specimens utilized local materials, the small quantity recovered cannot be attributed to unavailability as was the case with hammerstones. Rather, the simplest interpretation is that vegetal processing, by grinding at least, was not a common activity at the site. One interesting situation might account for the destruction of an unknown number of these tools, however. An example of a grinding slab was recovered inside Feature 6 , where it seemed to have functioned as a hearthstone (Fig. 36, bottom center; Fig. 37,b far right). If it was customary, at this time period at least, to dispose of exhausted grinding implements in a hearth where the limestone rock would crack and break up along with other hearthstones, there would be an unknown number of these tools that would never be recovered.

SHELL (403)

Only three specimens of shell were recovered, all examples of the marine 01 ivella shell fashioned into beads for stringing along their longitudinal axis (Fig. 26,j). Two of the five specimens were associated with Feature 7 , an area of concentrated artifactual material on and immediately below the surface in Area Red (Figs. 11, 12). The stratigraphic position of these artifacts is consistent with their chronological association in the Late Prehistoric period (see Appendix I.B, Part 8).

\section{BONE}

No bone or antler tools were recovered during Phase III mitigation activities. The complete absence of antler flakers is at first surprising, in view of the extensive chipped stone assemblage generated by manufacturing and maintenance activities at the site. On the other hand, the poor preservation of faunal remains in general would affect bone tools in an equal 
manner; and the prevalence of the percussion mode of chipping stone would limit the initial number of flakers to begin with.

\section{PREHISTORIC POTTERY (476)}

Twenty-five sherds were recovered; 22 specimens were from Feature 7 in Area Red (see Appendix I.B, Part 9), reinforcing the chronological association of this feature with the Late Prehistoric period.

Attribute analysis of the sherds demonstrated that they were morphologically and technologically similar enough to be subsumed within the same type of pottery. Only one sherd was a rim fragment (Fig. 26,k), having a rounded 7 i.p $2.0 \mathrm{~mm}$ thick, slightly incurving orientation but with a straight form, and an estimated vessel diameter at the aperture of ca. $15 \mathrm{~cm}$. The remaining specimens were body sherds, ranging in thickness from a maximum of $9.8 \mathrm{~mm}$ to a minimum of $1.9 \mathrm{~mm}$; mean thickness is $5.9 \mathrm{~mm}$. Tempering material is visible in most specimens, measuring from 0.25-1.0 $\mathrm{mm}$ in diameter; the temper has been identified as bone fragments. Exterior color is a moderate yellowish brown (10 YR 5/4), with interiors slightly darker (5 YR 5/4). There is no decoration. All characteristics justify inclusion of this assemblage in the Leon Plain pottery type.

\section{HISTORIC ARTIFACTS}

Only 38 specimens of Euro-American manufacture were recovered (see Appendix I.B, Part 10). Four items were sherds of undecorated whiteware, glazed on both sides. They are possibly fragments of the same vessel, as all were collected on the surface in Area Green. Five pieces of rusted metal from unidentifiable objects and 29 sherds of miscellaneous bottle glass complete the inventory. No component of historic activity is identified at the site.

\section{SUMMARY ANALYSIS}

Table 24 summarizes the counts and percentages of a 11 major artifact categories in the 41 BX 300 Phase III mitigation collection. Nonchipped stone specimens account for less than one-tenth of one percent $(0.08 \%)$, indicating that prehistoric activities utilizing chipped stone tools predominated at the site.

The relationship of chipped stone tools (1.29\%) to manufacturing and maintenance debris $(98.71 \%)$ is somewhat misleading, in that some of the almost 100,000 unretouched flakes undoubtedly functioned as expedient tools. Nevertheless, the enormous quantity of nontool material argues strongly for chipped stone workshop activity as one of the primary raisons d'etre for 41 BX 300.

Flintknapping cannot have been the sole activity performed at 41 BX 300 , however, since the nearby sites of 41 BX 299 and 41 BX 301 would have been satisfactory for this, and perhaps they were the source of raw material. The 
balance of the tool assemblage provides directions for additional activity identification: a predominance of piercing, cutting, and scraping tools oriented toward faunal procurement and processing, and the conspicuous absence of woodworking and vegetal processing tools in any but the smallest quantities. The tool component of the artifact collection thus supports the preliminary interpretations made on the basis of feature and ecofactual analyses.

\section{DESCRIPTION AND ANALYSIS OF FEATURES}

The classic definition of features as "things that are not brought back to the 1aboratory or museum" (Hester, Heizer, and Graham 1975:131) prevailed during mitigation activities at 41 BX 300. Ten features were identified during the course of the field work, numbered consecutively as they were recorded from "2" through "11." The number "1" was not employed to designate a feature, as it was necessary to have some code for material not associated with a feature. Some of the field and laboratory forms had an entry for "feature number," and as the leaving of blanks was actively discouraged, "1" was entered to indicate a nonfeature provenience.

Within the total of 10 features was a surprising morphological variety, and it was helpful to establish a classificatory scheme despite the relatively small number of members. Two major categories were employed, one characterized by the concentrated presence of aboriginally burned rock, and one by its virtual absence. Three types of burned rock features were identified: one midden, five hearths, and one scatter. The three features without a significant amount of burned rock were all designated occupation floors.

Table 25 provides basic data in a comparative format for al1 10 features, each of which is individually described later. Artifacts and ecofacts identified as associated with, and special samples collected from, each feature, are summarized in Table 27; more specific descriptions and analyses are provided in subsequent sections.

\section{BURNED ROCK MIDDEN}

\section{FEATURE 2}

Feature 2, the sole burned rock midden classified at 41 BX 300, was also the only feature identified prior to the initiation of Phase III mitigation activities.

Phase I activity in the fall of 1975 determined that the site needed further investigation based on the recording of an extensive scatter of chipped stone debris and the recovery of projectile points attributable to both the middle and later periods of the Central Texas Archaic. It was during the Phase II investigations early in 1976, however, that the presence of a burned rock midden was first ascertained (Kelly 1976; Hester, Katz, and Kelly 1977). 
TABLE 25. FEATURE DATA

\begin{tabular}{|c|c|c|c|c|c|c|c|c|c|c|c|c|}
\hline \multirow[b]{2}{*}{ Type of Feature } & \multirow[b]{2}{*}{$\begin{array}{l}\text { Feature } \\
\text { Number }\end{array}$} & \multirow[b]{2}{*}{$\begin{array}{l}\text { Site } \\
\text { Area }\end{array}$} & \multirow[b]{2}{*}{$\begin{array}{l}\text { Dimension } \\
E-W(m)\end{array}$} & \multirow[b]{2}{*}{$\begin{array}{l}\text { Dimension } \\
\mathrm{N}-\mathrm{S}(\mathrm{m})\end{array}$} & \multirow[b]{2}{*}{$\begin{array}{l}\text { Average } \\
\text { Thickness }(\mathrm{cm})\end{array}$} & \multicolumn{2}{|c|}{$\begin{array}{l}\text { Average Depth } \\
\text { Below Ground } \\
\text { Surface } \\
\end{array}$} & \multirow[b]{2}{*}{$\begin{array}{l}\text { Area } \\
\left(m^{2}\right)\end{array}$} & \multirow[b]{2}{*}{$\underset{\left(\mathrm{m}^{3}\right)}{\text { Volume }}$} & \multicolumn{2}{|c|}{$\begin{array}{l}\text { Burned Rock } \\
\text { Per Square Meter }\end{array}$} & \multirow[b]{2}{*}{$\begin{array}{l}\text { Associated } \\
\text { Soil Stratuml }\end{array}$} \\
\hline & & & & & & $\begin{array}{l}\text { Top } \\
(\mathrm{cm})\end{array}$ & $\begin{array}{l}\text { Bot tom } \\
\text { (cml) }\end{array}$ & & & $\begin{array}{l}\text { Average } \\
\text { Size (cm) }\end{array}$ & $\begin{array}{c}\text { Average } \\
\text { Volumle }(\mathrm{cc})\end{array}$ & \\
\hline Midden* & 2 & Red & 17.00 & 15.01 & 68.0 & -15.0 & 53.0 & 255.17 & 173.52 & 6 & 76,250 & Topsoil \\
\hline \multirow[t]{5}{*}{ Hearth* } & 3 & Red & 2.00 & 1.90 & 32.5 & 10.0 & 42.5 & 3.80 & 1.24 & 12 & 40,625 & Topsoil \\
\hline & 6 & Red & 2.00 & 2.00 & 10.0 & 25.0 & 35.0 & 4.00 & 0.40 & est.10 & 40,625 & Topsoi? \\
\hline & 9 & Green & 2.50 & - & 28.0 & 18.0 & 46.0 & - & - & est. 7 & -- & Gravel \\
\hline & 10 & White & 2.00 & 1.90 & 25.0 & 20.0 & 45.0 & 3.8 & 0.95 & 20 & 15,000 & Clay \\
\hline & 11 & Yellow & 1.60 & 2.00 & 25.0 & 20.0 & 45.0 & 3.2 & 0.80 & 8 & 15,000 & Clay \\
\hline Scatter & 8 & Red & 2.00 & 3.50 & 10.0 & 30.0 & 40.0 & $7.0^{+}$ & 0.70 & est. 7 & 90,000 & Topsoil \\
\hline \multirow[t]{3}{*}{ 0ccupation Floor } & 4 & Red & 2.00 & 2.00 & 5.0 & 15.0 & 20.0 & 4.0 & 0.20 & 5 & 2,720 & Topsoil \\
\hline & 5 & Red & 6.00 & 4.00 & 16.0 & 40.0 & 56.0 & 24.0 & 3.84 & 7 & 12,477 & Gravel \\
\hline & 7 & Red & 4.00 & 3.00 & 29.0 & 1.0 & 30.0 & 12.0 & 3.48 & 3 & 813 & Topsoil \\
\hline
\end{tabular}

* Burned Rock 
TABLE 26. FEATURE ASSOCIATIONS

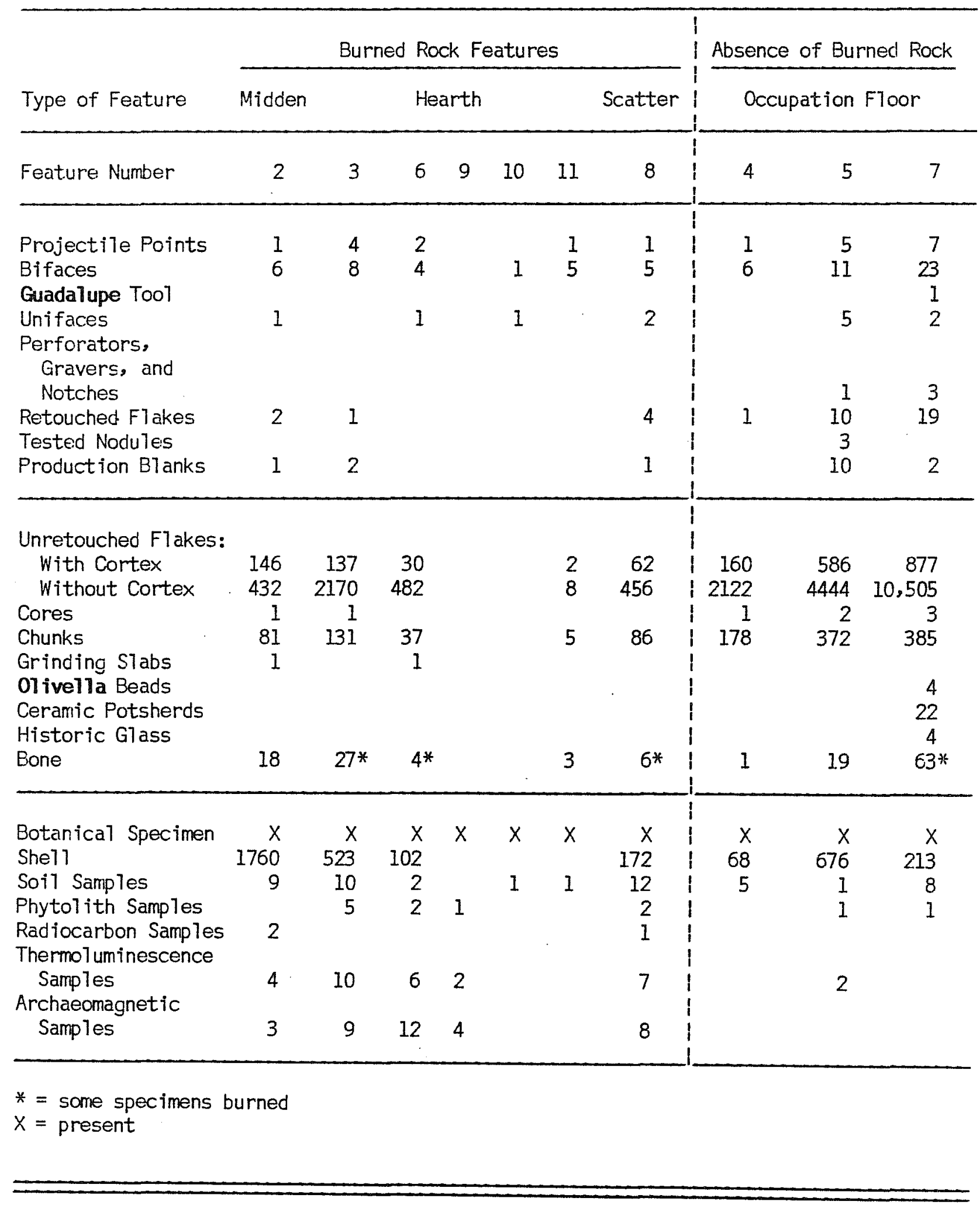


Phase II subsurface investigation was conducted by means of $1-x 1-\mathrm{m}^{2}$ excavation units dug in locations of burned rock and artifact surface concentrations (Figs. 5,b; 11; 12), three of which were inside the periphery of the feature as determined during Phase III (Figs. 11; 12). An unsuccessful attempt was made to document the areal extent of the feature by plotting the surface concentration of burned rock and by boring auger holes into the site along cleared survey lanes (Fig. 5,a). The actual size, shape, depth, architecture, and chronological affilitation of this burned rock midden feature were not determined until the Phase III investigations.

Not only was the presence of the burned rock midden known prior to the beginning of Phase III field work, but its investigation formed a 1 arge portion of the overall research design set forth in the proposal submitted to Interagency Archeological Services-Denver. For this reason, as well as its size and anticipated complexity, a great deal of time and effort was allocated to its investigation. A variety of excavation methods and techniques was employed as a consequence of the importance accorded this feature.

The initial stage of investigation consisted of efforts to ascertain the horizontal extent and circumferential configuration of the midden. Toward this end, a series of isolated units was excavated, the first established at the approximate apex of the feature as determined by telescopic level. From these units in Block 066 (066003, 066013, 066014), additional units proceeded north in Block 056 and east into Block 067 (Figs. 11; 12). As the initial intention was only to locate the edge of the feature, excavation ceased in a unit once the topmost layer of burned rocks was exposed. The exposure was at (and actually above by $c a .15 \mathrm{~cm}$ ) the surface of the ground in the first units, but the presence of burned rocks gradually occurred deeper and deeper as the periphery of the midden was approached. Figure 32, a shows the top 1 ayer of the midden at ground surface near its apex, and the same top 1 ayer is shown in Figure $32, \mathrm{~b}$ at least $20 \mathrm{~cm}$ below the ground surface $18 \mathrm{~m}$ distant from the apex at the very edge of the feature.

The edge of the feature was defined as the absence of a continuous and concentrated presence of burned rock. After one portion of the edge had been located between Units 066018 and 066020 (Figs. 11, 12), a circle was drawn on the field map using the instrument-determined apex as the center and the distance from apex to edge as a radius. While it was never expected that the feature would exhibit the configuration of a perfect circle, the placement of additional units at or near the extrapolated periphery would be greatly facilitated. Four isolated units excavated in Block 056 and two each in Blocks 055 and 065 (Figs. 11, 12) succeeded in confirming the approximately circular orientation of the feature's circumference along its entire northern hemisphere.

Determination of the internal stratigraphy of the midden, its architectual characteristics, and its southern edge were all accomplished with a single trench (Hotel) cut from the north edge completely through the center of the midden (Figs. 10, 11, 12, 22). The trench extended about $10 \mathrm{~m}$ beyond the southern edge of the feature to enable investigation of extra-peripheral activity, to identify possible associated features, and to observe "norma subsurface stratigraphy. India-E, a perpendicular trench to Hotel, was cut 
Site 41 BX 300/Features
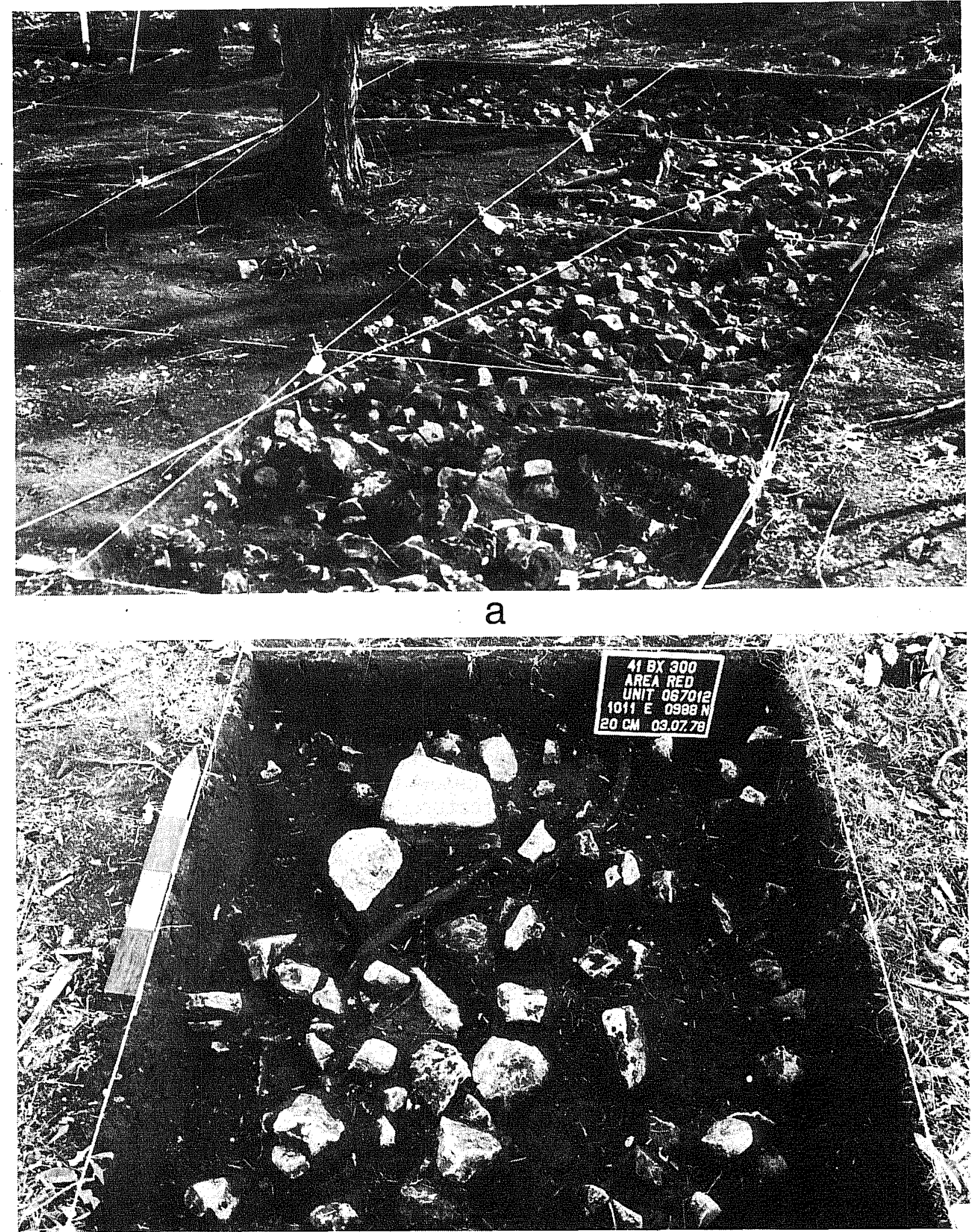

$\mathrm{b}$

Figure 32. Views of Feature 2. a, Feature 2 at the ground surface (Area Red); b. Feature 2, $20 \mathrm{cr}$ below the ground surface (Area Red). 
to provide a stratigraphic intersection near the center of the midden (Figs. 14,a; 23), to investigate possible extraperipheral activity on the midden's west side, and to physically isolate one quadrant of the entire feature.

This northwest quadrant was the scene of most of the subsequent activity during the investigation of Feature 2. Extensive and detailed profiles were drawn along the entire lengths of Hotel (Fig. 22) and India-E trenches (Figs. 14,a; 23), providing accurate data on the nature of the transition between the burned rocks of the midden and the former surface of the ground. It was the intention to document the behavior involved in, and to provide a date for, the inception of the midden. Using a front-end loader, the midden rocks were stripped off to within several courses of the bottommost layer over the entire northwest quadrant. The nature of the midden-submidden transition was investigated by standard excavation techniques in two isolated units (055066 and 055084) previously established to identify the midden periphery (Figs. 11; 12). The submidden zone itself was subjected to an intensive experiment in total recovery (see Excavation Procedures) by excavating $14 \mathrm{~cm}$, beginning at the midden-submidden transition, centimeter by centimeter, over all of Unit 055088 and portions of the adjacent three units at the intersection of Hotel and India-E trenches (Figs. 14,a; 33,a).

Other excavation activities associated with Feature 2 included additional trenching on the east side and the search for associated activity beyond the periphery of the midden (Figs. 11, 12). The trenches, Juliet and Omega, were cut to complete the stratigraphic profile drawing record of the feature. Previously drawings had been made of the north and south portions in Hotel trench and the western portion in India-E trench; Omega-W trench provided data in the fourth quadrant (Fig. 23). Block excavations in grid Block 056 northeast of the midden and grid Block 076 southeast of the midden (Figs. 11, 12) were initially established to locate peripheral features and document associated activities and behavior. A total of five features was identified in both block excavations; but as it turned out, their affiliations were with three other cultural periods and not with the midden at all. These features, numbered 3 through 7 , are discussed later.

The physical characteristics of Feature 2 conform in every respect to a classic central Texas burned rock midden. In plan view it presents an elliptical configuration (Figs. 11, 12), measuring approximately $17 \mathrm{~m}$ along its major axis (east to west) and $15 \mathrm{~m}$ along its minor axis (north to south) for an area of about $255 \mathrm{~m}^{2}$. In profile it appears domed, with a wedgeshaped cross section approximately $68 \mathrm{~cm}$ thick at the butt end (midden center) and tapering to only six centimeters at the periphery of the feature and the blade of the wedge (Figs. 22, 23). Its volume of space was calculated at $173.5 \mathrm{~m}^{3}$, assuming a relatively horizontal base and smooth, sloping sides.

Feature 2 was constructed almost totally of 1 imestone rocks, burned completely to a grayish white color, with patches of pink and purple representing burned impurities, and having a powdery surface of disintegrating rock material. Rock size was consistently small, averaging six centimeters and ranging not more than two centimeters in either direction from this mean diameter. Distribution of rock was uniform throughout the 


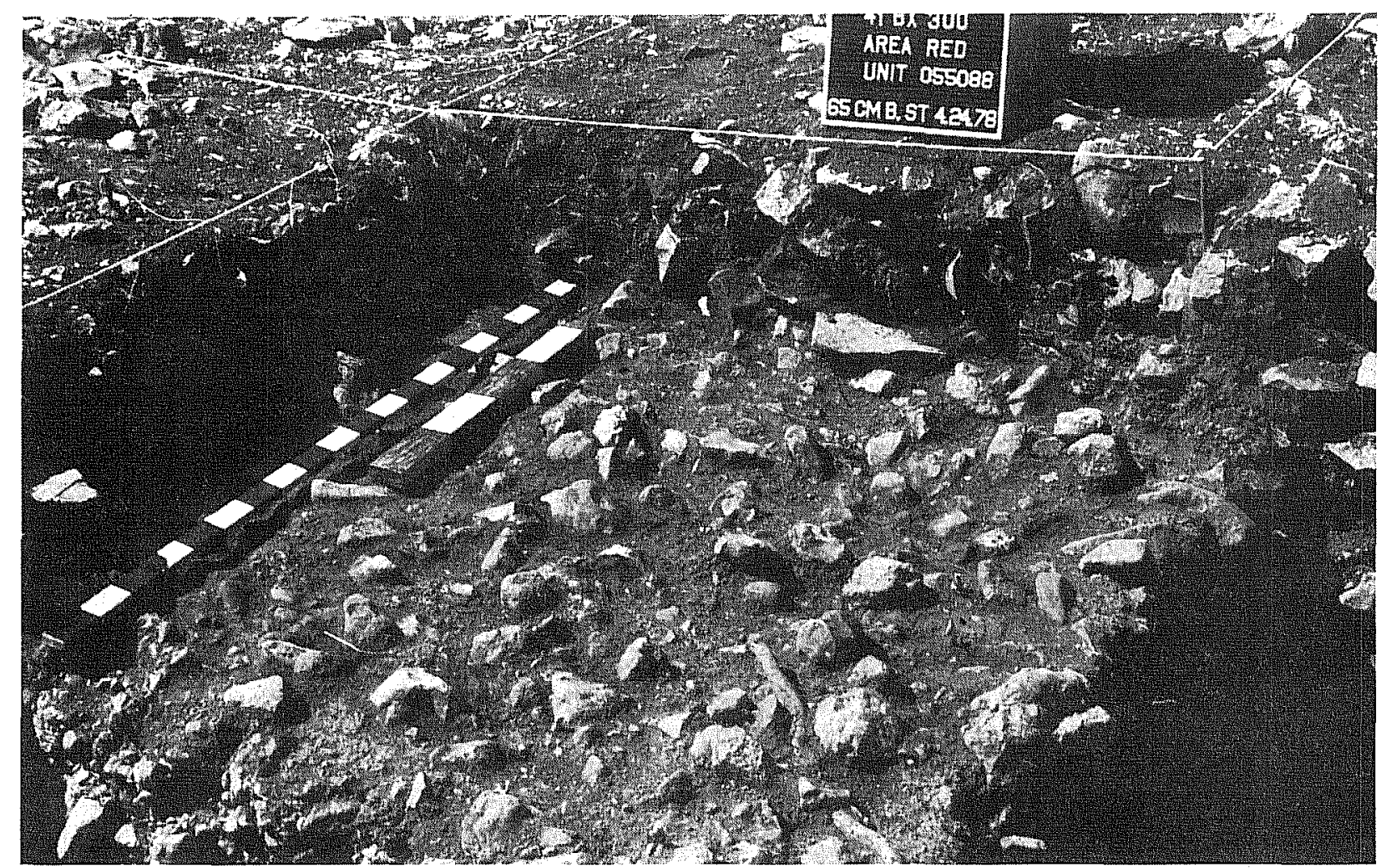

a

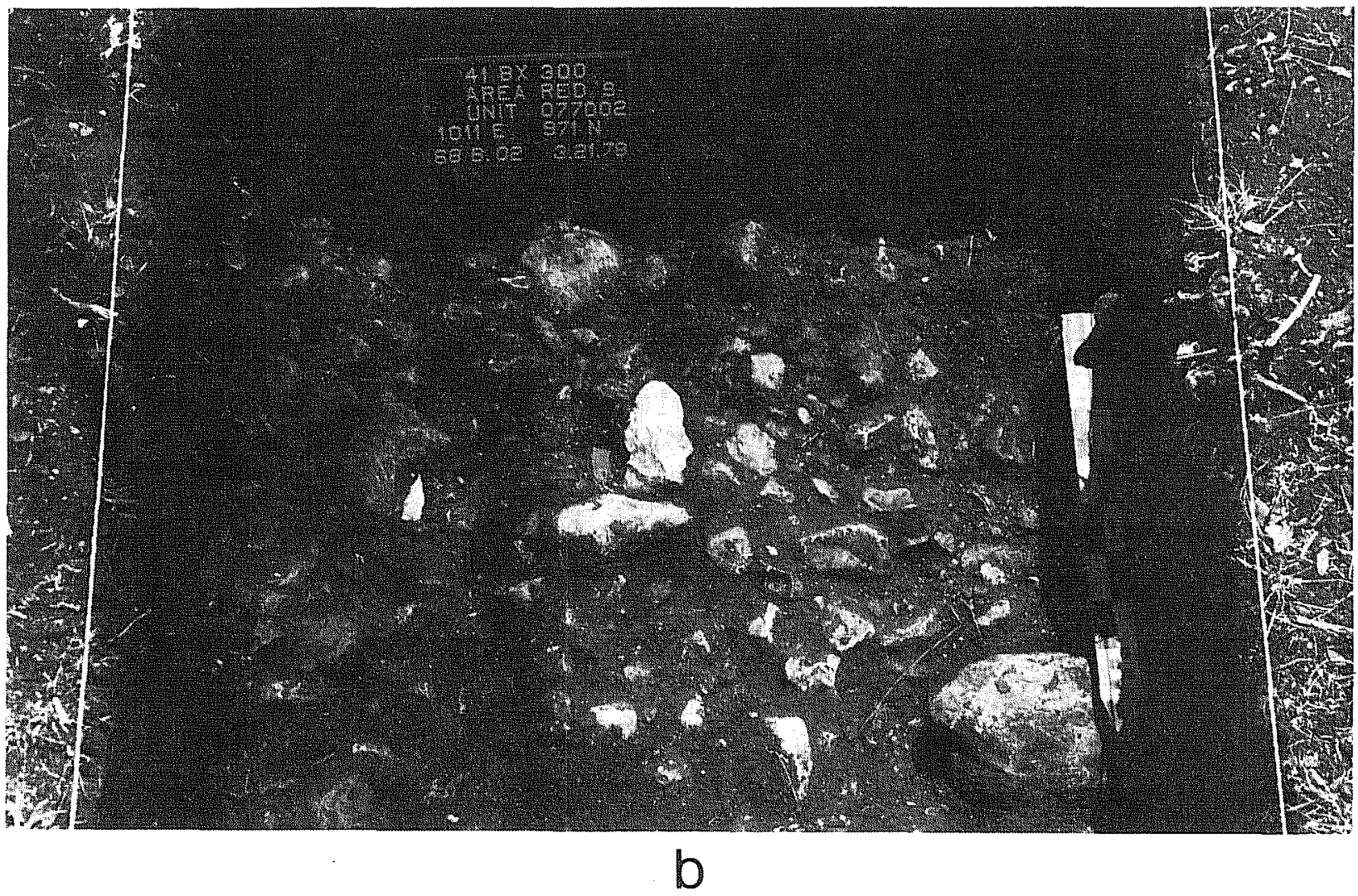

Figure 33. Views of Features 2 and $5 . \quad$ a. Feature 2, $65 \mathrm{~cm}$ be 1 ow the ground surface (Area Red); b, Feature 5, completed excavation unit (Area Red). 
feature (Fig. 16,a), and no internal concentrations of rock were identified in any trench wall or excavation unit. Volume of burned rock comprising this feature was estimated to be $76,250 \mathrm{~cm}^{3}$ per cubic meter, or 13,230,900 cc total volume.

The interstices between the burned limestone were filled with topsoil, normally dark brown but stained almost black by contact with the midden rocks. Flecks of charcoal and burned earth occurred throughout the midden soil matrix, but no concentrations or large pieces were identified to suggest in situ burning. No burned earth was identified within the matrix, nor did the submidden zone immediately below the limestone rocks exhibit any evidence of heat alteration. Neither rock configuration nor soil characteristics suggested any burning activity in the location of the midden. It is concluded that this particular feature falls into the functional category of "community dump" (Sorrow 1969; Hester 1970; Peter 1982; Howard 1983).

Associated artifactual material, or rather the lack of it, bears out this interpretation of a passive, rather than an active, feature locus. Manufactured chipped stone tools (i.e., points, bifaces, unifaces) recovered from Feature 2 excavations during Phase III investigations total only 10 (Table 30), and some of these are associated with the midden-submidden transition and are probably premidden in time. However, even allowing for these 10 artifacts, the result is only four artifacts per cubic meter of hand-excavated midden fill (37 $2.68 \mathrm{~m}^{3}=$ hand-excavated volume). The five recorded hearths (Features 3,6, 9, 10, and 11), by way of comparison, vary from three to 15 artifacts per cubic meter, and yet each represents less than $1 \%$ of the volume of the midden. While the preservation of faunal and floral material was not very good in Feature 2, the number of bone and seed specimens is on a level with other features at the site (see Table 30) rather than commensurate with the size and extent of the midden.

Given that the burned rock midden most likely represents the refuse from contemporaneous and adjacent fire features, it is possible to infer the activity associated with these features by what little was recovered in the midden. A17 the tools suggest faunal procurement and processing, and the presence of bone further supports this hypothesis. The peripheral fire features which eventually generated the burned rock and associated artifactual and ecofactual debris probably functioned as a heat source for cooking meat and/or smoking hides and skins.

Although chronological samples were collected for radiocarbon, thermoluminescence, and archaeomagnetic dating (see Table 26), establishing a date for the midden's 1 ifespan was unsuccessful (see Ecofacts and Special Samples). Relative dating by means of chronologically diagnostic artifacts, in this case projectile points, was the only means available. Of the eight points or point fragments associated with the feature, only one was recovered under the rigid provenience controls imposed by the Phase III investigation. It is identified as a Travis point (Table 27) and was found at the very bottom of the burned rock zone where the Del Rio clay stratum contacted the feature. Three other points from the Phase II investigations that could be typed either confidently or provisionally also fall within the same general time range as the one recovered in the Phase III investigations. AT7 four date to the early portion of the Middle Archaic (Table 28), and this is thus the 
Site 41 BX 300/Features

TABLE 27. CHRONOLOGICALLY DIAGNOSTIC ARTIFACTS ASSOCIATED WITH FEATURES

\begin{tabular}{|c|c|c|c|c|c|c|c|c|c|c|}
\hline \multirow[b]{2}{*}{ Period and Type } & \multicolumn{10}{|c|}{ Feature Number } \\
\hline & 2 & 3 & 4 & 5 & 6 & 7 & 8 & 9 & 10 & 11 \\
\hline \multicolumn{11}{|l|}{ LATE PREHISTORIC } \\
\hline $\begin{array}{l}\text { Toyah } \\
\text { Unidentifiable arrow point }\end{array}$ & & & & & & $\begin{array}{l}1 \\
2\end{array}$ & & & & \\
\hline \multicolumn{11}{|l|}{ LATE ARCHAIC } \\
\hline $\begin{array}{l}\text { Castroville } \\
\text { Darl } \\
\text { Ensor } \\
\text { Frio } \\
\text { Marcos } \\
\text { Montel1 } \\
\text { Unidentifiable dart point }\end{array}$ & & $\begin{array}{l}1 \\
1 \\
1\end{array}$ & 1 & 1 & 1 & $\begin{array}{l}1 \\
1\end{array}$ & 1 & & & \\
\hline \multicolumn{11}{|l|}{ MIDDLE ARCHAIC } \\
\hline $\begin{array}{l}\text { Bulverde } \\
\text { Lange } \\
\text { Pedernales } \\
\text { Travis } \\
\text { Guadalupe tool }\end{array}$ & 1 & 1 & & $\begin{array}{l}1 \\
1 \\
2\end{array}$ & 1 & $\begin{array}{l}1 \\
1\end{array}$ & & & & 1 \\
\hline
\end{tabular}


TÁBLE 28. CHRONOLOGICAL ASSOCIATIONS OF PROJECTILE POINTS

\begin{tabular}{|c|c|c|c|c|c|}
\hline $\begin{array}{l}\text { Central } \\
\text { Texas Phase }\end{array}$ & $\begin{array}{l}\text { Salado Creek } \\
\text { Watershed } \\
\text { Local Period }\end{array}$ & Date Range & $\begin{array}{l}\text { Projectile } \\
\text { Point Type }\end{array}$ & $\begin{array}{l}\text { Type } \\
\text { Quantity }\end{array}$ & $\begin{array}{c}\text { Total } \\
\text { Quantity }\end{array}$ \\
\hline \multicolumn{5}{|c|}{ LATE PREHISTORIC PERIOD } & 11 \\
\hline Toyah & 11 & A.D. $1350-1800$ & $\begin{array}{l}\text { Perdiz } \\
\text { Toyah }\end{array}$ & $\begin{array}{l}2 \\
1\end{array}$ & 3 \\
\hline Austin & 10-Late & A.D. $750-1350$ & $\begin{array}{l}\text { Edwards } \\
\text { Scallorn }\end{array}$ & $\begin{array}{l}2 \\
1\end{array}$ & 3 \\
\hline & 11/10-Late & A.D. $750-1800$ & $\begin{array}{r}\text { Unidentifiable } \\
\text { Arrow points }\end{array}$ & 5 & 5 \\
\hline \multicolumn{5}{|c|}{ LATE ARCHAIC PERIOD } & 83 \\
\hline Driftwood & 10-Early & A.D. $600-750$ & $\begin{array}{l}\text { Dar } 1 \\
\text { Matamoros } \\
\text { Figueroa }\end{array}$ & $\begin{array}{l}3 \\
1 \\
3\end{array}$ & 7 \\
\hline Twin Sisters & 9-Late & A.D. $200-600$ & $\begin{array}{l}\text { Ellis } \\
\text { Ensor } \\
\text { Fairland } \\
\text { Frio }\end{array}$ & $\begin{array}{r}1 \\
19 \\
7 \\
12\end{array}$ & 39 \\
\hline Uvalde & 9-Early & $\begin{array}{l}\text { A.D. } 200- \\
250 \text { B.C. }\end{array}$ & $\begin{array}{l}\text { Castroville } \\
\text { Marcos } \\
\text { Montel1 }\end{array}$ & $\begin{array}{r}11 \\
5 \\
10\end{array}$ & 26 \\
\hline & 10-Ear7y/9 & & $\begin{array}{c}\text { Unidentifiable } \\
\text { Dart points }\end{array}$ & 11 & 11 \\
\hline \multicolumn{5}{|c|}{ MIDDLE ARCHAIC PERIOD } & 54 \\
\hline $\begin{array}{l}\text { San Marcos } \\
\text { Round Rock }\end{array}$ & $\begin{array}{l}8 \\
7 \text {-Late }\end{array}$ & $\begin{aligned} 600-250 & \text { B.C. } \\
1500-600 & \text { B.C }\end{aligned}$ & $\begin{array}{l}\text { Lange } \\
\text { Langtry } \\
\text { Pedernates }\end{array}$ & $\begin{array}{r}1 \\
4 \\
13\end{array}$ & $\begin{array}{r}1 \\
17\end{array}$ \\
\hline $\begin{array}{l}\text { Marsha11 } \\
\text { Ford } \\
\text { Clear Fork }\end{array}$ & $\begin{array}{l}7-E a r 7 y \\
6\end{array}$ & $\begin{array}{l}2100-1500 \text { B.C. } \\
2600-2100 \text { B.C. }\end{array}$ & $\begin{array}{l}\text { Bulverde } \\
\text { La Jita } \\
\text { Nolan } \\
\text { Pandale } \\
\text { Travis }\end{array}$ & $\begin{array}{r}13 \\
1 \\
10 \\
1 \\
11\end{array}$ & $\begin{array}{l}13 \\
23\end{array}$ \\
\hline \multicolumn{5}{|c|}{ EARLY ARCHAIC PERIOD } & 7 \\
\hline $\begin{array}{l}\text { Oaka11a } \\
\text { Jarre11 }\end{array}$ & $\begin{array}{l}\text { 5-Late } \\
\text { 5-Early }\end{array}$ & $\begin{array}{l}3100-2600 \text { B.C. } \\
4100-3100 \text { B.C. }\end{array}$ & $\begin{array}{l}\text { Martindale } \\
\text { Uvalde }\end{array}$ & $\begin{array}{l}0 \\
2 \\
3\end{array}$ & $\begin{array}{l}0 \\
5\end{array}$ \\
\hline San Geronimo & 4 & 4800-4100 B.C. & Gower & 1 & 1 \\
\hline Circleville & 3 & $6500-4800$ B.C. & Angostura & 1 & 1 \\
\hline $\begin{array}{l}\text { PALEO-INDIAN } \\
\text { PERIOD }\end{array}$ & $2 / 1$ & $8000-6500$ B.C. & & 0 & 0 \\
\hline
\end{tabular}


terminus post quem of the midden, based on the definite provenience of Travis points at the base of the feature. The midden is interpreted as being associated with the middle portion of the Middle Archaic, or the Round Rock phase, which spans the period from ca. 1500-600 B.C. (Prewitt 1983). (This corresponds to the latter portion of Salado Creek Watershed Local Period 7 [B]ack and McGraw 1985]). Even without stratigraphic and artifactual evidence supporting such a chronological interpretation, the odds favor any single midden being associated with the Round Rock phase. As Prewitt (1981:80) states, "This phase appears to represent the peak of burned rock midden use on the Edwards PTateau and associated physiographic regions." Local Period 7 was also the period of major accumulation for two of the four burned rock middens investigated at the Panther Springs Creek site (41 BX 228; B7ack and McGraw 1985:299-300).

\section{BURNED ROCK HEARTHS}

\section{FEATURE 3}

Feature 3, a smal1 concentration of burned 1 imestone rocks was uncovered during a search for activity areas assocjated with Feature 2, the burned rock midden. A block excavation in the southeastern portion of Area Red in grid Block 076 (Figs. 11; 12) included Units 076037 and 076038, the two squares in which almost all of the feature was situated. Consequently, most of Feature 3 was exposed at one time, permitting a smooth transition to the more appropriate excavation of a feature as a natural entity which supersedes the artificial constraints of horizontal units and vertical levels.

As part of the excavation design for Feature 3, one half of one unit was left unexcavated until the arrival of an archaeomagnetic technician from the University of $0 k 7$ ahoma. The west half of Unit 076038 is thus indicated as a blank on the feature plan drawing (Fig. 34), as it was important to keep the hearth rocks covered with soil until their removal as archaeomagnetic samples. Once removed (Fig. 35,a), of course, they were not available for recording as part of the feature plan. However, by leaving a portion of the feature totally unexcavated, an excellent cross section of the feature's interior was provided by the vertical face of the western side of Unit 076038 (Fig. 35,b).

The configuration of the feature was almost circular, measuring $2.0 \mathrm{~m}$ east to west by $1.9 \mathrm{~m}$ north to south. While the tops of the feature rocks began only $10 \mathrm{~cm}$ below the present ground surface, the base of the feature was situated $42.5 \mathrm{~cm}$ below the ground surface, for an average thickness of $32.5 \mathrm{~cm}$ (Table 25). This rather large vertical dimension was in part accounted for by a slight depression at the base of the hearth, although it was not pronounced enough to be characterized as a basin. More responsible for the feature's overal1 height was the size of the 7 imestone rocks, averaging $12 \mathrm{~cm}$ in diameter. The volume of the feature is calculated at $1-1 / 4 \mathrm{~m}^{3}$, covering an area of almost $4 \mathrm{~m}^{2}$.

The rocks showed definite evidence of burning, having the characteristic gray color and powdery exterior texture, but their size suggests they were either not burned for very long or not at a very high heat, or both conditions. 
Site 41 BX 300/Features

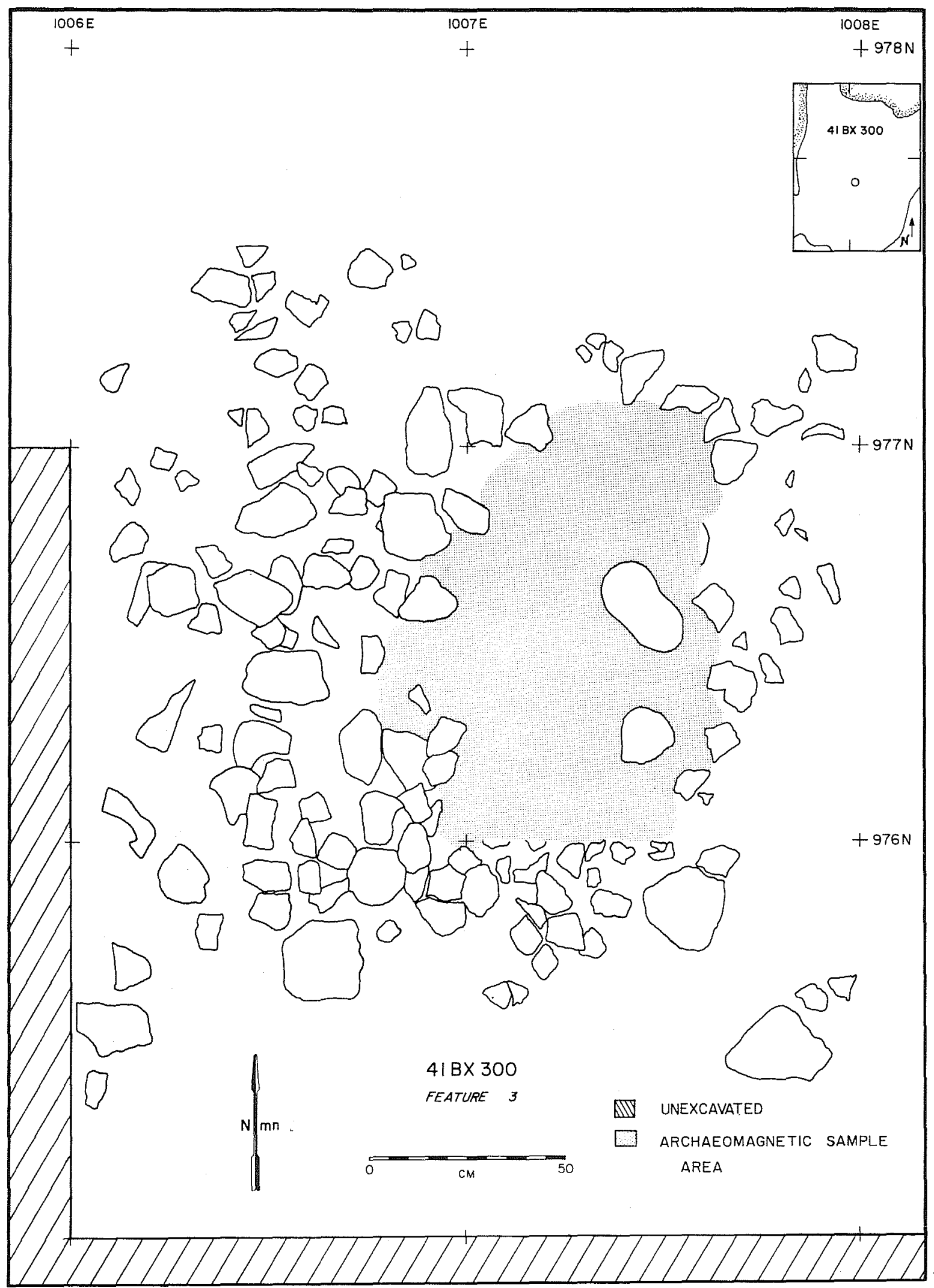

Figure 34. Plan Drawing of Feature 3, Area Red. 
Site 41 BX 300/Features
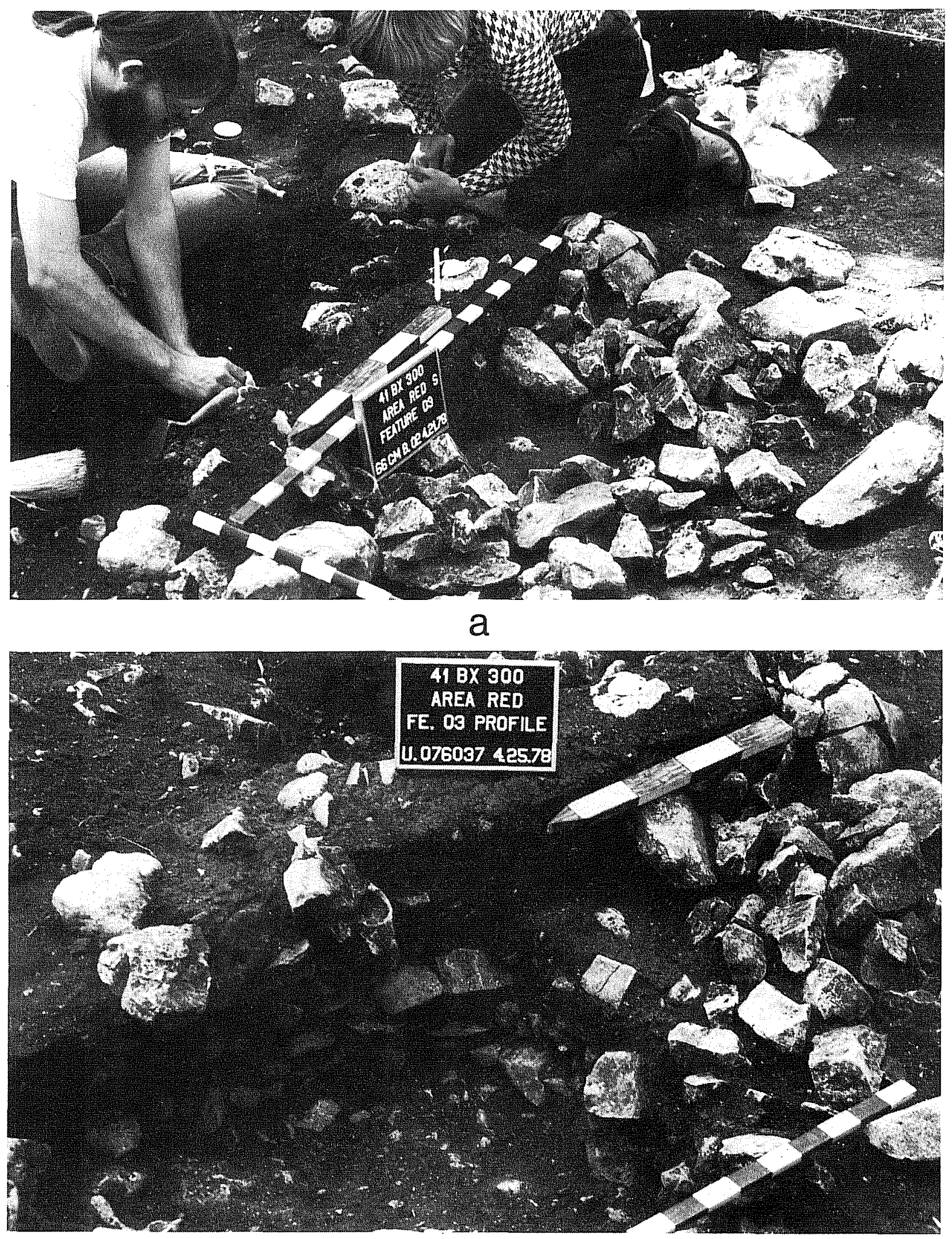

b

Figure 35. Views of Feature 3. a, archaeomagnetic sampling of Feature 3 (Area Red); b, partial plan and cross section of Feature 3 (Area Red). 
Experiments have demonstrated that 1 imestone rocks will fragment when subjected to repeated heating, regardless of temperature, as their water content decreases (Witkind 1977). The fact that the Feature 3 rocks were 1 arge, and many were 7 acking fracture lines suggesting imminent breakup, indicates limited reuse. The lack of high temperatures was indicated by the hardening or reddish discoloration of the soil immediately beneath the hearth rocks. Neither thermoluminescence nor archaeomagnetic dating of the feature was successful: the rocks of this feature were simply not heated hot enough for either method to work (see Ecofacts and Special Samples).

The fact that Feature 3 served as a hearth, or at least a fire area, is based on the presence of burned rocks in a configuration ubiquitous in central and south Texas archaeological contexts, and universaliy interpreted as a type of feature used sparingly in time. A look at the associated artifacts and ecofacts (Table 26) strongly suggests an association with faunat procurement and processing activities: projectile points, bifaces, unifacially retouched flakes, and burned animal bone. A fire may have been lit in the hearth, but quickly extinguished, providing only smoke for processing animal meat or hides while at the same time slowly baking the hearth rocks. The almost total absence of charcoal in any size or quantity would also be explained by the limited need for wood in a baking or smoking fire, as opposed to one kept hot and bright for warmth or open fire cooking.

Associated floral material has been identified and interpreted as associated with either the last or first quarter of the year (see Ecofacts and Special Samples; Table 16), in other words, with cold weather. This is the traditional deer hunting season in the locality today, and it is intriguing to speculate as to whether this might not have been the case prehistorically as we11.

Dating the feature must rely on relative means, the association of chronologically diagnostic projectile points as with Feature 2. No charcoal was recovered for radiocarbon dating, and the thermoluminescence and archaeomagnetic procedures were not successful due to insufficient heating of the hearth rocks. Three of the four associated projectile points, typed as Castroville, Dar1, and Ensor (Table 27), suggest this feature was associated with the Late Archaic, spanning the period from ca. 250 B.C. to A.D. 750 (Prewitt 1983). This corresponds to Local Period 9 (Black and McGraw 1985). The stratigraphic situation of Feature 3, i.e., completely in the topsoil zone and higher than the burned rock midden relative to their bases, suggests a date later than Feature 2. The fourth identifiable point type, a Bulverde stem fragment, would have been approximately contemporaneous with the burned rock midden, Feature 2.

\section{FEATURE 6}

Feature 6, a hearth, is comparable to the hearth previously described, Feature 3 , in many respects. Both were first recorded at about the same time during the investigations and in the same manner, within a block excavation designed to locate activity areas peripheral to the midden (Figs. 11, 12). Feature 6 was approximately five meters northeast of Feature 3 and was situated in the topsoil zone at approximately the same depth. Their spatial 
relationship to each other and to the midden prompted speculation at the time that a whole series of small hearths might encircle the midden and that a functional relationship might exist between both types of features. However, subsequent refinement of the chronological relationship between the midden and these two hearths has eliminated this possibility.

Feature 6 was circular in shape, having a diameter of two meters. As was the case with Feature 3 , the necessity of leaving archaeomagnetic samples covered at the time of recording leaves a black spot in the plan drawing (Fig. 36). Feature 6 appears much thinner than Feature 3, having a thickness of only $10 \mathrm{~cm}$ (Table 25). This is primarily due to the nature of the constituent rocks, which are much flatter than those used in Feature 3 (compare Figs. $35, a, b$ and $37, b)$, and, in fact, one of the stones used in the hearth functioned previously as a grinding slab (Figs. 37,b, far right; 36, center bottom; 38). Both hearths have approximately the same average size of burned rock; and since their areas are comparable, so also are their volumes of burned rock per cubic meter (Table 25). However, a comparison of plan views (Figs. 34, 36) indicates that averages can be misleading and that the features actually look quite different.

Feature 6 appears to be two distinct features (Fig. 36), but it was not initially recorded that way nor excavated accordingly. The western half (Fig. 37,b) is composed of large rocks, most exceeding the $10-12 \mathrm{~cm}$ feature average in diameter. The eastern half is more similar to rocks from the midden, averaging about six centimeters in diameter and exhibiting the angular facets characteristic of heat breakup. Following the conclusions reached in the discussion of Feature 3, Feature 6 can be interpreted as having two components. The one with large stones represents either an area which functioned at $10 \mathrm{w}$ heat or was abandoned before it was reused many times. The other area, with smaller rocks, represents either an area used at high heat or an area subjected to repeated reuse and ultimately abandoned in favor of the area immediately to the west.

The relative heating temperatures of these two areas within Feature 6 might have been determined by thermoluminescence processing, but the above argument was not formulated in time. Only the larger stones from the western half were analyzed, with the now predictable results of low heating insufficient for dating. Had Feature 6 been treated as two distinct features, fine details such as soil hardness and discoloration and relative amounts of charcoal flecks may have been recorded separately for each portion. As it stands, however, there is only the gross morphology on which to base an interpretation.

Associated material is 1 imited, perhaps representing another significant difference from the nearby Feature 3. As Table 26 indicates, in almost every category, Feature 3 greatly exceeds Feature 6 in the amount of material recovered. If the association of a grinding slab inside Feature 6 can be extrapolated to postulate a vegetal processing function for Feature 6 , then its morphological and artifactual differences with Feature 3 and its proposed faunal processing function take on even greater significance.

On the other hand, the chronological placement of Feature 6 is unfortunately weak, and its differences with Feature 3 may reflect group behavior at 


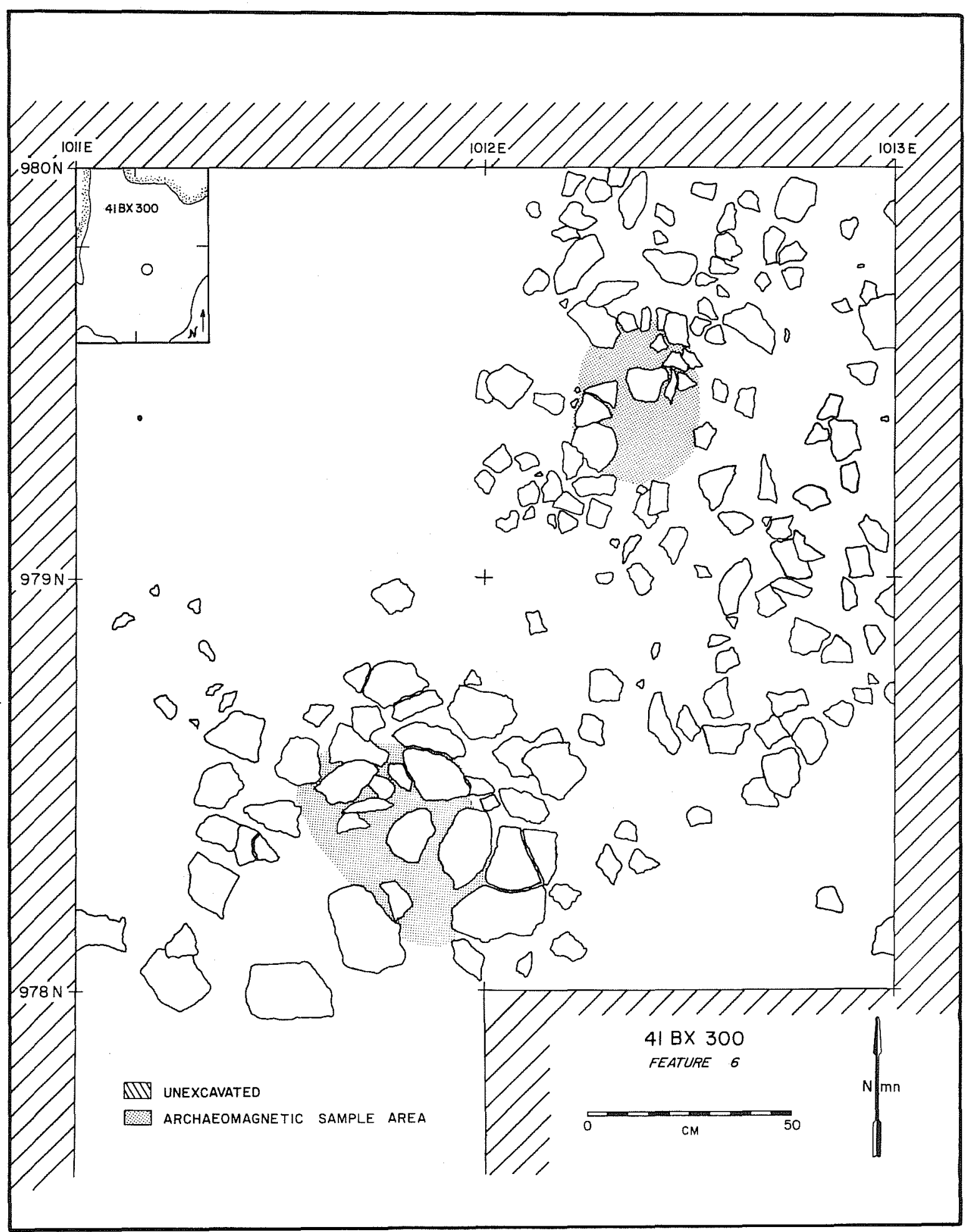

Figure 36. Plan Drawing of Feature 6, Area Red. 


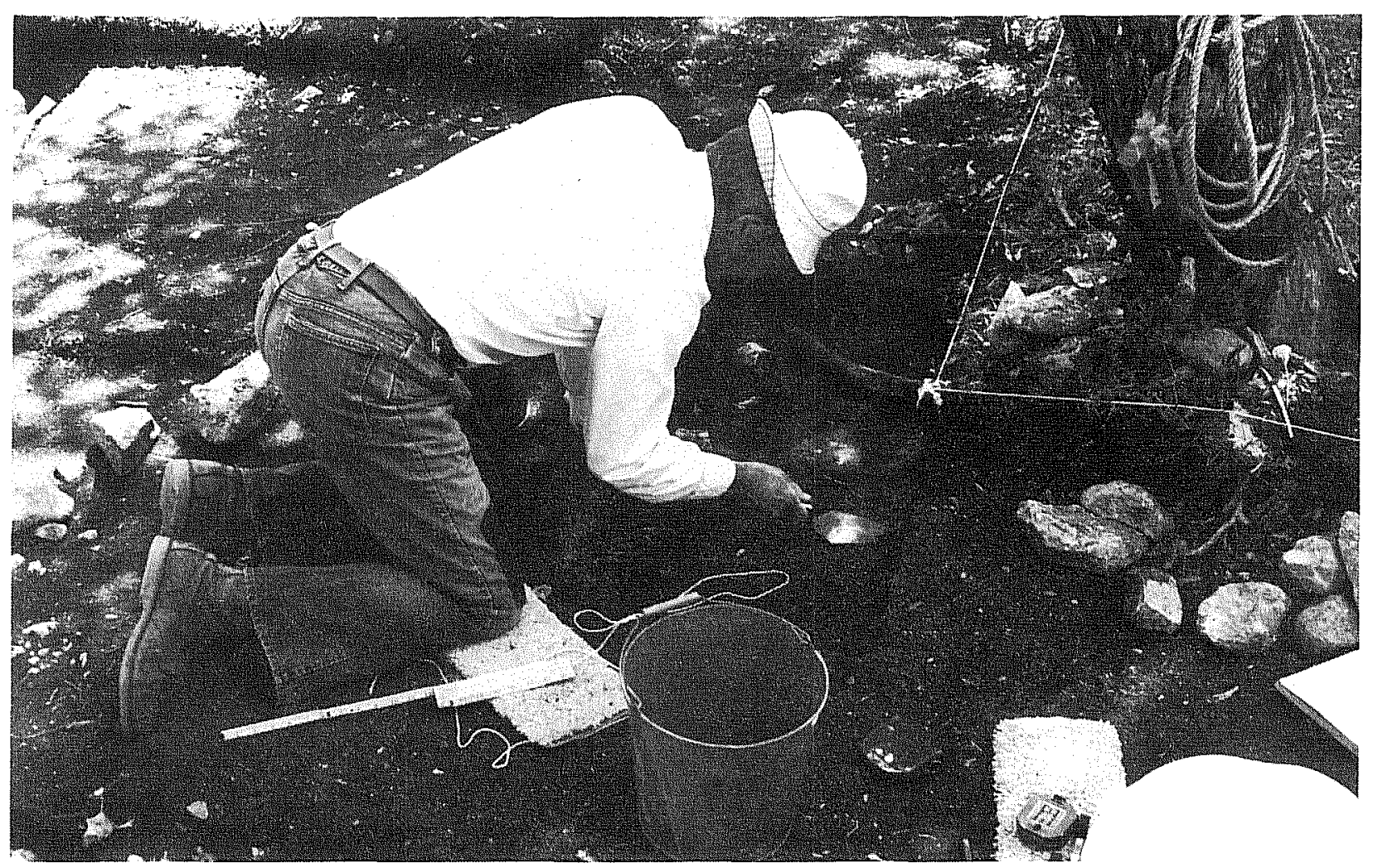

a

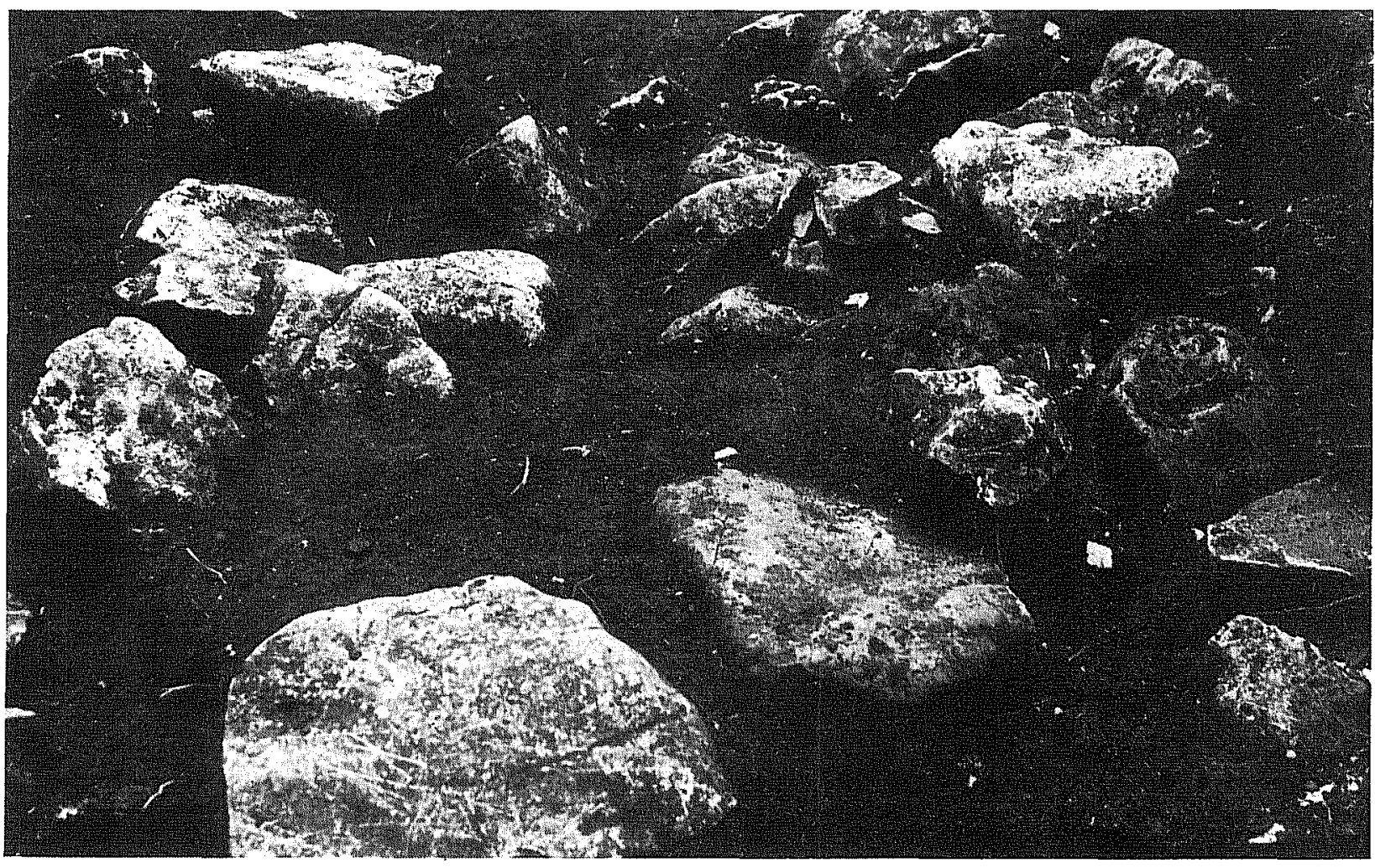

b

Figure 37. Views of Features 4 and 6. a, Feature 4, during excavation (Area Red); b. Feature 6, prior to archaeomagnetic sampling (Area Red). 


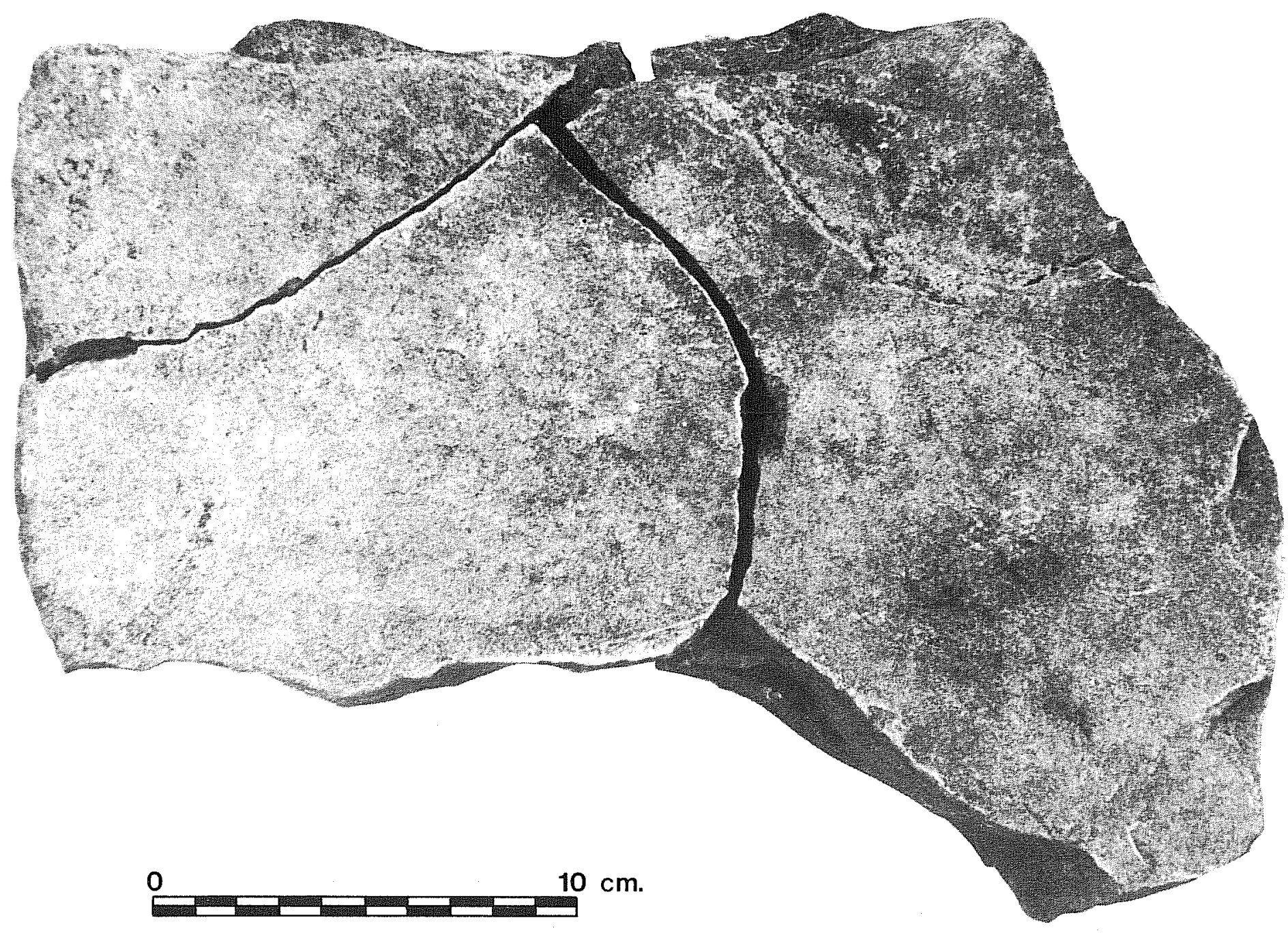


different times rather than contemporaneous functional variations. One large, probably wide, bladed projectile point with a lateral edge and barb was recovered from Feature 6 . The slight recurve between edge and barb leads to a very tentative identification of the point as a Marcos type. This association would place the feature early in the Late Archaic Uvalde phase (Prewitt 1983), spanning the years 250 B.C. to A.D. 200, and thus similar in time to Feature 3. The tentativeness of the point typing, the compressed stratigraphy at the site, the rather common occurrence of earlier points in later contexts at the site and vice versa, al1 make the dating of Feature 6 by artifactual association difficult. Stratigraphically, and this may be the best chronological device, it is comparable to Feature 3. Also comparable may have been the time of its use, interpreted to be fall or winter based on botanical analysis (see Ecofacts and Special Samples; Table 16). A final comparability is the recovery of Bulverde point fragments from both features (Table 27), presumably associated with the earlier and stratigraphically lower burned rock midden, Feature 2.

\section{FEATURE 9}

Feature 9, a hearth, was uncovered in the wall of Echo trench and represents the only feature recorded in Area Green during the Phase III investigations. This is somewhat surprising in view of the extensive trenching in Area Green (Figs. 8, 10, 11), instituted expressly to uncover evidence of cultural activity. The block and isolated unit excavations of the Phase II investigations (Figs. 10,11) recovered sufficient artifactual material to warrant further investigation; and hundreds of flakes were recovered during Phase III by screening trench backdirt. Nevertheless, no features were identified in the topsoil zone which could be associated with the Late Archaic and Late Prehistoric periods material recovered by hand excavation in this area during Phase II (Table 4).

Feature 9 was comprised of burned 1 imestone rocks, oriented in a 1 inear manner in the north wall of Echo trench and extending east to west for about $2.5 \mathrm{~m}$ (Figs. 39,b;40). Although the rocks were surrounded by topsoit, the feature appeared to have been constructed in a basin-shaped depression in the gravel subsoil beneath the topsoil. With the exception of a single large rock (Fig. 39,b), the associated stones were generally small and angular, averaging about seven centimeters in diameter. The hearth thus appears to fall into that subclass of this type of feature characterized by high temperature and/or continued reuse, resulting in the dissolution of originally much larger rocks.

No artifactual or ecofactual material was recovered during investigation of the feature, which only consisted of cleaning, profile drawing, and special sampling. Analysis of botanical specimens (see Table 16) suggested that this feature was open during the fall or winter seasons. While this is similar to interpretations of the seasonality of Features 3 and 6 , Feature 9 should predate both of these hearths by virtue of its stratigraphic situation. At its latest, it should be contemporaneous with the midden, but more likely is a date early in the Middle Archaic period or Tate in the Early Archaic period when the gravel (and clay) zone was the ground surface of the site. Contemporaneity with the clay soil beneath the midden would allow cross 
Site 41 BX 300/Features
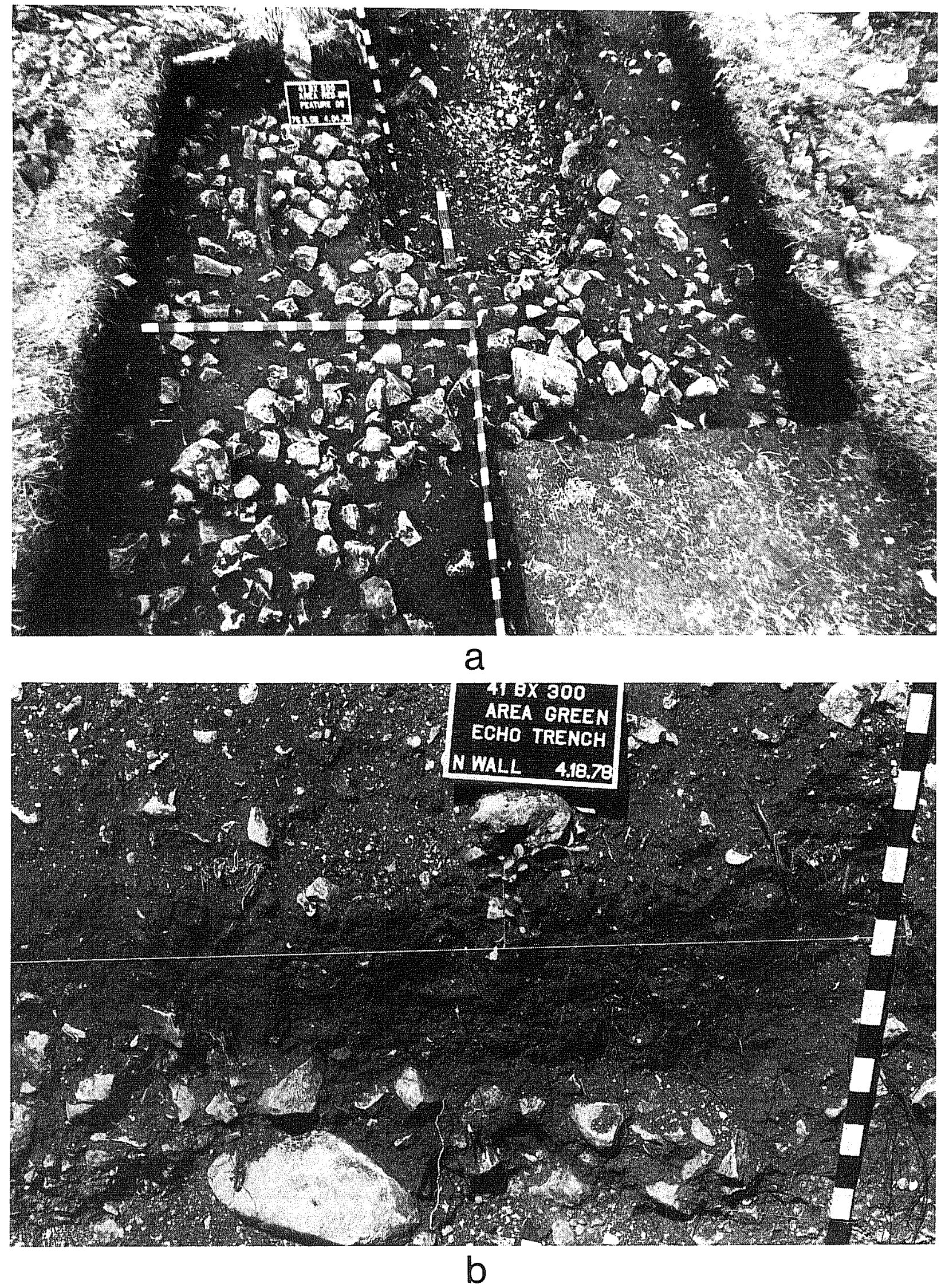

Figure 39. Views of Features 8 and 9. a, Feature 8, comp 1 eted excavation (Area Red); b. Feature 9, profile in Echo Trench (Area Green). 


\section{$41 \mathrm{BX} 300$ \\ FEATURE 9 \\ ECHO TRENCH NORTH WALL \\ $1015 \mathrm{~N}$ meter line}

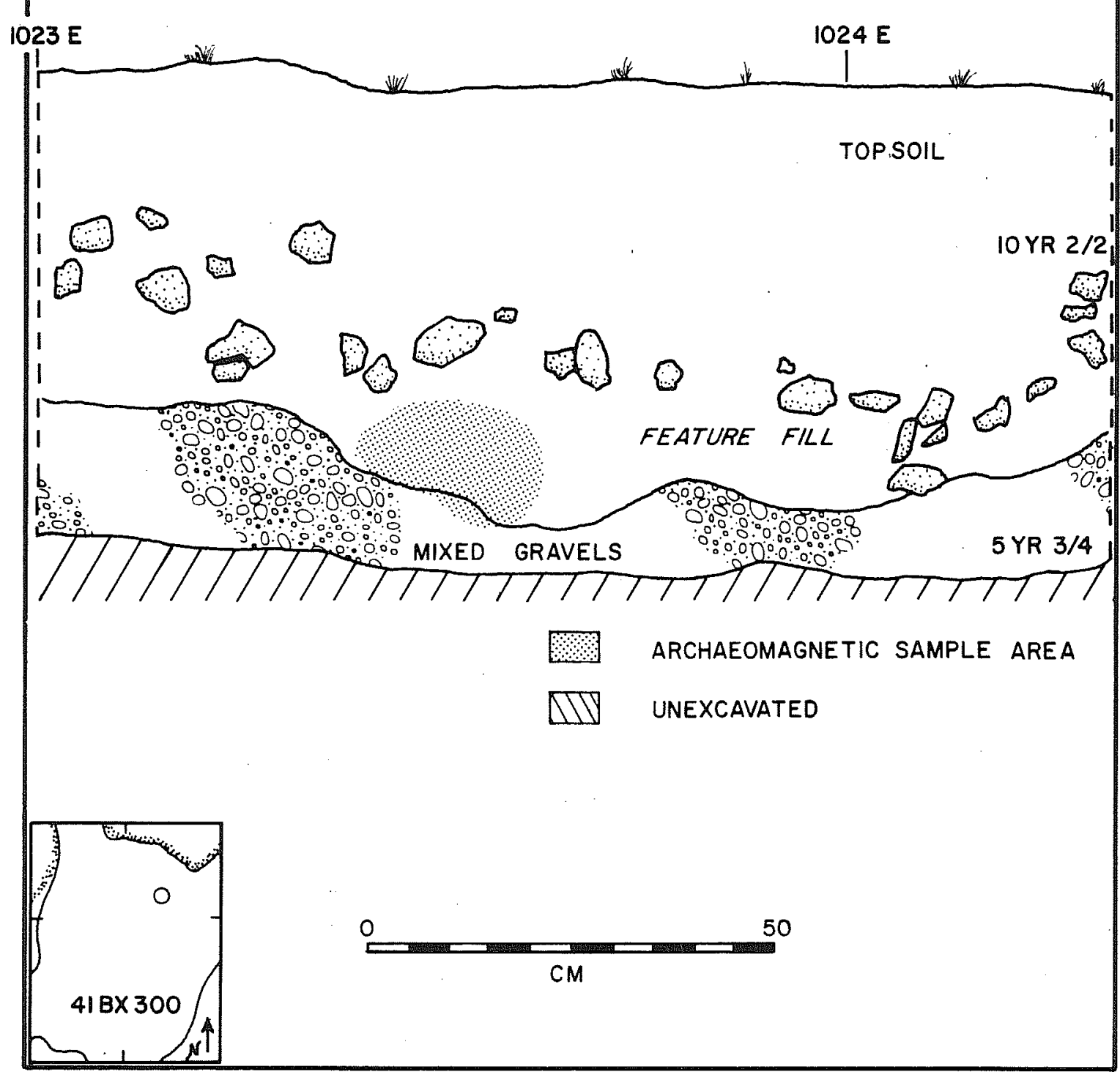

Figure 40. Profile Drawing of Feature 9, Area Green. 
dating by means of the submidden Travis points to the Clear Fork phase, ca. 2600-2100 B.C. (Prewitt 1983) and Local Period 6 (Black and McGraw 1985). Supporting data from archaeomagnetic and thermoluminescence analyses is not available, as only larger rocks were selected for processing, and they were not heated long enough or hot enough.

Circumstances did not permit full investigation of Feature 9, so data about its geometry and morphology remain incomplete.

\section{FEATURE 10}

Feature 10, a hearth, was identified in the wall of Kilo trench, cut through Area White on the eastern side of the site (Figs. 8, 10, 11). As Area White had not been previously investigated by excavation, and Feature 10 was the only feature to be recorded in this portion of the site, it was decided to fully investigate this hearth. A trench section was opened and the complete feature exposed; because it also appeared in the trench wall, both plan and profile were visible simultaneously (Figs. 41,a; 42).

Feature 10 was exactly the same size as Feature 3 , measuring 2.0 m east to west by $1.9 \mathrm{~m}$ north to south. This is the only point of similarity, however. Feature 10 rocks were 1 arger, averaging $20 \mathrm{~cm}$ in diameter, but fewer in number, so that the total volume of Feature 10 was about $20 \%$ less than that of Feature 3, and the volume of burned rock per cubic meter was almost twothirds Tess (Table 25).

Rock size suggests the feature was hardly used or was used for a low heat function. The associated artifacts are, unfortunately, limited in number and equally, unfortunately, not 1 imited in function (Table 26). The few cutting and scraping tools recovered would serve for both faunal or vegetal processing. No bones were recovered from this feature, and the botanical analysis was inconclusive (Table 16).

Its stratigraphic position within the top of the Del Rio clay stratum (Fig. 42) suggests a date comparable to Feature 9 and the clay soil beneath the midden, i.e., the Clear Fork phase, early in the Middle Archaic or the end of the Early Archaic period at the earliest.

\section{FEATURE 11}

Like Features 9 and 10, Feature 11, a hearth, was first identified in a trench wall, in this case at the north end of Charlie trench in Area Yellow at the southern end of the site (Figs. 8, 10, 11). Like Area White, Area Yellow was previously uninvestigated by excavation and was being trenched for the express purpose of uncovering evidence of cultural activity. Consequently, a trench section was opened, and the entire extent of Feature 11 exposed (Figs. 41,b; 43).

The morphology of Feature 11 is quite different from that of Feature 10, and yet they are seen as complementary features. Feature 11 was elliptical in geometry, measuring $1.6 \mathrm{~m}$ east to west by $2.0 \mathrm{~m}$ north to south for an area of 
Site 41 BX 300/Features

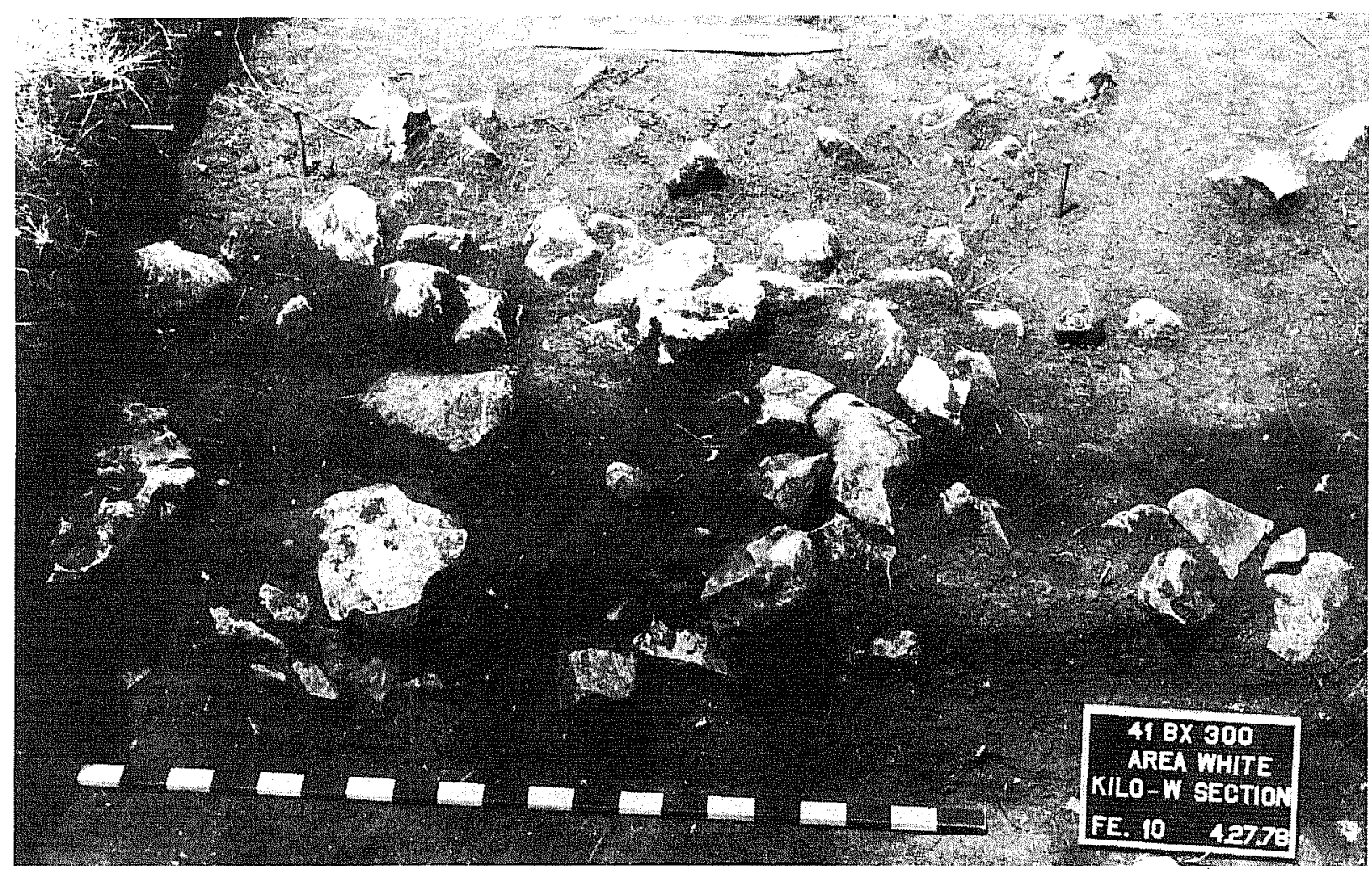

a

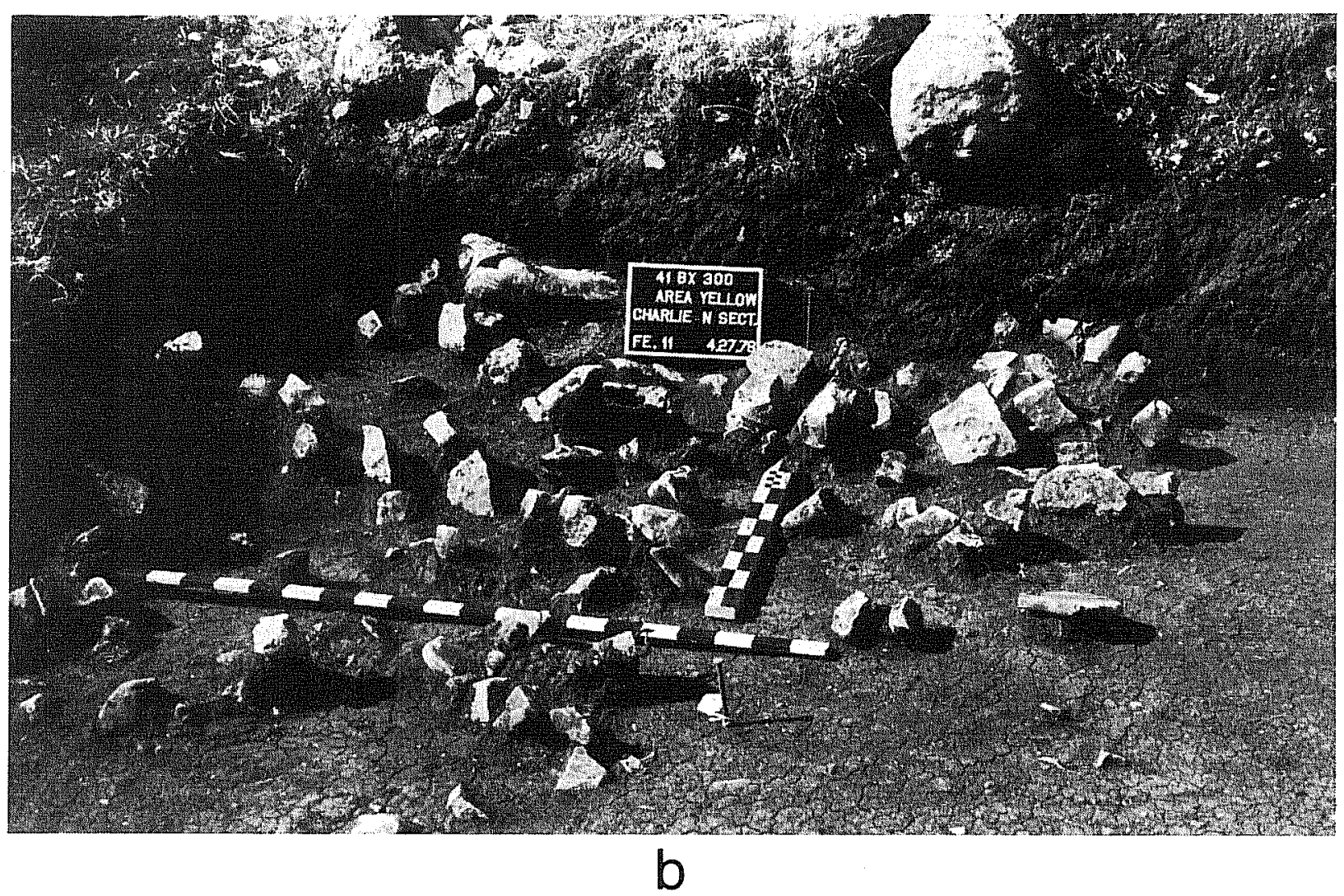

Figure 41. Views of Features 10 and 11. a, Feature 10, p 1 an and cross section (Area White); b. Feature 11, completed excavation (Area Yellow). 


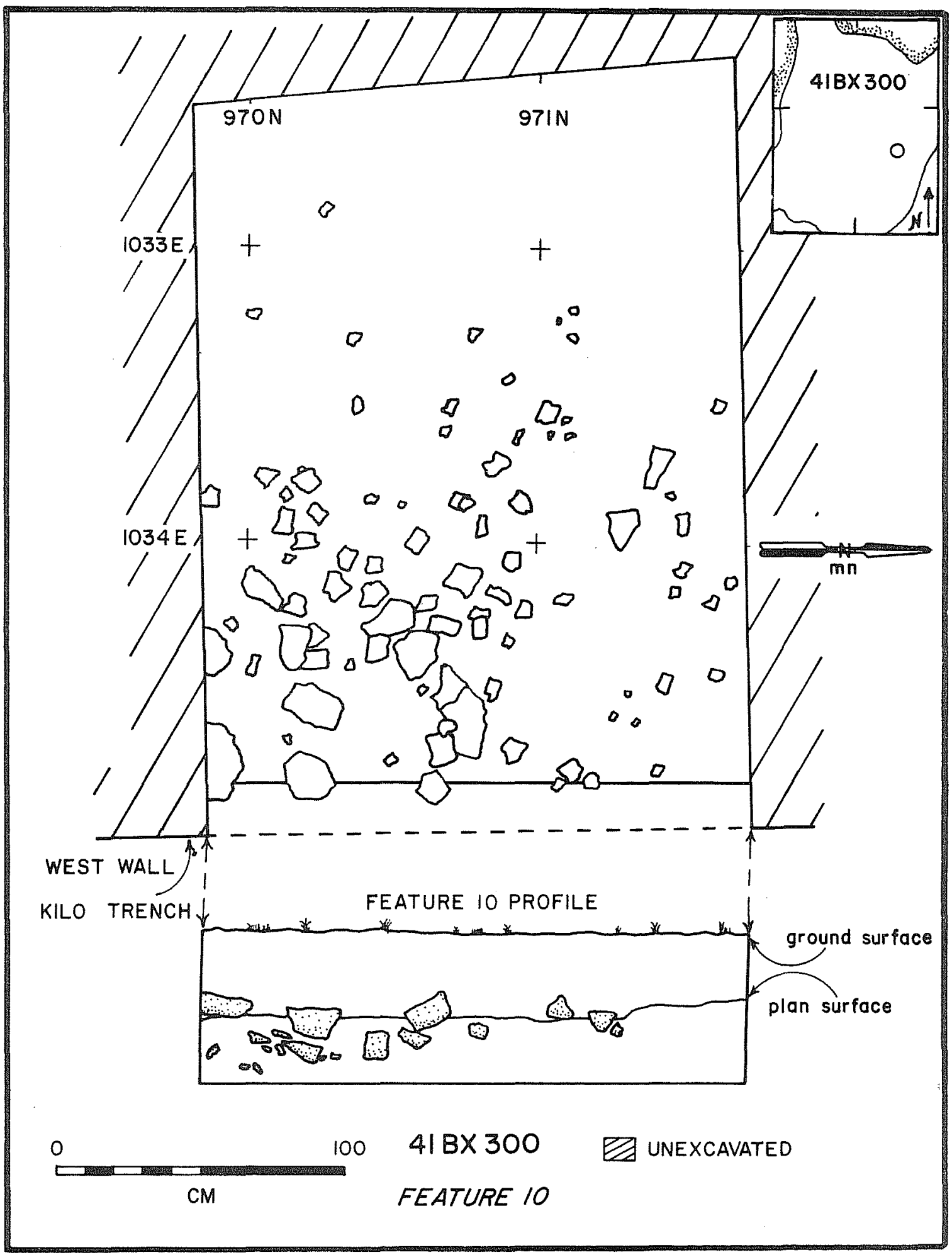

Figure 42. Plan and Profile Drawings of Feature 10, Area White. 


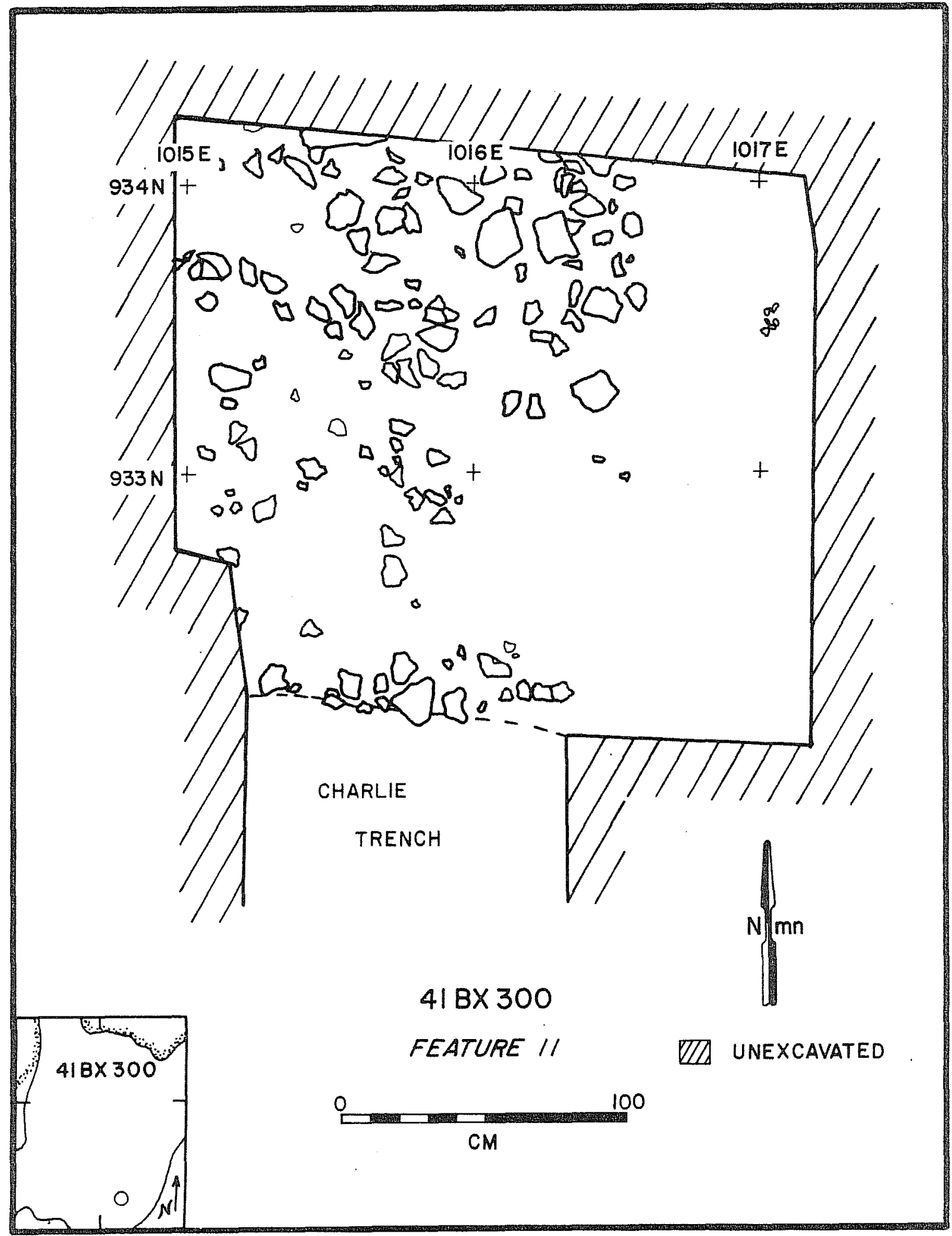

Figure 43. Plan Drawing of Feature 11, Area Yellow. 
$3.2 \mathrm{~m}^{2}$ compared with $3.8 \mathrm{~m}^{2}$ for Feature 10 . Feature 11 rocks were smal1 and angular, averaging eight centimeters in diameter; but both features average the same volume of burned rock per square meter (Table 25). It almost seems as though Feature 10 evolved into Feature 11 after sufficient time and usage.

Cultural material occurred in Feature 11 in relatively greater quantity as compared to Feature 10 (Table 30), e.g., more bifaces, flakes, and a few scraps of bone. This fact perhaps supports the interpretation that Feature 11 was an exhausted version of Feature 10 . They were contemporaneous as we 11, at least on a stratigraphic basis. Both began $20 \mathrm{~cm}$ below ground surface, extended to $45 \mathrm{~cm}$ below the ground surface, and were in direct contact with the Del Rio clay stratum. The single associated projectile point, identified as a Bulverde, supports a date in the Middle Archaic period.

\section{BURNED ROCK SCATTER}

\section{FEATURE 8}

Feature 8 was first identified at the south end of Hotel trench, physically separated from the edge of the midden by approximately five meters of undisturbed topsoil (Fig. 22, bottom right). What appeared to be another hearth in the profile of the trench end wall turned out to be a solid and extensive distribution of burned rock (Figs. 39,a; 44).

The dimensions noted in Table 25 represent the extent of excavation, so the calculated area of $7 \mathrm{~m}^{2}$ is on $7 y$ a minimum. It is not known how extensive this scatter of burned rocks was, as the period allocated for field work ended before investigations were completed. The feature consisted of one course of sma11, angular burned limestone rocks, averaging about seven centimeters in diameter. The similarity of these rocks to those constituting the matrix of the midden is considered to be more than a coincidence, and a relationship is postulated between the two features.

The stratigraphic situation of Feature 8 at the bottom of the topsoil stratum is comparable to that of the midden. Underlying the scatter was a remnant of the Del Rio clay, in which cultural material was located (to be described in conjunction with the occupation floor designated Feature 5). Suffice it to say now that the Feature 5 material is comparable in age to the Travis points underlying the midden, thus reinforcing a stratigraphic correspondence with artifactual cross dating.

Material associated with the burned rock scatter generally matches the categories of midden material (Table 26); the quantities are smaller, as befitting the relative proportions of the two features. Tools include implements for procuring and processing animals, and pieces of burned bone were recovered (Table 20).

The single projectile point from Feature 8 is unfortunately an Ensor type, suggesting a date for the feature during the Twin Sisters phase of the Late Archaic, ca. A.D. 200-600. This post-dates the midden and conflicts with the stratigraphic interpretation. 


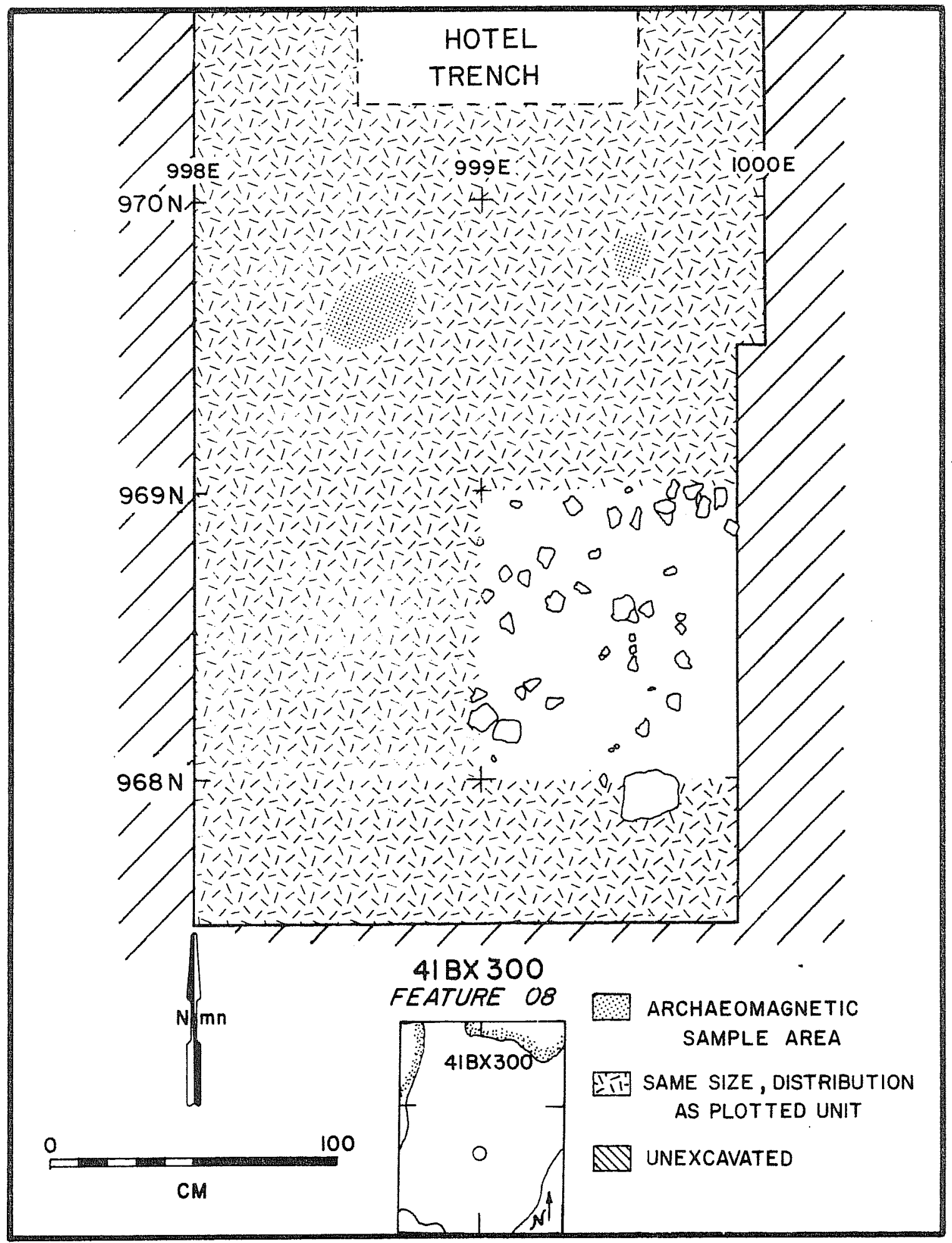

Figure 44. Plan Drawing of Feature 8, Area Red. 
Both features, however, exhibit similarities in stratigraphic situation, artifact association, constituent elements, and thus presumably in function. It is postulated that Feature 8 represents the very beginning of a second midden at 41 BX 300 .

\section{OCCUPATION FLOORS}

The designation of an occupation floor as a feature, or a feature as an occupation floor for that matter, deserves a brief introduction. An occupation floor ideally represents an actual prehistoric living surface, but in actuality it is an archaeologically defined synchronic plane. A11 material associated with that plane is considered contemporaneous, even though the plane may be discontinuous. Other strata and features at the site may be associated with the living floor by analytical means, particularly by the mutual presence of diagnostic artifacts. The definition of the occupation floor, and by extrapolation of the synchronic plane, may be by means of corresponding absolute depths, by stratigraphic relationships, by diagnostic artifacts, and usually by two or more of the above.

\section{FEATURE 4}

Feature 4 is perhaps a classic example of an occupation floor. The segment investigated occurs in three units $(076019$, 076029, 076030) situated between Features 3 and 6 in the southeastern portion of Area Red (Figs. 11; 12). These two hearths were considered to be contemporaneous during the course of their excavation. Assuming this, the area between them, and at a level corresponding to the ground surface at the time the hearths were in use, should provide the conditions for an occupation floor. A 5-cm zone was defined for the floor, bounded at the upper end, by the depth of a projectile point found lying flat, and on the lower end, by an extension of both hearth levels.

Excavation of this $5-\mathrm{cm}$ level proceeded very carefulty (Fig. 37,a), and each artifact and ecofact was individually recorded following the procedures of the Total Inventory Recovery Experiment (see Excavation Procedures).

Table 26 indicates that the material categories associated with Feature 4 general1y match those of Features 3 and 6 , with Feature 3 being a closer match in quantity as well. The proximity of the floor area to the features suggested this would be the case, as activities immediately preceding or following use of the fire areas would be expected to take place on this spot. Tools for faunal procurement and processing and burned bone (Table 20) reflect the activity postulated for Feature 3 ; botanical evidence for a winter season (Table 16) matches a similar seasonal interpretation for both Features 3 and 6 ; and the Frio point (Tables 27, 28) found on the occupation floor dates the floor to the middle of the Late Archaic (Prewitt 1983), the same period as Feature 3 and possibly Feature 6 as wetl. 


\section{FEATURE 5}

Feature 5, an occupation floor, was defined by stratigraphic means, and as such was identified in several different portions of the site. It was associated with either the top of the Del Rio clay stratum or the Edwards 1 imestone stratum, depending on which makes contact with the base of the present topsoil zone. Elements of this feature were known from beneath the midden (Feature 2); below Feature 8, the burned rock scatter (Fig. 22, bottom right); and underlying the complex of hearths and living area in Area Red designated as Features 3, 4, and 6 (Figs. 11; 12; 33,b).

In the case of the previous occupation floor, Feature 4, it was the proximity and level of the two hearths that helped set the parameters for defining it. In defining Feature 5, the three hearths designated Features 9, 10, and 11 were associated with the occupation floor (Feature 5) because of their stratigraphic situation at the contact of the topsoil and either gravel (Feature 9) or clay (Features 10,11).

Diagnostic artifacts, specifically projectile points, also assist with this definition. Of the five points recovered in the appropriate stratigraphic context in 12 units of investigation, two are Travis points (Table 27). As two other Travis points were recovered from under the midden in a similar stratigraphic situation, the living floor as a whole is assigned to a date early in the Middle Archaic Clear Fork phase, ca. 2600-2100 B.C. (Prewitt 1983), and corresponding to Local Period 6 (Black and McGraw 1985). The remaining three points recovered at the base of the topsoil are Tater in time and associated with subsequent occupations at the site; these include fragments of a Pedernales and a Montell and a Lange point (Tables 27, 28 ). Having observed the topsoil develop large cracks when excessively dry, it is not surprising to find thin, heavy artifacts moving to lower levels within the site. The subsoil strata of clay or gravel catch this material and stop its descent, resulting in a mixed association of material. As a consequence, no single artifact can be employed for interpretive purposes. In the case of assigning Feature 5 to the Clear Fork phase, however, the consistent stratigraphic association and multiple occurrence of the same type of point substantiate the dating.

One advantage of defining an occupation floor is the increase in material elements that can be associated with features and with the cultural period in general. Feature 5 artifact categories (Table 26) add to those known from Features 10 and 11 , although the range of tools is similar. Chipped stone tools for faunal procurement and processing, and some pieces of animal bone, provide support for the function suggested for the hearths. Stone tool manufacture and maintenance are also indicated, activities which the hearths could not document. Finally, botanical data (Table 16) suggest a fall or winter occupation; seasonal data which were also lacking from an analysis of the hearths alone.

\section{FEATURE 7}

Feature 7, an occupation floor, was defined in yet another manner, by the presence of a diagnostic artifact type. An isolated unit intended to seek 
activity peripheral to the midden yielded a sherd of Leon Plain pottery (Fig. $26, k)$ close to the surface of the ground. A block excavation eventually resulted, covering $12 \mathrm{~m}^{2}$ of area (Figs. $10 ; 11 ; 12 ; 14, \mathrm{~b}$ ). The feature was defined by the presence of pottery, and the final depth was $30 \mathrm{~cm}$ below the ground surface. It is perhaps more accurate to refer to Feature 7 as an occupation "zone" rather than "floor."

Other diagnostic artifacts recovered from this feature include four marine shell beads (Fig. 26,j) and a Perdiz point (Fig. 26,b), which, when added to 22 sherds and the proximity to the present ground surface, strongly argues for a Late Prehistoric period occupation at the site. There is evidence that both the Toyah and Austin phases are comingled in the feature material, as well as dart points from earlier occupations and historic material postdating the Late Prehistoric (Tables 26, 27).

The 1 arge number of chunks and flakes recovered (Table 26) argues strongly for tool manufacture and maintenance activities. Faunal procurement and processing are also indicated by the chipped stone assemblage; and bone, some burned, was recovered in relatively large quantity compared to other components at the site. Identification of deer and antelope (Table 19) indicates big game hunting. No processing feature was attributable to this component of the site's occupational history, and the focus of Late Prehistoric activity at the site seems to have been at Feature 7.

\section{SUMMARY AND EVALUATION}

\section{BACKGROUND AND IMPLEMENTATION OF THE PHASE III MITIGATION PROJECT}

Site 41 BX 300 is located in northern Bexar County, situated on the west bank of Long, or Elm Waterhole, Creek in the upper Salado Creek watershed (Figs. $1,3,4)$. The most prominent physical feature in the site locality is a permanent spring-fed pool known as Elm Waterhole, which forms the northern boundary of the site (Figs. $1 ; 2, a ; 3$ ).

Prior to the middle of the Holocene, two streams flowed by the present archaeological site, one on each side (Fig. 3). The interchannel divide, now the present site locus, was subject to periodic flooding, alluvial deposition, and erosional activity to a demonstrable, but quantitatively unknown, degree (see Evans, this report). Formation of the sinkhole (designated EIm Waterhole), pirated the water from one stream, an event accompanied by movement of the other channel farther east to its present configuration (Figs. 1,3). Only at this time, somewhere in the middle of the post-Pleistocene geological period, would the site have been physically stable enough to have been attractive for human occupational activity. Based on the interpretations of the geomorphological data from the site, cultural remains at the site associated with the Paleo-Indian and Early Archaic periods would represent the losses of an occasional passerby or more likely the redeposition of material left or lost outside the boundaries of the present site. In situ occupational material and features would not be expected until the early part of the Middle Archaic period beginning ca. 2600 B.C. with the Clear Fork phase (Prewitt 1983). This corresponds to Salado Creek Watershed Local Period 6 (Black and McGraw 1985). 
The current project is the culmination of a series of archaeological investigations instituted in conjunction with the planning and construction of Soil Conservation Service Floodwater Retarding Structure 13A in the upper Salado Creek watershed. The University of Texas Archeological Survey first recorded 41 BX 300 and five adjacent sites in 1971 (Dibble 1979), sites which were later investigated in 1975 and 1976 by the CAR-UTSA (Kelly 1975; Hester, Katz, and Kel7y 1977).

Archaeological investigations in the site vicinity were accomplished in three sequent phases. Phase I was the reconnaissance in 1975 which reassessed three impacted sites: $41 \mathrm{BX} 299,41 \mathrm{BX} 300$, and 41 BX 301 (Kel1y 1975). Sites 41 BX 299 and 41 BX 30.1 were identified as chipped stone procurement sites, and 41 BX 300 was considered a multicomponent occupation area. Phase II, conducted in 1976, consisted of limited testing at $41 \mathrm{BX} 300$ and $41 \mathrm{BX}$ 301 (Hester, Katz, and Kelly 1977). A combination of significant archaeological data potential and severe adverse impact from construction activities encouraged the SCS to fund this phase. Three additional sites-$41 \mathrm{BX} 484,41 \mathrm{BX} 485$, and $41 \mathrm{BX} 486$--were recorded at this time as well.

Results of testing at 41 BX 301 (Katz 1978) suggested that the site served as a source of chipped stone raw material, but not as a workshop. Nodules were tested and quarry blanks produced, as evidenced by the substantial amount of primary decortication flakes; but the paucity of interior flakes, bifacial blanks and preforms, and broken tools suggested production was accomplished elsewhere (see Table 4). The investigations at 41 BX 300 determined that at least one burned rock midden was buried at the site, and that several chronologically distinct occupations were present in horizontally distinguishable portions of the site (Hester, Katz, and Kelly 1977). As limited testing served only to emphasize the scientific value of $41 \mathrm{BX} 300$, about three and one-half acres of the richest cultural deposits were left intact during construction of the dam. Unfortunately, removal of soil entirely around $41 \mathrm{BX} 300$ left it pedestaled and subject to accelerated erosional activity (Figs. $2, \mathrm{~b} ; 6 ; 7 ; 8$ ). In response to the impending loss of cultural material and scientific information, a third phase of mitigation was funded by the Denver office of the National Park Service's Interagency Archeological Services. The field work was carried out in 1978, with the results and interpretations presented in this report.

\section{RESULTS OF THE PHASE III MITIGATION PROJECT}

\section{EXCAVATION}

The site area, calculated at $13,800 \mathrm{~m}^{3}$ (see Table 9), was subdivided three times to facilitate both horizontal and vertical control of collection and excavation activities. An initial division into five areas (Fig. 8) was accomplished by reference to the Phase II findings of horizontally distinguishable chronological features (Hester, Katz, and Kelly 1977) and the surface data compiled during constant monitoring of the site between 1976 and 1978. Then the site area was gridded into 10-m blocks (Fig. 9), each of which was in turn divided into 100 one-meter square units. These units became the basic excavation device for the project, and each bore a unique 
numerical designation based on its associated $10-\mathrm{m}$ block and its position within the block.

During the 60 days of activity at the site, approximately $335 \mathrm{~m}^{3}$ of soil were excavated, representing $3.5 \%$ of the site area extant after construction of the dam (see Table 9). The excavations included 121 one-meter square units and 18 trenches, the latter totaling about $381 \mathrm{~m}$ in length (see Tables 7,9 ). Surface collection, employing the $10-\mathrm{m}$ blocks as central units, intensively covered $57 \%$ of the present site area (see Table 8 ).

\section{STRATIGRAPHY}

The stratigraphy at the site is deceptively simple. There are three strata: topsoil, subsoil, and bedrock. Site bedrock is the Edwards 1 imestone, and elements of Del Rio clay are present as subsoil in different portions of the site. The Del Rio clay is easily erodable and was subjected to significant erosional forces due to the former presence of two streams; both factors account for its spotty remains. Alluvial deposition of the present topsoil began when the site geomorphology stabilized in the middle of the postPleistocene.

Cultural material associated with the earliest occupational episodes at the site, those of the early Middle Archaic period were situated on or immediately above the Edwards limestone or Del Rio clay subsoil strata; subsequent occupations, from the late Middle Archaic through the Late Prehistoric periods, were associated with the topsoil stratum. No stratigraphic distinctions were observable within the topsoil, and chronological interpretations of material associated with this stratum are based on diagnostic artifacts and gross elevational relations between the recorded features.

\section{FEATURES}

of the 10 features identified and recorded during Phase III activities, four were in direct association with either the gravel or clay subsoils. Three (Features 9, 10, and 11) were hearths, composed of burned 1 imestone rocks (Figs. 39,b; 40-43) and associated with chipped stone cutting and scraping tools in small numbers (Table 26). The top of the gravel and clay subsoil, at the point of contact with the bottom of the topsoil, was interpreted as an occupation floor of the early part of the Middle Archaic period (Clear Fork phase) and designated Feature 5 accordingly (Fig. 33,b). Artifacts from the occupation floors were associated with the presumed contemporaneous hearths, including projectile points diagnostic of their proposed temporal association (Table 26).

The single burned rock midden (Feature 2) recorded at the site, and a burned rock scatter (Feature 8) interpreted as a nascent midden mound, were stratigraphically situated at the bottom of the topsoil stratum and are thus later in the Middle Archaic period than are the three hearths and occupation floor previously discussed. The midden was approximately circular (Figs. 11, 12), measuring $17 \mathrm{~m} \times 15 \mathrm{~m}$ along its major and minor axes and composed of 
small, angular burned rocks in a dark, ashy matrix. The midden was constructed from a single course of rocks at its periphery to a maximum thickness of. $68 \mathrm{~cm}$ at its apex in the center (Figs. 22; 23;32;33,a). Material associated with the midden fill includes quantities of interior flakes and molluscan remains, but the number of identifiable tools and tool fragments is negligible (Table 26). No evidence of internal stratigraphy or patterning of matrix constituents was recognized.

The scatter of burned rocks (Feature 8) located south of the midden 7 ies at a stratigraphic level equivalent with the base of the midden. The full extent of Feature 8 was not determined, due to incomplete excavation (Figs. 39,a; 44). While associated cultural material was sparse, stratigraphic and material similarities between Feature 8 and the midden (Feature 2) assign both to the Round Rock phase of the late part of the Middle Archaic period (Table 26).

Two additional hearths (Features 3 and 6) and the presumed occupational floor between them (Feature 4) were stratigraphically above the burned rock scatter and the base of the midden. The hearths were roughly similar in size, shape, constituent burned rock, and associated material (Figs. 34-37). Feature 6 had the unusual element of a grinding slab reused as a hearth rock, (Fig. 38), but in general the artifacts are chipped stone cutting and scraping tools and debris (Table 26). The horizontal plane on which the two features were lying was considered a contemporaneous occupation floor (Feature 4), and associated material augmented from the two hearths identified activities and established chronological relationships (Table 26).

Feature 7 was essentially an artifact concentration, localized in a 12-m² area on and just beneath the surface of the site (Figs. $11 ; 12 ; 14, b$ ). Associated artifacts (Table 26) support the stratigraphic positioning and indicate a Late Prehistoric date for Feature 7, the 1 ast occupation at the site.

\section{MATERIAL RECOVERED}

Table 29 summarizes the general categories of material recovered during Phase III activities. A variety of special samples was collected, oriented either toward chronological interpretations or environmental reconstruction. The amount of charcoal recovered was in all instances too 1 imited for dating by radiocarbon, although the four largest amounts were submitted for an unsuccessful attempt. The remaining samples of wood charcoal proved most valuable, however, for both species. identification and seasonality interpretations (see Table 15). Both archaeomagnetic (Fig. 35, a; Table 22) and thermoluminescence (Table 23) samples of burned 7 imestone hearth and midden rocks proved unsuccessful for dating purposes, due to low firing temperatures. Samples of soil from a variety of levels and features throughout the site provided several different analyses, in particular mechanical and organic content (see Tables 13, 14) and the generation of additional vegetal and floral material for species identification and seasonal interpretations (see Table 16). Special samples of soil were taken for phytolith identification (Fig. 16,b; Table 17), which in turn would 
TABLE 29. SUMMARY OF ALL MATERIAL RECOVERED DURING PHASE III MITIGATION ACTIVITIES AT 4 I BX 300

\begin{tabular}{|c|c|c|}
\hline Type of Material & $\begin{array}{l}\text { Number of } \\
\text { Specimens }\end{array}$ & $\begin{array}{c}\text { Percentage of Total } \\
\text { Collection }\end{array}$ \\
\hline $\begin{array}{l}\text { Prehistoric Artifacts } \\
\text { Stone } \\
\text { Other }\end{array}$ & $\begin{array}{r}101,563 \\
101,533 \\
30\end{array}$ & 91.76 \\
\hline Historic Artifacts & 38 & 0.04 \\
\hline Total Artifacts & 101,601 & $(91.80)$ \\
\hline $\begin{array}{l}\text { Ecofacts } \\
\text { Faunal } \\
\text { Seeds } \\
\text { Vegetal } \\
\text { Molluscan } \\
\text { Mineral }\end{array}$ & $\begin{array}{r}117 \\
88 \\
43 \\
5,513 \\
3,120\end{array}$ & $\begin{array}{l}0.10 \\
0.08 \\
0.04 \\
4.98 \\
2.82\end{array}$ \\
\hline Totàl Ecofacts & 8,881 & $(8.02)$ \\
\hline $\begin{array}{l}\text { Samples } \\
\text { Soil } \\
\text { Phytolithic } \\
\text { Charcoal } \\
\text { Radiocarbon } \\
\text { Archaeomagnetic } \\
\text { Thermoluminscence }\end{array}$ & $\begin{array}{r}79 \\
29 \\
13 \\
4 \\
37 \\
39\end{array}$ & $\begin{array}{l}0.07 \\
0.03 \\
0.01 \\
0.00 \\
0.03 \\
0.04\end{array}$ \\
\hline Total Samples & 201 & $(0.18)$ \\
\hline Grand Total & 110,683 & 100.00 \\
\hline
\end{tabular}


provide environmental data through time; the analysis, unfortunately, was not successfut.

During the course of collection and excavation, nonartifactual material of various kinds was recovered. Land snail shells were the most numerous; a large percentage of the total was associated with the midden and recovered centimeter-by-centimeter in an experimental excavation of a single interior unit. Noncultural lithic material is represented by samples of burned limestone and natural chert nodules recovered as much by accident as by design. Animal bone, seeds, and other floral items were eagerly sought after for their value in interpreting site functions and environment, but the numbers of all these ecofacts were disappointingly small (Table 29).

The only items recovered in sizeable quantities were chipped stone flakes, representing the manufacture and maintenance of chipped stone tools (Table 24). Prehistoric tools of other materials and historic items of all materials (Appendix I.B, Parts 7-10) were so limited as to be inconsequential in functional and chronological interpretations (Table 29). of the identifiable chipped stone tools and tool fragments, the overwhelming majority represent presumed piercing, cutting, and scraping functions, i.e., faunal procurement and processing. Fabricating tools are essentially nonexistent, despite the evidence for tool production provided by the amount of processual debris. Appendix I provides categorical and locational data for all manufactured chipped stone tools; chipped stone tool by-product data is available at the UTSA-CAR.

\section{ENVIRONMENT AND SEASONALITY}

The results of the botanical, faunal, and molluscan analyses a11 agree that environmental conditions during all occupational episodes at the site were much the same as they are today.

Although the amount of floral material was not great, most was associated with features due to its recovery from soil samples (see Table 16). The chronological range of these cultural features extends from the early part of the Middle Archaic (ca. 2600 B.C.) through the Late Prehistoric period (ca. A.D. 1800), but a comparison of identifiable excavated specimens (Table 16) with contemporary data for the site (Appendix II) shows close similarities throughout this 4400-year time span.

Despite an even smaller sample of identifiable faunal material, a similar situation occurs. Examples of deer or antelope and armadillo were recovered from the late part of the Middle Archaic period midden (Feature 2) and from the Late Prehistoric occupation area (Feature 7; Table 19). The faunal analyst (H. Wooldridge) concludes that,

a pattern of exploitation of both the mixed scrub forest and grassland prairie is indicated. . . All species represented within the assemblage are found in the area today; from the data at hand, it would appear that conditions were much the same as today. 
A similar conclusion is reached by the molluscan analyst ( $\mathrm{H}$. Murray), based on over 5500 specimens recovered from all units of investigation:

In summary, the molluscan fauna from $41 \mathrm{BX} 300$ suggests that the ecology of the site at the time of habitation was similar to the area today. These data indicate that the area was a semiarid, wooded grassland.

Botanical data suggest the time of the year for occupational activity was during the colder months, i.e., the last and the first quarters of the year, or during the fall and winter seasons. Recovered material includes elm winter buds, juniper pollen, crucifer seeds, short shoots, and immature grasses, a 71 of which are produced in cold weather. These were recovered from cultural features ranging in time from the early part of the Middle Archaic (Features 5 and 9), through the 7 ate part of the Middle Archaic (Feature 2) and the Late Archaic (Features 3 and 6), to the Late Prehistoric period (Feature 7; see Table 16).

The site may, of course, have been active at other seasons of the year during any of the various chronological periods, but the available evidence favors a cold weather occupation during most of the site's documented usage. Moreover, there is a direct relationship between the season and the nature of the activities performed, in that the seasonal data were recovered from cultural contexts associated with burned rock, chipped stone, and faunal remains (compare Tables 16 and 26).

\section{OCCUPATIONAL SUMMARY}

Four sequent episodes of occupation can be documented as a result of the 41 BX 300 archaeological projects. Table 30 summarizes their characteristics, and each is briefly discussed. Beginning in the early part of the Middle Archaic period, ca. 4600 years ago, occupation can be demonstrated for a span of 4400 years until the end of the Late Prehistoric period, possibly as recentiy as ca. 200 years ago. Documentation of these episodes includes in situ diagnostic artifacts, associated features, and chronologically consistent stratigraphic positioning and interrelationships. By the same token, the absence of features, the variable stratigraphic recovery of diagnostic artifacts, and the paucity of the latter, a 11 indicate the absence of occupational activity during the Paleo-Indian, Early Archaic, and Historic periods.

\section{EVIDENCE FOR PRE-MIDDLE ARCHAIC OCCUPATION}

The geomorphological investigation of the site area concluded that the waterhole probably originated no earlier than the middle of post-Pleistocene times (see Introduction). This event occurred in conjunction with the deflection of one of two streams adjacent to the site; the result was that a location suitable for human activity and occupation was created. It is not surprising, therefore, that there is a total absence of Paleo-Indian projectile points in the $41 \mathrm{BX} 300$ collection, in that the site did not exist in late or terminal Pleistocene times. 


\begin{tabular}{|c|c|c|c|c|c|c|c|c|}
\hline \multirow{2}{*}{$\begin{array}{l}\text { Cultural Stages } \\
\text { (after Prewitt } \\
1981,1983 \text { ) }\end{array}$} & \multirow{2}{*}{$\begin{array}{l}\text { Salado Creek } \\
\text { Watershed Local } \\
\text { Period (Black } \\
\text { and McGraw 1985) }\end{array}$} & \multirow{2}{*}{$\begin{array}{l}\text { Temporal } \\
\text { Range } \\
\end{array}$} & \multirow{2}{*}{$\begin{array}{r}\text { Olagnostic Artifacts } \\
(N \geq 2)\end{array}$} & \multicolumn{3}{|c|}{ Characteristics } & $:$ & \multirow[b]{2}{*}{$\begin{array}{l}1 \text { Time } \\
1 \text { of } \\
1 \text { Year }\end{array}$} \\
\hline & & & & $\begin{array}{l}\text { Use of } \\
\text { Site Area }\end{array}$ & \begin{tabular}{|l|} 
Assoclated \\
Burned Rock \\
Features
\end{tabular} & $\begin{array}{l}\text { Assoclated } \\
\text { Occupation } \\
\text { Floor }\end{array}$ & $\begin{array}{l}\text { Activities } \\
\text { Performed }\end{array}$ & \\
\hline $\begin{array}{l}\text { Late } \\
\text { Prehistoric }\end{array}$ & $\begin{array}{c}1 \\
\vdots \\
1 \\
1 \\
1\end{array}$ & A.D. $750-$ & $\begin{array}{l}\text { Perdiz, Edwards } \\
\text { points; Leon Plain } \\
\text { pottery; marine } \\
\text { shell beads }\end{array}$ & $\begin{array}{l}\text { Restricted } \\
\left(12 \mathrm{~m}^{2}\right) \\
\end{array}$ & None & Feature 7 & $\begin{array}{l}\text { Chipped stone tool } \\
\text { production; fauna1 } \\
\text { procurement and } \\
\text { processing }\end{array}$ & $\begin{array}{l}\text { Fall } \\
\text { and } \\
\text { winter } \\
\text { W }\end{array}$ \\
\hline Late Archate & $\begin{array}{c}1 \\
1 \\
1 \\
1 \\
1 \\
1 \\
-1\end{array}$ & $\begin{array}{l}\text { A.D. } 750- \\
250 \text { B.C. } \\
\end{array}$ & $\begin{array}{l}\text { Castroville, Darl, } \\
\text { Ensor, Falrland, } \\
\text { Figueroa, Frio, } \\
\text { Marcos, Montell } \\
\text { points }\end{array}$ & $\begin{array}{l}\text { Moderate } \\
\text { (Areas Red } \\
\text { and Green) }\end{array}$ & $\begin{array}{l}\text { Circular } \\
\text { hearths } \\
\text { (Features } 3 \\
\text { and 6) } \\
\end{array}$ & Feature 4 & $\begin{array}{l}\text { Chipped stone tool } \\
\text { production; faunal } \\
\text { procurement and } \\
\text { processing; vege- } \\
\text { tal processing }\end{array}$ & $\begin{array}{l}\text { Fall } \\
\text { and } \\
\text { winter } \\
\end{array}$ \\
\hline $\begin{array}{l}\text { Late in the } \\
\text { I Middle Archatc } \\
\text { I }\end{array}$ & $\begin{array}{c}1 \\
1 \\
1 \\
1 \\
1 \\
1 \\
1\end{array}$ & 250- 1500 B.C. & $\begin{array}{l}\text { Langtry, Pedernales } \\
\text { points }\end{array}$ & $\begin{array}{l}\text { Limfted } \\
\text { (Area Red) } \\
1\end{array}$ & $\begin{array}{l}\text { Midden } \\
\text { (Feature 2); } \\
\text { Scatter } \\
\text { (Feature 8) }\end{array}$ & $\begin{array}{l}\text { None } \\
\text { Identified } \\
1\end{array}$ & $\begin{array}{l}\text { Chlpped stone tool } \\
\text { production; faunal } \\
\text { procurement and } \\
\text { processing, vege- } \\
\text { tal processing }\end{array}$ & $\begin{array}{l}\text { Fall } \\
\text { and } \\
\text { winter }\end{array}$ \\
\hline $\begin{array}{l}\text { Early in the } \\
\text { Middle Archatc } \\
\end{array}$ & $\begin{array}{c}1 \\
1 \\
1 \\
1 \\
1 \\
1\end{array}$ & $\begin{array}{l}1500- \\
2600 \text { B.C. }\end{array}$ & $\begin{array}{l}\text { Bulverde, Nolan, } \\
\text { Travis points } \\
\end{array}$ & $\begin{array}{l}\text { Extensfve } \\
\text { (all Areas) } \\
\end{array}$ & $\begin{array}{l}\text { Circular } \\
\text { hearths } \\
\text { (Features } \\
9,10,11 \text { ) } \\
\end{array}$ & Feature 5 & $\begin{array}{l}\text { Chipped stone tool } \\
\text { production; faunal } \\
\text { procurement and } \\
\text { processing }\end{array}$ & $\begin{array}{l}\text { Fall } \\
\text { and } \\
\text { winter }\end{array}$ \\
\hline
\end{tabular}


An Early Archaic presence is documented in the general vicinity of 41 BX 300 , as evidenced by the collection of diagnostic projectile points donated to the CAR by the Menger brothers (Table 2). Seven projectile points from this period (Table 28) were recovered during the mitigation activities, but their proveniences (Appendix I. B, Part 1) do not suggest an occupation of the site. The earliest point, an Angostura, was found in redeposited topsoil in the northwest (Area Blue) portion of the site, as was one of the three Uvalde points which date about 2000 years later. Another Uvalde point was recovered from the surface in the south (Area Yellow) portion, as was the single Gower point dating 1000 years earlier. Two Martindale points were collected from the surface in the central (Area Red) portion; and the third Uvalde point was recovered from trench backdirt in the northeast (Area Green) portion.

The eight Guadalupe tools, diagnostic of the late part of the Early Archaic period, exhibit a similarly varied distribution. Two were excavated from the subsoil zone, one each in the southern (Area Yellow) and central (Area Red) portions of the site. Two others, however, were excavated from the topsoil, both in Area Red and one in direct association with the Late Prehistoric occupation area (Feature 7). Three were recovered in trench backdirt (two in Area Yel1ow and one in Area Blue); and the last was a surface find in Area Yellow.

In summary, among the seven Early Archaic points, three temporal phases are represented; four are surface finds and one (the earliest) is in definitely redeposited topsoil; and four of the five areas of the site are represented among the point proveniences. The eight Guadalupe tools, while more temporally restricted, show an equaliy varied provenience distribution. No features associated with this period were identified; and in fact the earliest features recorded at the site are on the bedrock and date to the Middle Archaic. None of the seven Early Archaic points were associated with later features, although one of the Guadalupe tools was recovered in a Late Prehistoric context. There does not seem to be any evidence for postulating an occupation, or even any activity, at 41 BX 300 prior to the early Middle Archaic period.

EARLY MIDDLE ARCHAIC PERIOD (Salado Creek Watershed Local Periods 6 and [Early] 7, 2600-1500 B.C.)

The smal1 number and unpatterned locations of the diagnostic Early Archaic period artifacts do not indicate intentional and organized activities. In contrast, the early portion of the Middle Archaic period is well represented and firmly established at the site. The artifacts and features assigned to this stage are all associated with either the Edwards limestone or Del Rio clay subsoil strata, below or at the contact with the topsoil stratum. Based on the geomorphological interpretations of the site (see Environmental Characteristics) conditions for occupation only became stable enough at the time that topsoil began forming. The early portion of the Middle Archaic period is thus not only the earliest documented occupation, but the earliest possible occupation.

The clarity of the stratigraphic position below or at the contact with the topsoil/subsoil stratum facilitated the assignment of material and features 
to the early part of the Middle Archaic period. The result was one of extensive use of the site locality during this time. Wherever the subsoil was exposed during the investigation, artifacts were recovered. Three hearths were recorded; one was in a trench wall (Feature 9), but two (Features 10 and 11) were completely excavated. The following pattern of hearth utilization behavior is suggested. Local limestone cobbles were employed, averaging $20 \mathrm{~cm}$ in diameter. A hearth was reused until the rocks cracked into pieces about eight centimeters in diameter, and then the hearth was abandoned in place. During the lifespan of the hearth, direct and peripheral activities resulted in an increasing amount of artifactual and ecofactual material deposited in the feature, which was also left in place when the hearth became inactive.

The nature of the artifacts associated with the features indicates activities related to faunal processing: cooking, smoking, hideworking, and the like. The tools and tool fragments recovered are almost exclusively those whose function is interpreted as cutting and scraping (Table 26). Small numbers of animal bone (Tables 20, 26) support this interpretation. Projectile points and additional faunal processing tools were recovered in other parts of the site in association with the subsoil (Feature 5). The diagnostic point types of Bulverde, Nolan, and Travis further strenghten the chronological position of this occupation as the early part of the Middle Archaic period; they were recovered in appropriate stratigraphic position (see Appendix I. B, Part 1) and in relatively large quantities (Table 28 ).

Another behavioral aspect of this period is the 1 arge number of flakes and chunks recovered from the living surface, as compared with a virtual absence of these items from the hearths (see Table 26). This suggests that the activities of tool manufacture and maintenance were quite prevalent as far as the occupation extended, but that a clear demarcation was made between flintknapping areas and those areas devoted to heat-related faunal processing. While vegetal procurement and processing may have taken place, the artifact assemblage does not reflect these activities. No grinding implements or fragments were recovered, nor were any large scraping or chopping tools.

The identification of juniper pollen, elm winter bud scales, and crucifer seeds (Table 16) in soil associated with cultural material suggests activities at the site were conducted at least during the colder months of the last quarter (fal1) and the first quarter (winter) of the year. Since all analyses (faunal, botanical, molluscan) indicates an environment in the past similar to that at the site today, it can be postulated that faunal behavior would likewise be similar and that deer hunting would be most successful during the colder months. Lithic raw material for tool production and hearth tasks, as well as water, were immediately adjacent to the site and available year round, making animal hunting the primary scheduling variable.

LATE MIDDLE ARCHAIC PERIOD (Salado Creek Watershed Local Periods 7 [Late] and $8,1500-250$ B.C.)

Evidence of occupation during the late part of the Middle Archaic period is both distinctive and elusive. Its distinctiveness derives from two unique 
features at $41 \mathrm{BX} 300$ which are assigned to the period; its elusiveness stems from the fact that the features represent secondary deposition of cultural material, making activity reconstruction and extra-feature material associations uncertain.

Stratigraphically situated at the base of the topsoil stratum is the bottom of the single burned rock midden recorded at the site (Feature 2). Adjacent to the midden on the south and at the same stratigraphic level is a level concentration of burned rock designed as a "scatter" (Feature 8). Stratigraphically these two features are contemporaneous and younger than the early part of the Middle Archaic period occupation of the subsoil-topsoil transition. An Ensor point at the top of the scatter and Travis points recovered from below the midden more firmly establish these features as representing the late part of the Middle Archaic period.

Because the burned rock midden is so characteristic of the central Texas Archaic cultures, and yet its exact function is still interpreted in a variety of ways, much time and effort were expended in its investigation. Trenches, isolated units, backhoe stripping, and centimeter-by-centimeter excavation in one portion were techniques employed (Figs. 11, 12). Specifically, the three most prevalent hypotheses-rock oven, intersecting hearths, and community dump (cf. Sorrow 1969; Hester 1970; Prewitt 1976; Peter 1982; Howard 1983)--were tested against the data recovered from $41 \mathrm{BX} 300$. While the midden fill consisted of burned 1 imestone rocks in a matrix of fine, black, ashy soil, no evidence was recovered of in situ burning. The subsoil at the base of the midden was neither colored nor hardened, but rather it was identical to soil in all other stratigraphically similar portions of the site. No internal concentrations of burned rock were identified, such as would be expected if individual hearths were constructed and then abandoned in place. Nor was any larger form of architectural design encountered, which might have been interpreted as an oven.

The nature and degree of material remains support the architectural picture of unpatterned construction representing a disposal activity. Chipped stone artifacts of all categories are extremely sparse, considering the area and volume of the feature (see Table 26). The only items recovered in any quantity were land snail shells (see Table 26), and this is interpreted as due to a habitat of disturbed, moist, organic soil rather than of any cultural basis. The reconstruction of activities conducted by the occupants of the site during the 1 ate part of the Middle Archaic period can only be suppositional, based on the nature of tools presumed to have been discarded by the people whose general disposal pattern resulted in a midden. Activities of both faunal and vegetal processing can be postulated, for in addition to cutting and scraping tools there was a fragment of a grinding slab. Chipped stone tool manufacture and maintenance are documented by flakes with and without cortex, chunks, a core, and a production blank (see Table 26). Seasonality preferences cannot be determined due to the disturbed and redeposited nature of the soil, although deer bones (see Table 19) and crucifer seeds (Table 16) suggest the cold weather seasons of the year.

Extent of occupation is also indeterminate, as the original burned rock features which eventually became the constituent elements of the midden no longer exist. This is an irony of the "community dump" variety of midden: 
the presence of this feature suggests, almost by definition, that in situ contemporaneous hearths will not be present at the same site. At 41 BX 300 , only the midden and the nearby burned rock scatter can be associated with the late part of the Middle Archaic period, which "technically" Timits the extent of occupation to Area Red. The provenience of diagnostic projectile points also tends to support a focus in Area Red (compare Table 28 with Appendix I. B, Part 1).

One additional observation pertains to the relationship between the midden and the scatter. Both are characterized by the same size, shape, and kind of rocks (see Table 25), as well as by the same artifact and ecofact associations (see Table 26). The scatter is on the same horizontal plane as the base of the midden, and the former is interpreted as a nascent midden which in time would have presumably been simjlar to the latter. It is unfortunate that the total size and overall configuration of the scatter is not known. What can be said is that the midden does not seem to have been built up in a specific area and later expanded by gravity. Rather, an extensive area of ground seems to have been employed, perhaps equaling the area of the feature at maturity. Exhausted hearth rocks were then deposited over this entire area, building up to a summit rather than flowing outward in a constantly expanding circumference.

LATE ARCHAIC PERIOD (Salado Creek Watershed Local Periods 9 and 10 [Early], C. 250 B.C. -A.D. 750 )

The horizontal plane on which two burned limestone hearth features (Features 3 and 6) resided provided the control for establishing a Late Archaic period occupation. Artifactual material between the hearths was considered associated with this period, representing an occupation floor (Feature 4) contemporaneous with the hearths. The occupation was revealed within the topsoil stratum, stratigraphically higher and thus younger than that of the burned rock midden. Chronologically diagnostic projectile points of the Castroville, Darl, Ensor, Frio, and Marcos types, directly associated with the hearths or lying on the occupation floor, substantiate assignment of this occupation to the Late Archaic period.

Hearth behavior in this period seems to involve using a feature until the rocks became too small to function properly, and then abandoning the hearth in place. Feature 6 (Figs. $36 ; 37$, b) exhibits two components, one with larger rocks than the other. The larger rock component is more intact, with a circular orientation. The part with smaller, more angular rocks is more extensive and nongeometrical, exhibiting all the characteristics of an abandoned hearth. Feature 3 (Figs. 34, 35), with its larger rocks (averaging $12 \mathrm{~cm}$ in diameter) and geometrical configuration, is not considered to have been exhausted when it was abandoned.

Subsistence activities during the Late Archaic period can be postulated from material recovered in or adjacent to the hearths. Bifacially and unifacially retouched chipped stone tools and flakes indicate faunal processing in conjunction with the hearths (see Table 26), and the animal bone in the features substantiates this activity (see Tables 20, 26). A relatively large number of projectile points (see Table 28) indicates vigorous faunal 
procurement in the vicinity of the site. Vegetal processing is well documented by the presence of a grinding slab as an integral part of Feature 6 (Fig. 36, a, bottom center; Fig. 38). Crucifer seeds and elm winter bud scales, which could only have been deposited in cold weather, were recovered from both features and the intervening occupation floor (see Table 16), suggesting associated activities took place in the fall and winter.

The activities of tool manufacture and maintenance are documented by a Targe number of $\mathrm{flakes}$ and chunks, both inside one of the hearths and between the two hearths. In fact, the number of items from each category are very similar for both types of features (see Table 26). This may indicate that flintknapping and faunal processing activities overlapped and were much less spatially distinct than was the case during the early part of the Middle Archaic period. Total usage of the site area seems to have centered on Areas Red and Green, based primarily on the provenience of projectile points diagnostic of the Late Archaic (compare Table 26 with Appendix I. B, Part 1).

LATE PREHISTORIC PERIOD (Salado Creek Watershed Local Periods 10 [Late] and 11, ca. A.D. $750-1800$ )

The final prehistoric occupation, and the last one documented at the site, is at once the most restricted and the most intensive. Documented only in a $12-\mathrm{m}^{2}$ portion of Area Red, this period extends from the surface down only 29 $\mathrm{cm}$ (Feature 7 in Figs. 11; 12; 14,b). Supporting the stratigraphic position of a late occupation are the diagnostic artifacts such as arrow points, pottery, and marine shell beads (see Table 26).

The intensity of occupation is evidenced by the exceptional quantity of material recovered from a very small area. Within an excavated volume of on $1 \mathrm{y} 3.48 \mathrm{~m}^{3}$ over 11,000 flakes were recovered, representing fully half (50.32\%) of the flakes from a 1110 features at the site (Table 26). There are twice as many flakes, and more chunks, from Feature 7 than from Feature 5 , the early portion of the Middle Archaic occupation floor which extends over the entire site (see Table 26).

The nature of this material documents the activities of chipped stone tool manufacture and maintenance, undoubtedly utilizing the nearby resource areas. The occupation represents more than just a flintknapping workshop, however, as the faunal material indicates. Again, the quantity of bone exceeds by a factor of three that from the early part of the Middle Archaic occupation floor, with twice as many items as were recovered from the two Late Archaic hearths combined (see Table 26). The identifiable specimens are either deer or antelope (see Table 19), indicating large mammal hunting. Identifiable seeds and buds indicate a fall or winter usage of the site, based on the cold weather production of the floral items (see Table 16).

No burned rock features were documented within the occupation zone associated with this stage, nor was any burned rock recovered which might have indicated the presence of a stone feature. It is possible, however, to postulate that faunal processing did take place. Some of the animal bone recovered was burned (see Table 20), and charcoal saturated with animal fat was retrieved from a soil sample (see Table 15) taken out of the occupational matrix. No 
evidence of vegetal processing can be produced, either by way of grinding tools or chipped stone tool forms. However, the 22 sherds of Leon Plain pottery recovered from the feature do indicate a container for an indeterminate function.

\section{HISTORIC PERIOD (Post-A.D. 1800)}

The 38 specimens of historic material were recovered primarily from the northeast (Area Green) portion of the site and from either the surface or the topsoil zone (Appendix I.B, Part 20). Four pieces of bottle glass were associated with Feature 7 , the Late Prehistoric occupation area that was a surface and topsoil feature itself. No historic features or foundations were located, nor were the historic artifacts concentrated in any manner as to suggest activity. There does not seem to be any Historic period occupation at 41 BX 300 , although the northeast portion of the site seems to have been the focus of whatever minor visitation(s) which took place.

\section{BEHAVIORAL TRENDS THROUGH TIME}

Occupants of 41 BX 300 from the Middle Archaic to the Late Prehistoric periods engaged in the procurement and processing of faunal resources. This is determined by the remains of animal bones; by the recovery of the appropriate tools for piercing, cutting, and scraping; and by evidence for heating or cooking in the form of burned rock features and/or animal fatsaturated charcoal. Vegetal procurement and processing can be documented during the late part of the Middle Archaic and Late Archaic periods, but not during the early part of the Middle Archaic and Late Prehistoric periods. These activities may indeed have been conducted during these periods, but the artifacts needed for determination were not recovered.

Also characterizing each successive occupation was the production of chipped stone tools. Taking advantage of resource localities on both sides of 41 BX 300 , each group seems to have brought nodules and blanks back to the occupation area for shaping and sharpening. Whether people arrived at 41 BX 300 in order to take advantage of the 1 ithic resources and ate while producing their tools, or whether the attraction was the subsistence resources, and tools were produced because raw material was at hand, could not be determined. The site was occupied by all groups during the cold months of the year, i.e., during the fall and winter seasons. The time of the year in which the site was utilized was most likely determined by the availability of faunal resources. This locality was chosen over others probabiy because of the nature of the supporting resources: a convenient supply of stone and a constant source of water.

Variation in behavior through time is most apparent in the treatment of burned rock during and after its use in the heating process. A close similarity exists between the early part of the Middle Archaic people and the Late Archaic people, both of whom built small circular hearths, used them until the rocks broke up, and then built new hearths close by. The people during the late part of the Middle Archaic probably built the same kind of hearth; but once exhausted, it was their custom to deposit the exhausted 
rocks in a designated area. Over time a mound built up, giving rise to a typical central Texas burned rock midden. During the Late Prehistoric period, no rocks seem to have been employed, or at least none were recovered; burning did take place, however.

Spatial utilization of the site is another variable. Remains of the early part of the Middle Archaic occupation were recovered over the entire site area, whereas the succeeding later portion of the Middle Archaic is much more 1 imited in space (Area Red). During the Late Archaic, slightly more space may have been utilized (both Areas Red and Green yielded diagnostic items), but the Late Prehistoric is by far the most restricted in space utilization.

By contrast, occupational intensity is greatest in the Late Prehistoric period, if sheer numbers of artifacts and ecofacts are any indication. Using this same measure, the early part of the Middle Archaic and Late Archaic are similar in intensity, with the late part of the Middle Archaic being the lightest occupation despite its association with the most extensive features. If volume of burned rock is used as a measure of population density, however, as Gunn does in his evaluation of several hypotheses, then the 7 ate part of the Middle Archaic period (characterized by the midden and scatter) represents the densest occupation. This would be followed demographically by the early part of the Middle Archaic and the Late Archaic, with comparable but smaller amounts of burned rock and thus presumably people. The combination of a small living area and the absence of burned rock, which characterizes the Late Prehistoric occupation, would indicate a very small number of people utilizing the site. Just what the relationships are between number of artifacts, space utilized, feature number and size, and population density cannot be determined from the data at hand.

The fact is that 41 BX 300 does not represent a full range of human subsistence and settlement activities, and consequently the usual rules for estimating density and longevity do not apply. Site 41 BX 300 was a special use locality, most likely utilized by distinct subgroups of the general population. That the site served several basic needs in the aboriginal hunting and gathering lifeway is evidenced by the fact that much the same activities took place there for over four millenia, despite successive changes in cultural patterns within the region. The differences observed can be attributed to idiosyncratic and stylistic elements of culture, rather than the more basic aspects of subsistence and adaptation to the regional environment. The fact that similar subsistence activities could occur over such a span of time is undoubtedly due to the unique natural feature of $41 \mathrm{BX}$ 300: Elm Waterhole. This constant source of water is related to a remarkably unchanging local environment from the early part of the Middle Archaic to the present, a natural constancy to which can be attributed the cultural similarities of over four millenia of site occupation.

\section{EVALUATION OF THE RESEARCH DESIGN}

\section{RESEARCH AREAS}

Investigation of the four sectors identified in the research design was accomplished by dividing the site into five areas, each designated by a 
different color (see Fig. 8). Each area was subjected to controlled surface collection by means of $10-\mathrm{m}^{2}$ blocks (see Fig. 9) and by at least two machinedug trenches penetrating through the topsoil and subsoil zones to bedrock (see Fig. 10). Hand-excavated isolated units and blocks were dug to investigate anomalies and to expose any cultural features encountered (see Fig. 11).

Results of the mitigation activity indicate that there were preferences for occupation in certain areas of the site at different periods in prehistory, but this is more a factor of extent of occupation than location of occupation. No Paleo-Indian artifacts were recovered during mitigation or are documented from previous collection or testing activities. The Early Archaic artifacts are scattered around the site, due to redeposition and curation by subsequent peoples rather than an indication of an unfocused occupation.

The earliest documented occupation occurred in the early part of the Middle Archaic period, with these people exploiting the entire site area. The occupation, associated with subsoil, was documented everywhere trenches or units penetrated beneath the topsoil. The later Middle Archaic occupation was more limited in area, focusing on the burned rock midden and scatter in the central portion of the site. Following this, the Late Archaic occupation was situated in the central and northeast areas, a more restricted space than the early part of the Middle Archaic occupation, but more expansive than the late part of the Middle Archaic occupation. The Late Archaic people did have a midden (left by the later Middle Archaic occupation) to contend with, which probably removed much of the central portion of the site from active use. The most restricted occupation occurred in the Late Prehistoric period, when only $12 \mathrm{~m}^{2}$ in the east-central portion of the site seem to have been intensively used. While no Historic period occupation was documented, contemporary material was limited almost entirely to the northeast portion of the site.

\section{RESEARCH OBJECTIVES}

The interrelatedness of the 10 objectives suggest that their exposition be conducted in narrative form rather than in the itemized manner in which they were presented earlier in this report. This narrative appears in the preceding material, including the results of investigations and the occupational history of the site.

By way of evaluation, it can be stated that al1 but one of the objectives were successfully achieved. Burned rock features are classified, their functions defined (Objective 1), and their accumulation processes reconstructed (Objective 2). Artifacts are also classified, their functions interpreted (Objective 3 ), and where possible they are dated and chronologically ordered (Objective 4). Specific activities are identified in each area and stratigraphic level of the site (Objective 6) and at different times in the occupational history of the site, enabling the reconstruction of partial 1 ifeways as they intersected the site during each cultural period (Objective 5). The reconstruction of the site environment (Objective 10) and a recognition of its stability integrated quite well with the similarity in 
subsistence patterns documented throughout the occupational history of the site (Objectives 8 and 9).

Onty Objective 7 , concerned with group size, was not fully achievable, due to the uniqueness of the site: small subsets of the population utilizing the site for short periods of time during only certain seasons of the year for very specific activities. This picture was apparently repeated during three major cultural periods encompassing nine sequent phases over a period of up to 4400 years, regardless of the larger population aggregates characterizing the larger region of south-central Texas during each phase and period.

\section{RESEARCH HYPOTHESES (JoeT Gunn)}

The measure of a site is its contribution to the general understanding of culture history and culture process in a region. Site 41 BX 300 provided some surprises and left some disappointments with respect to pre-excavation prognostications of its worth, as all sites do. Our judgements of preexcavation worth and expected outcomes of the excavations were presented in the project proposal in four general theoretical constructs which tap some of the current concerns in south-central Texas regional archaeology. The first of these, the Positive Sedimentation Hypothesis concerns the depositional characteristics of the site. The second, the 0ccupation Floor Trajectory Hypothesis, pertains to the sequencing of occupation floors/areas of the site and how the sequence relates to the ubiquitous burned rock midden problem in central Texas. The third and fourth hypotheses, Population Variation on a Broad Ecotone Hypothesis and General 0ccupation Density Hypothesis, approach the problem of hunter-gatherer demographics and adaptation in the peculiar south-centra] Texas environment.

\section{Positive Sedimentation Hypothesis}

Before the project began, 41 BX 300 appeared to be a very complex stratigraphic situation. The northwest (Area Blue) sector was very deep and was presumed to contain Late Paleo-Indian remains. The other sectors appeared to be shallow and horizontally stratified with late Holocene (0-5000 B.P.) deposits. This suggested to us that the stratigraphy of the site needed major attention to explain the existence of the site. We posed the problem in the context of previous experience in the area north of San Antonio.

The Positive Sedimentation Hypothesis suggested that deep sites would occur in more broken terrain where activities were limited to circumscripted locales. The repeated occupation of a circumscripted locale would enrich the soil with human camp residue, encourage vegetation, and result in sediment capture during overbank flooding. The cycle of human occupation, vegetation, and flooding would result in a positive feedback 10op which would account for the depth of the site.

Close scrutiny of the site by Glen Evans showed that the complex outer appearance of the site could be explained rather simply by a dome of bedrock, an interfluve between two old streams, which was cut off by the Elm Waterhole 
sink. Once the old interfluve was overlaid by sediments it assumed the complex appearance we first observed.

Intensive investigation of the interfluve showed that the horizontal stratification was spurious, apparently a product of sampling during the testing phases of the project. A rather simple layered stratigraphy emerged over the bedrock and remnants of early Del Rio Clay, which fit very well with the proposed central Texas Middle Archaic and Late Archaic cultural sequence.

Perhaps the most interesting question to arise out of the excavations was why the sediments only accumulated on the interfluve during the late Holocene when the sinking of Elm Waterhole probably posed the present conditions immediately after the Pleistocene.

Schumm (1965) attempted to model the complicated relationships between climate and sedimentation in river systems. At the most abstract level that theory transiates as follows. When the climate is moist, the uplands will be well vegetated, and this vegetation will hold upland sediments in place. As a result, uplands, particularly in colluvial contexts, will accumulate sediments. Valleys, by contrast, will be sediment-starved, and rivers will erode their beds. Dry climate will impoverish the upland vegetation resulting in erosion in the uplands. Valleys will receive this sediment, probably more than they are able to transport, and therefore will agrade during dry times.

Site $41 \mathrm{BX} 300$ is located in the headward section of E7m Waterhole Creek and therefore is predominantly an upland site. However, the Elm Waterhole sink apparently provided some protection for the site, making the buildup of sediments during the late Holocene possible. Baker and Penteado-Orellana (1977) have shown that conditions were more moist during the late Holocene than the middle Holocene near Austin. We can presume that during the more pluvial conditions of the late Holocene the balance of circumscribed human occupation on the remnant interfluve, the moist climate, and the flooding resulted in deposition at the site as we have described it.

During the dry middle Holocene there may not have been human occupation of the site; and if there was, there was not enough vegetation to hold what was deposited. Schumm's model explains the absence of pre-late Holocene remains. Presumably the Angostura point found in the area of the site was a redeposited or curated artifact of the early Holocene.

\section{Occupation Floor Trajectory Hypothesis}

Early impressions of 41 BX 300 suggested a complex horizontal stratigraphy. Among the components of the stratigraphy was a classic burned rock midden, a standard feature of Middle Archaic sites in the central Texas region. The presence of the midden and surrounding, differing areas of the site immediately aroused interest relative to the function of middens.

Two possibilities were immediately apparent. Were the surrounding sectors of the site sequential with the midden and therefore representative of site functions and adaptations before and after the midden time, or were they 
contemporary with the midden and possibly serving complementary purposes to the midden?

The question of the function of middens can be analyzed logically as follows. If a midden has rocks mixed with soil and habitation refuse it can be construed as a littered occupation floor, habitation and refuse. This has been referred to as a "midden with rocks." If a midden has little soil plus habitation refuse and is almost all rocks, it is probably a discard pile, and habitation areas are likely to be complementary to the midden. Any given location will be habitation or refuse. The latter system is 1 ikely to generate the classic "burned rock midden."

The $41 \mathrm{BX} 300$ excavations showed that the initial impression of a complex horizontal stratigraphy was spurious. Four layered levels of occupation in the site revealed that hearth usage was rather consistent through the first three 1ayers: the Clear Fork, Round Rock, and Twin Sisters phases. However, a vast intensification of activity during the Round Rock phase apparently produced a refuse problem akin to urban garbage pollution in a small way. The result was that the center of the site, once no longer usable due to pollution, was abandoned, and areas adjacent to the midden were used for hearths, the expended residues being cast up on the growing midden.

The activity apparently resulted in enough positive sedimentation to cover the lower reaches of the midden. Later, Twin Sisters hearths were built in the higher levels; they were of similar density to the Clear Fork hearths, reflecting a reduction in activity.

The uppermost Late Prehistoric levels, while well represented in the artifact inventory, are not characterized by rock-related hearths and so apparently represent a fundamentally different cooking style and/or adaptation.

The on/off midden problem was first broached by Hester (1971) at the La Jita site and has since come under study by Gunn and Mahula (1977). Gunn and Mahula noted a reduction in the size of rocks involved through time similar to the one found at $41 \mathrm{BX} 300$. Site $41 \mathrm{BX} 300$ provides the first very clear anatysis of the problem.

\section{Population Variation on a Broad Ecotone}

Gunn (1977) has suggested that the unstable character of south-central Texas climate would result in marked variations in population density during the Holocene. An analysis of skimpy ethnohistorical data suggested that population rose about one person per $1000 \mathrm{~km}^{2}$ per $1 \mathrm{~mm}$ of precipitation. This probably reflects a basic relationship between the biomass and human occupation. Analysis of modern crop yields has shown that as global climate cools, the amount of biomass increases to the west (Jones 1979). We therefore expected to see the effects of climate changes reflected in the demography of central Texas and 41 BX 300.

Baker and Penteado-Orellana (1977) found evidence of a marked 1ate Holocene pluvial in central Texas approximately between 2000 and 3000 years ago. This corresponds to the typologically dated late part of the Middle Archaic period 
Site 41 BX 300/Summary and Evaluation

(2250-3400 B.P.) at $41 \mathrm{BX} 300$ which contained the burned rock midden. We assume that the quantities of material associated with the late part of the Middle Archaic reflect a substantial increment in population and activity at the site. This is probably due to moister conditions in general in central Texas. The evidence of less activity before and after the late part of the Middle Archaic are taken to suggest less population.

In the terminology proposed by Binford (1980) and modified by Gibson and Gunn (1984), the spartan furnishings of the components before and after the late part of the Middle Archaic suggest "foragers," people who came to collect and hunt, and probably consumed most of what they gathered on the spot. The visits during the late part of the Middle Archaic, however, suggest massive food preparations, probably to be carried back to a home base somewhere else, the "collectors" in the Binford terminology.

We were specifically interested in whether the foragers were more western or "Desert Culture" people as opposed to eastern collectors. No specific evidence was adduced relative to this problem from 41 BX 300 so evidence remains circumstantial, that is to say, that the Clear Fork phase remains a Pecos-related tradition, and the Round Rock phase was a local Balconian and southeasternlike tradition by inference (Weir 1976; Prewitt 1981:79).

\section{General Occupation Density Hypothesis}

The thought was expressed in the original proposal that $41 \mathrm{BX} 300$, being the upland site it is, would be more useful and used during moister periods. Presumably population would vary in density, and technology would reflect variation between wet and dry climate.

Since the project started it has become evident to several investigators that upland sites are probably very sensitive indicators of demographic characteristics of a region because of their marginal status (Parry 1978; Gunn and Brown 1982). They will be utilized when resources in the more accessible river bottoms are overused. Perry's studies of the upland farms of historic Britain and Gunn and Brown's (1982) work with the uplands of prehistoric western Louisiana make this abundantly clear.

Site 41 BX 300 appears to support the general hypothesis. Central and south Texas sites appear to reflect inflated populations during the late Holocene pluvial. Site 41 BX 300 shows that the uplands were exploited in coordination with this demographic bulge. A7so, the technology changes with the demography. The midden process accompanies the denser populations.

\section{Summary}

While the stratigraphy did not turn out to have the subtle inuendoes we expected, there were substantial gains of knowledge to be made from the rather straightforward vertical sequence at 41 BX 300 . The deposits are limited to the time after the site was stablized by isolation below the waterhole sink and after climate conditions became favorable to upland vegetation to hold sediments. 
The site demonstrates impressively that technology, the hearth/midden process, changed with demographic trends. The demography appears to have shifted in reasonable concert with general climatic trends, probably in direct response to local available biomass.

The problem of the relationship of middens to adjacent areas may not have been brought to final resolution, given the variable geomorphic contexts in which they are found, but 41 BX 300 provides an impressive body of information on the upland midden context.

\section{REFERENCES CITED}

Adovasio, J. M., J. D. Gunn, J. Donahue, and R. Stuckenrath

1978 Meadowcroft Rockshelter, 1977: An Overview. American Antiquity $43: 632-651$.

Adovasio, J. M., J. D. Gunn, J. Donahue, R. Stuckenrath, J. E. Guilday, and K. Voltman

1980 Yes, Virginia, It Really Is That 01d: A Reply to Haynes and Meade. American Antiquity 45:588-595.

Baker, G.

1959 Opal Phytoliths in Some Victorian Soils and Red Rain Residues. Australian Journal of Botany 7:64-87.

Baker, V. R. and M. M. Penteado-Orellana

1977 Adjustment to Quaternary CTimatic Change by the Colorado River in Central Texas. Journal of Geology 85:395-422.

Barnes, V. E.

1974 Geological Atlas of Texas. San Antonio Sheet. Robert Hamilton Cutler Memorial Edition. Bureau of Economic Geology, The University of Texas at Austin.

Binford, L. R.

1980 Willow Smoke and Dogs' Tails: Hunter and Gatherer Settlement Systems and Archaeological Site Formation. American Antiquity $45(1): 5-15$.

BTack, S. L. and A. J. McGraw

1985 The Panther Springs Creek Site: Cultural Change and Continuity in the Upper Salado Creek Watershed, South-Central

Texas. Center for Archaeological Research, The University of

Texas at San Antonio, Archaeological Survey Report 100. 
Blair, W. F.

1950 The Biotic Provinces of Texas. The Texas Journal of Science 2(1):93-117.

Bryant, V. M., Jr.

1969 Late Ful7-Glacial and Post-Glacial Pollen Analys is of Texas Sediments. Unpublished Ph.D. dissertation, Department of Anthropology, The University of Texas at Austin.

Bryant, V. M., Jr. and H. J. Shafer

1977 The Late Quaternary Paleoenvironment of Texas: A Model for the Archeologist. Bulletin of the Texas Archeological Society 48:1-26.

Campbe11, T. N.

1975 The Payaya Indians of Southern Texas. Southern Texas Archaeological Association, Special Report 1.

1977 Ethnic Identities of Extinct Coahuiltecan Populations: Case of the Juanca Indians. Texas Memorial Museum, The PearceSellards Series 26. Austin.

Chaplin, R. E.

1971 The Study of Animal Bones from Archeological Sites. Seminar Press, New York.

Collins, M. B.

1970 On the Peopling of Hitzfelder Cave. Bulletin of the Texas Archeological Society 41:301-304.

Cox, D.

1977 A Preliminary Report on "Early Man" Artifacts Found in Northeast Bexar County. La Tierra 4(3):7-9.

Dibble, D. S.

1979 Archeological Reconnaissance in the Salado Creek Watershed, Bexar County, Texas. Texas Archeological Salvage Project, The University of Texas at Austin, Survey Report 9.

Dibble, D. S. and D. Lorrain

1968 Bonfire Shelter: A Stratified Bison Kill Site, Val Verde County, Texas. Texas Memorial Museum, Miscellaneous Papers 1. Austin. 
Di17ehay, T. D.

1974 Late Quaternary Bison Population Changes on the Southern Plains. Plains Anthropologist 19(65):180-196.

Evans, G. L.

1961 The Friesenhahn Cave. Texas Memorial Museum, Butletin 2. Austin.

Fawcett, W. B., Jr.

1970 The Bacon Quarry Site: A Prehistoric Flint Quarry and Knapping Site in Bexar County. Manuscript on file, Texas Archeological Research Laboratory, The University of Texas at Austin.

1972 The Prehistory of Bexar County: A Study of Previous Work in South Central Texas. Lower Plains Archeological Society, But7etin 2:23-44.

Fawcett, W. B., Jr. and P. R. McGuff

1970 The Bacon House Site: A Historic Excavation Technique Study in Northern Bexar County. John Marshall High School Archeology Club, Bulletin 1. San Antonio, Texas.

Fox, A. A.

1975 An Archaeological Assessment of the Southern Portions of the 01 mos Basin, Bexar County, Texas. Center for Archaeological Research, The University of Texas at San Antonio, Archaeological Survey Report 9.

1977 An Archaeological Assessment of the San Antonio 201 Wastewater Treatment Project. Center for Archaeological Research, The University of Texas at San Antonio, Archaeological Survey Report 41.

Gagliano, S. M.

1967 Occupation at Avery Island. Louisiana State University, Baton Rouge.

Gerstle, A., T. C. Kel1y, and C. Assad

1978 The Fort Sam Houston Project: An Archaeological and Historical Assessment. Center for Archaeological Research, The University of Texas at San Antonio, Archaeological Survey Report 40. 
Gibson, E. C. and J. Gunn

1984 Survey of the Eastern Half of LBJ State Historic Park, June 1982. In Occupation and Settlement in the Lower Fredericksburg Basin of the Edwards Plateau. Center for Archaeological Research, The University of Texas at San Antonio, Special Report 14 (in preparation).

Givens, R. D.

1968 A Preliminary Report on Excavations at Hitzfelder Cave. Bulletin of the Texas Archeological Society 38:47-56.

GouTd, F.W.

1969 Texas Plants: A Checklist and Ecological Summary. Revised Publication MP-585. The Texas A\&M University System, The Texas Agricultural Experiment Station. College Station.

Gunn, J.

1977 An Envirocultural system for Central Texas. In Hop Hill: Culture and Climatic Change in Central Texas, edited by Joe 1 Gunn and Royce Mahula:257-276. Center for Archaeological Research, The University of Texas at San Antonio, Special Report 5.

1979 Occupation Frequency Simulation on A Broad Ecotone. In Transformations: Mathematical Approaches to Culture Change, edited by Colin Renfrew and Kenneth L. Cooke:257-274. Academic Press, New York.

Gunn, J. and D. 0. Brown (eds.)

1982 Eagle Hi17: A Late Quaternary Upland Site in Western Louisiana. Center for Archaeological Research, The University of Texas at San Antonio, Special Report 12.

Gunn, J. and T. R. Hester

n.d. First General Level Analys is of Center for Archaeological Research Site Survey Data. Manuscript on file with authors.

Gunn, J., J. E. Ivey, and T. R. Hester

1977 Interpretations, Predictive Models and Recommendations. In An Archaeological Survey of the Radium Springs Area, Southern New Mexico, edited by T. R. Hester:113-133. Center for Archaeological Research, The University of Texas at San Antonio, Archaeological Survey Report 26. 
Gunn, J. and R. Mahula (eds.)

1977 Hop Hi17: Culture and Climatic Change in Central Texas. Center for Archaeological Research, The University of Texas at San Antonio, Special Report 5.

Gunn, J. and E. R. Prewitt

1975 Automatic Classification of Projectile Points from West Texas. Plains Anthropologist 20(68):139-149.

Gunn, J. and F. A. Weir

1976 Tool Kit Hypotheses: A Case of Numerical Induction. Newsletter of Lithic Technology 5(3):31-40.

Halpern, R. E.

1978 Collection and Processing of Constant Volume Samples of Soil from 41 BX 300. Manuscript on file at the Center for Archaeological Research, The University of Texas at San Antonio.

Hester, T. R.

1968 Paleo-Indian Artifacts from Sites Along San Miguel Creek: Atascosa, Frio, and McMullen Counties. Bulletin of the Texas Archeological Society 39:147-161.

1970 Burned Rock Midden Sites on the Southwestern Edge of the Edwards Plateau, Texas. Plains Anthropologist 15(50):237-248.

1971 Archeological Investigations at the La Jita Site, Uvalde County, Texas. Bulletin of the Texas Archeological Society $42: 51-148$.

1975 Late Prehistoric Cultural Patterns Along the Lower Rio Grande of Texas. Bulletin of the Texas Archeological Society 46:107126.

1976 Late Pleistocene Aboriginal Adaptations in Texas. In Papers on Paleo-Indian Archaeology in Texas, edited by T. R. Hester:1-14. Center for Archaeological Research, The University of Texas at San Antonio, Special Report 3.

1979 Early Populations in Prehistoric Texas. Archaeology $32(6): 26-33$.

1980 Digging Into South Texas Prehistory. Corona Publishing Company, San Antonio, Texas. 
Hester, T. R. (continued)

1981 Tradition and Diversity Among the Prehistoric Hunters and Gatherers of Southern Texas. Plains Anthropologist 26(92):119-128.

1986 The Texas-Idaho Obsidian Connection. La Tierra 13(2):2-5.

Hester, T.R. (assembler)

1974 Archaeological Survey of Areas Proposed for Modification in the Salado Creek Watershed, Bexar County, Texas. Center for Archaeological Research, The University of Texas at San Antonio, Archaeological Survey Report 3.

Hester, T. R., J. Gunn, and P. R. Katz

1977 A Proposal for Archaeological Mitigation at Site 41 BX 300 , Salado Creek Watershed, Bexar County, South-Central Texas. On file at the Center for Archaeological Research, The University of Texas at San Antonio.

Hester, T. R., R. F. Heizer, and J. A. Graham

1975 Field Methods in Archaeology. Sixth edition. Mayfield Publishing Company, Palo Alto, California.

Hester, T. R., P. R. Katz, and T. C. Kelly

1977 A Report on Intensive Survey Investigations at Archaeological Sites 41 BX 300 and 41 BX 301, Floodwater Retarding Structure 13A, Salado Creek Watershed, Texas. Manuscript on file, Center for Archaeological Research, The University of Texas at San Antonio.

Hester, T. R. and H. Kohnitz

1975 The Chronological Placement of "Guadalupe" Tools. La Tierra $2(2): 22-25$.

Howard, C. D.

1971 Paleo Surface Finds in Bexar County. Manuscript on file, Texas Archeological Research Laboratory, The University of Texas at Austin.

1974 Pajeo-Indian Surface Finds in Bexar County. La Tierra $1(3): 14-17$. 
Howard, M. A.

1983 A Quantitative Study of the Booker Site and Other Burned Rock Midden Sites of the Lake Travis Basin, Central Texas. Unpublished M.A. thesis, Department of Anthropology, The University of Texas at Austin.

Hsu, D. P. and R. W. RaTph

1968 An Appraisal of the Archeological Resources of Cibolo Reservoir, Wilson County, Texas. State Building Commission, Archeological Survey Report 1. Austin.

Ingtis, J. M.

1964 A History of Vegetation on the Rio Grande Plain. Texas Parks and Wildlife Bulletin 45. Austin.

Jennings, J. D.

1974 Prehistory of North America. McGraw-Hi11, New York. Johnson, L., Jr.

1964 The Devil's Mouth Site, A Stratified Campsite at Amistad Reservoir, Val Verde County, Texas. Department of Anthropology, The University of Texas at Austin, Archaeology Jones, R. Series 6 .

1979 Recent Crop Yields and Climate in Texas. In Impact of Climatic Change, Working Papers (June 1979), Assembled by J. Gunn. Research by the Center for Archaeological Research, The University of Texas at San Antonio, for the Ewing Halsell Foundation of San Antonio and The United States Bureau of Reclamation.

Katz, P. R.

1978 Results of Intensive Survey Activities at 41 BX 301 , Floodwater Retarding Structure 13A, Salado Creek Watershed, Texas. Manuscript on file, Center for Archaeological Research, The University of Texas at San Antonio.

Katz, S. R.

1977 An Archaeological Test Excavation at John James Park, City of San Antonio, Texas. Center for Archaeological Research, The University of Texas at San Antonio, Archaeological Survey Report 38. 
Kelley, J.

1959 The Desert Cultures and the Balcones Phase: Archaic Manifestations in the Southwest and Texas. American Antiquity $24(3): 276-288$.

Kelly, T. C.

1975 Letter to Mr. Logan Crews on the Floodwater Retarding Structure 13A Locality. On file, Center for Archaeological Research, The University of Texas at San Antonio.

1976 Field Notes for the 1976 Intensive Testing Operations at 41 BX 300. Manuscript on file, Center for Archaeological Research, The University of Texas at San Antonio.

Kelly, T. C. and T. R. Hester

1976 Archaeological Investigations at Sites in the Upper Cibolo Creek Watershed, Central Texas. Center for Archaeological Research, The University of Texas at San Antonio, Archaeological Survey Report 17.

Krieger, A. D.

1964 Early Man in the New World. In Prehistoric Man in the New World, edited by J. D. Jennings and E. Norbeck:23-87. University of Chicago Press.

McGraw, A. J., F. Valdez, Jr., and I. W. Cox

1977 Archaeological Survey of Areas Proposed for Modification in the Encino Park Development, Northern Bexar County, Texas. Center for Archaeological Research, The University of Texas at San Antonio, Archaeological Survey Report 39.

Orchard, C. D.

1938 Letter to A. T. Jackson dealing with Bexar County sites. On file, Texas Archeological Research Laboratory, The University of Texas at Austin.

Orchard, C. D. and T. N. Campbel1

1954 Evidence of Early Man from the Vicinity of San Antonio, Texas. The Texas Journal of Science 6(4):454-465.

1960 Southwestern Pottery from Sites in the Vicinity of San Antonio, Texas. Texas Archeology 4(2):7-8. 
Parry, M. L.

1978 Climate Change, Agriculture, and Settlement. Folkstone, Dawson, England.

Peter, D. E.

1982 Alternate Perspectives on Burned Rock Middens. In Archaeological Investigations at the San Gabriel Reservoir Districts, Central Texas. Volume 2, edited by T.R. Hay:20-120-15. Archaeology Program, Institute of App 7 ied Sciences, North Texas State University, Denton.

Pilsbry, H. A.

1940 Land Mollusca of North America (North of Mexico). Vol. I, Part 2. Academy of Natural Science, Monograph 3:i $i$, 575-994.

1946 Land Mol1usca of North America (North of Mexico). Vol. II, Part I. Academy of Natural Science, Monograph 3:iii, 1-520.

Prewitt, E. R.

1966 Preliminary Report on the Devil's Rockshelter Site, Val Verde County, Texas. The Texas Journal of Science 18(2):206-224.

1976 The Rogers Spring Site: 1974 Investigations. Manuscript on file, Texas Archeological Survey, The University of Texas at Austin.

1981 Cultural Chronology in Central Texas. Bulletin of the Texas Archeological Society 52:65-89.

1983 From Circleville to Toyah: Comments on Central Texas Chronology. Bulletin of the Texas Archeological Society $54: 201-238$.

Robinson, R. L.

1979 Biosilica and Climatic Change at 41 GD 21 and 41 GD 21A. In Archaeological Investigations of Two Prehistoric Sites on the Coleto Creek Drainage, Goliad County, Texas, by D. Fox:102113. Center for Archaeological Research, The University of Texas at San Antonio, Archaeological Survey Report 69.

n.d. Biosilica as an Indicator of the Paleoenvironment of the South Texas Coastal Plain. Center for Archaeological Research, The University of Texas at San Antonio, Special Report 7 (in preparation). 
Site 41 BX 300/References Cited

Rock Color Chart Committee

1948 Rock-Color Chart. Geological Society of America, Boulder, Colorado.

Rovner, I.

1971 Potential of Opal Phytoliths for Use in Paleoecological Reconstruction. Quaternary Reséarch 1:343-359.

1980 History and Development of Plant Opal Phytolith Analysis. Paper presented at the annual meeting of the Society for American Archaeology, Philadelphia.

Schuetz, M. K.

1960 Report on the Martinez Creek Survey. Manuscript on file, Witte Memorial Museum, San Antonio.

Schumm, S. A.

1965 Quaternary Paleohydrology. In the Quaternary of the United States, edited by H. Wright, Jr. and D. Frey:783-794. Princeton University Press, Princeton.

Scurlock, D. and W. R. Hudson, Jr.

1973 An Archeological Investigation of Walker Ranch. Office of the State Archeologist, Texas Historical Commission, Special Report 9. Austin.

Sol1berger, J. B. and T. R. Hester

1972 The Strohacker Site: A Review of the Pre-Archaic Manifestations in Texas. Plains Anthropologist 17(58), Pt. $1: 326-344$.

Sorrow, W.

1969 Archeological Investigations at the John Ischy Site: A Burnt Rock Midden in WilTiamson County, Texas. Texas Archeological Salvage Project, The University of Texas at Austin, Paper 18. Sorrow, W. M., H. J. Shafer, and R. E. Ross

1967 Excavations at Stillhouse Hollow Reservoir. Texas Archeological Salvage Project, The University of Texas at Austin, Papers 11.

Spielmann, K. A.

1983 Late Prehistoric Exchange Between the Southwest and Southern Plains. Plains Anthropologist 28(102):257-272. 
Story, D. A.

1980 Adaptive Strategies of Archaic Cultures of the West Gulf Coast Plain. Unpublished manuscript on file, Center for Archaeological Research, The University of Texas at San Antonio.

Suhm, D. A. and E. B. Jelks

1962 Handbook of Texas Archeology: Type Descriptions. Texas Archeological Society, Special Publication 1 and Texas Memorial Museum, Bulletin 4. Austin.

Taylor, F. B., R. B. Hailey, and D. L. Richmond

1962 Soil Survey of Bexar County, Texas. U.S. Department of Agriculture, Soil Conservation Service, Series 1962:12. Washington, D.C.

Turner, E. S. and T. R. Hester

1985 A Field Guide to Stone Artifacts of Texas Indians. Texas Monthly Press, Austin.

Uecker, $\mathrm{H}$.

1966 Unpub7ished notes on the Cutaway site (41 BX 37). On file, Center for Archaeological Research, The University of Texas at San Antonio.

Weir, F. A.

1976 The Central Texas Archaic. Unpublished Ph.D. dissertation, Department of Anthropology, Washington State University, Pul7man.

Wesolowsky, A. B., T. R. Hester, and D. R. Brown

1976 Archaeological Investigations at the Jetta Court Site (41 TV 151), Travis County, Texas. Bulletin of the Texas Archeological Society 47:25-88.

Wise, $J$.

1964 An Inventory of Artifacts from an Archaic Workshop in Bexar County, Texas: Robard's Site. Manuscript on file, Witte Memorial Museum, San Antonio. 
Witkind, W. M.

1977 An Experiment in Stone Boiling. In Hop Hill: Culture and Climatic Change in Central Texas, by J. Gunn and R. Mahula:205-208. Center for Archaeological Research, The University of Texas at San Antonio, Special Report 5.

Woerner, M. C. and L. Highley

1983 The Bromley F. Cooper Collection of Pre-Archaic and Archaic Dart Points from McMullen County. La Tierra 10(1):3-31.

Woolford, S. W.

1935 Types of Archeological Sites in Bexar County, Texas. Witte Memorial Museum, Bulletin 4. San Antonio.

Word, J. H. and C. L. Douglas

1970 Excavations at Baker Cave, Val Verde County, Texas. Texas Memorial Museum, Bulletin 16. Austin. 


\section{APPENDIX I \\ MATERIALS RECOVERED AT 41 BX 300}

\section{A. CLASSIFICATION TYPE CODES}

Code

Number
Code

Number

HISTORICAL TYPES

Earthenware, white paste, decorated

$\begin{array}{ll}1 & \text { Edgeware } \\ 2 & \text { Banded (Mocha, etc.) } \\ 3 & \text { Hand painted } \\ 4 & \text { Transfer print } \\ 5 & \text { Flown blue } \\ 6 & \text { Spongeware }\end{array}$

7 Decal print

8 Solid color

9 Lusterware

10 Tin-enameled (Faience and DeTft)

11 Bennington ware

12 Other decorated

Earthenware, white paste, undecorated

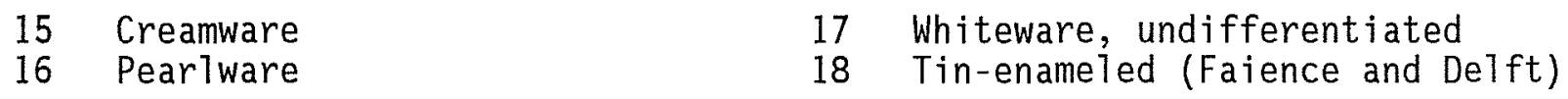

Earthenware, colored paste, decorated

20 Lead-glazed

21 Tin-enameled (Majolica)

22 Ung1azed

Earthenware, colored paste, undecorated

25 Lead-glazed

26 Tin-enameled (Majolica)

27 Unglazed

Stoneware

$30 \quad$ A7kaline-glazed

31 Texas-glazed

Porcelain

35 Decorated

Ceramics: Nonvessel

40 Water and other piping

41 Tobacco pipe

42 Marbles

43 Door knobs

44 Do11 parts

45 Insulators
32 Other glazed (salt-glazed, etc.)

33 Slipped and unglazed

36 Undecorated

46 Buttons

47 Brick

48 Tile (Colonial and Mexican)

49 Tile (Anglo-American and recent)

50 Other ceramics 
Code

Number

Glass: Vessels

51 Dark Green (and "BTack")

52 Light Green (and "01ive")

53 Light Green (1ike 7-Up bottles)

54 Aquamarine

55 Brown

56 Clear

Glass: Flat

65 Window

66 Mirror

Glass: Other Objects
Code

Number
57 Purple

58 Blue

59 White (opaque and "mi7k")

60 Red

61 Other vessel colors

70 Buttons

71 Jeweiry (beads, inlays, etc.)

72 Other glass objects (figurines, etc.)

73 Mason jar Tiners

Metal

75 Kitchen and household (pans, pots, utensits, etc.)

76 Architectural (nails, hinges, lock parts, etc.)

77 Furniture hardware (sma17 hinges, drawer pu71s, tacks, etc.)

78 Gun parts

79 Ammunition (bullets, cartridges, etc.)

80 Clothing and tailoring (buttons, scissors, pins, etc.)

81 Coins

82 Personal items (keys, pocket knife, etc.)

83 Construction tools (axes, saws, etc.)

84 Farming tools (hoes, spades, etc.)

85 Toys

86 Stable and barn items (saddle parts, bits, stirrups, etc.)

87 Military hardware (swords, insignias, uniform buttons, etc.)

88 Containers (boxes, cans, etc.)

89 Miscellaneous hardware (bolts, nuts, washers, chains, etc.)

90 Unidentified metal (including iron, copper and alloys, lead, etc.)

91 Barbed wire

Bone

95 Kitchen refuse, carved bone handles, etc.

Chert

100 Gunflints, etc. 
Code

Number
Code

Number

Worked Stone

115 Millstones, Finger ring stones, etc.

PREHISTORIC TYPES

Point Types

$\begin{array}{ll}201 & \text { Abasolo } \\ 202 & \text { Almagre } \\ 203 & \text { Angostura } \\ 204 & \text { Be11 } \\ 205 & \text { Bulverde } \\ 206 & \text { Carrizo } \\ 207 & \text { Castrovi1le } \\ 208 & \text { Catán } \\ 209 & \text { Cliffton } \\ 210 & \text { Clovis } \\ 211 & \text { Cuney } \\ 212 & \text { Darl } \\ 213 & \text { Desmuke } \\ 214 & \text { Early Corner } \text { Notched } \\ 215 & \text { Edgewood } \\ 216 & \text { Edwards } \\ 217 & \text { Elam } \\ 218 & \text { El1is } \\ 219 & \text { Ensor } \\ 220 & \text { Ensor-Frio } \\ 221 & \text { Fairland } \\ 222 & \text { Folsom } \\ 223 & \text { Fresno } \\ 224 & \text { Frio } \\ 225 & \text { Golondrina } \\ 226 & \text { Gower } \\ 227 & \text { Harre11 } \\ 228 & \text { Kinney } \\ 229 & \text { La Jita } \\ 230 & \text { Lange } \\ 231 & \text { Langtry } \\ 232 & \text { Lerma } \\ 233 & \text { Marcos } \\ 234 & \text { Marsha11 } \\ 235 & \text { Martindale } \\ & \text { } \\ & \end{array}$

\begin{tabular}{ll}
236 & Matamoros \\
237 & Meserve \\
238 & Montel1 \\
239 & Morhiss \\
240 & Morri11 \\
241 & Nolan \\
242 & Paisano \\
243 & Palmillas \\
244 & Pandale \\
245 & Pandora \\
246 & Pedernales \\
247 & Perdiz \\
248 & Plainview \\
249 & Refugio \\
250 & Scal1orn \\
251 & Scottsbluff \\
252 & Shumla \\
253 & Starr \\
254 & Tortugas \\
255 & Triangular (Early) \\
256 & Toyah \\
257 & Travis \\
258 & Trinity \\
259 & Uvalde \\
260 & We11s \\
261 & Williams \\
262 & Young \\
263 & Zavala (cf. Figueroa) \\
264 & Arrow Point Fragment \\
& (unidentifiable) \\
265 & Dart Point Fragment \\
& (unidentifiable) \\
266 & Other ( \\
267 & Other ( \\
268 & Other ( \\
\hline & \\
\hline
\end{tabular}


Code

Number

Bifaces

280 Chopper

281 Quarry blank with cortex

282

283

$283 a$

$283 b$

283c Triangular and subtriangular

Unifaces

300

301

302

303

304

305

306

307

Unilaterally trimmed

Bilaterally trimmed

Unilateraliy and end trimmed

Bilaterally and end trimmed

Double end trimmed

Concave

Ovate trimmed

Circular trimmed

Blades

320

321

322

323

Blade, prismatic formal

Flake blade

Notched blade

Notched flake blade

Cores

330

331

332

333

334

335

345

346

347

348

349

355

356

357
Single platform prepared

Single platform unprepared

Double platform prepared

Double platform unprepared

Multiple platform, prepared

Multiple platform, unprepared

Typed Tools

Clear Fork tool, bifacial

Clear Fork tool, unifacial

01 mos tool

Nueces tool

Guadalupe tool

Miscellaneous Tools

Burin

Burin spal1

Perforator
Code

Number

283d Lanceolate

284 Distal fragment

285 Medial fragment

286 Proximal fragment

287 Lateral fragment

288 Fragment unidentifiable

289 Quarry blank without cortex

308 Miscellaneous or irregular

309 Beaked

310 Notched

311 Uniface fragment

312 Single end trimmed

313 Semicircular

314 Double concave

315 Plane

324 Blade fragment

325 Trimmed, 1 edge

326 Trimmed, 2 edges

336 B1ade-core

337 Double platform, prepared and unprepared

338 Multiplatform, prepared and unprepared

GuadaTupe tool preform

Clear Fork tool preform

Guadalupe tool fragment

Clear Fork tool fragment

Graver

Notch (miscellaneous)

Denticulate 
Code

Number

Flakes

370 Primary cortex

371 Secondary cortex

372 Interior

373 P1 atform Cortex

374 Retouched flake with cortex

Ground Stone

380 Hammerstone

381 Mano (complete)

382 Mano (fragment)

383 Metate (complete)

384 Metate (fragment)

Bone (also see entry 500)

390

391 Retouched

392 Polished

Antler

398 Tine Tool

She11, Tools Only (also see entry 700)

400 Edge-altered mussel

401 Perforated musse1

Features

410 Hearth

411 Fire feature (other)

412 Storage

Burned Materials

420 Charcoal

421 Burned 1imestone

422 Burned sandstone

Samples

450 Thermoluminescence

451 Radiocarbon

204 Prehistoric Ceramics
Code

Number

375 Retouched without cortex

376 Chunk

377 Tested nodule

378 Burned chunk

385 Multifunctional ground stone implement

386 Ground stone fragment

387 Grooved Abrader

388 Gypsum rods

393 Flaker

394 Aw
413 Occupation floor

414 Other

423 Burned chert

424 Heat spal1

452 Wood species sample

453 Archeomagnetic 


$475 \quad$ Unidentifiable
Code
Number

ECOFACTUAL TYPE CODES

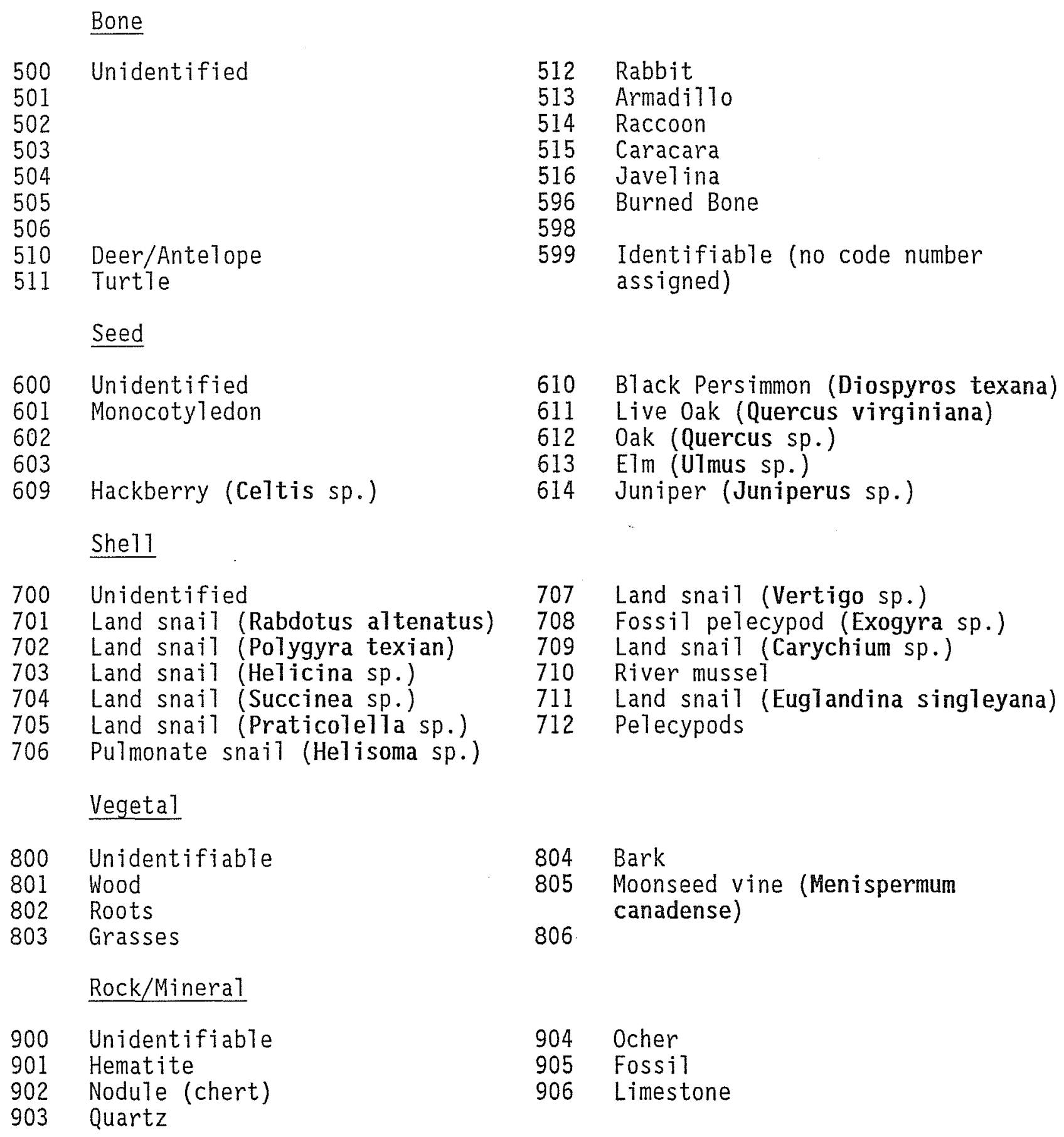

476

Leon Plain

Code
Number 


\section{B. PROVENIENCE AND MEASUREMENTS FOR ALL ARTIFACTS RECOVERED AT 41 BX 300}

The artifacts listed in the following pages are classified as chipped stone tools, in that they are characterized by the presence of intentional retouching on one or more edges or faces. The purpose of this chipping is to create and maintain a functionally efficient overall shape and working edge $(s)$.

Not included in this appendix are those chipped stone artifacts which are not tools themselves, but rather represent stages of manufacture or the debris from manufacturing and maintenance activities. The quantities of these groups of artifacts are such that inclusion in this report, even as an appendix, is not practical. Provenience and other data for these components of the mitigation collection are available to interested researchers in a series of computer printouts maintained with the project records at the Center for Archaeological Research and on magnetic tape by the Computer Resources Center, both located on the main campus of The University of Texas at San Antonio. To facilitate use of the collection, the printouts and computer files are cross-indexed by (1) catalog number; (2) provenience (unit/level/depth); (3) feature/non-feature association; and (4) classification type.

The chipped stone tools are divided into six parts, according to major groups: projectile points, bifaces, unifaces, typed tools, specialized tools, and retouched flakes. Ground stone, shel1, prehistoric ceramics, and historic artifacts are also included in this appendix with provenience information. Subdivision of each group follows the system of classification types previously provided, in numerically coded order. Provenience and metric data are provided for individual artifacts, not for lots or groups of specimens.

Similar data are provided for each specimen. The first entry is a catalog number. Metric data follows, including the weight in grams and maximum length, width, and thickness in millimeters. Provenience data include the feature number, if the specimen was recovered in association with one. The unit or block is designated by a six-digit number; if the last three digits are zeros, a block is indicated. Trenches are designated by the first four letters of their name. Depth below ground surface is measured in centimeters from the edge of the particular unit. The stratum from which the specimen was recovered is designated by the following codes:

TS Topsoil

SS Subsoit

SG Subsoil-gravel transition

MG Mixed grave1

No Not applicable (for trench backdirt or surface collection)

FZ Feature zone 
Site 41 BX 300/Appendix I

Oz Occupation zone

MZ Midden zone

SM Submidden

A comment column includes the following entries:

PROV Exact provenience recorded

SCRE Screen recovery by unit-Tevel

SURF Recovered by block surface collection

BACK Recovered from trench backdirt

Incomplete specimens have the incomplete measurement(s) and their weight enclosed in parentheses. 


\begin{tabular}{|c|c|c|c|c|c|c|c|c|c|c|}
\hline $\begin{array}{l}\text { Classifi- } \\
\text { cation } \\
\text { Type Code }\end{array}$ & $\begin{array}{c}\text { Catalog } \\
\text { Number }\end{array}$ & $\begin{array}{l}\text { Weight } \\
(g)\end{array}$ & $\begin{array}{c}\text { Maximum } \\
\text { Length } \\
(\mathrm{mm})\end{array}$ & $\begin{array}{l}\text { Maximum } \\
\text { Width } \\
\text { (mm) }\end{array}$ & $\begin{array}{l}\text { Maximum } \\
\text { Thickness } \\
\text { (mm) }\end{array}$ & $\begin{array}{l}\text { Feature } \\
\text { Number }\end{array}$ & $\begin{array}{l}\text { Unit/ } \\
\text { Trench/ } \\
\text { Block }\end{array}$ & $\begin{array}{c}\text { Depth Below } \\
\text { Ground } \\
\text { Surface }\end{array}$ & $\begin{array}{l}\text { Stratum } \\
\text { Desig- } \\
\text { nation }\end{array}$ & Comment \\
\hline
\end{tabular}

PART 1. PROJECTILE POINTS

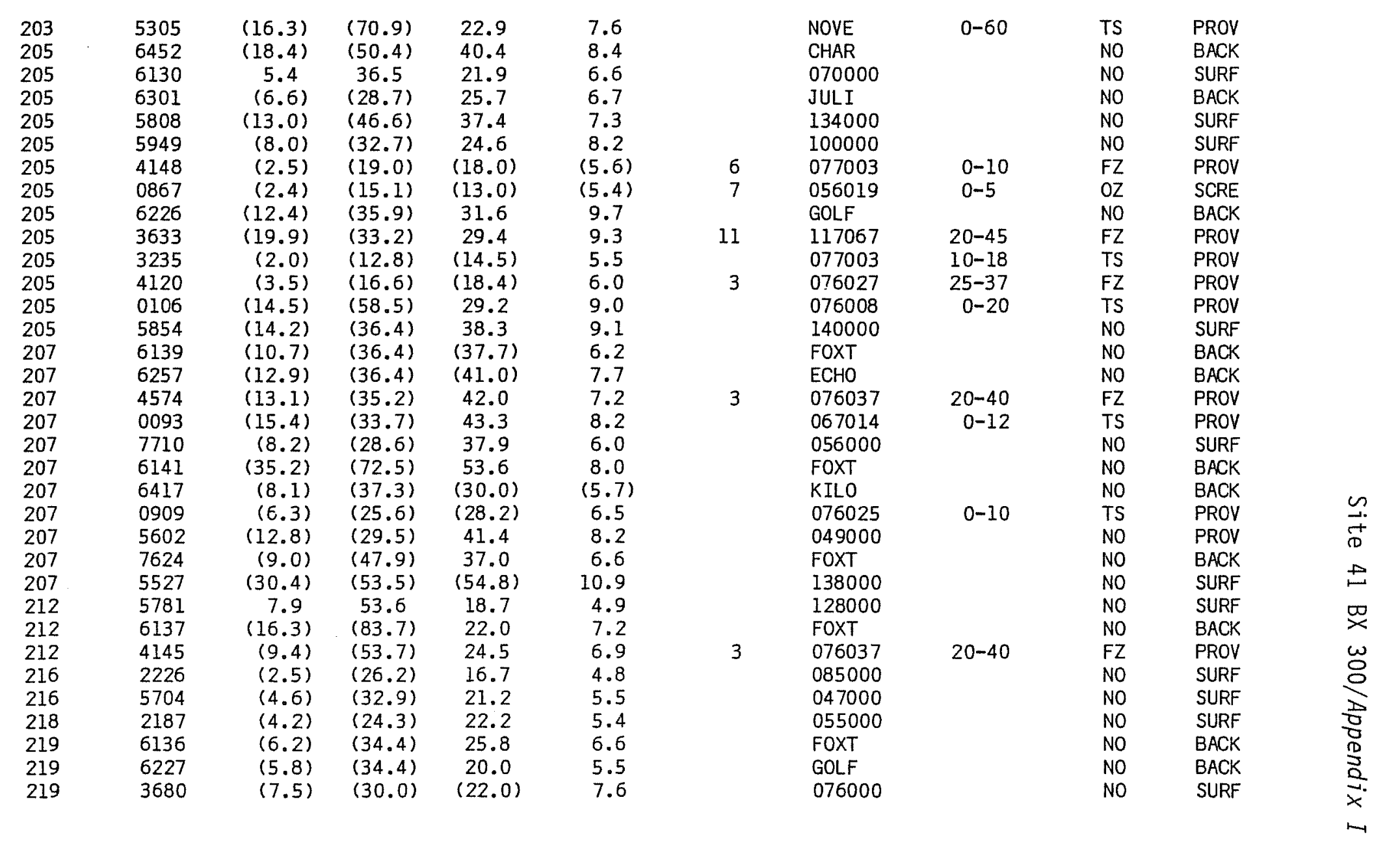




\begin{tabular}{|c|c|c|c|c|c|c|c|c|c|c|}
\hline $\begin{array}{l}\text { Classifi- } \\
\text { cation } \\
\text { Type Code }\end{array}$ & $\begin{array}{r}\text { Catalog } \\
\text { Number }\end{array}$ & $\begin{array}{l}\text { Weight } \\
(\mathrm{g})\end{array}$ & $\begin{array}{l}\text { Maximum } \\
\text { Length } \\
(\mathrm{mm})\end{array}$ & $\begin{array}{l}\text { Maximum } \\
\text { Width } \\
\text { (mm) }\end{array}$ & $\begin{array}{l}\text { Maximum } \\
\text { Thickness } \\
\quad(\mathrm{mm})\end{array}$ & $\begin{array}{l}\text { Feature } \\
\text { Number }\end{array}$ & $\begin{array}{l}\text { Unit/ } \\
\text { Trench/ } \\
\text { Block }\end{array}$ & $\begin{array}{l}\text { Depth Below } \\
\text { Ground } \\
\text { Surface }\end{array}$ & $\begin{array}{l}\text { Stratum } \\
\text { Desig- } \\
\text { nation }\end{array}$ & Comment \\
\hline \multicolumn{11}{|l|}{ PART 1.} \\
\hline 219 & 4576 & $(4,4)$ & $(32.9)$ & 20.6 & 4.9 & 3 & 076037 & $20-40$ & $F Z$ & PROY \\
\hline 219 & 0973 & $(4.6)$ & $(22.8)$ & $(20.4)$ & 6.4 & & 077012 & $0-10$ & TS & PROV \\
\hline 219 & 2074 & $(4.1)$ & $(24.6)$ & $(24.1)$ & 5.2 & & 077003 & $10-18$ & TS & PROV \\
\hline 219 & 2230 & $(4.6)$ & $(32.3)$ & 17.5 & 5.4 & & 024000 & & NO & SURF \\
\hline 219 & 2263 & $(3.4)$ & $(20.4)$ & 17.2 & 5.7 & & 021000 & & NO & SURF \\
\hline 219 & 5480 & $(9.6)$ & $(40.4)$ & 29.3 & 6.2 & & GOLF & & NO & BACK \\
\hline 219 & 0090 & $(4.5)$ & $(26.6)$ & $(20.3)$ & 5.7 & & 075090 & $0-20$ & TS & PROV \\
\hline 219 & 5933 & $(5.7)$ & $(38.5)$ & 18.7 & 5.9 & - & 129000 & & NO & SURF \\
\hline 219 & 2186 & $(6.1)$ & $(33.2)$ & 24.2 & 6.6 & & 055000 & & NO & SURF \\
\hline 219 & 5451 & $(5.4)$ & $(27.9)$ & $(25.4)$ & 5.2 & & 012000 & & NO & SURF \\
\hline 219 & 7711 & $(4.9)$ & $(33.4)$ & $(20.3)$ & 5.4 & & 085000 & & NO & SURF \\
\hline 219 & 6261 & $(5.4)$ & $(41.6)$ & 18.7 & 5.6 & & $\mathrm{ECHO}$ & & NO & BACK \\
\hline 219 & 6358 & $(3.9)$ & $(24.3)$ & 20.3 & 6.0 & & 023000 & & NO & SURF \\
\hline 219 & 6521 & $(4.1)$ & $(26.9)$ & 19.9 & 5.0 & & INDI & & NO & BACK \\
\hline 219 & 1699 & 4.7 & 33.2 & 21.3 & 4.8 & 8 & 085009 & $30-43$ & $\mathrm{FZ}$ & PROV \\
\hline 219 & 0082 & 3.5 & 36.1 & 22.4 & 4.3 & & 056044 & $30-41$ & TS & PROV \\
\hline 219 & 2174 & $(5.4)$ & $(32.4)$ & $(23.9)$ & 6.7 & & 055000 & & NO & SURF \\
\hline 221 & 6367 & $(4.3)$ & $(29.6)$ & 21.9 & 5.0 & & 013000 & & NO & SURF \\
\hline 221 & 5833 & $(4.5)$ & $(25.7)$ & 24.1 & 4.9 & & 146000 & & NO & SURF \\
\hline 221 & 6263 & $(5.3)$ & $(38.0)$ & 20.0 & 4.2 & & ECHO & & NO & BACK \\
\hline 221 & 6222 & $(4.9)$ & $(33.2)$ & $(24.4)$ & 5.3 & & GOLF & & NO & BACK \\
\hline 221 & 6268 & $(5.1)$ & $(21.7)$ & 23.4 & 5.7 & & ECHO & & NO & BACK \\
\hline 221 & 5691 & $(5.0)$ & $(29.7)$ & 21.2 & 4.6 & & 028000 & & NO & SURF \\
\hline 221 & 6142 & $(5.3)$ & $(33.5)$ & 19.0 & 6.3 & & FOXT & & NO & BACK \\
\hline 224 & 6416 & $(13.1)$ & $(51.0)$ & 30.6 & 7.6 & & KILO & & NO & BACK \\
\hline 224 & 6218 & $(6.8)$ & $(27.8)$ & 29.4 & 6.0 & & GOLF & & NO & BACK \\
\hline 224 & 6260 & $(7.2)$ & $(38.7)$ & $(24.5)$ & 5.4 & & $\mathrm{ECHO}$ & & NO & BACK \\
\hline 224 & 6502 & $(7.7)$ & $(41.0)$ & 26.9 & 6.5 & & ALFA & & NO & BACK \\
\hline 224 & 3945 & $(5.6)$ & $(32.9)$ & 24.0 & 6.5 & & 075100 & $0-20$ & TS & SCRE \\
\hline 224 & 0150 & (11.6) & $(43.7)$ & 35.4 & 7.0 & 4 & 076019 & $10-20$ & $\mathrm{OZ}$ & PROV \\
\hline 224 & 5528 & $(4.0)$ & 34.0 & (18.9) & 5.2 & & 138000 & & NO & SURF \\
\hline 224 & 6944 & 4.0 & 34.0 & 15.6 & 5.5 & & 077002 & $10-18$ & TS & SCRE \\
\hline 224 & 0495 & $(5.2)$ & (33.3) & 25.7 & 5.4 & & 077022 & $0-10$ & TS & PROV \\
\hline 224 & 1109 & $(4.4)$ & $(29.6)$ & 21.0 & 5.3 & & 024079 & $0-15$ & TS & SCRE \\
\hline
\end{tabular}




\begin{tabular}{|c|c|c|c|c|c|c|c|c|c|c|}
\hline $\begin{array}{l}\text { Classifi- } \\
\text { cation } \\
\text { Type Code }\end{array}$ & $\begin{array}{c}\text { Catalog } \\
\text { Number }\end{array}$ & $\begin{array}{l}\text { Weight } \\
\text { (g) }\end{array}$ & $\begin{array}{l}\text { Maximum } \\
\text { Length } \\
(\mathrm{mm})\end{array}$ & $\begin{array}{l}\text { Maximum } \\
\text { Width } \\
(\mathrm{mm})\end{array}$ & $\begin{array}{l}\text { Maximum } \\
\text { Thickness } \\
(\mathrm{mm})\end{array}$ & $\begin{array}{l}\text { Feature } \\
\text { Number }\end{array}$ & $\begin{array}{l}\text { Unit/ } \\
\text { Trench/ } \\
\text { Block }\end{array}$ & $\begin{array}{c}\text { Depth Below } \\
\text { Ground } \\
\text { Surface }\end{array}$ & $\begin{array}{l}\text { Stratum } \\
\text { Desig- } \\
\text { nation }\end{array}$ & Comment \\
\hline
\end{tabular}

PART 1. PROJECTILE POINTS (continued)

\begin{tabular}{|c|c|c|c|c|c|c|c|c|c|c|}
\hline 224 & 6818 & $(6.6)$ & $(28.4)$ & 24.2 & 6.4 & & 076026 & $0-10$ & TS & SCRE \\
\hline 224 & 5983 & $(5.2)$ & $(33.2)$ & 24.0 & 5.6 & & 069000 & & NO & SURF \\
\hline 226 & 5885 & $(8.2)$ & $(41.1)$ & 28.2 & 7.1 & & 111000 & & NO & SURF \\
\hline 229 & 6266 & $(11.9)$ & $(56.4)$ & 24.5 & 8.3 & & $\mathrm{ECHO}$ & & NO & BACK \\
\hline 230 & 0147 & $(18.9)$ & $(75.2)$ & $(37.9)$ & 9.2 & 5 & 076018 & $20-30$ & $\mathrm{OZ}$ & PROV \\
\hline 231 & 0500 & $(10.8)$ & $(50.3)$ & 27.6 & 8.2 & & 077022 & $0-10$ & $\mathrm{TS}$ & PROV \\
\hline 231 & 2099 & 6.2 & 37.8 & 25.6 & 5.2 & & 077003 & $10-18$ & TS & PROV \\
\hline 231 & 0346 & $(5.4)$ & $(35.6)$ & 35.9 & 5.2 & & 011028 & $10-20$ & TS & SCRE \\
\hline 231 & 2184 & 10.2 & 47.3 & 22.9 & 8.9 & & 055000 & & NO & SURF \\
\hline 233 & 6220 & $(9.2)$ & $(31.6)$ & 37.5 & 6.6 & & GOLF & & NO & BACK \\
\hline 233 & 5177 & $(15.2)$ & $(47.4)$ & 34.8 & 7.6 & 7 & 056016 & $9-12$ & $\mathrm{OZ}$ & PROV \\
\hline 233 & 5312 & $(3.3)$ & $(27.8)$ & $(25.7)$ & 3.8 & & 041000 & & NO & SURF \\
\hline 233 & 0124 & $(8.4)$ & $(30.0)$ & 34.3 & 6.2 & & 076008 & $0-20$ & TS & PROV \\
\hline 233 & 1684 & $(8.1)$ & $(36.2)$ & 34.3 & 5.9 & & 077003 & $0-10$ & TS & PROV \\
\hline 235 & 4032 & $(5.8)$ & $(34.3)$ & 22.3 & 7.7 & & 076037 & & NO & SURF \\
\hline 235 & 5580 & $(10.1)$ & $(42.2)$ & 33.3 & 6.3 & & 046000 & & NO & SURF \\
\hline 236 & 2193 & 6.7 & 37.5 & 23.0 & 6.4 & & 066000 & & NO & SURF \\
\hline 238 & 6138 & 17.1 & 60.6 & 37.8 & 6.6 & & FOXT & & NO & BACK \\
\hline 238 & 6146 & $(15.0)$ & $(55.0)$ & 38.4 & 6.8 & & FOXT & & NO & BACK \\
\hline 238 & 6215 & $(7.9)$ & $(32.9)$ & $(32.7)$ & $(5.4)$ & & GOLF & & NO & BACK \\
\hline 238 & 6121 & 5.8 & 37.0 & 21.5 & 5.9 & & 059000 & & NO & SURF \\
\hline 238 & 6402 & $(5.9)$ & $(22.6)$ & 35.8 & 6.2 & & LIMA & & NO & BACK \\
\hline 238 & 6148 & $(6.6)$ & $(28.4)$ & $(36.0)$ & $(5.2)$ & & FOXT & & NO & BACK \\
\hline 238 & 1609 & $(16.0)$ & $(43.5)$ & $(43.3)$ & 7.7 & 5 & 076010 & $29-39$ & $O Z$ & PROV \\
\hline 238 & 0064 & $(5.6)$ & $(25.2)$ & $(28.6)$ & 5.1 & & 066020 & $10-21$ & TS & PROV \\
\hline 238 & 5782 & $(7.4)$ & $(24.8)$ & 35.9 & 6.6 & & 128000 & & NO & SURF \\
\hline 238 & 0135 & $(7.2)$ & $(40.9)$ & 30.0 & 5.5 & 7 & 056027 & $0-5$ & $\mathrm{OZ}$ & PROV \\
\hline 241 & 6394 & 9.7 & 48.0 & 23.9 & 7.0 & & 024000 & & NO & SURF \\
\hline 241 & 6214 & 12.1 & 52.8 & 24.5 & 9.0 & & GOLF & & NO & BACK \\
\hline 241 & 6147 & $(16.1)$ & $(53.8)$ & 27.5 & 10.0 & & FOXT & & NO & BACK \\
\hline 241 & 4117 & 10.0 & 50.0 & 29.1 & 6.6 & & 077003 & $18-28$ & TS & PROV \\
\hline 241 & 1218 & $(4.2)$ & $(23.9)$ & $(22.6)$ & 5.6 & & 067014 & $10-19$ & TS & SCRE \\
\hline 241 & 5820 & $(10.6)$ & $(39.2)$ & $(31.8)$ & 7.8 & & 134000 & & NO & SURF \\
\hline 241 & 5985 & $(4.6)$ & $(26.0)$ & 26.0 & 5.3 & & 070000 & & NO & SURF \\
\hline
\end{tabular}


PART 1. PROJECTILE POINTS (continued)

\begin{tabular}{|c|c|c|c|c|c|c|c|c|c|c|}
\hline 241 & 0232 & $(12.2)$ & $(23.5)$ & $(15.5)$ & $(6.0)$ & & 055088 & $51-65$ & SM & PROV \\
\hline 241 & 0104 & $(8.9)$ & $(43.6)$ & 22.9 & 8.6 & & 056046 & $20-29$ & TS & PROV \\
\hline 241 & 2233 & $(4.4)$ & $(23.6)$ & 25.4 & 6.7 & & 056000 & & NO & SURF \\
\hline 244 & 5481 & $(7.7)$ & $(45.0)$ & 19.3 & 6.0 & & GOLF & & NO & BACK \\
\hline 246 & 6286 & $(21.9)$ & $(64.6)$ & 34.4 & 7.8 & & DELT & & NO & BACK \\
\hline 246 & 6140 & $(11.3)$ & $(37.4)$ & $(31.6)$ & 8.6 & & FOXT & & NO & BACK \\
\hline 246 & 6213 & $(7.0)$ & $(27.5)$ & $(30.5)$ & 7.6 & & GOLF & & NO & BACK \\
\hline 246 & 6430 & $(6.8)$ & $(30.4)$ & $(31.0)$ & 5.3 & & BRAV & & NO & BACK \\
\hline 246 & 9100 & $(29.3)$ & $(60.0)$ & 42.9 & 10.5 & & BRAV & & NO & BACK \\
\hline 246 & 9110 & $(11.5)$ & $(43.7)$ & 33.4 & 7.7 & & CHAR & & NO & BACK \\
\hline 246 & 4600 & $(4.2)$ & $(26.2)$ & $(19.2)$ & 6.4 & 5 & 076018 & $20-30$ & $\mathrm{OZ}$ & SCRE \\
\hline 246 & 5539 & $(6.8)$ & $(36.3)$ & $(30.3)$ & 6.6 & & 010000 & & NO & SURF \\
\hline 246 & 0494 & (11.8) & $(42.7)$ & $(34.2)$ & 8.4 & & 076049 & $0-10$ & TS & PROV \\
\hline 246 & 0501 & $(6.6)$ & $(30.0)$ & $(22.4)$ & 6.4 & & 077022 & $0-10$ & TS & PROV \\
\hline 246 & 0911 & $(17.1)$ & 63.4 & $(30.5)$ & 7.8 & & 077021 & $0-10$ & TS & PROV \\
\hline 246 & 5992 & $(8.9)$ & $(41.2)$ & 27.7 & 7.0 & & 110000 & & NO & SURF \\
\hline 246 & 5419 & $(9.5)$ & $(42.6)$ & $(33.7)$ & 6.9 & & 032000 & & NO & SURF \\
\hline 247 & 0584 & $(1.4)$ & $(23.2)$ & 14.2 & 2.9 & & 066020 & $0-10$ & TS & PROV \\
\hline 247 & 7811 & $(1.9)$ & $(25.1)$ & $(15.9)$ & 2.9 & & FOXT & & NO & BACK \\
\hline 250 & 6262 & 6.2 & 48.3 & 17.7 & 4.4 & & ECHO & & NO & BACK \\
\hline 256 & 7893 & $(0.5)$ & $(6.0)$ & $(10.5)$ & $(3.2)$ & 7 & 056026 & $0-9$ & $\mathrm{OZ}$ & SCRE \\
\hline 257 & 5099 & 12.7 & 62.5 & 24.3 & 18.4 & 2 & 055084 & $23-46$ & $M Z$ & PROV \\
\hline 257 & 1610 & 10.2 & 52.7 & 20.6 & 8.0 & 5 & 077002 & $28-38$ & $\mathrm{OZ}$ & PROV \\
\hline 257 & 5181 & 7.4 & 41.4 & 19.5 & 7.1 & 5 & 066038 & $20-60$ & $O Z$ & PROV \\
\hline 257 & 1389 & $(7.2)$ & $(40.6)$ & 20.3 & 6.8 & & 055089 & $30-61$ & SM & SCRE \\
\hline 257 & 6135 & 6.9 & 39.1 & 19.8 & 6.8 & & FOXT & & NO & BACK \\
\hline 257 & 1667 & 4.5 & 31.7 & 15.9 & 6.2 & 7 & 056019 & $5-10$ & $\mathrm{OZ}$ & PROV \\
\hline 257 & 6426 & $(11.9)$ & $(47.3)$ & 24.7 & 9.2 & & BRAV & & NO & BACK \\
\hline 257 & 6217 & $(7.8)$ & $(34.3)$ & $(22.9)$ & 7.0 & & GOLF & & NO & BACK \\
\hline 257 & 5616 & 11.8 & 53.5 & 22.5 & 8.0 & & 113000 & & NO & SURF \\
\hline 257 & 6427 & $(17.4)$ & $(60.7)$ & 26.9 & 11.5 & & BRAV & & NO & BACK \\
\hline 259 & 6265 & 8.5 & 48.0 & 25.1 & 8.9 & & ECHO & & NO & BACK \\
\hline 259 & 6577 & $(10.1)$ & $(39.9)$ & 28.7 & 8.7 & & NOVE & & NO & BACK \\
\hline 259 & 5529 & $(4.8)$ & $(30.0)$ & $(15.9)$ & 6.8 & & 138000 & & NO & SURF \\
\hline
\end{tabular}




\begin{tabular}{|c|c|c|c|c|c|c|c|c|c|c|}
\hline $\begin{array}{l}\text { Classif } i- \\
\text { cation } \\
\text { Type Code }\end{array}$ & $\begin{array}{c}\text { Catalog } \\
\text { Number }\end{array}$ & $\begin{array}{l}\text { Weight } \\
\text { (g) }\end{array}$ & $\begin{array}{l}\text { Maximum } \\
\text { Length } \\
(\mathrm{mm})\end{array}$ & $\begin{array}{l}\text { Maximum } \\
\text { Width } \\
\text { (mm) }\end{array}$ & $\begin{array}{l}\text { Maximum } \\
\text { Thickness } \\
\text { (mm) }\end{array}$ & $\begin{array}{l}\text { Feature } \\
\text { Number }\end{array}$ & $\begin{array}{l}\text { Unit/ } \\
\text { Trench/ } \\
\text { Block }\end{array}$ & $\begin{array}{c}\text { Depth Below } \\
\text { Ground } \\
\text { Surface }\end{array}$ & $\begin{array}{l}\text { Stratum } \\
\text { Desig- } \\
\text { nation }\end{array}$ & Comment \\
\hline
\end{tabular}

PART 1. PROJECTILE POINTS (continued)

\begin{tabular}{|c|c|c|c|c|c|c|c|c|c|c|}
\hline 263 & 6264 & 3.9 & 35.0 & 15.3 & 5.5 & & $\mathrm{ECHO}$ & & NO & BACK \\
\hline 263 & 6429 & $(4.0)$ & $(27.8)$ & 11.4 & 6.4 & & BRAV & & NO & BACK \\
\hline 263 & 5676 & 3.2 & 27.7 & 16.5 & 4.6 & & 027000 & & NO & SURF \\
\hline 264 & 0829 & $(1.4)$ & $(18.5)$ & $(12.9)$ & 2.4 & 7 & 056017 & $0-6$ & $O Z$ & SCRE \\
\hline 264 & 0985 & $(0.8)$ & $(17.7)$ & $(12.3)$ & $(3.5)$ & & 075099 & $0-20$ & TS & PROV \\
\hline 264 & 6216 & $(1.2)$ & $(27.4)$ & 13.9 & 2.0 & & GOLF & & NO & BACK \\
\hline 264 & 4395 & $(1.4)$ & $(24.6)$ & $(14.2)$ & $(3.5)$ & & 076047 & $10-20$ & TS & SCRE \\
\hline 264 & 2708 & $(9.0)$ & $(14.6)$ & $(8.8)$ & $(3.0)$ & 7 & 056026 & $0-9$ & $\mathrm{OZ}$ & SCRE \\
\hline 265 & 2228 & $(10.8)$ & 45.0 & $(31.7)$ & 6.6 & & 024000 & & NO & SURF \\
\hline 265 & 2229 & 20.8 & 58.6 & 42.1 & 8.3 & & 024000 & & NO & SURF \\
\hline 265 & 5165 & $(10.6)$ & $(55.0)$ & $(25.3)$ & 7.9 & 6 & 077003 & $28-38$ & $\mathrm{FZ}$ & PROV \\
\hline 265 & 0100 & $(8.4)$ & $(25.0)$ & 33.6 & 7.1 & & 065015 & $0-20$ & TS & PROV \\
\hline 265 & 9941 & $(4.2)$ & $(32.8)$ & $(17.9)$ & 4.9 & & 076026 & $0-10$ & TS & SCRE \\
\hline 265 & 2736 & $(11.2)$ & $(30.9)$ & 40.0 & 7.8 & & 114071 & $0-15$ & TS & PROV \\
\hline 265 & 5655 & 8.2 & 33.0 & 25.1 & 7.8 & & 113000 & & NO & SURF \\
\hline 265 & 6021 & $(4.1)$ & $(31.5)$ & 20.4 & 4.8 & & 090000 & & NO & SURF \\
\hline 265 & 1107 & $(14.8)$ & $(40.6)$ & 39.3 & 8.7 & & GOLF & & NO & BACK \\
\hline 265 & 5934 & $(16.6)$ & $(58.5)$ & $(33.9)$ & 8.4 & & 129000 & & NO & SURF \\
\hline 265 & 6144 & $(24.6)$ & $(40.4)$ & $(31.7)$ & 7.4 & & FOXT & & NO & BACK \\
\hline
\end{tabular}

\section{PART 2. BIFACES}

\begin{tabular}{|c|c|c|c|c|c|c|c|c|c|}
\hline $283 a$ & 5968 & 26.4 & 44.9 & 37.6 & 18.7 & 129000 & & NO & SURF \\
\hline $283 a$ & 2295 & 32.6 & 46.6 & 49.4 & 13.5 & 002000 & & NO & SURF \\
\hline $283 a$ & 6045 & 39.7 & 54.7 & 44.4 & 17.8 & 168000 & & NO & SURF \\
\hline $283 a$ & 5734 & 32.4 & 44.8 & 46.6 & 11.9 & 031000 & & NO & SURF \\
\hline $283 a$ & 3553 & 36.9 & 47.0 & 45.0 & 15.7 & 119036 & $5-46$ & TS & PROV \\
\hline $283 a$ & 7562 & 54.5 & 60.6 & 54.6 & 17.3 & FOXT & & NO & BACK \\
\hline $283 a$ & 0012 & 15.9 & 41.7 & 33.5 & 9.8 & 011029 & $0-10$ & TS & PROV \\
\hline $283 b$ & 7853 & 26.8 & 62.0 & 38.6 & 11.9 & GOLF & & NO & BACK \\
\hline $283 b$ & 6190 & 15.0 & 48.7 & 31.4 & 9.9 & GOLF & & NO & BACK \\
\hline $283 b$ & 6169 & 19.2 & 51.3 & 32.4 & 9.3 & FOXT & & NO & BACK \\
\hline $283 b$ & 6572 & 195.6 & 100.5 & 64.8 & 28.0 & KILO & & NO & BACK \\
\hline
\end{tabular}




\begin{tabular}{|c|c|c|c|c|c|c|c|c|c|c|}
\hline $\begin{array}{l}\text { Classifi- } \\
\text { cation } \\
\text { Type Code }\end{array}$ & $\begin{array}{l}\text { Catalog } \\
\text { Number }\end{array}$ & $\begin{array}{l}\text { Weight } \\
\text { (g) }\end{array}$ & $\begin{array}{l}\text { Maximum } \\
\text { Length } \\
(\mathrm{mm})\end{array}$ & $\begin{array}{l}\text { Maximum } \\
\text { Width } \\
\text { (mm) }\end{array}$ & $\begin{array}{c}\text { Maximum } \\
\text { Thickness } \\
(\mathrm{mm})\end{array}$ & $\begin{array}{l}\text { Feature } \\
\text { Number }\end{array}$ & $\begin{array}{l}\text { Unit/ } \\
\text { Trench/ } \\
\text { Block }\end{array}$ & $\begin{array}{c}\text { Depth Below } \\
\text { Ground } \\
\text { Surface }\end{array}$ & $\begin{array}{l}\text { Stratum } \\
\text { Desig- } \\
\text { nation }\end{array}$ & Comment \\
\hline PART 2. & BIFACES (CO & tinued) & & & & & & & & \\
\hline $283 b$ & 7563 & 151.8 & 91.0 & 64.0 & 29.8 & & FOXT & & NO & BACK \\
\hline $283 b$ & 5633 & 32.4 & 62.3 & 45.9 & 8.9 & & 036000 & & NO & SURF \\
\hline $283 b$ & 0131 & 51.1 & 61.4 & 40.4 & 19.2 & 3 & 076018 & $0-20$ & TS & PROV \\
\hline $283 b$ & 2205 & 80.08 & 74.5 & 60.5 & 22.0 & & 066000 & & NO & SURF \\
\hline $283 b$ & 7564 & 88.8 & 76.5 & 54.6 & 18.6 & & FOXT & & NO & BACK \\
\hline $283 b$ & 6514 & 87.2 & 80.9 & 53.9 & 21.6 & & INDI & & NO & BACK \\
\hline $283 b$ & 7688 & 46.6 & 62.0 & 52.0 & 13.0 & & $\mathrm{ECHO}$ & & NO & BACK \\
\hline $283 b$ & 7560 & 94.7 & 76.3 & 64.0 & 19.6 & & $\mathrm{ECHO}$ & & NO & BACK \\
\hline $283 b$ & 6459 & 98.2 & 75.6 & 58.5 & 20.2 & & CHAR & & NO & BACK \\
\hline $283 b$ & 7638 & 79.7 & 74.4 & 50.0 & 21.6 & & $\mathrm{ECHO}$ & & NO & BACK \\
\hline $283 b$ & 7689 & 100.7 & 93.0 & 64.5 & 16.9 & & ECHO & & NO & BACK \\
\hline $283 b$ & 6479 & 29.9 & 58.0 & 45.1 & 11.4 & & OMEG & & NO & BACK \\
\hline $283 b$ & 5299 & 18.6 & 41.9 & 36.8 & 9.3 & & 022096 & $0-60$ & SS & PROV \\
\hline $283 c$ & 3074 & 245.3 & 134.2 & 67.3 & 31.4 & & 047020 & $0-90$ & TS & PROV \\
\hline $283 c$ & 6251 & 43.1 & 77.5 & 53.5 & 11.0 & & ECHO & & NO & BACK \\
\hline $283 c$ & 5563 & 24.9 & 58.0 & 31.4 & 13.2 & & 041000 & & NO & SURF \\
\hline $283 c$ & 6295 & 31.8 & 59.4 & 47.3 & 16.0 & & DELT & & NO & BACK \\
\hline $283 c$ & 5587 & 31.4 & 77.0 & 40.8 & 10.2 & & 036000 & & NO & SURF \\
\hline $283 c$ & 6500 & 10.3 & 49.9 & 30.6 & 12.0 & & ALFA & & NO & BACK \\
\hline $283 c$ & 6170 & 19.1 & 45.0 & 34.6 & 12.5 & & FOXT & & NO & SURF \\
\hline $283 c$ & 6269 & 19.2 & 62.8 & 28.3 & 11.9 & & $\mathrm{ECHO}$ & & NO & BACK \\
\hline $283 \mathrm{c}$ & 5634 & 7.9 & 43.7 & 25.2 & 7.6 & & 036000 & & NO & SURF \\
\hline $283 c$ & 0294 & 6.8 & 38.0 & 28.3 & 5.8 & & 011039 & $10-20$ & TS & SCRE \\
\hline $283 c$ & 2297 & 9.6 & 46.9 & 24.7 & 9.3 & & 062000 & & NO & SURF \\
\hline $283 c$ & 1608 & 8.2 & 42.9 & 29.0 & 7.2 & & 077003 & $0-10$ & TS & PROV \\
\hline $283 c$ & 0014 & 9.1 & 42.5 & 32.6 & $6 . \overline{6}$ & & 011028 & $10-20$ & $\mathrm{TS}$ & PROV \\
\hline $283 c$ & 7831 & 51.9 & 72.0 & 43.0 & 20.2 & & GOLF & & NO & BACK \\
\hline $283 c$ & 6219 & 39.0 & 85.0 & 44.5 & 12.0 & & GOLF & & NO & BACK \\
\hline $283 c$ & 6094 & 15.8 & 58.7 & 32.7 & 9.6 & & 109000 & & NO & SURF \\
\hline $283 c$ & 6359 & 29.4 & 52.8 & 38.3 & 13.8 & & 023000 & & NO & SURF \\
\hline $283 c$ & 0055 & 23.2 & 46.6 & 34.4 & 16.7 & & 056083 & $0-13$ & TS & PROV \\
\hline $283 c$ & 7833 & 34.6 & 74.5 & 48.8 & 10.4 & & GOLF & & NO & BACK \\
\hline $283 c$ & 3080 & 109.8 & 100.0 & 55.3 & 23.3 & & 048012 & $0-90$ & TS & PROV \\
\hline $283 c$ & 0073 & 39.1 & 79.3 & 36.6 & 14.2 & & 056064 & $0-20$ & TS & PROV \\
\hline
\end{tabular}

PART 2. BIFACES (continued) 


\begin{tabular}{|c|c|c|c|c|c|c|c|c|c|c|}
\hline $\begin{array}{l}\text { Classifi- } \\
\text { cation } \\
\text { Type Code }\end{array}$ & $\begin{array}{l}\text { Catalog } \\
\text { Number }\end{array}$ & $\begin{array}{l}\text { Weight } \\
(g)\end{array}$ & $\begin{array}{c}\text { Maximum } \\
\text { Length } \\
(\mathrm{mm})\end{array}$ & $\begin{array}{l}\text { Maximum } \\
\text { Width } \\
\text { (mm) }\end{array}$ & $\begin{array}{l}\text { Maximum } \\
\text { Thickness } \\
\text { (mm) }\end{array}$ & $\begin{array}{l}\text { Feature } \\
\text { Number }\end{array}$ & $\begin{array}{l}\text { Unit/ } \\
\text { Trench/ } \\
\text { Block }\end{array}$ & $\begin{array}{c}\text { Depth Below } \\
\text { Ground } \\
\text { Surface }\end{array}$ & $\begin{array}{l}\text { Stratum } \\
\text { Desig- } \\
\text { nation }\end{array}$ & Comment \\
\hline
\end{tabular}

PART 2. BIFACES (continued)

$\begin{array}{lrrrrr}283 \mathrm{c} & 6458 & 44.2 & 72.0 & 44.0 & 18.6 \\ 283 \mathrm{c} & 3587 & 56.0 & 81.4 & 48.8 & 16.2 \\ 283 \mathrm{~d} & 2254 & 6.3 & 36.0 & 17.8 & 6.0 \\ 283 \mathrm{~d} & 5494 & 2.9 & 25.4 & 14.8 & 4.6 \\ 283 \mathrm{~d} & 7690 & 89.1 & 105.0 & 34.5 & 22.8 \\ 283 \mathrm{~d} & 7814 & 27.8 & 105.0 & 25.8 & 11.4 \\ 283 \mathrm{~d} & 7561 & 67.4 & 87.4 & 39.7 & 20.6 \\ 283 \mathrm{~d} & 6580 & 143.0 & 110.6 & 58.5 & 23.0 \\ 283 \mathrm{~d} & 5875 & 81.3 & 87.3 & 52.6 & 17.3 \\ 283 \mathrm{~d} & 5542 & 43.9 & 59.9 & 33.8 & 22.6 \\ 283 \mathrm{~d} & 6513 & 39.9 & 58.7 & 38.5 & 16.7 \\ 283 \mathrm{~d} & 6512 & 13.8 & 46.4 & 22.3 & 10.3 \\ 283 \mathrm{~d} & 6777 & 11.6 & 39.6 & 22.7 & 10.5 \\ 283 \mathrm{~d} & 6475 & 9.4 & 49.6 & 26.7 & 7.5 \\ 284 & 3942 & (0.6) & (15.7) & (12.0) & (2.6) \\ 284 & 2709 & (5.7) & (25.9) & (26.7) & (7.3) \\ 284 & 0866 & (2.2) & (12.7) & (18.0) & (5.2) \\ 284 & 0080 & (39.6) & (89.0) & 47.6 & 9.8 \\ 284 & 0572 & (2.2) & (22.8) & (20.7) & (4.6) \\ 284 & 0075 & (3.9) & (32.5) & (20.0) & (5.2) \\ 284 & 0061 & (16.9) & (56.6) & 30.0 & 9.0 \\ 284 & 0138 & (16.8) & (34.2) & 49.6 & 8.7 \\ 284 & 0083 & (4.6) & (36.6) & (30.7) & (5.7) \\ 284 & 0099 & (15.9) & (31.0) & (42.6) & 12.3 \\ 284 & 0065 & (4.6) & (38.1) & (26.4) & (6.0) \\ 284 & 0103 & (55.6) & (89.6) & 52.5 & 8.7 \\ 284 & 0910 & (12.0) & (39.3) & (33.7) & 10.0 \\ 284 & 0113 & (10.4) & (46.4) & (31.3) & 8.5 \\ 284 & 0151 & (1.6) & (22.8) & (9.9) & (11.0) \\ 284 & 0139 & (16.2) & (47.3) & (36.5) & (8.5) \\ 284 & 0469 & (17.1) & (53.0) & 30.0 & 9.0 \\ 284 & 0807 & (12.9) & (61.4) & (29.6) & (6.4) \\ 284 & 1330 & (2.6) & (20.5) & (21.9) & (7.5) \\ 284 & 0914 & (1.1) & (20.0) & (14.0) & (4.3)\end{array}$

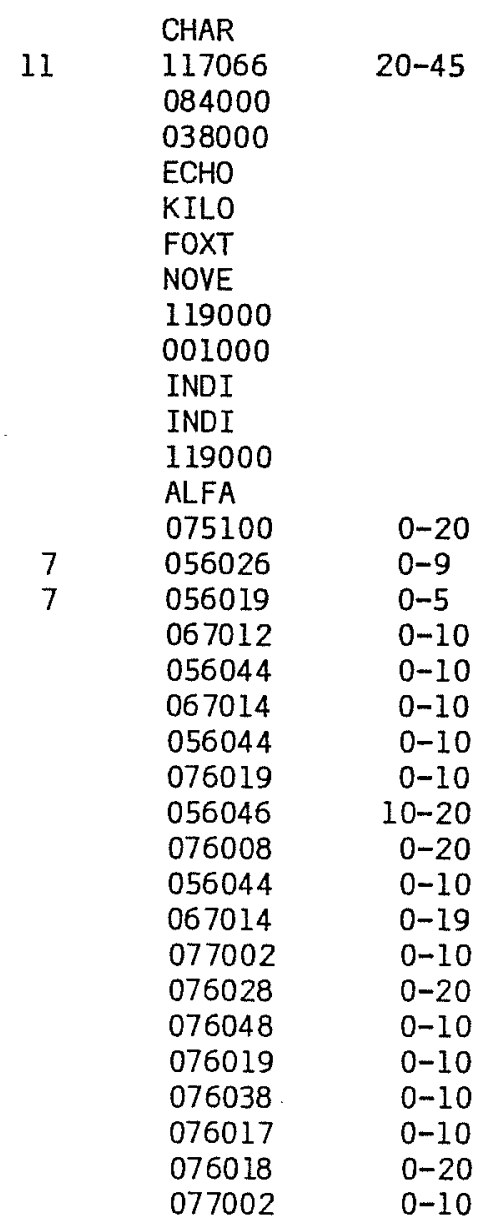

\begin{tabular}{ll} 
NO & BACK \\
FZ & PROV \\
NO & SURF \\
NO & SURF \\
NO & BACK \\
NO & BACK \\
NO & BACK \\
NO & BACK \\
NO & SURF \\
NO & SURF \\
NO & BACK \\
NO & BACK \\
NO & SURF \\
NO & BACK \\
TS & SCRE \\
OZ & SCRE \\
OZ & SCRE \\
TS & PROV \\
TS & SCRE \\
TS & PROV \\
TS & PROV \\
TS & SCRE \\
TS & PROV \\
TS & PROV \\
TS & PROV \\
TS & PROV \\
TS & PROV \\
TS & SCRE \\
TS & PROV \\
TS & SCRE \\
TS & PROV \\
TS & SCRE \\
TS & SCRE \\
TS & PROV \\
& \\
\hline
\end{tabular}


Classification

Catalog Weight Maximum

aximum Maximum

Unit/ Depth Below

Stratum

$(\mathrm{mm})$

(mm)

(mm)

Feature

Trench/

Ground

Desig-

Nefor

PART 2. BIFACES (continued)

$\begin{array}{rrrrrr}284 & 0527 & (0.1) & (9.2) & (6.5) & (1.2) \\ 284 & 0570 & (0.3) & (10.0) & (5.0) & (3.0) \\ 284 & 7785 & (12.7) & (45.0) & (33.4) & (8.3) \\ 284 & 7797 & (0.1) & (13.3) & (5.0) & (1.8) \\ 284 & 7796 & (0.2) & (10.8) & (5.2) & (1.7) \\ 284 & 7139 & (7.5) & (29.4) & (27.7) & 8.5 \\ 284 & 7863 & (4.2) & (18.7) & (22.6) & (9.9) \\ 284 & 7583 & (12.5) & (50.0) & (41.9) & (6.9) \\ 284 & 7795 & (2.2) & (15.3) & (21.0) & 5.6 \\ 284 & 7923 & (1.2) & (14.0) & (16.5) & (4.8) \\ 284 & 7889 & (2.1) & (10.4) & (20.4) & 7.3 \\ 284 & 3615 & (3.3) & (29.6) & (16.6) & (6.8) \\ 284 & 0644 & (1.2) & (11.9) & (16.8) & (5.7) \\ 284 & 2071 & (17.3) & (43.0) & (38.3) & (10.3) \\ 284 & 3943 & (0.7) & (13.4) & (11.9) & (4.4) \\ 284 & 1213 & (6.7) & (39.4) & (26.5) & (11.9) \\ 284 & 1671 & (5.1) & (34.0) & (23.3) & (5.4) \\ 284 & 2283 & (6.5) & (18.5) & (26.7) & (6.9) \\ 284 & 7784 & (7.8) & (37.7) & (32.0) & (12.0) \\ 284 & 7913 & (0.3) & (8.3) & (8.2) & (3.0) \\ 284 & 6992 & (0.4) & (9.5) & (9.4) & (2.3) \\ 284 & 6991 & (0.6) & (11.9) & (10.5) & (3.4) \\ 284 & 7112 & (1.4) & (14.7) & (9.6) & 4.7 \\ 284 & 7138 & (2.1) & (17.3) & (11.9) & (5.2) \\ 284 & 7074 & (1.7) & (11.5) & (12.8) & (6.0) \\ 284 & 7113 & (0.8) & (21.5) & (14.5) & (3.3) \\ 284 & 7775 & (13.7) & (22.8) & (45.2) & (8.0) \\ 284 & 7864 & (1.4) & (11.5) & (14.0) & (5.3) \\ 284 & 7009 & (1.1) & (13.8) & (12.8) & (4.5) \\ 284 & 7582 & (2.6) & (29.3) & (17.0) & (4.8) \\ 284 & 0489 & (10.5) & (42.0) & (33.4) & (8.0) \\ 284 & 5381 & (0.5) & (11.4) & (9.4) & (3.9) \\ 284 & 0780 & (3.8) & (24.2) & (24.3) & (8.4) \\ 284 & 4040 & (10.2) & (34.0) & (33.3) & (8.6)\end{array}$

\begin{tabular}{|c|c|c|c|}
\hline 066018 & $0-15$ & TS & SCRE \\
\hline 056044 & $21-30$ & TS & SCRE \\
\hline 077000 & & NO & SURF \\
\hline 067000 & & NO & SURF \\
\hline 067000 & & NO & SURF \\
\hline 076030 & $0-10$ & TS & SCRE \\
\hline JULI & & NO & BACK \\
\hline HOTE & & NO & BACK \\
\hline 067000 & & NO & SURF \\
\hline 075090 & $0-20$ & TS & SCRE \\
\hline 095000 & & NO & SURF \\
\hline 119013 & $0-5$ & TS & PROV \\
\hline 056064 & $0-20$ & TS & SCRE \\
\hline 077003 & $10-18$ & TS & PROV \\
\hline 075100 & $0-20$ & TS & SCRE \\
\hline 076014 & & TS & SCRE \\
\hline 075100 & $0-20$ & TS & PROV \\
\hline 064000 & & NO & SURF \\
\hline 077000 & & NO & SURF \\
\hline 056046 & $20-29$ & TS & SCRE \\
\hline 076027 & $0-10$ & TS & SCRE \\
\hline 076027 & $0-10$ & TS & SCRE \\
\hline 076019 & $0-10$ & TS & SCRE \\
\hline 076030 & $0-10$ & TS & SCRE \\
\hline 077013 & $14-24$ & TS & SCRE \\
\hline 076019 & $0-10$ & TS & SCRE \\
\hline 104000 & & NO & SURF \\
\hline JULI & & NO & BACK \\
\hline 077013 & $0-14$ & TS & SCRE \\
\hline OMEG & & NO & BACK \\
\hline 076039 & $0-10$ & TS & PROV \\
\hline 085009 & $0-20$ & TS & SCRE \\
\hline 076008 & $0-20$ & TS & SCRE \\
\hline 076038 & $0-10$ & TS & SCRE \\
\hline
\end{tabular}




\begin{tabular}{|c|c|c|c|c|c|c|c|c|c|c|}
\hline $\begin{array}{l}\text { Classifi- } \\
\text { cation } \\
\text { Type Code }\end{array}$ & $\begin{array}{r}\text { Catalog } \\
\text { Number }\end{array}$ & $\begin{array}{l}\text { Weight } \\
(g)\end{array}$ & $\begin{array}{c}\text { Maximum } \\
\text { Length } \\
(\mathrm{mm})\end{array}$ & $\begin{array}{l}\text { Maximum } \\
\text { Width } \\
(\mathrm{mm})\end{array}$ & $\begin{array}{l}\text { Maximum } \\
\text { Thickness } \\
(\mathrm{mm})\end{array}$ & $\begin{array}{l}\text { Feature } \\
\text { Number }\end{array}$ & $\begin{array}{l}\text { Unit/ } \\
\text { Trench/ } \\
\text { Block }\end{array}$ & $\begin{array}{c}\text { Depth Below } \\
\text { Ground } \\
\text { Surface }\end{array}$ & $\begin{array}{l}\text { Stratum } \\
\text { Desig- } \\
\text { nation }\end{array}$ & Comment \\
\hline
\end{tabular}

PART 2. BIFACES (continued)

\begin{tabular}{|c|c|c|c|c|c|c|c|c|c|}
\hline 284 & 0056 & $(8.1)$ & $(32.0)$ & $(36.7)$ & $(7.0)$ & 056083 & $0-13$ & TS & PROV \\
\hline 284 & 4026 & $(4.1)$ & $(33.2)$ & $(20.7)$ & $(5.8)$ & 076037 & $0-10$ & TS & SCRE \\
\hline 284 & 1409 & $(0.5)$ & $(8.4)$ & $(11.3)$ & $(2.5)$ & 056023 & $20-30$ & TS & SCRE \\
\hline 284 & 4444 & $(0.3)$ & $(8.4)$ & $(6.5)$ & $(2.2)$ & 076047 & $0-10$ & TS & SCRE \\
\hline 284 & 4113 & $(0.1)$ & $(4.7)$ & $(4.3)$ & $(1.4)$ & 056046 & $20-29$ & TS & SCRE \\
\hline 284 & 4425 & $(1.6)$ & $(25.0)$ & $(11.4)$ & $(4.3)$ & 076048 & $0-10$ & TS & SCRE \\
\hline 284 & 0108 & $(8.3)$ & $(29.6)$ & $(21.6)$ & $(9.4)$ & 065013 & $0-20$ & TS & PROV \\
\hline 284 & 4707 & $(0.3)$ & $(6.3)$ & $(4.6)$ & $(2.3)$ & 077003 & $10-18$ & TS & SCRE \\
\hline 284 & 2234 & (1.8) & $(20.9)$ & $(9.8)$ & $(4.9)$ & 056000 & & NO & SURF \\
\hline 284 & 4423 & $(0.4)$ & $(9.0)$ & $(6.2)$ & $(2.5)$ & 076048 & $10-20$ & TS & SCRE \\
\hline 284 & 5141 & $(0.3)$ & $(11.4)$ & $(10.0)$ & $(2.3)$ & MD & & & \\
\hline 284 & 6623 & $(3.4)$ & $(32.0)$ & $(19.8)$ & $(5.9)$ & MD & & & \\
\hline 284 & 0065 & $(6.0)$ & $(35.8)$ & 23.3 & 6.0 & 056044 & $0-10$ & TS & PROV \\
\hline 284 & 6851 & $(1.0)$ & $(9.9)$ & $(9.4)$ & $(2.4)$ & 077012 & $10-25$ & TS & SCRE \\
\hline 284 & 6328 & $(6.2)$ & $(35.8)$ & $(28.3)$ & $(5.7)$ & HOTE & & NO & BACK \\
\hline 284 & 6481 & $(6.6)$ & $(38.5)$ & $(33.9)$ & $(4.6)$ & OMEG & & NO & BACK \\
\hline 284 & 9264 & $(12.5)$ & $(43.2)$ & $(25.9)$ & 12.6 & 076020 & $0-5$ & TS & SCRE \\
\hline 284 & 9263 & $(1.3)$ & $(9.2)$ & $(12.7)$ & 5.5 & 056044 & $21-30$ & TS & SCRE \\
\hline 284 & 9262 & $(0.6)$ & $(6.2)$ & $(3.4)$ & $(1.3)$ & 077003 & $0-10$ & TS & SCRE \\
\hline 284 & 6523 & $(5.3)$ & $(33.0)$ & $(24.5)$ & $(5.0)$ & INDI & & NO & BACK \\
\hline 284 & 6304 & $(3.8)$ & $(27.6)$ & $(26.4)$ & $(4.0)$ & JULI & & NO & BACK \\
\hline 284 & 9255 & $(1.7)$ & $(15.6)$ & $(15.9)$ & $(3.3)$ & 076017 & $0-10$ & TS & SCRE \\
\hline 284 & 6526 & $(3.5)$ & $(31.0)$ & $(14.2)$ & $(5.4)$ & INDI & & NO & BACK \\
\hline 284 & 6837 & $(1.1)$ & $(16.2)$ & $(11.6)$ & $(2.2)$ & 075090 & $0-20$ & TS & SCRE \\
\hline 284 & 7830 & $(55.7)$ & $(76.4)$ & $(55.0)$ & 14.3 & 042000 & & NO & SURF \\
\hline 284 & 5446 & $(1.5)$ & $(52.0)$ & $(29.2)$ & 8.0 & 042000 & & NO & SURF \\
\hline 284 & 6798 & $(27.9)$ & $(73.4)$ & $(29.0)$ & 10.5 & 167000 & & NO & SURF \\
\hline 284 & 5450 & $(38.1)$ & $(71.4)$ & $(52.0)$ & 9.3 & 012000 & & NO & SURF \\
\hline 284 & 6800 & $(7.2)$ & $(51.4)$ & $(21.0)$ & 5.0 & 100000 & & NO & SURF \\
\hline 284 & 6794 & (13.8) & $(36.9)$ & $(35.0)$ & 8.5 & 109000 & & NO & SURF \\
\hline 284 & 6001 & $(2.1)$ & $(16.2)$ & $(19.5)$ & 4.5 & 167000 & & NO & SURF \\
\hline 284 & 7555 & (16.6) & $(46.7)$ & $(37.4)$ & 8.5 & 120000 & & NO & SURF \\
\hline 284 & 6059 & $(14.8)$ & $(49.5)$ & $(40.0)$ & 10.4 & 080000 & & NO & SURF \\
\hline 284 & 6020 & $(18.6)$ & $(50.5)$ & $(45.7)$ & 18.2 & 090000 & & NO & SURF \\
\hline
\end{tabular}




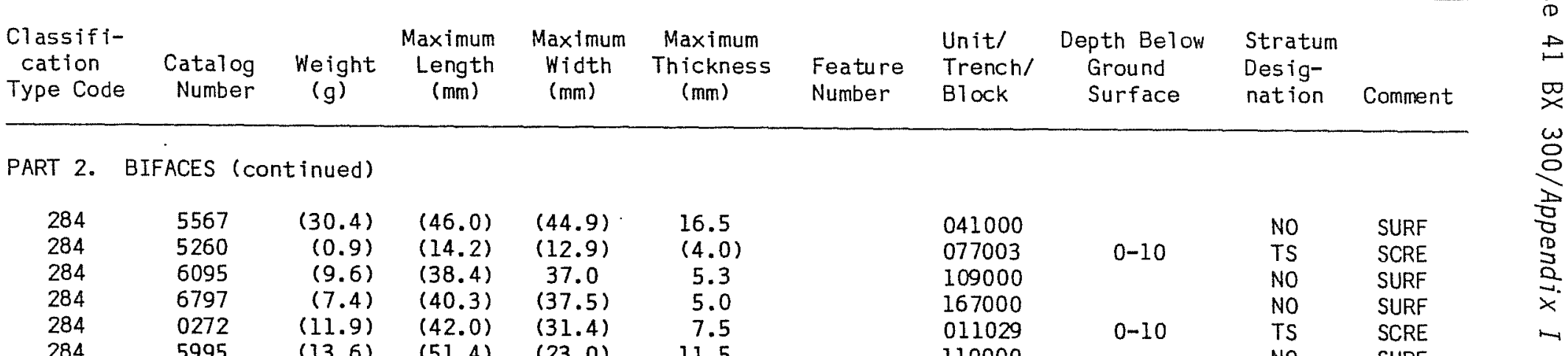

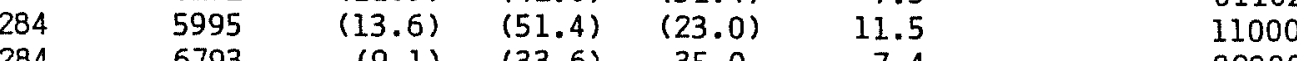

$\begin{array}{lllll}6791 & (4.5) & (42.0) & (18.9) & 4.2\end{array}$

$\begin{array}{lllll}5538 & (2.2) & (23.7) & (22.2) & 4.2\end{array}$

$\begin{array}{lllll}0003 & (0.8) & (11.6) & (13.0) & 2.3\end{array}$

$\begin{array}{lllll}5951 & (4.2) & (29.7) & (28.4) & (4.3)\end{array}$

$\begin{array}{llll}6796 & (6.4) & (31.3) & (29.0)\end{array}$

$6799 \quad(2.5) \quad 20.9 \quad 17.0 \quad 5.0$

$\begin{array}{lllll}7844 & (2.9) & (26.0) & (12.7) & 4.5\end{array}$

$\begin{array}{lllll}5982 & (1.0) & (19.1) & (9.4) & 1.4\end{array}$

$\begin{array}{lllll}7607 & (11.9) & (40.3) & (36.5) & 9.3\end{array}$

$\begin{array}{lllll}7594 & (12.9) & (45.0) & (37.0) & 8.5\end{array}$

$\begin{array}{lrrrr}7845 & (2.1) & (19.3) & (13.4) & 4.6 \\ 7566 & (129.0) & (93.5) & 76.0 & 28.4\end{array}$

$\begin{array}{lllll}7566 & (129.0) & (93.5) & 76.0 & 28.4\end{array}$

$\begin{array}{lllll}7835 & (39.8) & (66.4) & (46.4) & 12.8\end{array}$

$\begin{array}{lllll}7592 & (14.9) & (38.3) & (44.6) & 10.5\end{array}$

$\begin{array}{lllll}7569 & (9.6) & (36.2) & (35.6) & 8.4\end{array}$

$\begin{array}{llll}7571 & (6.3) & (29.6) & (34.2)\end{array}$

$\begin{array}{llll}7848 & (4.0) & (24.9) & (22.2)\end{array}$

5646

7567

7840

7846

7842

7843

5678

6163

5586

(6.4)

$(33.4) \quad(23.6)$

$\begin{array}{lll}(29.9) & (53.7) \quad(48.9)\end{array}$

$\begin{array}{lll}(6.7) \quad(25.6) \quad(26.9) & (1.5) \quad(10.4)\end{array}$

$\begin{array}{lll}(1.5) & (10.4) \quad(19.0)\end{array}$

$(1.0)$

(9.6) (12.2)

$\begin{array}{lll}(1.2) \quad(18.4) \quad(14.9) & (1.4)\end{array}$

$\begin{array}{lll}(9.9) & (41.4) \quad 37.0\end{array}$

$\begin{array}{lll}(15.6) \quad(44.3) \quad 50.4 & (2.3)\end{array}$

$(6.1) \quad(24.2) \quad(25.0)$

$(45.4) \quad(44.2)$

7.0

6.4

5.7

14.5

7.8

4.8

(2.5)

3.7

5.5

8.2

7.9

900000

001000

011040

100000

110000

167000

GOLF

069000

FOXT

047000

GOLF

ECHO

GOLF

035000

$\mathrm{ECHO}$

ECHO

GOLF

039000

ECHO

GOLF

GOLF

GOLF

GOLF

027000

FOXT

046000

ECHO

$0-10$

SURF

SURF

SURF

SURF

SCRE

SURF

SURF

SURF

BACK

SURF

BACK

SURF

BACK

BACK

BACK

SURF

BACK

BACK

BACK

SURF

BACK

BACK

BACK

BACK

BACK

SURF

BACK

13.2

BACK 


\begin{tabular}{|c|c|c|c|c|c|c|c|c|c|c|}
\hline $\begin{array}{l}\text { Classifi- } \\
\text { cation } \\
\text { Type Code }\end{array}$ & $\begin{array}{r}\text { Catalog } \\
\text { Number }\end{array}$ & $\begin{array}{l}\text { Weight } \\
\text { (g) }\end{array}$ & $\begin{array}{c}\text { Maximum } \\
\text { Length } \\
(\mathrm{mm})\end{array}$ & $\begin{array}{l}\text { Maximum } \\
\text { Width } \\
\text { (mm) }\end{array}$ & $\begin{array}{l}\text { Maximum } \\
\text { Thickness } \\
(\mathrm{mm})\end{array}$ & $\begin{array}{l}\text { Feature } \\
\text { Number }\end{array}$ & $\begin{array}{l}\text { Unit/ } \\
\text { Trench/ } \\
\text { Block }\end{array}$ & $\begin{array}{c}\text { Depth Below } \\
\text { Ground } \\
\text { Surface }\end{array}$ & $\begin{array}{l}\text { Stratum } \\
\text { Desig- } \\
\text { nation }\end{array}$ & Comment \\
\hline
\end{tabular}

PART 2. BIFACES (continued)

\begin{tabular}{|c|c|c|c|c|c|c|c|c|c|c|}
\hline 284 & 7839 & $(9.6)$ & $(44.9)$ & $(30.6)$ & 17.5 & GOLF & & NO & BACK & \\
\hline 284 & 7600 & $(20.9)$ & $(54.6)$ & $(31.7)$ & 10.0 & 046000 & & NO & SURF & \\
\hline 284 & 7568 & $(14.1)$ & $(42.9)$ & $(37.4)$ & 10.6 & $\mathrm{ECHO}$ & & NO & BACK & \\
\hline 284 & 7841 & $(2.8)$ & $(28.4)$ & $(21.2)$ & $(5.0)$ & GOLF & & NO & BACK & \\
\hline 284 & 7837 & $(12.4)$ & $(43.6)$ & $(31.3)$ & 6.9 & GOLF & & NO & BACK & \\
\hline 284 & 6376 & $(29.4)$ & $(54.9)$ & $(48.3)$ & 12.2 & 035000 & & NO & SURF & \\
\hline 284 & 6145 & $(6.9)$ & $(38.4)$ & $(20.3)$ & $(5.6)$ & FOXT & & NO & BACK & \\
\hline 284 & 6386 & $(17.8)$ & $(45.3)$ & $(33.4)$ & 10.0 & 034000 & & NO & SURF & \\
\hline 284 & 7838 & $(14.7)$ & $(49.0)$ & $(34.3)$ & 8.8 & GOLF & & NO & BACK & \\
\hline 284 & 7570 & $(39.8)$ & $(66.2)$ & $(48.7)$ & 11.5 & $\mathrm{ECHO}$ & & NO & BACK & \\
\hline 284 & 7610 & $(1.3)$ & $(14.6)$ & $(11.0)$ & $(2.7)$ & FCXT & & NO & BACK & \\
\hline 284 & 7847 & $(26.1)$ & $(43.7)$ & $(47.9)$ & 12.2 & GOLF & & NO & BACK & \\
\hline 284 & 7611 & $(2.8)$ & $(26.9)$ & $(15.5)$ & 4.6 & FOXT & & NO & BACK & \\
\hline 284 & 7612 & $(4.4)$ & $(32.3)$ & $(22.0)$ & $(5.4)$ & FOXT & & NO & BACK & \\
\hline 284 & 7608 & $(3.6)$ & $(20.4)$ & $(22.0)$ & $(4.5)$ & FOXT & & NO & BACK & \\
\hline 284 & 7609 & $(1.6)$ & $(20.9)$ & $(15.8)$ & $(3.4)$ & FOXT & & NO & BACK & \\
\hline 284 & 7573 & $(1.4)$ & $(13.6)$ & $(15.1)$ & $(4.2)$ & $\mathrm{ECHO}$ & & NO & BACK & \\
\hline 284 & 7572 & $(5.2)$ & $(34.3)$ & $(28.8)$ & $(5.6)$ & $\mathrm{ECHO}$ & & NO & BACK & \\
\hline 284 & 7836 & $(20.4)$ & $(64.6)$ & $(43.4)$ & 8.4 & GOLF & & NO & BACK & \\
\hline 284 & 6198 & $(11.6)$ & $(37.3)$ & $(34.8)$ & 11.1 & GOLF & & NO & BACK & \\
\hline 284 & 7834 & $(7.0)$ & $(40.3)$ & $(28.0)$ & $(6.5)$ & GOLF & & NO & BACK & $\sim$ \\
\hline 284 & 7577 & $(11.3)$ & $(45.0)$ & $(31.4)$ & 9.3 & $\mathrm{ECHO}$ & & NO & BACK & $\vec{r}$ \\
\hline 284 & 7574 & $(3.1)$ & $(21.8)$ & $(18.4)$ & 4.6 & $\mathrm{ECHO}$ & & NO & BACK & i \\
\hline 284 & 5753 & $(7.8)$ & $(37.2)$ & $(29.6)$ & 5.5 & 137000 & & NO & SURF & \pm \\
\hline 284 & 6461 & $(39.9)$ & $(48.3)$ & $(51.7)$ & 9.0 & CHAR & & NO & BACK & \\
\hline 284 & 5947 & $(19.6)$ & $(43.0)$ & $(39.0)$ & 11.2 & 129000 & & NO & SURF & $\stackrel{\mathscr{x}}{x}$ \\
\hline 284 & 5530 & $(22.8)$ & $(88.2)$ & $(37.3)$ & 7.3 & 138000 & & NO & SURF & $\omega$ \\
\hline 284 & 6773 & $(11.3)$ & $(48.6)$ & 31.0 & 7.1 & CHAR & & NO & BACK & 용 \\
\hline 284 & 5881 & $(1.4)$ & $(17.3)$ & $(8.5)$ & 3.8 & 119000 & & NO & SURF & 0 \\
\hline 284 & 6764 & $(1.7)$ & $(15.2)$ & $(14.6)$ & 3.5 & 037000 & & NO & SURF & $\frac{D}{7}$ \\
\hline 284 & 3568 & $(16.9)$ & $(34.8)$ & $(35.1)$ & 12.6 & 123019 & $0-13$ & TS & PROV & 8 \\
\hline 284 & 6476 & $(10.5)$ & $(39.9)$ & $(30.9)$ & 7.5 & ALFA & & NO & BACK & $\stackrel{D}{S}$ \\
\hline 284 & 5769 & $(27.6)$ & $(60.3)$ & $(32.2)$ & 12.7 & 139000 & & NO & $\begin{array}{l}\text { SURF } \\
\text { SUR }\end{array}$ & $\overrightarrow{0}$ \\
\hline 284 & 1096 & $(1.0)$ & $(9.8)$ & $(8.9)$ & 3.3 & 123009 & $15-25$ & SG & SCRE & $\bar{x}$ \\
\hline
\end{tabular}




\begin{tabular}{|c|c|c|c|c|c|c|c|c|c|c|}
\hline $\begin{array}{l}\text { Classifi- } \\
\text { cation } \\
\text { Type Code }\end{array}$ & $\begin{array}{l}\text { Catalog } \\
\text { Number }\end{array}$ & $\begin{array}{l}\text { Weight } \\
\text { (g) }\end{array}$ & $\begin{array}{l}\text { Maximum } \\
\text { Length } \\
(\mathrm{mm})\end{array}$ & $\begin{array}{l}\text { Maximum } \\
\text { Width } \\
(\mathrm{mm})\end{array}$ & $\begin{array}{l}\text { Maximum } \\
\text { Thickness } \\
\text { (mm) }\end{array}$ & $\begin{array}{l}\text { Feature } \\
\text { Number }\end{array}$ & $\begin{array}{l}\text { Unit/ } \\
\text { Trench/ } \\
\text { Block }\end{array}$ & $\begin{array}{c}\text { Depth Below } \\
\text { Ground } \\
\text { Surface }\end{array}$ & $\begin{array}{l}\text { Stratum } \\
\text { Desig- } \\
\text { nation }\end{array}$ & Comment \\
\hline
\end{tabular}

PART 2. BIFACES (continued)

\begin{tabular}{|c|c|c|c|c|c|c|c|c|c|c|}
\hline 284 & 6449 & $(1.7)$ & $(10.0)$ & $(15.1)$ & 6.4 & & BRAV & & NO & BACK \\
\hline 284 & 5744 & $(6.6)$ & $(36.9)$ & $(38.8)$ & 5.7 & & 124000 & & NO & SURF \\
\hline 284 & 6770 & $(2.4)$ & $(26.9)$ & $(11.6)$ & 3.9 & & BRAV & & NO & BACK \\
\hline 284 & 5710 & $(1.6)$ & $(14.0)$ & $(15.7)$ & 3.4 & & 047000 & & NO & SURF \\
\hline 284 & 7114 & $(1.2)$ & $(18.9)$ & $(8.6)$ & 3.2 & 4 & 076019 & $0-10$ & $F Z$ & PROV \\
\hline 284 & 0120 & $(9.6)$ & $(44.5)$ & $(29.0)$ & 5.5 & 7 & 056028 & $0-5$ & $O Z$ & PROV \\
\hline 284 & 0119 & $(9.8)$ & $(39.6)$ & $(34.9)$ & 6.7 & 7 & 056028 & $0-5$ & $O Z$ & PROV \\
\hline 284 & 2606 & $(0.6)$ & $(8.9)$ & (4.8) & 1.0 & 7 & 056006 & $0-5$ & $O Z$ & SCRE \\
\hline 284 & 7379 & $(0.7)$ & $(5.5)$ & $(9.0)$ & 1.9 & 7 & 056008 & $7-10$ & $O Z$ & SCRE \\
\hline 284 & 0897 & $(0.9)$ & $(12.4)$ & $(6.9)$ & 1.8 & 7 & 056029 & $5-10$ & $O Z$ & PROV \\
\hline 284 & 0868 & $(0.9)$ & $(13.9)$ & $(9.2)$ & 1.4 & 7 & 056019 & $0-5$ & $O Z$ & SCRE \\
\hline 284 & 4542 & $(1.3)$ & $(17.9)$ & $(13.6)$ & 3.2 & 3 & 076037 & $10-20$ & $\mathrm{FZ}$ & PROV \\
\hline 284 & 3748 & $(22.4)$ & $(35.9)$ & 42.0 & 15.4 & 10 & 079095 & $27-44$ & $\mathrm{FZ}$ & PROY \\
\hline 284 & 2560 & $(1.4)$ & $(18.7)$ & $(12.1)$ & 3.6 & 8 & 075100 & $30-38$ & $F Z$ & PROV \\
\hline 284 & 7283 & $(2.3)$ & $(14.2)$ & $(20.3)$ & 7.0 & 8 & 075100 & $30-38$ & $F Z$ & SCRE \\
\hline 284 & 4559 & $(1.4)$ & $(15.0)$ & $(14.9)$ & 4.2 & 6 & 077012 & $25-35$ & $F Z$ & PROV \\
\hline 284 & 3826 & $(20.1)$ & $(51.9)$ & $(49.4)$ & 11.0 & & 077003 & $18-28$ & TS & PROV \\
\hline 284 & 5089 & $(7.2)$ & $(32.4)$ & $(29.7)$ & 6.3 & 2 & 055084 & $23-46$ & $M Z$ & PROV \\
\hline 284 & 5087 & $(1.8)$ & $(25.0)$ & $(9.4)$ & 3.7 & 2 & 055084 & $23-46$ & $M Z$ & SCRE \\
\hline 284 & 4599 & $(1.2)$ & $(17.5)$ & $(13.4)$ & 2.6 & 5 & 076018 & $20-30$ & $O Z$ & SCRE \\
\hline 284 & 1614 & $(1.7)$ & $(14.2)$ & 21.8 & 3.2 & 5 & 076010 & $29-39$ & $O Z$ & PROV \\
\hline 284 & 7214 & $(2.8)$ & $(23.9)$ & 24.8 & 4.6 & 5 & 077002 & $38-42$ & $O Z$ & SCRE \\
\hline 284 & 5169 & $(6.2)$ & $(41.0)$ & $(24.9)$ & 6.6 & 3 & 076037 & $40-50$ & $\mathrm{FZ}$ & PROV \\
\hline 284 & 7284 & $(0.7)$ & $(8.0)$ & $(5.9)$ & 2.0 & 8 & 085010 & $30-38$ & $F Z$ & SCRE \\
\hline 284 & 6448 & $(84.0)$ & $(86.5)$ & $(72.3)$ & $(15.2)$ & & BRAV & & NO & BACK \\
\hline 284 & 6573 & $(13.9)$ & $(81.0)$ & $(51.3)$ & 5.2 & & KILO & & NO & BACK \\
\hline 285 & 0898 & $(13.3)$ & $(40.3)$ & 36.0 & 7.6 & 7 & 056009 & $10-15$ & $\mathrm{OZ}$ & PROV \\
\hline 285 & 0480 & $(2.9)$ & $(34.9)$ & 11.6 & $(4.6)$ & 7 & 056016 & $0-9$ & $O Z$ & PROV \\
\hline 285 & 0134 & $(2.7)$ & $(11.4)$ & $(17.2)$ & $(7.0)$ & 7 & 056029 & $0-5$ & $O Z$ & PROV \\
\hline 285 & 0481 & 45.3 & $(33.6)$ & $(58.9)$ & $(9.2)$ & 7 & 056009 & $0-5$ & $O Z$ & PROV \\
\hline 285 & 0907 & $(11.2)$ & $(30.0)$ & $(37.0)$ & 8.0 & & 076025 & & TS & PROV \\
\hline 285 & 0059 & $(13.8)$ & $(30.3)$ & 39.4 & 8.2 & & 056093 & $0-12$ & TS & PROV \\
\hline 285 & 0141 & $(15.2)$ & $(40.3)$ & $(49.6)$ & $(8.9)$ & & 076038 & $0-10$ & TS & PROV \\
\hline 285 & 0114 & $(6.7)$ & $(28.4)$ & $(38.4)$ & $(5.7)$ & & 076028 & $0-20$ & TS & SCRE \\
\hline
\end{tabular}




\begin{tabular}{|c|c|c|c|c|c|c|c|c|c|c|}
\hline $\begin{array}{l}\text { Classifi- } \\
\text { cation } \\
\text { Type Code }\end{array}$ & $\begin{array}{r}\text { Catalog } \\
\text { Number }\end{array}$ & $\begin{array}{l}\text { Weight } \\
(g)\end{array}$ & $\begin{array}{l}\text { Maximum } \\
\text { Length } \\
(\mathrm{mm})\end{array}$ & $\begin{array}{l}\text { Maximum } \\
\text { Width } \\
\text { (mm) }\end{array}$ & $\begin{array}{l}\text { Maximum } \\
\text { Thickness } \\
\text { (mm) }\end{array}$ & $\begin{array}{l}\text { Feature } \\
\text { Number }\end{array}$ & $\begin{array}{l}\text { Unit/ } \\
\text { Trench/ } \\
\text { Block }\end{array}$ & $\begin{array}{c}\text { Depth Below } \\
\text { Ground } \\
\text { Surface }\end{array}$ & $\begin{array}{l}\text { Stratum } \\
\text { Desig- } \\
\text { nation }\end{array}$ & Comment \\
\hline
\end{tabular}

PART 2. BIFACES (cont inued)

\begin{tabular}{|c|c|c|c|c|c|c|c|c|c|c|}
\hline 285 & 0483 & $(8.7)$ & $(44.4)$ & $(20.0)$ & $(8.3)$ & & 076048 & $0-10$ & TS & PROV \\
\hline 285 & 0904 & $(29.4)$ & $(34.8)$ & 46.8 & 12.7 & & 077002 & $0-10$ & TS & PROV \\
\hline 285 & 0484 & $(2.2)$ & $(19.2)$ & $(19.4)$ & $(8.0)$ & & 076027 & $25-37$ & TS & PROV \\
\hline 285 & 7793 & $(18.6)$ & $(36.9)$ & 40.6 & 8.6 & & 024000 & & NO & SURF \\
\hline 285 & 7794 & $(3.2)$ & $(19.7)$ & $(18.4)$ & $(4.7)$ & & 024000 & & NO & SURF \\
\hline 285 & 7865 & $(7.2)$ & $(25.0)$ & $(34.2)$ & 7.4 & & JULI & & NO & BACK \\
\hline 285 & 7140 & (4.1) & $(32.5)$ & $(16.6)$ & $(5.5)$ & & 076030 & $0-10$ & TS & SCRE \\
\hline 285 & 5086 & $(18.9)$ & $(66.8)$ & $(32.0)$ & $(8.9)$ & 2 & 055066 & $0-8$ & $M Z$ & PROV \\
\hline 285 & 7921 & $(6.1)$ & $(17.8)$ & $(34.2)$ & $(7.6)$ & & 076048 & $0-10$ & TS & SCRE \\
\hline 285 & 1691 & $(22.3)$ & $(28.8)$ & 50.0 & 11.6 & & 085009 & $0-20$ & TS & PROV \\
\hline 285 & 2275 & $(2.4)$ & $(15.7)$ & $(20.9)$ & $(4.6)$ & & 056000 & & NO & SURF \\
\hline 285 & 5242 & $(2.9)$ & $(19.7)$ & $(22.0)$ & $(5.4)$ & & 076027 & $10-25$ & TS & SCRE \\
\hline 285 & 1693 & $(2.5)$ & $(24.4)$ & $(20.0)$ & $(3.5)$ & & 085009 & $0-20$ & TS & PROV \\
\hline 285 & 1673 & $(2.7)$ & $(15.5)$ & $(25.0)$ & $(4.6)$ & & 075099 & $0-20$ & TS & PROV \\
\hline 285 & 4421 & $(4.4)$ & $(23.0)$ & $(19.7)$ & $(6.0)$ & & 076048 & $10-20$ & TS & SCRE \\
\hline 285 & 4616 & $(8.6)$ & $(34.2)$ & 25.4 & 9.4 & & 076039 & $0-10$ & TS & SCRE \\
\hline 285 & 4040 & $(10.2)$ & $(34.0)$ & $(33.3)$ & $(8.6)$ & & 076039 & $0-10$ & TS & SCRE \\
\hline 285 & 0056 & $(8.1)$ & $(32.0)$ & $(36.7)$ & $(7.0)$ & & 056083 & $0-13$ & TS & PROV \\
\hline 285 & 4112 & $(9.9)$ & $(23.3)$ & 28.4 & 10.0 & & 056046 & $10-20$ & TS & SCRE \\
\hline 285 & 0070 & $(6.5)$ & $(17.0)$ & $(31.6)$ & $(8.3)$ & & 066020 & $0-10$ & TS & PROV \\
\hline 285 & 0906 & $(6.4)$ & $(33.3)$ & $(20.4)$ & $(7.3)$ & & 076025 & $0-10$ & TS & PROV \\
\hline 285 & 0127 & $(12.7)$ & $(25.5)$ & $(37.4)$ & $(9.6)$ & & 056023 & $20-30$ & TS & PROV \\
\hline 285 & 4305 & (1.1) & $(17.9)$ & $(11.6)$ & $(3.5)$ & & 076039 & $0-10$ & TS & SCRE \\
\hline 285 & 6995 & $(5.3)$ & $(30.5)$ & $(23.2)$ & $(5.8)$ & & 076027 & $0-10$ & TS & SCRE \\
\hline 285 & 6305 & $(5.2)$ & $(15.5)$ & $(29.6)$ & 10.4 & & JULI & & NO & BACK \\
\hline 285 & 5473 & $(8.9)$ & $(36.0)$ & $(24.8)$ & 8.3 & & 042000 & & NO & SURF \\
\hline 285 & 5565 & $(1.9)$ & $(12.0)$ & $(18.6)$ & 3.0 & & 046000 & & NO & SURF \\
\hline 285 & 6401 & $(23.1)$ & $(44.9)$ & 39.6 & 9.3 & & LIMA & & NO & BACK \\
\hline 285 & 0275 & $(18.7)$ & $(27.4)$ & 47.3 & 11.2 & & 011029 & $0-10$ & TS & SCRE \\
\hline 285 & 5994 & $(4.1)$ & $(18.7)$ & $(24.4)$ & 5.0 & & 110000 & & NO & SURF \\
\hline 285 & 5733 & $(13.2)$ & $(30.6)$ & $(36.3)$ & 10.0 & & 031000 & & NO & SURF \\
\hline 285 & 6195 & $(18.8)$ & $(35.3)$ & $(38.5)$ & 10.0 & & GOLF & & NO & BACK \\
\hline 285 & 7615 & $(8.6)$ & $(47.5)$ & $(18.0)$ & 6.4 & & GOLF & & NO & BACK \\
\hline 285 & 7641 & $(6.6)$ & $(33.3)$ & 20.0 & 7.2 & & $\mathrm{ECHO}$ & & NO & BACK \\
\hline
\end{tabular}




\begin{tabular}{cccccccccc}
$\begin{array}{c}\text { Classifi- } \\
\text { cation } \\
\text { Type Code }\end{array}$ & $\begin{array}{c}\text { Catalog } \\
\text { Number }\end{array}$ & $\begin{array}{c}\text { Weight } \\
(\mathrm{g})\end{array}$ & $\begin{array}{c}\text { Maximum } \\
\text { Length } \\
(\mathrm{mm})\end{array}$ & $\begin{array}{c}\text { Maximum } \\
\text { Width } \\
(\mathrm{mm})\end{array}$ & $\begin{array}{c}\text { Maximum } \\
\text { Thickness } \\
(\mathrm{mm})\end{array}$ & $\begin{array}{l}\text { Feature } \\
\text { Number }\end{array}$ & $\begin{array}{l}\text { Unit/ } \\
\text { Brench/ } \\
\text { Block }\end{array}$ & $\begin{array}{l}\text { Depth Below } \\
\text { Ground } \\
\text { Surface }\end{array}$ & $\begin{array}{l}\text { Stratum Desig- } \\
\text { nation }\end{array}$ \\
\hline
\end{tabular}

PART 2. BIFACES (continued)

\begin{tabular}{|c|c|c|c|c|c|c|c|c|c|c|}
\hline $\begin{array}{l}285 \\
285\end{array}$ & $\begin{array}{l}5601 \\
7623\end{array}$ & $\begin{array}{l}(14.7) \\
(11.8)\end{array}$ & $\begin{array}{l}(45.0) \\
(43.4)\end{array}$ & $\begin{array}{c}24.5 \\
(24.5)\end{array}$ & $\begin{array}{r}10.9 \\
8.5\end{array}$ & & $\begin{array}{l}049000 \\
\text { GOLF }\end{array}$ & & $\begin{array}{l}\text { NO } \\
\text { NO }\end{array}$ & $\begin{array}{l}\text { SURF } \\
\text { BACK }\end{array}$ \\
\hline 285 & 6297 & $(20.5)$ & 46.4 & $(23.0)$ & 13.3 & & DELT & & NO & $\begin{array}{l}\text { BACK } \\
\text { BACK }\end{array}$ \\
\hline 285 & 7614 & $(6.2)$ & $(21.6)$ & $(30.5)$ & 6.4 & & FOXT & & NO & BACK \\
\hline 285 & 6391 & $(5.9)$ & $(27.9)$ & $(28.0)$ & 6.6 & & 024000 & & NO & SURF \\
\hline 285 & 6371 & $(12.8)$ & $(40.3)$ & $(38.0)$ & 5.6 & & 013000 & & NO & SURF \\
\hline 285 & 6255 & $(5.8)$ & $(23.8)$ & $(31.4)$ & 6.9 & & ECHO & & NO & BACK \\
\hline 285 & 6171 & $(4.8)$ & $(24.9)$ & $(17.4)$ & 7.6 & & FOXT & & NO & BACK \\
\hline 285 & 5585 & $(9.6)$ & $(22.0)$ & $(32.0)$ & 8.9 & & 046000 & & NO & SURF \\
\hline 285 & 5617 & $(21.2)$ & $(45.9)$ & $(32.1)$ & 11.4 & & 113000 & & NO & SURF \\
\hline 285 & 5756 & $(1.9)$ & $(14.7)$ & $(15.0)$ & $(4.3)$ & & 137000 & & NO & SURF \\
\hline 285 & 5817 & $(42.4)$ & $(73.7)$ & $(62.0)$ & 9.1 & & 133000 & & NO & SURF \\
\hline 285 & 6771 & $(15.9)$ & $(50.7)$ & 28.8 & 8.2 & & ALFA & & NO & BACK \\
\hline 285 & 6778 & $(8.8)$ & $(27.2)$ & 26.3 & 9.8 & & 033000 & & NO & SURF \\
\hline 285 & 6765 & $(8.5)$ & $(31.2)$ & $(29.0)$ & 7.3 & & 113000 & & NO & SURF \\
\hline 285 & 6477 & $(5.2)$ & $(27.9)$ & $(22.8)$ & 5.5 & & ALFA & & NO & BACK \\
\hline 285 & 5657 & $(10.2)$ & $(25.4)$ & $(39.0)$ & 8.5 & & 127000 & & NO & SURF \\
\hline 285 & 5837 & $(5.1)$ & $(19.8)$ & $(20.0)$ & 8.4 & & 133000 & & NO & SURF \\
\hline 285 & 7575 & $(2.1)$ & $(10.2)$ & $(19.2)$ & 6.5 & & ECHO & & NO & BACK \\
\hline 285 & 2263 & $(5.7)$ & $(20.3)$ & 27.6 & 6.4 & & & & & \\
\hline 285 & 4575 & $(2.4)$ & $(21.6)$ & $(17.9)$ & 4.2 & 3 & 076037 & $20-40$ & $F Z$ & SCRE \\
\hline 285 & 4150 & $(3.6)$ & $(20.3)$ & $(24.6)$ & 4.3 & & 077012 & MD & TS & SCRE \\
\hline 285 & 0928 & $(4.9)$ & $(19.4)$ & $(21.4)$ & 7.0 & 5 & 076010 & $0-19$ & $0 Z$ & PROV \\
\hline 285 & 0472 & $(10.8)$ & $(33.0)$ & $(43.7)$ & $(9.9)$ & 7 & 056017 & & $O Z$ & PROV \\
\hline 285 & 2272 & $(16.7)$ & $(38.0)$ & 32.8 & 12.8 & & 076000 & & NO & SURF \\
\hline 285 & 4376 & $(4.4)$ & $(33.7)$ & 18.8 & 5.3 & 3 & 076038 & $10-20$ & $F Z$ & SCRE \\
\hline 286 & 7900 & $(12.2)$ & $(27.5)$ & $(13.3)$ & $(5.6)$ & & 056026 & $9-12$ & $O Z$ & SCRE \\
\hline 286 & 0457 & $(12.5)$ & $(46.4)$ & 21.0 & 12.6 & & 056027 & $0-5$ & $O Z$ & PROV \\
\hline 286 & 0479 & $(2.3)$ & $(16.2)$ & $(21.0)$ & $(5.0)$ & & 056019 & $0-5$ & $0 Z$ & PROV \\
\hline 286 & 6345 & $(15.3)$ & $(70.7)$ & 19.6 & 9.0 & & HOTE & & NO & BACK \\
\hline 286 & 0089 & $(24.9)$ & $(52.8)$ & 30.6 & 14.9 & & 075090 & $0-20$ & TS & PROV \\
\hline 286 & 0111 & $(19.3)$ & $(40.2)$ & 35.9 & 10.0 & & 065013 & $0-20$ & TS & PROV \\
\hline 286 & 0062 & $(26.6)$ & $(36.9)$ & 50.4 & 13.7 & & 056064 & $0-20$ & TS & PROV \\
\hline 286 & 0980 & $(13.6)$ & $(36.7)$ & $(32.3)$ & 9.6 & & 077013 & $0-14$ & TS & PROV \\
\hline
\end{tabular}




\begin{tabular}{|c|c|c|c|c|c|c|c|c|c|c|}
\hline $\begin{array}{l}\text { Classifi- } \\
\text { cation } \\
\text { Type Code }\end{array}$ & $\begin{array}{c}\text { Catalog } \\
\text { Number }\end{array}$ & $\begin{array}{l}\text { Weight } \\
\text { (g) }\end{array}$ & $\begin{array}{c}\text { Maximum } \\
\text { Length } \\
(\mathrm{mm})\end{array}$ & $\begin{array}{l}\text { Maximum } \\
\text { Width } \\
\text { (mm) }\end{array}$ & $\begin{array}{c}\text { Maximum } \\
\text { Thickness } \\
\text { (mim) }\end{array}$ & $\begin{array}{l}\text { Feature } \\
\text { Number }\end{array}$ & $\begin{array}{l}\text { Unit/ } \\
\text { Trench/ } \\
\text { Block }\end{array}$ & $\begin{array}{c}\text { Depth Below } \\
\text { Ground } \\
\text { Surface }\end{array}$ & $\begin{array}{l}\text { Stratum } \\
\text { Desig- } \\
\text { nation }\end{array}$ & Comment \\
\hline
\end{tabular}

PART 2. BIFACES (continued)

\begin{tabular}{|c|c|c|c|c|c|c|c|c|c|c|}
\hline 286 & 0452 & $(25.8)$ & $(44.0)$ & $(44.9)$ & 11.4 & 076027 & $0-10$ & TS & SCRE & \\
\hline 286 & 0153 & $(8.8)$ & $(23.9)$ & $(34.6)$ & 7.3 & 076048 & $0-10$ & TS & PROV & \\
\hline 286 & 0913 & $(7.9)$ & $(23.3)$ & $(33.3)$ & $(7.0)$ & 077002 & $0-10$ & TS & PROV & \\
\hline 286 & 0129 & $(18.6)$ & $(35.8)$ & 51.3 & $(10.0)$ & 076018 & $0-20$ & TS & PROV & \\
\hline 286 & 0496 & $(43.4)$ & $(50.6)$ & $(64.7)$ & $(17.8)$ & MD & & & & \\
\hline 286 & 0140 & $(11.6)$ & $(39.3)$ & $(27.9)$ & 9.4 & 076029 & $0-10$ & TS & PROV & \\
\hline 286 & 0488 & $(13.9)$ & $(47.0)$ & 39.0 & 7.7 & 076049 & $0-10$ & TS & PROV & \\
\hline 286 & 0975 & $(22.2)$ & $(54.6)$ & $(30.0)$ & $(13.3)$ & 077012 & $25-35$ & TS & PROV & \\
\hline 286 & 0681 & $(0.1)$ & $(9.6)$ & $(4.6)$ & $(2.0)$ & 067014 & $0-10$ & TS & SCRE & \\
\hline 286 & 7777 & $(30.4)$ & $(42.0)$ & $(53.9)$ & $(11.4)$ & 104000 & & NO & SURF & \\
\hline 286 & 7907 & $(1.9)$ & $(15.7)$ & $(20.7)$ & $(4.9)$ & 056044 & $0-10$ & TS & SCRE & \\
\hline 286 & 7774 & $(7.2)$ & $(20.5)$ & $(28.6)$ & 6.0 & 077001 & & NO & SURF & \\
\hline 286 & 7867 & $(15.2)$ & $(34.0)$ & $(37.0)$ & 10.8 & JULI & & NO & BACK & \\
\hline 286 & 7141 & $(1.9)$ & $(14.6)$ & $(21.0)$ & $(4.9)$ & 076030 & $0-10$ & TS & SCRE & \\
\hline 286 & 7010 & $(1.1)$ & $(6.4)$ & $(24.6)$ & $(4.6)$ & 077013 & $0-14$ & TS & SCRE & \\
\hline 286 & 7908 & $(1.4)$ & $(12.8)$ & $(13.2)$ & $(5.9)$ & 056044 & $0-10$ & TS & SCRE & \\
\hline 286 & 3617 & $(21.6)$ & $(51.9)$ & 36.8 & 9.6 & 119023 & $0-5$ & TS & PROV & \\
\hline 286 & 2276 & $(12.4)$ & $(27.0)$ & 46.3 & 7.9 & 056000 & & NO & SURF & \\
\hline 286 & 1587 & $(15.2)$ & $(45.3)$ & $(33.0)$ & 8.6 & 095000 & & NO & SURF & \\
\hline 286 & 2259 & $(39.1)$ & $(50.6)$ & 54.0 & 10.3 & 021000 & & NO & SURF & \\
\hline 286 & 6836 & $(2.4)$ & $(15.7)$ & $(19.0)$ & $(5.0)$ & 075090 & $0-20$ & TS & SCRE & \\
\hline 286 & 0755 & $(9.9)$ & $(38.7)$ & 24.0 & 9.8 & 056044 & $0-10$ & TS & SCRE & 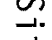 \\
\hline 286 & 0081 & $(7.9)$ & $(36.7)$ & $(19.7)$ & 10.0 & 067014 & $0-10$ & TS & PROV & $\stackrel{+}{\mathbb{D}}$ \\
\hline 286 & 0052 & $(12.1)$ & $(44.0)$ & $(28.3)$ & $(9.3)$ & 066013 & $0-13$ & TS & PROV & + \\
\hline 286 & 0079 & $(4.5)$ & $(27.0)$ & $(29.0)$ & $(5.9)$ & 067014 & $0-10$ & TS & PROV & 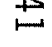 \\
\hline 286 & 0101 & $(5.6)$ & $(43.6)$ & $(15.6)$ & $(5.6)$ & 056046 & $20-29$ & TS & PROV & $\Phi$ \\
\hline 286 & 0146 & $(6.9)$ & $(38.4)$ & $(22.8)$ & $(6.4)$ & 076019 & $10-20$ & TS & PROV & $x$ \\
\hline 286 & 6306 & $(9.5)$ & $(39.0)$ & 25.6 & 7.0 & JULI & & NO & BACK & $\omega$ \\
\hline 286 & 6815 & $(1.0)$ & $(16.3)$ & $(10.0)$ & $(1.7)$ & 076026 & $0-10$ & TS & SCRE & 8 \\
\hline 286 & 6850 & $(2.3)$ & $(25.4)$ & $(12.0)$ & $(4.9)$ & 077012 & $10-25$ & TS & SCRE & D \\
\hline 286 & 9257 & $(0.9)$ & $(10.4)$ & $(8.0)$ & $(2.3)$ & 065015 & $0-20$ & TS & SCRE & 뭉 \\
\hline 286 & 5449 & $(34.7)$ & $(59.0)$ & $(49.0)$ & $(9.5)$ & 012000 & & NO & SURF & D \\
\hline 286 & 5445 & $(23.4)$ & $(40.0)$ & 50.9 & 8.2 & 042000 & & NO & SURF & $\bar{a}$ \\
\hline \multirow[t]{2}{*}{286} & 6071 & (13.4) & $(49.4)$ & $(28.6)$ & 10.0 & 079000 & & NO & SURF & $\vec{x}$ \\
\hline & & & & & & & & & & $\rightarrow$ \\
\hline
\end{tabular}




\begin{tabular}{|c|c|c|c|c|c|c|c|c|c|}
\hline $\begin{array}{l}\text { Classifi- } \\
\text { cation } \\
\text { Type Code }\end{array}$ & $\begin{array}{c}\text { Catalog } \\
\text { Number }\end{array}$ & $\begin{array}{l}\text { Weight } \\
(g)\end{array}$ & $\begin{array}{l}\text { Maximum } \\
\text { Length } \\
(\mathrm{mm})\end{array}$ & $\begin{array}{l}\text { Maximum } \\
\text { Width } \\
\text { (mm) }\end{array}$ & $\begin{array}{l}\text { Maximum } \\
\text { Thickness } \\
(\mathrm{mm})\end{array}$ & $\begin{array}{l}\text { Feature } \\
\text { Number }\end{array}$ & $\begin{array}{l}\text { Unit/ } \\
\text { Trench/ } \\
\text { Block }\end{array}$ & $\begin{array}{l}\text { Depth Below } \\
\text { Ground } \\
\text { Surface }\end{array}$ & $\begin{array}{l}\text { Stratum } \\
\text { Desig- } \\
\text { nation Comment }\end{array}$ \\
\hline
\end{tabular}

PART 2. BIFACES (continued)

\begin{tabular}{|c|c|c|c|c|c|c|c|c|c|}
\hline 286 & 5993 & $(14.6)$ & $(36.6)$ & 26.9 & 9.7 & 110000 & & NO & SURF \\
\hline 286 & 5417 & $(20.5)$ & $(34.9)$ & 45.3 & 11.0 & 199000 & & NO & SURF \\
\hline 286 & 9094 & $(14.7)$ & $(45.0)$ & 29.7 & 6.6 & KILO & & NO & BACK \\
\hline 286 & 0417 & $(5.8)$ & $(38.3)$ & $(19.5)$ & 7.0 & 011027 & $0-10$ & TS & SCRE \\
\hline 286 & 6579 & $(25.4)$ & $(58.3)$ & $(29.5)$ & 10.0 & NOVE & & NO & BACK \\
\hline 286 & 5898 & $(27.4)$ & $(44.6)$ & 46.3 & 9.3 & 099000 & & NO & SURF \\
\hline 286 & 7551 & $(24.8)$ & $(25.6)$ & $(41.0)$ & 15.6 & 109000 & & NO & SURF \\
\hline 286 & 0274 & $(27.4)$ & $(36.0)$ & 44.4 & 14.0 & 011029 & $0-10$ & TS & SCRE \\
\hline 286 & 9095 & $(7.0)$ & $(29.0)$ & 25.9 & 8.4 & KILO & & NO & BACK \\
\hline 286 & 5540 & $(27.6)$ & $(44.2)$ & 45.0 & 11.6 & 010000 & & NO & SURF \\
\hline 286 & 0013 & $(7.9)$ & $(26.6)$ & 42.5 & 7.2 & 011029 & $0-10$ & TS & PROV \\
\hline 286 & 6134 & $(7.8)$ & $(34.6)$ & $(39.9)$ & 5.0 & 070000 & & NO & SURF \\
\hline 286 & 5540 & $(27.8)$ & $(44.0)$ & 46.0 & 12.0 & 010000 & & NO & SURF \\
\hline 286 & 9095 & $(7.2)$ & $(29.0)$ & 25.9 & 8.3 & KILO & & NO & BACK \\
\hline 286 & 6134 & $(7.6)$ & $(30.7)$ & 40.0 & 5.9 & 700000 & & NO & SURF \\
\hline 286 & 6096 & $(2.4)$ & $(13.3)$ & 17.3 & 5.9 & 109000 & & NO & SURF \\
\hline 286 & 7616 & $(51.8)$ & $(64.3)$ & 55.9 & 12.7 & GOLF & & NO & BACK \\
\hline 286 & 3108 & $(6.8)$ & $(22.3)$ & $(34.9)$ & 5.6 & 026069 & $0-60$ & TS & PROV \\
\hline 286 & 9094 & $(14.9)$ & $(44.3)$ & 28.5 & 7.0 & KILO & & NO & BACK \\
\hline 286 & 3108 & $(6.7)$ & $(34.2)$ & $(22.3)$ & 5.6 & 026069 & $0-60$ & TS & PROV \\
\hline 286 & 5540 & $(27.9)$ & $(44.0)$ & $(45.2)$ & 11.4 & 001000 & & NO & SURF \\
\hline 286 & 7645 & $(20.8)$ & $(47.3)$ & $(39.5)$ & 9.5 & $\mathrm{ECHO}$ & & NO & BACK \\
\hline 286 & 3111 & 8.1 & $(34.2)$ & $(19.8)$ & 6.0 & 026089 & $0-60$ & TS & PROV \\
\hline 286 & 6134 & 7.5 & $(32.3)$ & $(40.0)$ & 6.0 & 070000 & & NO & SURF \\
\hline 286 & 9095 & 7.1 & $(29.0)$ & $(25.7)$ & 8.3 & KILO & & NO & BACK \\
\hline 286 & 6096 & 2.5 & $(15.0)$ & $(17.2)$ & $(5.8)$ & 109000 & & NO & SURF \\
\hline 286 & 7655 & 97.1 & $(57.5)$ & $(72.8)$ & 14.3 & DELT & & NO & BACK \\
\hline 286 & 3094 & 28.3 & $(39.0)$ & $(42.7)$ & 15.8 & 037058 & $0-70$ & TS & PROV \\
\hline 286 & 7602 & 45.4 & $(64.5)$ & $(43.6)$ & 14.0 & 035000 & & NO & SURF \\
\hline 286 & 7595 & 46.8 & $(48.6)$ & $(57.0)$ & 16.5 & 130000 & & NO & SURF \\
\hline 286 & 3105 & 13.8 & $(45.5)$ & $(31.4)$ & 5.7 & 027032 & $0-72$ & $S G$ & PROV \\
\hline 286 & 7652 & 16.2 & $(37.3)$ & $(42.9)$ & 7.0 & $\mathrm{ECHO}$ & & NO & BACK \\
\hline 286 & 7648 & 62.8 & $(69.0)$ & $(59.0)$ & 16.0 & $\mathrm{ECHO}$ & & NO & BACK \\
\hline 286 & 7647 & 8.8 & $(35.6)$ & $(35.2)$ & 7.6 & $\mathrm{ECHO}$ & & NO & BACK \\
\hline
\end{tabular}




\begin{tabular}{|c|c|c|c|c|c|c|c|c|c|c|}
\hline $\begin{array}{l}\text { Classifi- } \\
\text { cation } \\
\text { Type Code }\end{array}$ & $\begin{array}{r}\text { Catalog } \\
\text { Number }\end{array}$ & $\begin{array}{l}\text { Weight } \\
(g)\end{array}$ & $\begin{array}{l}\text { Maximum } \\
\text { Length } \\
(\mathrm{mm})\end{array}$ & $\begin{array}{l}\text { Maximum } \\
\text { Width } \\
\text { (mm) }\end{array}$ & $\begin{array}{l}\text { Maximum } \\
\text { Thickness } \\
\text { (mm) }\end{array}$ & $\begin{array}{l}\text { Feature } \\
\text { Number }\end{array}$ & $\begin{array}{l}\text { Unit/ } \\
\text { Trench/ } \\
\text { Block }\end{array}$ & $\begin{array}{c}\text { Depth Below } \\
\text { Ground } \\
\text { Surface }\end{array}$ & $\begin{array}{l}\text { Stratum } \\
\text { Desig- } \\
\text { nation }\end{array}$ & Comment \\
\hline
\end{tabular}

PART 2. BIFACES (continued)

\begin{tabular}{|c|c|c|c|c|c|c|c|c|c|c|}
\hline 286 & 7617 & 15.2 & $(41.6)$ & $(33.2)$ & 10.6 & GOLF & & NO & BACK & \\
\hline 286 & 7654 & $(28.7)$ & $(47.3)$ & 37.3 & 10.6 & $\mathrm{ECHO}$ & & NO & BACK & \\
\hline 286 & 6252 & $(12.8)$ & $(29.8)$ & 44.5 & 9.8 & $\mathrm{ECHO}$ & & NO & BACK & \\
\hline 286 & 5495 & $(56.8)$ & $(40.8)$ & 59.4 & 20.3 & 038000 & & NO & SURF & \\
\hline 286 & 5474 & $(27.5)$ & $(39.4)$ & 47.0 & 10.7 & 037000 & & NO & SURF & \\
\hline 286 & 7642 & $(4.6)$ & $(38.0)$ & $(26.8)$ & 2.6 & $\mathrm{ECHO}$ & & NO & BACK & \\
\hline 286 & 7649 & $(39.1)$ & $(54.0)$ & $(46.0)$ & 14.9 & $\mathrm{ECHO}$ & & NO & BACK & \\
\hline 286 & 6387 & $(6.2)$ & $(32.0)$ & $(26.7)$ & 8.9 & 034000 & & NO & SURF & \\
\hline 286 & 7591 & $(22.6)$ & $(36.4)$ & $(55.7)$ & $(10.0)$ & 034000 & & NO & SURF & \\
\hline 286 & 7646 & $(5.9)$ & $(41.0)$ & $(24.2)$ & 6.3 & $\mathrm{ECHO}$ & & NO & BACK & \\
\hline 286 & 5709 & $(24.6)$ & $(56.4)$ & 42.6 & 17.8 & 047000 & & NO & SURF & \\
\hline 286 & 7601 & $(11.0)$ & $(25.0)$ & 38.3 & 8.7 & 046000 & & NO & SURF & \\
\hline 286 & 7643 & $(9.9)$ & $(23.6)$ & 42.9 & 8.7 & $\mathrm{ECHO}$ & & NO & BACK & \\
\hline 286 & 6375 & $(16.4)$ & $(31.5)$ & 40.7 & 10.0 & 035000 & & NO & SURF & \\
\hline 286 & 7618 & $(14.6)$ & $(45.6)$ & 28.2 & 8.5 & GOLF & & NO & BACK & \\
\hline 286 & 7650 & $(5.7)$ & $(22.4)$ & $(26.6)$ & 6.0 & $\mathrm{ECHO}$ & & NO & BACK & \\
\hline 286 & 7619 & $(1.0)$ & $(9.7)$ & $(9.6)$ & 3.2 & GOLF & & NO & BACK & \\
\hline 286 & 6296 & $(23.0)$ & $(43.2)$ & $(42.5)$ & 10.2 & DELT & & NO & BACK & \\
\hline 286 & 7644 & $(10.5)$ & $(30.5)$ & $(39.2)$ & $(5.6)$ & $\mathrm{ECHO}$ & & NO & BACK & \\
\hline 286 & 3077 & $(4.1)$ & $(30.0)$ & $(17.0)$ & $(6.8)$ & 048013 & $0-90$ & TS & PROV & $\sim$ \\
\hline 286 & 7651 & $(17.5)$ & $(56.0)$ & $(25.7)$ & 10.6 & ECHO & & NO & BACK & $\cong$ \\
\hline 286 & 7621 & $(13.9)$ & $(40.0)$ & $(33.9)$ & $(9.2)$ & GOLF & & NO & BACK & $\stackrel{+}{D}$ \\
\hline 286 & 7604 & $(11.3)$ & $(39.5)$ & 31.4 & 18.4 & FOXT & & NO & BACK & + \\
\hline 286 & 7622 & $(7.0)$ & $(44.0)$ & 17.5 & 7.2 & GOLF & & NO & BACK & $\rightleftarrows$ \\
\hline 286 & 7605 & $(2.6)$ & $(25.8)$ & $(13.7)$ & $(4.6)$ & FOXT & & NO & BACK & $\infty$ \\
\hline 286 & 7620 & $(1.1)$ & $(16.4)$ & $(8.2)$ & $(3.0)$ & GOLF & & NO & BACK & $\bar{x}$ \\
\hline 286 & 7812 & $(4.9)$ & $(31.7)$ & $(27.3)$ & $(5.4)$ & FOXT & & NO & BACK & $\omega$ \\
\hline 286 & 6370 & $(10.7)$ & $(38.8)$ & $(22.8)$ & 9.6 & 013000 & & NO & SURF & 8 \\
\hline 286 & 5485 & $(34.1)$ & $(67.1)$ & $(40.0)$ & 11.9 & GOLF & & NO & BACK & Dे \\
\hline 286 & 6166 & $(23.9)$ & $(42.7)$ & $(41.6)$ & 11.7 & FOXT & & NO & BACK & $\overline{8}$ \\
\hline 286 & 5677 & $(10.2)$ & $(33.6)$ & $(33.4)$ & 6.7 & 027000 & & NO & SURF & 品 \\
\hline 286 & 5604 & $(10.5)$ & $(33.8)$ & 26.7 & 9.4 & 049000 & & NO & SURF & $\vec{\Omega}$ \\
\hline 286 & 5584 & $(15.2)$ & $(31.1)$ & 37.2 & 10.6 & 046000 & & NO & SURF & $\bar{x}$ \\
\hline 286 & 5618 & $(33.9)$ & $(52.0)$ & $(59.3)$ & 7.9 & 113000 & & NO & SURF & \\
\hline
\end{tabular}




\begin{tabular}{|c|c|c|c|c|c|c|c|c|c|c|}
\hline $\begin{array}{l}\text { Classifi- } \\
\text { cation } \\
\text { Type Code }\end{array}$ & $\begin{array}{l}\text { Catalog } \\
\text { Number }\end{array}$ & $\begin{array}{l}\text { Weight } \\
(g)\end{array}$ & $\begin{array}{l}\text { Maximum } \\
\text { Length } \\
(\mathrm{mm})\end{array}$ & $\begin{array}{l}\text { Maximum } \\
\text { Width } \\
\text { (mm) }\end{array}$ & $\begin{array}{l}\text { Maximum } \\
\text { Thickness } \\
\text { (mm) }\end{array}$ & $\begin{array}{l}\text { Feature } \\
\text {. Number }\end{array}$ & $\begin{array}{l}\text { Unit/ } \\
\text { Trench/ } \\
\text { Block }\end{array}$ & $\begin{array}{c}\text { Depth Below } \\
\text { Ground } \\
\text { Surface }\end{array}$ & $\begin{array}{l}\text { Stratum } \\
\text { Desig- } \\
\text { nation }\end{array}$ & Comment \\
\hline
\end{tabular}

PART 2. BIFACES (continued)

\begin{tabular}{|c|c|c|c|c|c|c|c|c|c|c|}
\hline 286 & 6478 & $(73.4)$ & $(78.9)$ & $(48.4)$ & 17.3 & & ALFA & & NO & BACK \\
\hline 286 & 3562 & $(53.0)$ & $(63.0)$ & $(43.5)$ & 15.2 & ' & 123009 & $0-15$ & TS & PROV \\
\hline 286 & 5773 & $(14.9)$ & $(44.0)$ & $(36.3)$ & 10.3 & & 117000 & & NO & SURF \\
\hline 286 & 6772 & $(4.1)$ & $(25.1)$ & $(22.3)$ & 6.7 & & ALFA & & NO & BACK \\
\hline 286 & 5508 & $(10.1)$ & $(28.6)$ & $(42.3)$ & 7.0 & & 115000 & & NO & SURF \\
\hline 286 & 6450 & $(6.1)$ & $(23.9)$ & $(28.9)$ & 6.5 & & BRAV & & NO & BACK \\
\hline 286 & 6462 & $(10.4)$ & $(30.0)$ & $(31.5)$ & $(10.5)$ & & CHAR & & NO & BACK \\
\hline 286 & 9108 & $(6.2)$ & $(27.3)$ & $(28.8)$ & 7.2 & & CHAR & & NO & BACK \\
\hline 286 & 4537 & $(8.8)$ & $(22.8)$ & $(36.6)$ & 9.8 & 4 & 076029 & $10-15$ & $O Z$ & PROV \\
\hline 286 & 0476 & $(5.1)$ & $(32.6)$ & $(20.9)$ & 6.2 & 7 & 056018 & $0-5$ & $O Z$ & PROV \\
\hline 286 & 5180 & $(7.6)$ & $(38.2)$ & $(20.9)$ & $(6.6)$ & 7 & 056026 & $9-15$ & $O Z$ & PROV \\
\hline 286 & 4118 & $(10.5)$ & $(29.3)$ & $(36.8)$ & 6.7 & 3 & 076037 & $10-20$ & $\mathrm{FZ}$ & PROV \\
\hline 286 & 4571 & $(12.5)$ & $(33.9)$ & $(38.3)$ & 7.8 & 3 & 076037 & $20-40$ & $F Z$ & PROV \\
\hline 286 & 3879 & $(25.7)$ & $(55.7)$ & 36.3 & 13.4 & 11 & 117077 & $20-45$ & $F Z$ & PROV \\
\hline 286 & 3578 & $(38.2)$ & $(56.9)$ & 48.6 & 12.9 & 11 & 117077 & $20-45$ & $F Z$ & PROV \\
\hline 286 & 3608 & $(18.4)$ & $(41.0)$ & 35.4 & 10.6 & 11 & 117067 & $0-20$ & $\mathrm{FZ}$ & SCRE \\
\hline 286 & 4567 & $(32.6)$ & $(58.4)$ & 47.0 & 12.2 & 6 & 077012 & $35-45$ & $\mathrm{FZ}$ & PROV \\
\hline 286 & 4695 & $(10.8)$ & $(53.5)$ & $(20.5)$ & 10.6 & 6 & 077003 & $10-18$ & $\mathrm{FZ}$ & SCRE \\
\hline 286 & 5247 & $(62.0)$ & $(55.7)$ & 55.9 & 16.6 & 2 & 055084 & $23-46$ & $M Z$ & SCRE \\
\hline 286 & 5090 & $(116,3)$ & $(87.2)$ & 57.2 & 20.0 & 2 & 055084 & $23-46$ & $M Z$ & PROV \\
\hline 286 & 5100 & $(8.3)$ & $(29.0)$ & 24.1 & 9.9 & 2 & 055084 & $0-23$ & $M Z$ & SCRE \\
\hline 286 & 2053 & $(15.2)$ & $(25.8)$ & $(40.0)$ & 15.1 & 5 & 076010 & $29-39$ & $O Z$ & PROV \\
\hline 286 & 0144 & $(20.3)$ & $(51.7)$ & 36.8 & 9.6 & 5 & 076018 & $20-30$ & $O Z$ & PROV \\
\hline 286 & 0919 & $(41.6)$ & $(45.5)$ & 59.2 & 14.6 & 5 & 077022 & $20-30$ & $\mathrm{OZ}$ & PROV \\
\hline 286 & 0927 & $(10.9)$ & $(19.4)$ & 47.6 & 10.5 & 5 & 076010 & $0-19$ & $O Z$ & PROV \\
\hline 286 & 0153 & $(31.7)$ & $(51.8)$ & 36.2 & 13.7 & & 076048 & $0-10$ & TS & PROV \\
\hline 286 & 5868 & $(8.2)$ & $(34.9)$ & $(22.3)$ & 7.0 & & 116000 & & NO & SURF \\
\hline 286 & 4111 & $(0.6)$ & $(7.2)$ & $(17.0)$ & $(3.3)$ & & 056046 & $20-29$ & TS & SCRE \\
\hline 286 & 7282 & $(1.2)$ & $(17.9)$ & $(12.9)$ & 2.9 & 8 & 085010 & $30-38$ & $\mathrm{FZ}$ & SCRE \\
\hline 286 & 5122 & $(1.3)$ & $(9.1)$ & $(11.9)$ & 3.4 & 5 & 077022 & $20-30$ & $O Z$ & SCRE \\
\hline 286 & 2261 & $(25.6)$ & $(44.5)$ & 38.0 & 14.6 & & 021000 & & NO & SURF \\
\hline 286 & 2183 & $(21.4)$ & $(38.4)$ & 30.6 & 15.0 & & 055000 & & NO & SURF \\
\hline 286 & 0903 & $(7.1)$ & $(33.0)$ & 19.5 & 8.3 & & 077002 & $M D$ & TS & SCRE \\
\hline 286 & 7639 & $(76.7)$ & $(63.2)$ & 46.7 & 23.0 & & $\mathrm{ECHO}$ & & NO & BACK \\
\hline
\end{tabular}




\begin{tabular}{|c|c|c|c|c|c|c|c|c|c|c|}
\hline $\begin{array}{l}\text { Classifi- } \\
\text { cation } \\
\text { Type Code }\end{array}$ & $\begin{array}{r}\text { Catalog } \\
\text { Number }\end{array}$ & $\begin{array}{l}\text { Weight } \\
\text { (g) }\end{array}$ & $\begin{array}{c}\text { Maximum } \\
\text { Length } \\
(\mathrm{mm})\end{array}$ & $\begin{array}{l}\text { Maximum } \\
\text { Width } \\
\text { (mm) }\end{array}$ & $\begin{array}{l}\text { Maximum } \\
\text { Thickness } \\
\text { (mm) }\end{array}$ & $\begin{array}{l}\text { Feature } \\
\text { Number }\end{array}$ & $\begin{array}{l}\text { Unit/ } \\
\text { Trench/ } \\
\text { Block }\end{array}$ & $\begin{array}{c}\text { Depth Below } \\
\text { Ground } \\
\text { Surface }\end{array}$ & $\begin{array}{l}\text { Stratum } \\
\text { Desig- } \\
\text { nation }\end{array}$ & Comment \\
\hline
\end{tabular}

PART 2. BIFACES (continued)

\begin{tabular}{|c|c|c|c|c|c|c|c|c|c|c|c|}
\hline 286 & 7692 & $(11.2)$ & $(40.2)$ & 30.3 & 7.3 & & $\mathrm{ECHO}$ & & NO & BACK & \\
\hline 286 & 5461 & $(49.2)$ & $(49.2)$ & $(50.4)$ & 14.6 & & 037000 & & NO & SURF & \\
\hline 286 & 7852 & $(2.3)$ & $(25.0)$ & $(11.7)$ & $(4.0)$ & & GOLF & & NO & BACK & \\
\hline 286 & 3584 & $(6.5)$ & $(31.9)$ & 29.5 & 5.2 & 11 & 117066 & $20-45$ & $F Z$ & PROV & \\
\hline 286 & 7549 & $(6.2)$ & $(52.0)$ & $(34.7)$ & 6.4 & & 080000 & & NO & SURF & \\
\hline 286 & 7779 & $(5.2)$ & $(29.4)$ & 26.9 & 6.0 & & 067000 & & NO & SURF & \\
\hline 286 & 6511 & $(9.6)$ & $(41.6)$ & 24.0 & 7.8 & & INDI & & NO & BACK & \\
\hline 286 & 7550 & $(10.5)$ & $(36.3)$ & 29.8 & 9.4 & & 109000 & & NO & SURF & \\
\hline 287 & 0069 & $(10.2)$ & $(31.0)$ & $(27.7)$ & 7.5 & & 056044 & $10-21$ & TS & PROV & \\
\hline 287 & 0492 & $(33.5)$ & 53.7 & $(39.4)$ & 18.5 & & 076049 & $0-10$ & TS & PROV & \\
\hline 287 & 0084 & $(4.2)$ & 27.3 & $(25.3)$ & 12.0 & & 067012 & $10-20$ & TS & PROV & \\
\hline 287 & 0449 & $(16.1)$ & $(45.8)$ & $(37.5)$ & $(6.9)$ & & 011028 & $0-10$ & TS & SCRE & \\
\hline 287 & 0149 & $(13.2)$ & $(42.4)$ & $(23.7)$ & 13.4 & & 076037 & $0-10$ & TS & PROV & \\
\hline 287 & 0976 & $(39.8)$ & $(69.6)$ & $(46.4)$ & 20.2 & & 077012 & $25-35$ & TS & PROV & \\
\hline 287 & 7927 & $(1.9)$ & $(15.5)$ & $(20.5)$ & $(4.0)$ & & 056064 & $0-20$ & TS & SCRE & \\
\hline 287 & 0645 & $(1.6)$ & $(15.0)$ & $(16.2)$ & $(4.2)$ & & 056064 & $0-20$ & $\mathrm{TS}$ & SCRE & \\
\hline 287 & 0072 & $(17.3)$ & $(36.6)$ & $(30.9)$ & $(10.4)$ & & 066020 & $0-10$ & TS & PROV & \\
\hline 287 & 0067 & $(3.2)$ & $(33.5)$ & $(18.0)$ & $(4.6)$ & & 056064 & $0-20$ & $\mathrm{TS}$ & PROV & \\
\hline 287 & 0076 & $(3.8)$ & $(36.4)$ & $(13.9)$ & $(6.8)$ & & 067012 & $0-10$ & TS & PROV & \\
\hline 287 & 0007 & $(10.7)$ & $(39.0)$ & $(25.3)$ & 10.4 & & 011039 & $0-10$ & TS & SCRE & $\vec{r}$ \\
\hline 287 & 7637 & $(2.1)$ & $(18.3)$ & $(16.4)$ & 4.3 & & GOLF & & NO & BACK & D \\
\hline 287 & 7606 & $(39.4)$ & $(57.6)$ & $(41.0)$ & 23.6 & & FOXT & & NO & BACK & $D$ \\
\hline 287 & 6176 & $(6.7)$ & $(40.0)$ & $(18.1)$ & $(5.7)$ & & FOXT & & NO & BACK & \\
\hline 287 & 6165 & (1.5) & $(16.7)$ & $(13.7)$ & 3.9 & & FOXT & & NO & BACK & $\stackrel{\mathscr{x}}{x}$ \\
\hline 287 & 6184 & $(3: 6)$ & $(31.9)$ & $(12.3)$ & 6.5 & & GOLF & & NO & BACK & $\omega$ \\
\hline 287 & 5970 & $(16.5)$ & $(25.2)$ & $(34.6)$ & 10.0 & & 129000 & & NO & SURF & o \\
\hline 287 & 7357 & $(12.2)$ & $(39.8)$ & $(30.3)$ & 8.7 & 4 & 076030 & $10-15$ & $\mathrm{OZ}$ & SCRE & 0 \\
\hline 287 & 3296 & $(17.4)$ & $(48.2)$ & $(24.4)$ & 15.2 & 3 & 076037 & $10-20$ & $\mathrm{FZ}$ & PROV & $\vec{D}$ \\
\hline 287 & 5095 & $(5.2)$ & $(24.8)$ & $(24.6)$ & 6.2 & 8 & 085029 & $0-5$ & $\mathrm{FZ}$ & PROV & 응 \\
\hline 287 & 4139 & $(28.1)$ & $(45.6)$ & $(34.0)$ & 14.8 & 6 & 077012 & $35-45$ & $\mathrm{FZ}$ & PROV & $\stackrel{D}{J}$ \\
\hline 287 & 7207 & $(1.7)$ & $(8.7)$ & $(17.2)$ & 5.8 & & 076028 & $0-20$ & TS & SCRE & $\vec{Q}$ \\
\hline 288 & 0482 & $(1.9)$ & $(14.2)$ & $(24.0)$ & $(3.9)$ & 7 & 056026 & $0-9$ & $\mathrm{OZ}$ & PROV & $\vec{x}$ \\
\hline 288 & 2710 & $(3.6)$ & $(25.4)$ & $(21.6)$ & $(5.9)$ & 7 & 056026 & $0-9$ & $O Z$ & SCRE & -1 \\
\hline
\end{tabular}




\begin{tabular}{|c|c|c|c|c|c|c|c|c|c|c|}
\hline $\begin{array}{l}\text { Classifi- } \\
\text { cation } \\
\text { Type Code }\end{array}$ & $\begin{array}{l}\text { Catalog } \\
\text { Number }\end{array}$ & $\begin{array}{c}\text { Weight } \\
\text { (g) }\end{array}$ & $\begin{array}{l}\text { Maximum } \\
\text { Length } \\
(\mathrm{mm})\end{array}$ & $\begin{array}{l}\text { Maximum } \\
\text { Width } \\
\text { (mm) }\end{array}$ & $\begin{array}{l}\text { Maximum } \\
\text { Thickness } \\
\text { (mm) }\end{array}$ & $\begin{array}{l}\text { Feature } \\
\text { Number }\end{array}$ & $\begin{array}{l}\text { Unit/ } \\
\text { Trench/ } \\
\text { Block }\end{array}$ & $\begin{array}{c}\text { Depth Below } \\
\text { Ground } \\
\text { Surface }\end{array}$ & $\begin{array}{l}\text { Stratum } \\
\text { Desig- } \\
\text { nation }\end{array}$ & Comment \\
\hline IRT 2. & FACES $(C$ & inved) & & & & & & & & \\
\hline 288 & 0478 & $(11.8)$ & $(27.9)$ & $(41.9)$ & $(15.4)$ & 7 & 056009 & $0-5$ & $O Z$ & PROV \\
\hline 288 & 2690 & $(6.5)$ & $(20.5)$ & $(35.4)$ & $(10.0)$ & 7 & 056016 & $0-9$ & $O Z$ & SCRE \\
\hline 288 & 7910 & $(1.6)$ & $(21.9)$ & $(13.0)$ & $(5.2)$ & 7 & 056009 & $0-5$ & $O Z$ & SCRE \\
\hline 288 & 1451 & $(7.0)$ & $(15.7)$ & $(9.2)$ & $(4.9)$ & 7 & 056019 & $0-5$ & $O Z$ & SCRE \\
\hline 288 & 1248 & $(2.2)$ & $(16.0)$ & $(22.2)$ & $(4.9)$ & 7 & 056027 & $0-5$ & $\mathrm{OZ}$ & SCRE \\
\hline 288 & 7438 & $(2.4)$ & $(21.9)$ & $(13.5)$ & $(8.2)$ & 7 & 056026 & $9-12$ & $O Z$ & SCRE \\
\hline 288 & 0112 & $(6.3)$ & $(43.8)$ & $(21.0)$ & $(8.9)$ & & 076028 & $0-20$ & TS & SCRE \\
\hline 288 & 0490 & $(12.7)$ & $(52.0)$ & $(22.4)$ & $(11.3)$ & & 076039 & $0-10$ & TS & PROV \\
\hline 288 & 5494 & $(10.0)$ & $(48.4)$ & $(23.4)$ & $(8.2)$ & & 038000 & & NO & SURF \\
\hline 288 & 0787 & $(3.6)$ & $(26.5)$ & $(22.6)$ & $(5.0)$ & & 065015 & $0-20$ & TS & SCRE \\
\hline 288 & 0782 & $(0.4)$ & $(11.0)$ & $(6.9)$ & $(2.8)$ & & 076008 & $0-20$ & TS & SCRE \\
\hline 288 & 7787 & $(61.3)$ & $(64.7)$ & 55.9 & $(15.0)$ & & 024000 & & NO & SURF \\
\hline 288 & 7901 & $(8.6)$ & $(44.2)$ & $(25,0)$ & $(6.2)$ & & 056044 & $0-10$ & TS & SCRE \\
\hline 288 & 7772 & $(4.6)$ & $(36.9)$ & $(19.3)$ & 8.6 & & 064000 & & NO & SURF \\
\hline 288 & 7776 & $(12.4)$ & 48.0 & $(24.6)$ & $(8.8)$ & & 076000 & & NO & SURF \\
\hline 288 & .6929 & $(2.9)$ & 31.5 & $(17.6)$ & $(4.9)$ & & 077002 & $0-10$ & TS & SCRE \\
\hline 288 & 7786 & $(9.2)$ & 37.3 & $(19.0)$ & 9.0 & & 024000 & & NO & SURF \\
\hline 288 & 7868 & $(3: 8)$ & $(24.3)$ & $(24.4)$ & $(6.3)$ & & JUL I & & NO & BACK \\
\hline 288 & 7909 & $(0.4)$ & $(9.3)$ & $(10.5)$ & $(2.8)$ & 7 & 056009 & $10-15$ & $O Z$ & SCRE \\
\hline 288 & 7581 & $(21.9)$ & $(55.6)$ & $(35.4)$ & $(9.0)$ & & 063000 & & NO & SURF \\
\hline 288 & 7771 & $(21.2)$ & 50.8 & $(26.6)$ & $(14.5)$ & & 064000 & & NO & SURF \\
\hline 288 & 7914 & (6.9) & $(31.5)$ & $(17.5)$ & 10.2 & & 076048 & $10-20$ & TS & SCRE \\
\hline 288 & 7919 & $(10.0)$ & $(36.5)$ & $(36.4)$ & $(5.9)$ & & 076048 & $0-10$ & TS & SCRE \\
\hline 288 & 7578 & $(14.3)$ & $(36.4)$ & $(29.9)$ & 12.5 & & 063000 & & NO & SURF \\
\hline 288 & 7870 & $(4.3)$ & 36.9 & $(18.3)$ & 4.6 & & JULI & & NO & BACK \\
\hline 288 & 7922 & $(2.9)$ & $(21.9)$ & $(18.8)$ & $(5.7)$ & & 077021 & $0-10$ & TS & SCRE \\
\hline 288 & 7809 & $(9.8)$ & $(39.8)$ & $(26.7)$ & $(11.5)$ & & 056000 & & NO & SURF \\
\hline 288 & 4647 & $(3.9)$ & $(30.0)$ & 19.3 & 6.5 & & 089016 & $0-42$ & TS & PROV \\
\hline 288 & 6885 & $(2.5)$ & $(23.7)$ & $(16.7)$ & 5.6 & & 076049 & $0-10$ & TS & SCRE \\
\hline 288 & 3944 & $(11.6)$ & 36.0 & 25.2 & 19.7 & & 075100 & $0-20$ & TS & SCRE \\
\hline 288 & 5241 & $(2.5)$ & $(18.2)$ & $(14.0)$ & 7.5 & & 076027 & $10-25$ & TS & SCRE \\
\hline 288 & 2093 & $(0.4)$ & $(12.3)$ & $(9.9)$ & 3.4 & & 077003 & $10-18$ & TS & PROV \\
\hline 288 & 1672 & $(20.1)$ & $(42.9)$ & 15.8 & 14.0 & & 075099 & $0-20$ & TS & PROV \\
\hline 288 & 0105 & $(11.4)$ & $(24.2)$ & $(36.0)$ & 10.6 & & 056046 & $20-29$ & TS & PROV \\
\hline
\end{tabular}




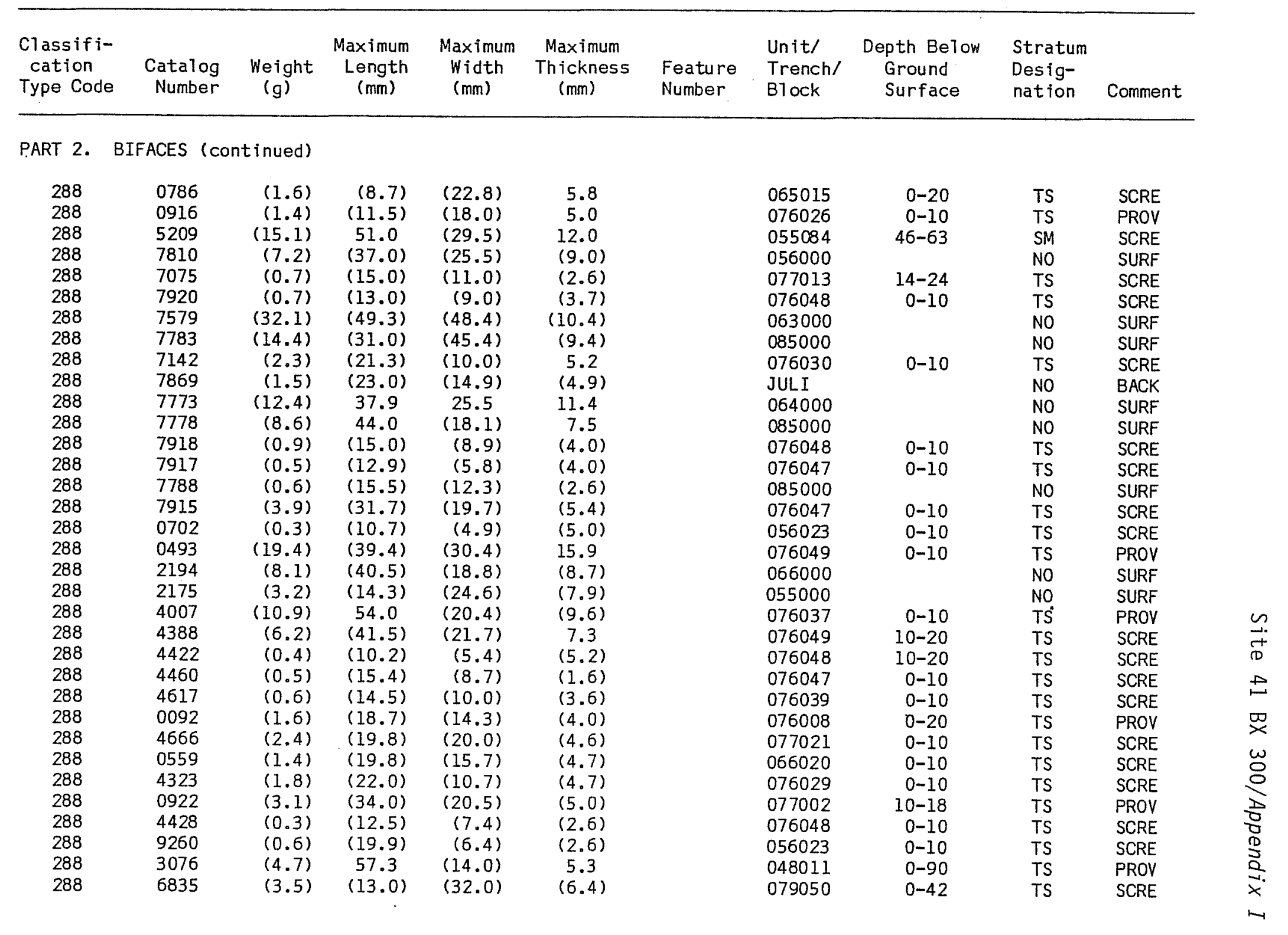




\begin{tabular}{|c|c|c|c|c|c|c|c|c|c|c|}
\hline $\begin{array}{l}\text { Classifi- } \\
\text { cation } \\
\text { Type Code }\end{array}$ & $\begin{array}{c}\text { Catalog } \\
\text { Number }\end{array}$ & $\begin{array}{c}\text { Weight } \\
(\mathrm{g})\end{array}$ & $\begin{array}{l}\text { Maximum } \\
\text { Length } \\
(\mathrm{mm})\end{array}$ & $\begin{array}{l}\text { Maximum } \\
\text { Width } \\
(\mathrm{mm})\end{array}$ & $\begin{array}{l}\text { Maximum } \\
\text { Thickness } \\
\text { (mm) }\end{array}$ & $\begin{array}{l}\text { Feature } \\
\text { Number }\end{array}$ & $\begin{array}{l}\text { Unit/ } \\
\text { Trench/ } \\
\text { Block }\end{array}$ & $\begin{array}{c}\text { Depth Below } \\
\text { Ground } \\
\text { Surface }\end{array}$ & $\begin{array}{l}\text { Stratum } \\
\text { Desig- } \\
\text { nation }\end{array}$ & Comment \\
\hline
\end{tabular}

PART 2. BIFACES (continued)

\begin{tabular}{|c|c|c|c|c|c|c|c|c|c|}
\hline 288 & 6886 & $(1.6)$ & $(8.0)$ & $(17.4)$ & $(5.1)$ & 076049 & $0-10$ & TS & SCRE \\
\hline 288 & 9261 & $(1.4)$ & $(7.7)$ & $(23.0)$ & $(4.0)$ & 056023 & $0-10$ & TS & SCRE \\
\hline 288 & 6849 & $(6.5)$ & $(27.0)$ & $(19.8)$ & 14.4 & 077012 & $10-25$ & TS & SCRE \\
\hline 288 & 6524 & $(1.9)$ & $(18.9)$ & $(9.3)$ & 6.5 & INDI & & NO & BACK \\
\hline 288 & 6920 & $(1.8)$ & $(22.4)$ & $(9.3)$ & 6.0 & 076010 & $0-19$ & $O Z$ & SCRE \\
\hline 288 & 6993 & $(8.6)$ & $(36.2)$ & $(23.6)$ & 8.5 & 076027 & $0-10$ & TS & SCRE \\
\hline 288 & 6525 & $(3.9)$ & $(23.2)$ & $(17.3)$ & 7.7 & INDI & & NO & BACK \\
\hline 288 & 9256 & $(4.6)$ & $(29.4)$ & $(19.6)$ & 6.2 & 065015 & $0-20$ & TS & SCRE \\
\hline 288 & 9258 & $(0.9)$ & $(7.5)$ & $(10.7)$ & $(3.2)$ & 066020 & $0-10$ & TS & SCRE \\
\hline 288 & 6920 & $(0.9)$ & $(21.0)$ & $(9.4)$ & 6.4 & 076010 & $0-19$ & TS & SCRE \\
\hline 288 & 5437 & $(9.4)$ & $(42.7)$ & $(40.9)$ & 10.9 & $0: 1000$ & & NO & SURF \\
\hline 288 & 6085 & $(23.6)$ & 49.0 & $(35.3)$ & 12.3 & 089000 & & NO & SURF \\
\hline 288 & 5566 & $(17.6)$ & 55.6 & $(25.8)$ & 9.7 & 041000 & & NO & SURF \\
\hline 288 & 6795 & $(25.3)$ & $(41.4)$ & $(33.7)$ & 17.9 & 800000 & & NO & SURF \\
\hline 288 & 7553 & $(29.4)$ & $(49.0)$ & $(41.5)$ & 11.0 & 001000 & & NO & SURF \\
\hline 288 & 7803 & $(12.6)$ & $(31.2)$ & $(37.6)$ & 8.8 & 002000 & & NO & SURF \\
\hline 288 & 0010 & $(10.9)$ & 53.2 & $(25.4)$ & 7.3 & 011030 & $0-10$ & TS & SCRE \\
\hline 288 & 6790 & $(13.4)$ & $(48.4)$ & $(35.6)$ & 8.0 & 168000 & & NO & SURF \\
\hline 288 & 6044 & $(2.6)$ & 25.7 & $(10.9)$ & 5.4 & 168000 & & NO & SURF \\
\hline 288 & 6058 & $(0.9)$ & $(8.6)$ & $(5.7)$ & $(2.3)$ & 080000 & & NO & SURF \\
\hline 288 & 7802 & $(18.6)$ & 34.4 & $(26.0)$ & 8.6 & 002000 & & NO & SURF \\
\hline 288 & 7552 & $(6.4)$ & $(20.5)$ & $(28.0)$ & 9.5 & 001000 & & NO & SURF \\
\hline 288 & 5415 & $(10.6)$ & $(32.0)$ & 29.6 & 9.5 & 199000 & & NO & SURF \\
\hline 288 & 7804 & $(7.4)$ & $(27.6)$ & $(21.3)$ & 14.3 & 002000 & & NO & SURF \\
\hline 288 & 0444 & $(4.1)$ & $(18.6)$ & $(20.0)$ & 6.7 & 011016 & $30-40$ & SS & SCRE \\
\hline 288 & 0001 & $(6.7)$ & 42.6 & $(14.5)$ & 8.3 & 011020 & $0-10$ & TS & SCRE \\
\hline 288 & 7554 & $(9.7)$ & $(44.4)$ & $(19.0)$ & 9.0 & 199000 & & NO & SURF \\
\hline 288 & 7556 & $(6.6)$ & $(20.0)$ & $(21.4)$ & 16.4 & 041000 & & NO & SURF \\
\hline 288 & 6097 & $(9.4)$ & $(31.6)$ & $(31.2)$ & 6.8 & 109000 & & NO & SURF \\
\hline 288 & 7557 & $(4.6)$ & $(27.7)$ & $(21.0)$ & 8.3 & 041000 & & NO & SURF \\
\hline 288 & 6110 & $(5.7)$ & $(20.0)$ & 32.3 & 7.3 & 099000 & & NO & SURF \\
\hline 288 & 2241 & $(6.7)$ & $(20.7)$ & $(28.0)$ & 7.1 & 022000 & & NO & SURF \\
\hline 288 & 2255 & $(1.0)$ & $(13.0)$ & $(7.5)$ & 3.6 & 021000 & & NO & SURF \\
\hline 288 & 4661 & 0.7 & 16.3 & 11.2 & 1.7 & 089056 & $42-132$ & SS & PROV \\
\hline
\end{tabular}




\begin{tabular}{|c|c|c|c|c|c|c|c|c|c|c|}
\hline $\begin{array}{l}\text { Classifi- } \\
\text { cation } \\
\text { Type Code }\end{array}$ & $\begin{array}{c}\text { Catalog } \\
\text { Number }\end{array}$ & $\begin{array}{l}\text { Weight } \\
(g)\end{array}$ & $\begin{array}{l}\text { Maximum } \\
\text { Length } \\
(\mathrm{mm})\end{array}$ & $\begin{array}{l}\text { Maximum } \\
\text { Width } \\
(\mathrm{mm})\end{array}$ & $\begin{array}{l}\text { Maximum } \\
\text { Thickness } \\
(\mathrm{mm})\end{array}$ & $\begin{array}{l}\text { Feature } \\
\text { Number }\end{array}$ & $\begin{array}{l}\text { Unit/ } \\
\text { Trench/ } \\
\text { Block }\end{array}$ & $\begin{array}{c}\text { Depth Below } \\
\text { Ground } \\
\text { Surface }\end{array}$ & $\begin{array}{l}\text { Stratum } \\
\text { Desig- } \\
\text { nation }\end{array}$ & Comment \\
\hline
\end{tabular}

PART 2. BIFACES (continued)

\begin{tabular}{|c|c|c|c|c|c|c|c|c|c|}
\hline 288 & 7829 & 10.9 & $(37.0)$ & $(25.6)$ & 9.5 & 011000 & & NO & SURF \\
\hline 288 & 0418 & 10.9 & $(34.4)$ & $(27.7)$ & 9.6 & 011027 & $0-10$ & TS & SCRE \\
\hline 288 & 5906 & 4.2 & $(19.2)$ & $(19.1)$ & 5.7 & 168000 & & NO & SURF \\
\hline 288 & 5953 & 2.9 & $(19.7)$ & 17.8 & 5.2 & 100000 & & NO & SURF \\
\hline 288 & 5996 & 1.6 & $(19.8)$ & 18.8 & 3.7 & 110000 & & NO & SURF \\
\hline 288 & 0009 & 7.8 & $(21.0)$ & 31.9 & 7.0 & 011030 & $0-10$ & TS & SCRE \\
\hline 288 & 6789 & 4.1 & $(23.0)$ & $(24.4)$ & 6.1 & 110000 & & NO & SURF \\
\hline 288 & 6570 & 3.2 & $(22.5)$ & $(15.6)$ & 4.2 & KILO & & NO & BACK \\
\hline 288 & 7675 & 6.7 & (19.3) & $(35.3)$ & 7.2 & GOLF & & NO & BACK \\
\hline 288 & 7628 & 7.3 & $(17.3)$ & $(45.5)$ & 10.0 & FOXT & & NO & BACK \\
\hline 288 & 6298 & 7.3 & 33.0 & 38.6 & 4.6 & DELT & & NO & BACK \\
\hline 288 & 7673 & 2.6 & 26.0 & $(14.3)$ & 4.0 & GOLF & & NO & BACK \\
\hline 288 & 6350 & $(16.6)$ & $(44.5)$ & $(32.6)$ & 8.2 & 014000 & & NO & SURF \\
\hline 288 & 7678 & $(10.0)$ & $(39.0)$ & $(27.2)$ & 8.6 & GOLF & & NO & BACK \\
\hline 288 & 6202 & $(9.2)$ & $(32.6)$ & $(17.0)$ & 9.6 & GOLF & & NO & BACK \\
\hline 288 & 7683 & $(1.8)$ & 18.5 & $(10.0)$ & 4.5 & GOLF & & NO & BACK \\
\hline 288 & 7682 & $(1.1)$ & $(13.4)$ & $(7.3)$ & 3.4 & GOLF & & NO & BACK \\
\hline 288 & 7687 & $(3.9)$ & $(34.3)$ & $(13.4)$ & 5.9 & GOLF & & NO & BACK \\
\hline 288 & 7670 & $(5.1)$ & $(40.5)$ & $(20.0)$ & 5.4 & GOLF & & NO & BACK \\
\hline 288 & 7665 & $(3.9)$ & $(25.0)$ & $(21.6)$ & 7.0 & $\mathrm{ECHO}$ & & NO & BACK \\
\hline 288 & 7634 & $(4.2)$ & 30.0 & $(18.2)$ & 5.6 & FOXT & & NO & BACK \\
\hline 288 & 5700 & $(24.6)$ & $(51.3)$ & $(40.7)$ & 11.6 & 028000 & & NO & SURF \\
\hline 288 & 7653 & $(18.2)$ & $(31.0)$ & 43.4 & 12.3 & 010000 & & NO & SURF \\
\hline 288 & 7687 & $(3.0)$ & $(32.3)$ & $(17.0)$ & 5.0 & GOLF & & NO & BACK \\
\hline 288 & 5707 & $(11.9)$ & $(29.6)$ & 31.4 & 8.0 & 047000 & & NO & SURF \\
\hline 288 & 7635 & $(8.8)$ & $(38.7)$ & $(22.4)$ & 9.4 & FOXT & & NO & BACK \\
\hline 288 & 7684 & $(6.7)$ & $(27.3)$ & $(29.4)$ & 7.0 & GOLF & & NO & BACK \\
\hline 288 & 7680 & $(5.9)$ & $(27.9)$ & $(23.2)$ & 6.8 & GOLF & & NO & BACK \\
\hline 288 & 6360 & $(37.1)$ & $(58.0)$ & $(26.4)$ & $(23.7)$ & 025000 & & NO & SURF \\
\hline 288 & 7627 & $(8.7)$ & $(31.4)$ & $(25.7)$ & 6.9 & FOXT & & NO & BACK \\
\hline 288 & 7677 & $(3.8)$ & $(35.0)$ & $(13.7)$ & 5.7 & GOLF & & NO & BACK \\
\hline 288 & 7660 & $(3.6)$ & $(16.4)$ & $(18.5)$ & 7.2 & $\mathrm{ECHO}$ & & NO & BACK \\
\hline 288 & 7630 & $(5.6)$ & $(38.1)$ & $(22.5)$ & 5.4 & FOXT & & NO & BACK \\
\hline 288 & 5732 & $(2.3)$ & 21.4 & $(11.3)$ & 6.0 & 031000 & & NO & SURF \\
\hline
\end{tabular}




\begin{tabular}{|c|c|c|c|c|c|c|c|c|c|c|}
\hline $\begin{array}{l}\text { Classift- } \\
\text { cation } \\
\text { Type Code }\end{array}$ & $\begin{array}{c}\text { Catalog } \\
\text { Number }\end{array}$ & $\begin{array}{l}\text { Weight } \\
\text { (g) }\end{array}$ & $\begin{array}{l}\text { Maximum } \\
\text { Length } \\
(\mathrm{mm})\end{array}$ & $\begin{array}{l}\text { Maximum } \\
\text { Width } \\
\text { (mm) }\end{array}$ & $\begin{array}{l}\text { Maximum } \\
\text { Thickness } \\
\text { (mm) }\end{array}$ & $\begin{array}{l}\text { Feature } \\
\text { Number }\end{array}$ & $\begin{array}{l}\text { Unit/ } \\
\text { Trench/ } \\
\text { Block }\end{array}$ & $\begin{array}{c}\text { Depth Below } \\
\text { Ground } \\
\text { Surface }\end{array}$ & $\begin{array}{l}\text { Stratum } \\
\text { Desig- } \\
\text { nation }\end{array}$ & Comment \\
\hline \multicolumn{11}{|c|}{ BIFACES (continued) } \\
\hline 288 & 6254 & $(1.5)$ & $(15.8)$ & $(13.0)$ & 3.0 & & $\mathrm{ECHO}$ & & NO & BACK \\
\hline 288 & 7624 & $(7.1)$ & $(30.3)$ & $(28.3)$ & $(6.6)$ & & FOXT & & NO & BACK \\
\hline 288 & 7598 & $(17.4)$ & $(38.5)$ & 38.8 & 10.5 & & 047000 & & NO & SURF \\
\hline 288 & 7681 & $(5.9)$ & $(45.8)$ & $(22.0)$ & $(7.6)$ & & GOLF & & NO & BACK \\
\hline 288 & 7672 & $(7.9)$ & $(36.0)$ & $(24.9)$ & 8.0 & & GOLF & & NO & BACK \\
\hline 288 & 7668 & $(1.7)$ & $(24.6)$ & (9.1) & $(4.0)$ & & $\mathrm{ECHO}$ & & NO & BACK \\
\hline 288 & 7663 & $(2.9)$ & $(33.5)$ & $(8.2)$ & $(4.0)$ & & $\mathrm{ECHO}$ & & NO & BACK \\
\hline 288 & 7658 & $(25.9)$ & $(30.9)$ & 37.2 & 15.8 & & $\mathrm{ECHO}$ & & NO & BACK \\
\hline 288 & 7667 & $(3.8)$ & $(14.5)$ & $(21.2)$ & 8.0 & & $\overline{\mathrm{ECHO}}$ & & NO & BACK \\
\hline 288 & 7671 & $(2.5)$ & $(18.0)$ & $(11.0)$ & 9.7 & & GOLF & & NO & BACK \\
\hline 288 & 7636 & $(16.9)$ & $(47.5)$ & $(33.2)$ & 9.9 & & FOXT & & NO & BACK \\
\hline 288 & 7669 & $(1.2)$ & $(18.9)$ & $(5.6)$ & $(3.9)$ & & $\mathrm{ECHO}$ & & NO & BACK \\
\hline 288 & 7679 & $(6.8)$ & $(27.3)$ & $(18.7)$ & 9.9 & & GOLF & & NO & BACK \\
\hline 288 & 7662 & $(0.8)$ & $(5.8)$ & $(10.0)$ & $(3.2)$ & & $\mathrm{ECHO}$ & & NO & BACK \\
\hline 288 & 5474 & $(2.4)$ & $(28.4)$ & $(10.8)$ & $(3.5)$ & & 037000 & & NO & SURF \\
\hline 288 & 7664 & $(3.6)$ & $(33.3)$ & $(14.0)$ & $(5.4)$ & & $\mathrm{ECHO}$ & & NO & BACK \\
\hline 288 & 7666 & $(7.4)$ & $(37.2)$ & $(15.5)$ & $(12.0)$ & & $\mathrm{ECHO}$ & & NO & BACK \\
\hline 288 & 7661 & $(2.1)$ & $(22.0)$ & $(15.2)$ & 4.5 & & $\mathrm{ECHO}$ & & NO & BACK \\
\hline 288 & 7659 & $(2.4)$ & $(26.2)$ & $(13.2)$ & 3.9 & & ECHO & & NO & BACK \\
\hline 288 & 7626 & $(2.3)$ & $(21.0)$ & $(14.2)$ & $(4.8)$ & & FOXT & & NO & BACK \\
\hline 288 & 7633 & $(1.7)$ & $(16.0)$ & $(14.6)$ & $(4.2)$ & & FOXT & & NO & BACK \\
\hline 288 & 7656 & $(1.4)$ & $(17.3)$ & $(13.4)$ & $(2.8)$ & & ECHO & & NO & BACK \\
\hline 288 & 7676 & $(2.3)$ & $(17.3)$ & $(16.6)$ & 5.5 & & GOLF & & NO & BACK \\
\hline 288 & 7674 & $(1.7)$ & $(22.5)$ & $(7.6)$ & 6.0 & & GOLF & & NO & BACK \\
\hline 288 & 3114 & $(6.3)$ & $(48.8)$ & $(14.6)$ & 12.8 & & 048015 & $0-90$ & SG & PROV \\
\hline 288 & 7625 & $(4.9)$ & $(30.9)$ & $(19.8)$ & 6.3 & & FOXT & & NO & BACK \\
\hline 288 & 7629 & $(2.9)$ & $(36.4)$ & $(11.0)$ & $(5.3)$ & & FOXT & & NO & BACK \\
\hline 288 & 7632 & $(8.1)$ & $(31.0)$ & $(25.0)$ & $(7.5)$ & & FOXT & & NO & BACK \\
\hline 288 & 7597. & $(5.3)$ & $(26.9)$ & $(18.7)$ & 7.3 & & 047000 & & NO & SURF \\
\hline 288 & 7599 & $(6.7)$ & $(37.8)$ & $(18.0)$ & 6.7 & & 047000 & & NO & SURF \\
\hline 288 & 5768 & $(19.2)$ & $(45.4)$ & $(38.2)$ & 7.6 & & 139000 & & NO & SURF \\
\hline 288 & 5780 & $(7.6)$ & $(33.4)$ & $(26.3)$ & 6.4 & & 128000 & & NO & SURF \\
\hline 288 & 5969 & $(71.9)$ & $(57.5)$ & $(57.4)$ & 16.4 & & 129000 & & NO & SURF \\
\hline 288 & 6451 & $(1.2)$ & $(19.0)$ & $(9.3)$ & 3.0 & & BRAV & & NO & BACK \\
\hline
\end{tabular}




\begin{tabular}{|c|c|c|c|c|c|c|c|c|c|c|}
\hline $\begin{array}{l}\text { Classifi- } \\
\text { cation } \\
\text { Type Code }\end{array}$ & $\begin{array}{c}\text { Catalog } \\
\text { Number }\end{array}$ & $\begin{array}{l}\text { Weight } \\
(\mathrm{g})\end{array}$ & $\begin{array}{l}\text { Maximum } \\
\text { Length } \\
(\mathrm{mm})\end{array}$ & $\begin{array}{l}\text { Maximum } \\
\text { Width } \\
\text { (mm) }\end{array}$ & $\begin{array}{l}\text { Maximum } \\
\text { Thickness } \\
(\mathrm{mm})\end{array}$ & $\begin{array}{l}\text { Feature } \\
\text { Number }\end{array}$ & $\begin{array}{l}\text { Unit/ } \\
\text { Trench/ } \\
\text { Block }\end{array}$ & $\begin{array}{c}\text { Depth Below } \\
\text { Ground } \\
\text { Surface }\end{array}$ & $\begin{array}{l}\text { Stratum } \\
\text { Desig- } \\
\text { nation }\end{array}$ & Comment \\
\hline
\end{tabular}

PART 2. BIFACES (continued)

\begin{tabular}{|c|c|c|c|c|c|c|c|c|c|c|}
\hline 288 & 6774 & $(7.9)$ & $(32.6)$ & $(28.7)$ & 5.8 & & BRAV & & NO & BACK \\
\hline 288 & 5835 & $(6.6)$ & $(22.3)$ & $(23.7)$ & 7.3 & & 133000 & & NO & SURF \\
\hline 288 & 5757 & $(35.7)$ & $(43.7)$ & $(41.2)$ & 15.3 & & 137000 & & NO & SURF \\
\hline 288 & 6776 & $(18.5)$ & $(27.3)$ & $(34.0)$ & 13.7 & & 129000 & & NO & SURF \\
\hline 288 & 5821 & $(11.5)$ & $(35.5)$ & 27.6 & 7.6 & & 134000 & & NO & SURF \\
\hline 288 & 6767 & $(9.1)$ & $(35.2)$ & $(24.6)$ & 7.3 & & 128000 & & NO & SURF \\
\hline 288 & 3502 & (8.1) & $(27.0)$ & 21.8 & 10.6 & & 123009 & $0-15$ & TS & PROV \\
\hline 288 & 1054 & $(1.2)$ & $(13.4)$ & $(7.6)$ & 4.6 & & 123019 & $13-25$ & $S G$ & SCRE \\
\hline 288 & 5509 & $(10.1)$ & $(46.9)$ & $(24.2)$ & 6.3 & & 115000 & & NO & SURF \\
\hline 288 & 5805 & $(2.9)$ & $(22.3)$ & $(14.6)$ & 5.2 & & 114000 & & NO & SURF \\
\hline 288 & 6768 & $(27.4)$ & $(47.3)$ & $(39.2)$ & 10.3 & & 137000 & & NO & SURF \\
\hline 288 & 6792 & $(4.6)$ & 32.6 & 21.5 & 4.3 & & 100000 & & NO & SURF \\
\hline 288 & 3241 & $(2.8)$ & $(20.9)$ & $(17.6)$ & 5.4 & 4 & 076019 & $10-20$ & $0 Z$ & PROV \\
\hline 288 & 3747 & $(2.6)$ & $(22.0)$ & $(15.3)$ & 5.2 & 4 & 076019 & $10-20$ & $0 Z$ & PROV \\
\hline 288 & 3241 & $(1.4)$ & $(20.6)$ & $(16.6)$ & 3.9 & 4 & 076019 & $10-20$ & $\mathrm{OZ}$ & PROV \\
\hline 288 & 7201 & $(2.1)$ & $(23.4)$ & $(17.2)$ & $(5.2)$ & 5 & 076038 & $40-50$ & $O Z$ & SCRE \\
\hline 288 & 7054 & $(1.0)$ & 18.7 & $(6.4)$ & $(2.8)$ & 5 & 075099 & $41-46$ & $\mathrm{OZ}$ & SCRE \\
\hline 288 & 7782 & $(5.6)$ & $(16.2)$ & $(27.4)$ & 10.4 & & 085000 & & NO & SURF \\
\hline
\end{tabular}

PART 3. UNIFACES

\begin{tabular}{|c|c|c|c|c|c|c|c|c|c|c|}
\hline 301 & 4006 & $(14.8)$ & $(44.6)$ & $(34.8)$ & $(14.7)$ & 5 & 076010 & $29-39$ & $\mathrm{OZ}$ & SCRE \\
\hline 301 & 1692 & $(2.7)$ & $(24.9)$ & $(22.6)$ & $(4.2)$ & & 085009 & $0-20$ & TS & PROV \\
\hline 301 & 2660 & $(7.7)$ & $(17.3)$ & $(37.3)$ & $(11.7)$ & 7 & 056009 & $0-5$ & $0 Z$ & SCRE \\
\hline 301 & 2304 & 122.7 & 113.0 & 48.0 & 19.6 & 8 & 085009 & $20-30$ & $\mathrm{FZ}$ & PROV \\
\hline 301 & 0485 & 314.3 & 105.0 & 84.8 & 34.2 & & 076027 & $10-25$ & TS & PROV \\
\hline 302 & 6356 & 15.3 & 67.5 & 55.2 & 38.4 & & 045000 & & NO & SURF \\
\hline 302 & 5447 & 24.5 & 52.2 & 40.6 & 11.9 & & 042000 & & NO & SURF \\
\hline 302 & 1339 & 18.0 & 38.7 & 24.9 & 20.4 & 5 & 077022 & $30-40$ & $O Z$ & SCRE \\
\hline 302 & 7354 & 11.3 & 38.6 & 19.4 & 16.4 & 5 & 076027 & $50-66$ & $\mathrm{OZ}$ & SCRE \\
\hline 302 & 6341 & 35.3 & 49.2 & 45.8 & 12.9 & & HOTE & & NO & BACK \\
\hline 303 & 6340 & 35.5 & 49.0 & 40.0 & 17.6 & & HOTE & & NO & BACK \\
\hline 303 & 0892 & 39.3 & 54.6 & 42.0 & 20.0 & 7 & 056016 & $0-9$ & $0 Z$ & PROV \\
\hline
\end{tabular}




\begin{tabular}{|c|c|c|c|c|c|c|c|c|c|c|}
\hline $\begin{array}{l}\text { Classifi- } \\
\text { cation } \\
\text { Type Code }\end{array}$ & $\begin{array}{c}\text { Catalog } \\
\text { Number }\end{array}$ & $\begin{array}{l}\text { Weight } \\
(g)\end{array}$ & $\begin{array}{l}\text { Maximum } \\
\text { Length } \\
(\mathrm{mm})\end{array}$ & $\begin{array}{l}\text { Maximum } \\
\text { Width } \\
\text { (mm) }\end{array}$ & $\begin{array}{l}\text { Maximum } \\
\text { Thickness } \\
\text { (mm) }\end{array}$ & $\begin{array}{l}\text { Feature } \\
\text { Number }\end{array}$ & $\begin{array}{l}\text { Unit/ } \\
\text { Trench/ } \\
\text { Block }\end{array}$ & $\begin{array}{c}\text { Depth Below } \\
\text { Ground } \\
\text { Surface }\end{array}$ & $\begin{array}{l}\text { Stratum } \\
\text { Desig- } \\
\text { nation }\end{array}$ & Comment \\
\hline PART 3. U & FACES $(c$ & ntinued) & & & & & & & & \\
\hline 303 & 0950 & $(50.5)$ & $(60.2)$ & 48.0 & 12.3 & 2 & 056040 & & $M Z$. & PROV \\
\hline 303 & 3749 & 55.4 & 62.8 & 49.2 & 19.0 & 10 & 089004 & $0-28$ & $\mathrm{FZ}$ & PROV \\
\hline 303 & 5863 & $(22.7)$ & $(52.4)$ & 43.3 & $(9.0)$ & & 116000 & & NO & SURF \\
\hline 303 & 0498 & 19.0 & 48.2 & 39.0 & 10.8 & & 077022 & $0-10$ & TS & PROV \\
\hline 303 & 6276 & $(18.5)$ & $(50.9)$ & 28.3 & 10.6 & & ECHO & & NO & BACK \\
\hline 303 & 2181 & $(25.5)$ & $(33.2)$ & 55.0 & 10.2 & & 055000 & & NO & SURF \\
\hline 303 & 4149 & 158.5 & 97.8 & 63.0 & 21.8 & 6 & 077012 & $25-35$ & $\mathrm{FZ}$ & PROV \\
\hline 303 & 7530 & 11.5 & 64.7 & 12.8 & 9.2 & & $\mathrm{MD}$ & & & \\
\hline 303 & 7517 & $(30.3)$ & $(61.0)$ & 46.2 & 10.6 & & $M D$ & & & \\
\hline 303 & 0125 & 51.3 & 60.8 & 50.4 & 11.5 & & 076018 & $0-20$ & TS & PROV \\
\hline 306 & 2303 & 154.4 & 79.7 & 54.9 & 34.7 & 8 & 085009 & $30-43$ & $\mathrm{FZ}$ & PROV \\
\hline 306 & 5561 & 32.5 & 60.3 & 31.6 & 18.2 & & 041000 & & & SURF \\
\hline 308 & 5071 & 112.2 & 82.0 & 54.0 & 29.0 & 5 & 077012 & & $O Z$ & PROV \\
\hline 308 & 6294 & $(24.5)$ & $(34.2)$ & 49.2 & $(14.6)$ & & DELT & & NO & BACK \\
\hline 308 & 6000 & $(14.5)$ & $(37.5)$ & 32.8 & 13.6 & & 167000 & & NO & SURF \\
\hline 311 & 7096 & $(13.3)$ & $(30.0)$ & $(32.2)$ & $(13.9)$ & 5 & 077002 & & $\mathrm{OZ}$ & SCRE \\
\hline 311 & 2944 & $(67.5)$ & $(89.6)$ & $(60.9)$ & $(16.2)$ & & 113080 & & TS & PROV \\
\hline 311 & 0142 & $(30.7)$ & $(54.0)$ & $(34.8)$ & $(14.7)$ & & 076029 & & TS & PROV \\
\hline 311 & 6398 & $(16.7)$ & 59.0 & $(17.5)$ & 11.9 & & 024000 & & NO & SURF \\
\hline 312 & 0054 & 36.5 & 49.0 & 34.6 & 15.4 & & 066013 & $0-13$ & TS & PROV \\
\hline 312 & 7515 & $(16.5)$ & $(34.2)$ & 41.3 & 11.1 & & MD & & & \\
\hline 313 & 2282 & 47.0 & 56.6 & 45.7 & 11.0 & & 076000 & & & SUR \\
\hline 313 & 2180 & 32.0 & 49.9 & 46.5 & 15.5 & & 055000 & & & SUR \\
\hline
\end{tabular}

PART 4. TYPED TOOLS

\begin{tabular}{|c|c|c|c|c|c|c|c|c|c|c|}
\hline 346 & 0477 & 43.6 & 69.7 & 45.7 & 15.7 & & 065019 & $20-85$ & $M G$ & PROV \\
\hline 349 & 5884 & 198.4 & 100.0 & 52.4 & 38.0 & & 133000 & & NO & SURF \\
\hline 349 & 6582 & 74.7 & 74.6 & 38.5 & 32.9 & & NOVE & & NO & BACK \\
\hline 349 & 6463 & 106.5 & 94.7 & 40.7 & 27.6 & & ALFA & & NO & BACK \\
\hline 349 & 3574 & 64.9 & 58.4 & 48.6 & 25.5 & & 123009 & $25-35$ & $M G$ & PROV \\
\hline 349 & 0971 & 66.4 & 81.0 & 37.4 & 20.8 & & 075010 & $48-92$ & MG & PROV \\
\hline 349 & 0456 & $(58.7)$ & $(57.4)$ & 34.2 & 31.4 & 7 & 056027 & $0-5$ & $0 Z$ & PROV \\
\hline
\end{tabular}




\begin{tabular}{|c|c|c|c|c|c|c|c|c|c|c|}
\hline $\begin{array}{l}\text { Classifi- } \\
\text { cation } \\
\text { Type Code }\end{array}$ & $\begin{array}{c}\text { Catalog } \\
\text { Number }\end{array}$ & $\begin{array}{l}\text { Weight } \\
(g)\end{array}$ & $\begin{array}{l}\text { Maximum } \\
\text { Length } \\
(\mathrm{mm})\end{array}$ & $\begin{array}{l}\text { Maximum } \\
\text { Width } \\
\text { (mm) }\end{array}$ & $\begin{array}{c}\text { Maximum } \\
\text { Thickness } \\
(\mathrm{mm})\end{array}$ & $\begin{array}{l}\text { Feature } \\
\text { Number }\end{array}$ & $\begin{array}{l}\text { Unit/ } \\
\text { Trench/ } \\
\text { Block }\end{array}$ & $\begin{array}{l}\text { Depth Below } \\
\text { Ground } \\
\text { Surface }\end{array}$ & $\begin{array}{l}\text { Stratum } \\
\text { Desig- } \\
\text { nation }\end{array}$ & Comment \\
\hline
\end{tabular}

PART 4. TYPED TOOLS (continued)

\begin{tabular}{|c|c|c|c|c|c|c|c|c|}
\hline $\begin{array}{l}350 \\
350\end{array}$ & $\begin{array}{l}6470 \\
1679\end{array}$ & $\begin{array}{l}308.2 \\
118.1\end{array}$ & $\begin{array}{r}114.0 \\
90.8\end{array}$ & $\begin{array}{l}63.3 \\
48.4\end{array}$ & $\begin{array}{l}38.7 \\
29.0\end{array}$ & $\begin{array}{l}\text { ALFA } \\
075100\end{array}$ & $20-30$ & $\begin{array}{l}\text { BACK } \\
\text { PROV }\end{array}$ \\
\hline
\end{tabular}

PART 5. SPECIALIZED TOOLS

\begin{tabular}{|c|c|c|c|c|c|c|c|c|c|c|}
\hline 357 & 0486 & $(21.5)$ & $(50.7)$ & 49.6 & 12.7 & & 076027 & $10-25$ & TS & PROV \\
\hline 357 & 0121 & $(13.9)$ & $(50.5)$ & 34.6 & 8.7 & 7 & 056028 & $0-5$ & $\mathrm{OZ}$ & SCRE \\
\hline 357 & 2858 & $(13.2)$ & $(34.0)$ & $(39.8)$ & 8.4 & & 118044 & $48-90$ & SS & PROV \\
\hline 357 & 6223 & 7.6 & 42.9 & 42.3 & 6.5 & & GOLF & & NO & BACK \\
\hline 357 & 0497 & $(7.3)$ & $(40.8)$ & $(32.3)$ & $(5.3)$ & & 077022 & $0-10$ & TS & PROV \\
\hline 357 & 0921 & $(1.8)$ & $(27.6)$ & $(10.5)$ & $(4.7)$ & & 077002 & $10-18$ & TS & PROV \\
\hline 357 & 3236 & $(1.3)$ & $(20.6)$ & $(9.7)$ & $(5.0)$ & 5 & 075099 & $41-46$ & $O Z$ & PROV \\
\hline 357 & 0924 & $(3.2)$ & $(42.9)$ & $(10.0)$ & $(4.6)$ & & 077002 & $18-28$ & TS & PROV \\
\hline 357 & 0983 & 8.3 & 48.8 & 25.5 & 6.7 & & 075100 & $0-20$ & $\mathrm{TS}$ & PROV \\
\hline 357 & 6425 & 25.2 & 67.6 & 54.4 & 10.4 & & BRAV & & NO & BACK \\
\hline 357 & 5513 & 22.5 & 52.4 & 31.6 & 10.0 & & 029000 & & NO & SURF \\
\hline 357 & 5804 & $(16.3)$ & $(48.8)$ & 35.4 & 13.0 & & 114000 & & NO & SURF \\
\hline 357 & 0895 & 32.5 & 58.2 & 42.3 & 13.7 & 7 & 056006 & $0-5$ & $O Z$ & PROV \\
\hline 357 & 1690 & $(6.9)$ & $(44.6)$ & 17.6 & 7.3 & & 085010 & $0-20$ & TS & PROV \\
\hline 358 & 6647 & 10.1 & 48.9 & 29.9 & 7.3 & & 138000 & & NO & SURF \\
\hline 358 & 9096 & 55.2 & 78.5 & 51.0 & 18.0 & & LIMA & & NO & BACK \\
\hline 358 & 6128 & 26.4 & 66.5 & 40.7 & 10.7 & & 060000 & & NO & SURF \\
\hline 358 & 1329 & 13.3 & 52.0 & 36.0 & 9.3 & & 076018 & $0-20$ & TS & SCRE \\
\hline 358 & 5520 & 22.8 & 53.3 & 38.7 & 12.0 & & 138000 & & NO & SURF \\
\hline 358 & 5452 & 27.4 & 48.0 & 46.0 & 11.9 & & 012000 & & NO & SURF \\
\hline 358 & 5705 & 19.5 & 47.0 & 30.8 & 15.0 & & 047000 & & NO & SURF \\
\hline 358 & 6627 & 8.9 & 42.3 & 24.0 & 7.3 & & 138000 & & NO & SURF \\
\hline 358 & 0085 & 8.7 & 38.4 & 25.4 & 12.0 & & 056023 & $0-10$ & TS & PROV \\
\hline 358 & 6661 & $(1.1)$ & $(20.9)$ & $(16.0)$ & $(3.0)$ & & 138000 & & NO & SURF \\
\hline 358 & 6725 & 31.8 & 55.0 & 32.4 & 22.8 & & BRAV & & NO & BACK \\
\hline 358 & 6188 & 16.3 & 36.2 & 44.0 & 15.2 & & GOLF & & NO & BACK \\
\hline 358 & 6615 & 3.9 & 28.6 & 23.0 & 5.9 & & 080000 & & NO & SURF \\
\hline 358 & 6383 & 20.6 & 40.4 & 41.4 & 13.5 & & 034000 & & NO & SURF \\
\hline
\end{tabular}




\begin{tabular}{|c|c|c|c|c|c|c|c|c|c|c|}
\hline $\begin{array}{l}\text { Classifi- } \\
\text { cation } \\
\text { Type Code }\end{array}$ & $\begin{array}{c}\text { Catalog } \\
\text { Number }\end{array}$ & $\begin{array}{l}\text { Weight } \\
\text { (g) }\end{array}$ & $\begin{array}{l}\text { Maximum } \\
\text { Length } \\
(\mathrm{mm})\end{array}$ & $\begin{array}{l}\text { Maximum } \\
\text { Width } \\
(\mathrm{mm})\end{array}$ & $\begin{array}{c}\text { Maximum } \\
\text { Thickness } \\
\text { (mm) }\end{array}$ & $\begin{array}{l}\text { Feature } \\
\text { Number }\end{array}$ & $\begin{array}{l}\text { Unit/ } \\
\text { Trench/ } \\
\text { Block }\end{array}$ & $\begin{array}{l}\text { Depth Below } \\
\text { Ground } \\
\text { Surface }\end{array}$ & $\begin{array}{l}\text { Stratum } \\
\text { Desig- } \\
\text { nation }\end{array}$ & Comment \\
\hline ART 5. S & CIAL IZED & TOOLS & ont inued) & & & & & & & \\
\hline 358 & 5543 & 12.7 & 32.0 & 36.4 & 8.9 & & 001000 & & NO & SURF \\
\hline 358 & 6457 & 10.4 & 43.7 & 23.5 & 10.0 & & CHAR & & NO & BACK \\
\hline 358 & 0006 & 13.6 & 37.7 & 36.0 & 9.3 & & 011019 & $0-10$ & TS & SCRE \\
\hline 358 & 5579 & 8.5 & 41.9 & 28.4 & 9.0 & & 046000 & & NO & SURF \\
\hline 358 & 6192 & 7.5 & 37.0 & 21.0 & 10.4 & & GOLF & & NO & BACK \\
\hline 358 & 6661 & 13.1 & 56.4 & 17.0 & 18.3 & & 138000 & & NO & SURF \\
\hline 359 & 5999 & 32.6 & 45.8 & 53.5 & 13.7 & & 167000 & & NO & SURF \\
\hline 359 & 2293 & 10.5 & 43.0 & 24.9 & 9.3 & & 002000 & & NO & SURF \\
\hline 359 & 5701 & 24.4 & 68.7 & 42.4 & 10.0 & & 028000 & & NO & SURF \\
\hline 359 & 5521 & 53.9 & 57.5 & 52.3 & 18.4 & & 138000 & & NO & SURF \\
\hline 359 & 5418 & 71.8 & 81.7 & 52.0 & 15.6 & & 102000 & & NO & SURF \\
\hline 359 & 6753 & 14.2 & 56.0 & 27.4 & 7.6 & & 037000 & & NO & SURF \\
\hline 359 & 6640 & 27.3 & 50.4 & 33.0 & 12.0 & & GOLF & & NO & BACK \\
\hline 359 & 1585 & 59.6 & 69.4 & 44.4 & 23.0 & & 095000 & & NO & SURF \\
\hline 359 & 7124 & 4.3 & 34.0 & 21.9 & 5.8 & & 076030 & $0-10$ & TS & SCRE \\
\hline 359 & 5957 & 54.1 & 86.4 & 36.4 & 16.0 & & 100000 & & NO & SURF \\
\hline 359 & 5562 & 28.8 & 54.0 & 42.5 & 14.3 & & 041000 & & NO & SURF \\
\hline 359 & 6185 & 81.5 & 93.9 & 55.8 & 25.2 & & GOLF & & NO & BACK \\
\hline 359 & 6504 & 134.1 & 82.6 & 64.6 & 27.8 & & ALFA & & NO & BACK \\
\hline 359 & 5589 & 44.5 & 74.8 & 31.0 & 15.9 & & 041000 & & NO & SURF \\
\hline 359 & 6624 & 11.3 & 44.0 & 29.4 & 9.8 & & 099000 & & NO & SURF \\
\hline 359 & 6787 & 13.1 & 38.6 & 40.6 & 9.8 & & OMEG & & NO & BACK \\
\hline 359 & 1664 & 8.9 & 40.0 & 27.8 & 6.0 & & 065002 & $0-40$ & $\mathrm{TS}$ & PROV \\
\hline 359 & 5671 & $(14.6)$ & $(28.3)$ & 29.0 & 15.7 & & 048000 & & NO & SURF \\
\hline 359 & 2171 & 4.1 & 27.6 & 22.2 & 6.4 & & 055000 & & NO & SURF \\
\hline 359 & 7851 & 41.9 & 65.6 & 41.5 & 13.6 & & 055000 & & NO & SURF \\
\hline 359 & 6620 & 25.4 & 52.6 & 36.9 & 14.0 & & 167000 & & NO & SURF \\
\hline 359 & 5414 & 18.9 & 46.4 & 36.6 & 10.2 & & 020000 & & NO & SURF \\
\hline 359 & 6699 & 17.1 & 48.6 & 30.3 & 13.9 & & GOLF & & NO & BACK \\
\hline 359 & 4238 & 3.5 & 22.3 & 19.0 & 4.8 & & 059085 & $0-42$ & TS & PROV \\
\hline 359 & 5803 & 3.9 & 31.8 & 24.7 & 4.3 & & 114000 & & NO & SURF \\
\hline 359 & 6465 & 85.9 & 81.7 & 66.0 & 18.2 & & ALFA & & NO & BACK \\
\hline 359 & 6629 & 64.9 & 60.6 & 71.7 & 19.4 & & 137000 & & NO & SURF \\
\hline 359 & 6159 & 26.6 & 60.3 & 40.4 & 11.0 & & FOXT & & NO & BACK \\
\hline
\end{tabular}




\begin{tabular}{|c|c|c|c|c|c|c|c|c|c|c|}
\hline $\begin{array}{l}\text { Classifi- } \\
\text { cation } \\
\text { Type Code }\end{array}$ & $\begin{array}{c}\text { Catalog } \\
\text { Number }\end{array}$ & $\begin{array}{l}\text { Weight } \\
(g)\end{array}$ & $\begin{array}{l}\text { Maximum } \\
\text { Length } \\
(\mathrm{mm})\end{array}$ & $\begin{array}{l}\text { Maximum } \\
\text { Width } \\
\text { (mm) }\end{array}$ & $\begin{array}{l}\text { Maximum } \\
\text { Thickness } \\
\text { (mm) }\end{array}$ & $\begin{array}{l}\text { Feature } \\
\text { Number }\end{array}$ & $\begin{array}{l}\text { Unit/ } \\
\text { Trench/ } \\
\text { Block }\end{array}$ & $\begin{array}{c}\text { Depth Below } \\
\text { Ground } \\
\text { Surface }\end{array}$ & $\begin{array}{l}\text { Stratum } \\
\text { Desig- } \\
\text { nation }\end{array}$ & Comment \\
\hline
\end{tabular}

PART 5. SPECIALIZED TOOLS (continued)

\begin{tabular}{|c|c|c|c|c|c|c|c|c|c|c|c|}
\hline 359 & 0981 & 17.3 & 47.0 & 40.2 & 9.4 & & 077013 & $0-14$ & TS & PROV & \\
\hline 359 & 3075 & 18.2 & 43.7 & 38.7 & 10.6 & & 048011 & $0-90$ & TS & PROV & \\
\hline 359 & 5443 & 15.6 & 43.2 & 38.3 & 13.7 & & 042000 & & NO & SURF & \\
\hline 359 & 6659 & 14.2 & 51.5 & 35.0 & 12.2 & & ECHO & & NO & BACK & \\
\hline 359 & 6610 & 16.1 & 49.0 & 32.3 & 11.0 & & 002000 & & NO & SURF & \\
\hline 359 & 6656 & 11.1 & 39.5 & 29.4 & 8.0 & & $\mathrm{ECHO}$ & & NO & BACK & \\
\hline 359 & 6655 & 6.6 & 34.0 & 24.2 & 9.2 & & $\mathrm{ECHO}$ & & NO & BACK & \\
\hline 359 & 6628 & 4.9 & 31.4 & 25.5 & 6.3 & & 134000 & & NO & SURF & \\
\hline 359 & 2196 & 6.3 & 32.0 & 20.0 & 7.3 & & 066000 & & NO & SURF & \\
\hline 359 & 5496 & 4.2 & 32.6 & 21.8 & 5.0 & & 038000 & & NO & SURF & \\
\hline 359 & 2238 & 3.2 & 28.6 & 14.5 & 5.0 & & 024000 & & NO & SURF & \\
\hline 359 & 6612 & 3.2 & 22.0 & 14.6 & 5.0 & & 001000 & & NO & SURF & \\
\hline 359 & 6653 & 3.8 & 24.6 & 21.9 & 6.3 & & GOLF & & NO & BACK & \\
\hline 359 & 4321 & 2.1 & 22.0 & 19.0 & 4.9 & & 076029 & $0-10$ & TS & SCRE & \\
\hline 359 & 6611 & 2.6 & $(19.3)$ & 24.3 & 4.0 & & 002000 & & NO & SURF & \\
\hline 359 & 6757 & 79.6 & 68.6 & 52.0 & 26.8 & & 056000 & & NO & SURF & \\
\hline 359 & 2277 & 15.2 & 48.6 & 35.5 & 17.9 & & 056000 & & NO & SURF & \\
\hline 359 & 5526 & 8.0 & 36.9 & 30.0 & 7.0 & & 138000 & & NO & SURF & \\
\hline 359 & 6660 & 17.7 & 56.0 & 28.0 & 13.2 & & $\mathrm{ECHO}$ & & NO & BACK & 3 \\
\hline 359 & 5807 & 20.6 & 42.6 & 37.3 & 11.0 & & 134000 & & NO & SURF & $\stackrel{+}{\mathbb{D}}$ \\
\hline 359 & 5972 & 16.3 & 34.0 & 36.7 & 11.0 & & 069000 & & NO & SURF & $\rightarrow$ \\
\hline 359 & 6652 & 12.6 & 51.0 & 37.4 & 9.3 & & GOLF & & NO & BACK & $=$ \\
\hline 359 & 7886 & 8.0 & 43.0 & 22.9 & 8.4 & & 059000 & & NO & SURF & $\infty$ \\
\hline 359 & 0918 & 6.3 & 36.6 & 24.3 & 7.5 & & 077002 & $10-18$ & TS & PROV & $x$ \\
\hline 359 & 5619 & 6.5 & 29.0 & 24.2 & 6.4 & & 113000 & & NO & SURF & $\omega$ \\
\hline 359 & 5737 & 4.8 & 38.3 & 21.0 & 5.7 & & 137000 & & NO & SURF & 8 \\
\hline 359 & 5853 & 5.7 & 29.4 & 26.4 & 5.9 & & 123000 & & NO & SURF & $\lambda$ \\
\hline 359 & 6073 & 4.8 & 27.9 & 18.9 & 8.3 & & 079000 & & NO & SURF & $\overrightarrow{0}$ \\
\hline 359 & 7895 & $(5.6)$ & $(30.9)$ & $(21.2)$ & 5.7 & 7 & 056026 & $0-9$ & $O Z$ & SCRE & D \\
\hline 359 & 2185 & $(9.4)$ & $(39.5)$ & 29.4 & 6.9 & & 055000 & & NO & SURF & $\overrightarrow{0}$ \\
\hline
\end{tabular}




\begin{tabular}{|c|c|c|c|c|c|c|c|c|c|c|}
\hline $\begin{array}{l}\text { Classifi- } \\
\text { cation } \\
\text { Type Code }\end{array}$ & $\begin{array}{c}\text { Catalog } \\
\text { Number }\end{array}$ & $\begin{array}{l}\text { Weight } \\
\text { (g) }\end{array}$ & $\begin{array}{c}\text { Maximum } \\
\text { Length } \\
(\mathrm{mm})\end{array}$ & $\begin{array}{l}\text { Maximum } \\
\text { Width } \\
\text { (mm) }\end{array}$ & $\begin{array}{l}\text { Maximum } \\
\text { Thickness } \\
(\mathrm{mm})\end{array}$ & $\begin{array}{l}\text { Feature } \\
\text { Number }\end{array}$ & $\begin{array}{l}\text { Unit/ } \\
\text { Trench/ } \\
\text { Block }\end{array}$ & $\begin{array}{c}\text { Depth Below } \\
\text { Ground } \\
\text { Surface }\end{array}$ & $\begin{array}{l}\text { Stratum } \\
\text { Desig- } \\
\text { nation }\end{array}$ & Comment \\
\hline
\end{tabular}

PART 6. RETOUCHED FLAKES

\begin{tabular}{|c|c|c|c|c|c|c|c|c|c|c|}
\hline 374 & 6164 & 40.0 & 53.4 & 50.8 & 11.3 & & FOXT & & NO & BACK \\
\hline 374 & 6022 & 68.6 & 56.4 & 57.8 & 17.9 & & 090000 & & NO & SURF \\
\hline 374 & 2189 & 54.2 & 67.4 & 53.0 & 17.8 & & 105000 & & NO & SURF \\
\hline 374 & 2659 & 28.4 & 65.4 & 27.5 & 17.3 & 7 & 056009 & $0-5$ & $\mathrm{OZ}$ & SURE \\
\hline 374 & 0461 & $(29.2)$ & $(39.9)$ & 40.2 & 17.9 & 7 & 056008 & $0-5$ & $\overline{O Z}$ & PROV \\
\hline 374 & 1670 & $(13.2)$ & $(30.7)$ & $(44.6)$ & $(10.7)$ & 7 & 056029 & $10-15$ & $O Z$ & PROV \\
\hline 374 & 1246 & 44.8 & 49.5 & 41.7 & 22.3 & 7 & 056027 & $0-5$ & $O Z$ & SCRE \\
\hline 374 & 0912 & 12.8 & 40.9 & 33.7 & 8.5 & & 076026 & $0-10$ & TS & PROV \\
\hline 374 & 0115 & 28.5 & 79.6 & 33.6 & 7.6 & & 076028 & $0-20$ & TS & SCRE \\
\hline 374 & 2220 & 39.5 & $6] .0$ & 42.4 & 15.9 & & 062000 & & NO & SURF \\
\hline 374 & 6604 & 73.9 & 38.3 & 94.8 & 21.6 & & $0 C 2000$ & & NO & SURF \\
\hline 374 & 6191 & 48.1 & 54.6 & 48.3 & 14.7 & & GOLF & & NO & BACK \\
\hline 374 & 6278 & 65.3 & 64.9 & 49.6 & 20.8 & & $\mathrm{ECHO}$ & & NO & BACK \\
\hline 374 & 0779 & $(13.2)$ & $(31.0)$ & 28.4 & 14.6 & & 076008 & $0-20$ & TS & SCRE \\
\hline 374 & 6172 & 45.7 & 56.4 & 46.9 & 19.6 & & FOXT & & NO & BACK \\
\hline 374 & 9106 & 34.8 & 52.7 & 39.0 & 17.9 & & CHAR & & NO & BACK \\
\hline 374 & 3529 & 31.8 & 54.0 & 55.0 & 13.0 & & 118039 & $48-90$ & SS & PROV \\
\hline 374 & 0071 & 57.6 & 69.8 & 50.7 & 14.7 & & 056044 & $10-21$ & TS & PROV \\
\hline 374 & 6754 & 43.3 & 47.6 & 54.6 & 15.0 & & DELT & & NO & BACK \\
\hline 374 & 6277 & 20.6 & 41.7 & 41.4 & 12.3 & & $\mathrm{ECHO}$ & & NO & BACK \\
\hline 374 & 6196 & 14.6 & 35.0 & 29.7 & 12.5 & & FOXT & & NO & BACK \\
\hline 374 & 6162 & 26.2 & 71.4 & 27.9 & 14.3 & & FOXT & & NO & BACK \\
\hline 374 & 5727 & 33.2 & 52.0 & 37.5 & 13.7 & & 031000 & & NO & SURF \\
\hline 374 & 5711 & 37.7 & 63.9 & 29.4 & 16.4 & & 047000 & & NO & SURF \\
\hline 374 & 7877 & 41.3 & 58.7 & 53.6 & 14.3 & & $\mathrm{ECHO}$ & & NO & BACK \\
\hline 374 & 0133 & 10.2 & 38.4 & 24.0 & 9.6 & & 076017 & $0-10$ & TS & PROV \\
\hline 374 & 5883 & 10.0 & 33.7 & 26.0 & 10.6 & & 119000 & & NO & SURF \\
\hline 374 & 6603 & 109.3 & 64.6 & 75.0 & 22.4 & & 002000 & & NO & SURF \\
\hline 374 & 6597 & 79.1 & 91.8 & 52.5 & 22.2 & & 001000 & & NO & SURF \\
\hline 374 & 6599 & 26.4 & 43.7 & 38.6 & 16.4 & & 002000 & & NO & SURF \\
\hline 374 & 0066 & 34.1 & 44.6 & 50.7 & 12.7 & & 056044 & $30-41$ & TS & PROV \\
\hline 374 & 5469 & 34.2 & 41.9 & 54.9 & 12.8 & & 037000 & & NO & SURF \\
\hline 374 & 0242 & 15.3 & 60.0 & 28.0 & 9.6 & & 011030 & $0-10$ & TS & SCRE \\
\hline 374 & 5590 & 68.7 & 72.0 & 43.7 & 21.9 & & 041000 & & NO & SURF \\
\hline
\end{tabular}




\begin{tabular}{|c|c|c|c|c|c|c|c|c|c|c|}
\hline $\begin{array}{l}\text { Classifi- } \\
\text { cation } \\
\text { Type Code }\end{array}$ & $\begin{array}{c}\text { Catalog } \\
\text { Number }\end{array}$ & $\begin{array}{l}\text { Weight } \\
\text { (g) }\end{array}$ & $\begin{array}{l}\text { Maximum } \\
\text { Length } \\
(\mathrm{mm})\end{array}$ & $\begin{array}{l}\text { Maximum } \\
\text { Width } \\
(\mathrm{mm})\end{array}$ & $\begin{array}{c}\text { Maximum } \\
\text { Thickness } \\
\text { (mm) }\end{array}$ & $\begin{array}{l}\text { Feature } \\
\text { Number }\end{array}$ & $\begin{array}{l}\text { Unit/ } \\
\text { Trench/ } \\
\text { Block }\end{array}$ & $\begin{array}{c}\text { Depth Below } \\
\text { Ground } \\
\text { Surface }\end{array}$ & $\begin{array}{l}\text { Stratum } \\
\text { Desig- } \\
\text { nation }\end{array}$ & Comment \\
\hline
\end{tabular}

PART 6. RETOUCHED FLAKES (continued)

\begin{tabular}{|c|c|c|c|c|c|c|c|c|c|c|}
\hline 374 & 2269 & 19.0 & 46.9 & 35.9 & 13.0 & 011000 & & NO & SURF & \\
\hline 374 & 0373 & 2.8 & 22.6 & 22.7 & 5.5 & 011029 & $0-20$ & TS & SCRE & \\
\hline 374 & 1048 & 6.7 & 29.0 & 21.5 & 13.0 & 011020 & $0-10$ & TS & SCRE & \\
\hline 374 & 6601 & 142.1 & 80.8 & 62.6 & 31.5 & 042000 & & NO & SURF & \\
\hline 374 & 2243 & 100.1 & 76.8 & 63.0 & 23.3 & 022000 & & NO & SURF & \\
\hline 374 & 5864 & 81.7 & 81.4 & 53.6 & 19.0 & 116000 & & NO & SURF & \\
\hline 374 & 6438 & 105.8 & 111.4 & 49.7 & 20.0 & BRAV & & NO & BACK & \\
\hline 374 & 6740 & 53.4 & 50.6 & 54.2 & 15.1 & 134000 & & NO & SURF & \\
\hline 374 & 6727 & 159.2 & 89.9 & 73.2 & 30.6 & BRAV & & NO & BACK & \\
\hline 374 & 6632 & $(4.7)$ & $(31.0)$ & $(16.1)$ & 7.8 & BRAV & & NO & BACK & \\
\hline 374 & 6677 & $(11.5)$ & 51.8 & $(21.9)$ & 9.2 & ALFA & & NO & BACK & \\
\hline 374 & 6048 & $(6.3)$ & $(34.5)$ & $(30.1)$ & 6.0 & 168000 & & NO & SURF & \\
\hline 374 & 6633 & 15.9 & 40.2 & 37.3 & 10.0 & BRAV & & NO & BACK & \\
\hline 374 & 5826 & 40.6 & 50.9 & 43.0 & 22.8 & 134000 & & NO & SURF & \\
\hline 374 & 5770 & 34.6 & 55.5 & 45.2 & 15.3 & 139000 & & NO & SURF & \\
\hline 374 & 6415 & 122.7 & 74.0 & 68.7 & 20.6 & KILO & & NO & BACK & \\
\hline 374 & 6751 & 100.6 & 102.5 & 63.7 & 14.0 & ALFA & & NO & BACK & \\
\hline 374 & 6633 & 3.0 & 20.8 & 22.9 & 4.3 & BRAV & & NO & BACK & \\
\hline 374 & 5761 & 137.2 & 75.2 & 58.1 & 35.0 & 139000 & & NO & SURF & \\
\hline 374 & 6779 & $(24.2)$ & $(30.4)$ & 46.9 & 13.7 & 038000 & & NO & SURF & 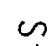 \\
\hline 374 & 5755 & 14.7 & 43.9 & 34.0 & 9.8 & 137000 & & NO & SURF & $\ddot{+}$ \\
\hline 374 & 6663 & 9.5 & 43.2 & 24.4 & 10.2 & 138000 & & NO & SURF & D \\
\hline 374 & 6722 & 41.0 & 56.0 & 33.4 & 18.2 & 113000 & & NO & SURF & 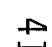 \\
\hline 374 & 6734 & 14.7 & 39.0 & 32.8 & 11.6 & 113000 & & NO & SURF & \\
\hline 374 & 5798 & $(29.3)$ & $(40.7)$ & 39.4 & 15.6 & 114000 & & NO & SURF & $\underset{x}{x}$ \\
\hline 374 & 6634 & $(31.4)$ & 52.0 & $(30.9)$ & 15.4 & BRAV & & NO & BACK & \\
\hline 374 & 6662 & 204.2 & 87.3 & 61.4 & 38.6 & 138000 & & NO & SURF & $\omega$ \\
\hline 374 & 6724 & 25.6 & 47.2 & 32.0 & 16.0 & BRAV & & NO & BACK & 0 \\
\hline 374 & 5838 & 36.3 & 54.5 & 45.4 & 16.9 & 133000 & & NO & SURF & $D$ \\
\hline 374 & 5941 & 29.6 & 50.0 & 39.2 & 13.3 & 129000 & & NO & SURF & 웅 \\
\hline 374 & 6631 & 5.6 & 29.3 & 28.0 & 5.8 & BRAV & & NO & BACK & $\stackrel{\mathbb{D}}{3}$ \\
\hline 374 & 2250 & 60.3 & 55.6 & 55.3 & 19.3 & 084000 & & NO & SURF & $\overrightarrow{0}$ \\
\hline 374 & 5421 & 29.7 & 45.4 & 36.9 & 18.4 & 032000 & & NO & SURF & $\bar{x}$ \\
\hline 374 & 6602 & 30.2 & 55.7 & 30.7 & 16.5 & 002000 & & NO & SURF & $\rightarrow$ \\
\hline
\end{tabular}




\begin{tabular}{|c|c|c|c|c|c|c|c|c|c|c|}
\hline $\begin{array}{l}\text { Classifi- } \\
\text { cation } \\
\text { Type Code }\end{array}$ & $\begin{array}{c}\text { Catalog } \\
\text { Number }\end{array}$ & $\begin{array}{l}\text { Weight } \\
(\mathrm{g})\end{array}$ & $\begin{array}{l}\text { Maximum } \\
\text { Length } \\
\text { (mm) }\end{array}$ & $\begin{array}{l}\text { Maximum } \\
\text { Width } \\
\text { (mm) }\end{array}$ & $\begin{array}{l}\text { Maximum } \\
\text { Thickness } \\
\quad(\mathrm{mm})\end{array}$ & $\begin{array}{l}\text { Feature } \\
\text { Number }\end{array}$ & $\begin{array}{l}\text { Unit/ } \\
\text { Trench/ } \\
\text { Block }\end{array}$ & $\begin{array}{l}\text { Depth Below } \\
\text { Ground } \\
\text { Surface }\end{array}$ & $\begin{array}{l}\text { Stratum } \\
\text { Desig- } \\
\text { nation }\end{array}$ & Comment \\
\hline PART $6 . \quad F$ & TOUCHED $F$ & AKES ( $\mathrm{CO}$ & ntinued) & & & & & & & \\
\hline 374 & 2296 & 56.9 & 66.8 & 51.8 & 14.9 & & 002000 & & NO & SURF \\
\hline 374 & 5544 & 92.8 & 66.2 & 49.5 & 31.0 & & 001000 & & NO & SURF \\
\hline 374 & 5472 & 41.4 & 61.0 & 29.0 & 21.6 & & 042000 & & NO & SURF \\
\hline 374 & 0002 & 26.5 & 52.8 & 31.9 & 14.6 & & 011020 & $0-10$ & TS & SCRE \\
\hline 374 & 6600 & 17.1 & 50.4 & 27.8 & 10.5 & & 002000 & & NO & SURF \\
\hline 374 & 5313 & 25.1 & 48.5 & 45.8 & 14.5 & & 011030 & $0-10$ & TS & SCRE \\
\hline 374 & 9237 & 17.4 & 31.0 & 28.0 & 14.7 & & 021000 & & NO & SURF \\
\hline 374 & 5436 & 19.2 & 39.5 & 29.9 & 9.9 & & 011000 & & NO & SURF \\
\hline 374 & 6720 & $(26.4)$ & $(65.0)$ & 45.4 & 11.3 & & FOXT & & NO & BACK \\
\hline 374 & 6434 & $(171.1)$ & $(89.0)$ & $(69.4)$ & 25.1 & & BRAV & & NO & BACK \\
\hline 374 & 6678 & 19.0 & 59.9 & 38.2 & 10.3 & & ALFA & & NO & BACK \\
\hline 374 & 6676 & $(35.5)$ & $(33.7)$ & 47.5 & 19.3 & & ALFA & & NO & BACK \\
\hline 374 & 6732 & 15.2 & 36.8 & 38.9 & 10.0 & & 113000 & & NO & SURF \\
\hline 374 & 3614 & 26.6 & 49.5 & 32.0 & 14.2 & & 119013 & $0-5$ & TS & PROV \\
\hline 374 & 6005 & 38.6 & 40.0 & 33.3 & 19.2 & & 167000 & & NO & SURF \\
\hline 374 & 6057 & 18.2 & 47.0 & 28.8 & 14.0 & & 080000 & & NO & SURF \\
\hline 374 & 5897 & 168.1 & 68.2 & 77.8 & 30.0 & & 099000 & & NO & SURF \\
\hline 374 & 6118 & 31.7 & 55.9 & 36.5 & 15.0 & & 059000 & & NO & SURF \\
\hline 374 & 6607 & 6.7 & 30.5 & 20.4 & 7.3 & & 070000 & & NO & SURF \\
\hline 374 & 6664 & 13.5 & 41.6 & 31.2 & 8.7 & & 138000 & & NO & SURF \\
\hline 374 & 5907 & 18.4 & 49.0 & 27.5 & 16.7 & & 168000 & & NO & SURF \\
\hline 374 & 5988 & 66.2 & 51.3 & 45.7 & 28.4 & & 070000 & & NO & SURF \\
\hline 374 & 6089 & 29.9 & 59.2 & 44.6 & 9.8 & & 089000 & & NO & SURF \\
\hline 374 & 6679 & 40.6 & 60.0 & 43.4 & 15.9 & & ALFA & & NO & BACK \\
\hline 374 & 6057 & 13.7 & 40.0 & 19.4 & 15.5 & & 080000 & & NO & SURF \\
\hline 374 & 6726 & 14.9 & 42.1 & 25.5 & 9.8 & & BRAV & & NO & BACK \\
\hline 374 & 5621 & 8.2 & 21.7 & 38.6 & 8.2 & & 113000 & & NO & SURF \\
\hline 374 & 6605 & 43.7 & 56.4 & 30.9 & 18.7 & & 100000 & & NO & SURF \\
\hline 374 & 6606 & 40.2 & 56.3 & 50.7 & 14.3 & & 089000 & & NO & SURF \\
\hline 374 & 6630 & 7.3 & 25.6 & 18.2 & 12.3 & & BRAV & & NO & BACK \\
\hline 374 & 5786 & 8.6 & 41.7 & 31.2 & 8.2 & & 128000 & & NO & SURF \\
\hline 374 & 6608 & 23.4 & 49.2 & 35.5 & 17.0 & & 167000 & & NO & SURF \\
\hline 374 & 6675 & $(9.8)$ & $(27.6)$ & $(31.1)$ & 10.0 & & ALFA & & NO & BACK \\
\hline 374 & 6077 & 68.4 & 74.0 & 36.7 & 25.6 & & 079000 & & NO & SURF \\
\hline
\end{tabular}




\begin{tabular}{|c|c|c|c|c|c|c|c|c|c|c|}
\hline $\begin{array}{l}\text { Classifi- } \\
\text { cation } \\
\text { Type Code }\end{array}$ & $\begin{array}{c}\text { Catalog } \\
\text { Number }\end{array}$ & $\begin{array}{l}\text { Weight } \\
\text { (g) }\end{array}$ & $\begin{array}{l}\text { Maximum } \\
\text { Length } \\
(\mathrm{mm})\end{array}$ & $\begin{array}{l}\text { Maximum } \\
\text { Width } \\
(\mathrm{mm})\end{array}$ & $\begin{array}{l}\text { Maximum } \\
\text { Thickness } \\
\text { (mm) }\end{array}$ & $\begin{array}{l}\text { Feature } \\
\text { Number }\end{array}$ & $\begin{array}{l}\text { Unit/ } \\
\text { Trench/ } \\
\text { Block }\end{array}$ & $\begin{array}{c}\text { Depth Below } \\
\text { Ground } \\
\text { Surface }\end{array}$ & $\begin{array}{l}\text { Stratum } \\
\text { Desig- } \\
\text { nation }\end{array}$ & Comment \\
\hline
\end{tabular}

PART 6. RETOUCHED FLAKES (continued)

\begin{tabular}{|c|c|c|c|c|c|c|c|c|c|c|c|}
\hline & 374 & 1698 & 436.1 & 122.3 & 86.4 & 41.3 & 8 & 075099 & $20-28$ & $F Z$ & PROV \\
\hline & 374 & 4540 & 285.6 & 85.6 & 88.4 & 31.8 & & 077012 & $25-35$ & $\mathrm{TS}$ & PROV \\
\hline & 374 & 0087 & 254.6 & 120.6 & 62.9 & 26.3 & & 067014 & $10-19$ & $\mathrm{TS}$ & PROV \\
\hline & 374 & 7866 & 37.0 & 55.1 & 43.2 & 12.5 & & JULI & & NO & BACK \\
\hline & 374 & 6783 & 44.3 & 56.7 & 45.0 & 17.3 & & HOTE & & NO & BACK \\
\hline & 374 & 6509 & 23.4 & 52.3 & 38.0 & 15.4 & & INDI & & NO & BACK \\
\hline & 374 & 6333 & $31: 9$ & 54.3 & 35.0 & 19.0 & & HOTE & & NO & BACK \\
\hline & 374 & 5235 & 28.7 & 45.2 & 37.4 & 16.7 & & 076027 & $10-25$ & TS & SCRE \\
\hline & 374 & 0088 & 16.7 & 32.0 & 39.3 & 8.5 & & 065015 & $0-20$ & $\mathrm{TS}$ & PROV \\
\hline & 374 & 0077 & 88.0 & 97.4 & 50.5 & 22.3 & & 056044 & $30-41$ & TS & PROV \\
\hline & 374 & 0966 & 46.2 & 60.7 & 54.5 & 12.0 & & 075080 & $0-42$ & TS & PROV \\
\hline & 374 & 2197 & 11.7 & 45.2 & 20.9 & 11.0 & & 066000 & & NO & SURF \\
\hline & 374 & 6786 & 117.5 & 90.6 & 62.0 & 23.2 & & JULI & & NO & BACK \\
\hline & 374 & 4624 & 36.1 & 58.2 & 29.1 & 17.2 & & 076039 & $0-10$ & TS & SCRE \\
\hline & 374 & 2264 & 22.1 & 38.7 & 34.0 & 15.7 & & 085000 & & NO & SURF \\
\hline & 374 & 2707 & $(9.4)$ & $(32.6)$ & $(19.2)$ & 17.6 & 7 & 056026 & $0-9$ & $\mathrm{OZ}$ & SCRE \\
\hline & 374 & 5176 & 123.9 & 77.4 & $(50.9)$ & 27.1 & 7 & 056016 & $9-12$ & $O Z$ & PROV \\
\hline & 374 & 2487 & $(16.5)$ & $(33.2)$ & $(47.3)$ & 10.4 & 5 & 075100 & $38-48$ & $\mathrm{OZ}$ & PROV \\
\hline & 374 & 7249 & 33.8 & 52.3 & 41.0 & 17.0 & 3 & 076038 & $20-40$ & $\mathrm{FZ}$ & SCRE \\
\hline & 374 & 2302 & 73.8 & 81.8 & 49.3 & 25.6 & 8 & 075099 & $20-28$ & $\mathrm{FZ}$ & PROV \\
\hline & 374 & 3582 & 59.8 & 81.9 & 74.6 & 10.0 & 11 & 117066 & $20-45$ & $\mathrm{FZ}$ & PROV \\
\hline & 374 & 0467 & $(18.5)$ & 42.7 & $(30.0)$ & 12.6 & 7 & 056028 & $0-5$ & $\mathrm{OZ}$ & PROV \\
\hline & 374 & 2307 & 115.8 & 109.4 & 58.4 & 18.4 & 8 & 075099 & $28-41$ & $\mathrm{FZ}$ & PROV \\
\hline & 374 & 0972 & 142.6 & 69.8 & 61.2 & 29.5 & 2 & 055099 & $0-31$ & $M Z$ & PROV \\
\hline & 374 & $521 \overline{5}$ & $(74.1)$ & $(73.9)$ & $(66.1)$ & 21.8 & 2 & 055066 & $0-8$ & $M Z$ & SCRE \\
\hline & 374 & 1613 & $(3.6)$ & $(27.7)$ & 28.6 & 5.2 & & 077003 & $0-10$ & $\mathrm{TS}$ & PROV \\
\hline & 374 & 7355 & $(11.2)$ & $(49.0)$ & $(25.7)$ & 8.6 & 5 & 076037 & $50-66$ & $O Z$ & SCRE \\
\hline & 374 & 7205 & $(15.2)$ & $(39.9)$ & $(37.9)$ & 13.4 & 5 & 076038 & $40-50$ & $\overline{O Z}$ & SCRE \\
\hline & 374 & 5072 & 105.3 & 67.2 & 49.4 & 34.8 & 5 & 077012 & 49-53 & $\mathrm{OZ}$ & PROV \\
\hline . & 374 & 4601 & 30.2 & 64.7 & 29.1 & 16.0 & 5 & 076018 & $20-30$ & $\overline{O Z}$ & SCRE \\
\hline & 374 & 1692 & $(5.9)$ & 39.7 & $(16.8)$ & 6.9 & & 085009 & $0-20$ & $\mathrm{TS}$ & PROV \\
\hline & 374 & 6314 & $(50.8)$ & 69.5 & $(50.4)$ & 15.6 & & JULI & & NO & BACK \\
\hline & 374 & 7904 & $(4.8)$ & $(30.6)$ & $(18.2)$ & 7.8 & & 076048 & $0-10$ & TS & SCRE \\
\hline & 374 & 0086 & $(10.0)$ & 36.8 & $(24.0)$ & 8.1 & & 056023 & $0-10$ & TS & PROV \\
\hline
\end{tabular}


PART 6. RETOUCHED FLAKES (cont inued)

$\begin{array}{rrcccr}374 & 7849 & (17.1) & (39.5) & 34.6 & 15.9 \\ 374 & 0095 & 3.9 & 27.0 & 22.8 & 5.0 \\ 374 & 1605 & 10.2 & 49.0 & 23.2 & 8.2 \\ 374 & 0078 & (27.4) & (41.6) & (43.0) & 15.9 \\ 374 & 2285 & (40.2) & (72.7) & (29.8) & 15.0 \\ 374 & 0110 & (48.3) & (43.5) & 45.5 & 24.4 \\ 374 & 0117 & 45.4 & 57.3 & 41.6 & 15.8 \\ 374 & 2301 & (37.2) & (41.5) & 54.4 & 17.6 \\ 374 & 0123 & 15.8 & 52.5 & 33.7 & 7.0 \\ 374 & 0979 & 16.6 & 45.6 & 36.8 & 10.7 \\ 374 & 7854 & 13.1 & 43.0 & 30.1 & 10.9 \\ 374 & 7880 & (11.2) & 50.4 & (22.9) & 10.0 \\ 374 & 2256 & 29.0 & 48.1 & 37.0 & 13.7 \\ 374 & 7871 & 19.7 & 56.0 & 32.8 & 14.6 \\ 374 & 1569 & 49.1 & 66.2 & 39.9 & 14.5 \\ 374 & 6338 & 167.5 & 105.0 & 84.4 & 21.3 \\ 374 & 0152 & (29.2) & (45.5) & 43.6 & 16.1 \\ 374 & 6840 & 70.4 & 66.0 & 43.9 & 21.3 \\ 374 & 2287 & 67.4 & 58.0 & 55.1 & 18.9 \\ 374 & 1212 & (13.6) & (40.4) & 33.6 & 7.7 \\ 374 & 2239 & 26.8 & 57.4 & 29.4 & 12.8 \\ 374 & 6488 & (12.9) & (37.8) & 32.7 & 9.5 \\ 374 & 2279 & 61.8 & 80.4 & 38.7 & 23.5 \\ 374 & 4430 & 20.0 & 58.3 & 38.9 & 10.4 \\ 374 & 7801 & 40.6 & 59.9 & 39.5 & 16.3 \\ 374 & 7800 & 26.4 & 46.9 & 38.4 & 15.6 \\ 374 & 0805 & 20.2 & 68.7 & 23.1 & 12.9 \\ 374 & 7896 & (10.5) & (31.0) & 21.7 & 13.2 \\ 374 & 7580 & (19.7) & (40.5) & (29.3) & 17.8 \\ 374 & 6785 & 20.4 & 47.3 & 33.4 & 12.9 \\ 374 & 6782 & 18.6 & 41.7 & 31.9 & 14.0 \\ 374 & 6508 & 9.9 & 39.8 & 18.0 & 13.0 \\ 374 & 4408 & (4.4) & (21.6) & (19.8) & 9.0 \\ 374 & 4207 & (18.1) & 40.2 & (36.0) & 11.3\end{array}$

\begin{tabular}{|c|c|c|c|c|}
\hline & 065000 & & NO & SURF \\
\hline & 065015 & $0-20$ & TS & PROV \\
\hline & 077013 & $14-24$ & TS & PROV \\
\hline & 067012 & $0-10$ & TS & PROV \\
\hline & 064000 & & NO & SURF \\
\hline & 076008 & $0-20$ & TS & PROV \\
\hline & 056046 & $29-41$ & TS & PROV \\
\hline & 085009 & $0-20$ & TS & PROV \\
\hline 7 & 056028 & $0-5$ & $O Z$ & PROV \\
\hline & 077013 & $0-14$ & TS & PROV \\
\hline & 063000 & & NO & SURF \\
\hline & 095000 & & NO & SURF \\
\hline & 076000 & & NO & SURF \\
\hline & 066000 & & NO & SURF \\
\hline & 063000 & & NO & SURF \\
\hline & HOTE & & NO & BACK \\
\hline $0-10$ & 076048 & & TS & PROV \\
\hline $0-20$ & 075090 & & TS & SCRE \\
\hline & 064000 & & NO & SURF \\
\hline $10-19$ & 067014 & & TS & SCRE \\
\hline & 104000 & & NO & SURF \\
\hline & ONIEG & & NO & BACK \\
\hline & 056000 & & NO & SURF \\
\hline & 076048 & $0-10$ & TS & SCRE \\
\hline & 002000 & & NO & SURF \\
\hline & 104000 & & NO & SURF \\
\hline & 076017 & $0-10$ & TS & SCRE \\
\hline & 076039 & $0-10$ & TS & SCRE \\
\hline & 063000 & & NO & SURF \\
\hline & JULI & & NO & BACK \\
\hline & HOTE & & NO & BACK \\
\hline & INDI & & NO & BACK \\
\hline & 076048 & $10-20$ & TS & SCRE \\
\hline & 055088 & $51-65$ & SM & PROV \\
\hline
\end{tabular}




\begin{tabular}{|c|c|c|c|c|c|c|c|c|c|c|}
\hline $\begin{array}{l}\text { Classifi- } \\
\text { cation } \\
\text { Type Code }\end{array}$ & $\begin{array}{c}\text { Catalog } \\
\text { Number }\end{array}$ & $\begin{array}{l}\text { Weight } \\
(\mathrm{g})\end{array}$ & $\begin{array}{l}\text { Maximum } \\
\text { Length } \\
(\mathrm{mm})\end{array}$ & $\begin{array}{l}\text { Maximum } \\
\text { Width } \\
\text { (mm) }\end{array}$ & $\begin{array}{l}\text { Maximum } \\
\text { Thickness } \\
\text { (mm) }\end{array}$ & $\begin{array}{l}\text { Feature } \\
\text { Number }\end{array}$ & $\begin{array}{l}\text { Unit/ } \\
\text { Trench/ } \\
\text { Block }\end{array}$ & $\begin{array}{l}\text { Depth Below } \\
\text { Ground } \\
\text { Surface }\end{array}$ & $\begin{array}{l}\text { Stratum } \\
\text { Desig- } \\
\text { nation }\end{array}$ & Comment \\
\hline
\end{tabular}

PART 6. RETOUCHED FLAKES (continued)

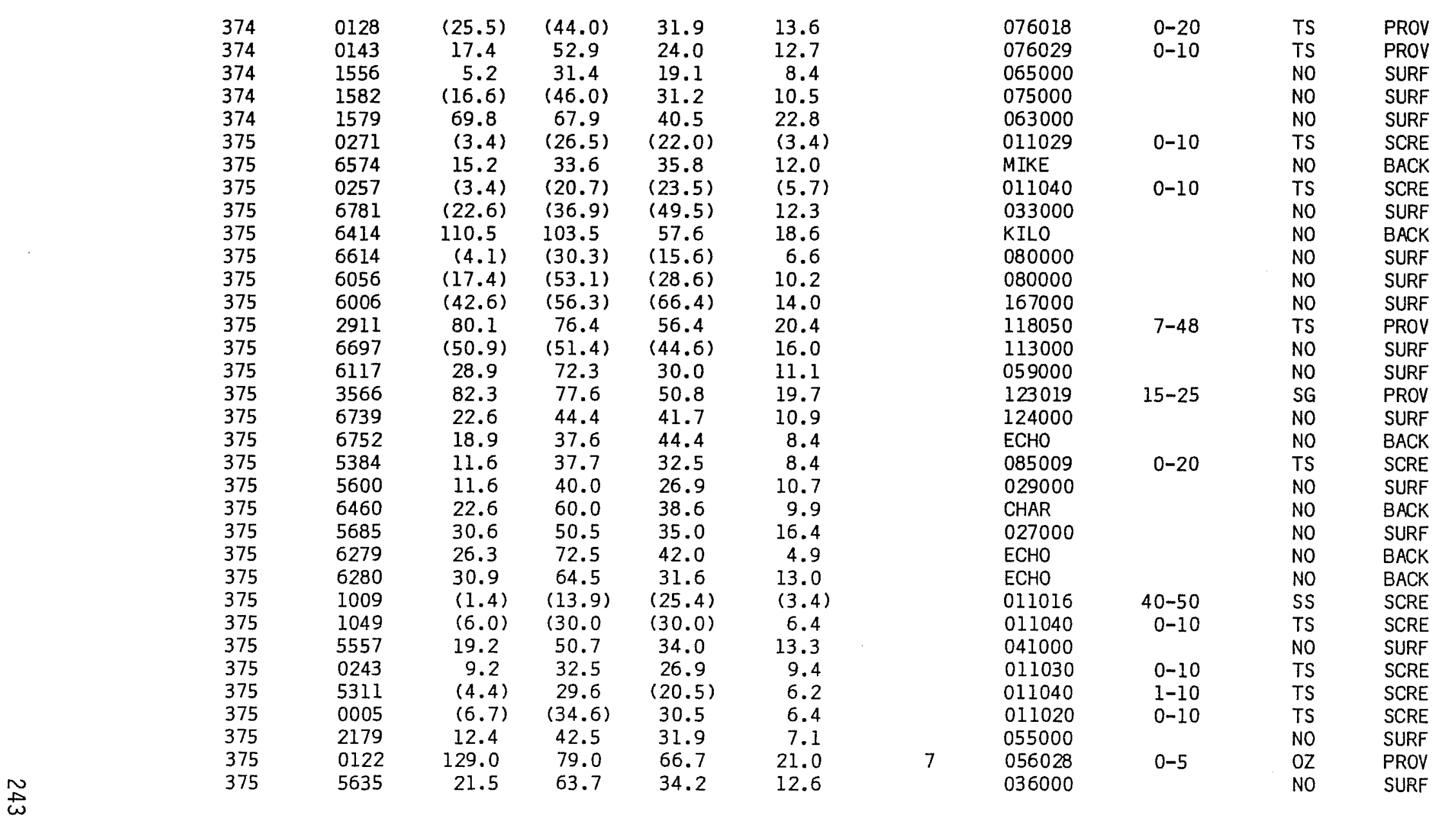




\begin{tabular}{|c|c|c|c|c|c|c|c|c|c|c|}
\hline $\begin{array}{l}\text { Classifi- } \\
\text { cation } \\
\text { Type Code }\end{array}$ & $\begin{array}{c}\text { Catalog } \\
\text { Number }\end{array}$ & $\begin{array}{l}\text { Weight } \\
(g)\end{array}$ & $\begin{array}{l}\text { Maximum } \\
\text { Length } \\
(\mathrm{mm})\end{array}$ & $\begin{array}{l}\text { Maximum } \\
\text { Width } \\
\text { (mm) }\end{array}$ & $\begin{array}{l}\text { Maximum } \\
\text { Thickness } \\
\text { (mm) }\end{array}$ & $\begin{array}{l}\text { Feature } \\
\text { Number }\end{array}$ & $\begin{array}{l}\text { Unit/ } \\
\text { Trench/ } \\
\text { Block }\end{array}$ & $\begin{array}{c}\text { Depth Below } \\
\text { Ground } \\
\text { Surface }\end{array}$ & $\begin{array}{l}\text { Stratum } \\
\text { Desig- } \\
\text { nation }\end{array}$ & Comment \\
\hline ART 6. & TOUCHED & AKES (CO & ntinued) & & & & & & & \\
\hline 375 & 0471 & 107.3 & 79.4 & 51.0 & 26.0 & 7 & 056027 & $0-5$ & $O Z$ & PROV \\
\hline 375 & 0126 & 24.5 & 55.0 & 35.6 & 16.5 & 7 & 056028 & $0-5$ & $\overline{O Z}$ & PROV \\
\hline 375 & 1665 & $(60.2)$ & $(45.3)$ & 77.0 & 15.3 & 7 & 056019 & $5-10$ & $\mathrm{OZ}$ & PROV \\
\hline 375 & 2706 & $(8.0)$ & $(31.3)$ & $(29.9)$ & $(7.0)$ & 7 & 056026 & $0-9$ & $\mathrm{OZ}$ & SCRE \\
\hline 375 & 7924 & $(8.2)$ & $(17.6)$ & $(38.0)$ & $(10.2)$ & 7 & 056027 & $0-5$ & $\mathrm{OZ}$ & SCRE \\
\hline 375 & 3919 & $(8.0)$ & $(10.7)$ & $(23.0)$ & $(3.0)$ & 7 & 056029 & $10-15$ & $O Z$ & SCRE \\
\hline 375 & 0470 & $(8.0)$ & $(26.6)$ & $(43.8)$ & $(7.3)$ & 7 & 056018 & $0-5$ & $O Z$ & PROV \\
\hline 375 & 0460 & $(1.7)$ & $(10.3)$ & $(25.0)$ & $(5.0)$ & 7 & 056028 & $0-5$ & $O Z$ & PROV \\
\hline 375 & 3093 & 172.4 & 113.0 & 78.7 & 18.7 & & 037047 & $0-70$ & SG & PROV \\
\hline 375 & 0915 & 15.4 & 37.5 & 35.4 & 9.5 & & 077022 & $10-20$ & TS & PROV \\
\hline 375 & 3628 & $(6.9)$ & 39.9 & $(24.6)$ & 4.8 & & 123009 & $0-15$ & TS & SCRE \\
\hline 375 & 5940 & 26.4 & 41.7 & 29.6 & 14.2 & & 129000 & & NO & SURF \\
\hline 375 & 3630 & 5.0 & 25.0 & 28.2 & 17.0 & & 123009 & $0-15$ & TS & SCRE \\
\hline 375 & 5620 & 10.0 & 43.6 & 23.3 & 7.3 & & 113000 & & NO & SURF \\
\hline 375 & 6749 & 12.9 & 52.0 & 36.0 & 6.9 & & CHAR & & NO & BACK \\
\hline 375 & 6404 & 11.1 & 41.4 & 36.5 & 6.3 & & LIMA & & NO & BACK \\
\hline 375 & 6616 & $(3.5)$ & $(29.9)$ & $(20.4)$ & 4.8 & & 080000 & & NO & SURF \\
\hline 375 & 6621 & 5.3 & 29.4 & 23.6 & 7.0 & & 167000 & & NO & SURF \\
\hline 375 & 5932 & 18.4 & 45.0 & 26.6 & 12.7 & & 168000 & & NO & SURF \\
\hline 375 & 6078 & 11.8 & 41.4 & 25.2 & 8.2 & & 079000 & & NO & SURF \\
\hline 375 & 6673 & 31.9 & 45.6 & 48.4 & 12.1 & & ALFA & & NO & BACK \\
\hline 375 & 3629 & 3.2 & 17.0 & 22.2 & 5.0 & & 123009 & $0-15$ & $\mathrm{TS}$ & SCRE \\
\hline 375 & 6412 & 15.2 & 33.9 & 36.7 & 10.5 & & KILO & & NO & BACK \\
\hline 375 & 5752 & 39.3 & 53.2 & 46.3 & 10.4 & & 137000 & & NO & SURF \\
\hline 375 & 2257 & 31.2 & $(40.4)$ & 54.8 & 12.3 & & 021000 & & NO & SURF \\
\hline 375 & 5593 & 91.7 & 63.8 & 51.8 & 21.8 & & 001000 & & NO & SURF \\
\hline 375 & 5444 & 26.3 & 48.6 & 36.0 & 15.5 & & 032000 & & NO & SURF \\
\hline 375 & 5896 & 68.3 & 90.5 & 45.0 & 17.9 & & 099000 & & NO & SURF \\
\hline 375 & 6769 & 26.1 & 61.4 & 38.0 & 13.1 & & ALFA & & NO & BACK \\
\hline 375 & 9111 & 53.8 & 55.0 & 52.3 & 19.7 & & CHAR & & NO & BACK \\
\hline 375 & 6723 & 10.4 & $(35.0)$ & 29.2 & 9.4 & & 119000 & & NO & SURF \\
\hline 375 & 6650 & 11.4 & 43.7 & 41.8 & 6.4 & & 138000 & & NO & SURF \\
\hline 375 & 5872 & 43.6 & $(48.0)$ & 35.6 & 23.7 & & 119000 & & NO & SURF \\
\hline 375 & 5825 & 18.1 & 66.8 & 44.6 & 7.2 & & 134000 & & NO & SURF \\
\hline
\end{tabular}




\begin{tabular}{|c|c|c|c|c|c|c|c|c|c|c|}
\hline $\begin{array}{l}\text { Classifi- } \\
\text { cation } \\
\text { Type Code }\end{array}$ & $\begin{array}{l}\text { Catalog } \\
\text { Number }\end{array}$ & $\begin{array}{l}\text { Weight } \\
(\mathrm{g})\end{array}$ & $\begin{array}{l}\text { Maximum } \\
\text { Length } \\
(\mathrm{mm})\end{array}$ & $\begin{array}{l}\text { Maximum } \\
\text { Width } \\
\text { (mm) }\end{array}$ & $\begin{array}{c}\text { Maximum } \\
\text { Thickness } \\
\text { (mm) }\end{array}$ & $\begin{array}{l}\text { Feature } \\
\text { Number }\end{array}$ & $\begin{array}{l}\text { Unit/ } \\
\text { Trench/ } \\
\text { Block }\end{array}$ & $\begin{array}{l}\text { Depth Below } \\
\text { Ground } \\
\text { Surface }\end{array}$ & $\begin{array}{l}\text { Stratum } \\
\text { Desig- } \\
\text { nation }\end{array}$ & Comment \\
\hline
\end{tabular}

PART 6. RETOUCHED FLAKES (continued)

\begin{tabular}{|c|c|c|c|c|c|c|c|c|c|}
\hline 375 & 6672 & 33.7 & 54.1 & 37.7 & 17.0 & ALFA & & NO & BACK \\
\hline 375 & 5650 & 22.6 & 44.6 & 40.7 & 11.1 & 124000 & & NO & SURF \\
\hline 375 & 5754 & $(11.2)$ & 44.3 & $(26.6)$ & 8.5 & 137000 & & NO & SURF \\
\hline 375 & 5776 & $(47.9)$ & $(53.4)$ & 46.6 & 23.0 & 117000 & & NO & SURF \\
\hline 375 & 6780 & 31.2 & 56.6 & 37.4 & 11.8 & 033000 & & NO & SURF \\
\hline 375 & 6439 & 1.1 & 16.7 & 6.9 & 2.0 & BRAV & & NO & BACK \\
\hline 375 & 6695 & 10.4 & 44.0 & 27.3 & 9.3 & 113000 & & No & SURF \\
\hline 375 & 3627 & $(6.5)$ & $(24.6)$ & 31.6 & 5.0 & 123009 & $0-15$ & $\mathrm{TS}$ & SCRE \\
\hline 375 & 6696 & $(24.1)$ & 48.9 & $(39.0)$ & 11.9 & 113000 & & NO & SURF \\
\hline 375 & 6750 & 33.4 & 55.8 & 45.1 & 9.6 & CHAR & & NO & BACK \\
\hline 375 & 6049 & 151.1 & 100.8 & 81.0 & 19.3 & 168000 & & NO & SURF \\
\hline 375 & 6036 & 37.7 & 62.3 & 45.0 & 20.4 & 110000 & & NO & SURF \\
\hline 375 & 5987 & 9.8 & 43.2 & 26.4 & 8.3 & 070000 & & NO & SURF \\
\hline 375 & 6646 & 3.9 & 29.4 & 20.0 & 8.1 & 138000 & & NO & SURF \\
\hline 375 & 5849 & $(14.6)$ & $(34.8)$ & 32.3 & 10.7 & 133000 & & NO & SURF \\
\hline 375 & 6613 & 6.9 & 40.0 & 24.2 & 5.6 & 059000 & & NO & SURF \\
\hline 375 & 6622 & 30.0 & 62.6 & 47.1 & 9.7 & 099000 & & NO & SURF \\
\hline 375 & 6619 & 43.9 & 59.3 & 34.3 & 20.6 & 167000 & & NO & SURF \\
\hline 375 & 5506 & 25.9 & 41.4 & 37.0 & 12.9 & 115000 & & NO & SURF \\
\hline 375 & 6103 & 6.6 & 30.7 & 18.2 & 8.9 & 109000 & & NO & SURF \\
\hline 375 & 6505 & 17.3 & 57.9 & 34.4 & 9.2 & ALFA & & NO & BACK \\
\hline 375 & 6617 & 30.1 & 62.5 & 32.8 & 13.2 & 080000 & & NO & SURF \\
\hline 375 & 6649 & 14.9 & 43.6 & 31.2 & 10.7 & 138000 & & NO & SURF \\
\hline 375 & 5451 & 47.6 & 51.4 & 51.4 & 21.4 & 120000 & & NO & SURF \\
\hline 375 & 5785 & 159.2 & 102.5 & 105.2 & 56.3 & 128000 & & NO & SURF \\
\hline 375 & 5745 & $(3.4)$ & $(17.8)$ & $(20.2)$ & 4.3 & 124000 & & NO & SURF \\
\hline 375 & 5956 & $(22.6)$ & $(38.2)$ & $(34.0)$ & 8.2 & 129000 & & NO & SURF \\
\hline 375 & 6456 & 17.5 & 64.2 & 17.7 & 14.3 & CHAR & & NO & BACK \\
\hline 375 & 6618 & 13.7 & 41.4 & 32.3 & 9.5 & 167000 & & NO & SURF \\
\hline 375 & 6625 & 8.4 & 39.2 & 28.6 & 7.6 & 099000 & & NO & SURF \\
\hline 375 & 6648 & 9.1 & 42.3 & 25.2 & 7.5 & 138000 & & NO & SURF \\
\hline 375 & 6671 & 5.1 & 28.2 & 21.2 & 5.3 & BRAV & & NO & BACK \\
\hline 375 & 1675 & 137.8 & 95.3 & 64.6 & 30.6 & 075100 & 20.30 & $\mathrm{OZ}$ & PROV \\
\hline 375 & 2221 & 121.4 & 84.9 & 69.4 & 21.4 & 077000 & & NO & SURF \\
\hline
\end{tabular}




\begin{tabular}{|c|c|c|c|c|c|c|c|c|c|c|}
\hline $\begin{array}{l}\text { Classifi- } \\
\text { cation } \\
\text { Type Code }\end{array}$ & $\begin{array}{c}\text { Catalog } \\
\text { Number }\end{array}$ & $\begin{array}{l}\text { Weight } \\
(g)\end{array}$ & $\begin{array}{l}\text { Maximum } \\
\text { Length } \\
\text { (mm) }\end{array}$ & $\begin{array}{l}\text { Maximum } \\
\text { Wfdth } \\
(\mathrm{mm})\end{array}$ & $\begin{array}{l}\text { Maximum } \\
\text { Thickness } \\
\quad(\mathrm{mm})\end{array}$ & $\begin{array}{l}\text { Feature } \\
\text { Number }\end{array}$ & $\begin{array}{l}\text { Unit/ } \\
\text { Trench/ } \\
\text { Block }\end{array}$ & $\begin{array}{l}\text { Depth Below } \\
\text { Ground } \\
\text { Surface }\end{array}$ & $\begin{array}{l}\text { Stratum } \\
\text { Desig- } \\
\text { nation }\end{array}$ & Comment \\
\hline \multicolumn{11}{|c|}{ IRT 6. RETOUCHED FLAKES (continued) } \\
\hline 375 & 7903 & 4.5 & 28.5 & 22.8 & 5.6 & & 066014 & $0-12$ & TS & SCRE \\
\hline 375 & 7123 & 20.4 & 44.8 & 38.2 & 13.2 & & 076030 & $0-10$ & TS & SCRE \\
\hline 375 & 0097 & 13.2 & 45.2 & 25.0 & 11.5 & & 076008 & $0-20$ & TS & PROV \\
\hline 375 & 2210 & 146.0 & 112.0 & 75.9 & 20.1 & & 077000 & & NO & SURF \\
\hline 375 & 7883 & 27.6 & 47.0 & 42.8 & 11.0 & & 095000 & & NO & SURF \\
\hline 375 & 4409 & 14.1 & 48.2 & 37.0 & 9.8 & & 076048 & $10-20$ & TS & SCRE \\
\hline 375 & 2192 & 6.7 & 34.9 & 20.9 & 9.6 & & 066000 & & NO & SURF \\
\hline 375 & 4538 & $(8.6)$ & $(24.3)$ & $(40.0)$ & $(6.2)$ & 4 & 076029 & $10-15$ & $\mathrm{OZ}$ & PROV \\
\hline 375 & 0458 & 5.6 & 35.2 & 24.0 & 5.0 & 7 & 056027 & $0-5$ & $O Z$ & PROV \\
\hline 375 & 0920 & 6.1 & 41.2 & 27.1 & 3.7 & 5 & 077022 & $20-30$ & $O Z$ & PROV \\
\hline 375 & 1622 & $(9.8)$ & $(37.2)$ & 32.9 & 6.7 & & 077003 & $0-10$ & TS & PROV \\
\hline 375 & 7203 & $(5.2)$ & $(28.7)$ & 21.5 & 5.0 & 5 & 076038 & $40-50$ & $O Z$ & SCRE \\
\hline 375 & 7204 & $(9.7)$ & $(31.2)$ & $(24.3)$ & 8.2 & 5 & 076038 & $40-50$ & $\mathrm{OZ}$ & SCRE \\
\hline 375 & 7206 & $(25.8)$ & $(48.6)$ & $(46.3)$ & 12.3 & 5 & 076038 & $40-50$ & $O Z$ & SCRE \\
\hline 375 & 6263 & $(5.3)$ & $(38.0)$ & 20.0 & 4.2 & & $\mathrm{ECHO}$ & & NO & BACK \\
\hline 375 & 0905 & $(16.0)$ & $(29.4)$ & $(42.8)$ & $(10.1)$ & & 076025 & $0-10$ & TS & PROV \\
\hline 375 & 0982 & $(18.2)$ & $(39.4)$ & 31.0 & 17.3 & & 077013 & $0-14$ & TS & PROV \\
\hline 375 & 0057 & $(8.6)$ & $(42.3)$ & $(41.1)$ & 9.7 & & 056093 & $0-12$ & TS & PROV \\
\hline 375 & 1570 & $(14.6)$ & $(56.2)$ & 37.2 & 7.6 & & 063000 & & NO & SURF \\
\hline 375 & 6510 & 14.2 & 40.4 & 31.0 & 8.4 & & INDI & & NO & BACK \\
\hline 375 & 7125 & 10.1 & 42.5 & 34.5 & 12.9 & & 076030 & $0-10$ & TS & SCRE \\
\hline 375 & 0674 & $(26.0)$ & $(40.7)$ & $(46.6)$ & 10.3 & & 066020 & $21-31$ & TS & SCRE \\
\hline 375 & 1683 & 16.2 & 50.6 & 35.8 & 9.3 & & 085010 & $0-20$ & TS & PROV \\
\hline 375 & 1211 & $(10.6)$ & 45.6 & $(28.8)$ & 8.0 & & 067014 & $10-19$ & TS & SCRE \\
\hline 375 & 1695 & $(51.6)$ & 67.3 & $(45.6)$ & 19.7 & & 085009 & $0-20$ & TS & PROV \\
\hline 375 & 2273 & $(17.2)$ & $(40.1)$ & 36.0 & 8.4 & & 056000 & & NO & SURF \\
\hline 375 & 0102 & 51.1 & 58.6 & 45.8 & 17.0 & & 075090 & $0-20$ & TS & PROV \\
\hline 375 & 2195 & $(21.8)$ & $(30.0)$ & 48.5 & 11.9 & & 066000 & & NO & SURF \\
\hline 375 & 6344 & $(10.2)$ & $(28.2)$ & 29.9 & 8.7 & & HOTE & & NO & BACK \\
\hline 375 & 7799 & $(7.9)$ & $(34.8)$ & $(30.0)$ & 7.8 & & 104000 & & NO & SURF \\
\hline 375 & 7878 & $(2.4)$ & $(16.6)$ & $(22.7)$ & $(3.2)$ & & GOLF & & NO & BACK \\
\hline 375 & 7824 & $(7.1)$ & $(37.0)$ & 28.1 & 9.6 & & 063000 & & NO & SURF \\
\hline 375 & 0107 & 163.7 & 92.9 & 77.0 & 21.9 & & 056023 & $20-30$ & TS & PROV \\
\hline 375 & 1689 & 81.6 & 81.2 & 64.0 & 17.0 & 5 & 075099 & $28-41$ & $O Z$ & PROV \\
\hline
\end{tabular}




\begin{tabular}{cccccccc}
$\begin{array}{c}\text { Classifi- } \\
\text { cation } \\
\begin{array}{c}\text { Type Code } \\
\text { Number }\end{array}\end{array}$ & $\begin{array}{c}\text { Weight } \\
(\mathrm{g})\end{array}$ & $\begin{array}{c}\text { Maximum } \\
\text { Length } \\
(\mathrm{mm})\end{array}$ & $\begin{array}{c}\text { Maximum } \\
\text { Width } \\
(\mathrm{mm})\end{array}$ & $\begin{array}{c}\text { Maximum } \\
\text { Thickness } \\
(\mathrm{mm})\end{array}$ & $\begin{array}{l}\text { Feature } \\
\text { Number }\end{array}$ & $\begin{array}{c}\text { Unit/ Brench/ Bock } \\
\text { Blopth Below }\end{array}$ & $\begin{array}{c}\text { Stratum } \\
\text { Surface }\end{array}$ \\
\hline
\end{tabular}

PART 6. RETOUCHED FLAKES (cont inued)

\begin{tabular}{|c|c|c|c|c|c|c|c|c|c|c|}
\hline 375 & 2240 & 35.6 & 58.4 & 45.5 & 12.3 & & 024000 & & NO & SURF \\
\hline 375 & 4041 & $(3.6)$ & 26.1 & $(21.4)$ & 4.8 & & 076038 & $0-10$ & TS & SCRE \\
\hline 375 & 4110 & 1.9 & 22.4 & 9.9 & 4.8 & & 056046 & $20-29$ & TS & SCRE \\
\hline 375 & 0063 & 38.7 & 57.3 & 40.9 & 16.0 & & 056044 & $0-10$ & TS & PROV \\
\hline 375 & 0058 & 22.8 & 47.9 & 28.4 & 14.5 & & 056093 & $0-12$ & TS & PROV \\
\hline 375 & 7821 & $(2.8)$ & $(20.2)$ & $(21.4)$ & $(4.0)$ & & 063000 & & NO & SURF \\
\hline 375 & 2305 & $(62.1)$ & $(58.0)$ & 65.0 & 19.6 & 8 & 085009 & $20-30$ & $\mathrm{FZ}$ & PROV \\
\hline 375 & 0926 & $(15.1)$ & $(36.6)$ & 42.0 & 11.3 & & 077012 & $10-25$ & $\overline{\mathrm{TS}}$ & PROV \\
\hline 375 & 4525 & $(8.1)$ & $(22.0)$ & 37.6 & 11.0 & & 077003 & $18-28$ & TS & SCRE \\
\hline 375 & 4459 & 1.7 & 31.8 & 16.0 & 2.8 & & $07 E 047$ & $0-10$ & TS & SCRE \\
\hline 375 & 7894 & 1.0 & 12.3 & 7.7 & 3.2 & 7 & 056026 & $0-9$ & $\mathrm{OZ}$ & SCRE \\
\hline 375 & 4394 & 16.0 & 37.4 & 29.0 & 12.5 & & 076046 & & TS & SCRE \\
\hline 375 & 7798 & 49.4 & 50.0 & 50.6 & 21.0 & & 104000 & & NO & SURF \\
\hline 375 & 5206 & 31.8 & 55.6 & 38.7 & 15.2 & & 055084 & $23-46$ & SM & SCRE \\
\hline 375 & 7822 & 7.6 & 44.2 & 24.0 & 6.0 & & 063000 & & NO & SURF \\
\hline 375 & 7823 & $(2.9)$ & $(17.3)$ & 21.4 & 5.0 & & 063000 & & NO & SURF \\
\hline 375 & 7825 & $(10.0)$ & $(33.0)$ & 35.5 & 7.0 & & 063000 & & NO & SURF \\
\hline 375 & 7826 & $(8.9)$ & $(35.9)$ & $(26.4)$ & 7.8 & & 063000 & & NO & SURF \\
\hline 375 & 7827 & $(23.9)$ & $(33.8)$ & 50.4 & 16.1 & & 063000 & & NO & SURF \\
\hline 375 & 7850 & $(5.5)$ & $(35.0)$ & 19.4 & 6.9 & & 055000 & & NO & SURF \\
\hline 375 & 7857 & $(3.2)$ & $(22.6)$ & $(27.3)$ & 3.5 & & 065000 & & NO & SURF \\
\hline 375 & 7882 & 11.2 & 49.7 & 28.2 & 9.4 & & 095000 & & NO & SURF \\
\hline 375 & 7828 & 9.0 & 42.9 & 24.2 & 6.0 & & 063000 & & NO & SURF \\
\hline 375 & 7859 & $(3.4)$ & $(25.9)$ & $(21.0)$ & 4.2 & & 065000 & & NO & SURF \\
\hline 375 & 7884 & $(3.4)$ & $(18.0)$ & 26.1 & 4.6 & & 095000 & & NO & SURF \\
\hline 375 & 7905 & 11.0 & 40.6 & 30.4 & 9.6 & & 076047 & $0-10$ & TS & SCRE \\
\hline 375 & 6857 & 15.2 & 42.6 & 34.6 & 7.5 & & 077012 & $0-10$ & TS & SCRE \\
\hline 375 & 4429 & $(5.8)$ & $(31.3)$ & $(26.9)$ & 3.2 & & 076048 & $0-10$ & TS & SCRE \\
\hline 375 & 3958 & 6.3 & 38.9 & 23.9 & 6.4 & & 075099 & $0-20$ & TS & SCRE \\
\hline 375 & 5276 & $(5.9)$ & $(28.2)$ & $(18.5)$ & $(7.6)$ & & 055084 & $0-23$ & TS & SCRE \\
\hline 375 & 5277 & $(4.3)$ & $(33.2)$ & $(22.5)$ & 4.0 & & 055084 & $0-23$ & $\mathrm{TS}$ & SCRE \\
\hline 375 & 2172 & 15.4 & 54.6 & 20.6 & 11.4 & & 055000 & & NO & SURF \\
\hline 375 & 2300 & $(15.6)$ & $(43.9)$ & $(36.0)$ & 12.0 & & 062000 & & NO & SURF \\
\hline 375 & 0451 & $(6.2)$ & $(38.4)$ & 19.4 & 6.3 & & 076027 & $0-10$ & TS & SCRE \\
\hline
\end{tabular}


PART 7. GROUND STONE

\begin{tabular}{|c|c|c|c|c|c|c|c|c|c|c|}
\hline 380 & 5895 & 277.2 & 86.0 & 42.3 & 38.9 & & 099000 & & NO & SURF \\
\hline 381 & 5668 & 785.4 & 135.0 & 69.7 & 56.0 & & 027000 & & NO & SURF \\
\hline 382 & 3115 & $(180.5)$ & $(71.7)$ & 52.0 & 40.3 & & 036054 & $0-90$ & TS & PROV \\
\hline 384 & 9103 & $(216.4)$ & $(101.5)$ & $(81.0)$ & 35.0 & & CHAR & & NO & BACK \\
\hline 384 & $9504^{\circ}$ & $(744.5)$ & $(106.3)$ & $(129.7)$ & 33.3 & & 027000 & & NO & SURF \\
\hline 384 & 4119 & $(3679.1)$ & $(282.0)$ & $(205.0)$ & 58.0 & 6 & 077013 & $14-24$ & $\mathrm{FZ}$ & PROV \\
\hline 384 & 5712 & $(90.2)$ & $(95.2)$ & 75.8 & 10.0 & & 047000 & & NO & SURF \\
\hline 384 & 6204 & $(66.2)$ & 60.4 & $(86.0)$ & 9.0 & & GOLF & & NO & BACK \\
\hline 384 & 5665 & $(386.8)$ & $(99.0)$ & $(112.4)$ & 20.9 & & 027000 & & NO & SURF \\
\hline 384 & 5672 & $(1030.2)$ & $(119.4)$ & $(112.8)$ & 45.0 & & 027000 & & NO & SURF \\
\hline 384 & 6131 & $(466.4)$ & $(90.0)$ & $(99.6)$ & 35.1 & & 070000 & & NO & SURF \\
\hline 384 & 5490 & $(835.4)$ & $(112.0)$ & $(161.0)$ & 39.3 & & 015000 & & NO & SURF \\
\hline 386 & 6424 & $(99.0)$ & $(99.5)$ & $(59.6)$ & 18.2 & & BRAV & & NO & BACK \\
\hline 386 & 5088 & $(29.0)$ & $(32.9)$ & $(38.3)$ & 17.2 & 2 & 055084 & $23-46$ & $M Z$ & PROV \\
\hline
\end{tabular}




\begin{tabular}{|c|c|c|c|c|c|c|c|c|c|c|}
\hline $\begin{array}{l}\text { Classifi- } \\
\text { cation } \\
\text { Type Code }\end{array}$ & $\begin{array}{c}\text { Catalog } \\
\text { Number }\end{array}$ & Quantity & $\begin{array}{l}\text { Maximum } \\
\text { Length } \\
(\mathrm{mm})\end{array}$ & $\begin{array}{l}\text { Maximum } \\
\text { Width } \\
(\mathrm{mm})\end{array}$ & $\begin{array}{l}\text { Maximum } \\
\text { Thickness } \\
\text { (mm) }\end{array}$ & $\begin{array}{l}\text { Feature } \\
\text { Number }\end{array}$ & $\begin{array}{l}\text { Unit/ } \\
\text { Trench/ } \\
\text { Block }\end{array}$ & $\begin{array}{c}\text { Depth Below } \\
\text { Ground } \\
\text { Surface }\end{array}$ & $\begin{array}{l}\text { Stratum } \\
\text { Desig- } \\
\text { nation }\end{array}$ & Comment \\
\hline
\end{tabular}

PART 8. SHELL

\begin{tabular}{llllllll}
403 & 0828 & 2 & 7 & 056017 & $0-6$ & OZ & SCRE \\
403 & 2687 & 2 & 7 & 056016 & $0-9$ & $0 Z$ & SCRE \\
403 & 5569 & 1 & & & 001000 & SURF \\
\hline
\end{tabular}

PART 9. PREHISTORIC CERAMICS

\begin{tabular}{|c|c|c|c|c|c|c|}
\hline 476 & 0130 & 7 & 056028 & $5-9$ & $O Z$ & PROV \\
\hline 476 & 0132 & 7 & 056028 & $5-9$ & $O Z$ & PROV \\
\hline 476 & 0303 & & 011038 & $10-20$ & TS & SCRE \\
\hline 476 & 0453 & 7 & 056027 & $0-5$ & $O Z$ & PROV \\
\hline 476 & 0454 & 7 & 056027 & $0-5$ & $O Z$ & PROV \\
\hline 476 & 0455 & 7 & 056027 & $0-5$ & $O Z$ & PROV \\
\hline 476 & 0462 & 7 & 056027 & $0-5$ & $O Z$ & PROV \\
\hline 476 & 0463 & 7 & 056027 & $0-5$ & $0 Z$ & PROV \\
\hline 476 & 0464 & 7 & 056027 & $0-5$ & $\mathrm{OZ}$ & PROV \\
\hline 476 & 0465 & 7 & 056027 & $0-5$ & $O Z$ & PROV \\
\hline 476 & 0466 & 7 & 056027 & $0-5$ & $O Z$ & PROV \\
\hline 476 & 0473 & 7 & 056027 & $0-5$ & $O Z$ & PROV \\
\hline 476 & 0825 & 7 & 056017 & $0-6$ & $O Z$ & SCRE \\
\hline 476 & 0850 & 7 & 056028 & $0-5$ & $O Z$ & SCRE \\
\hline 476 & 0893 & 7 & 056016 & $0-9$ & $O Z$ & PROV \\
\hline 476 & 0900 & 7 & 056029 & $10-15$ & $O Z$ & PROV \\
\hline 476 & 1666 & 7 & 056029 & $5-10$ & $O Z$ & PROV \\
\hline 476 & 2158 & & 022000 & & NO & SURF \\
\hline 476 & 2688 & 7 & 056016 & $0-9$ & $O Z$ & SCRE \\
\hline 476 & 5178 & 7 & 056026 & $9-12$ & $\mathrm{OZ}$ & PROV \\
\hline 476 & 5196 & 7 & 056026 & $9-12$ & $O Z$ & SCRE \\
\hline 476 & 5207 & 7 & 056026 & $9-12$ & $O Z$ & SCRE \\
\hline 476 & 5208 & 7 & 056026 & $9-12$ & $\mathrm{OZ}$ & SCRE \\
\hline 476 & 6351 & & 045000 & & NO & SURF \\
\hline 476 & 7760 & 7 & 056028 & $0-5$ & $O Z$ & SCRE \\
\hline
\end{tabular}




\begin{tabular}{ccccccccc}
\hline $\begin{array}{c}\text { Classifi- } \\
\text { cation } \\
\text { Type Code }\end{array}$ & $\begin{array}{c}\text { Catalog } \\
\text { Number }\end{array}$ & $\begin{array}{c}\text { Maximum } \\
\text { Length } \\
(\mathrm{mm})\end{array}$ & $\begin{array}{c}\text { Maximum } \\
\text { Width } \\
(\mathrm{mm})\end{array}$ & $\begin{array}{c}\text { Maximum } \\
\text { Thickness } \\
(\mathrm{mm})\end{array}$ & $\begin{array}{l}\text { Feature } \\
\text { Number }\end{array}$ & $\begin{array}{l}\text { Unit/ } \\
\text { Brench/ } \\
\text { Block }\end{array}$ & $\begin{array}{c}\text { Depth Below } \\
\text { Ground } \\
\text { Surface }\end{array}$ & $\begin{array}{l}\text { Stratum Desig- } \\
\text { nation }\end{array}$ \\
\hline
\end{tabular}

PART 10. HISTORIC ARTIFACTS

$\begin{array}{lll}17 & 2154 & 1 \\ 17 & 2155 & 1 \\ 17 & 2156 & 1 \\ 17 & 2157 & 1 \\ 51 & 6299 & 3 \\ 52 & 0627 & 1 \\ 52 & 6300 & 1 \\ 53 & 0172 & 2 \\ 53 & 0607 & 1 \\ 53 & 1460 & 1 \\ 53 & 5713 & 1 \\ 53 & 6239 & 1 \\ 55 & 5674 & 1 \\ 56 & 5460 & 4 \\ 56 & 5673 & 3 \\ 59 & 1490 & 2 \\ 67 & 0709 & 1 \\ 67 & 0716 & 1 \\ 67 & 2202 & 1 \\ 67 & 2645 & 1 \\ 72 & 2763 & 1 \\ 79 & 6242 & 1 \\ 79 & 6329 & 1 \\ 89 & 1576 & 1 \\ 90 & 7878 & 1 \\ 91 & 0235 & 1\end{array}$

\begin{tabular}{|c|c|c|c|c|}
\hline & 028000 & & NO & SURF \\
\hline & 028000 & & NO & SURF \\
\hline & 028000 & & NO & SURF \\
\hline & 028000 & & NO & SURF \\
\hline & DELT & & NO & BACK \\
\hline & 066016 & $0-13$ & TS & SCRE \\
\hline & DELT & & NO & BACK \\
\hline & 066013 & $0-13$ & TS & SCRE \\
\hline & 066014 & $0-12$ & TS & SCRE \\
\hline 7 & 056019 & $5-10$ & $O Z$ & SCRE \\
\hline & 047000 & & NO & SURF \\
\hline & ECHO & & NO & BACK \\
\hline & 027000 & & NO & SURF \\
\hline & 037000 & & NO & SURF \\
\hline & 027000 & & NO & SURF \\
\hline 7 & 056007 & $0-5$ & $O Z$ & SCRE \\
\hline & 056023 & $0-10$ & TS & SCRE \\
\hline & 056023 & $10-20$ & TS & SCRE \\
\hline & 066000 & & NO & SURF \\
\hline 7 & 056009 & $0-5$ & $\mathrm{OZ}$ & SCRE \\
\hline & 124031 & $0-15$ & TS & PROV \\
\hline & ECHO & & NO & BACK \\
\hline & HOTE & & NO & BACK \\
\hline & 063000 & & NO & SURF \\
\hline & GOLF & & NO & BACK \\
\hline & 011019 & $0-10$ & TS & SCRE \\
\hline
\end{tabular}




\title{
APPENDIX II
}

\section{VEGETATIONAL ANALYSIS OF 41 BX 300}

\author{
(John E. Cook and Michae1 Laquey)
}

Archaeological site 41 BX 300 is located within the Blackland Prairie vegetational area, approximately $7.2 \mathrm{~km}$ east of U.S. 281, and $0.4 \mathrm{~km}$ north of FM 1604. The native vegetation is classed as true prairie with little bluestem as a climax dominant decreaser. Other associated grass decreasers are sideoats grama, plains lovegrass, Canada wildrye, green sprangletop, indiangrass, and Texas cupgrass. Dominant grass increasers are hairy grama, buffalograss, curlymesquite, slim tridens, Texas wintergrass, fall witchgrass, hairy dropseed, feather bluestem, and Wright threeawn. Forb increasers include: bush sunflower, orange zexmania, and sagewort (Taylor, Hailey, and Richmond 1966). The grasses of the site have been too disturbed to make any positive identification. At present, the site is dominated by invaders, which include: prickly pear, at least two species of yucca, whitebrush, condalia, agarita, Ashe juniper, Texas persimmon, and live oak. There is one permanent body of water on the site. The dominant riparian woody species is cedar elm. Much of the native riparian vegetation has been disturbed. At present, it is primarily characterized by invader species, i.e., Texas persimmon and agarita (see Tab7e 31).

Three 1 ine transects consisting of 20 intervals of three meters each were used to measure vegetational characteristics, such as density, frequency, and dominance (see Table 32). The results indicated that $57 \%$ of the site is covered by woody vegetation, and $43 \%$ of the site is grass, forb, or bare ground. The dominant woody vegetation is cedar elm, Texas persimmon, and mesquite. Agarita and whitebrush form the dominant brush cover. Due to the disturbed condition of the site, no climax grasses were evident. The riparian vegetational complex is too disturbed to draw any conclusions.

\section{REFERENCES CITED}

Corre11, D. S. and M. C. Johnston

1970 Manual of Vascular Plants of Texas. Texas Research Foundation, Renner, Texas.

Taylor, F. B., R. B. Hailey, and D. L. Richmond

1966 Soil Survey - Bexar County, Texas. U.S. Department of Agriculture, Soil Conservation Service, Series 1962(12). 
TABLE 31. DOMINANT VEGETATIVE SPECIES AT 41 BX 300

\section{List of Dominant Species of Site}

\author{
Cedar elm \\ Texas persimmon \\ Mesquite \\ Agarita \\ Live oak \\ Ashe juniper \\ Whitebrush \\ Brazil or Capul Negro \\ Trecul Yucca \\ Cat-brier \\ Prickly pear
}

\author{
UTmus crassifolia \\ Diospyros texana \\ Prosopis glandulosa \\ Berberis trifoliolata \\ Quercus fusiformis \\ Juniperus Ashei \\ Aloysia 1igustrina \\ Condal ia hookeri \\ Yucca treculeana \\ Simi 1 ax Bona-nox \\ Opuntia lindheimeri
}

\section{List of Native Grasses and Forbs}

Dominant Grass Decreasers:

Little bluestem

Sideoats grama

Plains lovegrass

Canada wildrye

Green sprangletop

Indiangrass

Texas cupgrass

Dominant Grass Increasers:

Hairy grama

Buffalograss

Curlymesquite

STim tridens

Texas wintergrass

Fall witchgrass

Hairy dropseed

Feather bluestem

Wright threeawn
Andropogon scoparius

Bouteloua curtipendula

Eragrostis sp.

Elymus canadensis

Leptochloa dubio

Sorghastrum sp.

Eriochloa sericea
Bouteloua hirsuta Buchloe dactyloides

Hilaria belangeri

Tridens muticus

Stipa Teucotrida

Leptoloma cognatum

Sporobolus sp.

Andropogon sp.

Aristida sp.

Dominant Forb Increasers:

Bush sunflower, Orange Zexmania, and Sagewort

Other Dominant Grass and Forb Invaders:

Hairy tridens, purple threeawn. Texas grama, queensdelight, tumblegrass, red grama, Evax, buffalobur, mealycup sage, threeawn.

Sources: Corre11 and Johnston (1970); Taylor, Hailey, and Richmond (1966). 
TABLE 32. VEGETATIONAL DENSITY, FREQUENCY, AND DOMINANCE AT 41 BX 300

\begin{tabular}{|c|c|c|c|c|c|c|c|c|c|}
\hline & A & B & c & D & $E$ & $F$ & G & $H$ & I \\
\hline & $\begin{array}{c}\text { Total } \\
\text { Individuals }\end{array}$ & $\begin{array}{l}\text { Total } \\
\text { Intercept } \\
\text { Length }\end{array}$ & $\begin{array}{l}\text { Intervals } \\
\text { in which } \\
\text { Recorded }\end{array}$ & $\begin{array}{l}\text { Relative } \\
\text { Density } \\
\text { A/A Total }\end{array}$ & $\begin{array}{l}\text { Dominance } \\
\text { B/Transect } \\
\text { (Tota1) }\end{array}$ & $\begin{array}{l}\text { Relative } \\
\text { Dominance } \\
\text { B/B Total }\end{array}$ & $\begin{array}{l}\text { Frequency } \\
\text { C/Intervais }\end{array}$ & $\begin{array}{l}\text { Relative } \\
\text { Frequency } \\
\text { G/G Total }\end{array}$ & $\begin{array}{c}\text { Important } \\
\text { Value } \\
D+F+H\end{array}$ \\
\hline Mesquite & 11 & 70 & 11 & 9.8 & 11.7 & 10.8 & 18.3 & 9.8 & 30.4 \\
\hline Whitebrush & 9 & 29 & 9 & 8.0 & 4.8 & 4.5 & 15.0 & 8.0 & 20.5 \\
\hline Ashe Juniper & 3 & 4 & 3 & 2.7 & 0.7 & 0.6 & 5.0 & 2.7 & 6.0 \\
\hline Agarita & 15 & 40 & 15 & 13.4 & 6.7 & 6.2 & 25.0 & 13.3 & 32.9 \\
\hline Persimmon & 13 & 82 & 13 & 11.6 & 13.7 & 12.7 & 21.7 & 11.6 & 35.9 \\
\hline Cedar Elm & 24 & 156 & 24 & 21.4 & 26.0 & 24.1 & 40.0 & 21.4 & 66.9 \\
\hline Condalta & 1 & 1 & 1 & 0.9 & 0.2 & 0.2 & 1.7 & 0.9 & 2.0 \\
\hline Live Oak & 1 & 7 & 1 & 0.9 & 1.2 & 1.1 & 1.7 & 0.9 & 2.9 \\
\hline Grass/Bare & 35 & 257 & 35 & 31.3 & 42.8 & 39.8 & 58.3 & 31.2 & 102.3 \\
\hline Total & 112 & 646 & & & & & 186.7 & & \\
\hline
\end{tabular}




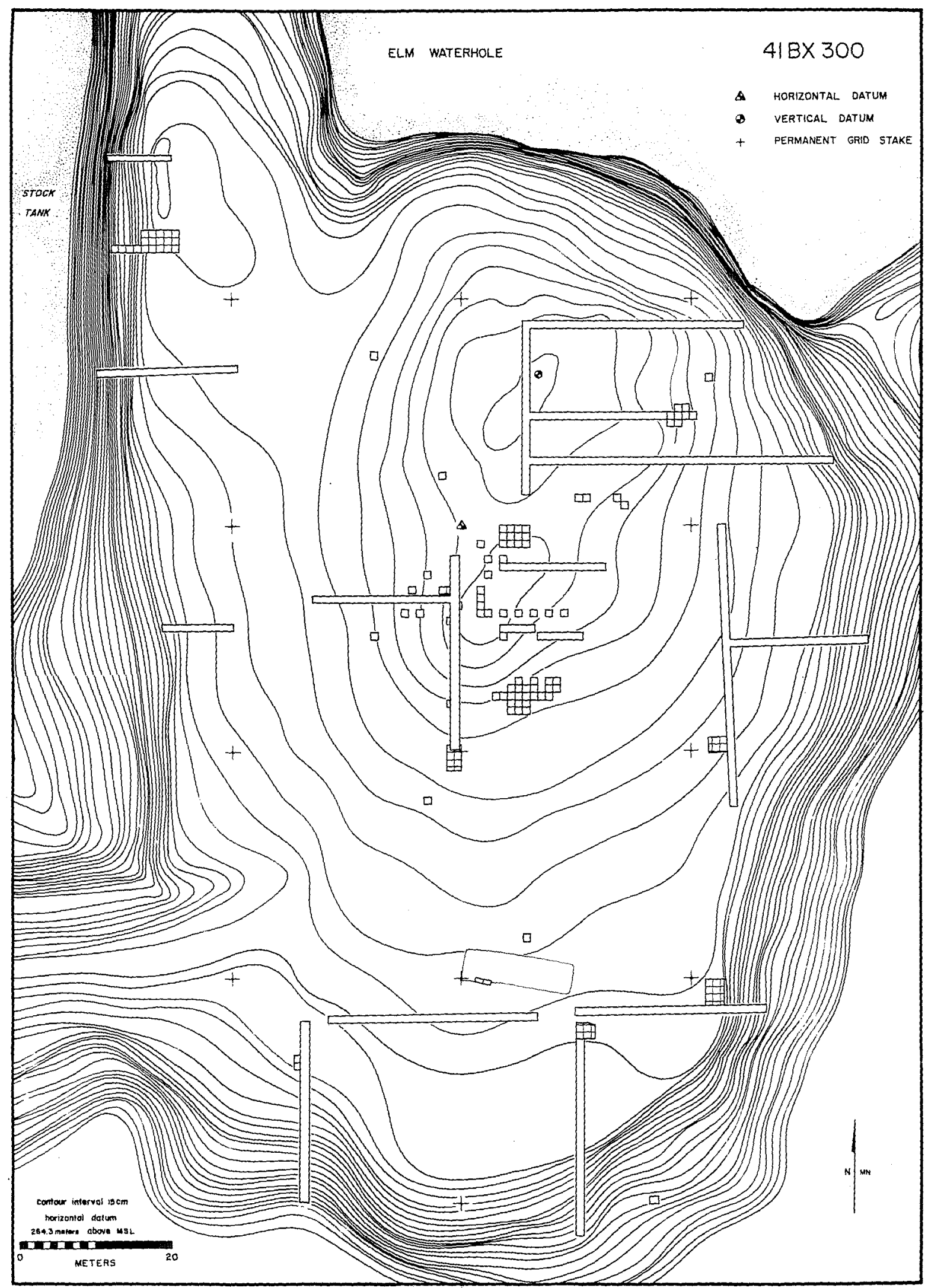

Figure 10. Contour Map of Site, Showing A11 Trenches and Units Excavated During A11 Phases. 
